California State University, Monterey Bay

Digital Commons@ @ CSUMB

$1-15-2019$

\title{
1939 - A History of the Water Resources Branch, US Geological Survey, Volume I, From Predecessor Surveys to June 30, 1919
}

Follow this and additional works at: https://digitalcommons.csumb.edu/hornbeck_usa_2_f

Part of the Business Commons, Education Commons, Engineering Commons, Life Sciences Commons, Physical Sciences and Mathematics Commons, and the Social and Behavioral Sciences Commons

\section{Recommended Citation}

"1939 - A History of the Water Resources Branch, US Geological Survey, Volume I, From Predecessor Surveys to June 30, 1919" (2019). Miscellaneous Federal Documents \& Reports. 8.

https://digitalcommons.csumb.edu/hornbeck_usa_2_f/8

This Book is brought to you for free and open access by the Federal Government Documents at Digital Commons @ CSUMB. It has been accepted for inclusion in Miscellaneous Federal Documents \& Reports by an authorized administrator of Digital Commons @ CSUMB. For more information, please contact digitalcommons@csumb.edu. 
Earlier volumes (unpublished), Robert Follansbee, author:

Volume II: July 1,1919 , to June 30,1928 ,

Volume III: July 1, 1928, to June 30,1939 , and

Volume IV: July 1, 1939, to June 30, 1947.

Published volume:

Volume V: July 1, 1947, to April 30, 1957, George E. Ferguson et al (1990).

Any use of trade names and trademarks in this publication is for descriptive purposes only and does not constitute endorsement by the U.S. Geological Survey.

Cover art by James A. Tomberlin, 1990. 
Billone

\begin{abstract}
A History of the Water Resources Branch, U.S. Geological Survey: Volume 1, From Predecessor Surveys TO JUNE 30, 1919
\end{abstract}

By Robert Follansbee 


\section{U.S. DEPARTMENT OF THE INTERIOR BRUCE BABBITT, Secretary}

U.S. GEOLOGICAL SURVEY

Gordon P. Eaton, Director

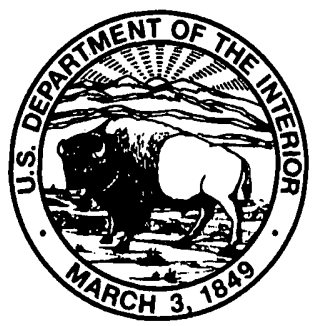

UNITED STATES GOVERNMENT PRINTING OFFICE: 1994

For sale by the Branch of Distribution, U.S. Geological Survey, Federal Center, Box 25286, Denver, CO 80225

Library of Congress Cataloging-in-Publication Data

Follansbee, Robert, 1879-1952.

A history of the Water Resources Branch of the United States Geological Survey. Volume I, From predecessor Surveys to June 30, 1919 / by Robert Follansbee.

Includes indexes.

1. Geological Survey (U.S.). Water Resources Division-History.

2. Water resources development-United States-History.

3. Hydrology-United States-Hisotry. I. Title

TC423.F644 1994 


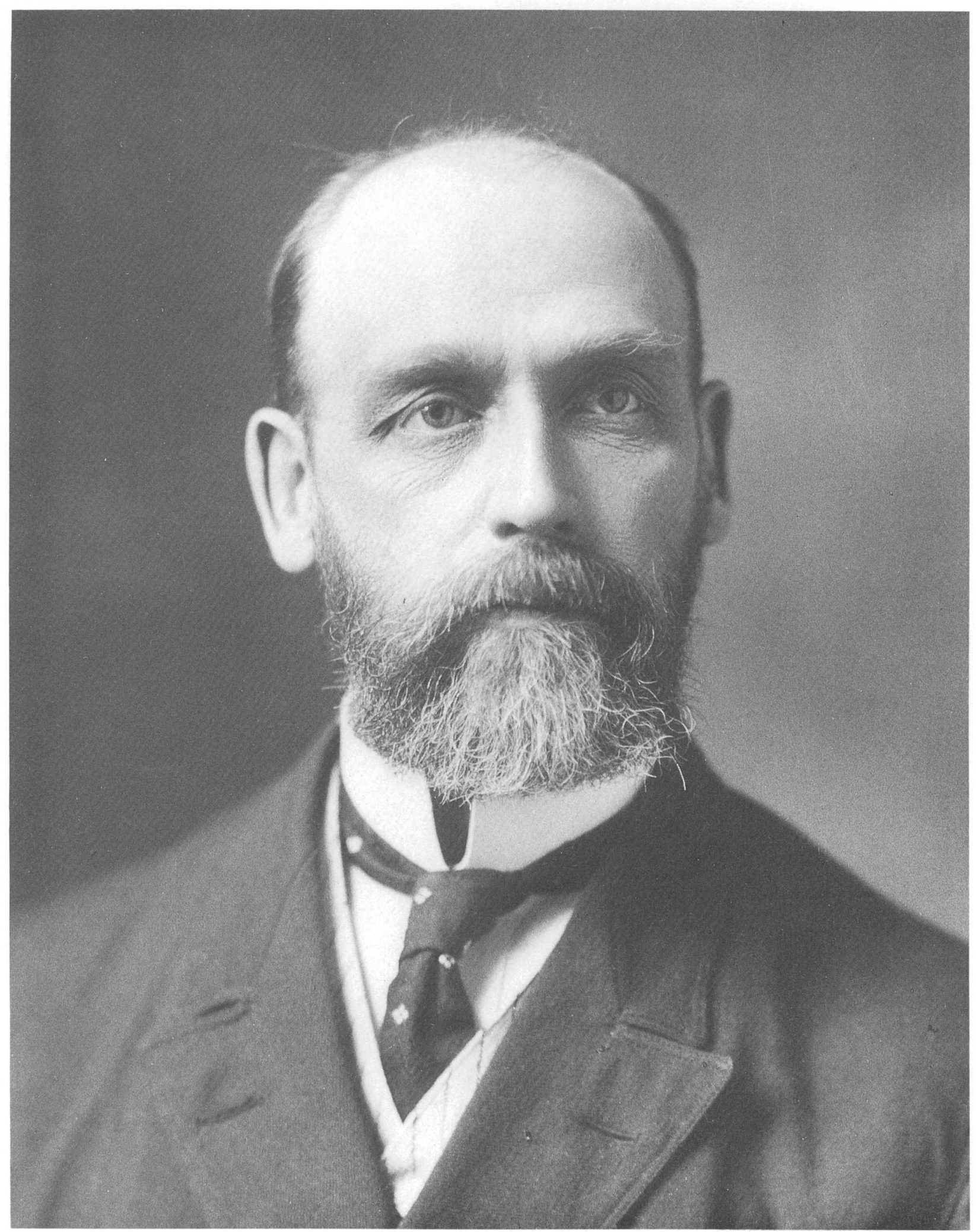

Frederick Haynes Newell (1862-1932)

(From U.S. Geological Survey Professional Paper 778, 1972. Photograph number "Portraits 652," USGS Photographic Library.) 



\section{FOREWORD}

This volume is the first in a series of chronological summaries of the activities and achievements of the Water Resources Division of the U.S. Geological Survey. First published in 1939 through private subscription by interested personnel, Volume $I$ is now available as a public document. The manuscripts of the following three volumes that cover the years 1919-47, all by the author of this volume, were reproduced by the Division in the 1950's for internal use only. Their publication for public use remains one of the Division's goals.

Robert Follansbee, the author, was the Water Resources Division's district engineer for Montana (1906-8), the upper Mississippi District (1909-11), and Colorado-Wyoming (1912-48). He completed Volume II in 1939, Volume III in 1944, and Volume IV after his retirement in 1949. Follansbee died in 1952 at age 73.

Volume V, which covers 1947-57, by George E. Ferguson and others, was published in 1990 . Volume VI, in preparation, will add an additional decade of Division history.

The volumes have been edited for publication, in accordance with U.S. Geological Survey and U.S. Government Printing Office standards, by Sandra Holmes, Water Resources Division.

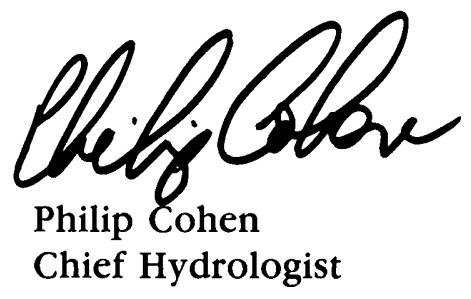





\section{CONTENTS}

Frontispiece

Page

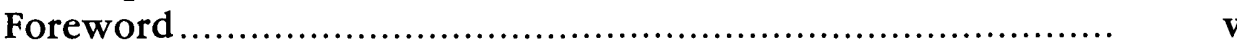

Part I-Frederick Haynes Newell................................. 1

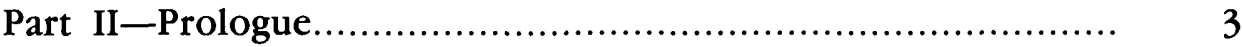

Part III-Predecessor surveys................................... 5

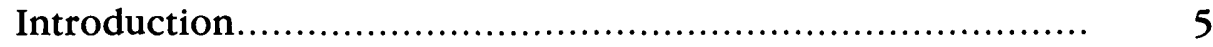

King Survey......................................................... 5

Hayden Survey ..................................................... 8

Powell Survey ..................................................... $\quad 11$

Wheeler Survey................................................. 13

Importance of topographic mapping in predecessor surveys.. $\quad 15$

Part IV-Inception and early years of the Geological Survey.... 17

Events leading to the creation of the Geological Survey....... 17

Relation of the Geological Survey to its predecessors.......... 20

Organization of the Geological Survey........................... 20

Clarence King, Director........................................ 20

Major John Wesley Powell, Director.......................... 22

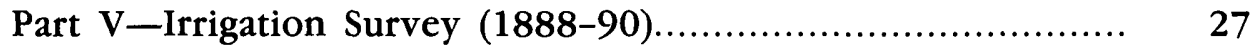

Organization of the Hydrographic Survey....................... 27

Development of the art of stream gaging...................... $\quad 30$

Influence on the Survey of the Colorado plan of operation... 33

The Camp at Embudo, New Mexico............................. 34

Organization .................................................. $\quad 34$

Camp routine ................................................. 36

Instruments and methods..................................... 37

Further work by the Hydrographic Survey.................... $\quad \mathbf{4 1}$

Selection of streams to be investigated......................... $\quad \mathbf{4 1}$

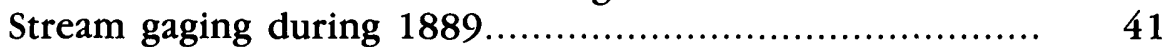

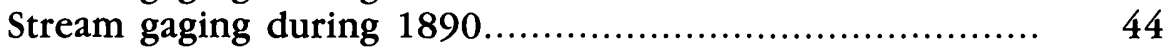

Denver rating station........................................ 45

Improvement in equipment.................................... $\quad 45$

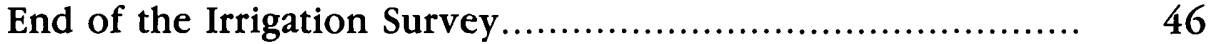

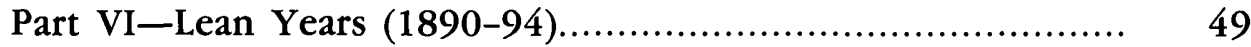

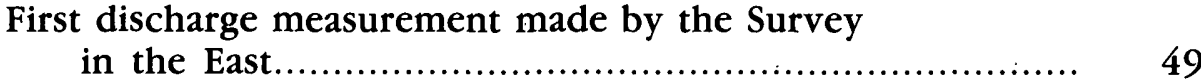

Chain Bridge gaging station................................... $\quad 50$

Other activities................................................ $\quad 50$

First specific appropriation for stream gaging.................. 51

Part VII-Years of per-diem appointments (1894-1902).......... 53

Transfer of Arthur Powell Davis to Hydrography............... 53

Resumption of work in the West................................. 53

Work in the East.............................................. 55 
Part VII-Years of per-diem appointments (1894-

1902)-Continued

Further extension of work in the West.......................... 55

Chevy Chase rating station....................................... 56

Adoption of Price meter......................................... 57

Los Angeles rating station.................................... $\quad 58$

Extension of work to southern Appalachian region............. $\quad 58$

Increases in appropriations.................................... $\quad 60$

Expansion of permanent work force.............................. $\quad 60$

Extension of field work.......................................... 61

Stream gaging.................................................. 61

Reservoir surveys............................................ 62

Methods used in stream gaging................................ 62

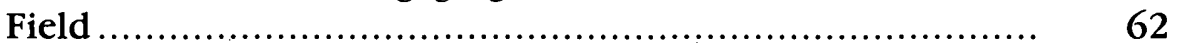

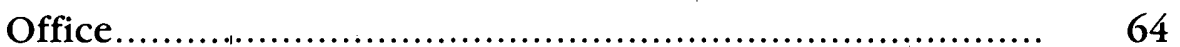

Improvement in equipment...................................... 64

Publication of annual records.................................... 64

Special investigations......................................... 65

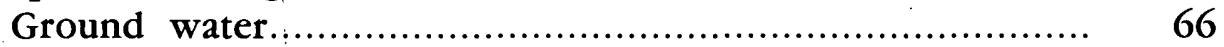

Summary of stream-gaging work (1894-1902)............... 67

Western States.............................................. 67

North Dakota................................................ 67

Nebraska...................................................... $\quad 68$

Kansas and Indian Territory ............................. $\quad 69$

Colorado......................................................... 69

Wyoming ..................................................... 71

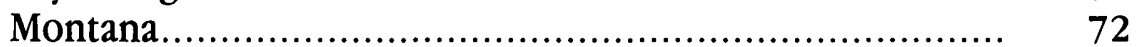

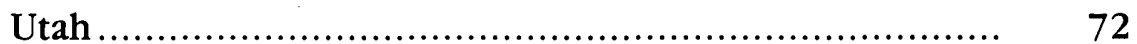

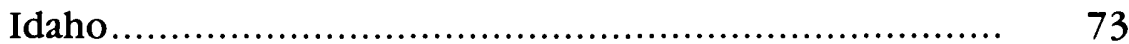

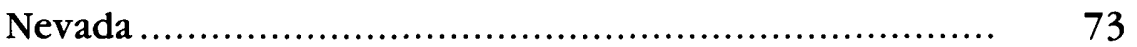

Washington and Oregon.................................... 73

California......................................................... 74

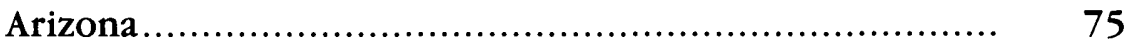

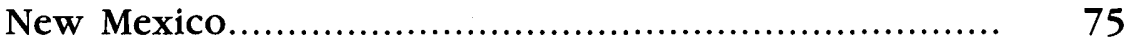

Texas......................................................... 75

Southern States.............................................. $\quad 76$

Virginia and West Virginia..................................... $\quad 76$

North Carolina and South Carolina......................... $\quad 76$

Georgia, Alabama, Tennessee, and Mississippi............. $\quad 76$

Eastern States................................................... $\quad 77$

Pennsylvania ................................................. $\quad 77$

New York.................................................. $\quad 77$

Michigan .................................................... $\quad 78$

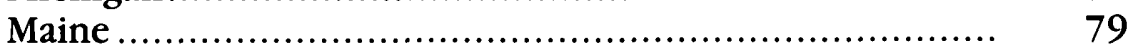

Passage of the Reclamation Act............................... 79

Part VIII-The Hydrographic Branch (1902-6).................. 83

Enlargement of scope of hydrography.......................... $\quad 83$

Increase in permanent force................................... $\quad 84$

Organization of Washington office.............................. 85

Organization of districts........................................ $\quad 86$

New districts.................................................... 87 
Part VIII-The Hydrographic Branch (1902-6) - Continued

New districts-Continued

Chicago District

87

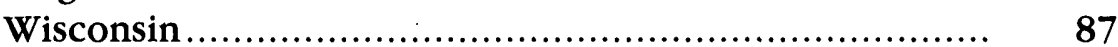

Methods...

88

Standardization of existing methods.......................... 88

New office methods....................................... 89

Ice measurements................................................. 91

State cooperation................................................ 94

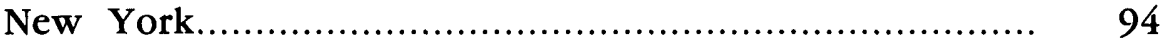

Maine ............................................................ 94

New Hampshire............................................... 94

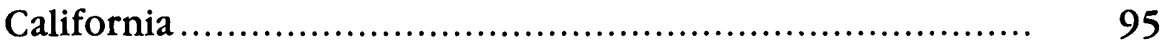

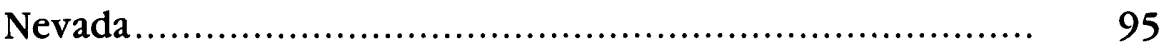

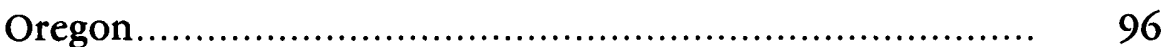

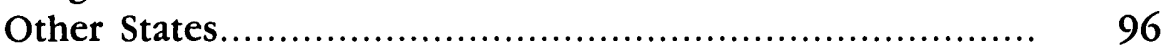

River surveys.................................................. 96

Georgia .................................................... 97

Cooperation with Topographic Branch..................... 97

Maine .......................................................... 98

Wisconsin .................................................... 98

Virginia .......................................................... 99

North Carolina.................................................... 100

Summary of work by districts.................................. 100

New England District............................................ 100

New York District............................................... 101

Middle Atlantic States District.................................... 102

South Atlantic and Eastern Gulf States District................ 102

Texas District................................................... 103

Chicago District................................................. 103

Wisconsin .................................................. 103

Minnesota .................................................... 103

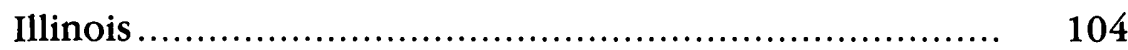

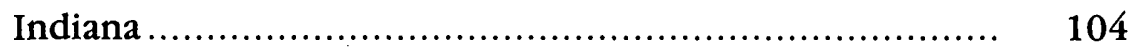

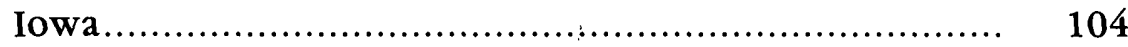

Missouri........................................................ 104

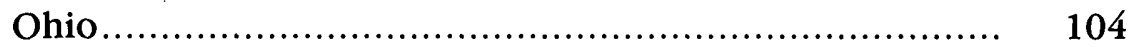

Upper Peninsula of Michigan............................ 105

Kentucky ...................................................... 105

North Dakota District.......................................... 105

Denver District................................................. 105

Colorado..................................................... 105

New Mexico................................................ 106

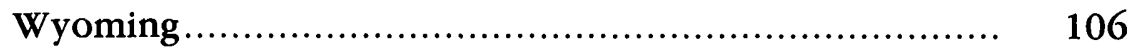

Nebraska ...................................................... 106

Kansas ......................................................... 107

South Dakota............................................... 107

Uinta Indian Reservation.................................... 108

Oklahoma-Eastern New Mexico District.......................... 108

Montana District................................................ 108 
Part VIII-The Hydrographic Branch (1902-6)—Continued

Summary of work by districts-Continued

Idaho District..................................................... 109

Utah District (including southeastern Idaho)................... 109

Nevada District................................................... 109

Washington District........................................... 110

Oregon District.................................................. 110

California District.............................................. $\quad 110$

Arizona District.................................................. 111

Division of Hydrology............................................ 112

Eastern section................................................ 113

Western section.............................................. 114

Division of Hydro-Economics................................. 115

Reduction in appropriation................................... 118

Marshall $O$. Leighton appointed chief hydrographer............. 119

Progress in Branch activities to June 30, 1906................. 119

Part IX-Early years of the Water Resources Branch

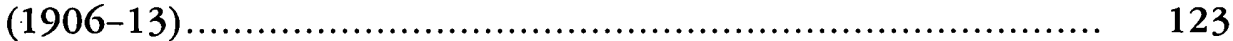

Change in name................................................ 123

General organization........................................... 124

Washington office............................................ 124

Field ......................................................... 125

Further opposition to the stream-gaging appropriation item.. 126

Conservation movement............................................ 128

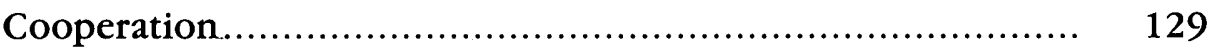

States ....................................................... 129

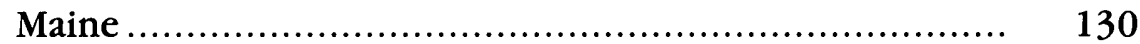

Vermont ...................................................... 130

Massachusetts ................................................. 131

New York................................................... 131

North Carolina .................................................. 132

Tennessee .................................................. 132

Maryland, Georgia, and Alabama........................... 133

Illinois ........................................................ 133

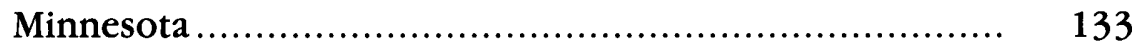

North Dakota.................................................. 134

Nebraska .................................................... 134

Montana...................................................... 134

Wyoming ................................................... 135

Colorado ................................................... 135

New Mexico.................................................. 136

Idaho....................................................... 137

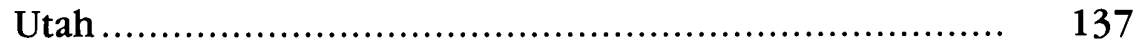

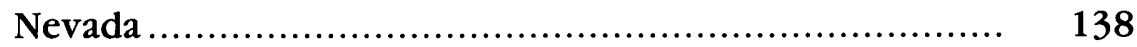

Washington................................................. 138

Oregon ................................................... 139

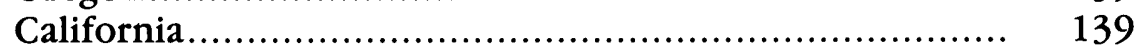

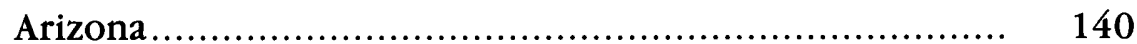

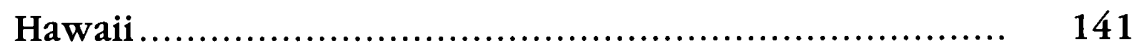

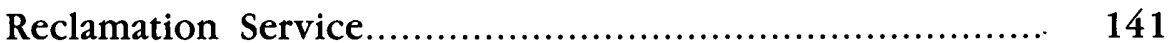

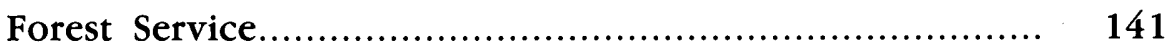

White Mountains investigation.............................. 142

Indian Service............................................... 143 
Part IX-Early years of the Water Resources Branch

(1906-13)-Continued

New districts.

Alaskan cooperation.......................................... 144

Ohio River District........................................... 145

Minnesota District.............................................. 146

Hawaii District................................................. 146

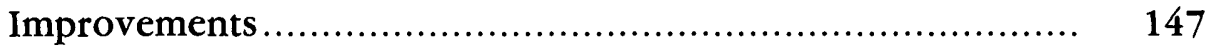

Equipment...................................................... 147

Automatic gages............................................. 149

Methods ...................................................... 153

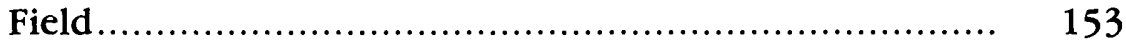

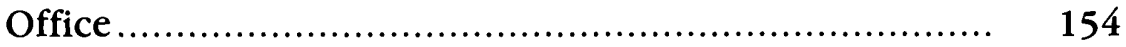

Annual reports.................................................... 154

Winter records................................................... 156

Control.............................................................. 157

Point of zero flow......................................... 158

Conferences ...................................................... 158

Division of Water Utilization.................................... 160

River surveys................................................... 162

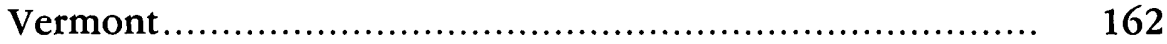

Washington ................................................ 162

Minnesota ..................................................... 162

Tennessee .................................................. 163

Special investigations............................................... 164

Mining debris................................................... 164

Water-power census............................................. 165

Undeveloped power......................................... 165

Developed power.............................................. 166

Swamp and overflowed lands............................... 166

White Mountains................................................ 167

Summary of district operations................................. 169

New England and New York Districts........................ 169

Maine District.............................................. $\quad 170$

Middle Atlantic [States] District............................. 170

South Atlantic [States] District............................... 170

Chicago District............................................. 171

Ohio River District......................................... 172

Upper Mississippi River District............................... 173

Upper Missouri River District.................................. 173

South Dakota District............................................ 174

Rocky Mountain District.................................... 174

Colorado........................................................ 175

Wyoming .................................................... 176

New Mexico............................................. 176

Nebraska .................................................. $\quad 176$

Uinta Indian Reservation.................................... 176

Oklahoma-New Mexico District.................................. 176

Texas District..................................................... 177

Great Basin District......................................... 177 
Part IX-Early years of the Water Resources Branch

(1906-13)-Continued

Summary of district operations-Continued

Idaho District................................................ 178

Columbia River District....................................... 178

California District......................................... $\quad 180$

Nevada ..................................................... 181

Arizona ............................................................... 181

Hawaii District................................................. 181

Alaska ......................................................... 183

Division of Water Quality...................................... 187

Division of Ground Water..................................... 189

States ........................................................ 190

Ohio .......................................................... 191

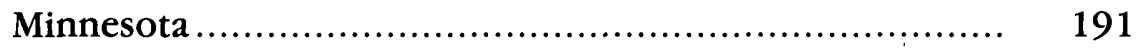

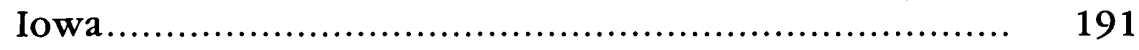

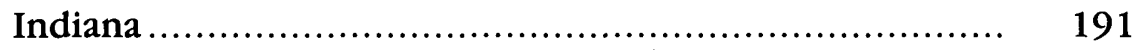

Utah ........................................................ 191

New Mexico................................................ 192

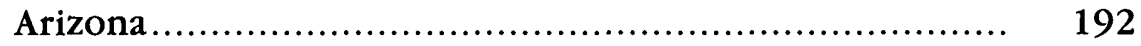

California.................................................. 192

Oregon and Washington................................... 193

Indian reservations.......................................... 193

Evaluation of the period...................................... 193

Part X-Maturing years (1913-19)................................. 195

Nathan Clifford Grover appointed chief hydraulic engineer... 197

General organization............................................... 198

Washington, D.C., office.................................. 198

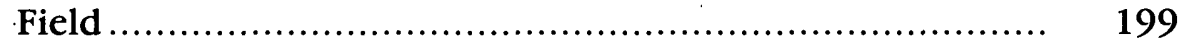

Appropriations ............................................... 200

Cooperation ........................................................ 200

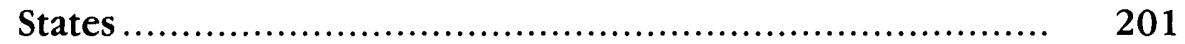

Maine ..................................................... 201

New Hampshire ............................................ 201

Vermont ................................................. $\quad 202$

Massachusetts .............................................. 202

New York................................................ 203

North Carolina.......................................... 203

Georgia............................................... $\quad 203$

Alabama....................................................... 203

West Virginia............................................. 203

Kentucky .............................................. 203

Tennessee ............................................... 203

Illinois .................................................... 204

Wisconsin ............................................... 205

Minnesota .................................................... 205

Iowa ........................................................ 206

North Dakota................................................. 206

South Dakota................................................ 206

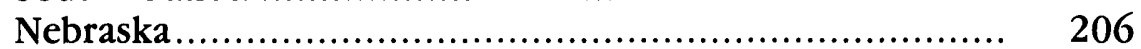


Part X-Maturing years (1913-19)-Continued

Page

\section{Cooperation-Continued}

States-Continued

Kansas

Texas.

Montana ....................................................... 208

Wyoming ................................................. 208

Colorado.................................................... 208

New Mexico............................................. 208

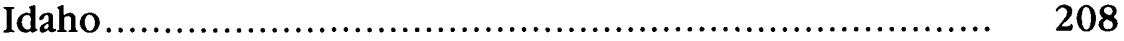

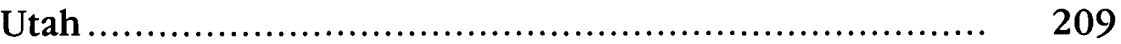

Nevada ........................................................ 210

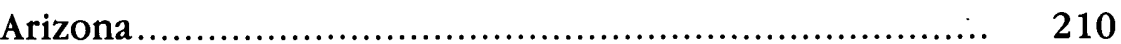

Washington ................................................. 210

Oregon ........................................................ $\quad 210$

California ....................................................... 211

Hawaii ..................................................... 212

Federal .......................................................... 213

Reclamation Service..................................... 213

Forest Service.............................................. $\quad 214$

Indian Service........................................... 215

National Park Service....................................... 215

Army Engineers.............................................. 216

Joint operation of international stations........................ 216

Current meters..................................................... 218

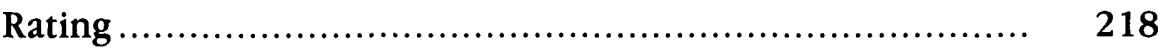

Modification .................................................... 219

Improvement in equipment.................................... $\quad 219$

Water-stage recorders.......................................... 220

Gaging-station equipment....................................... 221

Artificial controls................................................... 224

Field equipment.................................................. $\quad 226$

Winter records............................................... 227

Motorcycles and automobiles................................. 228

Studies of effect of variable slope on discharge................. 232

Integrators ...................................................... 233

Refinement in office methods................................. 234

Annual reports............................................... 235

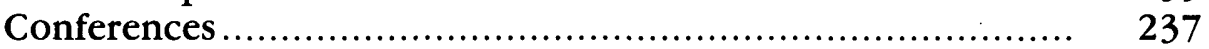

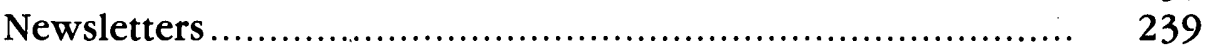

Special investigations............................................. 240

Public Health Service, Ohio River.................................. 240

Tides in Golden Gate............................................ 241

Summary of district operations................................... 242

New England District........................................... 242

Maine District.................................................... 243

New York District................................................ 243

Middle Atlantic States District.................................. 243

South Atlantic States District.................................... 244

Ohio River District......................................... 245

Illinois ....................................................... 245 
Part X-Maturing years (1913-19)

Summary of discrict operations-Continued

Upper Mississippi River District............................. 246

Upper Missouri River District............................... 247

Kansas District................................................ 247

Texas District................................................... 248

Rocky Mountain District.................................... 249

New Mexico District....................................... 250

Idaho District.......................................... $\quad 250$

Great Basin District.......................................... 252

Arizona ................................................ 254

Washington District...................................... 255

Oregon District............................................ $\quad 256$

California District........................................... 258

Alaska District................................................ 260

Hawaii District............................................. 262

Division of Ground Water........................................ 263

Quantitative investigations.................................. 263

Areal surveys.............................................. 266

Indian reservations......................................... 267

Desert watering places...................................... 267

Exploratory drilling......................................... $\quad 269$

War work.................................................... $\quad 270$

Division of Water Quality...................................... 271

Division of Water Utilization................................... 272

Division of Enlarged and Stock-Raising Homesteads........... 273

Division of Power Resources.................................... 275

War activities.................................................. 276

Evaluation of the years from 1913 to $1919 \ldots \ldots \ldots \ldots \ldots \ldots \ldots . . . . . . . . . . .277$

Name index................................................... 281 


\title{
Part I-Frederick Haynes Newell
}

\author{
Hydrographer-IN-Charge 1894-1902
}

Chief Hydrographer 1902-6

Each one sees his contemporaries and associates in a light that is somewhat different from that in which they are seen by others, because his mental pictures depend upon the reaction of their minds and personalities on his own mind and personality. To me, Frederick Haynes Newell was outstanding as a man of vision, as an organizer of personnel, and as an inspirer of those who were working with him.

F.H. Newell could see farther into the future than most men. He visualized the value of water in the development of a great Nation, and he initiated and developed systematic studies of its varying quantities, of its chemical qualities with relation to its utility in agriculture and industry, and of its availability for many uses and in all sections of the country. Working under the inspiring leadership of Major John Wesley Powell, he was definitely responsible, under the general direction of Captain Clarence E. Dutton, for organizing systematic work by the Federal Government in the study of water and in making available to the public the essential facts related to the utility of water. With little to guide him, he operated an experimental camp in 1888 at Embudo, N. Mex., on the Rio Grande, for studying methods of gaging streams and for training a small group of engineers. From this small beginning, he gradually built up a system of work and an organization of engineers, inadequately trained as we would think today but loyal and devoted to the task of recording streamflow. Methods and instruments were improved with experience, and personnel were added as funds became available.

Edited for publication by Sandra L. Holmes.
It was the enthusiasm of F.H. Newell that kept the work going during the trying early days of inadequate funds and of professional opposition. Many engineers were originally opposed to the conduct of such work by the Federal Government, in the belief that the field should be left to engineers in private practice. They soon realized, however, the great value to the profession of systematic records and the utter impossibility of collecting such records by any other than governmental agencies. It was due to the foresight of F.H. Newell that the work, originally limited to the collection of records of river discharge, was expanded into the fields of underground water and chemical quality of water. By 1907, when he became Director of the Reclamation Service and severed formal connections with the U.S. Geological Survey (USGS), he had put the water-resources work on a stable and recognized basis of continuity and utility.

Between 1902 and 1907, as chief engineer of the newly established Reclamation Service, he had devoted much of his energies to that organization and to the problems of irrigation. The Reclamation Service and its accomplishments became F.H. Newell's enduring monument. His personality and characteristics, however, were conspicuous in both organizations, but they doubtless became more apparent in the Reclamation Service because it was in that organization that he did his major work.

F.H. Newell, as I knew him, was outstanding also in his sense of relative values; he was was not troubled by details but devoted his energies to the important objectives. He was not and probably never could have been a designer of details, but he was preeminently 
an organizer and user of men for the accomplishment of definite major purposes. He was outstanding in his ability to select men, to organize them into groups for the accomplishment of specific purposes, and to inspire them with that spirit of loyalty and accomplishment that gives life to an organization. He was outstanding as a man of democratic ways, of sympathy for his fellows, of consideration for the difficulties of his co-workers, and of absolute loyalty to his work and to all those associated with him in its accomplishment. He was, therefore, a conspicuous example of the best type of engineer-an engineer of men. 


\section{Part II-Prologue}

The beginnings of systematic studies of the water resources of the country and, therefore, the antecedents of the Water Resources Branch of the USGS are now (1938) 50 years old. The men who were active during the development of the early organization that later became the Water Resources Branch as we now know it and were responsible for the initiation of the investigations have either already passed from the stage or are approaching the age of retirement.

A history of the Water Resources Branch is interesting from several points of view, especially to those of us who have been a part of it. It presents the struggle to reach into the unknown and, by the development of methods and instruments as well as by the training of personnel, to create a new art and a new science, the slow progress of which those who come later and who have had no similar experience will perhaps marvel at. It presents many human characteristics, both inspiring and amusing, disclosed in the personal attributes and characteristics of men in their struggles against difficulties of many kinds to produce worthwhile results.

History does not write itself. Unless events are recorded, knowledge of them is soon lost. Many facts may be contained in official reports, but many more are contained in official or personal correspondence and still more are retained only in the memories of men. The personnel of any organization changes as years go by, files are destroyed or lost, and, unless positive effort is made, the time when the preparation of a history is possible soon passes.

I have therefore asked Robert Follansbee to undertake the task of writing a history of the Water Resources Branch while there is yet an opportunity to review correspondence contained largely in personal files and to converse with the men who were active in the initiation of water-resources investigations. He has accepted this task with pleasure and during the last 5 years has contributed many hours, days, weeks, and even months of his personal time to its preparation. He has conversed and corresponded with many of the men who were most intimately connected with the pioneer work in water-resources investigations. He has been especially fortunate in having had the active help of Frederick Haynes Newell, George Otis Smith, Arthur P. Davis, E.C. Murphy, Cyrus C. Babb, E.G. Paul, Maxie R. Hall, F.W. Hanna, Marshall Ora Leighton, John Clayton Hoyt, Herman Stabler, and others who were most active in the early years of the Branch. Follansbee joined the Branch in 1904 and has therefore a background of more than 30 years in his own right. He has been given the privilege of reviewing personal correspondence files. He has studied official files and reports, both Federal and State, and by many means and from many sources has brought together the essential facts of this history. Much that would be of interest may have been lost, but enough has remained to give a clear and reasonably complete picture of this great development. Follansbee has deliberately included many anecdotes of men and their actions, realizing that history is a record of human activities and accomplishments. He has therefore endeavored to present sufficient information relative to persons and their characteristics to make the whole record interesting, instructive, and, I believe, valuable.

In connection with and as an essential part of this history, Follansbee has compiled the outstanding facts related to the development of the science and art of measuring the flow of water in open channels throughout the world. Such compilation has been necessary in order to disclose the base from which the Survey hydrographers departed in their development of methods, instruments, and equipment; it is essential to the history because it shows the relation of the work of the Branch to other earlier work by many brilliant scholars; it 
emphasizes the slowness and difficulties of progress in a new field of endeavor; and, finally, it gives credit where credit is due. The presentation of information relative to early work in the measurement of flowing water in other countries increases also the value of the history by showing something of its background in a worldwide setting.

This history seems to me to be quite worth while as a record of progress in investigational work; as an account of a step in exploring the quantity, quality, and availability of waterthe world's most valuable mineral; as an indication of the inevitable slowness in making progress along new and untried lines of work; as a record of growth of public interest in facts relating to water and of public appreciation of the necessity for reliable information as a basis for sound national and local development; as an inspiration to greater endeavor in our daily tasks; and as an indicator of the debt we owe to those who blazed the trails that were at first followed with much difficulty and that have become the broad highways along which we now travel with ease.

Follansbee has, I believe, done a good job. Thanks are due to him and to the many men who have given freely of their information and time and thus have made the accomplishment of his task possible with results that are so satisfactory.

-Nathan C. Grover 


\section{Part III-Predecessor Surveys}

\section{INTRODUCTION}

At the close of the War Between the States in 1865, perhaps 2 million men, from both the North and the South, had an outlook on life that was far different from their outlook before they engaged in that gigantic struggle. The southerners, with much of their property gone, were anxious to seek new fields and make fresh starts in life. The northerners had seen enough of other parts of the country than that in which they had been reared to bring a spirit of unrest. Both southerners and northerners had the love of adventure that had been inherited from their common ancestors and, like the colonists of the 17 th century, they sought new lands in the direction of the setting sun. The aspiration of many of those who had taken part in the war was well expressed in a song of those days that contained the line "For Uncle Sam is rich enough to give us all a farm." Thus, the thoughts of many men turned toward that Eldorado far beyond the Mississippi River known as the Golden West. It would perhaps be more strictly true to say again turned westward because the movement to the far western part of the United States, which had really begun in the 1840's and continued through the 1850 's, had been interrupted by the war.

Prior to "America's Tragedy"- the War Between the States-the Federal Government, acting through the War Department, had made many exploratory surveys of the West, of which perhaps the most generally known were the Lewis and Clark explorations of 1804-6 and the Pike expedition of 1806-7. After the war, the Federal Government resumed its interest in the exploration of the West, but with the difference that whereas the earlier work had been directed by Army officers as a prerequisite to anticipated military operations and assisted by a few scientific civilian assistants, the post-war expeditions were directed largely by civilians, thus marking a deliberate departure from the earlier practice. Of the four surveys authorized within the first decade after the close of the war, two were entrusted to the Department of the Interior (DOI) and two to the War Department, of which one was conducted by a civilian and one was organized as a regular War Department expedition under Army officers. These post-war expeditions, or surveys as they should more properly be called, differed from the pre-war endeavors in the respect that they were more scientific in character and their members actually mapped topographically the regions studied. Two of the three surveys directed by civilians were created through the personal efforts of men who had lived in the West and who had developed that spirit of rugged individualism normal to the frontier. Because these four post-war surveysKing, Hayden, Powell, and Wheeler-led to the organization of the USGS, they constitute a proper and essential setting for the beginning of this history.

\section{KING SURveY}

The King Survey was brought about by the personal efforts of Clarence King, a young enthusiast in geology. In 1866, after several years as a volunteer assistant with the Geological Survey of California, King conceived the idea of connecting the geology of the East with that of the West by means of a geologic and topographic survey across the Cordilleran system at its widest part. At that time, there was no authentic map showing the topography continuously from California to the Great Plains (Clarence King, 1870-80, Report of the geological exploration of the 40th parallel, U.S. Army Prof. Paper 18, 7 vols., 1 atlas). He felt that the time was opportune for presenting his project to the Congress: Its leaders were directing their energies toward binding together the various parts of the country after the war, especially 
toward bringing California more intimately into national affairs because, during the war, there had been considerable apprehension lest that isolated State break away and set up an independent government. To this end, the subsidizing of the Union Pacific and Central Pacific railroads was one of the first steps taken by the Congress. It was believed, however, that national unity would be strengthened if the characteristics of the intermediate region were known in order that its natural resources, especially its mineral wealth, might be developed. This could be brought about by scientific exploration only.

Thus was the stage already set when Clarence King, a young man of 25 years, appeared on the scene in winter 1866-67, armed, as Samuel F. Emmons expressed it (Clarence King, Nat. Acad. Sci. Biogr. Memoirs, vol. 6, p. 27-55, 1909), with only a few letters of introduction from his old college professors and friends in California. By his winning personality, as well as the merits of his project, he enlisted the support not only of leaders in the Congress, including the senators from California, but also of General Andrew A. Humphreys, then Chief of Engineers, who, fortunately for Clarence King, was much interested in scientific exploration.

It was much easier then to obtain legislation that involved no direct appropriation. A.A. Humphreys made possible the diversion to the proposed survey of an unexpended balance of appropriations previously made for the survey of a military road across the continent. Accordingly, on March 2, 1867, the Congress authorized the geological exploration of the 40th parallel by the following Act (14 Stat. L., 457):

And be it further enacted, That the Secretary of War is hereby authorized to direct a geological and topographical exploration of the territory between the Rocky Mountains and the Sierra Nevada Mountains, including the route or routes of the Pacific Railroad: Provided, That the same can be done out of existing appropriations.

Clarence King was placed in charge of this survey with the title of United States Geologist. Although A.A. Humphreys was its sponsor and its finances were obtained from the War Department, it differed from previous War Department explorations in the important respect that it was conducted by a civilian with civilian assistants. The only military aspect of the Survey was the Army escort of about 20 soldiers and noncommissioned officers needed for protection in a region occupied by Indians. A.A. Humphreys' instructions to Clarence King required that he examine and describe the geological structures, geographical conditions, and natural resources of a belt of country extending from the 120th meridian eastward to the 105th meridian along the 40th parallel with sufficient expanse north and south to include the line of the Central and Union Pacific railroads, and as much more as could be done with accuracy and proper progress. Clarence King was also instructed to collect material for detailed maps of the chief mining districts, coal fields, salt basins, et cetera, as well as for a topographic map of the region traversed, and to conduct systematic observations of barometric and thermometric changes with constant study of the atmospheric conditions bearing upon the subjects of refraction and evaporation (ann. rept., Chief of engineers, app. V, p. 866, 1867-68). The first problems to be settled related to the method of mapping that formed the basis of the geologic work. This method was described by Clarence King in Appendix Z, page 1028 (1871-72), as follows:

The foundation of our explorations has been a continuous system of triangulation carried from mountain top to mountain top, over the whole extent of our work by the theodolite observations, upon stone monuments. These triangles have been located geographically, and their distances computed from a base and check base, and a system of astronomical stations. Within the primary triangles, a large number of secondary triangles were located, and from these, always working inwardly, a thorough system of minor triangles have been measured and the topography filled in by compass and gradienter, basing the system upon 300-foot grade curves (contours) located approximately by the barometer.

The scale of the maps was 4 miles to the inch.

The field work was started on July 27,1867 , with a force of 11 professional men, consisting of four geologists including Clarence King, four 
topographers, one botanist, one zoologist, and one photographer. In addition to the military escort of 20 men, there were the teamsters, cooks, laborers, et cetera, necessary for the camp equipage, transportation, and subsistence, and last, but by no means least, medical attendants.

The field work was discontinued on December 15, 1867, and resumed the following April for the open season of 1868 , and similarly for the open season of 1869 , when the 3 -year period originally contemplated came to an end. The work outlined was not completed, however, and without Clarence King's solicitation or prior knowledge, the Congress made an appropriation to continue the work for 3 more years (biographical sketch of Clarence King in USGS 23rd ann. rept., p. 202, 1902). Field work was accordingly resumed in 1870 and continued during the open seasons until November 13, 1872, when the regular field work was completed. During most of those 6 years, 1867-72, the field work was conducted by three parties led by Clarence King, Arnold Hague, and Samuel F. Emmons, all geologists.

In 1873, Clarence King alone conducted a field geological review of Archaean formations as well as a classification of the important mining districts visited. Until the final closing of the King Survey early in 1879, King was engaged in the preparation of the reports that were published as Professional Paper 18 of the Engineer Department, U.S. Army, in seven volumes under the titles of (1) Systematic geology, (2) Descriptive geology, (3) Mining industry, (4) Ornithology and Paleontology, (5) Botany, (6) Microscopical petrography, and (7) Odontornithe. The last volume, published in 1880 , was not really a report of the King Survey because its author, Othniel C. Marsh of Yale University, had not been a member of the Clarence King Survey team; the volume had apparently been financed by other War Department funds. Marsh stated (Geol. exploration of the 40th parallel: U.S. Army Prof. Paper 18, vol. 7 , p. xiii, 1880) that his report was the result of 10 years' investigation in the field, during which time he "had the continued assistance of Generals William Tecumseh
Sherman and Philip Henry Sheridan and many other Army officers in regions made dangerous by hostile Indians."

The publication of the Marsh report in the series of those of the King Survey was due to Clarence King's donation, for that purpose, of the balance of funds unspent at the close of his own work. At the conclusion of the work, the many collections in mineralogy, paleontology, and other branches of natural history were deposited in the Smithsonian Institution in Washington, D.C. The original field and manuscript records remained in the files of the Chief of Engineers.

The total appropriation for the King Survey until the close of field work in 1872 was $\$ 386,711$ (45th Cong., 3d sess., H. Misc. Docs., vol. 1 , no. 5 , p. 22 ), which did not include the funds necessary to complete the office work. The total direct cost of the King Survey and the resulting reports was, therefore, probably about $\$ 400,000$. There were other costs of unknown magnitude, such as those of the military escorts, that are not included in these figures.

In describing the work of his Survey, Clarence King said (USGS first ann. rept., p. 4, 1880) that geology was the sole object of the Survey (Clarence King felt so strongly about the importance of geology that, in this statement, he ignored the fact that he also made barometric and other observations in accordance with his instructions), and that 1867 marked the turning point in national geologic work when that science ceased to be dragged in the dust of rapid exploration and took a commanding position in the professional work of the country. For the first time, a government geologist was in independent command, able to guide the researches of competent professional assistants. Geology had been tolerated as a hindrance rather than an aid by the leaders of previous explorations charged with definite missions and had thus been made a sort of camp follower. In summing up his work, Clarence King said (Geol. exploration of the 40th parallel, vol. 1, p. 4):

Readers are recommended to bear in mind that this is not a geological survey but a rapid exploration of a very great area in which literally nothing but a 
few isolated details was before known. Unmapped, unstudied, it was terra incognita; and if in our difficult and arduous campaign we have done no more than outline the broader features of the geology, we have at least accomplished that, and have laid the foundation for those future slow and detailed surveys which we hope are sure to follow our pioneering labors.

\section{HAyden SURveY}

The Hayden Survey had the distinction of being the first government exploration of the West authorized to be made wholly by civilians under a civil branch of the government. Nebraska was granted statehood in 1867. In the general legislative act approved March 2, 1867, the act that authorized the King Survey, was the following paragraph (14 Stat. L., 471, sec. 2):

\begin{abstract}
And be it further enacted, That the unexpended balance $(\$ 5,000)$ of the appropriations heretofore made for defraying the expenses of the legislative assembly of the Territory of Nebraska is hereby diverted and set aside for the purpose of procuring a geological survey of Nebraska, said survey to be prosecuted under the direction of the commissioner of the General Land Office.
\end{abstract}

Dr. Ferdinand Vandiveer Hayden, a graduate of Albany Medical College, had become interested in geology during his college years. While exploring for fossils in the great region then generally known as Nebraska (it included not only the present State of Nebraska but also parts of adjacent territory), Hayden became so interested in the region that he determined to devote himself to the exploration of its geography and geology. During this work, undertaken first in the middle 1850's, he traveled at times with parties of the American Fur Company on their annual trips within that region (F.V. Hayden, Nat. Acad. Sci. Biogr. Memoirs, vol. 3, p. 395-413). Because of his investigations, Hayden was called on to serve as geologist and physician for the Warren and Raynolds explorations of the War Department, the first made in 1857 and the second in 1859 , under authority of the Congress (of several expeditions to the West sent out by the War Department, they had no direct connection with the predecessor surveys).

At the close of the War Between the States, Hayden, who had served as surgeon in the Army, was appointed professor of geology at the University of Pennsylvania. His chief interest continued to be in the exploration of the West, and his hope of resuming it lay in obtaining governmental aid for that purpose (W.H. Jackson, Hayden Survey photographer, oral commun., ca. 1938). Hayden's natural diffidence, which characterized his early years, prevented him from putting himself forward, but, fortunately, his work in Nebraska Territory was known by the Secretary of the Smithsonian Institution who recommended him for the new survey that was authorized when Nebraska was admitted to statehood (G.P. Merrill, The first one hundred years of American geology, p. 715, Yale University Press, New Haven, 1924). That official succeeded in having Hayden put in charge.

Accordingly, Hayden, with one geological assistant, Professor Fielding B. Meek who had previously been associated with him, proceeded to conduct a geological investigation of Nebraska. Following the general practice of those times, Hayden was authorized to purchase subsistence stores from the Army. The Nebraska investigation, which should not be considered a survey but rather a geologic reconnaissance because it was not based on a topographic survey, was completed during the first year (1867). Of the $\$ 5,000$ appropriated, $\$ 2,000$ went to Hayden for his salary, $\$ 1,000$ to Meek, $\$ 700$ to collectors and laborers, $\$ 300$ to chemistry, and $\$ 1,000$ to general expenses (Merrill, p. 509).

The next year, Hayden was given an additional $\$ 5,000$ and directed to extend his geologic explorations to Wyoming. In Cheyenne, Hayden organized a party of nine and conducted investigations in Wyoming territory during summer 1868 , similar to those conducted in Nebraska in 1867.

To show that disbursing officers were as slow in the 1860's as in more recent times and had the same lamentable effects on field men, it is only necessary to quote the following, written by Hayden on September 25, 1868 (U.S. Geol. Survey Terr., p. 88, 1868): 
No draft has yet come to me from the U.S. Treasury up to this date. I have borrowed money from the bank at 12 percent discount and drawn on my friends until I am very much embarrassed.

The report of the year's work, like the one for the previous year, was made to the Commissioner of the General Land Office.

In 1869, the Congress increased the appropriation to $\$ 10,000$ and put the Hayden Survey under the Secretary of the Interior who instructed Hayden to pay especial attention in that year to the geological, mineralogical, and agricultural resources of Colorado and New Mexico. With the enlarged appropriation, Hayden organized a party of 11 including, besides himself, a managing director, a mining engineer, an entomologist and botanist, and an artist. The greater part of the outfit was furnished by the quartermaster's department of the Army, and supplies were obtained from military posts en route (U.S. Geog. Surveys west of the 100th meridian, vol. 1, p. 700,1889 ). The work in 1869 may be considered to be the real beginning of the Hayden Survey, the work of the previous seasons having been little more than reconnaissance. The appropriation was increased to $\$ 25,000$ in 1870 , and Hayden increased the party to 20 , adding a naturalist, a meteorologist, and a geologist. In that year (1870), their activities were in Wyoming.

By this time, Hayden realized both the magnitude of the task involved in conducting a geological survey and the need for adequate maps. Accordingly, in spring 1871, he laid before the House Committee on Appropriations a plan for the geological and geographical exploration of the territories of the United States. This plan contemplated the gradual preparation of a series of geographical and geological maps on a uniform scale embracing each of the territories. It met with Congressional favor and his appropriation for that year was increased to $\$ 40,000$. The name of the Survey was then changed from the U.S. Geological Survey of the Territories to the U.S. Geological and Geographical Survey of the Territories because of its new mapping feature. With the augmented resources, Hayden conducted topographic mapping in connection with the geological investigations. The plan adopted, according to George M. Wheeler (U.S. Geog. Surveys west of the 100th meridian, vol. 1, p. 701,1889 ), was that of a topographic reconnaissance of the immediate line of march and of the country in sight from it, controlled by compass courses and odometer-measured distances, all to be checked by sextant latitudes.

The size of the party was 36 , including for the first time two topographers and other investigators with additional expertise. An escort of soldiers accompanied the party. The work was conducted in Montana and in Yellowstone Park. One important result of that season's work was the creation of Yellowstone National Park. A.C. Peale, an associate, stated that the idea originated with Hayden and that the law creating the park was written in great part by him, and its passage was due largely to his personal efforts (Merrill, p. 514).

Hayden's years spent in the West had dissipated his natural diffidence. He became so frank, forceful, and direct that he had the western people heartily and unanimously supporting him and was able to obtain larger appropriations for his work. He was greatly aided by the personal friendship of some of the highest officials of the government who never failed to support his surveys strenuously and successfully (Merrill, p. 526).

Thus Hayden obtained in 1872 a fourth successive increase in his appropriation, this time to $\$ 75,000$. During the remaining life of the Hayden Survey, the annual appropriation remained at that amount, except for 1876 when it was reduced to $\$ 65,000$. The great increase in the work in 1872 made it necessary for Hayden to resign his professorship in geology at the University of Pennsylvania (Merrill, p. 525).

With $\$ 75,000$ at his disposal in 1872 , Hayden organized two complete parties for work in the region of the headwaters of the Snake and Missouri Rivers. Hayden was in charge of one party and James Stevenson, his principal assistant, the other. The topographic mapping was strengthened by the addition of a system of triangulation.

As a result of the work in 1872, Hayden became convinced of the necessity for improving his topographic methods and obtained the services of James T. Gardner for the 1873 season. 
Gardner had been chief topographer of the King Survey, the field work for which had closed the previous year. About this addition to his personnel, Hayden wrote (U.S. Geol. and Geog. Surveys Terr., p. 10, 1872):

To render the organization more perfect so far as the topographical portion is concerned, J.T. Gardner, so long favorably known as the chief topographer of the King Survey, had become associated with me as chief of the topographical staff. Mr. Gardner thus expresses his conception of a true topographical map for geological purposes. 'It is necessary to carry over the country a systematic trigonometric and topographic survey checked by astronomical observations.' The work of the survey as contemplated by the present organization demands the very highest order of talent.

A base line between 6 and 7 miles long was carefully measured, chiefly along the tracks of the Kansas Pacific railroad near Denver, Colo. (U.S. Geol. and Geog. Surveys Terr., p. 7, 1874). From this base line, a system of triangulation covering the entire area surveyed was gradually expanded during the ensuing years. Thus, a triangulation net now superseded the route-reconnaissance method previously used. Latitude and longitude were determined astronomically by personnel of the U.S. Coast and Geodetic Survey (CGS).

Because of the hostility of the Indians in the Northwest, work in that region was temporarily discontinued in 1873, and activities were shifted to Colorado where they were continued until the end of 1876. During those years, the work was conducted by three parties. So thoroughly had Hayden been converted to a belief in adequate topographic maps that a topographer with a geologist as (possibly) principal assistant were generally placed in charge of the parties.

The Colorado work having been completed, the activities during the remaining 2 years of the Hayden Survey's existence were transferred to Wyoming and Idaho, beginning at the northern boundary of the King Survey. That the Indians were still a factor with whom to be reckoned is indicated by the fact that one party was robbed of its animals and a portion of its outfit, and at least half of the most valuable time for one season's work was lost.

The total appropriation for the Hayden Survey from its crude beginnings in 1867 to its close in 1879 was $\$ 690,000$. In addition, a small appropriation was made for the completion of the office work; there were doubtless other costs, such as those for the military escort, that are not included in the total shown (45th Cong., 3d sess., H. Misc. Doc., vol. 1, no. 5 , p. 22). The personnel, including camp assistants, increased from 10 in 1867 to 62 in 1878 (W.H. Jackson, oral commun., ca. 1938). The total area covered was 107,000 square miles. Of the territorial maps to be published as a result of the enlarged program, only that of Colorado had been completed by Hayden before the end of his survey, and only the map for that State (its status was changed from territory to State in 1876) was published at a scale of 4 miles to the inch with a 200-foot contour interval. A strip 36 miles wide along the northern part of the State, which was surveyed by Clarence King, and a strip 25 miles wide along the eastern border of the State, which was surveyed by General Land Office personnel, were used in completing the Colorado map.

Unlike the leaders of the other predecessor surveys who published reports by subject and frequently years after the field work had been completed, Hayden published 11 annual reports, each covering a season's work. He worked to make these reports available to the Congress at the earliest possible date. Immediately following the close of each field season, the scientific staff would gather in their winter quarters in Washington, D.C., in an office building on the site now [1938] occupied by the Washington Star newspaper to prepare reports on that field-season's work. [Ed. note: The Star ceased publication in 1981; the site is now (1991) occupied by the Washington Times newspaper.] Subsistence was not furnished to members of the Hayden Survey while they were on assignment in Washington, D.C., and some members of the party slept on cots in the office (W.H. Jackson, oral commun., ca. 1938).

When the Hayden Survey was abolished in 1879, much material still remained 
unpublished. Hayden was appointed geologist in the USGS in order to prepare this material for publication, and a special appropriation was made for that purpose. In 1882, when that fund was exhausted, five volumes of the geologic report remained uncompleted. At Hayden's request, the Secretary of the Interior committed, to the Director of the USGS, to the publication of those volumes (U.S. Geol. and Geog. Surveys Terr., 1878, pt. 1, p. 18, 1883). (The unpublished data on natural history were not inherited by the USGS.) In closing the work of his Survey, Hayden wrote (U.S. Geol. and Geog. Surveys Terr., 1878, pt. 1, p. 18, 1883):

The Survey does not claim that its work is absolutely accurate in detail but rather preliminary to the more thorough study which is to come in the future.

\section{Powell Survey}

The initiation of the Powell Survey, like that of the King Survey, was the result of the personal efforts of one man-Major John Wesley Powell who was destined to be one of the prime movers in the creation of the present USGS and its second director.

In 1867, Major Powell, a veteran of the War Between the States, was appointed professor of geology and natural history at the State Normal University of Illinois, an institution created largely through his efforts. With an annual allotment of $\$ 1,000$ for increasing the geological and zoological collections and supplemented by a part of his own $\$ 1,500$ salary, Powell made a trip to Colorado in summer 1867 with volunteer assistants, chiefly students. He was in Colorado again in 1868 with the same financial backing to which was added a small allotment from the Illinois Industrial State University (IISU), the predecessor of the University of Illinois.

Most of his party returned east in fall 1868 , but Powell and several hunters and trappers crossed the range to White River and spent the winter near a camp of Ute Indians. He then returned to Illinois and obtained permission to again divert his salary and other funds to the western work. The IISU allotted him $\$ 500$ and the Chicago Academy of Sciences contributed either $\$ 250$ or $\$ 500$. Small additional amounts were contributed by personal friends. In the explorations of 1869 , the proposal was that collections in natural history were to be shared with the contributing institutions. Powell had in mind, however, the examination of the geology of the courses of the canyons of the Green and Colorado Rivers involving the solution of the greatest remaining geographical problem in the United States (biographical sketch of John Wesley Powell in USGS 24th ann. rept., p. 275-276, 1903). The descent of these rivers was made that year. Although Powell succeeded in traversing the combined waterway from Green River, Wyo., to the mouth of the Virgin River, a distance of 1,000 miles, much of his equipment was lost and the effort was only partially successful from a scientific viewpoint.

Although Powell did not actually explore the Colorado River until 1869, he was considering it in spring 1868 as shown by the fact that on June 11, 1868, the Congress passed a joint resolution authorizing the Secretary of War "to issue rations for 25 men of the expedition engaged in the exploration of the Colorado River under the direction of Professor Powell" (40th Cong., 2d sess., J. Res. 34, p. 253, June 11, 1868); during Powell's Colorado River work, subsistence was furnished under that resolution (43d Cong., 1st sess., H.R. Misc. Doc. 265, p. 27, May 2, 1874).

Realizing that a successful exploration of the Colorado River required greater resources than had previously been at his command, Powell appealed for aid to his associates of the war days who were then in the Congress and, in July 1870 , the Congress appropriated $\$ 12,000$ for his use in exploring the Colorado River (16 Stat. L. 242). With this fund, he continued his explorations, devoting the energies of his party (himself as geologist, one geographer, two topographers, and five camp assistants) to an area in northern Arizona and southern Nevada.

The next year Powell addressed a letter to the Secretary of the Interior requesting an appropriation of $\$ 12,000$ for exploring the valley of the Green River, the most accessible approach to the Colorado River. This appropriation was made (16 Stat. L. 503) on March 3, 
1871 , its stated purpose being "for continuing the Survey of the Colorado of the West and its tributaries by Professor Powell, under the direction of the Smithsonian Institution."

Although the Powell Survey was thus placed under the direction of the Smithsonian Institution without its solicitation, the Smithsonian gave attention to the plans and execution of the work ( $43 \mathrm{~d}$ Cong., 1st sess., H.R. Misc. Doc. 265, p. 1, May 2, 1874). It may be assumed, however, that Powell was given free reign in planning and conducting his field work. On May 22, 1871, the party of 2 geologists, 4 topographers, 2 photographers, and 17 camp assistants left Green River, Wyo., on Powell's second voyage down the river, and reached Lees Ferry in northern Arizona in October. The winter was spent in surveying 12,000 square miles in Utah and Arizona. The appropriation for 1872 was increased to $\$ 20,000$. The descent of the Colorado was resumed in August of that year, but the water was so high that, on reaching the mouth of Kanab Creek, it was decided to suspend the river work. Topographic, geologic, and geodetic work was continued in the region, and 8,000 square miles adjacent to the Grand Canyon, chiefly in the Henry Mountains, were surveyed.

In transmitting to the Congress a progress report of the Powell Survey, the Secretary of the Smithsonian Institution stated in 1873 (42d Cong., 3d sess., H.R. Misc. Doc. 76, p. 12, Jan. 31, 1873):

In view of the results obtained at a comparatively moderate expense, I would respectfully commend the application of Prof. Powell for a renewed appropriation for continuing his exploration and surveys.

The professor has furnished a minute account of his method of carrying on the topographical survey, from a critical examination of which I am convinced the work has been done as well as the amount of the appropriation would permit, and the wants of the country at present require. The work is much more than a mere exploration, since it is founded on a system of triangulation on a base line of nine miles accurately measured.
In this progress report, Powell stated that the base line in the valley of the Kanab was about 49,000 feet long and was measured by using wooden rods leveled on trestles. From this base, a system of triangulation was expanded to cover the area surveyed, including secondary triangulation points for topographic sketching. The emphasis placed by Powell on the topographic mapping is indicated in that four topographers were employed for every one or two geologists.

The appropriation for 1873 was reduced to $\$ 10,000$ and was made for the purpose of completing the report (the Congress evidently understood that the survey of the Colorado River should be about completed by that time). With the lesser funds available, Powell's party that year consisted, besides himself, of a geologist, a geographer, two topographers, four general assistants, and several temporary helpers. The area covered was 6,000 square miles in southern Utah and northern Arizona.

In May 1874, Powell presented to the Congress, through the Secretary of the Smithsonian Institution, the results of his work during the previous season, which completed the field work on the Colorado River. In describing the area covered, he stated (43 Cong., 1st sess., H.R. Misc. Doc. 265, p. 27, May 2, 1874):

The territory as a whole presents more obstacles to the explorer than any other portion of the United States, as it is traversed by deep gorges and set with long lines of cliffs, in many places forming impassable barriers to travel; much of the country is also arid and destitute of vegetation.

Powell also suggested the propriety of a further appropriation for 1 year to enable him to connect his surveys with those of Clarence King on the north and Hayden on the east. His plea was successful and an appropriation of $\$ 15,000$ was made and the title of "Geographical and Geological Survey of the Rocky Mountain Region" was given to the Powell Survey in recognition of the expansion of his field of activities. The stress laid on the topographic work apparently accounted for Geographical preceding Geological in the title. So, the 1 year of work originally suggested by Powell (1874) stretched into 5 years: the 
Congress appropriated $\$ 25,000$ for 1875 , $\$ 30,000$ for $1876, \$ 50,000$ for 1877 , and $\$ 50,000$ for 1878 , the last year of the Powell Survey. Beginning with 1874 , the appropriations were expended under the Secretary of the Interior, following the precedent set for the Hayden Survey, and the Smithsonian Institution was no longer directly involved with the Powell Survey.

In 1874 , the technical personnel consisted of two geologists, one geographer, and four topographers, and an area of 15,000 square miles was surveyed in Wyoming, Utah, and Arizona. The increased appropriation in $\mathbf{1 8 7 5}$ permitted an increase in personnel to four geologists. Two of these later filled important roles in the present-day USGS: Grove Karl Gilbert, who had formerly been the geologist for the Wheeler Survey came to the Powell Survey in that year, and Captain Clarence E. Dutton, an officer in the Ordnance Corps with a love for and a knowledge of geology, was assigned by the War Department to Powell's work. Both geologists remained with Powell until his survey was superseded in 1879 by the present-day USGS. In 1876 , the number of topographers was increased to seven. In that year, the name of Almon $\mathrm{H}$. Thompson, who also subsequently played an important part in the USGS and who had been the geographer since 1870, was missing from Powell's personnel list. During the years 1874 to 1878 , about 10,000 square miles was surveyed each year, almost wholly within the Colorado River basin.

Just as Powell's interest in the Indian caused him to include ethnology in his activities, so his interest in the West and his broad vision in foreseeeing the reclamation of the "Great American Desert" led him to include a classification of the public lands for determining the extent and location of the irrigable, timber, mineral, and waste lands. In reporting on the arid lands, he suggested conditions for making them available for agriculture and grazing. He included also a statement on rainfall in the West, and reports on irrigation.

The area covered by the Powell Survey during the years $1867-78$ was 67,000 square miles (U.S. Geog. Surveys west of the 100th meridian, vol. 1, p. 713,1889$)$. The total
Federal appropriation for his work from 1870 to 1878 was $\$ 224,000$. The amount of funds contributed by scientific institutions prior to 1870 is unknown, but the fact that Powell went to the Congress for sufficient funds to conduct his work adequately indicates that any such amount must have been small. In addition to the Federal funds that were appropriated for field work, the Act of March 3, 1879, that created the USGS carried an item for $\$ 20,000$ to be used by the new organization in completing the reports of the Powell Survey.

The results of the Powell Survey were published in eight volumes, the first of which described the exploration of the Colorado River. Of the remaining seven volumes, one dealt with the arid lands and six with the geology of the area covered. These volumes were issued at intervals between 1875 and 1880 . When the Powell Survey was superseded by the USGS, all material (except that on ethnology, which was turned over to the Smithsonian Institution) was deposited with the USGS (letter from Major Powell to Senator Allison in U.S. Geog. Surveys west of the 100th meridian, vol. 1, p. 717-718).

\section{WheEler Survey}

Early in 1871, the War Department resumed its work of exploring the West, which had been interrupted by the War Between the States. As stated by Wheeler (U.S. Geog. Surveys west of 100th meridian, vol. 1, app. H, p. 761, 1889), the origin of his survey was the outgrowth of a legitimate need by the War Department for topographic maps of the vast area west of the Mississippi River within which military movements were constantly required. The survey was considered to be a continuation of the disconnected topographic work that the War Department had begun for special reasons before the war. The region designated for the work was the area west of the 100th meridian, an arbitrary line, and the survey was known, therefore, as the "U.S. Geographical Surveys West of the 100th Meridian."

Wheeler, an engineer officer who was put in charge of the survey, had been previously 
instructed to prepare himself for surveys and explorations in the interior as a general duty to be conducted as circumstances permitted. Although the Wheeler Survey was limited to the region west of the 100th meridian, it was hoped that eventually a complete and connected topographic survey of the whole United States would be made (U.S. Geog. Surveys west of the 100th meridian, vol. 1, app. H, p. 763,1889 ). The Wheeler plan was therefore, more ambitious than that of Hayden who contemplated only a survey of the western part of the country.

In his instructions for 1871 , Wheeler was directed to obtain correct topographical knowledge of the country south of the Central Pacific railroad in eastern Nevada and Arizona. He was to observe, so far as practical, everything relating to the physical features of the country, and also the number, habits, and dispositions of the Indians, and the facilities offered for building railroads or highways. In the following year, Wheeler was authorized to make a detailed topographic map of the entire region west of the 100 th meridian.

This was primarily a topographical survey, unlike the previous War Department explorations, and the most important problems related to the method to be used in making the maps. The problem presented, as Wheeler wrote (U.S. Geog. Surveys west of the 100th meridian, vol. 1 , app. $\mathrm{H}$, p. 331 et seq., 1889), was to prosecute rapidly the field work needed for accurate topographic maps that would be useful in military operations and administration over a vast area with a minimum expenditure of time and money. The problem was solved by a system of surveying designed to cover the entire West with sufficient accuracy to be shown on atlas sheets at a scale of 8 miles to the inch. Main astronomical stations were established on telegraph lines for ready comparison of time, and check belts of triangles were measured at intervals of 250 to 300 miles using the highest available grade of field astronomical instruments. Near each main station, a base line was laid out for use in checking and expanding the primary triangulation system, which consisted of triangles quadrilaterally connected with sides from 20 to 60 or 70 miles long, that covered the entire area. The field sheets were produced on a scale of 2 miles to the inch with a contour interval of 200 feet.

The personnel of the Wheeler Survey, in the order listed by Wheeler, consisted of officers both of the engineer corps and of the line, medical officers, those in charge of escorts, soldiers, and technical civilian assistants (U.S. Geog. Surveys west of the 100th meridian, vol. 1, app. H, p. 762, 1889). In the parties used during 1871, three engineer officers and one civilian were astronomical observers, seven civilians were geodetic and topographic assistants, and two privates and two civilians were barometric observers. After listing the topographic members of the party, Wheeler added 1 geological observer, 1 assistant geological observer, 1 zoological collector, 1 photographer, 2 surgeons, 8 clerks, guides, et cetera, 6 noncommissioned officers, 26 privates, packers, camp assistants, et cetera, making a party that must have numbered 70 or more.

The relatively minor part that geology played in the Wheeler Survey is obvious: of the 15 members engaged in different phases of mapping, only one geological observer and one geological assistant were employed. Of further significance is the fact that they were not called geologists but merely geological observers. Fortunately for the geological results obtained, the geological observer was Gilbert, who remained with the Wheeler Survey until 1875 when he became associated with the Powell Survey.

Wheeler has described his work in great detail, but as it was chiefly a geographic survey not merged with the USGS, it is sufficient for the purpose of this history to add that field work was conducted each year from 1871 to 1878 and covered 333,000 square miles in southern Colorado, New Mexico, Arizona, Utah, Nevada, and California.

The cost of the Wheeler Survey was $\$ 691,444.45$, exclusive of Army salaries $(\$ 85,129.11)$ and engraving and printing the maps $(\$ 87,080.14)$. The grand total was $\$ 863,653.70$ (U.S. Geog. Surveys west of the 100th meridian, vol. 1, app. H, p. 763, 1889).

The field work of the Wheeler Survey was terminated by the Act of March 3, 1879, which 
abolished the territorial surveys as of June 30 , 1879 , and created the USGS. As a result of this change, all records were deposited in the archives of the War Department, and nothing was turned over to the new USGS (U.S. Geog. Surveys west of the 100th meridian, vol. 1 , app. $H$, p. 726, 1889). The final results of the Wheeler Survey were published by the War Department in seven 'volumes. Seventyfive topographic atlas sheets, chiefly hachure maps, were also issued (USGS Bull. 222, p. 60-62, 1904).

In writing of his work, Wheeler showed plainly that it was primarily a topographic survey and that in his opinion the methods used were superior to those of other western surveys. He stated (U.S. Geog. Surveys west of the 100th meridian, vol. 1, p. 451, 1889) that the King, Hayden, and Powell Surveys were all controlled by the theoretical considerations of the geologist. His Survey, as he expressed it, "proceeded from the almost diametrically opposite standpoint" giving due weight to astronomic, geodetic, and topographic observations for the purpose of making maps showing all natural objects, means of communication, et cetera. The geologic and natural history phases of the survey were treated as incidental to the main purposes of producing reliable maps.

To show how strongly he felt on this subject as well as on the discontinuance of his survey, Wheeler's exact language is quoted (U.S. Geog. Surveys west of the 100th meridian, vol. 1, p. 451, 1889):

The latter [Wheeler Survey] may be considered as the only organized systematic general geographic and topographic work (both scientific and practical) ever begun by the General Government in the interior of the country. Geology in organic form was established in the Interior Department, but the vastly more important work of topography was disregarded and experienced Government engineer officers thus lost for this latter duty, resulting in a direct and positive step backward, without precedent throughout the civilized world.
Importance of Topographic MapPING IN Predecessor Surveys

As indicated in the foregoing brief descriptions of the activities of the predecessor surveys, the emphasis in the earlier surveys was placed on geologic work rather than topographic mapping, but much greater emphasis was placed on topographic mapping in the later surveys. In the 1860's, no mapping of large areas comparable with those areas covered by the predecessor surveys had been done and methods adapted to such work had not been developed. It apparently was not fully realized at the start that adequate presentation of geologic information required good topographic maps.

Hayden and Clarence King began their work in the same year (1867). Hayden had only $\$ 5,000$, which enabled him to make merely a geological reconnaissance. Clarence King was given sufficient funds and he was able to make adequate plans for his work from the start. Clarence King's experience in the California survey had demonstrated to his satisfaction the necessity for an accurate topographic map; in developing mapping methods, it appears probable that he had the advice of A.A. Humphreys, under whose direction he operated. As Hayden's appropriations were increased, he also developed a mapping program and his work lost its exploratory character and approached more nearly a real survey. But the methods he first used were unsatisfactory and when the opportunity arose, he obtained Clarence King's chief topographer. Powell's early surveys were undoubtedly of the reconnaissance type, but had greatly improved by 1873 and were based on a system of triangulation that was believed to be adequate. This improvement probably occurred in 1870 when the first Federal appropriation was made for the Powell Survey. Clarence King had then been conducting his work for 3 years, and knowledge of his methods was available to Powell.

Wheeler started his work in 1871 and prepared an elaborate system of triangulation controlled by astronomical stations; he was probably influenced by the methods of the CGS. 
His topographic expression, however, was not up to the standard set by his control system, probably because the engineer officers connected with his survey were chiefly interested in astronomical observations that required esoteric mathematical computations, which appealed to them as mathematicians and astronomers, and had not developed the technique of contour mapping. Wheeler also used the European system of hachures instead of contours in delineating the topography. As geology was a minor objective to Wheeler, the need for adequate topographic maps on a sufficiently large scale to be of real use was not appreciated and, as Powell stated after he became Director of the USGS, the mapping of the greater part of the area covered was on too small a scale and was too inaccurate to be used as a basis for geologic mapping. Thus it appears that to Clarence King, rather than to the other three surveyors, belongs the credit for initiating the methods of topographic mapping that were gradually developed into the present-day practice. 


\section{Part IV-Inception and Early Years of the Geological Survey}

\section{Events Leading to the Creation of the Geological Survey}

By 1874 , there were three separate surveys-Hayden, Powell, and Wheelerengaged in broadly similar work in the same general region being conducted by two separate Departments, War and Interior. The King Survey field work was completed in $\mathbf{1 8 7 2}$. The work in the three Surveys overlapped in many places. The rivalry became so intense that the influence of one party with the Congress was used to curtail the appropriations for the others, and there appeared to be grave danger that the Congress would cut off all government appropriations for work of this character (Clarence King, Nat. Acad. Sci. Biogr. Memoirs, vol. 6, p. 27-55, 1909).

The rivalry between the Powell and Hayden Surveys was particularly keen because they were very similar in character. There was also a conflict of interest between the Wheeler and Hayden Surveys because both had been authorized to prepare topographic maps of the western territories. Clarence King's influence with leading scientists and his tactful handling of the situation before the Congress averted the threatened cessation of the western surveys (biographical sketch of Clarence King in USGS 23d ann. rept., p. 203, 1902). As a result, the House of Representatives on April 15, 1874, passed the following resolution (43d Cong., 1st sess., H. Doc. 612):

Resolved, That the President of the United States be requested to inform the House what geographical and geological surveys, under different departments and branches of the Government, are operating in the same and contiguous areas of territory west of the Mississippi River, and whether it be not practicable to consolidate them under one department, or to define the geographical limits to be embraced by each.
In response to this inquiry, the War Department expressed the conviction that economy and efficiency would result from the consolidation of all such surveys in that Department. The Secretary of the Interior replied to the inquiry by stating that he believed all surveys of unoccupied public territory, except those for military purposes, should be consolidated in his Department (Herman Stabler, History and purpose of land classification in the Geological Survey, unpub.).

To settle the rival claims of the War and Interior Departments, the House Committee on Public Lands, reporting to the House May 26, 1874 , set forth the following conclusions ( $43 \mathrm{~d}$ Cong., 1st sess., H. Doc. 612):

That the surveys under the War Department, so far as the same are necessary for military purposes, should be continued; that all other surveys for geographical, geological, topographic, and scientific purposes should be continued under the direction of the Department of the Interior, and that suitable appropriations should be made by Congress to accomplish those results.

The Congress did not act on this resolution and the surveys continued as before with unabated rivalry. Finally, the controversy regarding the methods to be used and the agency to execute the surveys of the public domain reached a point where the Congress was unable to reach an agreement. Again Clarence King's advice reinforced by Powell's suggestion (biographical sketch of John Wesley Powell in USGS 24th ann. rept., p. 277, 1903) prevailed, and the Congress requested the National Academy of Sciences (NAS) be an expert referee to make definite recommendations. The following rider was attached to the 
Sundry Civil Act of June 20, 1878 (20 Stat. L. 230):

And the National Academy of Sciences is hereby required at their next meeting to take into consideration the methods and expenses of conducting all surveys of a scientific character under the War or Interior Department, and the surveys of the Land Office, and to report to Congress as soon thereafter as may be practicable, a plan for surveying and mapping the Territories of the United States, on such general system as will in their judgment secure the best results at the least possible cost.

In order to lessen the rivalry between the Powell and Hayden Surveys, pending the report of the NAS, the appropriations in the same bill (20 Stat. L. 230) limited each survey to separate areas as follows:

Under Prof. F.V. Hayden . . \$ \$75,000

Provided: That the money hereby appropriated shall be expended only in prosecuting said survey north of the fortysecond parallel and west of the one hundredth meridian.

Under Prof. J.W. Powell . . \$50,000

Provided: That the money hereby appropriated shall be expended only in prosecuting said surveys south of the fortysecond parallel and west of the one hundredth meridian.

Before formulating a plan as directed by the Congress, the NAS called on the Secretaries of War and Interior for reports of the survey activities under the direction of each. Most of the information received related to facilities for conducting the work and methods used, but Powell, with his usual breadth of vision, transmitted a lengthy report discussing the purposes to be served (Stabler, unpub.). He summarized his report by stating (45th Cong., 3d sess., H. Misc. Doc. 5 , vol. 1, p. 21 ):

It will be clear that a proper scientific survey embracing the geography of the public domain with the parceling of the lands, and the geology with all the physical characteristics connected therewith, is necessary for the following reasons:

First, to secure an accurate parceling of the public lands and enduring boundary lines.
Second, for the proper administration of the laws relating to the public lands.

Third, for a correct and full knowledge of the agricultural and mineral resources of the lands.

And, fourth, for all purposes of abstract sciences.

These considerations are ample to secure from the National Legislature all necessary financial endowments for the prosecution of the surveys. It should be remembered that the statesmen of America who compose and have composed our National Legislature have not been averse to the endowment of scientific research when such research is properly related to the industries of the people.

A committee of the NAS, consisting of Othniel C. Marsh, James D. Davis, William B. Rogers, John S. Newberry, William P. Trowbridge, Jr., Simon Newcomb, and Alexander Agassiz, an illustrious group of scientists, considered the problem and on November 26, 1878 , recommended to the NAS (1) that the CGS be transferred to the DOI and, in addition to its former work, be charged with the preparation of a geodetic survey of the whole public domain, a topographic survey comprising detailed topographic mapping and rapid reconnaissance, and land parceling surveys; and (2) that the Congress establish, under the DOI, an independent organization to be known as the "U.S. Geological Survey,"' to be charged with the study of geological structures and economic resources of the public domain (45th Cong., 3d sess., H. Misc. Doc. 5, vol. 1, p. 21). Although Clarence King does not appear to be taking part in the deliberations of the NAS, his biographer states (biographical sketch of Clarence King in USGS 23d ann. rept., p. 203, 1902) that the recommendations were along the lines laid down by him.

This report was adopted and transmitted to the Congress by the NAS. The proposed special legislation embodying the recommendations of the NAS was divided into two parts: first, an item in the Legislative, Executive, and Judicial appropriation bill creating the office of the Director of the USGS, providing his salary, defining his duties, and specifically terminating the Powell, Hayden, and Wheeler Surveys; 
and second, an item in the Sundry Civil bill appropriating $\$ 100,000$ for the new USGS.

Although both items were passed by the House where apparently the supporters of the NAS were in the majority, a protracted struggle took place in the Senate. Here the partisans of Hayden and Wheeler proved to be "last-ditch" fighters: Realizing that only through united action could they hope to defeat the proposed legislation with which Powell was identifiedand the Wheeler forces, apparently realizing further that of the two, Hayden was in the stronger position-Powell's opponents threw their support to Hayden. As a result, the item in the Sundry Civil bill was amended in the Senate by the addition of the words "of the Territories." Other amendments offered changed the Sundry Civil bill item to provide specifically and exclusively for the continuation of the Hayden Survey, and it was in this form that item was passed by the Senate. All reference to the new organization was deleted from the legislative bill. The final struggle occurred in conference. The bill died in conference but, in the closing hours of the session, the conferees on the Sundry Civil bill assumed legislative powers, and transferred from the dead legislative bill to the Sundry Civil bill all of the language that constituted the "Organic Act' of the USGS. When the conference report reached the Senate for ratification, this unusual and high handed proceeding was roundly denounced; however, after a brief debate in the closing hours of the session, the Senate on March 3, voted to concur in the conference report (G.O. Smith, A century of government geological surveys, Am. Jour. Sci., vol. 46, p. 184-185, July 1918). The law approved March 3, 1879 (20 Stat. L. 394) embodied the recommendations of the NAS to the extent of abolishing the Territorial Surveys and creating the USGS, but took no action on the proposal to transfer and enlarge the scope of the CGS. This law contained the following item:

For the salary of the Director of the Geological Survey, which office is hereby established under the Interior Department, who shall be appointed by the President, by and with the advice and consent of the Senate, six thousand dollars: Provided, That this officer shall have the direction of the Geological Survey and the classification of the pubiic lands, and examination of the geological structures, mineral resources, and products of the national domain. And that the Director and members of the Geological Survey shall have no personal or private interest in the lands or mineral wealth of the region under survey, and shall execute no private surveys or examinations for private parties or corporations; and the Geological and Geographical Survey of the Territories, and the Geographical and Geological Survey of the Rocky Mountain Regions, under the Department of the Interior, and the Geographical Surveys west of the one hundredth meridian, under the War Department, are hereby discontinued to take effect on the thirtieth day of June, eighteen hundred and seventy-nine. And all collections of rocks, minerals, soils, fossils and objects of natural history, archaeology, and ethnology, made by the Coast and Interior Survey, the Geologi cal Survey, or by any other parties for the Government of the United States, when no longer needed for investigations in progress, shall be deposited in the National Museum.

For the expenses of the Geological Survey, and the classification of the public lands, and the examination of the geological structures, mineral resources, and products of the National domain, to be expended under the direction of the Secretary of the Interior, one hundred thousand dollars.

In a period of 5 years, the haphazard policy of the Congress changed from one involving several independent surveys under different departments with no definite uniform objectives to one of concentration under a new organization with a definite goal. The Congress realized the scientific nature of the problem and appealed to the highest scientific body in the country for help in reaching a solution of the question.

Of the four heads of the surveys that were abolished by the Organic Act of March 3, 1879, Hayden, Clarence King, and Powell, were civilians and, on their records, each was eligible for appointment as Director of the newly created USGS. Of these three, Powell 
was outstanding because of the active part he had taken in the earlier surveys, his absorbing interest in the possible development of the "Great American Desert," his vigorous character, and his influence in persuading the Congress to create the USGS. The intensity of his struggle for the creation of the Survey, however, had unavoidably made enemies for him in public life. Powell realized that if he became the first Director, his effort would be thought to have been made primarily for his own aggrandizement, and he refused to allow his name to be considered (F.S. Dellenbaugh, The romance of the Colorado River, Knickerbocker Press, 1903).

Hayden, on the other hand, felt that he should be in charge of the new organization and that the appointment of another would be an unjust reflection on him (F.V. Hayden, Nat. Acad. Sci. Biogr. Memoirs, vol. 3, p. 395-413) because he had been authorized to make a survey of the entire West, whereas Powell had been limited to the Colorado River basin. His funds and personnel also had been considerably larger than those of Powell.

Clarence King, however, was confirmed as Director and took the oath of that office on May 24,1879 . That he was not particularly anxious for the position is indicated by the statement of Emmons that Clarence King accepted the appointment with the distinct understanding that he should remain only long enough to appoint the staff, organize the work, and guide the forces into full activity (Clarence King, Nat. Acad. Sci. Biogr. Memoirs, vol. 6, p. 27-55, 1909).

It is within the province of the historian to look behind the scenes and determine, if possible, the motives that inspired different acts. It is plain that Powell desired the directorship of the new organization eventually. Having eliminated himself from consideration for the position at the start, the choice narrowed down to Clarence King or Hayden. Of these two, Clarence King did not care particularly for the position, while Hayden was perhaps as interested as Powell himself in surveying the West and, if appointed Director, would probably retain the position indefinitely. Powell's hearty support went, therefore, to Clarence King for appointment as the first Director (biographical sketch of John Wesley Powell in USGS 24th ann. rept., p. 277,1903$)$. In his support of Clarence King, Powell was greatly aided by Carl
Schurz, then Secretary of the Interior, who opposed Hayden's appointment for reasons not now known (Merrill, p. 550).

\section{Relation of the Geological Survey to} ITS Predecessors

Of the four surveys that were discontinued when the USGS was created, the field work of the King Survey had been completed and the results had been or were being published by the War Department; Hayden was given an appointment as geologist in the new USGS in order that he might complete his reports for publication; the unpublished results of the Powell Survey came to the new organization; and all records of the Wheeler Survey remained in the War Department. The USGS, therefore, was the direct successor of the Powell and Hayden Surveys. Geologists and topographers from the Powell, Hayden, and King Surveys formed the first staff of the USGS.

\section{Organization of the Geological SuRvey}

\section{Clarence King, Director}

One of the first tasks of Clarence King as Director of the USGS was to select the technical staff on which the success of the new organization would so largely depend. The appointments were divided into two classes: first, those of the regular or permanent staff who were nominated by the Director and appointed by the Secretary, and second, those who were temporary and were appointed and revoked by the Director. As this was before the days of the Civil Service Commission, the Director was free to nominate whom he chose and he made his selections with the greatest care (USGS first ann. rept., p. 13, 1880). The requirements for regular appointment are shown in the form letter sent to applicants:

Sir:

Your communication of - - - relating to a position for - . - upon the staff of the 
United States Geological Survey has been received and placed upon file.

Your attention is respectfully called to the following Bureau Regulations concerning appointment:

The Geological Survey is divided into two independent divisions. These are:

1. General Geology, 2. Mining Geology.

Applicants for appointment under the Division of General Geology will be required to furnish proper evidence of a good working knowledge of mathematics, physics, chemistry, geology, and mineralogy, such evidence will consist of the degrees of universities, or the testimony of experts in the required branches, or the result of a written examination.

Applicants for appointment under the Division of Mining Geology must furnish equivalent evidence of a working knowledge of mathematics, mechanics, mining geology, chemistry, metallurgy, and the mineralogy of economic mineral products.

You are requested to comply with the above requirements and present your scientific credentials.

Very respectfully, Clarence King, Director

The first technical staff consisted of Samuel F. Emmons, Arnold Hague, Grove K. Gilbert, Ferdinand V. Hayden, Raphael Pumpelly, George F. Becker, and Clarence E. Dutton, geologists; Charles Doolittle Walcott, A.D. Blair, and J.P. Kimball, assistant geologists; Allen D. Wilson, chief topographer; and F.A. Clark, Sumner H. Bodfish, John H. Renshawe, R.U. Goode, Philo B. Wright, and Gilbert Thompson, topographers. The staff of nine geologists and seven topographers was indicative of the importance that topography was to play in the new organization, as was to be expected since Clarence King had from the beginning of his own survey stressed the importance of topographic mapping. The methods developed by Clarence King had later been adopted by Hayden; those methods had doubtless influenced Powell also, particularly when he began his general surveys in 1874 after the completion of the Colorado River work.

The technical staff connected the USGS with the predecessor surveys even more closely than did the inherited field material. Emmons and Hague, who had been geologists of the King Survey, headed the list of geologists. Gilbert had been geologist first with the Wheeler Survey and later with the Powell Survey. Hayden had been the director of his own survey and had been given the appointment in the USGS for the chief purpose of preparing for publication the reports of his own survey, a specific appropriation having been made for that purpose. Dutton had been detailed by the Army to the Powell Survey and was continued on detail to the USGS. F.A. Clark had been topographer in the King Survey, Wilson in both the King and Hayden Surveys, Renshawe and Bodfish in the Powell Survey, and Gilbert Thompson in the Wheeler Survey. John D. McChesney, the chief disbursing clerk, had been a clerk in the Wheeler Survey.

The law creating the USGS specified two distinct functions: (1) the classification of the public lands, and (2) the examination of the geological structure and mineral resources. The first question of policy confronting Clarence King related to the classification of the public lands. He was of the opinion that the Congress intended to have a rigid scientific classification of the public lands for the general information of the people of the country (USGS first ann. rept., p. 5, 1880), and not for the purpose of aiding the General Land Office, since he deemed it to be impractical for the USGS to classify lands in advance of sale without seriously impeding settlement.

The second question of policy related to the region to be covered. The term "national domain" specified in the Organic Act was ambiguous. It was apparently supposed by the framers of the law to apply to the entire United States, but, on the other hand, it might be held to refer only to the region of the public lands. With the small appropriation available for the beginning of the work of the Survey, Clarence King stated (USGS first ann. rept., p. 6, 1880):

I considered it best to confine the operations to the region of the public land, 
concerning which field there could be no question as to my legal authority. In the case, therefore, of the uncertainties arising from the language of the law, I have chosen the conservative side, and have neither invaded the functions of the General Land Office, nor placed my field parties outside the area of the public lands.

This restriction of area was not approved by the House of Representatives. When the House Appropriations Committee was informed of Clarence King's decision, a resolution extending the field of the USGS to the entire United States was recommended and promptly passed by the House. Action was delayed in the Senate and, in advance of favorable action, Clarence King adhered to his decision.

A third question of policy, although a minor one compared with the others, related to headquarters for the field parties. In remembering that much valuable time had been wasted during his own survey because of late appropriations and having headquarters in the East when the field work was in the West, Clarence King decided to have permanent field headquarters in the West. He divided the region of operation into four divisions: the first under Emmons in Denver, Colo., the second under Dutton in Salt Lake City, Utah, the third under Gilbert, also in Salt Lake City, and the fourth under Hague in San Francisco, Calif. (USGS first ann. rept., p. 6-7, 1880).

In planning the first field work, Clarence King adopted the principle that the USGS should be distinguished by the emphasis laid on the direct application of scientific results to the development of the country's mineral wealth (biographical sketch of Clarence King in USGS 23d ann. rept., p. 199, 1902), a principle that has been a guiding one to the present day. He planned further that the field work should be such that the results could be published within 2 years, thus making the results available promptly. He established a laboratory of experimental physics for determining the chemical and physical properties of rocks and rockforming materials under extreme conditions of temperature and pressure. The cost of the expensive equipment required for this laboratory was paid by Clarence King from his personal funds, and he obtained the services of the most prominent young physicists of that day for its operation (p. 205, 1902).

Clarence King resigned March 11, 1881. In his letter of resignation, he stated that the work of the office left no time for personal geologic work and he felt that he could render more important service to science as an investigator than as the executive head of a bureau (USGS second ann. rept., p. 11, 1882). Although he was director of the USGS somewhat less than 2 years, he perfected its organization and established its policies. The work was confined to the public-land States until specific authority was obtained from the Congress, shortly after Powell became director, to extend it over the entire United States (22 Stat. L. 302-329). The policy in regard to the classification of land was continued by King's successors until 1906 when the pressing needs of the Department led to an active awakening of the previously dormant function-not by superseding the machinery of the General Land Office, but by cooperating with it (Stabler, p. 17, unpub.). Permanent field headquarters were continued for some years, but finally were abandoned in favor of general headquarters in Washington, D.C.

\section{Major John Wesley Powell, Director}

When Clarence King resigned, John Wesley Powell, then Director of the Bureau of Ethnology, evidently felt the reasons that prevented his acceptance of the directorship of the USGS in 1879 no longer prevailed. He was appointed to that position almost immediately and sworn into office on March 19, 1881. So short was the time between King's resignation and Powell's appointment that the stage appears to have been set in advance. Powell indicated his interest in topographic mapping as an adequate base for geologic work by bringing additional topographers to the USGS, notably Almon $\mathrm{H}$. Thompson, his brother-in-law, who had been on the Powell Survey, and Henry Gannett, who had been on the Hayden Survey. Charles A. White, a geologist on the Powell Survey, also was appointed.

The first major change in Survey operations under Powell was the expansion of coverage 
to the entire United States. During the first year of USGS existence, the House had passed a resolution authorizing such extension, but the Senate had not acted on it and Clarence King evidently had not pushed the matter, being content for the time to confine activities to the Western States. Powell was apparently not satisfied with this restriction, however, and in the appropriation act for the fiscal year ending June 30,1883 , the USGS was required to make a geologic map of the United States (USGS fourth ann. rept., p. xiii, 1884). The preparation of a topographic map, the only adequate base for geologic representation, was involved in this requirement.

It was proposed to publish this general map on a scale of about 4 miles to the inch $(1: 250,000)$ in atlas sheets, each covering one degree of latitude and longitude. In order to expedite the work with the greatest economy, advantage was taken of all work previously done. The mapping by the King, Hayden, and Powell Surveys was used, but of that by the Wheeler Survey, Powell wrote (USGS fourth ann. rept., p. Xv, 1884):

(It) embraces an aggregate area of several hundred thousand square miles. A large part of this work was on a scale too small, and was done by methods too inaccurate to be utilized for the purposes of the Geological Survey; but an area of about 115,000 square miles was surveyed in such a manner as to be available for the present work.

Henry Gannett was put in charge of the topographic mapping. There was at this time no authority for the publication of topographic maps as such, however, so they could only be produced as bases for the geologic and economic maps that illustrated the resources and classification of the lands (USGS seventh ann. rept., p. 7, 1888).

Powell was particularly interested not only in topographic mapping but also in the reclamation of the arid lands of the West as evidenced by his numerous writings during the late 1870's. His interest in reclamation also continued after he became Director and he said that, although the immediate purpose of topographic maps was the presentation of areal geology, they might be useful for many other important purposes including the study of the great subject of irrigation. He continued, therefore, to press for national aid in irrigation. During the first years of Powell's directorship, the activities of the USGS were devoted to general geologic studies, chiefly of outstanding mining districts, to compilations of mineral and mining statistics, and to the production of topographic maps on which the geologic and mining information was presented.

Following the authorization to extend the USGS activities over the entire United States, topographic mapping was greatly expanded and, instead of being supervised by geologists to meet their own needs, was directed by Henry Gannett. Work in geology was separated more distinctly into geology and paleontology, and physical researches and gathering of statistics on mineral production continued without change.

The appropriations for the USGS were increased from $\$ 106,000$ in 1880 to $\$ 156,000$ in each of the two succeeding years, and thereafter by annual steps to a maximum of $\$ 635,240$ in 1888 . During the same period, other scientific bureaus, notably the Signal Service (the predecessor of the Weather Bureau) and the Hydrographic Office of the Navy, likewise had their appropriations greatly increased. In 1884, Congress, perturbed over mounting costs, provided in the Sundry Civil bill for a joint Congressional investigation to "consider the present organizations" of the bureaus mentioned "with the view to secure greater efficiency and economy in the administration of the public service in said bureaus." There were numerous hearings during 1885 and 1886 at which Powell appeared on behalf of the USGS. Questions were raised as to the value of the small-scale topographic maps, the slow rate of progress in completing the geologic map of the United States, and the propriety of the wide scope of the USGS scientific investigations and publications. Powell met these questions so successfully that a majority of the committee members reported that the USGS as a whole was "well conducted with economy and care, and disclosed the excellent administrative and business ability of its chief" (The U.S. Geol. Survey in Service Monographs of the U.S. Govt., no. 1, Institute for Government 
Research, p. 15-16, 1918). Thereafter the appropriations were increased annually until the depression years of the early 1890's when they were drastically cut to a low point of $\$ 488,000$ in 1893 , after which they were gradually increased again.

The USGS was first housed in a suite of office rooms furnished by the Smithsonian Institution in Washington, D.C., and in laboratory space furnished by the Smithsonian and in the American Museum of Natural History in New York City. During 1884-85, the USGS offices moved to the new rented building at $1330 \mathrm{~F}$ Street $\mathrm{N}$.W. in Washington (Hooe Building on a part of the site now (1938) occupied by the National Press Building), but the laboratories remained in the Smithsonian.

During the 1880's, Powell was pressing for national aid for irrigation and conditions were ripening for action by the Congress. Irrigation development had reached a nearly static stage because the settlers in the arid region had irrigated nearly all land within easy reach of the streams and, in most places, had used fully the natural flow of the streams during the irrigation season. Therefore, any considerable expansion of irrigation involved storage of water in large reservoirs, the reclamation of lands far removed from streams, and costs far higher than settlers could provide even when acting collectively. Senator Stewart of Nevada, an active champion of irrigation, returned to the Senate in the late 1880's after an absence of 12 years, and resumed his efforts to obtain national legislation to promote irrigation development (official report of the Irrigation Congress, Salt Lake City, Utah, Sept. 15-17, 1891, p. 19). With his powerful aid and that of other western members of Congress, the Senate on March 27, 1888 , passed the following resolution (USGS 10th ann. rept., pt. 2, p. 9, 1890):

Resolved, that the Secretary of the Interior is hereby directed to report to the Senate what appropriation is neceasary to enable the United States Geological Survey to carry into effect the joint resolution 'Directing the Secretary of the Interior by means of the Geological Survey to investigate the practicability of constructing reservoirs for the storage of water in the arid region of the
United States and to report to Congress,' approved March 20, 1888, and the several acts of Congress requiring such Geological Survey, under the direction of the Secretary of the Interior, to classify the public lands and furnish a map or maps showing the various divisions of the public domain suitable for agricultural, mineral and other purposes; and particularly to segregate the lands susceptible of irrigation, where irrigation is required, from other lands, and designating places for reservoirs, canals, and other hydraulic works.

Powell reported at length and recommended an initial appropriation of $\$ 250,000$. It was not until the Sundry Civil Appropriation Act was approved October 2,1888 , however, that the following provision appeared (USGS 10th ann. rept., pt. 2 , p. 9, p. 16-17, 1890):

For the purpose of investigating the extent to which the arid region of the United States can be redeemed by irrigation and the segregation of the irrigable lands in such arid region, and for the selection of sites for reservoirs and other hydraulic works necessary for the storage and utilization of water for irrigation and the prevention of floods and overflows, and to make the necessary maps, including the pay of employees in field and in office, the cost of all instruments, apparatus, and materials, and all other necessary expenses connected therewith, the work to be performed by the Geological Survey under the direction of the Secretary of the Interior, the sum of one hundred thousand dollars, or so much thereof as may be necessary. ${ }^{*}{ }^{*}$ * And all the lands which may hereafter be designated or selected by such United States surveys for sites for reservoirs, ditches, or canals for irrigation purposes, and all the lands made susceptible of irrigation by such reservoirs, ditches, or canals are from this time henceforth hereby reserved from sale as the property of the United States, and shall not be subject, after the passage of this act, to entry, settlement or occupation until further provided by law; Provided, That the President may at any time, in his discretion, by proclamation open any portion or all of the lands reserved by this provision to settlement under the homestead laws. 
Unfortunately, the Act authorizing the Irrigation Survey carried the seeds of its own destruction within the short period of 2 years but, within that 2-year period, the Irrigation Survey, progenitor of the Water Resources Branch, was born. Although there had been during the 1870's a growing appreciation, especially by Powell, of the importance of reliable records of the water resources in connection with the development of the West, the very little quantitative information on streamflow that was obtained consisted chiefly of a few miscellaneous measurements of discharge made by using floats. The work was incidental and without system; it was exploratory rather than orderly and, except as it may have been suggestive, had no significance with respect to the future studies of water resources. The Irrigation Survey, on the other hand, laid sound foundations for future work and certain of its activities have special significance in this history-especially those pertaining to methods, instruments, and equipment for systematic stream gaging-to consideration of problems related to the storage and economic use of water for irrigation, and to the selection and training of the men who, for more than a quarter of a century, were to lead in promoting, organizing, and operating the orderly investigation of the Nation's water resources. An account of the Irrigation Survey is, therefore, an integral and essential part of the history of the Water Resources Branch. 



\section{Part V-Irrigation Survey (1888-90)}

The Irrigation Survey involved the investigation of the possibilities of irrigating nearly half the area of the United States-an undertaking of magnitude never before attempted on the American continent. As Powell stated, its magnitude, novelty, and urgency combined to render the responsibility of its organization a heavy one (USGS 11 th ann. rept., pt. 2, p. 3, 1891). In order to conduct this new Congressional mandate, Powell organized the work under two divisions. The first division, the Topographic Survey, was for the preparation of topographic maps on which the lands susceptible of, or best suited to, irrigation might be shown together with possible reservoir and canal sites. This division was directed by Almon H. Thompson who had a number of the regular topographers of the USGS as his principal assistants. This force of USGS employees was largely supplemented by temporary field assistants, but no increase to the permanent organization was made (USGS 10th ann. rept., pt. 2 , p. 17,1890$)$. The second division, the Hydraulic Survey, was divided into the Hydrographic Survey, to measure the water supply, and the Engineering Branch, to locate and design the necessary irrigation structures. Powell believed that the most important part of the work of the Hydraulic Survey related to the measurement of water because it was necessary to ascertain how much water was available for irrigation in order to evaluate the extent to which the arid region could be reclaimed.

Powell's correspondence shows that he arranged with William Ham Hall, former State engineer of California, to supervise the Hydraulic Survey in the western part of the arid region, and with Edwin S. Nettleton, former State engineer of Colorado, to supervise the work in the eastern part (F.H. Newell, oral commun., ca. 1938). In order to relieve him- self of the burden of details connected with this new work, Powell transferred Dutton to the Irrigation Survey; Dutton, who had been in charge of the Division of Volcanic Geology in the USGS, was made chief engineer of the Hydraulic Survey.

The appointment of a chief engineer was resented by W.H. Hall and Nettleton because this action required them to report to or through the new officer instead of dealing directly with Major Powell as they had expected to do. Newell stated to the author that this feeling of resentment was accentuated by the fact that W.H. Hall and Nettleton were both older than Dutton and had had much wider experience in irrigation-one in California and the other in Colorado. Their resentment grew into opposition to the entrance of an outside organization (the Irrigation Survey) into the field they considered to be their own. They did little, therefore, to help the Hydraulic Survey. The records of disbursements indicate, however, that W.H. Hall was employed almost continuously during 1889-90, the end of the Irrigation Survey, and that Nettleton was employed several months during those years.

Only that part of the Irrigation Survey's personnel and work that related to the Hydrographic Survey, will be given further consideration in this history, since it was the progenitor of the Water Resources Branch.

\section{Organization of the Hydrographic SuRvey}

Powell realized the importance of knowledge of water supply, but he had no idea of the proper method to use in acquiring this knowledge, nor could Dutton, his chief 
engineer, enlighten him. He decided, however, that, whatever the methods (USGS 10th ann. rept., pt. 2, p. 8, 1890), "It will be necessary also to gauge a certain number of streams at all seasons of the year, so as to ascertain their total discharge and its seasonal distribution, and also to gauge a greater number of streams at certain seasons determined to be critical."

While preparing his estimates for the Irrigation Survey, Powell decided that the measurement of each stream at the point where records would be needed would require an enormous amount of money and that the work could be done in a cheaper way that would be altogether more satisfactory. Many men have since sought a cheap way for making satisfactory estimates of runoff. The variations in conditions affecting runoff-exposure, slope, soil, vegetation, temperature, seasons, ground moisture, and precipitation, and all the interrelations among them-are, of course, infinite. No reliable substitute has been found for actual records. Powell proposed to make topographic maps of the various drainage basins from which areas and slopes could be determined, to maintain gaging stations on a few of the streams, and to ascertain from the known areas, altitudes, general slopes, and rainfall, the amount of water that would be derived from each square mile of drainage basin. In deciding on this plan, which Powell stated was agreed to by his associates with the single exception of Dutton (report of special committee of the U.S. Senate on the irrigation and reclamation of arid lands, S. Rept. 928, 51st Cong., 1st sess., May 8, 1890), the man who was most concerned, it is evident that he was led by an unwavering faith in the efficacy of topographic maps to solve many problems - a faith that was so to influence him that his reliance on maps was used against him in the fight that developed later in the Congress over the continuation of the Irrigation Survey (S. Rept. 928, 51st Cong., 1st sess., May 8, 1890).

Powell had the ability to inspire men with his own high ideals. He could visualize the results he desired but would not concern himself with the details of their accomplishment. After stating that he wanted the rivers measured to ascertain how much water was in them, he was asked how it should be done. His characteristic reply was "I don't know; that is your job" (F.H. Newell, oral commun., ca. 1938). Dutton decided that it would be necessary to establish a camp of instruction to which a small group of selected young men of good education and high general intelligence would be sent to acquire a knowledge of the methods and instruments to be used in measuring the rivers of the arid region.

In view of the urgent need for starting the water-supply investigation at the earliest possible date following the availability of the appropriation in October 1888 , it was decided to have the camp at some place in the southwest where the weather would be sufficiently mild so that experimental work could be conducted during winter. Some years previously, while studying the Pueblo Indians, Powell had visited Embudo, N. Mex., on the Rio Grande. He selected Embudo as the site for the camp because it was situated in a canyon and was believed, therefore, to have a mild winter climate, and because it was accessible by railroad.

At about this time, Powell arranged to lecture at the Massachusetts Institute of Technology (MIT). In order to show him proper courtesy as well as to insure his remembering the appointment, a graduate student was requested to call upon him and escort him to the place where the lecture was to be given. This graduate student was Frederick Haynes Newell, who thus had his first meeting with Powell (F.H. Newell, oral commun., ca. 1938)-a meeting that was destined to have a profound effect on the life of the man who has been called "The Father of Systematic Stream Gaging." F.H. Newell graduated from MIT in 1885 as a mining engineer and, after several years' practice in that profession, returned for graduate work in geology. Shortly after the meeting with Powell, F.H. Newell wrote to Powell applying for a "job," and as soon as the appropriation act was effective (October 2, 1888) F.H. Newell was given the first full-time appointment on the Irrigation Survey (F.H. Newell, oral commun., ca. 1938). It was considered to be temporary, however, as were all appointments in the Irrigation Survey, and so was made by the Director himself. When F.H. Newell reported for duty in Washington, D.C., he was assigned to 
A.H. Thompson and Henry Gannett of the Topographic Survey for topographic mapping on the Humboldt River in Nevada. Fortunately for the present-day Water Resources Branch, A.H. Thompson advised F.H. Newell that, because he had had no experience in topographic mapping, it might be a good idea for him to go into the Hydrographic Survey, the work of which no one had any precise knowledge. F.H. Newell did not go to Nevada and was instead assigned to Dutton.

Within a short time, nine other young men were selected and assembled in Washington, D.C., for assignment to the camp of instruction. Of the 10 men including F.H. Newell, six had had college training, with Rennselaer and Massachusetts Institutes, Harvard, Yale, and the University of Virginia being represented. While awaiting orders, they used their time to read all available literature on stream gaging, meteorology, and allied subjects.

It is inferred that at first Dutton looked on J.B. Williams as the leader of this new group because he was the first to be sent into the field. The inference is based also on the fact that on November 21, 1888, F.H. Newell was ordered by Dutton to report to J.B. Williams for the temporary duty of selecting observing stations (as the river stations were called) in Colorado, New Mexico, and Arizona. Evidently the Rio Grande was considered the most important: it was stated in the instructions that a station was desired on that river near Jemez, N. Mex. F.H. Newell was instructed also to see Nettleton, the Colorado State engineer, in order to learn what stream gaging was being conducted in Colorado and what methods were being used, the measurement of rivers having been started in that State in $\mathbf{1 8 8 1}$. Thereafter, F.H. Newell was to proceed as directed by J.B. Williams, and no mention was made in his orders of the proposed camp of instruction that was about to be started, where George T. Quinby was in charge.

On receipt of his instructions, F.H. Newell started westward and, after finishing the reconnaissance near Jemez, proceeded to Santa Fe, N. Mex., to prepare his report. While there, he received the following letter dated November 30, 1888, from Dutton (from F.H. Newell correspondence files):

As soon as Mr. [J.B.] Williams is able to release you from the duties with him, you are instructed to proceed to the camp on the Rio Grande and take charge of its establishment and regulation, relieving Mr. Quinby. You are authorized to purchase whatever may be absolutely necessary and to employ hired men; but the obligations so incurred will be subject to disallowance by the Disbursing Officer if they are not in conformity with the rules and practices by which he must be governed.

All members of the Survey who are sent to the Camp of Instruction are hereby directed to report to you for duty. You are authorized to send them upon journeys of official business but the formal orders incorporated in their vouchers for travel expenses will be signed by me.

You are requested to keep record books of all official correspondence and a diary of the operations of the men in your charge; also as nearly as practicable a running account of all expenditures so far as you may be cognizant of them. You will appoint a custodian, whose duty it will be to keep track of all property purchased and make frequent inventories of the same, also to keep a daily register of the number of men present for duty at the camp, and of the rations received and consumed.

At the end of every month you will make to me a full report of the operations of that month.

$$
\begin{aligned}
& \text { Very respectfully Sir, etc., } \\
& \text { C.E. Dutton } \\
& \text { Capt. Ordnance in Charge }
\end{aligned}
$$

The letter is presented in full for several reasons, the most important being to call attention to the requirement that record books of all official correspondence and a diary of operations be kept. This requirement was scrupulously observed and the record books of correspondence and the diaries form the chief basis in this history of the early work of the Hydrographic Survey. In the 1880's, disallowances were made and inventories of property were required at frequent intervals, both of which remind the writer of the line from Kipling's poem The Vampire-“even as you and I." The latter part of the letter shows strongly Dutton's military background. Early 
in December, travel orders were given to the eight men remaining in Washington, D.C., and they reached Embudo December 9, 1888.

\section{Development of the Art of Stream GAGING}

Before describing the camp of instruction, a digression will be made to show the stage of development of the art of stream gaging at that time.

No one in the Irrigation Survey had a definite plan for collecting systematic records of streamflow, so various methods were to be tested. The rating of a stream was not entirely new, however, as considerable work of this kind had already been done in this and foreign countries. The earliest record of daily discharge appears to be that of the discharge of the Rhine River at Basel, Switzerland, covering the years 1809-21. The discharge was computed by Eytelwein's slope formula, modified as a result of a few surface-velocity measurements. The computation was made by applying a rating curve to the daily gage heights. The discharge of the Tiber River at Rome, Italy, was computed similarly by the same formula for a period of 11 years before 1836 . Similar records of discharge had also been obtained on the Adda and Po Rivers for many years before 1844 (A.A. Humphreys and H.L. Abbot, Physics and hydraulics of the Mississippi River, Bur. of Topog. Eng., U.S. Army Paper no. 4, 1861). It will be noted that all of these records were based on the slope method of computing discharge, although some velocity measurements were made on the Rhine River.

The first records of daily discharge based on actual measurement of velocity at various stages were probably those made by Charles Ellet, Jr. on the Ohio River near Wheeling, W. Va., during summer and fall 1849. The velocities were measured by means of floats. From the discharges so obtained, an empirical formula was derived that showed the relation of discharge to the depth of water on the bar that controlled the stage-discharge relation for the section of river to be rated. By means of this formula, a rating table was made that was applied to a daily record of depths on the bar, covering the years 1844-48. The mean velocity was deduced from the surface velocity by means of De Prony's formula for that purpose. In his report, Ellet stated that he believed that a study of this kind had never been made for any other river with equal care and accuracy, if indeed any authentic experiments of the kind had ever before been instituted (Charles Ellet, Jr., The Mississippi and Ohio Rivers, 1853).

From April to July 1849 and from March 1850 to February 1851, Lieutenant Robert A. Marr, who was attached to the Memphis Navy Yard (the Navy maintained inland navy yards in those days) measured the Mississippi River at Memphis, Tenn., using floats and, from the frequent discharges thus obtained and records of daily gage heights, presented tables of daily discharge for the periods covered. The mean velocity was deduced from the surface velocity by sinking floats to different depths (R.A. Marr, Observations on the Mississippi River at Memphis, March 1850 to March 1851, Washington Astronomical and Meteorological Observatory, vol. 3).

In 1851, Ellet was employed by the War Department to investigate the flood problem of the lower Mississippi River. Again he used floats for measuring the velocities and, from these velocities, he derived a formula and computed the discharges at different stages. Ellet stated that a formula for determining the actual discharge of the Mississippi for any given height was unnecessary as the discharge had already been measured directly, but that it would be convenient to have some means of determining approximately the increased height of a flood due to any given increase in volume. In applying this formula, Ellet observed that the slope of a rising stage was greater than the slope of the highest stage, and greater still than the slope of the falling stage. Comparisons of velocities at different depths were made by means of floats placed at different depths and the conclusion was reached that the mean velocity was about 2 percent greater than the surface velocity. The surface velocities, however, were used without correction in the discharge measurement (Ellet, 1853).

In 1851 when Ellet was measuring the Mississippi River, the War Department detailed 
A.A. Humphreys and H.L. Abbot also to investigate the flow of the Mississippi. Daily measurements of the discharge at Carrollton, La., were made by using floats from February 1851 to February 1852 and, from these discharge measurements, a rating table was constructed and applied to daily gage heights to obtain daily discharges. Field work was interrupted between 1852 and 1857 and, on being resumed, similar records of daily discharge were obtained by A.A. Humphreys and H.L. Abbot at Columbus, Ky., from December 1857 to November 1858; at Natchez, Miss., from January 8 to February 20, 1858; and at Vicksburg, Miss., from February 24 to December 15,1858 . In these measurements, vertical-velocity curves were obtained using floats submerged at different depths. The mean velocity in the entire cross section was computed and multiplied by the area to obtain the discharge. A study of the vertical-velocity curves showed that the velocity at different depths changed similar to the abscissae of a parabola with the $\mathrm{X}$-axis parallel to and below the water surface. A further study of these curves and the mathematics of parabolas led to the conclusion that the mean velocity ranged from 0.933 to 0.987 of the velocity at mid-depth, and a value of 0.95 was recommended.

The longest known record of river discharge is that of the Thames River near Teddington (London), England, begun in 1853 and continued to date [1938]. Discharge measurements were made at different stages and a rating table was constructed for application to daily gage heights. The early method of measuring the discharge is not now known, but since the early 1880 's, the record has been based on computations of discharge through orifices of the weir at Teddington (Engineer, Thames Conservancy, written commun., ca. 1938).

The Federal Government did not conduct extensive stream gaging from the beginning of the War Between the States until 1871 when the War Department began a survey of the Connecticut River with T.G. Ellis in charge. A straight section of the river at Thompsonville above Hartford, Conn., was selected. That a permanent control of the stage-discharge relation was appreciated by T.G. Ellis is indicated by the following quotation from the report of that survey (Ssurvey of the Connecticut River, rept. Chief of eng., 1878, app. B, p. 305):

The position selected was a straight section between permanent banks which are not overflowed. It is above rapids and therefore free from tidal influence. Its situation above the dam relieves it from any irregular backwater below the point selected for the observations, being just above the influence of the steeper slope upon the rapids in curving the surface of the water downward from its regular inclination above.

This position for observations being something of the character of a canal just above a discharge weir would be expected to give nearly a uniform volume of discharge for the same height of water and be less subject to variations of quantity at the same stage of the river than would ordinarily be the case if the stream did not discharge so freely below.

Discharge measurements were made both by floats and current meters. An improved German-made Woltmann current meter was used at first, but it was unsatisfactory. T.G. Ellis, therefore, devised the meter that bears his name. His meter was apparently the first of the cup type and the cups were probably suggested by those of the Robinson anemometer, invented about 1817. A rating table was made from the discharge measurements and applied to gage heights observed daily from 1871 to 1874 . Vertical-velocity curves were made in this work and the integration method was used at the end of each set to check the results. The discharge was obtained by multiplying the mean velocity in the cross section by the area. From a study of the velocities, it was found that velocity in mid-depth was 0.94 of the mean, and that the mean velocity was at 0.636 of the depth.

In 1878 , the office of State engineer was created in California and 12 gaging stations were established in the San Joaquin Valley. Henry meters, which were borrowed from the Army Engineers, were used. Vertical-velocity curves were used for reducing surface velocities to mean velocities. W.H. Hall, the State engineer, devised a method of plotting meanvelocity and area curves, thinking that more nearly correct results would be obtained for the 
shifting channels by separating area from velocity than by stage-discharge curves. Daily gage heights were observed and the rating table applied to them to obtain daily discharge. The California work continued until the office of the State engineer was abolished in 1888; the unfinished reports were turned over to the State mining engineer (C.E. Grunsky, oral commun., ca. 1938).

In 1881 , the State engineer of Colorado established gaging stations on the Cache la Poudre and Big Thompson Rivers and measured their flow for several months. In 1883 , a permanent station was constructed on the Cache la Poudre River at the mouth of the canyon and rated by using a current meter, using the integration method to determine the mean velocity in each vertical. A rating table was constructed and applied to the daily gage heights. The next year (1884), a timber-rating flume and a recording gage were installed. This station is still maintained and is believed to have had current-meter measurements made at it over a longer period than any other gaging station. It is also believed to have been the first recorderequipped station in the United States. Other stations were established and maintained by the State engineer during the next few years. A Fteley meter was used at first, but because it was too delicate for the rough mountain streams, a meter of the cup type was designed and operated successfully by State engineer Nettleton. Nettleton's starting and stopping device was patterned after that of the Fteley meter.

The city of Philadelphia, Pa., in a search for an additional water supply, hired Rudolph Hering in 1883 to conduct a study of the available resources. During that fall, Hering constructed low masonry weirs with timber crests on Perkiomen, Neshaminy, and Tohickon Creeks and equipped them with horizontalcylinder automatic gages, which were manufactured by Black and Pfister of New York.

The sharp-crested-weir formula was used for low stages and either current-meter measurements made from a boat held by a cable or float measurements were used for high stages. Apparently the engineer in charge of this investigation had little faith in the accuracy of either current-meter or float measurements, because he states (85th ann. rept., Philadelphia Water Dept., for 1886, App. G., p. 259, 1887) “*** and the measurements [were] checked by calculating the flow from the section of the stream and the surface slope as applied in Kutter's formula."

Hering's peace of mind was evidently restored by the comparison because he states that it was surprising how closely the results agreed. The type of meter used and the method of determining the mean velocity are not known to the author. Records were continued at these stations until 1912.

Considerable work had been done in determining mean velocity in addition to the work of measuring daily discharge. D. Ferrand Henry, in 1869, in connection with measurements of the St. Clair, Niagara, and St. Lawrence Rivers by current meter (presumably the blade meter that he invented) found that the coefficient to reduce 0.5 -depth velocity to mean velocity fluctuated from 0.94 to 0.98 with a mean of 0.95 , and that the velocity occurred at from 0.54 to 0.64 of the depth, with a mean of 0.595 (On the flow of water in canals and rivers in Jour. Franklin Inst., vol. 62, p. 167, et seq., 1871).

The Army Engineers used six Ellis meters simultaneously at different depths in measuring the discharge of the Mississippi River near Burlington, Iowa, in 1879, thus obtaining a vertical-velocity curve for each set of observations. The mean of all results for depths as great as 24 feet showed that the coefficient to reduce mid-depth velocities to the mean was 0.958 . The mean velocity was found to be at from 0.551 to 0.682 of the depth, with a mean of 0.622 (A. Mackenzie, Current meter observations on Mississippi River near Burlington, Iowa, 1879).

During the 1870's, Major Allen Cunningham made 565 sets of vertical-velocity curves using floats on the Ganges Canal in India, measuring at every foot in depth to the maximum depth of 11 feet. A study of these curves showed that the mean velocity occurred at from 0.587 to 0.620 of the depth, with a mean of 0.597 , or 0.6 . Cunningham stated that by considering the vertical-velocity curve to be nearly a common parabola, its properties 
indicated that $\mathrm{V}_{\mathrm{m}}=1 / 2($ Vel. at 0.211 of depth + Vel. at 0.789 of depth), which is practically the 0.2- and 0.8-depth method. Professor Von Wagner, in discussing the Ganges work, stated that he had compared this formula with a number of curves for the Weser, Elbe, Rhine, Danube, and other European rivers and found that it applied. He found also that the mean velocity occurred at 0.597 of the depth, and stated that he believed sufficiently accurate results could be obtained by using the 0.6-depth method (A. Cunningham, C.E., Recent hydraulic experiments, Proc. Inst. C.E., vol. 71, London, 1883).

When the Irrigation Survey entered the field, the art of stream gaging had already progressed from slope formulas through float measurements to current-meter measurements, and methods had been devised for obtaining the daily discharge by rating natural sections. There were also many results of vertical-velocitycurve studies showing the relation of 0.5 - and 0.6-depth velocities to the mean, the depth of the mean velocity, and the relation of 0.2 - and 0.8 -depth velocities to the mean. These results had all been published and, to the now unknown extent that they were available to those working under Dutton, served as the basis from which the Irrigation Survey engineers could proceed with their experiments in measuring the relatively small streams of the arid West.

Several different types of current meters had been manufactured, but they were obtainable only on order. Personnel of the Irrigation Survey borrowed meters wherever possible and experimented with them before deciding on which type to purchase.

\section{INFLUENCE ON THE SURVEY OF THE Colorado Plan of Operation}

When it was decided to have a camp of instruction, it seems to have been generally believed that the best way to conduct stream gaging was to have rather elaborately equipped camps situated at a few selected sites. Instruments, equipment, and methods were yet to be studied and developed and, in the early planning for measuring streamflow, there was probably no serious thought about whether or not field work could be conducted satisfactorily by an engineer working without assistants. Neither were there definite ideas as to how a gaging station could best be rated, that is, how the relations of stage to discharge could best be determined or expressed, or how a station rating, however obtained and expressed, could best be applied to a record of stage to obtain a record of discharge. Current meters and recorders were crude and known only to a few, and station equipment was largely undeveloped. The practical technique for obtaining systematic daily records of discharge was unknown.

Before the camp of instruction was started, F.H. Newell familiarized himself, as best he could, with the current practice in measuring streams as it had been developed from the work started by the State engineer of Colorado in 1881. Writing to Dutton from Santa Fe, N. Mex., F.H. Newell said:

Colorado has already put into practice an elaborate system of stream gauging [sic] and with a very small appropriation has obtained valuable results. The rather elaborately equipped camp which has been discussed will not, I fear, meet with any favor, rather the reverse with the engineers in Colorado. Stream gauging with them is reduced to a comparatively simple mechanical performance.

Relative to the proposed camp method, which required a camp outfit with cook and helpers in addition to two high-priced men, F.H. Newell stated further that exact measurement of streams could be made near the site of the camp, and that the best place for measuring a stream could be selected and very accurate results obtained at high cost. He also stated that on the other hand, under the Colorado plan, sites would be chosen for convenience and consequent cheapness in installation and operation; that the engineer in charge would go from place to place living on the country, hunting up sites and observers, setting gauges and finally rating the streams by meter; that as observers were broken in, their range of observations could be broadened and the accuracy of records 
increased by the installation of automatic gauges and the clearing of the channels; and finally that this system had given good results in Colorado and Wyoming at small expense.

Dutton was not convinced and replied as follows:

I believe we can do gauging [sic] as rapidly and cheaply as the State engineers can. As for accuracy-of course, it is useless to arrive at extreme accuracy, but at the same time we should not be too rough and loose in our methods. The gauging of large streams is a very different matter from the small ones. In neither case do I have the least idea that we can approximate much nearer than 10 percent.

Events show that the Colorado method was subsequently adopted.

\section{The Camp at Embudo, New Mexico}

\section{Organization}

P.H. Christie, a topographer detailed as special disbursing officer, was the first to arrive at Embudo early in December 1888. F.H. Newell arrived about the eighth, and the party from Washington, D.C., on the ninth. Twelve Army wall tents came on the 10th and all hands turned to and made camp on gently sloping ground overlooking the Rio Grande, but separated from it by the narrow-gauge track of a branch of the Denver and Rio Grande railroad that extended from Alamosa, Colo., to Santa Fe, N. Mex. Canvas tents were deemed to be sufficient for the men, but the commissary stores were housed in a wooden shelter.

By the 12th of December, the men who had been staying nearby in the tiny Mexican village of Embudo were housed under canvas. The men slept on folding cots at first, but Powell had misjudged the winter climate at Embudo, which had an altitude of about 5,800 feet, and they soon discarded the cots and slept in blankets on the dirt floors in which shallow holes were dug. A few, more ambitious than the rest, excavated a cave on a hillside where they slept until the camp goat fell down the chimney and generally wrecked things. A higher and stronger chimney was installed and the cave reoccupied. In passing, it may be noted

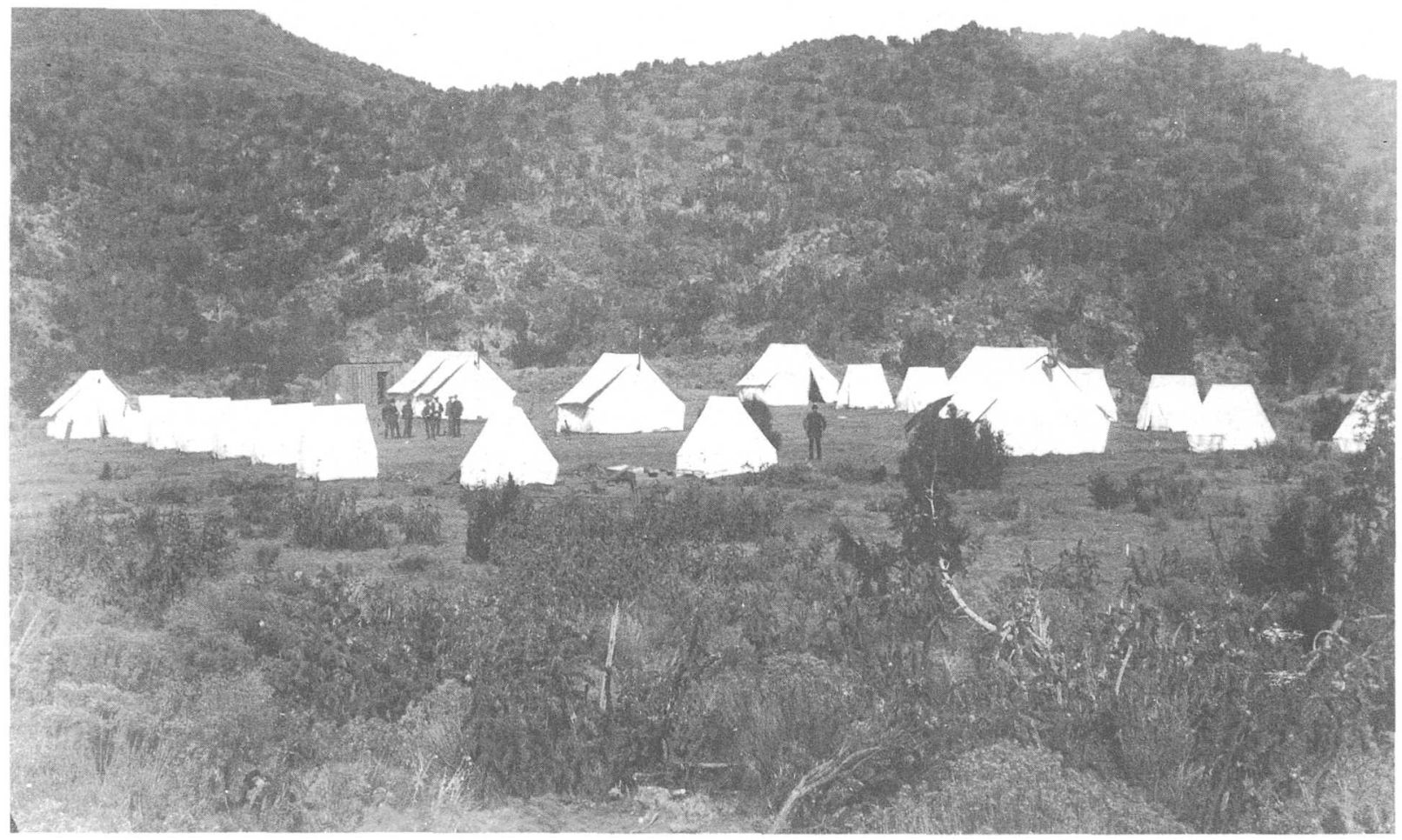

Camp Embudo, N. Mex., 1888-89. (From USGS Professional Paper 778, 1972. Photograph number "Portraits 162," USGS Photographic Library.) 

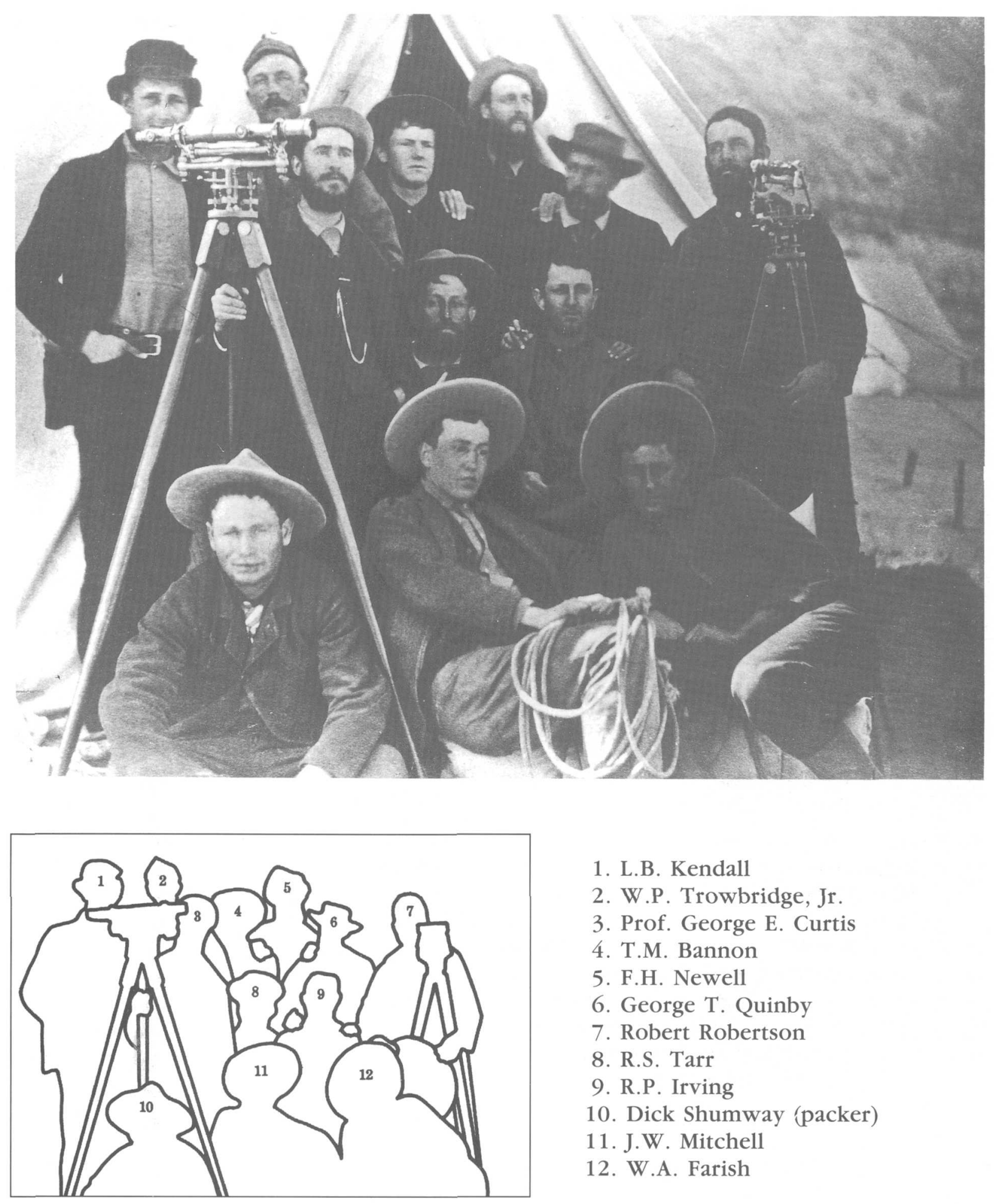

1. L.B. Kendall

2. W.P. Trowbridge, Jr.

3. Prof. George E. Curtis

4. T.M. Bannon

5. F.H. Newell

6. George T. Quinby

7. Robert Robertson

8. R.S. Tarr

9. R.P. Irving

10. Dick Shumway (packer)

11. J.W. Mitchell

12. W.A. Farish

Student hydrographers at Embudo, N. Mex., 1888-89. (From USGS Professional Paper 778, 1972. Photograph number “'Water-Supply Papers 164," USGS Photographic Library.) 
that the camp goat came to a lamentable end, having been sacrificed, not to Kali, the Hindu goddess, as goats usually are, but to that even sterner divinity, Science. Having unwisely swallowed the black-bulb thermometer used in the meteorological observation, the goat was killed and the thermometer recovered.

Within a few weeks after the organization of the camp, four more candidates for instruction arrived. The complete roster of the Irrigation Survey party during the short life of the camp was F.H. Newell in charge, T.M. Bannon, W.A. Farish, Frank Harrison, L.D. Hopson, R.P. Irving, L.B. Kendall, A.C. Lane, J.W. Mitchell, George T. Quinby, Robert Robertson, R.S. Tarr, William P. Trowbridge, Jr., and J.B. Williams. H.M. Dyar reported to camp in March. The monthly salaries ranged from $\$ 100$ for Newell and Williams to $\$ 75$ and $\$ 50$ for the others.

Professor George E. Curtis of Washburn College, Topeka, Kans., who had formerly been connected with the U.S. Signal Service, was instructor in the use of meteorological instruments; P.H. Christie was disbursing officer. These two, with the 14 students, Charley Hines (cook), Frank Fisher and Juan Romero (laborers), and Dick Shumway (packer), made up the party of 20 .

Of the 14 men to be trained, only one, Farish of Arizona, was a westerner. Although the intention to select young men of good education and high general intelligence was carried out in the main, there were a few who did not meet those requirements. Since the positions were classified as temporary, they were not filled through the Civil Service Commission. With no Civil Service requirement, pressure was brought to bear on Powell to appoint men who would not otherwise have been selected in return for Congressional favors in obtaining funds for the Irrigation Survey. Four men were appointed in that manner. Of one of these Dutton wrote that "----- is the worst of all. He has been a clerk at perhaps $\$ 6$ per week somewhere. You may find him capable of relieving you of some clerical work."

Trowbridge, who was 27 years old, was the oldest, and Farish and Mitchell, who were 20, were the youngest of the group to be trained.
F.H. Newell, only 26 years old and the instructor, felt that he must wear whiskers in order to add dignity.

\section{Camp Routine}

As soon as camp was established, the daily routine of work was initiated. An observer was appointed for each day to make general meteorological observations and to read evaporation (using an improvised pan made from a large bread pan) and river temperatures at 8 a.m. and 4 p.m. All barometers were read every alternate hour for use in obtaining the elevation of the camp as well as for practice. Curtis was in charge of this work. In addition, the observer for the day guarded the camp and "policed" it. The other men of the party were engaged in work related to stream gaging.

J.B. Williams selected a site for measuring the Rio Grande. A raft was built of four empty barrels and held in position by a rope that was stretched across the river. In an effort to expedite the stream gaging instruction, personnel of the Irrigation Survey importuned every other government office for a current meter that might be loaned for use at Embudo, but none appeared for some time. As it was impossible, without a current meter, to keep the men busy in a camp intended primarily for instruction in stream gaging, a waiting period for most of the men ensued. About half of the men conducted chip-float measurements of velocity at different points. Others ran levels along the river to obtain the slope. One of the difficulties in slope measurements of discharge related to the simultaneous measurement of the water surface at the upper and lower ends of the reach. Tomato cans with tacks driven in them were sunk in the bank at the water's edge in an attempt to establish fixed points for determining the elevation of the water surface, but the results were unsatisfactory.

A team of mules named Jesus and Satan and a buckboard were early acquisitions. Some of the men scoured the surrounding countryside for game to vary the monotony of the standard Army rations, which consisted of bacon, flour, baking powder, lard, dried fruit, and an allowance for fresh meat, if available. Powder 
and shot were issued to be used in shooting the rabbits and prairie dogs that abounded in the area. Even with such diversions, it was difficult to keep a group of active young men contented.

At last persistence brought results, and the Hydrographic Office of the Navy Department (probably to rid itself of the Survey insistence as well as of an instrument for which it had no further use) sent out a large Haskell meter that was designed for use on deep rivers and to be handled by a winch mounted on a large boat. Its weight exceeded 100 pounds. Because the Rio Grande during the low water of winter had depths ranging from 6 to 12 inches, it is apparent that the major problem presented by the new acquisition was finding sufficient water to wet it, and not its use in measuring discharge.

The Haskell propeller-type meter was designed in 1887 by E.E. Haskell of the CGS. In a letter to the author, Haskell states:

In New York Harbor, where we had to contend with the swell from passing boats of all kinds, we found the Price meter very unsatisfactory. We had to do all of our work from boats that were rolling and pitching a good deal of the time, thereby pumping the meters up and down through the water giving them a greatly increased registration.

Haskell states further that he was familiar with the tests conducted by General A. Mackenzie on the upper Mississippi River with meters of the cup (Ellis) and propeller types; the propeller type was shown to be less affected by vertical motion. Accordingly, Haskell's design was a propeller-type meter, but he drew the blades out to a point, which gave the meter head a conical appearance in order to make the blades self-clearing from debris, and thereby eliminated the chief defect of earlier meters of that type.

\section{INSTRUMENTS AND METHODS}

The large Haskell meter loaned by the Navy Department that was entirely unsuited to use on the Rio Grande did, however, serve as a model for a smaller and more compact instrument that was devised by the combined efforts of the men during the winter. One change was that the registering mechanism was replaced by a simple electrical device that clicked, and the clicks were counted to determine the rate of streamflow. J.B. Williams had more to do with design than any other man, and spent a considerable part of his time in Denver while the modified meter was made there.

Before the smaller meter was completed, a usable meter was improvised by supporting the blades of the larger Haskell meter in a smaller hanger. Haskell never accepted the change in the hanger and stated (Trans. Am. Soc. C.E., vol. 47, p. 387,1902$)$ that the modified meter was not a Haskell meter. The first weight used to keep the meter in place was either a large stone or, more probably, a bundle of several fish plates purloined from the nearby railroad.

Shortly after the arrival of the Haskell meter, a meter of the type designed by Nettleton for the Colorado work was obtained from the manufacturers in Denver. This meter, known variously as the Nettleton, Colorado, or Lallie meter, was of the cup type similar to that used by T.G. Ellis on the Connecticut River in the 1870 's. The five cups revolved on a vertical axis geared to register wheels placed directly above the revolving cups. It was constructed for use on a rod, and the cups could be placed close to the streambed. It was so light and portable that it was used almost exclusively during the later months of the instruction camp and for some years afterward on shallow streams where a rod meter was suitable. The only improvements to this meter were the covering of the gear wheels with glass to keep out dirt and the substition of a small rod working inside a larger one for a cord inside a hollow rod as the mechanism for starting and stopping the registration. The meter thus improved was known as the Bailey meter, taking its name from the manufacturer. Although most of the first current-meter work was done with either the Colorado or the Bailey meter, the original Haskell (rebuilt with special hanger) and two of the small Haskell meters were used later. W.H. Hall loaned to the Irrigation Survey a 2-bladed meter that he designed along the lines of the original Henry meter used in California, but this meter was not used. 
The integration method was used with the Colorado meter for determining the mean velocity in the vertical, as was done by the State engineer of Colorado. This method did not originate in Colorado, but had previously been used in Europe and also by T.G. Ellis on the Connecticut River in the 1870's. In using the integration method, the meter was first lowered through the water from the top to the bottom, then raised to the top, and this operation was repeated two or three times without pause. Each such observation was repeated from 4 to 6 times.

In the first computations of discharge, the mean velocity in the entire cross section was obtained and that value was multiplied by the area of the cross section. Somewhat later, however, this method, which had been used in the classic studies of A.A. Humphreys and H.L. Abbot on the Mississippi River in the 1850's, was superseded by the partial-area method in which the bottom was assumed to be a straight line between soundings and the end sections right triangles. These partial areas were 5, 10, or 20 feet wide, depending on the width of the river. The velocity was measured in the center of each such area.

Measurements were made from a boat or raft that was held in position by a rope or cable, and the points of soundings and velocity readings were indicated by overhead tag lines. The first measurements at the camp were made at the Embudo site "about one-half a mile upstream from the camp" (USGS Prof. Paper 778, p. 8, 1972). A few weeks later, early in January 1889 , a new site was selected half a mile downstream opposite the railroad station and frequent measurements were made there. An inclined staff gage was installed in January 1889 and thus the Embudo station became the first regular streamflow-gaging station installed by the USGS. Within 1 week or 2, a nilometer or recording gage was installed close to the staff gage. This recording gage was of the horizontal

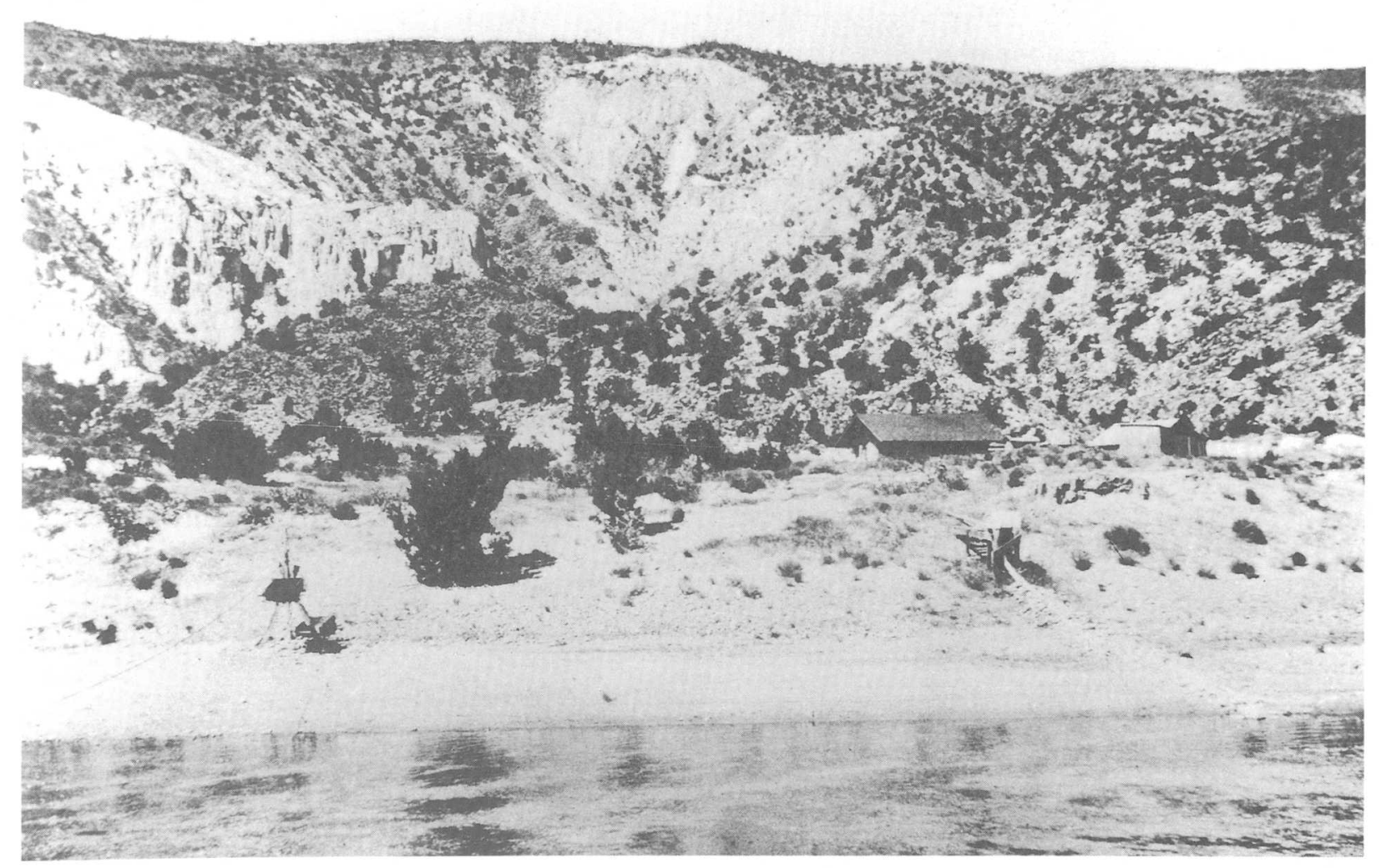

Embudo gaging station on the Rio Grande, N. Mex., about 1889). (From USGS Professional Paper 778, 1972. Photograph number "Water-Supply Papers 236," USGS Photographic Library.) 
cylinder type similar to the tide gages used by the CGS, and probably was obtained from that organization. Farish, in a letter to the author circa 1938, wrote that a small well was dug in the 7-foot bank close to its edge and connected with the river by a trench about 15 feet long, and a small wooden shelter for the nilometer was constructed over the well. Farish further wrote that the operation of the nilometer, however, was unsatisfactory, due chiefly to the drying of the ink on the recorder pen, and its use was discontinued. The ink had evidently been made for use in the humid climate in which the CGS operated, and was unsuitable for use in arid New Mexico.

At first the Egyptian term nilometer was used to denote any scale for measuring river stage. Dutton stated (USGS 10th ann. rept., pt. 2, p. 81, 1890) that Herodotus mentioned the nilometer in his writing on Egypt, but a somewhat careful search by the author through two different translations of the works of the "Father of History" has failed to verify the statement. Soon, however, the term nilometer was applied by Irrigation Survey hydrographers to recording instruments only and staff gages were known as "gauge rods." This use of the term nilometer continued in the Survey until the personnel of the stream gaging group changed following the creation of the Reclamation Service.

Because of the small fluctuations in flow of the Rio Grande during the winter, it was impossible for those assigned to the Embudo camp to develop a rating curve or to compute the daily discharge from gage heights. This was done in Washington, D.C., during the following winter (1889) after a wider range of measurements had been made.

In addition to measuring the discharge, many velocity readings were made at different depths from which vertical-velocity curves were constructed. Horizontal-velocity curves showing the difference in velocity at the same depth across the stream were also plotted, as had been done by A.A. Humphreys and H.L. Abbot. The discharge was also computed by Kutter's formula for comparison with the current-meter results. The Embudo station was located in a canyon where the sun did not penetrate until afternoon hours during the short winter days. Consequently, the ice that formed along the edges during the night remained until afternoon. Much trouble was caused also by the freezing of the meter.

One bond of sympathy between the pioneers of the Embudo camp and the members of the Water Resources Branch today [1938] is found in a note written in January 1889, which was short and to the point: "Stop watch dropped in river." Another incident that strikes a responsive chord at the present time was Dutton's explanation of the failure to receive certain forms: "There is a deadlock at the Government Printing Office, as there generally is, and it will take time to break it."

As the men became more or less proficient in stream gaging, they were sent away from Embudo on short trips to measure other streams. One of the longest of these trips, which was made by Robertson, Quinby, and Farish using the buckboard and mules and carrying a camp outfit, extended as far as Antonito in the San Luis Valley in Colorado, and included all side streams en route. The original Haskell meter mounted on a rod was used. While trying to ascertain why the meter wouldn't operate, the men took it apart and the many small pieces were placed in Quinby's hat for safety. When the parts were being reassembled, a vagrant zephyr upset the hat, spilling the parts in the sand. All were recovered but one tiny screw. The three men spent an equivalent of 9 man-hours sifting sand through their fingers before finding it. Evidently spare parts were not carried in those days. F.H. Newell reported on the results of this trip that " $\mathrm{Mr}$. Robertson has returned from Antonito and reports that he has not been able to use the Haskell meter at all on this trip. The constant journey, in spite of careful packing, disabled batteries, register, and wheel. I have just gone over each part and got the pieces in place again. A mechanic should be in each party that takes this meter as our experience has shown that an ordinary man cannot manipulate it successfully on a long trip. The other meter works at times. Whatever the results may be!"

As a result of the experience with both the Haskell and the Bailey meters, 10 more of the 
Baileys were ordered. They were more convenient to use and less liable to be disarranged than were the Haskell meters at that time.

The first accident in USGS stream gaging, which fortunately was not serious, was reported during the latter part of April as follows:

While Messrs. [J.B.] Williams and Farish were gauging [sic] yesterday with the Colorado meter, the raft became unmanageable in the swift current and the gaugers jumped for the rope as the only means of safety. While making their way to the shore, the rope (a new one) broke and left them to swim the remainder of the distance. Farish, who up to that point had held on to the meter, was then obliged to let it go in 5 feet of water. It could not be reached. The watch and note book carried by [J.B.] Williams were also lost.

Dutton showed his interest in the work at the camp by visiting it several times during the 5 months of its existence. Whenever he was in camp, he would lecture on some scientific topic. Powell was a visitor on one memorable occasion and gave a graphic account of his trip through the Grand Canyon.

On March 24, 1889, F.H. Newell was detailed to Utah and left Curtis in charge of the camp while the men were awaiting assignments to their new duties. This period, which lasted until the latter part of April, was chiefly one of waiting and the only work conducted was an occasional discharge measurement.

The unquenchable spirit of youth demanded an outlet, and with the party in charge of a man devoid of a sense of humor, it was natural that many pranks should be played at his expense. One of these pranks consisted of hiding all of the camp mules in a place provided in advance with baled hay, and then having one of the men announce in great excitement that the mules had been stolen. Curtis immediately telegraphed that alleged fact to Washington. Early the next day, everybody started out to hunt for the mules and, after loafing all day out of sight of camp, returned with the mules and announced that they had finally found them. Curtis again telegraphed Washington announcing the recovery of the mules and commending the men for their diligence in the search.

Another prank had to do with the sunshine recorder-one of Curtis' prized instruments. The instrument was so manipulated that, when the record was developed, it showed a very irregular line ending with "Go to Hell," thereafter known as the Sun's message to Curtis.

Finally, late in April, orders were received from Dutton assigning 11 of the original party to different parts of the West. Of the other three, one had left the camp before it ended, a second had sufficient excitement out of his trip west and was ready to resign, and a third didn't care to spend the rest of his life "jiggling a meter" and was transferred to the Topographic Branch.

The men left camp one by one as arrangements were finalized for their new work. The last view that one of them had was the almost deserted camp in the foreground of which stood a dejected looking burro, on his head a straw hat through which his ears protruded, and on each pair of legs overalls held up by string.

It had been expected that Curtis would be sent to the Washington, D.C., office to be in charge of computations. He was instead transferred to other work connected with the Irrigation Survey and does not appear again in the annals of the Hydrographic Survey.

Of the men selected for the hydrographic work, only F.H. Newell was considered to be a permanent member of the USGS because he was the only one given a Secretary's appointment. Dated April 16, 1889, when instruction at the Embudo camp had been completed, Dutton wrote to F.H. Newell:

In the progressive organization of the Survey the Director is of the opinion that the permanent officers should be classified and be regularly appointed by the Secretary of the Interior.

In this branch of the work it is designed, if you consent to accept the appointment, to appoint you an assistant engineer at $\$ 1,500$. In submitting his recommendation to the Secretary, the Director accompanies it with a statement of the record of the nominee showing 
that he is as the law required, 'a scientific man or a professional expert.'

\section{Further WORK BY THE HYdrographIC Survey}

Congress appropriated $\$ 250,000$ in March 1889 for further work by the Irrigation Survey, which included that of the Hydrographic Survey. In making the request for additional funds, Powell asked that $\$ 40,000$ be made immediately available: His reason for this was that "the season for irrigation will be largely passed this year before the first of July, so that for the new work I will lose the observations to be made during the season of irrigation. I want to employ at once this spring in all the regions of the country, stream-gaugers [sic], men who are gauging or measuring the amount of flow of those streams between now and the first of July, during the season of irrigation. I have enough money to keep my other force at work" (report of special committee of the U.S. Senate on the irrigation and reclamation of arid lands, S. Rept. 928, 51st Cong., 1st sess., May 8, 1890).

\section{Selection of Streams to be Investigated}

One of the pressing problems of water supply related to the Rio Grande in the vicinity of El Paso, Tex. It was alleged that the use of water for irrigation in Colorado and northern New Mexico in the Rio Grande basin had depleted the flow of the river to such an extent that longestablished privileges in its use by the inhabitants along the river in southern New Mexico and in the vicinity of El Paso, both in Texas and in Mexico, were seriously affected, and that the friendly relationship with Mexico was endangered. In an attempt to remedy this situation, the Irrigation Survey hired Major Anson Mills, a civil engineer of the U.S. Army, to survey a proposed reservoir site near El Paso. A man was detailed also to devote his entire time to measuring the discharge of the Rio Grande at El Paso. The aridity of Arizona, together with the possibility of large irrigation projects on the Salt,
Gila, and Verde Rivers, made it necessary to begin investigations in that State as soon as possible.

The possibilities of extending irrigation in Colorado, where the State already had a streamgaging system, offered an opportunity for possible cooperation. The State engineer, then confining his efforts chiefly to the South Platte River basin, also maintained a station on the Arkansas River near Canon City, Colo. Reduction in State funds, however, required him to discontinue work outside the South Platte River basin, and he wanted the USGS to take over the Canon City streamflow gaging station (from F.H. Newell correspondence files). The upper Rio Grande basin in Colorado was also selected for study because of the international aspects of the river. Other principal rivers of the arid West that afforded irrigation possibilities were also selected for gaging.

\section{Stream Gaging During 1889}

Under date of July 27,1889 , Dutton announced that "officers engaged upon hydrographic work will be designated as hydrographers and assistant hydrographers." Although 11 of the original party were assigned to stream gaging, changes were made soon afterward that resulted in the following assignments for 1889

\begin{tabular}{|c|c|}
\hline $\begin{array}{l}\text { Arkansas River } \\
\text { basin }\end{array}$ & $\begin{array}{l}\text { Robert Robertson } \\
\text { and R.P. Irving }\end{array}$ \\
\hline $\begin{array}{l}\text { Upper Rio Grande } \\
\text { basin }\end{array}$ & George T. Quinby \\
\hline $\begin{array}{l}\text { Rio Grande at } \\
\text { El Paso }\end{array}$ & H.M. Dyar \\
\hline Gila River basin & W.A. Farish \\
\hline $\begin{array}{l}\text { Truckee-Carson } \\
\text { basin }\end{array}$ & $\begin{array}{l}\text { William P. Trow- } \\
\text { bridge, Jr. }\end{array}$ \\
\hline Utah Territory & $\begin{array}{l}\text { Frederick H. Newell } \\
\text { and T.M. Bannon }\end{array}$ \\
\hline Snake Rive & L.D. Hopson \\
\hline $\begin{array}{l}\text { Upper Missouri } \\
\text { basin }\end{array}$ & J.B. Williams \\
\hline
\end{tabular}

Thus 10 of the 15 men who attended the camp of instruction conducted stream gaging during the first year. The comparative freedom 
of the resident hydrographers that has always characterized the unit of the USGS charged with the study of water had its inception in the work of the Hydrographic Survey. The instructions that accompanied the men's assignments were sufficiently broad to allow each to conduct the work in his territory in accordance with the necessities imposed by the notorious if not the noted "local conditions," and to exercise such choice of methods as would beget a personal pride in the accomplishments. Monthly reports to the Washington, D.C., office showing the progress of the work were required. Besides measuring the rivers, the hydrographers were instructed to keep records of evaporation, determine the silt content, and collect general information and data on the duty of water.

The first established station was on the Arkansas River near Canon City, Colo., in April 1889 , at the site of the station previously maintained by the State. A wire cable was stretched across the river from which a box was hung for use in making discharge measurements. Because the Bailey meter on a rod was used, it was necessary to have the box close to the water at all stages, so the box was suspended by pulleys so it could be lowered to the proper position. This was the first cable with a suspended car erected by the USGS, the Embudo cable having been used to hold a raft. The assignment of two hydrographers to the Arkansas River basin made it possible to install a number of stations promptly, and three were established during May 1889.

The Rio Grande stream-gaging station (cable and boat) at old Fort Bliss near El Paso, Tex., was established by J.B. Williams and Dyar in May. Dyar remained there as resident hydrographer; his only duties were to measure the discharge and the silt content of the river. Measurements were made at every considerable change of stage, and also at the same stage when the river was rising and falling. As Dyar states (written commun., ca. 1938), the work was rather unofficially under the direction of Anson Mills, and a part of the basement of the Anson Mills' home was used as a laboratory for the silt determinations.

Trowbridge established two stations in the Truckee-Carson River basin in May. Frank
Harrison had been sent there in April, but he had only made a reconnaissance and then dropped out of stream gaging. No other stations were established in that basin during 1889 because W.H. Hall, who was the supervisor of the work of the Irrigation Survey in that region, was apparently more interested in miscellaneous measurements of irrigation ditches and in reports on the operation of their headgates than in meter measurements at regular river stations.

Floods in the Gila River basin during 1889 delayed until August the establishment of stations there. It was necessary to erect cables from which boats were operated and, after the experience with a hemp rope at Embudo, wire cables were used. A near accident with a boat used in measuring a flood in the Gila River at the Buttes, Ariz., is described by Farish (written commun., ca. 1938) as follows:

I measured this flood from the boat with Charley Whitney to help me. He was very nervous as the boat was jumping and plunging like a bronco. In trying to reassure him and demonstrate how safe it was I walked out on the plank projecting over the bow, from which I operated the meter, and was thrown off. I went under the boat with the current and was just able to catch the stern of the boat and clamber in.

During that flood, Farish had no weight heavy enough to hold the Haskell meter in place, and improvised one from a bar of silver bullionhe was camped at that time at the site of the abandoned Silver Bell smelter. A friend of Farish had found a "frozen" charge that had been thrown away and had smelted it in a crude adobe furnace. In the emergency, the friend turned this bar over to Farish who recast it in an ordinary camp kettle, bored a hole in its center for the meter rod, and used it instead of a lead or iron weight as long as the Gila River was in flood. Computations show that it weighed about 80 pounds and was worth about $\$ 1,200$ at the then-value of silver, which was $\$ 1$ an ounce, according to Farish, making it undoubtedly the most valuable weight ever used in making a discharge measurement. Continued floods hampered the installation of gaging stations throughout that entire year, 


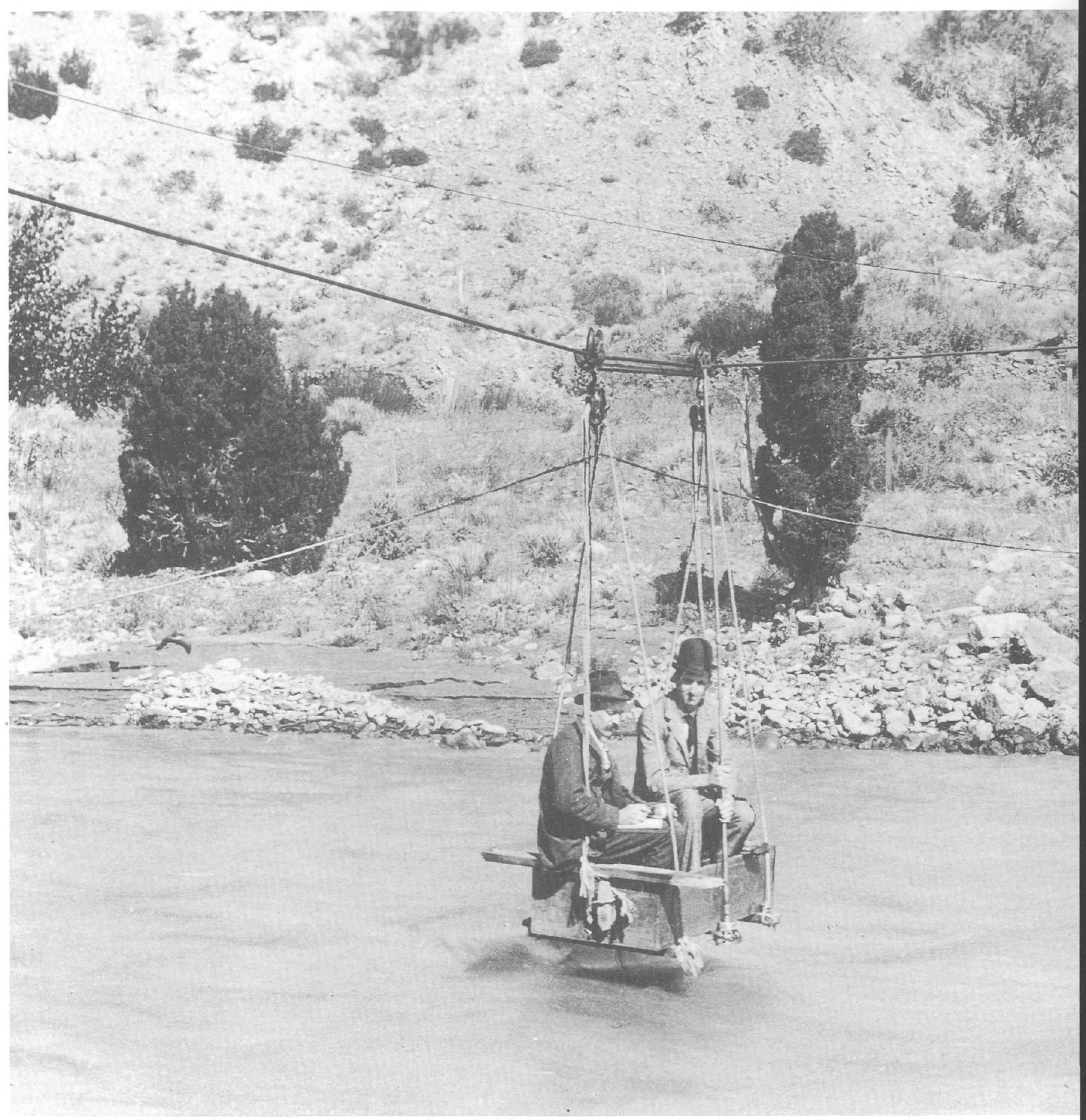

Gaging station Arkansas River at Canon City near Canyon, Colo. (Photograph plate $1 B$ in WSP 56, 1901. Photograph number "Water-Supply Papers 27," USGS Photographic Library.) 
although attempts were made to install them in the Salt and Verde River basins.

The establishment of stations in the upper Missouri River basin was delayed until August. Tarr, who had originally been assigned to that area, was detailed to other work and later resigned. It was not until J.B. Williams had erected cables on the Rio Grande and the Snake River that he was available for work in the upper Missouri River basin. Four stations were established in that basin in August and September.

The work in Utah was pushed actively and eight stations were established during the year. This maximum number was due not only to the assignment of two hydrographers in that Territory, but also to the fact that F.H. Newell had convinced the Mormon church authorities of the value of systematic stream gaging in connection with irrigation, and had arranged limited cooperation with various communities.

Elwood Mead, Territorial engineer of Wyoming, requested the USGS to extend stream gaging to Wyoming and offered to cooperate (written commun. from Dutton to F.H. Newell, date unknown). F.H. Newell was instructed to visit Mead and arrange for cooperation, if possible. Mead had made miscellaneous measurements in Wyoming in 1888 and, during that winter, had established a gaging station on the Laramie River at Woods Landing. The cost of installing this station was subsequently paid by the USGS, but that seems to have been the extent of the cooperation arranged by F.H. Newell (no stations were established in Wyoming during 1889).

No cooperation was arranged in Colorado as that State preferred to continue the work in the South Platte River basin without duplication or overlap by the USGS. This preference, as reported by a subsequent State engineer who was familiar with the State work at that time, was due to the State's objection to F.H. Newell's requirement that the original records obtained at cooperative stations be filed in Washington (L.G. Carpenter, oral commun., ca. 1938).

No work was conducted in California except in the Truckee-Carson River basin. W.H. Hall detailed Trowbridge to work in the basin, chiefly in Nevada.
In addition to the measurements made and other work conducted in establishing and operating the 26 regular stations, many miscellaneous measurements were made of other streams. No winter measurements were made after ice had formed because the art of gaging under ice cover had not yet been developed, nor was the value of winter records then recognized. At the end of the field season, F.H. Newell was recalled to Washington, D.C., after inspecting the work of several districts.

\section{Stirieam Gaiging DutiRING 1890}

In spring 1890 , stream gaging was pushed with renewed energy because records of discharge were urgently needed by the Engineering Survey as a basis for designing irrigation works. The only changes in personnel during the field season were in the upper Rio Grande basin where Quinby was succeeded by Dyar who, when illness forced him to resign, was later succeeded by W.B. Lane.

The supervision of the El Paso station was taken over by Anson Mills, who was making surveys and plans for the proposed international reservoir. He hired H.P. Crofts as resident hydrographer. The expenses of this station, however, continued to be paid by the Irrigation Survey.

After Hopson drowned, F.M. Smith was placed in charge of the work in Idaho. Stream gaging was expanded in every district except Utah; the greatest expansions were in the Arkansas, Truckee-Carson, and Snake River basins. The stations were equipped chiefly with inclined staff gages. A water-stage recorder, presumably of the type designed by Mead for use in Colorado and Wyoming, was installed on the Rio Grande near Del Norte, Colo., but better results could be obtained by daily staffgage readings. This was the second recorder installed during the life of the Irrigation Survey.

When the Hydrographic Survey was discontinued in August 1890, 44 gaging stations were being maintained by 9 hydrographers and assistants, 7 of whom bad been trained at the Embudo camp. F.H. Newell had graduallyg been 
given full charge of the work and by the end of the period was issuing the necessary instructions to the hydrographers. The records were published in the annual reports of the Survey. In publishing these records, the units "secondfoot" and "acre-foot" were adopted. Both units are believed to have been originated by the USGS, although possibly British engineers in India originated acre-foot.

\section{Denver Rating Station}

During the life of the Irrigation Survey, the current meters were rated at the Lake Archer reservoir of the Denver Water Company where a rating station had been constructed by Nettleton, courtesy of that company. A narrow slit about 150 feet long was made in the wooden covering of the reservoir and a light track was laid on each side. A small car, situated so as to carry the meter vertically in the center of the opening, was pulled forward and backward by hand on the track at uniform speeds using the ropes that ran to a drum. A course 100 feet long was laid off with sufficient track at either end to enable the operator to bring the car to the desired speed before entering the measured course. As the meter entered the course, the register and stop watch were automatically started and continued until the meter passed the 100 -foot mark, when the register and watch were stopped. The operation was repeated at different rates of speed. The ropes and drum were soon discarded, however, and the car was operated by direct manpower.

The graphical rather than analytical method was adopted for computing the rating. The analytical method may have been more accurate, but it involved considerable time as well as skill in mathematics, which might easily have led to gross errors when used by the average hydrographer [during the late 1800 's]. The graphical method was simpler and quicker, and had the advantage that diagrams always have over columns of figures: the discrepancies were conspicuous (USGS 11 th ann. rept., pt. 2, p. 11-12, 1891).

The Lake Archer rating station was used until 1909, after which date all Survey meters were rated in Washington, D.C., to insure uniformity. By 1903, however, it was discovered that the Lake Archer station was so placed as to be influenced by the slight current toward the outlet. Therefore, M.C. Hinderlider selected a new site far from the outlet and built a new track and car, the cost of which was paid by the USGS.

\section{IMPROVEMENT IN EQUIPMENT}

During this period, the most important changes in station equipment were the substitutions of wire cables for hemp ropes and a suspended car for a boat or raft. The first suspended car, as stated earlier, was built by Robertson on the Arkansas River near Canon City, Colo. It was the only one that was equipped with pulleys for lowering it to the water surface. The first car placed at a fixed distance from the cable was installed by Farish on the Salt River in Arizona in 1890, and was a box 12 inches deep, 4 feet wide, and 6 feet long suspended by ropes from sheaves that rolled on the cable.

During high water, the Haskell meter with cable was used. Trowbridge (oral commun., ca. 1938) designed a small rod-suspended meter with a single curved blade and used it almost continuously in his work. This meter was evidently a modification of the Hall meter, which was based on that of the Henry. The meter was left in Sacramento, Calif., when the work closed and nothing further is known about it.

Another piece of equipment designed by Trowbridge in accordance with W.H. Hall's ideas was a traveler by which means the hydrographer, while standing on the bank, could operate the meter from the cable stretched across the stream-moving it to the proper point in the cross section and lowering it to the desired depth in the water (Trowbridge, oral commun., ca. 1938). This traveler was used experimentally on the Tuolumne River at Modesto, Calif., a station that had previously been maintained by the State engineer of California. A similar device was tried by Farish on the Gila River at the Buttes 
station in Arizona. Although it worked satisfactorily for streams of moderate width, Farish (written commun., ca. 1938) made no further use of it because he preferred a boat and cable. A traveler was used a few times during the following year in measuring the Potomac River at Chain Bridge near Washington, D.C. (USGS Bull. 140, p. 57, 1890). Although W.H. Hall was anxious to have the USGS adopt the traveler, no further use was made of it. The cable and car had in general succeeded the cable and boat, which lessened the risk to hydrographers' lives, W.H. Hall's chief consideration in advocating the traveler. W.H. Hall was still a believer in the possibilities of the traveler, however, and in $\mathbf{1 9 2 2}$ he discussed the matter with the author in an endeavor to again interest the USGS in its use. In order to complete the history of the traveler to the time of the writing of this history [1938], it may be stated that USGS hydraulic engineer Charles $H$. Pierce made some use of it in Connecticut and Vermont from 1916 to 1919 .

In addition to measuring the streams, evaporation stations were maintained at 17 points. The floating 3-foot square pan, 18 inches deep, was designed for this purpose. Rainfall was measured at each evaporation station.

\section{End of the Irrigation Survey}

As stated previously, the Act that created the Irrigation Survey contained the seeds of its own destruction-the provisions for withdrawing, from entry, lands suitable for irrigation and for reservoir sites. The desire for early withdrawals caused Powell to issue the following instructions to Dutton on May 25, 1889 (USGS 10th ann. rept., pt. 2 , p. 55,1890 ):

The preliminary withdrawal of reservoir sites is an operation which should be conducted with secrecy and dispatch and every effort made to avoid being anticipated by jumpers and speculators.

Because it was not known at first what lands would be classified under this heading, the Attorney General ruled that all land must be withdrawn until the irrigable lands and reservoir sites could be designated. This ruling practically put the local land offices out of business because they depended on entry fees. It also created great antagonism among sheep and cattle owners who wanted the open range left intact.

Another cause contributing to dissatisfaction among local settlers was the rampant speculative spirit that has been ever present in the newer parts of the country since colonial days. When the Irrigation Survey was first proposed, the settlers of the arid regions thought that the water supply would be sufficient to irrigate all arable land. As the survey of canals proceeded, speculators filed on the surrounding land as fast as even tentative lines were staked out, even though the land was not subject to entry (F.H. Newell, oral commun., ca. 1938).

Partially because of this dissatisfaction, but chiefly because of the general interest in irrigation aroused by the creation of the Irrigation Survey, the Senate in 1889 appointed a special committee to investigate the whole subject of irrigation. This committee held hearings throughout the West and in Washington, D.C., and presented to Congress a majority report (report of Special Committee of the U.S. Senate on the irrigation and reclamation of arid lands, S. Rept. 928, 51st Cong., 1st sess., May 8, 1890) that voiced the dissatisfaction of the settlers as follows:

As the matter now stands, no entries can be made of, or title perfected to, any public lands of the United States requiring irrigation subsequent to October 2 , 1888. The people residing in two-fifths of the area of the United States wherein lie nearly all the public lands, are, by the construction given to this law, prevented from acquiring title to any public land fit for cultivation, and all settlements and improvements upon such land are suspended until further legislation can be had.

The report condemned Powell for diverting large sums of money from the work of the Hydraulic Survey, which was directly concerned with irrigation, in order to augment the funds for topographic mapping so that the latter work might be increased, chiefly in the arid regions. The purpose of this alleged diversion of funds was to help the Hydraulic Survey, particularly in segregating reservoir sites. 
The engineers in the Engineering Branch, however, felt that their work was not helped by having a greater number of topographic maps as much as it was hampered by the lesser funds thus available for the Hydraulic Survey.

Members of the committee believed irrigation pertained to agriculture instead of geology and differed from Powell as to the conduct of the Irrigation Survey, and they recommended the transfer of the Irrigation Survey to the Department of Agriculture (DOA) under the direction of a Commissioner of Irrigation to be appointed. They recommended also that, because the Weather Bureau was shortly to be transferred to the DOA, the hydrographic investigations be transferred also to the DOA in the belief that all information needed for the Irrigation Survey would be obtained without considerable extra cost.

That Powell had ardent supporters on the committee is indicated in that a strong minority report commended his conduct of the Irrigation Survey and opposed the recommendation of the majority. Thus the issue was put squarely before the Congress in what may be considered one of the early struggles over conservation. The final result was that the section of the Act of October 2,1888 , authorizing the segregation of lands for irrigation was repealed (USGS Bull. 131, p. 12,1895 ), and no appropriation was made for a continuation of the Irrigation Survey.

In a letter to hydrographers dated July 18 , 1890, F.H. Newell described the fight in Congress over the Irrigation Survey and continued, "In the present uncertainty, I would, however, advise all hydrographers to prepare to close up this work on short notice. Finish gaugings [sic] which are necessary to complete a series and concentrate all efforts during the few remaining days on the most important unfinished work. Transmit to this office all gauge height observations now on hand, gauging results, complete notebooks, and all other matters not needed. The present appropriation ceases on the day the President signs the Sundry Civil bill and, whether we continue or not, all accounts should be made up to that day."

In a letter dated August 8, F.H. Newell wrote:

The conference committee reported on the Sundry Civil bill to Congress with agreement on all points excepting land and irrigation questions. There will be a new committee appointed to settle these. There is no prospect of continuing the irrigation survey as a whole, but the arid region topography will probably go on-and we hope the hydrography also. Mr. Nettleton has resigned and the Director has asked me to carry on the work for the present on the same lines as heretofore. All hydrographers will please report directly to me in all matters-including rainfall and evaporation results.

On August 22, F.H. Newell wrote further:

I greatly regret to inform you that the hydrographic work will undoubtedly be cut off shortly. The property will probably be turned over to the nearest topographers. Please pay your observers for the month. Request your observers to send in reports weekly to this office until further notice. (It is hoped that a portion of this work can be carried on by active cooperation of the topographic field parties, using our meters).

A final communication from F.H. Newell dated August 26 stated: "The conference committee finally came to an agreement yesterday. The bill provides (only) $\$ 325,000$ for topography, onehalf of which is to be expended west of the 101 meridian. By this the irrigation survey is brought to a close as far as the engineering and hydrographic divisions are concerned."

The differences of opinion between Dutton and Powell regarding the management of the Irrigation Survey were probably responsible, in part, for the order issued by the War Department directing Captain (now Major) Dutton to report to the Ordnance Office on July 23, 1890, before final action with respect to the Irrigation Survey was taken by the Congress. Dutton's detail of 15 years to the USGS and one of its predecessors was thus closed. The hydrographers turned over their equipment, mules, and horses to the nearest topographic field parties. Of the nine hydrographers, Farish, Trowbridge, Bannon, and A.C. Lane transferred to the Topographic Branch and continued in that work for a year or more. Robertson and Irving returned to Virginia. Nothing is known of the other three (Quinby, Smith, and Williams) except that Williams committed suicide shortly afterward. 


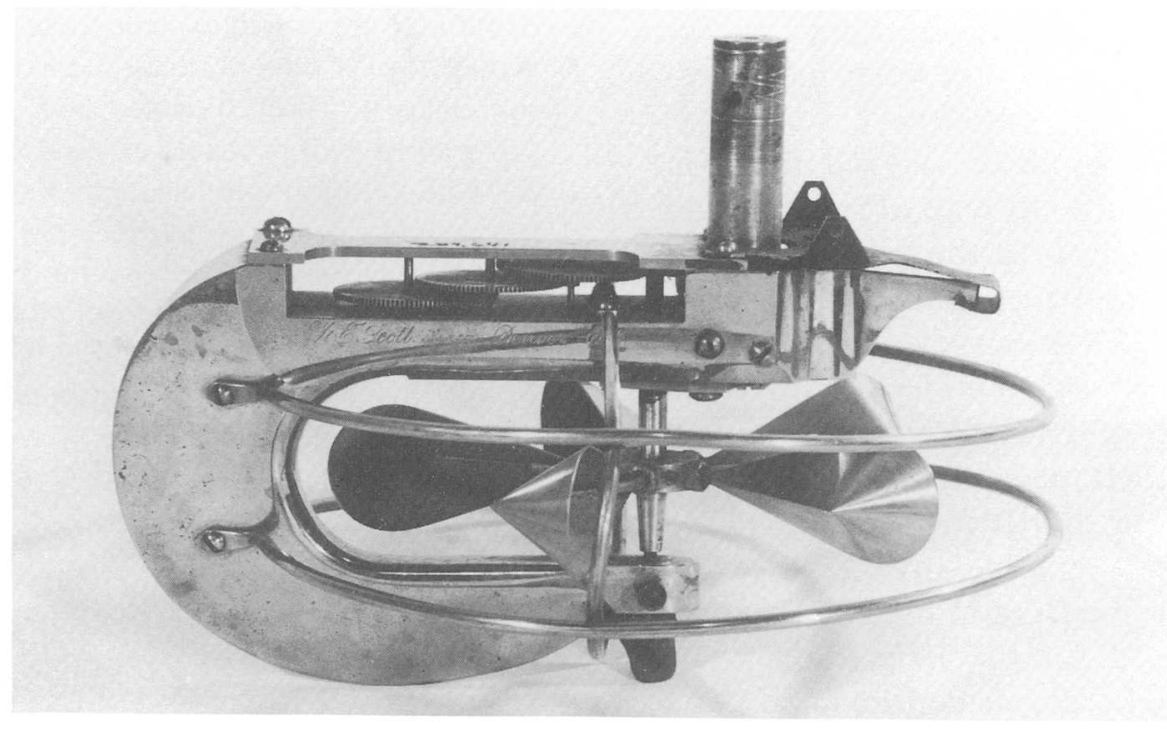

Edwin S. Nettleton's Colorado current meter. Nettleton, the State engineer of Colorado, designed his current meter in 1883 . It was manufactured by W.E. Scott \& Co. of Denver, Colo. Most of the discharge measurements made at Embudo, N. Mex., were accomplished with Nettleton's Colorado meter. (Photograph fig. 13 from Bull. 252: Contributions from the Museum of History and Technology, Paper 70, "William Gunn Price and the Price Current Meter,' by Arthur H. Frazier, 1967.)

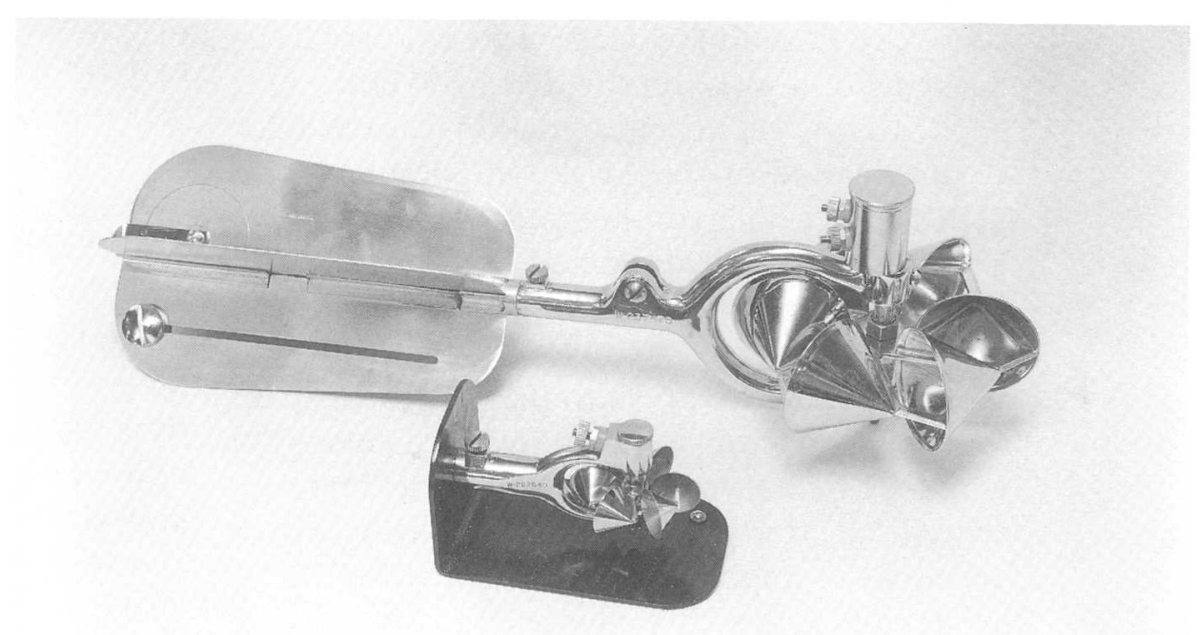

Type-AA Price current meter with a Pygmy meter on a carrying bracket in the foreground. This meter, changed in September 1937 by Rha L. Atkinson, had a reduced-indiameter lower bearing that was moved into a deeper cavity within the hub assembly. This modification further increased the volume and depth of the air pocket. The model was manufactured by W. \& L.E. Gurley and identified in their catalog as no. 622-AA. (Photograph fig. 38 from Bull. 252: Contributions from the Museum of History and Technology, Paper 70, "William Gunn Price and the Price Current Meter," by Arthur H. Frazier, 1967.) 


\section{Part VI-Lean Years (1890-94)}

The history of the 4 years 1890 to 1894 was unlike that of any other 4-year period antecedent to the Water Resources Branch. Without an appropriation for stream gaging, it was only through the untiring zeal of F.H. Newell and the sympathetic attitude of those in charge of the Topographic Branch that stream gaging continued even in an extremely attenuated form. In July, when it was apparent that the Congress would seriously cripple if not entirely discontinue stream gaging, Newell considered ways and means for carrying on. Henry Gannett and A.H. Thompson, who had charge respectively of the eastern and western divisions of topographic mapping, were sufficiently interested to finance a small amount of stream gaging with their funds (F.H. Newell, oral commun., ca. 1938). Records from Senate committee hearings indicated that it was comparatively easy at that time to divert funds from one use to another if those in charge saw fit to do so.

In order to tend to the details of the work with which F.H. Newell never concerned himself, Cyrus C. Babb, a recent graduate of the MIT, was given an appointment as field assistant on July 7, 1890. As this was a so-called temporary position, no civil service examination was required.

At the end of September 1890, F.H. Newell's title was changed from assistant engineer to topographer because his salary was to be paid from topographic funds. At about the same time, in order to conduct work in which he was deeply interested as well as to relieve the strain on topographic funds, F.H. Newell was transferred temporarily to the Census Office to direct a census of irrigation in the United States. This transfer lasted 6 months or more. The Census work was conducted in his USGS quarters on a per-diem basis, and he was able to supervise the stream gaging, which at first consisted chiefly in preparing for publication the records previously collected as well as those few records of gage height obtained after the end of the Irrigation Survey. No field work was conducted during the remainder of 1890 except on the Rio Grande at El Paso, Tex., where measurements were made by the local hydrographer.

In spring 1891, a small fund for expenses was made available by the Topographic Branch. Heretofore the Survey's stream-gaging activities had been limited to the arid west, but F.H. Newell felt that if he was to succeed in obtaining future funds for hydrography, it would be necessary to enlist eastern support by showing the value of streamflow records in the East. He felt also that the more experimental work on methods of recording streamflow was needed. The logical result was the establishment of a gaging station on the Potomac River almost within the shadow of the Capitol whence the hoped-for assistance was to come.

\section{First Discharge Measurement Made by the Survey In the East}

Before any of the proposed gaging stations in the East could be established, an unusual flood occurred in the Potomac River and an attempt was made on April 3, 1891, to measure the flow at Chain Bridge, 3 miles above Georgetown, District of Columbia, using a Haskell meter. The velocity was so great that it was difficult to submerge the meter. A 60pound iron weight was carried downstream as far as the rope could be let out and would not sink more than a few inches beneath the surface. Finally, the meter was attached to a 1 -inch iron rod and held in place by means of a stay line. Before the measurement was completed, a portion of the meter was carried away by drift (USGS Bull. 140, p. 57, 1896). This was the 
first discharge measurement attempted by the Survey in the eastern part of the country.

\section{Chain Bridge Gaging Station}

The first Survey gaging station in the East was established on May 1, 1891, on the Potomac River at Chain Bridge. A horizontal scale attached to the bridge was combined with a wire and weight for measuring the stage. This was the first chain or wire gage. Because of the tide, which had a range of about 3 feet, three readings a day were made at first, the readings being scheduled so that the heights of high and low tides were recorded. The so-called Hall traveler was first used in making the discharge measurements. Trowbridge, who had constructed the original traveler in California, installed this device with Babb's help (USGS Bull. 140 , p. 57, 1896). The many details of operating a meter by pulleys suspended from a cable with a 250 -foot span made it impractical for one man to operate the traveler on a river as large as the Potomac, so the device was soon abandoned and subsequent measurements were made from the bridge. The station was maintained until the end of 1893 when it was discontinued because of the lack of a reliable observer (USGS Bull. 131, p. 89, 1895).

Another station was established on Rock Creek in Washington, D.C., in July 1892 at the request of the District Commissioners (WSP 15, p. 22, 1898), and a water-stage recorder was installed there in the following month. If the recorders tried during the Irrigation Survey are excepted because they were unsuccessful and were therefore abandoned, then the recorder on Rock Creek was the first installed by the USGS. The Rock Creek station operated until November 1894.

\section{Other Activities}

There was no field work in 1892 until the latter part of that year; the exceptions were at El Paso, Tex., and a few miscellaneousdischarge measurements near Washington, D.C. The office work consisted of special studies and the computation of records, using old rating curves of the few stations for which records of gage height were obtained.

At about this time, F.H. Newell adopted the spelling "gage" instead of "gauge." As he informed the writer, "gage" was the Saxon spelling before the " $u$ " was inserted as a result of Norman influence on the language. F.H. Newell may have been influenced, however, by the adoption of "gage" in the Standard Dictionary.

Babb investigated the relation of the runoff of the Potomac River to the rainfall, and computed the runoff of the Savannah River at Augusta, Ga., from 1884 to 1891 , using Weather Bureau stage records and Army Engineer discharge measurements. He computed also similar records for the Connecticut River at Hartford, Conn., from 1878 to 1886. The status of one-half the hydrographic force changed from temporary to permanent when Babb was appointed assistant topographer on December 18, 1891 (Babb, oral commun., ca. 1938).

Funds for expenses were again made available by the Topographic Branch in the latter part of 1892 and both F.H. Newell and Babb made western trips, paying particular attention to irrigation. In 1893, F.H. Newell again made a western trip where he devoted more time to measurements at old stations than he did in 1892, and established five new stations, the first since 1890. During the 1893 field season, Babb (oral commun., ca. 1938) was transferred to the Geologic Branch for field work in the Southeast, thereby easing the strain on Topographic Branch funds; he measured the Tennessee River at Chattanooga, Tenn., where gage heights had been recorded by Signal Corps personnel since 1874. By the end of the 1893 topographic field season, T.M. Bannon had made measurements at stations on the Arkansas River and the Rio Grande.

By this time (1893), interest in river records had so grown in all parts of the country that much of the office work consisted in answering inquiries for more details of information than could be published in the annua 1 reports. One reason for this growth of interest was the USGS exhibit of stream-gaging equipment at the Chicago World's Fair in 1893. F.H. Newell 
seized on this unusual opportunity to bring the work to public attention.

Discharge measurements on the Rio Grande at El Paso, Tex., which had been made since 1889, were discontinued in June 1893. In spring 1894, F.H. Newell made measurements of Colorado streams in the Arkansas River basin and established new gaging stations. Babb established two gaging stations in the Potomac River basin-one on South Branch Potomac River near Springfield, W. Va., that was equipped with a wire gage, and the other on the Potomac River at Cumberland, Md., that was equipped with a vertical staff gage.

Before continuing the history of events that moved so swiftly after June 30,1894 , mention should be made of ground-water activities. That information about ground water should be gathered was first considered in 1891 when an unsuccessful attempt was made to persuade well drillers in the vicinity of Wheeling, W. Va., to bore the deepest well in the world and make temperature observations (F.H. Newell, oral commun., ca. 1938). During a study by personnel of the Geologic Branch of the ground water of a portion of the Great Plains, many well logs were obtained. The report on ground water was published in one of the annual reports, but the logs of wells were published in Bulletin 131 (1895) entitled "Report of Progress for the Division of Hydrography for the Calendar Years 1893 and 1894," by F.H. Newell. This procedure apparently recognized the study of ground water as a function of hydrography, and may be considered to be the beginning of work in ground water by that unit.

\section{First Specific Appropriation for Stream Gaging}

Powell resigned as Director of the USGS in May 1894 effective at the end of the fiscal year [June 30 in those days]. He had found it necessary to have another operation to obtain relief from a wound received in the War Between the States (he had lost one hand) from which he had suffered for many years. Charles D. Walcott, a geologist in the USGS since its organization, was appointed Powell's successor.
The year 1894 was the second year of the depression and economy was the watchword in the Congress. The appropriation for topographic mapping was reduced by the House from $\$ 209,200$ to $\$ 159,200$. Walcott informed F.H. Newell that the Topographic Branch could no longer pay the expenses of the hydrographic work, which consisted chiefly of the salaries of Babb and F.H. Newell, and stated that even if the topographic funds had not been reduced, he doubted the propriety of using them for hydrographic work. F.H. Newell had the choice, therefore, of obtaining funds for hydrography or resigning (A.P. Davis, oral commun., ca. 1938). His resourcefulness was shown strikingly in this instance: The Sundry Civil bill containing USGS items had already passed the House but, fortunately for the future of stream gaging, it had not passed the Senate. A.P. Davis stated (oral commun., ca. 1938) that F.H. Newell, looking naturally for support to that section of the country where the value of stream gaging was then most appreciated, induced Senator William V. Allen of Nebraska to offer an amendment in the Senate providing $\$ 25,000$ for stream gaging.

Additional support was, of course, necessary and F.H. Newell was very anxious to have help of Senator Hale of Maine who was one of the more influential men in the Senate. It appears to have been permissible in those days to intrude business on a Senator's leisure moments. Accordingly, one evening F.H. Newell called on the Senator and was ushered into the dining room where the Senator was sitting after dinner. F.H. Newell at once explained his mission. After listening carefully, Hale said, "I have been very much interested in what you have told me but I am not going to support your project. If it once starts, nothing can stop it and I do not favor an endless expense to the Government." (F.H. Newell stated (oral commun., ca. 1938) that while those are not the exact words, they express the thought.) F.H. Newell was at first much discouraged, but on further reflection decided that Senator Hale's statement of the case was really encouraging because he had indirectly admitted the value of the work. In spite of the failure to enlist Hale's support, the amendment was passed by the Senate. When the bill went to the House, the item for stream gaging was reduced to 
$\$ 12,500$ and the first specific appropriation for stream gaging became available in that amount on August 18, 1894. Senator Hale has been proven a true prophet when he said that if appropriations for stream gaging were once started nothing could stop them. With all the vicissitudes of the annual appropriations since that day and there have been many, the Congress has not failed to provide some amount of funding for gaging streams. 


\section{Part VII-Years of Per-Diem Appointments (1894-1902)}

During the period 1894 to 1902 , field work was actively resumed in the West and was extended to eastern and southern States. The Division of Hydrography, which had been the "poor relation" of the USGS during the lean years, now had a specific appropriation $(\$ 12,500)$ and was recognized as a regular unit of the organization. Because of the small funding available during the earlier years of this period, however, Hydrography was still a division of an older branch (the Topographic Branch) where it remained until it was transferred to the Geologic Branch in 1895. A few men with full-time appointments supervised the stream gaging and conducted the work of the Washington, D.C., office. Funds were insufficient, however, for the employment of full-time field hydrographers. This difficulty would be overcome only by obtaining the cooperation of qualified men who not only had a strong personal interest in the work but, what was most important, also had such permanent employment that they would not be dependent on USGS salaries. Therefore, professors of civil engineering and engineers in private practice who were familiar with local water problems were selected (J.C. Hoyt, personal papers, 1904). Their USGS employment was generally on the basis of $\$ 5$ a day when actually employed, plus necessary field expenses. These resident hydrographers, as they were designated, who were employed part-time only, were considered to be field assistants and were, therefore, not selected through the Civil Service Commission. Such employment continued throughout this entire period.

\section{Transfer of Arthur Powell Davis TO HYDROGRAPHY}

When the appropriation of $\$ 12,500$ for stream gaging became available on August 18, 1894,
Henry Gannett, then in charge of the Topographic Branch, told F.H. Newell that it was of course necessary to reduce the force of topographers because of the decrease in funds, and further that as Topography had helped Hydrography in the past, it would now be necessary for F.H. Newell to reciprocate by taking one of the topographers-any one whom he chose. During the lean years, F.H. Newell had tried to interest the topographers in stream gaging, and although he had not been very successful in this endeavor, Arthur Powell Davis, a nephew of John Wesley Powell, who had been connected with the Topographic Branch since 1884, had responded most satisfactorily. A.P. Davis' reason for this interest, as he told the author, was due to his belief in the important roles that were destined to be played in the future by water and stream gaging. Accordingly, A.P. Davis was selected for transfer.

The selection of A.P. Davis was made in September 1894 while he was in California. He was advised of his transfer on receipt of a telegram from F.H. Newell directing him to report at the National Irrigation Congress in Denver, Colo., which F.H. Newell would attend. Although A.P. Davis had not previously been connected with stream gaging, he became at once Newell's principal assistant and thereafter continued in that capacity. By his transfer, the personnel of the Division of Hydrography became F.H. Newell, A.P. Davis, Babb, and Mrs. Jennie T. Davis (no relation to A.P. Davis) as clerk.

\section{RESUMPTION OF WORK IN THE WeST}

With a specific though small appropriation for stream gaging, F.H. Newell made plans to resume field work in the West. He tried also to enlarge his acquaintance among western men, 
particularly engineers interested in irrigation. In order to keep field expenses as low as possible, F.H. Newell obtained railroad passes for A.P. Davis and for the resident hydrographers as each was appointed. Automobiles were not then available, so railroad fares constituted the heaviest potential item of field expense. Accordingly, annual passes were obtained from the western and southern railroads until the Hepburn Act of 1906 that prohibited passes for interstate travel (in a few instances, State laws prohibited passes prior to 1906; other States allowed passes for intrastate travel beyond 1905). At the National Irrigation Congress in Denver, Colo., September 3-8, 1894, F.H. Newell, through Mead, met O.V.P. Stout, professor of civil engineering at the University of Nebraska, and hired him for the stream gaging in Nebraska. Stout thus became the first perdiem appointee. After the Denver congress, F.H. Newell went to Wyoming to ascertain the need for stream gaging and the possibilities of cooperation in that State. Nothing, however, developed immediately from that trip.

Having met F.H. Newell in Denver, A.P. Davis was given general instructions regarding stream gaging and was directed to visit the western gaging stations and to expand the work as funds would permit. Equipped with a small Haskell meter, which was then one of the two types of meters used by the USGS, he visited the old gaging stations and hired resident hydrographers who would establish and operate stations in the Western States. A.P. Davis started from Denver, but he made no attempt to obtain a resident hydrographer for Colorado. Nettleton, the State engineer of Colorado, was conducting stream gaging in the South Platte River basin, and did not care to cooperate with the USGS. A.P. Davis, however, visited three stations in the Arkansas River and Rio Grande basins, which were being maintained by the USGS, and established stations on the Arkansas River at Pueblo, Colo., and on the Rio Grande at Alamosa, Colo., during the latter part of September 1894. After a side trip to New Mexico to visit the Embudo station and to establish a station on the Mora River near Watrous, A.P. Davis returned to Colorado and established stations on the Grand River (not Colorado River) at Grand Junction and the Gunnison River near Grand Junction.
En route to Montana, A.P. Davis established stations in Utah on the Green River near Blake [now named Green River], and on the Price River at Helper. He also visited the old station on the Provo River near Provo. His comment on the observer at that station (USGS Bull. 131, p. 59,1895$)$ applies to many other observers since that time:

The observer lives at some distance from this point and there are some doubts whether his readings of heights are entirely reliable.

A.P. Davis visited also the old Battle Creek station on the Bear River in Idaho. Here, as might be expected, he found the cable that had been unused for 4 years so loose that it had to be tightened. He then made a measurement from the cable using what he called a "suspended box." He reached Montana early in November 1894 and arranged with A.M. Ryon of the Montana State Agricultural College at Bozeman to operate the stations in the headwaters of the Missouri River.

A.P. Davis then proceeded to Boise, Idaho, where he hired Vincent Tompkins, previously with the Topographic Branch, as resident hydrographer. Three stations were established in Idaho and two in eastern Oregon. From Boise, A.P. Davis went to Utah in the latter part of November and hired as hydrographer Samuel Fortier whom F.H. Newell had met in Denver. Fortier, who was professor of civil engineering in the State Agricultural College at Logan, Utah, had formerly been chief engineer of the Bear River Canal.

When A.P. Davis reached California in late December, his pass on the Southern Pacific railroad was about to expire. Therefore, he visited the chief engineer of that company to obtain a new pass. The Southern Pacific Company bridge tenders had for a number of years been collecting gage-height records, and they were very interested in the stages and flow of the rivers. Chief Engineer Hood authorized A.P. Davis to establish additional stations at the Southern Pacific railroad bridges and to use bridge tenders or other company employees as observers. The California State Commissioner of Public Works was conducting an investigation during this time in the Sacramento Valley, 
including the measurement of flood discharges, but A.P. Davis made no attempt to arrange cooperation with him. Instead, he appointed J.B. Lippincott resident hydrographer, with whom he had formerly been associated in the Topographic Branch. Lippincott had resigned as topographer in 1892, and thereafter had maintained a civil engineering office in Los Angeles. Five stations were established in the San Joaquin Valley.

On January 17, 1895, A.P. Davis measured the Colorado River at Yuma, Ariz., where Southern Pacific Company employees had recorded stages for many years (Lippincott began measurements there in April 1896). A.P. Davis then went on to Santa Fe in January 1895 to arrange for stream gaging in New Mexico. He appointed as resident hydrographer P.E. Harroun, chief engineer of an irrigation company on the Rio Puerco and also chief engineer of the Albuquerque Land and Water Company. From New Mexico, A.P. Davis returned to Washington, D.C.

\section{WORK IN THE EAST}

Babb conducted the field work that revived stream gaging in the East. He reestablished the Chain Bridge station on December 31, 1894, where he installed a circular-face recorder, or nilometer. The nilometer was placed in a wooden box over a wooden well about 8 inches square and attached to one of the bridge piers (Babb, written commun., ca. 1938). The operation of this recorder was so unsatisfactory that it was replaced on March 16, 1895, with a repaired cylinder recorder (USGS Bull. 140, p. 61,1896$)$. It is believed that this latter recorder was the one used unsuccessfully several years before at Embudo. Babb's diary indicates that the repair job was not entirely successful:

Mar. 20, repaired and started nilometer.

Apr. 22, repaired nilometer.

June 19, nilometer string broken.

The Chain Bridge station was finally discontinued on December 31, 1895, because of the tidal influences. Before that time, however, a station was established February 9, 1895, on the Potomac River at Point of Rocks, Md. On April 15, Babb established a station on the Shenandoah River near Millville, W. Va., which was the first station in the East where measurements were made from a cable with suspended car.

\section{FURTHER EXTENSION OF WORK IN THE WEST}

The stream-gaging appropriation was increased to $\$ 20,000$ for the fiscal year 1896 . With a 60-percent increase in the appropriation, plans were made to expand still further the work in the West and to extend it in the Eastern States, particularly in the southern Appalachian region where water power was becoming important (see section on "Extension of work to southern Appalachian region" later in this report). The Division of Hydrography, which had been loosely organized during the previous year, was now organized more definitively. The work was divided into three classes, all under F.H. Newell's supervision. The first and principal class was stream gaging, the second was a detailed examination of geologic structures for ground water, and the third was a general reconnaissance for obtaining information as to methods of using water for power, irrigation, and domestic purposes. A.P. Davis was given general charge of the stream gaging and devoted his time chiefly to the work in the West where it was most needed. Babb directed the work in the East and South. Geologists were detailed from the Geologic Branch as needed for the ground-water studies. F.H. Newell himself, in connection with the general office work, studied the problems of water use largely through correspondence. Somewhat later, when the appropriation had been increased sufficiently, reservoir and irrigation surveys were resumed. The funds were generally allotted equally to stream gaging and reservoir and irrigation surveys, with a somewhat similar allotment to ground-water studies and for the preparation of water-use reports. The appropriation of $\$ 20,000$ for 1896 was made at the short session (in 1895) of the Congress, so it was possible to plan the enlarged program early in spring 1895 and A.P. Davis returned to the West to start work in Kansas, Colorado, and Wyoming, and to hire resident hydrographers.

That spring, 1895, the Kansas Legislature created the Board of Irrigation Survey and Experiment, which had many duties connected 
with irrigation using both surface and ground waters, one of which was the measurement of the streams. Members of the Board asked F.H. Newell's advice regarding the future program and, as there was a possibility of cooperation, A.P. Davis was instructed to make Kansas his first objective on his western trip. Following the usual procedure, A.P. Davis visited the State University at Lawrence to ascertain if it would be possible to employ a member of the engineering faculty as resident hydrographer. He discussed the matter with E.C. Murphy, professor of civil engineering, and found him willing to accept such an appointment. When A.P. Davis met with the Board at Topeka, Kans., he learned that the members wanted W.G. Russell to take charge of the proposed cooperative work. The basis of the cooperation was that the work was to be limited to rivers west of the 98th meridian, the region in which irrigation was desired, and that all expenses, which included equipment and supplies, except gage observer's salaries were to be paid by the USGS. A.P. Davis agreed that W.G. Russell should handle the work and arranged to give him a perdiem appointment as hydrographer. Kansas thus became the first State to cooperate with the USGS in stream gaging. Seven stations were established. When the plans for the cooperation became known, Murphy, who had understood that he was to be the resident hydrographer, felt that he should be given some stream-gaging work (A.P. Davis, oral commun., ca. 1938) and in July the USGS gave him a perdiem appointment for maintaining three stations in eastern Kansas.

At the conclusion of his Kansas work, A.P. Davis proceeded to Colorado in May where he found a changed attitude toward cooperation. A new State engineer and the effect of the depression on State funds were responsible for the change. The State had funds for operating only a few stations in the South Platte River basin where irrigation was of paramount importance. Other rivers of the State had been ignored, although records of their flow were needed. Filmore Cogswell, deputy State engineer, was willing to conduct the necessary field work if stations were established in the other basins. Cogswell's salary as deputy State engineer was on a per-diem basis, and
Sunday pay was not allowed unless he was actually conducting State work. Cooperation was arranged on the basis that the USGS would pay Cogswell's salary on Sundays when he conducted cooperative work, and the State would pay it on weekdays. The USGS also paid all field expenses.

Wyoming, like Colorado, had begun to gage streams at an early date. Mead, an assistant State engineer of Colorado, became Territorial engineer of Wyoming in 1888 and put into effect in that State, in a limited way, the Colorado practice of stream gaging. Although Mead had requested cooperation with the Irrigation Survey in 1889 , very little work was conducted at that time, probably because of lack of funds. He had, however, continued to conduct a small amount of stream gaging with Territorial and later State funds. When USGS funds became available in 1895, A.P. Davis visited Mead and arranged cooperation on the basis that the State would furnish the services of a hydrographer and the USGS would pay the field expenses.

In reporting on the cooperation, Mead wrote (biennial report, State eng. of Wyoming, 1895-96, p. 88):

The selection of streams was governed largely by the wishes of the U.S. Geological Survey. The needs of the State engineer's office and of the Survey are not exactly identical, the Survey desiring to measure streams having a perennial flow and sufficient volume to make them of more than local importance, while the Engineer's office most needs the records of streams having a fluctuating flow and whose waters are wholly or largely appropriated. Location has to be governed by available observers and accessibility for measuring.

\section{Chevy Chase Rating Station}

With the increase in field work, a station was needed near Washington, D.C., where the current meters could be rated. Heretofore this work had been done chiefly at the Denver Water Company's station in Denver, Colo.; two meters, however, had been rated at the Aqueduct reservoir near Washington in 1892. The task of constructing a rating station was 
assigned to Babb. In order to prepare himself for this assignment, he inspected the rating flume at Lawrence, Mass. When the appropriation became available in July 1895, Babb built the rating station that was first known as the Kensington rating station, and later as the Chevy Chase rating station. It was located at Chevy Chase Lake, Md., a small pond constructed by the Chevy Chase Land Company about 2 miles outside the District of Columbia boundary. The equipment consisted of a wharf 165 feet long and 5 feet 4 inches wide built across a small bay. Near the outer edge of the wharf was an 18-inch, 150-foot track of light T-rails on which a small car was pushed by hand. The car carried a vertical iron rod to which the meters were attached with a clearance of 8 inches between rod and wharf. At one end of the course, the depth of the water was 4 feet and, at the other end, 12 feet (USGS Bull. 140, p. 331-32, 1896).

A small Haskell meter that was subsequently used in Virginia was first rated at the new station on August 15, 1895 (Babb, oral commun., ca. 1938). The next meters rated were an Ellis, a large Haskell belonging to the U.S. Weather Bureau, and, on August 24, a large Price meter. The rating tables for the meters were constructed to show the velocity for the number of revolutions over 50 seconds of time. A year or so later, E.G. Paul lengthened the rating station track to 200 feet to provide for longer runs. The station was used until 1909, when the rating of current meters was transferred to the U.S. Bureau of Standards.

\section{Adoption of Price Meter}

The small Haskell meter was principally used until 1895 because of its lightness and ease of handling in bridge and cable measurements (when the meter was suspended by an electric light cord, 6-pound weights were used to hold it in place). A serious defect at this stage of its development was the relatively high friction that made it too sluggish to accurately record velocities of less than $1 / 2$-foot per second. The Bailey meter was still used for measuring flow in small streams and ditches, but it could not be suspended from a cable. Bailey meters were so delicate that it was cheaper to discard them when they became worn rather than repair them.

The large Haskell meter was found to have such a high rate of speed that it was impractical to use it during floods with the ordinary form of register that consisted of gear wheels, which indicated the revolutions, that were actuated by two wet cells, all enclosed in a large box. At a speed greater than five or six revolutions a second, the ratchet movement of the electrical device would occasionally skip and the wheels would fail to advance, or the indicator hand would sometimes jump forward two spaces. To overcome this difficulty, a large Haskell meter was altered: a small five-tooth wheel was inserted in front of the contact spring in the meter spindle. Then, every fifth revolution of the head caused the small wheel to open and close the circuit once, which caused the register to run with one-fifth the speed of the head (USGS Bull. 140, p. 14-15, 1896). Thus the first pentameter appeared.

With no type of meter satisfactory in all respects and faced with the necessity of purchasing additional meters to meet the needs of the expanding work, A.P. Davis was authorized to select the best meter available. An Ellis meter was tested and found to be satisfactory where velocities were not too high; however, a meter suitable for use under all conditions was needed. In March 1895, Stout first used a large Price meter, which was the property of the University of Nebraska. As this meter gave promise of filling the Survey's needs, Davis obtained one from Ryon at Bozeman, Mont., and rated it at the Denver rating station May 27, 1895 (USGS Bull. 140, p. 340, 1896). This was the first large Price meter owned by the USGS. Four additional large Price meters were purchased during 1895 . The results obtained with this meter were highly acclaimed by the field men because the meter could be used for measuring either high or low velocities. The Price meter measured velocities far greater than had been possible using other meters.

Because the Price type of meter was developed gradually for general use by the USGS, it is of interest to describe its origin as related by its inventor in a letter dated April 20, 1927, to then-USGS CHE Nathan C. Grover. William 
Gunn Price, a civilian assistant engineer employed by the Mississippi River Commission (1879-96), was detailed to measure the Ohio River at Paducah, Ky., in January 1882. His equipment consisted of an Ellis cup-type meter and a Herschel propeller-type meter. It was impossible to exclude water and silt from the bearings of either of these meters. The rising Ohio was so muddy that silt in the bearings of both meters adversely affected their ratings. Price asked the Commission to furnish a meter that would give accurate results under those conditions, but the only reply he received was that such a meter was not available and that he must do the best he could. About that time, Price conceived the idea of a meter with inverted cup bearings that would trap the air and exclude water and silt. Because vertical bearings were required to accomplish this, he selected the cup-type as the basis for his design (deduction of the author). Price made the drawings for the new meter one evening (no mention being made of the hour of retiring) and four mechanics completed the meter by the next afternoon. The original meter, known as Large Price Meter No. 1, is now in the Smithsonian Institution in Washington, D.C. It was patented in 1885 and manufactured by W. \& L.E. Gurley of Troy, N.Y. The quality of the new meter was indicated by the much more consistent measurements obtained with it than measurements obtained with other types of meters.

About 1895, a small Price acoustic meter that was for use on a rod was put on the market and the USGS tried that instrument also. The cups of that meter were cone-shaped, suggestive either of the Ellis and Colorado current meters or of the Robinson anemometer. In June 1895 , the USGS first purchased the acoustic meter and W.G. Russell used it in Kansas. The meter was extremely light and sensitive, and could be used on long rods when measuring from bridges. Both models of the Price meter were used extensively during the next 2 years. Although the large Price meter was superior to the Haskell meter, it was too large to be convenient.

In 1897 , F.H. Newell asked the resident hydrographers for suggestions for improving the equipment. As a result of the suggestions received, E.G. Paul, who was the mechanician of the division, designed the small Price meter by combining the cups of the acoustic meter with the general arrangement of the large meter. The sliding catch holding the two pieces of the tail in place was designed by Maxie $R$. Hall. The first small Price meter was again manufactured by W. \& L.E. Gurley, the makers of the other types of Price meters. It is known as Small Price Meter No. 1 and is also in the Smithsonian Institution in Washington, D.C. (This type of current meter was still being used by the USGS in 1938.)

\section{Los Angeles Rating Station}

At the beginning of this period (1894-1902), USGS meters in use in the West were rated at the Denver, Colo., station and those in the East, within the first year, at the new Chevy Chase (Kensington), Md., station. Lippincott soon found, however, that it was desirable for him to rate locally the meters used in Southern California, thus avoiding the delay involved in sending them to Denver or Washington, D.C. Accordingly, in 1897 or 1898, he arranged with the city of Los Angeles, for whom he was stream gaging, to have a rating station built. A cement-lined trough 4 feet wide and about 100 feet long was built along the edge of Buena Vista Reservoir near Los Angeles. An iron cable was stretched, suitably supported, above this trough; a two-wheel trolley, from which the meter was suspended into the water, "rode" the cable. The operator, who moved along one side of the trough, used a pole to move the trolley over a measured 100-foot-long course at different rates of speed. The Los Angeles station was used by the USGS until 1909 when it was decided to rate all meters in Washington, D.C., in order to insure uniformity.

\section{EXTENSION OF WORK TO SOUTHERN Appalachian Region}

In July 1895, Babb arranged with D.C. Humphreys, professor of civil engineering at Washington and Lee University at Lexington, Va., for a per-diem appointment as resident hydrographer in Virginia and for the establishment of four stations. After completing the Chevy Chase, Md., station, Babb started on a 


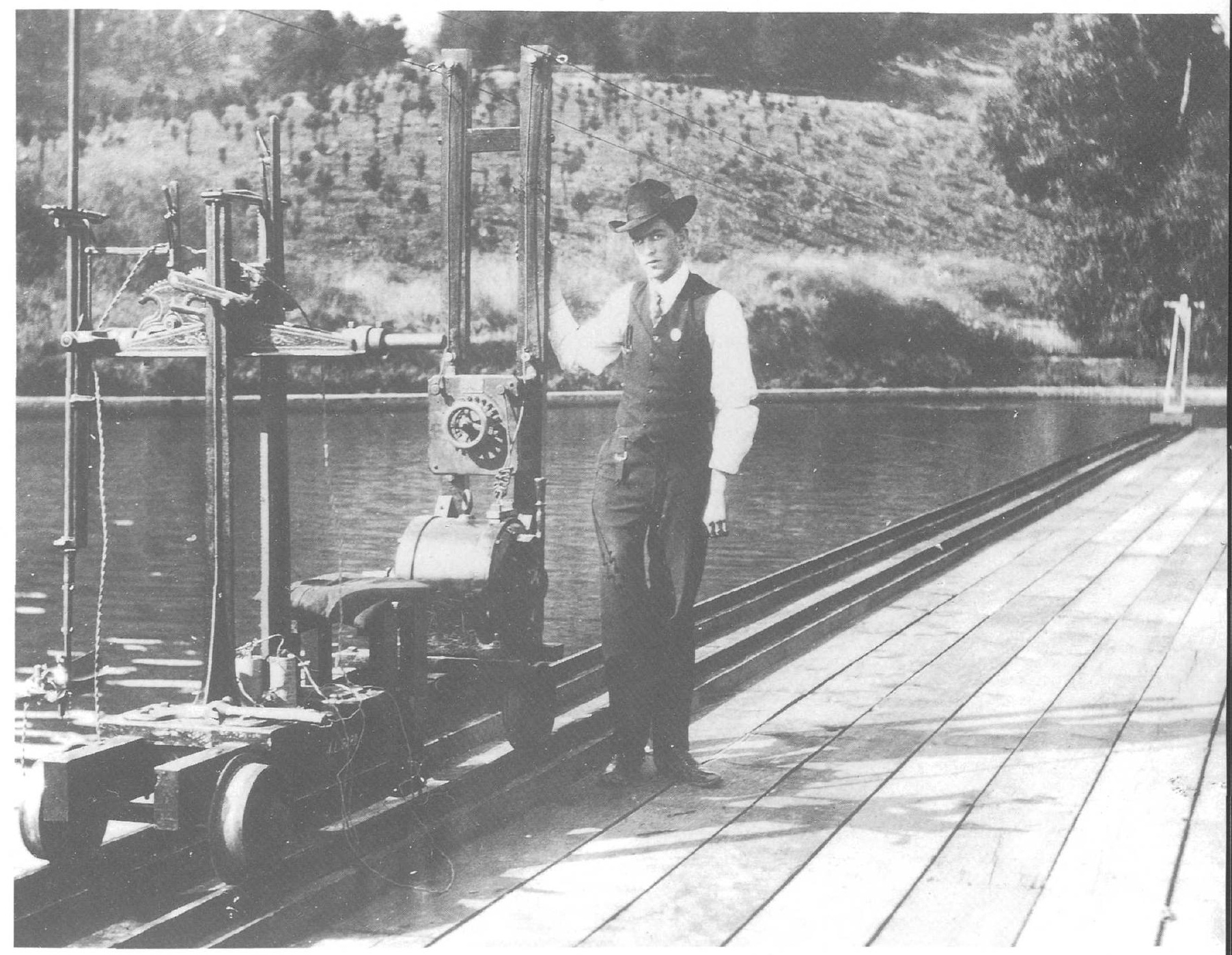

John Clayton Hoyt at the current-meter rating station at Los Angeles, Calif., ca. 1907-8. (Photograph plate 1A in WSP 247, 1910. Photograph number “'Hoyt, J.C. 56," USGS Photographic Library.)

southern trip in August 1895, going first to North Carolina. Water power was then of importance in that State and the State Geologist, Professor Joseph A. Holmes who later became chief of the Technological Branch of the USGS and still later Director of the U.S. Bureau of Mines, had in 1894 discussed with F.H. Newell the desirability of cooperation in river-measurement work because the use of the rivers was handicapped by a lack of records (biennial report of the State Geologist, 1893-94, p. 12). At Holmes' suggestion, E.W. Myers, an engineer employed by the North Carolina State Geological Survey, was given a per-diem Federal appointment as resident hydrographer.
Babb went next to Georgia where the use of water power was a live issue. The office of State Geologist had been revived in 1890 and a 5-year appropriation had been made for conducting a survey of the water powers of the State. During that survey, a few months' records of streamflow at nine gaging stations had been obtained, but the 5-year period had expired in 1895. Babb was unacquainted with anyone in Georgia and so, on arriving in Atlanta, made inquiries concerning the leading engineers and was referred to B.M. Hall who was then writing the final report of the Georgia State waterpower survey and was interested in stream gaging. The outcome was a Federal appointment for B.M. Hall as resident hydrographer in Georgia. 


\section{INCREASES IN APPROPRIATIONS}

The increases in appropriations during the next few years confirmed the truth of Senator Hale's prophecy that if once started nothing could stop stream gaging. F.H. Newell continued his efforts to educate the public as to the value of the work, and made it a rule to drop whatever he was doing to talk with any reporter who desired an interview. He also kept copies of press releases on a bulletin board in his office. During these critical years, Newell devoted the greater part of his time and energies to publicity, not only on behalf of stream gaging but of the much larger project of Federal irrigation for which stream gaging was a basic necessity. A.P. Davis told the author that F.H. Newell was the contact man between the USGS on the one hand and the Congress and the public on the other.

Additional financing was needed for the expansion of the work that was started in 1894 and 1895 and F.H. Newell, alert to all possibilities of increasing the funds, decided in spring 1896 to ask the Congress for more money for the remainder of that fiscal year. If he waited for the Sundry Civil bill in which the regular USGS items were carried, the funds would not be available because the Sundry Civil bill was the last of the regular supply bills to be considered. Its passage also would probably be delayed until some time in June because the Congress had its long session in 1896. With the aid of powerful Congressional friends, F.H. Newell succeeded in having inserted in the DOA bill for fiscal year 1897 , which was then pending, an item of $\$ 4,500$ for stream gaging by the Director of the USGS to be immediately available (Stat. L., vol. 29, p. 104). This is the only instance of an item for stream gaging by the USGS in any bill other than a regular DOI bill or a deficiency bill. The scheme worked. The DOA bill was signed on April 25, 1896, and the money was available from that date until June 30.

The appropriation for stream gaging was increased to $\$ 50,000$ in 1897 , and continued at that annual amount until and including the fiscal year 1900. The investigation of possible reservoir sites and irrigation projects had assumed such importance by 1900 because of the growing interest in Federal aid to irrigation that F.H. Newell again asked for a deficiency appropriation and an item for $\$ 20,000$ was included in the deficiency bill, which became available when the bill was signed on March 30, 1900 (Stat. L., vol. 31, p. 57). By 1900, the interest in stream gaging had increased to such an extent and the demands for records had become so great that the appropriation was increased to $\$ 100,000$. In his unpublished memoirs, F.H. Newell wrote that 1900 was an active year in educational efforts and that the western Congressmen of the Committee on Appropriations lent their cordial support. Although $\$ 250,000$ was requested for the fiscal year 1902, the Congress appropriated only $\$ 100,000$, the same as for the previous year. The failure of the Congress to appropriate a larger sum was not because of opposition to the work, but rather because it was thought best to await the formulation of a practical comprehensive scheme for irrigation and hydrographic surveys (USGS $22 \mathrm{~d}$ ann. rept., pt. 1, p. 36, 1901). The Director's report stated that the $\$ 100,000$ made available was sufficient to meet only a small number of the applications, which came from all parts of the country, for Federal aid in hydrographic work.

\section{Expansion of Permanent Work Force}

One of the most important effects of the increased appropriations was the expansion of the permanent work force that constituted the backbone of the organization. The first increase was accomplished by the transfer of E.G. Paul, with the title of assistant hydrographer, from another branch of the Survey on July 1, 1896. He was a mechanician and was put in charge of the equipment. Later, E.G. Paul also had direct charge of the field work in the vicinity of Washington, D.C., extending it gradually into Pennsylvania.

The next increase was made in May 1897 when Gerard H. Matthes was appointed hydrographic aide. This increase was necessary because of A.P. Davis' absence for work in Nicaragua. Matthes had met F.H. Newell on one of the latter's many trips and, having had some experience with current meters at a summer school of the MIT, he applied for a position. His appointment is believed to have been 
the first in the hydrographic organization as a direct result of civil service examination. No other full-time member had been brought into the organization, except by transfer, since Babb joined the Survey in 1890 , and he was appointed without civil service examination.

By 1898 , the reservoir surveys and irrigation investigations had assumed first importance in F.H. Newell's mind as the movement for national aid to irrigation greatly increased in strength. Consequently, the men who had previously directed the work of stream gaging were detailed to the reservoir surveys, and it was necessary to replace them. In that year, H.A. Pressey was appointed hydrographer, presumably through civil service certification, and was soon given virtual supervision of the hydrographic work in the East. Matthes was chiefly employed on reservoir surveys but, between field seasons, he gradually took charge of the preparation of the records for the annual reports and may be regarded as the first chief of the computing section. During this period, little supervision was exercised over the resident hydrographers beyond perhaps a yearly visit by F.H. Newell, A.P. Davis, or Babb.

\section{ExTENSION OF FIELD WORK}

\section{Stream Gaging}

Field work increased and expanded as a result of the rapidly mounting appropriations. Regular field work was being conducted from the Washington, D.C., office by E.G. Paul, chiefly on the Potomac River basin, and he became the resident hydrographer for the region. The first extension in E.G. Paul's field work was made in 1896 as a result of cooperation with Professor William Bullard Clark, State Geologist of Maryland, who paid the observers (USGS 18th ann. rept., pt. 4, p. 14, 1897).

By 1897 , irrigation in the central section of the State of Washington and water power on the Olympic Peninsula had become so important that it was necessary to give attention to the needs of that State. Accordingly, Babb appointed Sydney Arnold, a civil engineer of North Yakima, Wash., resident hydrographer in the Yakima Valley, and A. Judson Adams, a civil engineer of Port Angeles, Wash., resident hydrographer in the western part of the State.

In 1898, Thomas U. Taylor, professor of civil engineering at the University of Texas, was appointed resident hydrographer for Texas. Prior to his appointment, T.U. Taylor had been interested in the flow of Texas streams and had made miscellaneous measurements of them.

In 1898, cooperative stream gaging was extended to Ohio, a section of the country not hitherto covered by the USGS. Within the first few months of H.A. Pressey's connection with the USGS, he was instructed to arrange for cooperation that was sought by a State bureau that involved a new use of streamflow records. In the previous year, the Ohio Board of Health began stream gaging in connection with its responsibility for approval of all industrial and municipal water-supply and sewage-treatment projects in the State. In 1898, the Board attempted to obtain an annual appropriation of $\$ 25,000$ for use in cooperation with the USGS in a comprehensive stream-gaging program (C.E. Sherman, Ohio streamflow, pt. 1, Ohio State University Studies, vol. 1, no. 5, p. 19, Sept. 1932). The attempt was unsuccessful, but the Board had other funds available for stream gaging, and, like a great majority of State organizations since that day who have needed stream gaging, turned to the USGS for cooperation. Because the Board had an engineer, B.H. Flynn, who could do the field work, it was not necessary to pay his salary and so he was not given the usual per-diem appointment of resident hydrographer. The USGS share in the cooperation consisted of paying certain field expenses. Arrangements were made also with Professor C.N. Brown of the State University's civil engineering department to have his students maintain two stations. In 1901, what might be termed "malnutrition" set in and by spring 1902, the last of the stations was discontinued. Whether the end of the Ohio work was due more to lack of funds or to lack of interest is not now known. Work was also started in New York, Michigan, North Dakota, and Maine, but so near the end of this period that it will be described only in the "Summary of StreamGaging Work" section for that period. 
Reservoir Surveys

Irrigation investigations by the USGS had ended in 1890, but the hope of reclaiming the arid West persisted. That hope was promoted and strengthened by the activities of the National Irrigation Congress which met at 1- to 2-year intervals to arouse and increase interest in national aid for irrigation. Beginning in 1890, no USGS funds were available for continuing the irrigation investigations until 1896 when such investigations again became possible, either from streamgaging funds or from funds of investigations on Indian Reservations. The statutory authority remained for conducting these surveys because only that part of the Act of October 2, 1888, that created the Irrigation Survey had been repealed and which authorized the withdrawal of public lands from entry, occupation, and settlement (USGS 20th ann. rept., pt. 4, p. 26, 1900). Having this authority and the necessary funds, F.H. Newell was able to resume the irrigation investigations after a lapse of $5^{1 / 2}$ years. A.P. Davis was put in charge of the work and in December 1895 went to the Gila River basin to begin reservoir surveys on the Gila River Indian Reservation with $\mathrm{Babb}$ as his assistant. E.G. Paul was left to operate the gaging stations in the vicinity of Washington, D.C.

The irrigation investigations were gradually expanded to other sections of the West, and the personnel were added as needed. The investigations on the Gila River Indian Reservation were continued, the Congress having made a special appropriation for that work, and the Arizona investigations from which the Salt River project evolved were continued and enlarged. Lippincott conducted those investigations while A.P. Davis was in Nicaragua. In 1898, Matthes was assigned to reservoir surveys under F.H. Newell's personal direction and, in 1899, C.H. Fitch was transferred to that work from the Topographic Branch. Later, Jeremiah Ahern and C.R. Olberg were similarly transferred. These men conducted the work until the organization of the Reclamation Service in 1902.

\section{Methods Used in Stream Gaging}

FIELD

At the beginning of this period in 1894 , Bailey meters and the integration method for determining velocities were used in the West. But these meters and the integration method were soon abandoned. The small Haskell meters at first, and later the Price meters and the 0.6-depth method came into general use. However, the 0.6-depth method was not adopted in Colorado where the integration method had been developed until frequent comparisons with vertical velocity curves had shown it to be satisfactory. Similar comparisons were made in Georgia and New York. Lippincott, who was working in California, frequently obtained the mean velocity by measuring the top, middle, and bottom velocities. The top and bottom velocity method, an approximation to the later 0.2 - and 0.8-depth method, was likewise used in the Yakima Valley.

During high flow stages, it was very difficult to place the meter at the 0.6 or 0.5 depth (depending on the method used) because of the current, and various devices were tried for steadying the meter in the water. The most graphic account of the early difficulties in making high-water measurements and the methods used to overcome them were recorded by Lippincott in connection with the first high-water measurement of the Sacramento River at Red Bluff, Calif., January 22,1896 , reported in the USGS 18 th annual report (pt. 4, p. 363, 1897):

The gaging at the bridge was found very difficult. The Haskell meter was tried first and it was found impossible to count the revolutions, they were so rapid, and the meter could not be controlled in the water with any steadiness. With all of the battery that could be desired, and using the (large) Price meter which has a slow revolution, the recorder was unable to move with sufficient swiftness to make the count. By marking every tenth beat and not counting beyond ten, the revolutions of the Price meter were determined by using the sounder and counting by ear. With 44 pounds of lead on a 30 -foot line the meter could not be sunk in the ordinary way. It would run through the water in much the same way as a trout on a line. (Lippincott was evidently a disciple of Izaac Walton) ${ }^{* * *}$ The most potent element in steadying the meter was an increase in the length of the tail in the weights. A board 4 inches wide and 3 feet long was driven into the slot of the lead 
weight to act as a rudder. This controlled it in position, and it was found that by hanging the weights to the meter by means of 3 feet of baling wire, instead of fastening them directly to the meter standard, the meter could be sunk to depths of 15 feet and held steadily in the swiftest current. As bottom velocities could not be taken, and the mid-depths were uncertain, the surface velocities only were used and the mean velocity assumed as 95 percent.

Other hydrographers sought to steady the meter in the water by using inclined vanes attached above or below the meter in such way as to force the meter downward and upstream. These unsatisfactory methods were abandoned in favor of a line of fine wire running from a point just above the meter to some support upstream, which was usually a wire stretched across the river (USGS Bull. 140, p. 19, 1896). A method of measuring velocities during flood stage that was first used in the Yakima Valley consisted of applying a coefficient to the subsurface velocity to reduce it to the mean velocity in the vertical section. Arnold made a series of comparisons of the relation between the mean and subsurface velocities on four streams and arrived at an average coefficient of 0.85 , with a range from 0.76 to 0.96 (USGS 19th ann. rept., pt. 4, p. 482, 1898). The subsurface method was used for many years as standard practice during high-water measurements. Lippincott first called attention to the effect of the current in bowing the sounding line. During one flood, he observed that the high velocity in depths between 4 and 5 feet bowed the line so much that an error of 10 percent was disclosed by check soundings made with rods.

The field engineers' selection of methods for use in making measurements, particularly on eastern streams, is well described by Matthes in a letter to the author (ca. 1938):

Gaging streams in those pre-automobile days often called for much mental arithmetic to determine how best to devote the available time between trains; the number of sections into which a stream cross-section should be divided; whether to use the six-tenths depth or a more elaborate method; and whether to take
50 -second or 100 -second time intervals for counting buzzes; these were all functions of the time available, after due allowance had been made for hoofing from the railroad station to the gaging station and back, carrying a 5- and 10-pound weight in the current meter box. Western hydrographers had buggies or buckboards and consequently enjoyed greater freedom of movement, but we back-East chaps, at the start, rarely enjoyed such a luxury.

In computing the meter notes, the velocity at the point observed was assumed to be the average velocity for that portion of the stream on each side of the vertical plane in which the velocity was determined, extending half way to the next point of observation. The mean depth of the subsection was usually assumed to be either the depth at the place where the velocity was measured, or an average obtained by adding to twice the depth at the point of observation the depth on each side half way to the next point of observation and dividing by 4. The mean depth multiplied by the width and by the mean velocity gave the discharge in the subsection being considered.

Western stations were generally equipped with either inclined or vertical staff gages. Eastern stations on streams having larger ranges of stage and perhaps more ice and drift were usually equipped with wire gages attached to bridges. As it was apparently believed that the length of wire gages would remain unchanged, levels were not at first used to check the gages at frequent intervals. A striking example of misplaced faith in the fixed length of wire gages occurred on the Potomac River at Point of Rocks, Md., where $\mathbf{4 2}$ feet of wire was found to have stretched 1.78 feet in less than 2 years (WSP 15, p. 21, 1898). Faith in the unchanging length of wire gages was thereby shattered and checks with levels were made at more frequent intervals. Another result of this shattering of faith was the gradual substitution of chain for wire. The first chain gage having a windowsash weight and a copper rivet marker was installed by E.G. Paul on the Delaware River at Lambertville, N.J., in 1897. In those sections of the country having streams affected by ice, field work was suspended during the 
winter months because methods applicable to ice-bound streams had not yet been developed.

\section{OfFICE}

The resident hydrographers computed their own records with little or no supervision from the Washington, D.C., office. The usual extension of a rating curve was a tangent that gave results generally too small for the higher stages, although in some instances the results were too large. For the shifting sandy streams of Nebraska, Stout devised the method of correcting gage heights so that each measurement plotted on the standard rating curve, the correction between measurements being graduated. Stout told the author that this method was suggested by Ryon, who first used it in computing the records for the West Gallatin River at Salesville, Mont. At other stations, notably those on the Rio Grande and other streams in Arizona, it was necessary to make measurements at intervals of a few days and to base the estimates of daily discharge almost directly on the measurements with interpolations for those days when measurements were not made. The methods in use had become so widely accepted by 1901 that they were published in USGS Water-Supply Paper (WSP) 56 (1901).

\section{IMPROVEMENT IN EQUIPMENT}

When the Price meter first came into use, the counter or register that had been used with the Haskell meter continued to be used with the Price. This register was so heavy that an assistant was frequently needed to hold it during a measurement. (It was observed at the Embudo camp and elsewhere that the revolutions could easily be counted, so any recording device was unnecessary.) In order to eliminate the heavy counter, E.G. Paul devised the wet cell and buzzer enclosed in a small leather case. Although E.G. Paul's combination of cell and buzzer was a great improvement over the counter, it was not an unqualified success. A vivid account of the hydrographers' trials of patience in using it was contained in a letter from Matthes to the author (ca. 1938):

It (the buzzer) contained a zinc-carbon cell battery which required filling with water and dosing with a specially provided salt, and once its feeble current got to working, often as not the vibrating tongue of the electric device would vibrate itself out of adjustment, and relapse into a stupor in the midst of a gaging, usually at a time when the hydrographer was also gaging the minutes he had left to catch the next train.

Matthes might have added that another favorite time for the buzzer to "lie down" was when the hydrographer was making a cable measurement in the rain. In spite of its weaknesses, the buzzer was the best means then available for observing the number of revolutions; it was used until the combination of dry cell and telephone receiver was devised in 1907.

Another improvement in equipment that is worthy of record is the substitution of the lead flat-iron weights with large vanes for the magnified paper weights used previously. The flatiron weight was fastened to the weight hanger by a large brass pin, which had an eye in one end, and held in place by a cord attached to the meter yoke. Minor improvements were made in the small Price meter during this period, and stay lines came into use on large, swift streams, having been first successfully used with the Hall traveler.

When it is considered that the permanent work force was used chiefly for the reservoir surveys in the West and that the stream gaging was conducted almost entirely by per-diem appointees, it is not surprising that no other major improvements in equipment were made during the years 1894 to 1902 . Experience and the group action needed for such improvements were lacking.

\section{Publication of Annual Records}

Until and including 1900, the monthly discharge records and many daily discharge hydrographs were published in the annual reports of the USGS. The hydrographs, as Matthes, one of the early-day USGS engineers wrote to the 
author (ca. 1938), served to educate both engineers and legislators regarding the extreme irregularity in the discharge of streams and served as a powerful argument for regulation of reservoirs. The USGS published not only its own records, but also those from other sources that were believed to be reliable. F.H. Newell felt that more details than were published in the annual reports should be made available to the public at as early a date as possible, even though revisions might be necessary later. For the years 1893 to 1895 , such details were published in USGS Bulletins 131 (1895) and 140 (1896), as there was no other series of publications then available for that purpose. The Act containing the stream-gaging appropriation for 1897 authorized the USGS to publish a new series to be known as "Water-Supply Papers (WSP)," limited to 100 pages each. The limitation in pages applied until WSP 65 was published in 1902 with 334 pages. WSP 65 and 66 (1902) contained the station descriptions, discharge measurements, and gage heights for 1901. The monthly records of discharge for that year were published in WSP 75 (1903). Beginning with 1902, all records for the year for any river station were brought together in one paper. WSP 82 through 85 , all published in 1903 , were the first to contain the complete reports.

In the fiscal year 1897, the USGS was first authorized to prepare reports on the best methods of using the water resources of the arid and semiarid sections of the country. In preparing utilization reports, an attempt was made to present not only the facts disclosed by the examination and survey, but also to give examples of what had already been accomplished in the use of the water resources for power, irrigation, and municipal supply in order that the economic use of the water resources might be shown.

\section{Special InVestigations}

The unusual drought in the Potomac River basin during fall 1897 caused such low flow that an investigation of that basin was made (55th Cong., 2d sess., S. Doc. 90, p. 1). The investigation-which consisted of measuring the tributaries, obtaining water samples for sanitary analysis, and an incidental reconnaissance of developed and undeveloped water power-was conducted by A.P. Davis, E.G. Paul, and Matthes. The results were published in Senate Documents 90 and 211 (55th Cong., $2 \mathrm{~d}$ sess.) in response to a Senate resolution January 14,1898 , that directed the Secretary of the Interior "to transmit to the Senate any information which may be in the possession of the Director of the Geological Survey regarding the hydrography of the drainage basin of the Potomac, with particular reference to the source of pollution and the effect of such pollution upon the water supply of the city of Washington."

Following the establishment of national forests in the West, widespread interest was aroused in the possibility of creating national forests in the southern Appalachian region. One of the chief arguments for creating national forests was based on the assumed benefit to streamflow to be obtained from a protective forest cover, and Holmes was especially active in promoting an investigation of the streams in that region. He procured funds in $\mathbf{1 9 0 0}$ for such an investigation and F.H. Newell detailed H.A. Pressey to conduct it. The results were published in WSP 62 and 63, both published in 1902.

The special investigation of most lasting value conducted during this period was that by Murphy, the professor of civil engineering who had gone from the University of Kansas to Cornell University for graduate study in hydraulics, related to the accuracy of current-meter measurements. In 1900, F.H. Newell arranged with Cornell's College of Civil Engineering for Murphy to conduct a series of experiments in the Cornell hydraulic laboratory comparing the results of current-meter measurements with those of a standard sharp-crested weir. In this work, Murphy was assisted by both faculty and students of the university. The investigation, which began in May 1900 and was complete 1 year later, showed that the current meter, when used under favorable conditions, gave results agreeing within 2 percent with those of a standard sharp-crested weir, the most accurate method available for measuring the flow of considerable quantities of water. So far as the author is aware, this was the first 
comprehensive study of the accuracy of the current meter. The results were published in WSP 64 (1902). An earlier and less comprehensive comparison between current-meter and weir measurements was made before 1883 in the Sudbury conduit, which showed (Proc. Inst. C.E., vol. 75, London, 1883) that a current meter properly used would give results that were accurate within 1 percent.

\section{Ground Water}

Although the first appropriation (for 1895) for stream gaging included within its scope "the investigation of underground currents and artesian well," it was not until the next year that funds were considered sufficient for inaugurating the study of the ground water. It is probable that the drought then prevailing in the Western Plains States, which made groundwater supplies of outstanding importance, led F.H. Newell to begin ground-water studies at that time even though the total appropriation for that year was only $\$ 20,000$. The inclusion of the wording in the annual appropriation bills that authorized the investigation of underground currents was due in part to F.H. Newell's personal interest in the flow of liquids through the soil. In 1885, while at the MIT, he had prepared a thesis based on experiments showing the flow of oil through rock-that investigation being, as F.H. King states (USGS 19th ann. rept., pt. 2, p. 124, 1899), the earliest experimental data known bearing on the relations of pressure to the flow of fluids through rocks.

Until the next period of this History (the Hydrographic Branch, 1902-6), the groundwater work was conducted by geologists of the Geologic Branch, some of whom made the ground-water studies in connection with their regular geologic field work, whereas others made them while on detail to the Division of Hydrography. By this method, the overhead expenses of the ground-water work were practically nil (F.H. Newell, oral commun., ca. 1938). These men, as Walter Curran Mendenhall describes them (oral commun., ca. 1938), naturally thought in terms of earth structure instead of water. They were concerned with where water was to be found rather than with how much water underground sources might yield. It was not until the later years of this period that Professor Charles S. Slichter, a mathematician at the University of Wisconsin, devised methods for measuring rates of flow of ground water and hence for determining how much water could be obtained.

The first year of this period (1895) found Gilbert continuing his geologic studies in the Arkansas River basin, in which he paid special attention to the ground-water supply. So highly regarded was his work that as soon as the results were available, deep drilling was begun with confidence that water would be found in the areas indicated (USGS 17 th ann. rept., pt. 1, p. 75,1896$)$. This confidence was doubtless based on confidence in Gilbert personally: he, more than any other man, represented the true connecting link between the predecessor surveys and the present USGS. From 1871 until the formation of the present organization, Gilbert was a geologist, first with the Wheeler Survey in which he was chiefly responsible for whatever geologic merit the Wheeler Survey had (Herman Stabler, oral commun., ca. 1938), and later with the Powell Survey. He was one of the first geologists appointed by King on the creation of the USGS and he remained an honored member until his death in 1918. As Mendenhall states in the memorial (Bull. Geol. Soc. of America, vol. 31, p. 22-64, 1920), Gilbert was probably unsurpassed by any geologist of his time in sheer balance of mental powers. He recognized both his powers and his limitations and would not undertake that which he was not equipped to do. In his writings, Gilbert never supported a theory, but applied to every conceivable theory the acid test of fact, indifferent as to whether any of them could survive that ordeal. Professor Thomas Chrowder Chamberlin, another eminent geologist, states (Jour. of Geol., vol. 26, 1918) that it is doubtful whether the products of any other geologist of our day will escape future revision to a degree equal to the writings of Grove Karl Gilbert.

In that same year, 1895, geologist Nelson Horatio Darton, whose name was to be connected with ground-water studies for many years, began the reconnaissance work that led finally to his study of the Central Great Plains 
region, with special reference to the geologic conditions governing the occurrence of ground water. This study occupied the entire period covered by this volume, and in it he was assisted by various State and local geologists. In addition, Darton collected information relative to the ground waters of the Atlantic Coastal Plain from New Jersey to South Carolina. Darton was placed in charge of the groundwater work in 1903, which was limited chiefly to the West, and he had a number of assistants engaged in the investigations.

In that same year, 1895, a beginning was made, mainly through cooperating State geologists although also in connection with geologic studies by USGS geologists, in the compilation of statistics on both deep and artesian wells, and this activity continued throughout the period. In 1896, W.D. Johnson, a hydrographer in the Division of Hydrography, began studies that resulted in his report on the High Plains and their uses. In addition to these principal investigations, a number of minor ones were conducted that covered small areas and required only a few months of field work.

In the High Plains region, information was needed not only as to the availability of ground water, but also how to bring it to the surface for domestic and irrigation uses. Murphy, while holding a per-diem Survey appointment in addition to his professional position at the University of Kansas, conducted a series of experiments on the efficiency of windmills in raising water for irrigation (reported in WSP 41 and 42 published in 1901), and Professor Ozni P. Hood of the State Agricultural College of Kansas (later chief of the Technological Branch, U.S. Bureau of Mines) conducted experiments with different types of pumps (WSP 14, 1891). E.H. Barbour, State Geologist of Nebraska, also studied wells and windmills (WSP 29, 1899).

Although Slichter of the University of Wisconsin became associated in 1900 as consulting engineer on the USGS ground-water work for the development of a method of measuring rates of ground-water flow, his unofficial connections with that development dated from 1896. Early in the 1890's, F.H. King, also of the University of Wisconsin, began the study of the movement of water through soil in relation to the sizes of the soil grains and, during the investigations in 1894 , he asked Slichter to conduct certain phases of the study. While this joint investigation was being conducted in 1896, F.H. Newell proposed to F.H. King that the USGS assist financially in the study of the movement of ground waters, and Slichter was hired to develop certain phases (USGS 19th ann. rept., pt. 2 , p. 67,1899 ). In connection with such employment in 1900 , Slichter continued the investigation of methods of measuring rates of ground-water flow. The practical method that he developed aided greatly in changing the character of ground-water investigations to a quantitative basis, and in stressing engineering aspects relative to recovery of ground water.

In 1902, ground-water investigations began in California in the Salinas Valley, where conditions were unfavorable for water storage and the cost of fuel for pumping was high. An investigation of all possible ground-water sources in that valley was conducted by Homer Hamlin under Lippincott's supervision.

\section{Summary of Stream-Gaging Work (1894-1902)}

A summary of the events in each State completes the history of the years of per-diem appointments. This summary outlines the antecedent records of stage and discharge that were significant with respect to later USGS work, the development of cooperation under varying conditions of field procedures, and the development of instruments and equipment by different persons and under different conditions. These events reveal, to those who have watched the marked improvements made during the past 3 decades, the strong personalities and the resourcefulness of some of the early hydrographers. Among the hydrographers of this period who have left an imprint on methods, O.V.P. Stout, E.C. Murphy, M.R. Hall, and Robert E. Horton are outstanding. In the following pages, the States are presented in three groups: Western, Southern, and Eastern.

\section{Western States}

NORTH DAKOTA.-The Red River of the North was an important traffic route before the days of railroads, and so was improved early for 
navigation. The Army engineers began to record gage heights at Grand Forks, N. Dak., the headquarters for dredging operations, in April 1882 continuing with some interruptions, chiefly during periods of ice, until the station was taken over by the USGS in 1901. Although the chief interest related to stage, a few currentmeter measurements of discharge were made during the 1880's and 1890's. The Missouri River Commission, in a study of the navigability of the Missouri River, established a gage at Bismarck, N. Dak., about 1893. That organization, and later the Weather Bureau, collected records of stage up to about 1894 , but made no discharge measurements.

When stream gaging was revived in fall 1894, attention was given to possible operations in North Dakota, but F.H. Newell found that the water problems under consideration there related mainly to deep artesian wells. The rivers offered peculiar difficulties, not only for use in irrigation but also for the collection of accurate systematic records (USGS 16th ann. rept., pt. 1, p. 48,1896$)$. No attempt was made at that time, therefore, to measure the streams in that State. A severe flood in the Red River basin in 1897 , however, focused attention on the flood hazard in that basin, particularly in the spring of the year and, in 1900, land owners and business interests formed a tri-State drainage association looking for flood relief (P.T. Simms and F.V. King, Report on drainage and prevention of overflow in the valley of the Red River of the North, U.S. Dept. of Agr. Bull. 1017, p. 1, 1922). Doubtless influenced by this movement, C.M. Hall, professor of geology at North Dakota State Agriculture College, established a gaging station on the Red River near the international boundary with Canada.

During the next winter (1901), probably at C.M. Hall's suggestion, the State Legislature authorized the trustees of the Agricultural College to cooperate with the USGS in hydrographic investigations, and specified that the professor of geology of that institution should be the State's director of that work, thus making C.M. Hall the cooperating State official. With authority to cooperate and with an indefinite amount of State funds authorized to be drawn from the college appropriation (E.F. Chandler, written commun., ca. 1938), cooperation with the USGS was arranged on the basis of equal expenditures by the two parties (USGS 22d ann. rept., pt. 1, p. 32,1901$)$. The field work was conducted by C.M. Hall who established four gaging stations in the Red River basin and made a number of discharge measurements, using standard USGS equipment. His conception of the proper method of ascertaining the annual flow of a stream is shown by the following extract from his instructions, as quoted by E.F. Chandler (written commun., ca. 1938):

Toward the close of the season average all gage heights to date for the season, including estimates of what the gage heights will be for the remainder of the season. Watch the river closely, and when it happens for a day to be at precisely, to the hundredth of a foot, that expected average gage height for the year, make a current-meter measurement and you supposedly have the average daily, and hence the total annual discharge for the year.

Unfortunately for C.M. Hall, as E.F. Chandler wrote:

The gage heights for the remainder of the year were slightly different from his expectations, and several times he recomputed his expected average gage height and then hurried to the river to get a measurement at this new stage, a tenth or so different from his previous average stage. Finally he noted in his records after the last determined average stage had been measured, 'Average flow for the year, if gage height continues as predicted.'

It is hardly necessary to state that C.M. Hall's records were not published by the USGS. His death during winter 1902-3 brought his work to a close. During the 2 years of cooperation, E.F. Chandler reported that the State spent about $\$ 1,500$.

NEBRASKA.-When Stout (oral commun., ca. 1938) began his work as USGS hydrographer in fall 1894, he was given no special instructions but was expected to familiarize himself with the stream-gaging methods already developed and to devise new ones as needed. Influenced by a series of dry years and that effect 
on the water supplies for irrigation, particularly in the western part of the State, the Nebraska State Legislature created a State Board of Irrigation in 1895, which was charged with the measurement of the streams. The Board therefore furnished an engineering assistant to Stout and received in return the streamflow records obtained as a result of the work of both men. About half the cost during 1895 and 1896 was paid by the State (first bienn. rept., State Board of Irrigation, 1895-96). Cooperation on the basis of division of the work was put into effect early in 1897. Stout was in charge of the gaging of the larger streams of the State; the Board limited the gaging by its engineer to the smaller streams and ditches. Stout's work was financed entirely by the USGS, except during 1898 when USGS funds were exhausted and the State contributed $\$ 137.50$ (second bienn. rept., State Board of Irrigation, 1897-98, p. 128, 1899). As a result of the cooperation that continued during the entire period, Stout gradually used State employees to make measurements, the USGS paying their salaries as well as expenses. Stout reported (oral commun., ca. 1938) that railroad passes were abolished in Nebraska during this period, which forced him to curtail the field work.

Stout tried different instruments and methods. A Colorado meter was first used and with it he tried a method of obtaining the weighted mean velocity: he would hold the meter at each point in the cross section for a time that was proportional to the depth; the final registration on the dial, divided by the sum of the depth, gave a weighted mean velocity. Stout would integrate shallow narrow streams horizontally. His standards, however, were the integration and 0.6-depth methods. On March 29, 1895, on the Loup and Platte Rivers at Columbus, Nebr., Stout made the first USGS measurements using a large Price meter. Because the extreme shifting characteristics of the sandy streambeds of Nebraska made the computation of daily discharge from gage heights in the standard manner an impossibility, Stout devised the so-called Stout method for shifting channels. The method had first been tried by Ryon in Montana, but Stout developed and made practical use of it. The number of stations maintained during the period varied from 5 to 10 .
KANSAS AND INDIAN TERRITORY.-When A.P. Davis began the Kansas work in spring 1895 with W.G. Russell as resident hydrographer, stations were established chiefly in the western part of the State where interest in irrigation was active. The State Board of Irrigation Survey and Experiment paid the gage observers until November 1,1896 , a total of $\$ 541.51$ (rept. of Board of Irrigation Survey and Experiment, $1895-96$, p. 163, 1897), which represented the State's contribution to the cooperation. The Board ceased existence on that date and official records do not show that the Commissioner of Forestry and Irrigation, who was in charge of the State's further investigations, cooperated with the Survey (J.B. Spiegel, written commun., ca. 1938).

Besides the stations operated by Russell in cooperation with the State, Hood of the Kansas State Agricultural College established a station at Manhattan, Kans., and Murphy established a few stations in the eastern part of the State. The stations established by Murphy included one on the Kansas River at Lawrence, Kans., where gage heights had been recorded by private interests since 1880 . W.G. Russell soon took over the Manhattan station and, in 1899 when Murphy went to Cornell, W.G. Russell took over all stations in the eastern part of the State and conducted all field work during the remainder of the period. The Survey's first 'Price acoustic meter was sent to W.G. Russell in June 1895 and was used by him. In 1899 , W.G. Russell attempted stream gaging in Indian Territory, but the streambeds shifted so significantly that he was unable to obtain a sufficient number of discharge measurements. The stations were dropped at the end of the year. The maximum number of stations maintained in Kansas and the Indian Territory was 13 (USGS Bull. 140, p. 339, 1896).

COLORADO.-A description of work by the State of Colorado is desirable here because the program of systematic stream gaging, initiated by that State in the early 1880 's, largely influenced the USGS in its methods from the beginning of the Irrigation Survey. The law creating the office of State engineer in 1881 required him to make careful measurements of the maximum and minimum flow in cubic feet per second of each stream from which water was to be drawn 
for irrigation, commencing with those streams most used for irrigation (rept. of State eng. of Colorado, $1883-84$, p. 6). Two stations were established in that year, but they were discontinued after a few months because of lack of funds.

Nettleton became State engineer in 1883 and established gaging stations on the Cache la Poudre, Big Thompson, and St. Vrain Rivers, all tributaries of the South Platte River. Drift and large boulders had to be removed from the channels at the first two stations in order to obtain acceptable measuring sections. An 8-vane, double-pivoted Fteley meter was used at first, but experience soon indicated that it was too delicate for rough mountain torrents and too easily clogged with small debris. Accordingly, Nettleton designed the Colorado meter during 1884 .

The gaging stations were maintained only during the irrigation season. An inspection of the stations' cross-sections made at the end of the first season showed such complete changes in form that the records for that year were, as Nettleton expressed it, reduced to the level of approximations. Because of channel changes, the ditch owners on the Cache la Poudre raised $\$ 1,650$ to be used for building a timbermeasuring flume and a shelter for a water-stage recorder. The recorder, designed by Nettleton, was installed in spring 1884 . Because this recorder is believed to have been the first one placed on a river in the United States, a description of that installation as given by Nettleton (rept. of State Eng. of Colorado, 1883-84, p. 50) is presented:

On the left bank and opposite the middle of the flume (which was 8 feet high, 32 feet long, and 103.16 feet wide) is the instrument house, $8^{\prime} \times 10^{\prime}$ in which on a table the self-recording water gauge [sic] is placed. The gauging apparatus consists of a stand pipe connected with the flume by a horizontal pipe level with its floor. A galvanized-iron hollow cylinder, having conical ends, floats in the water in the stand pipe and is connected by a line with the self-recording machinery which stands on a table, placed above the stand pipe. This consists of a horizontal cylinder turned by a clock so that one revolution is made in a week. On this cylinder a sheet of profile paper is wound and this paper is divided by heavy lines into 7 equal parts, subdivided into 2-hour periods. A pencil is connected with the float in such a manner that the rise and fall of the float cause a proportional horizontal motion of the pencil.

The method that was adopted to determine the discharge was the measurement of the mean velocity in a number of vertical sections by integration and the multiplication of the mean velocity of the cross section so determined by its area. During high water, the measurements at the Cache la Poudre station were made from a boat attached to a cable stretched across the flume. Three men were required for this operation, one to operate the meter, a second to signal for starting and stopping the recording device and to time each integral operation by a stop watch, and a third, on shore, to move the boat across the stream. The flood of 1891, which occurred when the Chambers Lake dam broke, destroyed the recorder, so L.G. Carpenter of the Colorado State Agricultural College, who had operated the station for several years, installed a French instrument built by Richard Freres of Paris, France. The records of the Cache la Poudre station were so important to the ditch companies that they subscribed a fund to convert the French recorder into a longdistance recorder by stringing a single 12-mile wire from the gaging station to a receiving instrument in L.G. Carpenter's office in Fort Collins, Colo. Although the long-distance feature of the recorder was unsuccessful and soon discarded, it is believed to have been the first installation in the United States of a longdistance recorder in connection with stream gaging.

A recorder was installed on the Arkansas River at Pueblo, Colo., in 1885, at the request of the Pueblo Board of Trade, and operated through the irrigation seasons of 1885 and 1886. The shifts in the channel, however, caused the records of discharge to be only roughly approximate. The recorder was therefore moved 9 miles upstream in 1887 . No better results were obtained and, in 1888 , the station was moved to a site 2 miles above Canon City, 
Colo., where it was located when the Irrigation Survey took it over in 1889 . The cost of installation prevented the use of a recorder at this site and a staff gage was used instead. That the Colorado records were not altogether satisfactory is indicated by the following statement in the fifth biennial report of the State engineer of Colorado (1889-90, p. 17):

No little annoyance and uncertainty has resulted from the temporary and changeable character of our gaging stations. Excepting as to the station on the Cache la Poudre, the sites have been selected principally with the reference to convenience of observers. ${ }^{* *}$ Each flood storm will change the cross-section, scouring the bed or filling in with sand and eroding the banks, thus materially modifying the area and necessitating a new profile.

The cooperation arranged with the USGS in 1895 did not at first include the stations in the South Platte River basin because the State employed a hydrographer for that section. Filmore Cogswell, the deputy State engineer, was employed also as the USGS hydrographer. For the first 2 years, Cogswell devoted his energies to the stations outside the South Platte River basin, leaving those within the basin to the State hydrographer. Beginning in 1897, however, the State funds were too small to permit the employment of a hydrographer, and Cogswell and his successor conducted practically all of the field work in the State. In 1897, Cogswell was replaced as deputy State engineer by A. Lincoln Fellows who continued the cooperative stream gaging. When Fellows (oral commun., ca. 1938) took over the work, he had never seen a current meter, nor could the new State engineer enlighten him about stream gaging, so it was necessary for him to work out his own salvation.

Fellows used a large Price meter, and after experimenting with the integration and vertical-velocity-curve methods, decided that the 0.6-depth method was satisfactory. In 1899, Fellows was replaced as deputy State engineer. F.H. Newell then arranged to pay Fellows' salary full-time in order that he might continue stream gaging. He was to take the civil service examination as soon as convenient, but a convenient time did not come until 1902 after the passage of the Reclamation Act. During those 3 years, Fellows continued in charge of stream gaging in Colorado with headquarters in the State engineer's office. The State gave him an appointment as deputy State engineer without salary, probably to justify his continued use of the State engineer's office. As the USGS had previously paid all expenses except salary, and as it now paid the hydrographer's salary also, the only State funds contributed for Fellows' work during the remainder of this period totaled about $\$ 400$. In addition, the State employees made some measurements at USGS river stations close to State ditch stations. The action of the USGS in conducting the Colorado work with its own funds was welcomed by the State engineer, as reported in the report of State engineer of Colorado (1899-1900, p. 7):

It is fortunate that the cooperation of the Hydrographic Branch has been secured. The State is under great obligation to Prof. F.H. Newell for this arrangement.

Because of the interest in streamflow records, gage heights and discharges at the key stations during this period were published daily in the Denver newspapers, which had wide circulation throughout the State. On average, 25 stations were maintained, a number greater than in any other State. Investigations of reservoir sites and possible irrigation projects were started by Fellows in 1900.

WYOMING.-Wyoming, influenced by Colorado's example, began stream gaging in 1888 . The first regular station to be established was on the Laramie River near the State line. At the time of its establishment, the chief purpose of the station was for records of flow above the diversion ditches in Wyoming. Thirty-three years later, in 1921, the United States Supreme Court used these records and those of a successor station located several miles upstream to determine the flow of the Laramie River at the State line (Supreme Court of the United States, Oct. Term, 1921, No. 3, Wyoming $v$. Colorado, et al (June 5, 1922)). The decision, in connection with the Wyoming-Colorado water-rights case, is celebrated in western interstate water 
litigation annals because, in it, the Supreme Court first definitely sustained the doctrine of priority of appropriation regardless of State lines. The operation of the Wyoming stations was not limited to the irrigation season, but covered the greater part of the open-water period. In discussing the stream-gaging records, Wyoming State engineer Mead (bienn. rept., 1894, p. 128-129) wrote:

As stream gagings have been dependent upon more pressing duties, and as neither the time nor money, available for this work, has permitted its prosecution according to any systematic plan, some of the records are incomplete and some of the results can only be considered a close approximation.

Under the cooperative arrangement in effect from 1895 to 1901 , stream gaging was conducted by the Wyoming State engineer's office, field operations were conducted by the assistant State engineer, and expenses were paid by the USGS. By this arrangement, as the State engineer wrote (bienn. rept., 1895-96, p. 75):

The advantages have been reciprocal. The Survey was relieved of detailed supervision and the State obtained valuable data free of cost.

In 1901, however, the new State engineer did not continue the cooperation, but limited the State's activities to miscellaneous measurements, chiefly of ditches. A.J. Parshall, who as assistant State engineer had conducted the stream gaging for 2 years, was no longer in State employ and the USGS appointed him Wyoming resident hydrographer, paying both his perdiem salary and his expenses. At the end of the period in 1902, the stations had been reduced to one each on the three principal rivers in the State.

MONTANA.-When A.P. Davis went to Montana in fall 1894 , he revised the stream-gaging program in the headwaters of the Missouri River and began measurements of discharge of the Missouri River itself at Townsend, Mont., where a gage had been maintained since 1891 by the Missouri River Commission. As that Commission was interested almost wholly in navigation, daily stages had been observed but no discharge measurements had been made. Having completed the construction of the headwater stations, A.P. Davis turned their operation over to Ryon, who continued to operate them until he resigned from the Montana State Agricultural College in 1897; he was succeeded in the stream-gaging work by Roe Emery, son of one of the college trustees. Emery operated the stations until Samuel Fortier came to the college from Utah in 1899. In order to bring Fortier to Montana, an arrangement had been made whereby F.H. Newell, on behalf of the USGS, and Mead, on behalf of irrigation investigations in the DOA of which he was then chief, agreed to pay a portion of Fortier's salary, who in turn was to work for both organizations (Fortier, oral commun., ca. 1938). Thus Fortier became resident hydrographer. Like Ryon, he used students for the field work. By 1897 , stations needed to be established in other parts of the State because of irrigation investigations that were being made. Accordingly, Emery established stations in the Yellowstone River basin in northern Montana, and, in 1898, Babb established stations in the Missoula River basin and appointed F.D. Smith, a professor at the University of Montana at Missoula, resident hydrographer for western Montana. The increasing prospect of Federal aid in the irrigation of public lands led Babb to establish a station on the St. Mary River in 1901, and J.S. Baker, an assistant to Fortier, to establish four additional stations in the State early in $\mathbf{1 9 0 2 .}$ In 1901, Fortier was put in charge of all stations except those in the northern part of the State where irrigation investigations were in progress and Babb's assistants made the measurements. The stations first established had vertical staff gages, but Babb used wire gages when he installed the later stations; he had used wire gages since 1892 when he installed the first one on the Potomac River [in Maryland].

UTAH.-When work resumed in Utah in 1894 , two stations that were established in 1889 were still being maintained of which one, Bear River near Collinston, Utah, had been kept up by Fortier while he was the chief engineer of a canal company and before he joined the faculty of the Utah State Agricultural College. The work in the State continued under Fortier's direction, 
with a gradual increase in the number of stations until 1899 when he resigned to go to the Montana Agricultural College. Fortier was succeeded by G.L. Swendsen, both in his college work and as resident hydrographer for the USGS. Swendsen, like Fortier, used students for stream gaging, which was considered a field laboratory for the course in civil engineering. One result of this arrangement was to make the resident hydrographer careful, as perfunctory performances would not escape the sharp eyes of the students (Swendsen, oral commun., ca. 1938). In an attempt to improve the measuring conditions at one station, cobblestones were placed in the streambed to make it more uniform and stable-doubtless one of the earliest improvements of this kind made by the USGS.

The only cooperation in the State was represented by a small sum of money contributed by Cache County for a complete hydrographic investigation of Cache Valley. Fortier told the author that this was the first investigation that showed the consumptive duty of water. The office of Utah State engineer was created in 1897, and the keeping of records of flow of the State streams was among the prescribed duties. Unfortunately, the appropriations were insufficient to cover the costs, and the USGS furnished the only streamflow records available to the first State engineer and to those who succeeded him during this period (first bienn. rept., State eng. of Utah, 1897-98, p. 7).

In connection with an irrigation survey for the Indian Service, Babb established seven gaging stations in 1899 and 1900 on the Uinta Reservation and detailed C.T. Prall, one of his field assistants, as resident hydrographer. Prall continued in that capacity under Babb's supervision during the remainder of the period. The Indian Service paid all expenses of these stations.

IDAHO.-Unlike the States where the employment of college professors insured reasonable continuity of service, Idaho had five resident hydrographers during this period (1894-1902). Vincent Tompkins, who was employed when the work was started, was succeeded by Kendall, one of the novitiates at Embudo, N. Mex., who had transferred to the Division of Topog- raphy when the camp was closed. Kendall was superseded after one season by F.J. Mills, State engineer, who gave way to F.S. Shirley and he in turn to N.S. Dils, in 1899, who continued to the end of the period. Although the work was conducted in complete harmony with the State engineer who furnished some assistance, no State funds were provided (rept. of State eng. of Idaho, 1901-2, p. 110).

NEVADA. - When L.H. Taylor began the Nevada work in 1894, no stations were being operated. In that year, a station was established on the Carson River at the Brunswick dam near Empire, which had a crest about 2 inches wide and 95 feet long without end contractions. The flow over the dam was computed by the Francis formula for sharp-crested weirs to which was added the discharge through the millrace (USGS Bull. 140, p. 212, 1896). This was the first station established by the USGS where records were computed by a weir formula. L.H. Taylor supervised the stream gaging throughout the entire period and, in addition, spent a large amount of time, beginning in 1898 , in reservoir and irrigation investigations. In 1901, the newly created Nevada State Board of Irrigation entered into a contract with the USGS, which provided that each party should spend $\$ 1,000$ on hydrographic investigations, including both stream gaging and irrigation surveys. This contract is noteworthy in that it was the first formal agreement between the USGS and a State specifically providing for equal expenditures by both parties. It is regretted that a copy of this contract cannot be reproduced herein, but it is not now available from either State or USGS sources.

WASHINGTON AND OREGON.-When systematic work was started in Washington and Oregon in 1897, Babb appointed and instructed the resident hydrographers. As a result, wire gages were used at most of the new stations. The wire gage on the Walla Walla River at the Whitman station had a cantilever support, the first ever installed by the USGS. The early wire gages were sometimes stolen, like later chain gages when they were left unprotected, and these thefts were so frequent at one station that the substitution of an inclined staff was necessary. 
Sydney Arnold was resident hydrographer for the Yakima Valley and Oregon stations during the entire period. W.J. Ware, a civil engineer of Port Angeles, succeeded A.J. Adams in charge of the work on the Olympic Peninsula in 1898. All but one Oregon station had been discontinued by 1902 because of the lack of local interest. In Washington, on the other hand, the interest in water, both for irrigation and power, was strong.

CALIFORNIA.-When the California work began in December 1894, interest in the Sacramento Valley was strong. During that year, the State Commissioner of Public Works began an examination of the Valley, which consisted of surveys and measurements, using double floats, of flood discharges to supplement information obtained previously. The Weather Bureau was recording daily gage heights of the Sacramento River at Red Bluff, Calif., but the site at the bridge was so unfavorable for discharge measurements that A.P. Davis made no attempt to establish a gaging station there. In April 1895, Lippincott established a station 12 miles above Red Bluff at Jellys Ferry, Calif., that was maintained throughout the period. The gage was read by the county ferryman, and the ferry itself was used in making measurements. Because of litigation over water rights, the Kern Land Company had established a station on the Kern River in 1893 and had developed methods for determining the discharge of that shifting stream as accurately as was then possible. A.K. Warren, the company's hydrographer, installed a waterstage recorder of his own design, the first recorder installed in California for determining discharge.

Several stations were established on tributaries of the San Joaquin River whose headwaters were in the high Sierras and the first year's records showed, by the marked diurnal fluctuations of discharge, the effects of alternate melting and freezing of mountain snows. The beds of these streams at the stations were shifting. The method of computation devised by the Kern Land Company was adopted for the Kingsburg station. Weekly soundings were made by the observer and the area was computed. The discharge measurements were plotted with areas as ordinates and discharges as abscissae, thus obtaining a rating based on areas instead of gage heights. The areas obtained by the observer's weekly soundings were referred to gage heights. By combining the relations thus obtained with daily gage heights and adjusting for streambed changes between soundings, a table of daily areas was prepared. Daily discharge was computed by using the table of daily areas and the mean velocities determined by discharge measurements. This method was probably suggested by B.M. Hall's work while he was Georgia State engineer, when he first plotted areas and discharges as coordinates on the theory that velocities would change very little with changes in area, and, therefore, that the estimated daily discharges would be less liable to be in error if obtained directly from areas rather than from gage heights (C.E. Grunsky, oral commun., ca. 1938).

Only three regular stations were established by the USGS in the southern part of the State, one in 1895 and two in 1896 , due chiefly to the fact that water was so valuable in southern California that private and municipal interests were already obtaining records of the more important streams. Lippincott, however, made many miscellaneous measurements in that region, using a bicycle for transportation in much of his early work. In addition to conducting the stream gaging, he began reservoir and irrigation investigations in 1897. Among the sites surveyed was Hetch Hetchy, which some years later became, after a furious conservation fight, the chief unit in San Francisco's enlarged water system. Lippincott told the author that the $\$ 10,000$ needed for this survey was contributed personally but on behalf of the city by the then-mayor of San Francisco.

A continued drought in 1899 made it apparent that concerted action by interested associations must be obtained in order to investigate the possibility of storing water that was required by the existing irrigation systems. During fall 1899, the California Water and Forest Association was formed for the express purpose, as its president William Thomas informed the author (written commun., Feb. 17, 1933), of obtaining a State appropriation for an independent investigation of the storage and water-supply possibilities, as it was felt that the USGS was not doing sufficient work in 
California. Lippincott did not favor this independent investigation, and he succeeded in turning the efforts of the Association toward obtaining a State appropriation for cooperation with the USGS. Although a bill creating a Board of Water and Forest Commissioners, authorizing it to cooperate on an equal basis with the Federal Government and appropriating $\$ 107,200$ for the Board's use, was passed by the State Legislature, it failed to become a law (USGS 22d ann. rept., pt. 1, p. 33-34). Having failed to obtain State aid, the California Water and Forest Association, with the help of other organizations and including counties and towns, raised more than $\$ 6,000$, the greater part of which was used for an investigation in cooperation with the USGS. This investigation consisted of reconnaissance and instrumental surveys of reservoir sites and in maintenance of gaging stations in the San Francisco Bay drainage basin.

The regular work of reservoir surveys and stream gaging was also conducted by the USGS in southern California. Although the State did not cooperate after 1900 , the USGS continued to spend more Federal funds in California than in any other State during the balance of this period. There was a lively interest in streamflow in California, and much assistance in collecting records was received during this period from several companies. A small beginning was also made in ground-water investigations.

ARIZONA.-No resident hydrographer was appointed for Arizona. The sparse population of the State and the difficulty and expense of transportation made it impossible to conduct work in the usual manner. Stream gaging was limited during this period to a few gaging stations directly related to irrigation investigations of the USGS.

NEW MEXICO.-When work began in New Mexico in February 1895, the original Embudo station was one of the first visited by A.P. Davis and Harroun. Gage heights at this station had been recorded with some interruptions since 1889. By 1895, the original cable and boat had been replaced by a cable and car. The [near] El Paso station, which had been discontinued in 1893, was reestablished at a new site when Old Fort Bliss was abandoned. A new station was established on the Rio Grande near Buckman [near San Ildefonso, N. Mex.]. In 1897, the [near] El Paso station was taken over by the recently organized International [Water] Boundary Commission (IWBC), which was created to provide an equitable distribution of the waters of the Rio Grande between the United States and Mexico (55th Cong., 2d sess., S. Doc. 229, 1898). The change in the status of the station was made because the duties of the IWBC required an accurate knowledge of the flow near El Paso, and the instability of the streambed made necessary more measurements than could be obtained by the USGS. Again, a resident hydrographer was detailed solely to that station. Similarly, in 1901, the importance of a record of flow above the site of the proposed Elephant Butte reservoir, and the shifting characteristics of the streambed, caused the IWBC to also take over the station at San Marcial, N. Mex.

Throughout the period, only the stations on the Rio Grande itself were maintained, and Harroun's stream-gaging activities decreased as the IWBC increased its activities. He resigned in February 1902, and the USGS was so busy with irrigation investigations that a successor to continue the work at the Embudo and Buckman stations was not immediately appointed. Therefore, during the remainder of that year, the IWBC took over those stations and made measurements at 3-day intervals.

TEXAS. - In fall 1898, Babb, while on a western trip, stopped at Austin to inspect the Austin dam and met T.U. Taylor of the University of Texas. T.U. Taylor was interested in Texas rivers and had made some miscellaneous measurements. The result of this meeting was T.U. Taylor's appointment as resident hydrographer for Texas. So strong was public interest in stream gaging that, on the establishment of one station, T.U. Taylor was escorted to the site by a large contingent of citizens (although perhaps lacking the proverbial brass band) who watched with awe the process of measurement. When told that the meter used was an electric one, their faith in its accuracy was unbounded because the term "electric" signified marvelous qualities.

Because of the flash-flood characteristics of the Texas streams, it was difficult to obtain 
high-water measurements. When the hydrographer succeeded in reaching a station during a flood, he would remain for several days to make measurements as the river fell. Only by this practice was it possible to complete the rating curve for a station.

Three of the stations established in Texas were equipped with what T.U. Taylor called plumber's chains, attached to lead weights with brass tags at every foot-mark on the chain, measured from the end of the weight. These plumber's chains may be considered as variations of the second step in the evolution of the chain gage typified by the one installed on the Delaware River at Lambertville, N.J., in 1897. Besides operating the regular stations, T.U. Taylor measured the flow of the many large springs of the State.

In 1900, the IWBC, in connection with the work already started at the [near] El Paso station, extended its work to the lower Rio Grande and to its principal tributaries below El Paso. It was impossible to compute rating tables for these streams because of their shifting beds, and the estimated monthly discharge was based on daily discharges obtained directly from frequent discharge measurements.

\section{SOUTHERn STATES}

VIRGINIA AND WEST VIRGINIA.- Stream gaging in Virginia and West Virginia was maintained on a small basis by D.C. Humphreys as resident hydrographer. A few stations in Virginia that were easily reached from Washington, D.C., were operated by E.G. Paul, and two stations in the southern part of the State were operated by E.W. Myers.

NORTH CAROLINA AND SOUTH CAROLINA.-During this entire period, E.W. Myers was in charge of the stream gaging in North Carolina, and he also maintained a few stations in South Carolina. The State Geologist of North Carolina cooperated to the extent of paying a part of Myers' salary when he was engaged in streamgaging and water-power investigations, the other half being paid by the USGS. A maximum of 30 stations was maintained.

GEORGIA, ALABAMA, TENNESSEE, AND MISSISSIPPI.B.M. Hall, Georgia resident hydrographer, rapidly expanded stream gaging in Georgia and extended it into the neighboring states of Alabama, Tennessee, and Mississippi. B.M. Hall's son, Warren E. Hall, was a field assistant in the latter years of this period. In view of the interest in water power in Georgia as shown by the earlier work of the State Geological Survey, the State Geologist cooperated with the USGS as much as possible. This cooperation began in 1896 with the State paying gage observers. After the first year's cooperation, the State Geologist stated (adm. rept., State Geologist, year ending Oct. 15,1897, p. 5,1897$)$ that "the work of the water powers of the State it is my purpose to continue until the subject is complete. This information bids fair to be of great use to Georgia at no distant day. With the advance of electricity there will undoubtedly be a greater demand for water power." The amount spent for gage observers salaries was about $\$ 300$ yearly for the first 2 years, but, by 1899 , the Weather Bureau extended its flood forecasting into Georgia and paid the observers at a number of the USGS stations, thus reducing the State's contribution to some $\$ 200$ annually.

The Georgia example of cooperation with the USGS in studying its water powers undoubtedly influenced the State Geologist of the adjoining State of Alabama to do likewise. The amount paid annually by the State Geologist for observers in Alabama ranged from $\$ 69$ to $\$ 212$, the total for the period being $\$ 526.36$ (ann. repts., Geol. Survey of Alabama, years 1897 to 1902). In 1902, the Alabama State Geologist stated that the cooperative work would be continued until the water-power resources of the entire State were determined (Geol. Surv. of Alabama, rept. of progress, fiscal years 1900-1 and 1901-2, 1902). In 1900, stream gaging was extended into Mississippi and Tennessee.

One reason for the comparatively large number (30) of stations maintained in this region under the direction of B.M. Hall was the use made of Weather Bureau stations, which not only reduced the cost of observers, but in some instances made possible the computation of records of discharge for earlier years. In addition to the Weather Bureau stations, there were three others where B.M. Hall conducted measurements at which gage-height records had 
been obtained for long periods: gage heights had been recorded on the Savannah River at Augusta, Ga., since 1875; the Army Engineers had maintained a gage since 1888 on the Black Warrior River; and the Army Signal Corps established a gage on the Tennessee River at Chattanooga, Tenn., in 1879, which was taken over by the Weather Bureau in 1891. The Army Engineers had made some discharge measurements at these stations, and these measurements, together with others made subsequently by the USGS hydrographers, made possible the computation of the discharge for earlier years.

\section{EASTERn STATES}

PENNSYLVANIA.-The first stream gaging by the USGS in Pennsylvania occurred in 1897 on the Delaware and Susquehanna Rivers. The Harrisburg (Pa.) Water Company had obtained records of stage of the Susquehanna River since 1890. The zero of the Harrisburg gage was set at the low-water mark of 1804 , which indicates that 1804 was believed to be the year of lowest flow on the Susquehanna prior to 1890 . With the increase in available funds, the USGS expanded the work in 1899. Besides their use for other purposes, it was hoped that the records would aid in the discussion of the influence of forests on streamflow. The fact that the Commissioner of Forests was urging the passage of a State appropriation for cooperation with the USGS was doubtless not without influence in the USGS increasing its work in the State. The State Legislature evidently failed to make the recommended appropriation because no cooperation was arranged with Pennsylvania officials at that time. E.G. Paul was the resident hydrographer for Pennsylvania, but the term "resident" was evidently used with poetic license, inasmuch as his only periods of residence in the State were during the flying trips to the gaging stations several times a year.

NEW YORK.-A systematic record of the flow of the Croton River, the principal source of water supply for New York City, was begun by the city water department as early as 1868 . This record included both the flow diverted through the conduit and the waste over the spillway of the Old Croton dam (rept. of State eng. and surv. for 1901, p. 586, 1902). The next record was that of the Hudson River at Mechanicville, N.Y., begun by the Duncan Company at the paper mill and dam. The Albany Water Department maintained records at weirs on small streams near Albany, N.Y., during part of the years 1891 to 1894 .

The years 1895 and 1896 marked the real beginnings of stream gaging in New York State when George W. Rafter established a number of gaging stations at dams in connection with the upper Hudson storage survey. Rafter established additional stations in $\mathbf{1 8 9 8}$ for the U.S. Board of Engineers on Deep Waterways (BEDW). Altogether 20 stations were established before 1900 . The stations established by the BEDW were located at dams in order to obtain records as quickly as possible, particularly during the approaching winter season. Experiments on full-size models of similar sections of the many dams were conducted in 1899 at the Cornell University hydraulic laboratory to determine the coefficients for use in computing the discharge using weir formulas.

The BEDW computed the discharge of the Richelieu River, the outlet of Lake Champlain, from 1875 to 1901 , the longest record of discharge in the State. Records of lake elevations at Fort Montgomery, Rouses Point, N.Y., had been started on January 1, 1875, by the Army Engineers, and the construction in 1896 of a dam at Chambly, Quebec, Canada, 35 miles downstream, provided an opportunity to rate the discharge of the Richelieu River in terms of lake elevations (WSP 65, p. 38-39, 1902). These stations were only perfunctorily maintained during 1899, after the work of the BEDW had been completed, and Rafter wanted F.H. Newell to take over the stations and maintain them (R.E. Horton, written commun., ca. 1938). The transfer of the stations was made that fall, but no one was assigned to them. Robert E. Horton, a nephew of Rafter's who had been employed as an assistant engineer by the BEDW in the water-supply division, was given a per-diem appointment by the USGS to compute the records for 1899 .

By 1900, the growing demand for records of streamflow in connection with water supplies for the larger cities, coupled with the 
development of water power for use in manufacturing pulp and paper, led the New York State engineer and surveyor to recommend an appropriation for cooperative stream gaging. The State Legislature for 1900 enacted the following law (rept. of State eng. and surv. for 1900, p. $34-35,1901)$ :

The treasurer shall pay, on warrant of the comptroller, for the State engineer and surveyor, one thousand dollars to be used with the United States Geological Survey in hydrographic work connected with the measurements of the volume of streams and flow of water in the State of New York.

In commenting on the cooperation, the State engineer and surveyor, in the same report, stated that "the State received the full benefit of the Survey's experienced and skilled engineers and of their accurate instruments and methods and thus obtained at a nominal cost information which was already of evident value that would be increased by its continuance." As a result of the cooperation, R.E. Horton was given a per-diem appointment as resident hydrographer. There was no definite allotment of USGS funds for the New York work, but it was understood that the Survey would spend an amount at least equal to that of the State (R.E. Horton, written commun., ca. 1938).

In describing the first year's work, the State engineer and surveyor stated in his report for 1900 (p. 34-35, 1901):

Most of the former stations where observations have been and are still made are located at dams where it has been found that the records were rendered uncertain by the leakage of the dams, the changes in crest of the dam, by flashboards, and by leakages from flumes and other works connected with the dams. In selecting the new stations they have been located with a view of avoiding these uncertainties, by making observations in unobstructed reaches of the streams where the flow is, so far as possible, uniform, and where the flow of water at various stages can be determined by current meter.

Leakage through the dams and turbines was presumably measured by current meter and records of operation of the turbines were kept. The turbines were used as meters, and the discharge through each turbine at a given head and gate opening was determined from a rating of the same or similar type and size of turbine. The data on the ratings were furnished by the the Holyoke Water Power Co. from tests made in the Holyoke testing flume (R.E. Horton, written commun., ca. 1938). The first year's cooperation was so satisfactory and the requests for additional records so many that in 1901, the legislature increased the State appropriation to $\$ 1,500$.

In 1901, R.E. Horton wrote further, the water department of the city of New York wanted gaging stations established on streams in the Catskill region that might be considered possible sources of additional water supply, and city officials entered into cooperation with the USGS for that purpose, each party contributing $\$ 1,500$ annually until 1903. Harold $K$. Barrows, and three other engineers who did not remain long in the USGS, were successively in local charge of these stations under R.E. Horton's supervision. The type of gage installed during 1900-1 was the stranded (7-strand) clothesline cable first and the standard chain later.

Prior to the establishment of the New York City stations in 1901, no current-meter measurements had been made under ice because it was assumed that the records of such measurements at dams were not required. It was recognized, however, that such measurements, which involved special equipment, were needed in order to obtain winter records at regular gaging stations; R.E. Horton had done some experimental work with such equipment on streams in the vicinity of his office in Utica, N.Y. With the establishment of gaging stations for the city of New York, knowledge of the winter flow was essential and measurements under ice were begun. This marks the beginning of the USGS work of measuring streams by current meter under the ice; in other northern States, records at current-meter stations were discontinued during the ice period.

MICHIGAN.-In winter 1900-1 while on a vacation in Michigan, R.E. Horton spent most of his time trying to interest city officials, waterpower owners, and others in streamflow 
records. As a result, 13 stations were established during the next 2 years and the necessary field work was conducted by the interested parties. Having arranged this cooperation, R.E. Horton was given a definite allotment of USGS funds to supervise the work and compute the records.

MAINE.-For some years before 1901 when the USGS extended the work to Maine, a few records had been collected in connection with the water-power plants and had been furnished to the USGS for publication. The longest of these records was that of the Presumpscot River at the outlet of Sebago Lake (from 1887). Long before that, however, the people of Maine were stream-conscious; a record of the opening and closing dates of navigation on the Kennebec River began 2 years after the Revolutionary War and continued until 1911, a period of 127 years (WSP 561, p. 270-271, 1923).

In 1897, Dwight Porter of the MIT was employed by the USGS to study the waterpower streams of the State, based on existing streamflow records and personal observation. It was not until 4 years later, near the end of the present period, that the USGS started actual field work in Maine.

By 1901, water power had become so important that $\$ 500$ was raised by private subscription and placed at the disposal of the Governor's council for cooperation in measuring the streams having the greatest value for power (USGS 22d ann. rept., pt. 1, p. 31, 1901). In August 1901, H.A. Pressey went to Orono, Maine, to persuade a former classmate, then a professor of civil engineering at the University of Maine, to accept a per-diem appointment. In this he was successful, and so Nathan Clifford Grover first appears in this History. Grover was given neither advice nor supervision in stream gaging, only certain printed instructions, and the selection of the new stations to be installed was left completely to his judgment.

\section{Passage of the Reclamation Act}

[Author's note: The Reclamation Act was so far reaching in relation to the subsequent events of this History that the incidents leading to its enactment are given in considerable detail in the pages to follow.]
The opposition of the westerners to the withdrawal from entry of public lands suitable for irrigation and reservoir sites resulted in the discontinuation of appropriations for the Irrigation Survey in 1890. At that time, no further Federal reclamation action was wanted. The immediate desire of the westerners was expressed by the resolution adopted at the first meeting of the Irrigation Congress in Salt Lake City, Utah, September 15-17, 1891 :

Resolved, That this Congress is in favor of granting in trust, upon such conditions as shall serve the public interest, to the States and Territories needful of irrigation, all lands now a part of the public domain within such States and Territories, excepting mineral lands, for the purpose of developing irrigation, to render the lands now arid, fertile and capable of supporting a population.

The next irrigation congress, known as the International Irrigation Congress, was held October 10-14, 1893, in Los Angeles, Calif., and an address to the people of the United States setting forth the necessity for reclaiming the arid public lands was adopted. It was suggested that a national commission be created to study and report as soon as possible on the course to be followed. At this meeting, the belief was widely held that water was available for the irrigation of vast areas, and when Major Powell stated that the water supply was sufficient for only a small part of the available land, he was, as F.H. Newell told the author, roundly "hissed." Both F.H. Newell and A.P. Davis attended the Los Angeles Congress and, with Powell, were the Federal representatives. Although A.P. Davis at that time was a topographer, his interest in questions related to water supply led him to present a paper on the economic use of water. F.H. Newell presented a paper describing the USGS investigations.

In 1894, the Congress passed the Carey Act, which authorized a grant not to exceed 1 million acres of public land to each State in the arid region on the condition that such granted land be irrigated by any means the State might choose to adopt. Thus, the objective desired by the first irrigation congress was partially attained. As the lands susceptible to irrigation by individual and cooperative means had 
largely been reclaimed, most of the remaining lands could only be irrigated by large systems which proved, with some outstanding exceptions, to be beyond the means at the disposal of the States, and only a little progress was made in reclaiming the arid lands.

It is evident that the leaders in the irrigation movement had little faith in the Carey Act as a means of reclaiming large areas of land because, at the next irrigation congress held September 3-9, 1894, in Denver, Colo., shortly after that Act had been passed, resolutions were adopted that advocated the creation of a national irrigation commission to supervise such irrigation works as might be constructed by the Federal Government (official proc., p. 84).

The gradual change in the attitude of the westerners, which was destined to reverse itself completely within the next few years, was due to both nature and man. Nature brought the series of dry years to large areas of the West during the latter half of the 1890's, and man was responsible for the severe depression that followed the panic of 1893 . The depression was particularly severe in the West, whose people had always looked to the East for the capital needed for development. During those years, not only was that source of capital dried up, but loans were called, resulting in wholesale foreclosure and losses of property.

By September 1895, when the Irrigation Congress was held in Albuquerque, N. Mex., the temper of the westerners had changed so much that they again wanted the Irrigation Survey to continue under the DOI, and passed resolutions calling for an appropriation of $\$ 250,000$ for that purpose (official proc., Fourth Irr. Cong., Sept. 16-19, 1895, p. 68). The nationwide depression and the indifference if not actual hostility of easterners, however, prevented any Congressional action at that time. F.H. Newell attended the Irrigation Congress and read a paper on water supplies of the arid regions.

Discouragement not being a part of western psychology, delegates to the Fifth Irrigation Congress, which was held in Phoenix, Ariz., December 15-17, 1896, again passed resolutions calling for hydrographic surveys, specifically for reservoirs, and for the construction of storage reservoirs by the Federal
Government. At that congress the chairman said:
I The year of 1896 is about ended. Many an individual will be glad to see it die be- cause it has brought ruin and death to all of his business and financial enterprises. Perhaps no interest suffered more dis- astrously than irrigation.

Thus it was inevitable that Federal aid should be invoked, as none other was available. F.H. Newell was a delegate from the District of Columbia, and read a paper on national aid for water storage projects.

By this time, the general opinion was that Federal aid for irrigation should take the form of the construction of reservoirs. Delegates to the seventh session of the Irrigation Congress, which was held in Cheyenne, Wyo., September 1-3, 1898, passed resolutions calling for an appropriation of $\$ 100,000$ for a hydrographic survey for the measurement of streams, for surveys of reservoirs, and for sinking deep or artesian wells. At this session, the construction of reservoirs was given great prominence from quite a different angle-Captain H.M. Chittenden, Corps of Engineers, advocated the construction of reservoirs by the Federal Government as a part of the regular river and harbor work. Chittenden stated (official rept., Seventh Sess., Nat. Irr. Cong., Sept. 1-3, 1898, p. 79) that "if Montana and Idaho must have a share in the River and Harbor bill, how much better it would be if that share were put into great reservoirs rather than in works for navigation which is not a thing of the present." Chittenden's immediate interest in the subject seems to have been due to the fact that the Congress had appropriated $\$ 5,000$ for the Army Engineers survey of reservoir sites in Colorado and Wyoming and he had been in charge of that work. The thought of getting something for nothing, which has ever appealed to human nature, induced the Irrigation Congress to adopt resolutions favoring the construction of reservoirs by the Federal Government as a part of a national program of internal improvements. F.H. Newell was again a delegate, served on the committee on credentials, and read a paper on the measurement of streams and its relation to irrigation problems. 
By 1899 , it was apparent to the leaders in the irrigation movement that if tangible results were to be achieved, a more permanent organization would be necessary, rather than the loosely organized Irrigation Congress that changed each year, and that the active support of easterners must be enlisted. Accordingly, a group of seven, including George H. Maxwell, F.H. Newell, and Guy Mitchell, met in Wichita, Kans., on June 2, 1899, and initiated the organization of the National Irrigation Association, members of which promoted support for Federal irrigation financing among manufacturing and businessmen of the East who were interested in the western development of the country, which would provide a market for eastern products. The railroads were particularly interested in the association and contributed generously to the expenses of the executive committee, of which Maxwell of California was the chairman and "a live wire." He established headquarters in Washington and became the chief lobbyist for Federal reclamation aid. The efforts of the association were rewarded by the endorsement of Federal aid for irrigation by the three leading political parties in the presidential campaign of 1900.

As a result of the "new deal," the next irrigation congress was held not in the far West, as had all the preceding meetings, but in Chicago, Ill., within the territory where votes must be sought if the Congress was to grant the desired aid. At this congress, held Nov. 21-24, 1900, there were two schools of thought regarding Federal aid (official proc., Ninth Ann. Sess., Nat. Irr. Cong., November 21-24, 1900, p. 2). Chittenden again advocated the construction of reservoirs (inferentially as a part of the regular river and harbor work) and expressed the opinion that the Congress would be strongly opposed to putting the Government "into the irrigation business," stating that government and business must be divorced. The other school of thought was ably advocated by Congressman (later Senator) Francis Newlands of Nevada, who expressed the belief that the Federal Government, as the proprietor of large areas of public lands was justified, like any other proprietor, in preparing such lands for use and settlement.

If Federal aid was not to be limited to reservoir construction as a policy of internal improvement, then some means must be found for Federal financing of the work other than by direct appropriations. The means proposed by F.H. Newell in a paper on that subject consisted of setting up a fund to be derived from the sale of public lands; this fund would be used chiefly for the construction of reservoirs and main canals for irrigation and would be paid back by the settlers. The settlers would be expected to build their own laterals. The idea of something for nothing again prevailed and the resolutions adopted by the Ninth Irrigation Congress advocated the building of storage reservoirs under existing statutes, which meant as a part of the regular river improvement work. The Congress, however, was urged to appropriate $\$ 250,000$ for conducting hydrographic surveys.

The combination of the efforts of the dominant political leaders in New York State and an assassin's bullet aided in the successful outcome of the project of the irrigationists. To rid themselves of a governor whom they could not control, the political leaders of New York practically forced the Vice Presidential nomination of the Republican ticket, which was headed by William McKinley, on Theodore Roosevelt. That ticket was elected but, until September 1901, no progress in Federal irrigation was apparent because McKinley was not aggressively sympathetic with the West and its aspirations even though he advocated Federal aid to irrigation in his message to the Congress (official proc., 10th Nat. Irr. Cong., October 6-9, 1902 , p. 75). When McKinley was assassinated at the Pan American Exposition in Buffalo, N.Y., Roosevelt succeeded to the Presidency and conditions changed.

Roosevelt, as a result of his many years ranching in North Dakota, had developed a strong interest in and knowledge of the West and its needs. An equally important factor was his friendship for Gifford Pinchot, the outstanding conservationist of that period whose chief interest was in forests. Thus imbued with the spirit of conservation and having a natural interest in the West, it was inevitable that Roosevelt should espouse the cause of Federal aid to reclamation. His intense nature did not allow him to hesitate after his enthusiasm was aroused and, in his first message to the Congress in 
December 1901 less than 3 months after becoming president, Roosevelt urged the Federal reclamation of the arid West.

So successfully had the groundwork been laid by the irrigation interests and so powerful was Roosevelt's influence with the Congress that the Reclamation Act became law on June 17,1902 . The story of the actual struggle in the Congress was told by participants at the 10th session of the National Irrigation Congress held in Colorado Springs, Colo., October 6-9, 1902 (official proc., p. 35-36). Congressman Bell of Colorado gave the following account:

When we reached Congress the last session, every Representative from every arid and semi-arid State was invited to meet and we solemnly pledged ourselves that we should agree upon a bill without one single dissenting vote. We appointed one man from every State and Territory and agreed that whatever bill these men presented, when amended by that body, should be the bill of every Senator and Representative from every arid State and Territory in the Union. That made the nucleus around which this success was gathered. The departments of this government have reached a state in development that makes them very efficient, and I want to say that the Secretary of the Interior, while he was with us heart and soul had a department under him known as the Geological department, and that practically made the irrigation bill and passed it after it was made. That department *** with the Secretary of the Interior and the President gave us a prestige that made this bill pass.

There is no man present who did so much work in formulating, in propaganda, and in spending his money-he was almost the laughing stock of our enemies-as did Francis Newlands of Nevada. He not only pressed himself to the front with speech after speech, on every occasion, ${ }^{* * *}$ but he spent untold thousands of dollars in distributing literature in every niche and corner of the United States. He spent no less than $\$ 15,000$ in banquetting men who did not believe in the irrigation bill. *** Then he would invite as speakers of the evening Hydrographer F.H. Newell, Secretary Hitchcock and the experts from those departments of his own political faith and they had to listen to the most eloquent propaganda. And so our friend Newlands went on week after week, month after month, and quietly through the departments of this government overcame the opposition against us.

It is strange how the question grew. From the time I went there every man was introducing a bill for his own State. ${ }^{* * *}$ and finally Mr. Newlands picked up all our bills and from the bunch framed the Newlands-Hansbrough bill which is today the law of the land.

Another speaker called attention to the fact that F.H. Newell's suggestion to create an irrigation fund from the sale of public lands appealed to the people and their representatives in the Congress and received their endorsement.

The passage of the Reclamation Act profoundly altered the future of the Division of Hydrography by changing it from a minor division to a major branch of the USGS. And during the long struggle, Frederick Haynes Newell played an increasingly important part and was finally instrumental in changing the nature of Federal aid from the construction of reservoirs by the Army engineers to the construction of complete irrigation projects by the DOI. 


\section{Part VIII-The Hydrographic Branch (1902-6)}

The period of the Hydrographic Branch covers the years from the passage of the Reclamation Act in 1902 to F.H. Newell's selection of his successor as chief hydrographer of the Branch effective July 1, 1906. It was a sharply defined period that marked the immediate beginnings of the Water Resources Branch. The work of stream gaging had previously been directed by men who were chiefly interested in irrigation investigations and who gave little personal attention to stream gaging. The actual field work had been conducted by per-diem appointees whose chief interests were generally outside the USGS, a situation that did not promote the proper and necessary development of the technique of stream gaging.

During the period of the Hydrographic Branch, on the contrary, investigations of the water resources were supervised by men whose chief interests were in the work of the Branch, and the field work was generally conducted by men who gave their entire time and thought to it. The organization of the Reclamation Service had taken the older men, leaving a younger group who had not long been connected with the USGS to conduct the hydrographic work. The result was the codification of existing methods first rather than rapid advances in the art of stream gaging.

\section{ENLARGEMENT OF SCOPE OF HYDROGRAPHY}

The administration of the Reclamation Act, which was entrusted to the Secretary of the Interior, was largely delegated by him to the Director of the USGS in order that the experience and knowledge gained during the time when the USGS had conducted irrigation and reservoir surveys and water-supply investigations, might be fully used (USGS 23d ann. rept., p. 15, 1902). As a result, it was possible to start work almost immediately instead of waiting to form and train a new organization. Not only did the Reclamation Act greatly increase the USGS work, the Sundry Civil bill enacted June 28, 1902, by the Congress increased the stream gaging appropriation from $\$ 100,000$ to $\$ 200,000$. To meet this situation, the Division of Hydrography, which had been a part of the Geologic Branch, was expanded into the Hydrographic Branch, which ranked equally with the Geologic and Topographic Branches and surpassed them in the amount of available funds.

The Hydrographic Branch was divided into the Division of Hydrography (stream gaging), the Division of Hydrology (occurrence of ground water), the Division of HydroEconomics (quality of water relative to agriculture and industry), and the Reclamation Service (selection and construction of irrigation projects in accordance with the Reclamation Act). F.H. Newell was the logical man to direct the greatly enlarged work of the Hydrographic Branch and was placed in charge of it by the Director, with the title of Chief Hydrographer (CH). He was also designated chief engineer of the Reclamation Service.

Now that the work of the Branch required a permanent force of skilled engineers, all positions below that of Director, with a few minor exceptions, were classified under the Civil Service law and were filled only by examination (USGS 24th ann. rept., p. 181, 1903). So urgent was the demand for additional men that the Civil Service Commission held three examinations in the first year. The perdiem appointees who desired to give their entire time to the USGS, and that included many 
of them, qualified by examination and were given full-time appointments in the classified service. The engineering force of the Branch was divided into the grades of engineering aid with annual salaries from $\$ 720$ to $\$ 1,000$; assistant engineer, from $\$ 1,200$ to $\$ 1,600$; and engineer, from $\$ 1,800$ to $\$ 2,700$. The grade of aid was designed for young men, usually recent graduates from college. They were paid monthly salaries from $\$ 60$ to $\$ 75$ for a probationary period of 6 months and annual salaries from $\$ 900$ to $\$ 1,000$ thereafter. After 1 or 2 years, the aids were eligible for promotion to the grade of assistant engineer. When they reached that grade, they were considered regular officers of the USGS (WSP 93, p. 28-29, $1904)$. In addition to the different grades of engineers, the grade of hydrographer that ranked with that of engineer was given to a few men, chiefly those engaged in stream gaging and not likely to work in the Reclamation Service. In the history of this period, no attention, except incidentally, will be given to the activities of the Reclamation Service, because its work was generally separated from the investigations of surface and ground waters, except in connection with its own irrigation projects and the supervision of the stream gaging in the arid regions.

\section{InCRease in Permanent Force}

When the Hydrographic Branch was organized at the beginning of the period, the permanent force brought over from the Division of Hydrography consisted of H.A. Pressey, in charge of stream gaging in the East, G.H. Matthes, in charge of the computing section, and E.G. Paul, in charge of equipment and of stream gaging in the States near Washington, D.C. This force was increased within a few months by the addition of George B. Hollister, Marshall Ora Leighton, and John Clayton Hoyt.

Hollister, who had been a grain broker in Rutherford, N.J., was given an appointment in 1901 as publicity man in accordance with F.H. Newell's purpose of educating the public. He made a few miscellaneous river measurements in New Jersey, but his real work was the preparation of articles of a popular nature dealing with the USGS work. After the Hydrographic Branch was organized, Hollister was given an appointment as hydrographer, having presumably taken the civil service examination, and was brought to Washington, D.C., and given the position of chief executive officer in general charge of the Washington office with special reference to publicity (F.H. Newell, oral commun., ca. 1938).

In 1901, before the organization of the Hydrographic Branch, F.H. Newell needed an engineer who was qualified to study the quality of water and who would also be good at making public contacts, so he appealed to his alma mater to recommend someone having such qualifications. The MIT replied that Leighton was suited to his needs, that he had specialized in chemistry and biology, and was an excellent contact-man (F.H. Newell, oral commun., ca. 1938). Leighton was then health officer in Montclair, N.J. Accordingly, F.H. Newell went to Montclair and asked Leighton to prepare a report on sewage pollution in the metropolitan area near New York City and its effect on inland water resources in order, as Leighton said (oral commun., ca. 1938), to size up his technical ability before offering him a position. This report, completed in May 1902, was published as WSP 72 (1902). Evidently the test was successfully met because Leighton was given a perdiem appointment on July 1, 1902, pending qualification by civil service examination.

Matthes was anxious to begin irrigation investigations, under the Reclamation Act, with the possibilities for wider experience but, before he could do so, it was necessary to find his successor in the computing section where the field records were prepared for publication. J.C. Hoyt, who then computed in the CGS who had recently become interested in streamflow studies, was among Matthes' acquaintances. Matthes induced him to transfer to the USGS, which he did on September 3, 1902, to take charge of the computing section.

Murphy, who had been conducting special investigations for the USGS at the Cornell hydraulic laboratory, likewise took the civil service examination and, on October 9, 1902, was given an appointment as assistant engineer. After a few months of stream-gaging work in Nevada, Murphy was brought to Washington, 
D.C., and made inspector of stream gaging. In that trying position, he did much to improve the selection of sites for gaging stations, the technique of field work, and the accuracy of the resulting records. There is little of detail to record with respect to his work as inspector. One incident in connection with an inspection of T.U. Taylor's work in Texas, however, is worthy of note as it brings out the contrasting characteristics of the two personalities. Murphy was serious-minded and conscientious, being particularly saving in time on his field trips; T.U. Taylor, on the other hand, was an inveterate wag. On one trip, Murphy had asked T.U. Taylor to arrange a schedule that would enable him to see the maximum number of stations within the brief period that he could allot to Texas. Accordingly, T.U. Taylor arranged a schedule whereby relays of his assistants rushed the harassed inspector around a portion of the district, without stopping for $\mathbf{4 8}$ hours or more, during which time he had no sleep (Grover, written commun., ca. 1938).

At the beginning of the period, 20 resident hydrographers were conducting the field work on a per-diem basis. Of these, Grover, R.E. Horton, and M.R. Hall obtained civil service status within a few months, and were given full-time appointments to conduct stream gaging on a larger scale in their old districts. Myers transferred to the Reclamation Service. In the West, Fellows, Swendsen, L.H. Taylor, and Lippincott obtained civil service status and received fulltime appointments in the Reclamation Service. Some of them continued to supervise stream gaging also. D.C. Humphreys, W.G. Russell, Parshall, and T.U. Taylor retained their perdiem appointments and spent part of their time stream gaging in their old districts as in the past. Others, for unknown reasons, severed their connections with the hydrographic investigations.

The personnel enumerated may be considered the directing force of the organization during the earlier years of the period. Changes inevitably occurred, as indicated in the appropriate places in this History.

\section{Organization of the Washington OfFICE}

During 1902, stream gaging went forward largely by its own momentum. F.H. Newell was engrossed with the task of organizing the Reclamation Service and conducting the investigations required by the Reclamation Act. On January 1, 1903, F.H. Newell organized the Washington office force of the Branch. As already stated, Hollister was given the title of chief executive officer, but actual direction of stream gaging came either from H.A. Pressey or Matthes or, later, from J.C. Hoyt. H.A. Pressey resigned in 1903 and thereafter J.C. Hoyt, acting under F.H. Newell's general supervision, was the real directing force in stream gaging. The Division of Hydrology was created in January 1903, and the Hydro-Economics Division was organized in September of that year. The chiefs of these divisions reported directly to F.H. Newell, but it appears probable that the latter's supervision was general, and that to each was left the task of working out his own program.

By spring 1904, it was apparent to F.H. Newell that he could not give the required supervision to the enlarged work of the waterresources investigations, so on the first of July, Grover was brought to Washington, D.C., with the title of assistant chief hydrographer. Thereafter, until the end of the period, Grover, acting under F.H. Newell's general supervision, was in charge of the stream gaging, the hydrologic, and the hydro-economic activities.

Within a short time after Grover was put in charge of the water-resources activities, the policy began of bringing into the computing section newly-appointed junior engineers and having J.C. Hoyt train them for a few months in office computations. Training was also given in field methods because the stations in the neighboring States, formerly operated by E.G. Paul with one or two assistants, were taken over directly by the Washington office under Grover's supervision, and the field work related to them was conducted by engineers of the computing section. When calls for additional engineers came from the field, usually from the Reclamation Service, the computing section supplied them. As a result of this policy, many of the engineers who afterward rose to positions of responsibility had had experience in the Washington, D.C., office. When E.G. Paul was relieved of the maintenance of the gaging stations near Washington, he remained in 
charge of the equipment of the Branch until 1905 when he was superseded in this duty by W.G. Steward, who also rated the meters.

Several young engineers were kept continuously in the computing section. The first of these was F.H. Brundage whom J.C. Hoyt induced to transfer from the CGS in 1903, as he himself had done the year before. W.C. Sawyer was appointed engineèring aid and assigned to the Washington office that same year. At first he was E.G. Paul's assistant in stream gaging, but when that work was turned over to the computing section in 1904 , he became a member of that section. In January 1904 , Roy H. Bolster, who had been on Reclamation Service work in the West in 1903, joined the computing section and, in November 1904, the author, who had entered the Reclamation Service by transfer from the Lake Survey early in 1904, did likewise. Fred F. Henshaw was appointed in September 1905. Brundage and Sawyer did not stay in the Washington, D.C., office, but Bolster, Henshaw, and the author continued until the end of the period and formed, with J.C. Hoyt as chief, the regular force of the computing section. Harold D. Padgett, messenger, and Marion I. Walters, copyist, were also engaged in the work of the section. Other engineers were brought into the office during the winter to assist in computations, but they returned to the field in the spring.

The chief function of the computing section was the preparation of the records for publication. During this period, the base data and suggested rating curves were prepared by the district hydrographers and sent to the Washington, D.C., office where the records were computed. Correspondence both protracted and voluminous followed in some instances before rating curves were accepted by both district and Washington offices. The point of view of the District office staff was that the Washington office staff knew nothing about "local conditions," and personnel of the Washington office thought that the district office staff did not have the accumulative experience gained by studying rating curves from all parts of the country. Honors rested sometimes with one side and sometimes with the other.

The streamflow records were published annually during the period as WSP under the title "Report of progress of stream measurements." Curious inconsistencies appeared in the publication of those records. It was apparently felt that the accuracy of the records obtained at stations on streams with permanent or semipermanent beds for which the same rating tables were applied over considerable periods did not warrant the publication of daily discharges but, in order that the user of the records might check the computations, the discharge measurements, tables of daily gage heights, and rating tables were presented in addition to the computed monthly discharge, which was cautiously labelled "estimated monthly discharge." The less accurate records for shifting streams, on the other hand, were computed by a series of rating tables or by special methods, and the daily discharges were published as "mean daily discharges," whereas the more accurate monthly values were called "estimated mean monthly discharges." R.E. Horton urged the publishing of tables of daily discharge as well as daily gage heights and rating tables because he felt that the chief users of the New York records-the water-power interests-needed the daily discharges.

\section{Organization of Districts}

The organization of districts in the East was governed by different considerations from those in the reclamation States. In the East, with the field work in charge of engineers who gave their entire time to it and with the expansion of the field program with increased appropriations, there was a tendency to enlarge the district and to furnish younger men as assistants to conduct the routine stream gaging. In the West, the irrigation investigations in each State were conducted so intensively that a Reclamation Service engineer was assigned to supervise, and he designated one of his assistants to do the actual work. There were two exceptions to the single-State districts of the West: One was a district in the central part of the West that consisted of Colorado, Kansas, Nebraska, South Dakota, Wyoming, and parts of Utah, New Mexico, Oklahoma, and Indian Territory; the other was a district that consisted of the remaining parts of New Mexico, Oklahoma, and Indian 
Territory. An allotment from the stream-gaging appropriation was made to each engineer in charge of irrigation investigations, and he had that money for use in addition to allotments from the reclamation fund. It was the general rule that the cost of stream gaging prior to the selection of a project was paid from the streamgaging allotment, but the cost of gaging stations connected with definitely selected projects, especially if the stations had reached the construction state, was paid from the reclamation fund (R.F. Walter, oral commun., ca. 1938).

\section{New Districts}

With the increase in the stream-gaging appropriation from $\$ 100,000$ to $\$ 200,000$ effective July 1,1902 , F.H. Newell, with due regard to effective publicity, considered the enlarged appropriation as an opportunity for a countrywide expansion of the work, thereby adding support and consolidating the gains already made. The so-called "arid West" had been generally covered in a meager way, but the available funds had not previously permitted attention to the water resources of the populous States of the upper Mississippi River valley. This area, therefore, was selected first for organization.

\section{Chicago District}

F.H. Newell was so anxious to extend stream gaging to the upper Mississippi River valley that he started work there early in July 1902. In order to promote quality-of-water investigations as well as stream gaging, Leighton, whose duties during the next 4 years were to be connected primarily with quality-of-water work, was selected to be in charge of the district, and from the beginning he studied both quantity and quality of the surface waters. He went first to Ohio where the State Board of Health had been cooperating with the USGS until a few months before and arranged with B.H. Flynn, the Board's engineer, to establish and maintain certain gaging stations. Leighton visited Indiana next, but could see no need for stream gaging there. While in Indiana, however, he started an investigation of the pollution of streams by strawboard wastes, in cooperation with the State Board of Health. The Chicago Sanitary District of Illinois wanted a number of stations on the Illinois River in order to show the effects of diversions through the drainage canal, and Leighton arranged to establish them. The field work was conducted by E.H. Heilbron, an engineer of the Sanitary District, who was given the usual per-diem appointment for conducting the proposed work while remaining an employee of the Sanitary District.

After completing the upper Mississippi River valley reconnaissance, Leighton returned to Washington, D.C., took the civil service examination, and was appointed hydrographer effective December 1, 1902. F.H. Newell then decided to have Leighton conduct his work on quality of water from a Chicago, Ill., headquarters and to start the stream gaging as soon as civil service assistants could be obtained. Accordingly, Leighton established an office with one clerk in Chicago early in 1903. Within a few months, three engineering assistants were added to the district force and attention was given to stream gaging.

In February 1903, Leighton arranged for the establishment of gaging stations in Missouri. With the long-established precedent of enlisting the services of professors in engineering colleges, he met I.W. McConnell, professor of civil engineering at the Missouri School of Mines, Rolla, Mo., (now University of MissouriRolla) and induced him to operate the gaging stations until the district force could take over the work. In March 1903, Professor G.E. Waesche of Purdue University, Lafayette, Ind., established several stations in Indiana for the USGS. He had, on his own initiative in connection with his college work, established two stations near the university in 1901, and had maintained them for several months. In April 1903, Professor W.R. Hoag of the University of Minnesota, Minneapolis, Minn., established stations in southern Minnesota. Thus, by June 1903 , stream gaging was in progress in Illinois, Ohio, Missouri, and Indiana.

WISCONSIN.-Professor E.A. Birge, director of the Natural History Survey of Wisconsin, was conducting a biological survey of the Wisconsin lakes and in 1902 became interested in the 
rivers of the State. Accordingly, arrangements were made for the USGS to pay the expenses of maintaining a number of stations in Wisconsin under the supervision of Professor L.S. Smith of the University of Wisconsin in Madison. L.R. Stockman, a former student of Professor Smith, was appointed field assistant until he could take the civil service examination. Stockman received a regular appointment, effective in May 1903. Wisconsin was made a part of the Chicago District in 1903.

\section{MethodS}

\section{Standardization of Existing Methods}

In the previous period, equipment rather than methods was stressed and the small Price meter and various accessories had been developed. Because of a lack of supervision, uniform methods were not followed in the field work. Although the 0.6-depth method of velocity observations was generally used, the per-diem hydrographers had been left largely to their own devices. That condition changed early in the present period. J.C. Hoyt saw the need for uniform methods in computations and general office procedures, and Murphy saw a similar need in field practice. F.H. Newell therefore appointed a committee in 1903, which consisted of Murphy, J.C. Hoyt and Hollister, to prepare a hydrographic manual. Because Hollister, the executive officer in Washington, had had little experience in stream gaging, his appointment was apparently ex-officio. This committee, with the assistance of the more experienced resident hydrographers, described acceptable field and office methods and, on February 1, 1904, transmitted the hydrographic manual for publication. In his letter to C.D. Walcott, the Director of the USGS, transmitting the manuscript, F.H. Newell said that the manual (published in 1904 as WSP 94) was designed not only for the use of USGS engineers and engineers in private practice, but also for use in engineering schools so that graduates who would later enter the USGS might have some idea of the work.

The chain gage, which had first been used in 1897, was standardized and enclosed in a long wooden box (WSP 94, p. 16, 1904). The meter equipment consisted of the small Price meter, each revolution of which was indicated by the wet cell and buzzer (WSP 56, plate 11, 1901). The meter was attached by a spring snap to a double conductor cable of heavily insulated, number 14 to 16 flexible copper wire. Flatiron shaped lead weights with large vanes were used. Each weight was attached to the meter hanger by a large brass pin that had a loop in one end. A cord or small wire was passed through this loop and wound around the hanger to prevent the pin from slipping out and the weight from dropping off.

Considerable space in the manual was devoted to the determination of velocity. Several methods were described for obtaining the mean velocity in the vertical, classified as single point, multiple point, and integrationthe latter a hold-over from the days of the Bailey meter but seldom used in 1903. The single point methods described were the 0.6-depth (which was used generally) and the 1-foot depth for flood measurements. The multiple point method can be expressed by the formula $V=1 / 4$ (top $+2 X$ mid-depth + bottom velocities). Vertical-velocity curves were also described but were not recommended for general use because of the length of time required. Velocity observations were made by counting the number of revolutions in two equal periods of time, usually 50 seconds. Attention was called to the inaccuracy of the Price meter in recording velocities of less than half a foot per second, and to the rule made in May 1903, to wit, "When the velocity at a station becomes less than half a foot per second in more than 15 percent of the cross section, the measurements there should be discontinued."

Wading measurements were frequently made in order to use the best available sections, and the familiar Mackintosh wading pants became a regular part of the field man's equipment. These pants were cumbersome to carry in the days before the automobile and, in an effort to lighten the weight, the Washington office suggested the use of a very light "Fairy wader." The district hydrographers were advised of the new waders, and several adopted them. T.U. Taylor, in characteristic vein, replied that he 
had some "Fairy waders" obtained on his natal day, which were still giving efficient and satisfactory service (Grover, written commun., ca. 1938).

A change was made in the form of the current-meter notebook at about the time the manual was prepared. In the 1890's and the first years of the 20th century, as shown by a book now in the author's possession, it seems to have been customary to keep the observations of depth and velocity in a small book of vest-pocket size. In the front of the book was a table showing six-tenths values. The observations appear to have been copied from this book into a field book in which the computations of discharge were made. This procedure was doubtless designed to avoid the danger of losing the observations of previous measurements in the stream during the current measurements. Instead of continuing the use of two notebooks, the manual refers to a complete current-meter notebook that contained on the left-hand page columns for all steps in the computation, which is somewhat similar to the loose-leaf form adopted in 1908. On the opposite page, space and cross sections were provided for recording and computing the mean velocity from vertical-velocity curves (WSP 94, p. 50-51, 1904). After this new form of notebook was developed, considerable experimental field work was done to determine mean velocity from vertical-velocity curves and to study the relations of velocities observed at different points in the vertical to the mean velocity computed from vertical-velocity curves. In computing the meter notes, a modified prismoidal formula was used to compute double strips of equal width, to wit:

$$
\frac{a+4 b+c}{6} \text {. }
$$

This formula was applied both to areas and velocities (WSP 94, p. 47, 1904), and was F.W. Hanna's contribution to the manual. Previously the areas had been computed by averaging end areas, and the mid-velocity in the section had been used in computing the discharge. Office practice was standardized in the manual, which contained little new material but presented the best practice at that time.
The need for information on floods led the committee to include in the manual the statement that, at the end of each year, a watersupply paper on the destructive floods for the year would be prepared. This was probably Murphy's suggestion because the flood papers for 1903 (WSP 96, 1904), 1904 (WSP 147, 1905), and 1905 (WSP 162, 1906) were prepared by him and included reports furnished by other USGS engineers.

\section{New Office Methods}

The office methods developed between 1902 and 1906 related chiefly to the construction of rating curves. The first in point of time was the area-mean-velocity method, and the second was the loop-curve method for rising and falling stages. These methods applied only to stations that had practically permanent stage-discharge relations. (The term "control" is not used here because the concept of control was not developed until the first year of the next period.) A third method was devised by Bolster for computing daily discharges at stations that had no stable relation between stage and discharge.

In 1904, George F. Harley, while measuring streams and canals in the Yakima Valley, Wash., obtained numerous vertical-velocity curves, and conducted a number of experiments to determine whether it was possible for a verticalvelocity curve to become horizontal at the point of zero flow. In connection with these experiments, Harley (written commun., ca. 1938) made a number of measurements in an old flume with flaring sides and, while computing areas of cross sections of this flume, the idea occurred to him that the measurements would fluctuate as the ordinates to a parabola. While trying to fit the curve developed from the parabolic formula to the areas measured in the flume, the idea of an area curve arose. With the area curve, many discordant measurements were found to be caused by erroneous soundings or computations of areas. Following the development of the area curve, the next step was the development of its companion curve, that of mean velocity.

Heretofore, the practice had been to make rating-curve extensions, first as a tangent and 
later by continuing the curve with a degree of curvature gradually approaching a tangent, using limited extensions by logarithmic plotting. These methods were prone to serious error. During winter 1904-6, Hanna of the Chicago District, while he was in Washington, D.C., conducted a mathematical study of the properties of mean-velocity and area curves and presented a paper on them at the conference of Reclamation Service engineers in January 1905 (WSP 146, p. 80-87, 1905). This study defined the shapes of those curves under different conditions and, on the basis of the knowledge derived therefrom, the extension of the rating curve using area and mean-velocity curves was made with more assurance than before.

The effects of rising and falling stages on discharges at a given gage height was shown very clearly by two series of measurements made at the same time, one by Grover on the Allegheny River at Kittanning, Pa., and the other by Murphy on the Ohio River at Wheeling, W. Va. Attention had been called to this phenomenon by Ellet in his work on the Mississippi River in 1851, but no attempt had been made to make use of the information because there was too little data. From March 14 to 27, 1905, Murphy made 17 discharge measurements of the Ohio River beginning with 81,700 $\mathrm{ft}^{3} / \mathrm{s}$, increasing to $336,000 \mathrm{ft}^{3} / \mathrm{s}$, and decreasing to $149,000 \mathrm{ft}^{3} / \mathrm{s}$. The plotting of these measurements defined perfect loops for both the mean-velocity and rating curves above a discharge of $145,000 \mathrm{ft}^{3} / \mathrm{s}$ (J.C. Hoyt and K.G. Grover, River discharge, fourth ed., John Wiley and Sons, p. 99, 1920). From March 18 to 25, 1905, Grover made 22 discharge measurements of the Allegheny River beginning with 43,100 $\mathrm{ft}^{3} / \mathrm{s}$, increasing to $242,000 \mathrm{ft}^{3} / \mathrm{s}$, and decreasing to $83,100 \mathrm{ft}^{3} / \mathrm{s}$. These measurements defined similar loops. Although this property of a rating curve during rising and falling stages was not thereafter generally considered in constructing rating curves because of insufficient high-water measurements, it seemed to explain apparent discrepancies in the plotting of certain high-water measurements.

The Bolster method (J.C. Hoyt and K.G. Grover, p. 110) was devised early in 1906 for computing records of Tonto Creek in Arizona.
Regarding this method, Bolster (written commun., ca. 1938) makes the following comment:

I was led to devise the method from contemplation of the discouraging irregularity of plotted measurements of sandy, shifting streams. It occurred to me that for every day between measurements there must be a time rating curve and that for lack of knowledge to the contrary it must conform to what I called the 'law of parallelism of ratings with respect to ordinates.'

The Bolster method became standard procedure for computing daily discharge of shifting streams and was used until about 1915 when its use gradually gave way to a modification of the original Stout method.

A minor point in office procedure related to the number of significant figures used in the computations. At the beginning of this period, the number was left to the judgment of the hydrographers making the computations with the result that, in most cases, the last figure in the quantity was significant even though the quantities involved four or six figures. At the conference in January 1905, it was decided that the accuracy of stream-gaging records would not warrant a greater refinement than four significant figures (WSP 146, p. 210, 1905) and considerable labor would be saved by adhering to that number. The considerable savings in labor by using four figures led to further consideration of the subject and, in 1906, Bolster found that if three significant figures were used (with a still greater saving in labor), the percentage of error would not in general exceed one percent (WSP 201, p. 11, 1907), a value well within the limits of error of the field work. The rule of three significant figures has been generally followed since 1906 . The absurdity and waste of labor in carrying final results to more significant figures than the base data warrant is well illustrated by the following incident related by Bolster (written commun., ca. 1938):

I had significant-figure laws rather forcibly brought to my attention a year ago. I was working with two engineers * * * one (of which) had specialized in mathematics. They both insisted on running computations to 12 and 13 significant 
figures when the base data were extremely doubtful in the second significant figure. Since these computations were mechanically performed over several weeks, you can imagine the waste of time.

\section{ICE Measurements}

No attempt was made to measure ice-covered streams until after the close of the previous period. In the West where most of the stream gaging had been conducted, the flow during the irrigation season was of chief importance and, because the winter flow of many of the northern streams is small, there had been no particular incentive to devise methods for measuring discharge under an ice cover. With the extension of stream gaging to the Northeastern States, however, measurement of low-water flow was of as much importance in winter as in summer, particularly of those streams to be used for the water supplies of large cities and for power generation.

Before 1902 , so far as the search by the author through engineering literature has disclosed, no systematic attempt had been made to measure the discharge of ice-covered streams. Raucourt had made miscellaneous measurements on the ice-covered Neva River in Russia during the second decade of the last century, and found that the maximum velocity was a little below the middle of the deepest vertical (A.A. Humphreys and H.L. Abbot, Physics and hydraulics of the Mississippi River, Prof. Paper 4, Corps of Topogr. Eng., U.S. Army, 1861). The first recorded measurements under ice cover in the United States were made by the Army engineers on the Mississippi River at St. Paul, Minn., from March 4 to 19,1868 , with the meter under ice that ranged in thickness from 1.3 to 2.0 feet (Mississippi River Commission, Results of discharge observations, Mississippi River and its tributaries and outlets, $1838-1923$, p. 10,1925$)$. No information of the method used is available. The next recorded under-ice measurements were again made by the Army engineers on the Mississippi River at Crow Wing, Minn., for 40 days beginning in March 1882. The velocities were determined by vertical-velocity curves. The construction of reservoirs on the headwaters of the Mississippi River as an aid to navigation made it advisable to measure the flow at St. Paul, Minn., the head of navigation. The Army engineers, while conducting that work, made currentmeter measurements under ice during February and March 1890. The discharge was measured by using vertical-velocity curves measured at 20-foot intervals in cross sections 316 feet wide. A study was made of these curves and of those obtained in 1882 to determine the coefficient that should be applied in the mid-depth-velocity method, the standard of the Army engineers. The mean coefficient of the 1889 curves was 0.87459 (carried to 5 decimal places, after computing the equation of the curves by the aid of least squares), and 0.868 for the 1882 curves (extra decimals being forgotten by the author) (ann. rept., Chief of eng., U.S. Army, 1890, pt. 3, p. 2,104).

The first USGS attempt at under-ice measurements was in winter 1897-98 when Stout instructed R.H. Willis to investigate the winter flow of the North Platte River at Camp Clark, Nebr. Although Stout instructed Willis to make the measurements, he did not tell him how they were to be made, probably because he had no clear ideas. Willis spent some time in attempting to measure the flow at mid-depth, but conditions were unfavorable and no definite results were obtained.

In 1901, when stations were established on streams in the Catskill Mountains from which it was proposed to divert water to New York City, it became apparent to R.E. Horton that records during the ice period would be needed. He had previously studied the methods suitable for measuring ice-covered streams and, at the earliest possible date, began making measurements himself. R.E. Horton's first measurement was on Esopus Creek at Kingston, N.Y., on December 4, 1901. Within the next few days, ice measurements were made on Catskill and Rondout Creeks and Wallkill River. Being a frequent user of vertical-velocity curves during the open season, it was natural that R.E. Horton should use that method in determining the discharge under ice. The equipment used during these early ice measurements is best described in R.E. Horton's own words in a letter to the author (ca. 1938):

I soon developed equipment which comprised two light A-frames connected 
by a crossbar at the top and two crossbars about 3 feet above the bottom of each A-frame. A plank was laid between these and a tarpaulin spread over the structure. This formed a light portable housing which could be carried very easily by two persons. I had found by experiments on the Mohawk River at Utica, where my office was stationed, that a current meter would freeze instantly if taken out of the water in subfreezing weather, especially in the wind, and that its temperature must be above $32^{\circ}$ when it was immersed or it might become a nucleus for a mass of needle ice. Coach candles were purchased and several of these set on the plank in the enclosure. These were used to warm the current meter before it was put in the water, also to keep the operator's hands warm and dry. It was found that with this apparatus and with a laborer with proper tools to chop holes in the ice, good measurements under ice could be obtained with comfort and with nearly as great rapidity as open-water measurements.

Daily gage heights to the water surface were continued during the winter periods, and one or two ice measurements were made each winter at each of these groups of stations until the cooperation with New York City was terminated in 1903. Ice measurements were also made at other stations during 1903.

Another pioneer program of ice measurements that was even more extensive than R.E. Horton's work in New York was conducted by Stockman during winter 1903. As stated earlier, the technique of making ice measurements was as then undeveloped and each hydrographer was left to work out his own solution. Stockman developed vertical-velocity curves in those sections affected by slush ice, but used the 0.6-depth method, uncorrected, in clear water under ice. In computing areas, however, he considered only the depth below the bottom of the ice. A few Wisconsin ice measurements were made during the next winter, but that ended the program.

Several other ice measurements had been made by the USGS before 1905 . During January and March, 1904, Grover directed F.E. Pressey to make four ice measurements of the Kennebec River near North Anson, Maine. This station was apparently selected because of its accessibility, smooth ice cover, and positive knowledge that the ice cover had disturbed the stage-discharge relation (Grover, written commun., ca. 1938). These circumstances made it ideal for what may be called an out-of-doors laboratory for ice studies. The vertical-velocity curve method was tried at first, then the 0.6-depth velocity and integration methods, and finally the vertical-velocity curve method again. Gage heights were recorded to the water surface. A vivid picture of the human side of the first of these ice measurements is given by the notes in F.E. Pressey's original notebook made at the time of the measurement:

Depth of ice 1.5 to 2.0 feet shoe to meter standard lost here. Thermometer at 10 degrees below zero and strong wind blowing across current. Two feet of snow on the ice. Cold as 'blazes' and we were wading in two inches of slush and icy water. The meter standard was so covered with ice that it was extremely hard to read it correctly. The buzzer was kept in the inside pocket and didn't freeze.

F.E. Pressey described the phenomenon of pulsations under ice in his notes as follows:

The ice was 2.2 feet thick. The pulsations through the holes in the ice ranged from 0.1 to 0.4 foot. They occurred at about regular intervals of 45 pulsations to 50 seconds, and the holes seemed to have no connection as to time of pulsation, that is while one hole was spouting the other was receding.

W.D. Johnson made measurements on the Mississippi River near Sauk Rapids, Minn., in January 1904, and on the Minnesota River at Mankato, Minn. Hanna made several measurements in Iowa. Both used the integration method to determine velocities, and read the gage height to the bottom of the ice. In the latter part of December of that year and the first part of January 1905, Raymond Richards, under E.F. Chandler's direction, unexpectedly made an ice measurement at each of the stations in Minnesota. It was expected the streams would be open when the trip was planned, but 
Richards found the stations frozen when he reached them, and accordingly measured them through the ice. With no instructions for such work and realizing that the 0.6-depth method would not give the mean velocity, he used the 0.5-depth method in the expectation that a coefficient for it would be developed later (E.F. Chandler, written commun., ca. 1938). These measurements are believed to complete the list of ice measurements made before the January 1905 conference.

The vertical-velocity curves of the early New York work showed that the curves under ice were different from open-water curves, and that the maximum velocity occurred at 0.36 depth. The mean velocity was found to occur at two points, the average of 101 curves showing these points to be at 0.11 and 0.71 depth (F.H. Tillinghast, Records of flow at current-meter gaging stations during the frozen season in WSP 146, p. 144, 1905). Tillinghast's paper, which was read at the second conference of Engineers of the Reclamation Service held in Washington, D.C., January 3 to 12, 1905 , contained the first published account of ice measurements. The subject of ice measurements was a live one at that time because records of ice-covered streams were urgently needed. E.F. Chandler in the previous year had called attention to the error in some instances of applying open-water rating curves to gage heights of ice-covered streams, citing the example of the record of the Red River at Grand Forks, N. Dak., where the gage heights were observed with ice 2 feet thick (E.F. Chandler, written commun., ca. 1938).

As a result of the ensuing discussion, the conference delegates recommended that the permanent stations of the USGS should provide continuous records both winter and summer wherever possible, and that no estimates of discharge should be made for ice-covered streams unless they were based on discharge measurements made during the ice season. It was also recommended that sites for gaging stations should be selected where the best possible winter records could be obtained and that the northern hydrographers during that winter should make careful observations on one or two important rivers, experimenting with different methods. A committee consisting of
H.K. Barrows, Horton, and Murphy was appointed to compile at the end of the winter the data then available and formulate plans for future ice measurements (see WSP 146, p. 209-210, 1905).

In accordance with the conference recommendations, H.K. Barrows, who had succeeded Grover as district hydrographer in New England, made ice measurements at two stations during that winter, the Winooski River at Richmond, Vt., and the Kennebec River near North Anson, Maine. R.E. Horton made a series of measurements on the Raquette River at Massena Springs, N.Y. That his work was confined to one station was due, as he states in his letter to the author (ca. 1938), to the presence of large quantities of needle-ice that made measurements impossible at most of the stations. Gageheight records to the water surface were continued during the winter at most of the stations in New York (daily) and New England (weekly), with notes regarding ice conditions, as had been recommended by the conferees. Daily gage heights were continued during the winter in Minnesota.

No record of the recommendations of the committee appointed during the conference for future ice work has been found, but during winter 1905-6, ice measurements were made at $\mathbf{2 5}$ or more stations in New York, New England, Wisconsin, Minnesota, and North Dakota. Barrows and T.W. Norcross made a series of measurements on the Connecticut River at Orford, N.H., determining the slope at the same time. The slope was determined by cutting holes in the ice at the ends of three stretches that varied in length from 150 feet to 266 feet and obtaining the differences in elevation by a Y-level. The value of " $n$ " in Kutter's formula was computed from the slope and discharge (see WSP 187 , p. 87-88, 1907). This appears to have been the first study of its kind on icecovered streams.

At other stations, only one ice measurement was made and, although either daily or weekly gage height records were available, no attempt was made to compute the daily discharge during the ice period of that year. The basis of the experimentation in measuring flow under ice was the vertical-velocity curve, the only true method of obtaining mean velocity. The study of the field data was made at the beginning of 
the next period and the methods recommended were used for several years afterward, so its account is a part of the history discussed in Part X, Maturing Years (1913-19).

\section{State Cooperation}

This period heralded the virtual beginning of cooperation with State organizations, which later contributed so materially to the expansion of the USGS investigations of the water resources of the United States. Earlier, the cooperative agreements were generally informal and provided that the parties would contribute equally to the cooperative investigations. The work was generally conducted by USGS personnel.

Before 1902, as stated earlier, officials of several Western States had furnished records collected by their own engineers, the State geologist of North Dakota had contributed $\$ 1,500$ on the basis of equal cooperation, and the Nevada State Board of Irrigation had contributed $\$ 1,000$ on the basis of equal cooperation. The State Board of Irrigation Survey and Experiment of Kansas had paid several hundred dollars during 1895 and 1896 for gage observer salaries and several State Geologists in the Eastern and Southern States had paid gage observers in their respective States. California, New York, and Maine had contributed funds to be spent directly by the USGS.

\section{NEW YORK}

The action of the New York Legislature in appropriating $\$ 1,000$ in 1900 to enable the State engineer to cooperate with the USGS in stream gaging, in appropriating $\$ 1,500$ for each succeeding year except one during this period, and in gradually increasing amounts in succeeding years, marked the beginning of continuing and systematic State cooperation. The failure to appropriate funds for 1905 was due not to the unwillingness of the State engineer to cooperate (he was strongly in favor of the work), but rather to the unfortunate circumstance that the appropriation item was lost in the closing hours of the legislative session. Because the New York State Barge Canal was then being designed and a large amount of money was available to the Barge Canal office, some of that money was used for cooperation with the USGS and also for establishing and maintaining additional stations directly connected with the problems of the Barge Canal (R.E. Horton, written commun., ca. 1938).

\section{MAINE}

The Maine State Survey Commission entered into cooperation with the USGS in 1903 for a study of water-power possibilities. The records show that State funds spent on this investigation amounted to some $\$ 3,000$ for the 2 years 1903 and 1904 (letter from M. Reginald Stackpole to Grover, date now unknown). Cooperation continued during the remainder of the period, and the State funds were $\$ 4,300$ in 1905 and $\$ 3,600$ in 1906.

\section{New Hampshire}

The State of New Hampshire Legislature had enacted a law as early as 1896 relating to forestry and created a State Forestry Commission, but little had been accomplished for the forested areas of which those in the White Mountain region were of greatest interest. In the meantime, the rapid cutting of the forests indicated that some definite program for their protection should be adopted. The people in the southern Appalachian region were striving for the creation of a national forest reserve in that section, and this action suggested a similar possibility for the White Mountains.

The legislature of 1903 passed a resolution favoring such action by the Congress. One of the preliminary "Whereases" read as follows (State of New Hampshire bienn. rept., Forestry Comm., 1903-4, p. 42, 1904):

The establishment of such a reserve would $*^{* *}$ forever preserve the headwaters of several important streams, and thus benefit the commerce, industry, and agriculture of all the New England States, save one. 
Believing that the surest way to obtain such action by the Congress was to provide for a survey of the State's forestlands showing the need for such a reserve, the legislature appropriated $\$ 5,000$ for that purpose. The act making the appropriation provided among other things that the hydrographic possibilities of the streams were to be ascertained. Arrangements were made with the U.S. Bureau of Forestry to conduct the State survey and in outlining the procedure to be followed, the Secretary of Agriculture proposed, per the 1903-4 report, page 42 :

4. An investigation of the value of the forest as a conserver of the water supply, in which I hope to obtain the assistance of the U.S. Geological Survey. This will include the determination of the size, and condition of the watersheds tributary to large streams rising within the White Mountain region; of the effect of forest destruction upon the flow of those streams; and of the value, and amount of water power which is available.

That cooperation was effective on a dollarfor-dollar basis during the years from 1903 to 1904. The exact amount of funds contributed for stream gaging by the State cannot be determined, but is believed to have been about $\$ 750$ a year. At the end of the 2-year period, the hydrographic records were too few to define any relation between forest cover and streamflow, and the cooperation was continued throughout this period in order to obtain records covering a longer period. In 1905, the State contribution amounted to $\$ 764$, and to $\$ 2,000$ in 1906 (letter from Deputy State treasurer to the author, date now unknown).

\section{California}

The passage of the Reclamation Act in 1902 intensified the interest in irrigation that had already been strong in California. As a result, the State Legislature in 1903 provided for cooperation by the Act approved March 16, 1903, which read in part as follows (WSP 100, p. 15, 1904):

The State Board of Examiners are hereby empowered to enter into contracts with the Director of the United States Geological Survey * * * for the purpose of gaging streams, surveying reservoir sites and canal locations, for the conservation and utilization of the flood or storm waters of the State to the extent of fifteen thousand dollars.

This appropriation for the biennium amounted to $\$ 7,500$ annually, all of which was spent on stream gaging because the Reclamation Service provided funds for the reservoir and canal surveys. In this instance, the USGS more than matched the State funds in 1903 by allotting $\$ 10,400$ to California for stream gaging. Cooperation with California that started in 1903 has continued uninterrupted since that time, the State contribution having been increased to $\$ 10,000$ annually in 1905 and 1906.

\section{Nevada}

During 1903, cooperation of a somewhat different nature, following the precedent set in the years of the per-diem appointments, was arranged with the State of Nevada. The Nevada State Board of Irrigation entered into a contract with the USGS in 1900, which lasted until the passage of the Reclamation Act. When that Act was passed, its author, Congressman Francis Newlands of Nevada, was anxious to have a reclamation project started in his own State. He prepared a bill creating the office of State engineer in order to promote that objective by establishing existing water rights on a legal basis. One of the provisions of the bill required the Governor to appoint as State engineer a man recommended by the Secretary of the Interior. In accordance with this provision, A.E. Chandler, an engineer of the Reclamation Service, was appointed State engineer and thereafter considered the USGS district hydrographer. When cooperation was first arranged with A.E. Chandler as State engineer, the State auditor would not allow hotel bills as part of traveling expenses. The first cooperative arrangement was therefore made on the basis that the USGS would pay the hotel bills of A.E. Chandler and his assistants and the State would pay other expenses (A.E. Chandler, oral 
commun., ca. 1938). In 1905, the State Legislature passed a law allowing hotel bills as a part of travel expenses, and thereafter the cooperation was on the basis of the USGS allotting a lump sum to offset expenditures by State employees in connection with stream gaging. Reclamation Service employees who conducted stream gaging reported their results directly to the State engineer in his capacity as district hydrographer.

\section{Oregon}

Like all other arid-land States, Oregon was anxious to have irrigation projects started, but found that the State was not receiving the consideration it might otherwise receive because of inadequate water laws and local jealousies. The situation was aggravated by the fact that Oregon, because of its public lands, had contributed a larger amount to the reclamation fund than any other arid-land State (fourth ann. rept., Recl. Serv., p. 34, 1906). In an attempt to remedy this situation, the State in 1905 adopted a water code that provided, among other things, for a State engineer. The Governor favored Federal reclamation and wanted to appoint a State engineer recommended by the Director of the USGS in order to harmonize with the irrigation activities in the State. J.H. Lewis, who had conducted the Oregon stream gaging and general irrigation investigations during the previous 2 years under J.T. Whistler's supervision, was recommended for the position and appointed. When J.H. Lewis became the State engineer, State funds for cooperation in stream gaging were available under the following statute (Ch. 228, Gen. Law of Oregon, 1905):

Section 10. Hydrographic and Topographic Surveys and Cooperation with the U.S. Government.-The State Engineer shall make hydrographic and topographic surveys and investigations of each stream system and source of water supply in the State, beginning with those most used, obtaining and recording all available data pertaining to the water supply of this State. He is hereby authorized to cooperate with the agencies of the United States Government engaged in similar surveys and investigations, and in the construction of works for the development and use of the water supply of the State, expending for such purpose any money available for the work of his office.

For the purpose of making hydrographic and topographic surveys there is hereby appropriated out of any moneys in the treasury not otherwise appropriated the sum of $\$ 2,500$ annually for such hydrographic, and $\$ 2,500$ annually for such topographic surveys, such appropriations, however, being contingent upon the United States Government making a like apportionment for such purposes to be expended with the State.

J.H. Lewis had previously conducted the USGS stream gaging, and he proposed to continue to do so in addition to the regular work of State engineer. Thus, cooperation was arranged under J.H. Lewis' direction (J.H. Lewis, written commun., ca. 1938).

\section{Other States}

The State Geologists of Maryland, North Carolina, Georgia, and Alabama and the State engineer of Utah paid some gage observers in their respective States during the life of the Hydrographic Branch.

\section{River Surveys}

The great strides made during the opening years of the 20th century in the generation and transmission of electrical energy emphasized the importance and value of water-power resources. Of the two factors discharge and head, the stream-gaging records furnish one (the discharge) and river surveys the other (the head). D.C. Humphreys had conducted a reconnaissance profile survey of the the James River in Virginia as early as 1897 (USGS 19th ann. rept., pt. 4, p. 163-71, 1898), and a similar survey of the South Branch of the Shenandoah River in 1899 (USGS 22d ann. rept., pt. 4, p. 140-44, 1902). Although the costs of these 
surveys were not paid by the USGS, D.C. Humphreys was the USGS resident hydrographer, and the results were published by the USGS. As funds became available, such work was taken over by the USGS. The river survey at first was merely a line of levels along a river to determine elevations of the water's surface with no attempt to map either the course of the river or the topography of the river banks. The next step was a traverse survey in addition to the levels; some attention was paid to bank topography, but not in sufficient detail to warrant the publication of separate maps. The final step was a complete survey that showed not only the profile and course of the river, but detailed topography of the river banks as well, all published as maps showing plan, profile, and contours along the stream. In addition, possible reservoir sites, chiefly ponds and lakes, were surveyed in sufficient detail to permit storage studies to be conducted. The first river surveys by the Division of Hydrography were conducted during the closing years of the perdiem appointments as a result of the desire of the State Geologist of Georgia to have such work done.

\section{Georgia}

In his report for 1900, the Georgia State Geologist states:

For several years, I have been anxious to have the rivers of the State meandered and profiled from the fall-line up to the last shoal, available for water-power, in order to accurately locate and map a considerable number of valuable shoals, not hitherto accurately and correctly located, and many of them, not shown on any map. But for lack of sufficient appropriations, and because of more urgent demands, along other lines of our economic geology, I found it impossible to take up this very desirable work. Finally, I laid the matter before the Director and Chief Hydrographer of the U.S. Geological Survey, in person, the early part of last spring, and requested them to take up this, as a part of our cooperative work. The proposition was favorably received and Prof. [B.M.] Hall was instructed to put parties in the field, and to start the work at once.

From May to July 1900, B.M. Hall, resident hydrographer for the Southeastern States, conducted profile surveys of five rivers totaling $\mathbf{2 5 0}$ miles. In 1902, Maxie R. Hall surveyed 240 miles of river in Georgia. These were merely profile surveys made by a wye level with no traverse work. According to W.E. Hall (written commun., ca. 1938) who was in charge of one field party, however, the level notes were kept like those for transit work, and a careful running sketch was made in the notebook, thus making possible the drawing of what he called a "straight-line traverse" along the profile. Many benchmarks were set, and elevations observed at the top and bottom of every break in the water surface. In general, the surveys were conducted without camp equipment and the field parties stayed at farm houses en route. As W.E. Hall further states, this procedure involved a great deal of walking, and the surveyors obtained a very "personal" knowledge of each river. It is impossible to determine the cost of these surveys because, in the original records of expenditure, the expenses of stream gaging were not separated from those of river surveys. The available records, however, indicate that the USGS paid all costs of these river surveys. The results were recorded, either in the form of profiles or tables of elevations and distances, in different USGS publications, chiefly the 22d Annual Report, part IV (1902), and WSP's 107 (1904) and 197 (1907).

\section{CoOperation with Topographic Branch}

With the organization of the Hydrographic Branch and the general expansion and improvement of its work, it was apparent that a river survey, if it was to be of the most use, should be more than just a river profile, that it should result in topographic maps that showed the course of the river and the topography of the bank so as to indicate dam sites.

Cooperation for conducting river surveys was arranged with the Topographic Branch in 1903. During that year, the field work was 
conducted by W. Carvel Hall, and 19 rivers with a total length of 910 miles were surveyed under his direction. These rivers were all in the Southeastern States, except the Chippewa River in Wisconsin. Topographic Branch personnel used the plane-table method, and gave considerable attention to bank topography as well as to water-surface elevations. The resulting topographic sheets were not published, but profiles and tables of elevations and distances were published in WSP 115 (1905). The topographers were interested primarily in surveying with special reference to the production of topographic maps, so they did not present fully the other engineering features of the water-power sites and the cooperation was discontinued at the end of 1903. The Hydrographic Branch reverted to its earlier practice and its personnel conducted the field work themselves, although profiting from the cooperation in that they paid more attention to topography.

\section{MaIne}

The next river surveys were started in 1904 as a result of the cooperation that began in 1903 with the Maine State Survey Commission. This cooperative agreement provided not only for stream gaging, but also for an investigation of the State's water powers. Barrows, in summer 1904 , appointed as field assistant a former colleague on the engineering faculty of the University of Vermont, Professor A.D. Butterfield, to conduct the river surveys on which the waterpower studies depended. In planning for this work that was entirely new in New England, Barrows issued only general instructions because the most suitable methods were to be ascertained by trial and error. The purpose of these surveys was to furnish information regarding the total fall and the present developed water power, and to indicate clearly the points of possible additional developments. They were not to be considered detailed surveys from which future developments could be planned without additional field work, because surveys of that nature were within the province of private enterprise rather than the USGS. The surveys were to serve as a basis for planning further detailed surveys that would show the most feasible sites for future developments. The desired results involved the production of a fairly accurate regional map, a general topographic map of the river banks, and a profile of the river that, although not of the highest degree of accuracy, would closely approximate the true profile (Butterfield, personal papers, date unknown).

The streams and ponds surveyed were in the Androscoggin, Kennebec, and Penobscot River basins, the three largest river systems in the State. During 1904, Butterfield surveyed 151 miles of river and, in 1905, 37 miles of river and two lakes that offered possible storage capabilities. In 1905, Professor H.S. Boardman of the University of Maine who was another field assistant, conducted a profile survey of 56 miles of the Androscoggin River. By 1906, the water-power investigation had reached the point where storage was an important factor, and Butterfield spent that summer surveying many lakes and ponds while Boardman conducted river surveys.

The transit and stadia method with astronomical control had been previously used at a cost of about $\$ 18$ per mile for the finished maps, but it was felt that using the plane-table method with magnetic bearings would be sufficiently accurate for conducting surveys for storage, plus having the additional advantage of producing topographic maps in the field. Accordingly, the plane table was tried during 1906 and proved so successful that it was used thereafter. In 1907, Butterfield surveyed 34 miles of river and numerous ponds. The following year, he was replaced in the field by Boardman who surveyed 48 miles of river. During summer 1909, the last year of the Maine surveys, Butterfield surveyed 17 miles of river and numerous small ponds. The average cost of the plane-table surveys during those years was about $\$ 11.50$ per mile. The resulting maps of the surveys in the Kennebec and Penobscot River basins were used in the preparation of reports on water power in those basins, published as WSP's 198 (1907) and 279 (1912).

\section{WISCONSIN}

The interest in Wisconsin's water power, which had led to the start of stream gaging in 
that State in 1902, caused F.H. Newell to authorize Professor L.S. Smith in 1903 to prepare a report on the water powers of the northern part of the State. That report emphasized the need for river surveys, and the State Legislature made an appropriation for that purpose in 1905 in the following language (Wisconsin Laws of 1905, p. 819):

The geological and natural history survey of the State of Wisconsin is directed to cause a survey to be made of the water powers of the State for the purpose of ascertaining the amount of available water power in this State, developed and undeveloped, and the location of the same. Such work may be done in cooperation with the United States Geological Survey. Upon the completion of such survey a full report thereof shall be made to the governor for the use of the legislature. The sum of two thousand five hundred dollars or as much thereof as may be necessary is hereby appropriated.

In August of that year, the USGS entered into a contract with the State Survey whereby each would spend an equal amount. The field work was led by L.S. Smith, who described the work as follows (Water Powers of Wisconsin in Geol. and Nat. Hist. Survey Bull. 20, p. 4, 1908):

Survey parties were promptly placed in the field on some of the most important water power streams and the work of surveying and mapping the rivers was actively continued until the funds were exhausted. By means of a well-devised plan of work which, while insuring needed accuracy, avoided unnecessary refinement, as well as by a careful husbandry of the funds, the cost of this work has been about one-half that of a similar cooperative work in other states. [Author's note: In making this statement of comparative costs, Professor Smith did not know the cost of the later Maine surveys, which was not greatly in excess of that of his work.]

The plan was to use two parties on each survey: a wye-level party would run levels along the river setting benchmarks every 8 or 10 miles, and a transit party would tie to the benchmarks and use chiefly vertical angles to obtain elevations along the river and magnetic bearings and stadia to locate the banks and all section line crossing (L.S. Smith, written commun., ca. 1938). Between 1906 and 1908, six rivers having a total length of 579 miles were surveyed at a total cost of $\$ 5,000$, or about $\$ 8.60$ per mile including office work. This low cost, as L.S. Smith further wrote, was due not only to the methods used but quite as much to the fact that two ambitious and hardworking young engineering students were employed under his supervision. The inference is quite obvious that these young men, anxious to make a record, did not limit themselves to the regulation 42 hours or even 48 hours per week. The resulting maps, published in WSP 417 (1916), were the first separate river survey maps.

\section{VIRGINIA}

The State Geologist of Virginia, Dr. T.L. Watson, in spring 1906, wanted a survey of the Roanoke River in connection with a study of the State's water resources and offered to contribute $\$ 1,000$ for that purpose if the Hydrographic Branch would conduct the survey. This proposal was accepted and A.H. Horton was put in charge. The survey should properly be called the Roanoke-Staunton River survey because, by some quirk of nomenclature, the middle section for no apparent reason is called Staunton River. The portions of the hyphenated river to be surveyed extended from Weldon, N.C., a few miles below the Virginia-North Carolina line, to Roanoke, Va., near the headwaters, a distance of 230 miles. Within this section of the river, the Army engineers had conducted isolated surveys covering 100 miles, which data were used by A.H. Horton, thus reducing the distance actually surveyed to 130 miles. Camp equipment was necessary in this survey because the country to be traversed was sparsely settled. A level party of two men ran wye levels over practically the entire distance to furnish benchmarks for the survey. Although the level party camped with the transit party, it kept sufficiently far ahead to establish the needed benchmarks. The transit party, cook, and teamster numbered seven, making, with the 
level party, a total of nine men employed in the survey. The transit party observed elevations by vertical angles and measured distances by stadia. Although this was primarily a profile survey, the position of the foothills was mapped. The total cost of this 130-mile survey was $\$ 4,100$ and the cost about $\$ 32$ per mile of which about $\$ 9$ represented the cost of the levels and the remainder was the cost of the profile and traverse survey (A.H. Horton, survey of Roanoke River, unpub.). The resulting maps were published by the Virginia Geological Survey in Geological Series Bulletin 3, Hydrography of Virginia, in 1906 (WSP 558, p. 84,1926 ).

\section{North Carolina}

Between 1903 and 1906, the State Geologist of North Carolina, who was cooperating with the USGS in stream gaging, conducted extensive river surveys in that State. All costs were paid from State funds.

\section{Summary OF Work by Districts}

\section{New England District}

The New England District began with the work in Maine in 1901, for which Grover was employed as resident hydrographer. Grover took the civil service examination in 1902 and, on April 29, 1903, was given an appointment as hydrographer. His first appointment was on a per-diem basis to enable him to complete the year of teaching at the University of Maine in Orono. On July 1 , he was given a full-time appointment as engineer, his district was extended to include all of New England, and he moved his office from Orono to Bangor, Maine. At that time, the field work in Maine was conducted largely by F.E. Pressey, a former student of Grover's who had recently been appointed engineering aid. Barrows, professor of civil engineering at the University of Vermont at Burlington who had held a per-diem appointment since 1902, was appointed "When Actually Employed" assistant engineer on June 16,1903 , and continued to conduct the field work in New Hampshire and Vermont. The stations previously established in New Hampshire and Vermont and the station on the Connecticut River at Orford, N.H., which was previously maintained by R.E. Horton, were absorbed by the New England District. Before this, records of the flow of the Merrimack River at Lawrence, Mass., had been kept for some 50 years by the Essex Company, and records of the Pemigewasset River at Plymouth, N.H., had been kept since 1886 by the Locks and Canal Company of Lowell, Mass. These records, in addition to those collected at the station on the Connecticut River at Orford, N.H., that had been established by E.G. Paul in 1900 but later maintained by the USGS under R.E. Horton's direction, constituted the information regarding the flow of New Hampshire streams when the USGS work was begun in 1903.

A cooperative water-power study of Maine was arranged in 1903 to include surveys for determining storage as well as water-power possibilities. At about the same time, cooperation with New Hampshire was arranged through the State Forestry Commission.

The danger from backwater at stations located near the mouths of streams was not yet fully recognized. A station established March 28, 1903, and discontinued October 8, 1903, on the Lemoille River near its entrance to Lake Champlain is illustrative of occasional mistakes made during this period because of a lack of precedent or experience. The station was established when the lake level was high. For a time, when the stages of both the Lemoille River and Lake Champlain were gradually falling, the discharge measurements plotted consistently and it appeared that an excellent site had been selected. Later, the ensuing measurements plotted erratically, and it was not until Murphy visited the station on his first inspection trip in New England that the mystery was solved-Lake Champlain had fallen to a stage lower than when the first series of measurements had been made and, therefore, the backwater effect at the gage was different (WSP 97, 1904, p. 346).

When Grover transferred to Washington on July 1, 1904, Barrows was given a full-time appointment and succeeded him as district hydrographer. By that time, the USGS activities 
had been extended into each New England State, and Barrows (written commun., ca. 1938) moved the district office from Bangor, Maine, to more central Boston, Mass., on January 1, 1905. He had as assistants F.E. Pressey, Norcross, and S.K. Clapp. S.K. Clapp transferred to the Chicago District in 1905 , thus leaving only two assistants.

Although Massachusetts as a State had shown little interest in the flow of its streams, one of its bureaus, the Metropolitan Water and Sewerage Board, had collected records, generally from weirs, of certain streams related to the development of the city of Boston's water supply. The longest records were those for Lake Cochituate, begun in 1863, and those for Sudbury River, begun in 1875. From 1880 to 1900 , the Holyoke (Mass.) Water Power Company had collected records of the Connecticut River at Holyoke. Except for the work of those two organizations, little had been done relative to the measurement of flow of Massachusetts streams, and no cooperation had been arranged with the State (Barrows, written commun., ca. 1938).

\section{New York District}

R.E. Horton was in charge of the stream gaging in New York and in Michigan in 1902 when that State was officially added to his district. He was appointed hydrographer on January 1 , 1903 , and continued in charge of the work in New York and Michigan. New Jersey was temporarily added to the district for the first 6 months of 1903. In July, however, supervision of work in that State was taken over by E.G. Paul, but the field work was still conducted by one of R.E. Horton's assistants.

R.E. Horton had two assistant engineers, C.C. Covert and Tillinghast, and several noncivil service field assistants (from three to five) whose employment was not continuous. Three of these field assistants were young college professors, employed chiefly under R.E. Horton's direction to maintain gaging stations on streams near their colleges, in accordance with R.H. Newell's plan for building up a body of men who were interested in and had had experience in stream gaging.
In 1903, the Burr-Hering-Freeman Commission completed its investigations of possible sources of additional water supply for New York City and selected Esopus Creek. Thereupon the city officials decided that they no longer needed gaging stations on other streams in the Catskill Mountains and discontinued cooperation with the USGS (R.E. Horton, written commun., ca. 1938). The discontinuance of the city's cooperation necessitated a reduction of the force and Tillinghast was transferred to the Reclamation Service.

The maintenance of gaging stations at dams involved the computation of the flow over some weirs for which weir-formula coefficients had not been previously determined. Accordingly, in April 1903, R.E. Horton was authorized to conduct laboratory studies of models of such dams. He arranged with Professor Gardner S. Williams, director of the Cornell hydraulic laboratory, to conduct the experiments, using the local staff and advanced students. The laboratory work was done during April and May 1903 under R.E. Horton's supervision, and the coefficients thus obtained were published in WSP 150 (1906) (revised in WSP 200, 1907), which also contained revised computations of the 1899 and other experiments on models of dams and a review of all important previous experiments on flow over weirs (R.E. Horton, written commun., ca. 1938).

Because it was necessary to compute the flow through turbines in connection with gaging stations at dams, R.E. Horton brought together the results of tests of different makes and sizes of turbines and prepared rating tables showing the discharge with various gate openings and heads. The data were published in WSP 180 (1906).

Questions relative to city water supplies required the establishment of stations on streams that had shifting channels and flows as low as $1 \mathrm{ft}^{3} / \mathrm{s}$ or less, which were liable to be frozen during the winter. Cooperation was arranged with the local water company at Utica whereby they built weirs at seven stations and furnished the gage readings. R.E. Horton built check dams or barriers upstream to catch the shingle and gravel carried during floods and 
to prevent the pools above the weirs from filling.

The Chicago District was conducting considerable work in Wisconsin in 1904 and it was apparent that the stations in the Upper Peninsula of Michigan could be handled more economically by engineers working in Wisconsin than by those in the New York District. The Upper Peninsula, therefore, was transferred to the jurisdiction of the Chicago District.

Gage-height records were generally continued during the winter, but only a few discharge measurements were made under ice and estimates of flow were not made for the ice period. Records were maintained and discharges estimated throughout the entire year for the stations at dams. An attempt was made to keep the crests of the dams clear of ice. If this was impractical, the length of crest actually obstructed by ice was supposed to be measured and recorded daily.

\section{Middle Atlantic States District}

At the beginning of the period, the States of Pennsylvania, Maryland, Virginia, and West Virginia were combined to form a district with E.G. Paul as resident hydrographer. The size of the district was increased in July 1903 with the addition of New Jersey; the field work, however, was conducted by an assistant engineer of the New York District. The stations in Virginia and West Virginia were taken over by E.G. Paul in the latter part of 1902 when D.C. Humphreys severed his connection with the USGS. A full-time assistant was then necessary and, in July 1902, Sawyer was appointed engineering aid and assigned to the Middle Atlantic States District.

Grover took over the supervision of the stations in the district on July 1, 1904, and conducted the field work chiefly through members of the computing section. A.H. Horton also was assigned in 1905 to the Washington, D.C., office for stream gaging and river surveys under Grover's direction, but he was not a member of the computing section. With the change in operation of this District, stream gaging was extended into western Pennsylvania where a group of stations was established in the headwaters of the Ohio River during August and September. At the request of Dr. Clark, Maryland State Geologist, stations were established in December in northern Maryland on streams that might be used as sources of water supply for the city of Baltimore. Stations were established in Maryland and West Virginia in May 1906, and in the Shenandoah Valley in Virginia in June in preparation for the special investigation of the Potomac River basin.

An advantage obtained by having the many engineers of the computing section available for emergency field work was strikingly shown in March 1906 when the Susquehanna and Ohio Rivers reached usually high stages. Hurry-up orders were issued to all members of the computing section who departed for the stations in those river basins, one engineer to a station with instructions to make daily measurements for a period of 10 days to 2 weeks, or until the floods subsided. It was during those floods that loop-rating curves caused by rising and falling stages were observed.

\section{South Atlantic and Eastern Gulf States District}

When the stream-gaging organization was placed on a permanent civil service basis, B.M. Hall resigned his USGS position and returned to private practice. Maxie R. Hall, his brother, was given a civil service appointment as hydrographer on January 1, 1903, and put in charge of stream gaging in the Southeastern States. North Carolina, South Carolina, and part of Tennessee were added to the district in July 1903 when Myers transferred to the Reclamation Service. Warren E. Hall, who had previously been a field assistant, was appointed engineering aid on January 6, 1903, and J.M. Giles was appointed engineering aid on May 1, 1903. No further changes were made in the permanent organization until May 22, 1905, when Brent S. Drane, who had been a field assistant since 1902, was appointed engineering aid. Three field assistants were employed during 1905 after Giles had been transferred to stream gaging in New Mexico and Oklahoma. In May 1906, the District was extended to include Florida. 
The gaging stations were equipped about equally with chain and staff gages, and practically all measurements were made from either highway or railroad bridges. The equipment of one station deserves special notice. In 1903, Professor Fulton of the University of Tennessee devised a long-distance recorder and installed it on the Tennessee River at Chattanooga with the receiving instrument in the Weather Bureau office. This instrument, which was apparently successful because it was used for some years, appears to be the first successful long-distance recorder to be installed-the long-distance recorder installed by L.G. Carpenter on the Cache la Poudre River in Colorado was unsuccessful.

Cooperation with the State Geologists of Georgia and Alabama, who paid gage observers, continued during the entire period. The average annual amount that was paid to observers by the State of Alabama during the 4 years was $\$ 170$ (Geol. Survey of Alabama, Rept. of prog., fiscal years 1902-6, 1907). The amount contributed by the State of Georgia is unknown, but is believed to have been about the same. Some cooperation was in effect with the State Geologist of North Carolina, chiefly in connection with water-power surveys, and it appears that little State assistance was provided for actual stream gaging.

\section{TeXas District}

T.U. Taylor was in charge of Texas stream gaging from the beginning of the work in 1898 throughout the present period. He was given a per-diem civil service USGS appointment in 1903 and continued in his university work. T.U. Taylor made many measurements himself, and several assistants were employed at different times. Little field work was conducted beginning with 1906, when the funds were drastically curtailed.

The IWBC continued its work during the years 1902-6 and furnished the USGS complete records for eight stations on the Rio Grande that were maintained by the American section of the commission through W.W. Follett, consulting engineer. In addition, the IWBC furnished the discharge measurements and gage heights for three stations maintained on the lower Rio Grande by the Mexican Section.

\section{Chicago District}

Wisconsin was made a part of the Chicago District under Leighton in June 1903 and L.R. Stockman was added to the force. The personnel of this District were unique in that none of them had had any practical experience in stream gaging except Stockman. He had started the Wisconsin work under the supervision of L.S. Smith who was unfamiliar with USGS methods. Two striking results of the lack of experience were the discontinuance of many stations after a short time because of unsatisfactory measuring conditions, and the use of cables and boats that had elsewhere been generally abandoned following the development of cables and cars.

Leighton transferred to Washington, D.C., in September 1903 to take charge of the newlycreated Hydro-Economics Division, and E. Johnson Jr., one of his assistants, succeeded him as district hydrographer. Although Leighton (written commun., ca. 1938) had been in charge of the District, he had devoted his time chiefly to the quality of water investigations, and, virtually from the beginning, had left $\mathbf{E}$. Johnson Jr. in actual charge of the stream gaging. E. Johnson Jr. remained in charge of the District until early in 1905 when he transferred to the Reclamation Service and was succeeded by Hanna. In fall 1905, Hanna went to the Washington, D.C., office for the winter, and was succeeded in January 1906 by A.H. Horton. In 1904, E.F. Chandler was placed in charge of the work in southern Minnesota. In the next year, 1905, the original Chicago District force, having been reduced to Hanna as district hydrographer, was enlarged when S.K. Clapp transferred to Chicago from the New England District. In addition to the States of Illinois, Minnesota, Missouri, Indiana, Ohio, and Wisconsin, Iowa was added to the District in summer 1903, the northern (upper) peninsula of Michigan in 1904, and Kentucky in 1905.

WISCONSIN.-All stations in Wisconsin were located at bridges and were generally equipped with chain gages. Winter measurements, which had been made frequently in 1903 , were greatly reduced the next winter and discontinued entirely in 1905.

MINNESOTA.-Professor Hoag established two stations in southern Minnesota in April 1903. 
During the next month, E. Johnson Jr. established additional stations in the Mississippi and St. Louis River basins and turned them over to Hoag to operate. A station had been maintained in the Red River basin in the northwest corner of the State since 1901 in connection with the North Dakota stations in that basin. With the enlargement of the district force in 1903, the USGS was able to maintain the stations in the Mississippi and St. Louis River basins and took them over from Hoag in September.

The Army engineers began current-meter measurements at St. Paul, Minn., as early as 1866 because of the reservoirs that were built to aid navigation on the Mississippi River. The measurements continued intermittently until 1891, after which measurements were made almost daily during the summer and fall months until the end of 1897. Thereafter, a few measurements were made each year. Miscellaneous measurements were made at other points above St. Paul. Between 1881 and 1897, for three periods ranging from 5 months to a year, discharge measurements were made almost daily on the Crow River near its mouth. During summer and fall 1880 and again in 1881 , measurements of the Mississippi River were made almost daily at Winona, Minn. Between 1893 and 1895 , three gaging stations were established at or near the reservoirs and have been maintained since. Two additional stations were maintained for a year or so during the mid-1890's, and, from 1899 to 1904 , measurements were made almost daily at the outlet of Bigstone Lake on the upper Minnesota River. Measurements were made almost daily from May 1899 to May 1904 in the Red River basin at the outlet of Ottertail Lake, and similar measurements were made at the outlet of Red Lake from May 1899 to August 1901. Those records were not published currently, but the author copied them from records in the Army engineer's office in 1912 and published them in 1913 in a State Drainage Commission report entitled "Report of the Water Resources of Minnesota, 1911-12."

When A.H. Horton became district hydrographer in spring 1906, E.F. Chandler, assisted by Richards, maintained the Minnesota stations under the general supervision of the Chicago District. The Minnesota work continued to increase during the entire period and was at its maximum at the end of the period. Cables and cars at stations at bridges and cables and boats at other stations were used for streamflow measurements, and vertical staff gages were generally used for gage heights.

ILLINOIS.-The field work in the Illinois Valley was conducted by the Sanitary District employee Heilbron until 1905. The USGS paid all expenses, including his salary. The only cooperation given by the Sanitary District was to make Heilbron available, and for this the District received a copy of the records. The USGS conducted the field work during the remainder of the period.

INDIANA.- In July 1903, the USGS took over the operation of the stations that had been established by Professor Waesche and operated a maximum of eight stations during the remainder of the period. They, except two with staff gages, were equipped with chain gages and all were located at bridges.

IOwA.-In May 1903, Iowa was added to the Chicago District, which took over three stations that had been maintained by the city engineer of Boone. Four additional stations were established and maintained by the USGS. With the exception of one cable station, bridges were used for measurements and the stations were equipped with chain gages.

MISSOURI.-I.W. McConnell, who started the Missouri work in 1803, was given an appointment in the Reclamation Service during that year. Hanna, who succeeded him, found that four of the stations were too close to the mouths of the rivers and were influenced by backwater from the larger streams to which they were tributary. Hanna, therefore, discontinued those stations and established one new station. A number of additional stations were established and six were being maintaine in 1906.

OHIO.-Funds of the State Health Board of Ohio for stream gaging were exhausted in 1903, so the expense of the Ohio stations was borne by the USGS. The Health Board's engineer was 
given a per-diem appointment in the USGS and was paid by the USGS for his time spent in stream gaging. New stations were established, and unfavorably located old ones were discontinued, leaving nine in 1906 . The stations were all located at bridges and were generally equipped with chain gages.

UPPER PENINSULA OF MICHIGAN.-In spring 1904, the three stations in the Upper Peninsula, which had formed a part of New York District, were transferred to the Chicago District for operation.

KENTUCKY.-Hanna established three stations in Kentucky in spring 1905. The records obtained, however, were insufficient to permit computation of daily and monthly discharges.

\section{North Dakota District}

North Dakota's contribution to the reclamation fund was the second largest among contributions from the arid-land States (Second ann. rept., Reclamation Service, p. 25, 1904), and it was felt that a feasible irrigation project should be found there if possible. Accordingly, Babb and F.E. Weymouth went to North Dakota in April 1903 to locate a site. No stream-gaging records were available on the section of the State needing irrigation, so additional stations were established on those streams having possibilities for irrigation use. E.F. Chandler, assistant professor of mathmetics at the University of North Dakota, was given a per-diem appointment and put in charge of the proposed stream-gaging program. He reported directly to the Washington, D.C., office, thus making North Dakota an independent district. Thus began E.F. Chandler's part-time service that lasted nearly 30 years. Stream gaging was active during the remaining years of this period and 13 stations were being maintained at the end of the period. E.F. Chandler used his engineering students quite extensively and one of them, Raymond Richards, later became an assistant engineer in the USGS. The expense of the work was paid entirely from USGS funds except for limited voluntary cooperation and the office space furnished by the university.

\section{Denver District}

The Denver District, which had an area greater than any other, was formed August 1, 1903 , by consolidating the work previously conducted by resident hydrographers in Colorado, Wyoming, Nebraska, Kansas, northern New Mexico, and Oklahoma (including the Indian Territory). M.C. Hinderlider, who had previously been in charge of the Colorado work, was made district hydrographer.

Colorado was the most important State of the Denver District, not only from the standpoint of stream gaging but also because Denver was the headquarters of the Reclamation Service for the Rocky Mountain region. As the chief interest in stream gaging in the region related to irrigation, the USGS District Office was combined with that of the Reclamation Service. The stream-gaging activities of the District were too large for nominal supervision by an engineer of the Reclamation Service, the general practice in the West, so a district hydrographer was placed in direct charge who gave the greater part of his time to stream gaging. The Lake Archer station of the Denver District rated the current meters used in the mountainous region, and Reclamation Service employees were generally used for that purpose.

The first increase in size of the Denver District came in 1904 when the gaging stations on the Uinta Indian Reservation in eastern Utah were added. These stations had been maintained by Howard S. Reed as resident hydrographer and he continued in direct charge of them. The next increase occurred also in 1904 when South Dakota was made a part of the District. Raymond F. Walter continued to supervise the field work, however, which was conducted by his assistants in the Reclamation Service. The resident hydrographers of the District sent their field data to the Denver office for compilation and study before they were transmitted to Washington, D.C., for computation.

COLORADO.-Although Fellows was still in charge of stream gaging in Colorado during 1902, he was engaged chiefly in the irrigation investigations. Hinderlider was therefore appointed hydrographer and conducted the 
stream gaging under Fellows' general supervision. On January 1, 1903, Hinderlider was given a civil service appointment and placed in full charge of Colorado stream gaging. The Kansas $v$. Colorado suit in 1903 resulted in the creation of the Arkansas Valley Ditch Association, which contributed funds for the installation and maintenance of stations on the Arkansas River that were under the direction of State Engineer L.G. Carpenter. These stations were discontinued after 1903 because of lack of funds and the records were turned over to the USGS. The Reclamation Service was active in its investigations during these years, established and maintained a considerable number of stations, and turned over the records for computation and publication by the USGS. An impending reduction in the appropriation caused a drastic reduction in the number of stations early in 1908. At about the same time, the Reclamation Service completed its investigations and discontinued all stations except those few that were connected with the Uncompahgre project, which had then reached the construction stage. Among the personnel during this period were Ralph I. Meeker and William A. Lamb, both of whom held civil service appointments. Lamb transferred to the Oklahoma-Eastern New Mexico District early in 1906, leaving Meeker as the only full-time assistant in Colorado.

The gaging stations in Colorado were located at highway bridges except for five that were equipped with cables. The gages were chiefly vertical staffs, but there were five chain and three wire gages. The gage on the Grand River (now Colorado River) at Glenwood Springs is worthy of note. A recorder, installed in 1902, did not prove to be satisfactory. It was replaced by a gage invented by the observer: a metal float and counter-weight connected with a pliable wire passed over pulleys so arranged that a rise of 1 foot in river stage indicated a rise of half a foot on a scale. This station required not only a special gage, but also a special attachment to the meter because the high velocity of 18 to 20 feet per second at maximum stages made the counting of the revolutions of the large Price meter impossible. Accordingly, Hinderlider developed a penta head that indicated every fifth revolution. This penta head, which was manufactured by the Sachs-Lawlor Company of
Denver (Hinderlider, oral commun., ca. 1938), antedated by several years the attachment that J.C. Hoyt later devised for the small Price meter and which was made standard for USGS meters.

The expenses of stream gaging in Colorado were paid from the USGS stream-gaging appropriations except for those stations maintained directly by the Reclamation Service. The State did not cooperate. State hydrographers were engaged chiefly in measuring in ditches, but made a number of measurements at regular river-gaging stations.

NEW MEXICO.-At the beginning of the period, the USGS had no stations in New Mexico. The IWBC still operated the two Rio Grande stations. After New Mexico was added to the Denver District, stream gaging was conducted actively and the number of stations reached a maximum of 13 in 1903. After the reduction in available funds, however, and the transfer of several stations to the Oklahoma-Eastern New Mexico District, only two of the stations were operated by the Denver District at the end of the period. The Embudo station was discontinued at the end of 1903-its historic and longterm value did not at that time outweigh the lack of immediate practicality. The stations were operated directly from Denver, the field work was conducted chiefly by Meeker, and the expenses were paid from stream-gaging funds.

wYOMING.-A.J. Parshall, who had been a perdiem appointee during the previous years, was given a civil service appointment on February 2, 1903, and continued with the Wyoming work, reporting after August 1, 1903, to Denver, Colo., instead of Washington, D.C. The number of stations increased from 5 in 1902 to 11 in 1906. In addition, the Reclamation Service maintained a number of stations for projects under investigation. The stations were equipped chiefly with vertical staff gages and were located at bridges except for the cable station in the canyon below Pathfinder Dam. The expense of the Wyoming work was paid either from USGS or Reclamation Service funds because there was no State cooperation.

NEBRASKA.-Stout continued in charge of the Nebraska work during 1902 . The field work 
was conducted by State employees and by John C. Stevens who was then an engineering student at the University of Nebraska. J.C. Stevens took the civil service examination in fall 1902, was given an appointment as assistant engineer on March 1, 1903, and was put in charge of stream gaging in Nebraska and in the Black Hills of South Dakota. When Nebraska was added to the Denver District in August 1903, Stout severed his official connection with the work, although he always maintained a great personal interest in it. Somewhat later, the South Dakota work was turned over to Walter, and J.C. Stevens' attention was limited to the Nebraska stations. J.C. Stevens personally conducted most of the field work except at the North Platte stations in the western part of the State that were of importance for irrigation and where State employees made most of the measurements. J.C. Stevens was detailed to the Denver office in 1905 and the USGS appointed Adna Dobson, the State Engineer, as resident hydrographer in Nebraska. During the remainder of the period, Dobson conducted the field work using State employees. The expense was largely borne by USGS funds (Rept. of Nebraska State Board of Irr., 1905-6, p. 10, ca. 1907). Nine stations were maintained in 1906.

In 1902, the gages in Nebraska were about equally divided between staff and wire types, but the wire gages were all replaced by chain gages by the end of the period. All stations were located at bridges. A side light on observers is given by one particular experience in Nebraska: Suspecting that an observer who had to travel 5 miles to read gages on three channels of the Loup River was not reading the gages as often as the records showed, J.C. Stevens, with the help of the unsuspecting observer, installed in the farthest gage box a counter that would record each opening of the box. The observer was told some sort of fairy tale regarding the purpose of the counter to avoid arousing his suspicions. When J.C. Stevens and the observer visited the gage a month later and during which time the observer had reported daily gage heights, the counter registered nine. Confronted with this evidence, the observer confessed that nine was the number of times he had actually visited the station, and promised to do better.
KANSAS.-With increased funds available in 1902, W.G. Russell increased slightly the number of stations in Kansas. The greatest known flood in the Kaw River valley occurred during 1903, and the lack of adequate records demonstrated the value of systematic stream gaging in a region where irrigation was not widely practiced and where the water-power resources were unimportant. Hinderlider and W.G. Russell investigated this flood and established a group of so-called flood stations in cooperation with the Weather Bureau.

One incident connected with the flood investigations disclosed a hitherto unsuspected fact that Ananias had a descendant among the Survey hydrographers. While Hinderlider and W.G. Russell were making a discharge measurement at a bridge, a local resident drove onto the bridge and, as often happened, stopped to watch the proceedings. Finally he asked what was being done, and W.G. Russell replied that he and Hinderlider were government agents taking a census of the fish by means of their machine that recorded every fish passing up or downstream. The local resident sat for a time cogitating on this alleged information and then starting his team, remarked to the horses: "Well, by heck, that is the way, with all these government employees using up the taxpayers' money to get a lot of useless information" (Hinderlider, oral commun., ca. 1938).

During the entire period from the time the Kansas stream gaging was started in 1895 , the field work was conducted by W.G. Russell except for the few stations maintained by Murphy. Although given a civil service appointment in 1903, W.G. Russell continued on a perdiem basis during the entire period because the work did not require his full-time services. No State or other cooperation was received during those years because Kansans were not then "water-minded." The number of stations was reduced to three in 1905 .

SOUTH DAKOTA.-The Reclamation Service began investigations in South Dakota in spring 1903 under Walter who was appointed engineer on May 20, 1903. As records of flow were not available in the western part of the State, it was necessary to establish stations on the streams that were being investigated by the 
Reclamation Service. The gages were either vertical or inclined staffs. Discharge measurements were made by wading or from bridges at all but three stations. One of these three had a cable, but it was necessary to use floats to measure high-water discharge at the others.

UINTA INDIAN RESERVATION.-Babb started an intensive investigation of the St. Mary-Milk River project in June 1902 following the passage of the Reclamation Act, and transferred the resident hydrographer on the Uinta Indian Reservation to Montana as one of his assistants. Reed, who had for 3 years been a hydrographer on the Nicaragua and Isthmian Canal Commissions under A.P. Davis, was then put in charge of the Reservation stations. These stations were discontinued at the end of the period when the Reservation was thrown open to settlement, and the Indian Service, having no further interest, discontinued paying for that work. Reed transferred to the Reclamation Service for work in Arizona. During 1902 and 1903, the Uinta stations constituted an independent district, but they were attached to the Denver District in 1904 with Hinderlider in general charge. The reason for attaching these stations to the Denver District rather than to the Reclamation Service activities in Utah was due, as Swendsen (written commun., ca. 1938) states, to relative accessibility. At that time there was no road of any kind over the mountains from the Salt Lake side, whereas it was possible to reach Denver by train and "passable road."

\section{Oklahoma-New Mexico District}

The Oklahoma-New Mexico District had its beginning as two small Reclamation Service districts, one started in 1903 in Pecos Valley, N. Mex., and the other in 1902 in Oklahoma. By 1906, it was evident that the streams, which were prone to flash flooding, required more attention than had been given them, and a new District was formed that comprised practically all of Oklahoma and the eastern part of New Mexico. Giles, who had assisted M.R. Hall in the Southeastern States, was put in charge early in 1905 . The stream gaging was so closely related to the irrigation investigations that Giles made his headquarters with the Reclamation Service at Carlsbad, N. Mex.

The stations that were established during 1903-4 were equipped chiefly with inclined or vertical-staff gages, and the remainder had chain or wire gages. Discharge measurements were made when wading, except during high stages when bridges at most of the stations were used. Seven stations were equipped with cables and one with a boat. Four Oklahoma stations had no provision for making high-water measurements and it was necessary to use Kutter's formula. The stations were so widely scattered and the floods were so sudden that it was generally impossible to measure the high water, and use of the slope method was necessary to determine the high-water discharge. It is probable that at that time, more frequent use was made of the slope method in Oklahoma than in any other district. The district personnel, in addition to Giles who was district hydrographer, consisted of Lamb who came to the District from Colorado in 1906, and two field assistants.

\section{Montana District}

Investigations conducted previously in Montana indicated that the St. Mary-Milk River project was the most promising in the State, and Babb, who had conducted the preliminary surveys, was at the beginning of this period designated district engineer in charge of that project that included practically all of northern Montana. He took over the supervision of the stream gaging in the State from Fortier. Montana, on account of its great extent of semiarid land, available water supply, and large contribution to the Reclamation fund, was a very important State from the viewpoint of the Reclamation Service. Irrigation investigations were, therefore, increased in scope each year during this entire period. Additional gaging stations were established each year as the irrigation investigations showed a need for them. The earlier stations were generally equipped with wire gages that were later replaced by standard chains. The later stations had vertical staff gages. Most of the stations were located at bridges, but 12 had cables for high-water 
measurements. The field work, which was under Babb's general direction, was conducted by assistants of the engineers who were in charge of the irrigation projects. By 1904, however, the number of stations had so in creased that the full time of one or more assistants was spent on stream gaging. During that year, W.B. Freeman, who had joined the Reclamation Service in 1903, devoted his entire time to stream gaging; the other assistants spent part of their time on stream gaging. Among the assistants were A.E. Place who had been connected with the New York work, Stockman who had transferred from the Chicago District, and the author who had transferred from the U.S. Lake Survey to the Reclamation Service in April 1904. In spring 1905, H.M. Morse was put in actual charge of the work with headquarters at Billings, Mont., in order to be in close contact with the supervising engineer of the Reclamation Service.

\section{IDAHO District}

During 1901, D.W. Ross, State engineer of Idaho, conducted reservoir and canal surveys for the USGS along the Snake River where opportunities for large irrigation developments were among the best in the United States (Second ann. rept., Reclamation Service, p. 57, 1904). Soon after the passage of the Reclamation Act, D.W. Ross was put in charge of the greatly enlarged investigation and, in that capacity, supervised the stream gaging in the State throughout the entire period. All of the stations were equipped with vertical or inclined staffs, and about half of them had cable installation. Ferry boats were used at two of the stations.

Dils, who had been resident hydrographer since 1899 , conducted the actual stream gaging until summer 1903 when he was succeeded by several of D.W. Ross' assistants, none of whom spent their entire time stream gaging. In March 1906, E.C. LaRue transferred to Idaho from California and D.W. Ross put him in charge of the stream gaging during the remainder of the period. A series of seepage measurements along the Snake River were made during each irrigation season, in addition to the routine stream gaging. This work had been started by Dils in 1899 . In addition to the gaging stations maintained by D.W. Ross, Theron A. Noble, who was in charge of similar investigations in Washington, established and maintained a few stations in northern Idaho in connection with his investigations in that State.

\section{UTAH District}

\section{[INCLUding Southeastern IDAHo]}

Swendsen, who had previously been the Survey's resident hydrographer in Utah, was appointed engineer in the Reclamation Service in 1903 and was put in charge of the irrigation investigations that centered around the Utah and Bear Lakes projects. The actual stream gaging was conducted by assistants in the Reclamation Service under Swendsen's supervision. Staff gages, either vertical or inclined, were used and bridges were selected as sites for the stations wherever possible. Because of a lack of bridges in many parts of Utah, however, cables were used for high-water measurements to a greater extent than in most districts.

The State engineer established a gaging station in 1903 on the Weber River and maintained it during that season in connection with a determination of water rights. The next year, he arranged with Swendsen to operate it as a USGS station and agreed to pay half the gage observers' salaries at that station and at three others established by the USGS on that stream in 1904 (Fourth bienn. rept., State eng., p. 38, 1903-4). This item amounted to perhaps $\$ 100$ annually, which was the State's contribution to cooperative stream gaging during this period.

\section{Nevada District}

F.H. Newell was anxious to start construction of a project in Nevada at the earliest practical date because the Reclamation Act had been passed largely as the result of Congressman Newlands' activity. This fact, together with the provision for a State Engineer who was to cooperate in every possible way in irrigation investigations, outweighed the fact that Nevada had contributed far less to the Reclamation fund 
than any other Western State (Second ann. rept., Reclamation Service, p. 25, 1904). Accordingly, the investigations conducted by L.H. Taylor during the previous period were expedited. L.H. Taylor continued in charge of the irrigation investigations and was appointed engineer in 1903. Additional streamflow records were needed, and Murphy was detailed to establish the necessary stations. He not only established 11 stations, he also rebuilt several gages. Having completed the installation of these stations, Murphy transferred to the Washington, D.C., office in early 1903. L.H. Taylor continued in charge of stream gaging in the State until summer 1903 when cooperation was arranged with A.E. Chandler, the newly appointed State engineer who thereafter became the district hydrographer. A.E. Chandler resigned in 1905 and was succeeded by Henry Thurtell, as both State engineer and district hydrographer.

Bridges were few and far between in Nevada, and two-thirds of the stations were equipped with cables and cars. The gages were either vertical or inclined staffs.

\section{WASHINGTON DistRICT}

Private enterprise had demonstrated the success of irrigation in Washington, particularly in the Yakima Valley, before the passage of the Reclamation Act. As there were still vast areas of arid public land and lakes and rivers that provided storage sites of large capacity, there appeared to be excellent opportunities for Federal irrigation. Noble was given a per-diem appointment in fall 1902 and put in charge of irrigation investigations, including stream gaging. He was appointed engineer in the Reclamation Service in May 1903. Most of the gaging stations that were established and maintained during this period were related to irrigation investigations, but Noble's previous experience with waterpower developments led him to establish a number of stations on the Olympic Peninsula where there were opportunities for power development.

An extensive investigation of the capacity and use of the many canals in the Yakima Valley was begun in 1904 and continued during each irrigation season thereafter. Twenty-three river stations were being maintained at the end of the period. The field work was conducted by different assistants, among them Harley, who spent his entire time stream gaging during 1904, and W.C. Muldrow during 1905 and 1906.

\section{Oregon District}

The opportunities for irrigation in Oregon were not conspicuous, and it was not until 1903 that investigations began under the direction of Whistler who had been an engineer with the Isthmian Canal Commission where he had met A.P. Davis. Whistler was appointed engineer in the Reclamation Service in 1903. At that time, only one station, that on the Umatilla River, was being maintained by Sydney Arnold, who had conducted stream gaging for the USGS in Washington. Soon after irrigation investigations were started, Whistler put J.H. Lewis in charge of stream gaging, and within the first 2 years, J.H. Lewis installed and maintained 30 stations. State cooperation, which became effective in 1905, resulted in the installation of 26 additional stations. Several of these stations were maintained on the Klamath Reservation in cooperation with the Indian Service. A Friez automatic gage was installed on Miller Creek near Lorella, Oreg., in December 1905, and a similar gage was installed on the Williamson River near Klamath Agency, Oreg., in February 1906 because of the inability to obtain satisfactory observers at those sites. Many stations established during 1905 and 1906 were situated near the coast where the obvious possible use of the rivers was for water power rather than irrigation.

The major cost of stream gaging was paid by the Reclamation Service, except during 1906-7 when State cooperation made $\$ 5,000$ available, which was furnished in equal parts by the State engineer and the USGS. Among Whistler's assistants who conducted stream gaging under J.H. Lewis' direction were Steward and Sawyer, Sawyer having transferred to the Reclamation Service from the Middle Atlantic District in 1904.

\section{California District}

Lippincott, who was conducting irrigation investigations for the Reclamation Service, was 
maintaining two groups of gaging stations in California in 1902: (1) those in the San Francisco Bay drainage that included both the Sacramento and San Joaquin River basins, and (2) those in the southern part that included not only the great citrus region, but also the lower Colorado River. Stream gaging increased rapidly, due to the activities of the Reclamation Service, to State cooperation that began in 1903 , and to assistance furnished by waterpower companies. There were 65 gaging stations at the end of the period. These stations were equipped with staff gages, except two that were equipped with automatic gages. A Friez gage was used on the Kings River near Sanger, Calif. The measuring equipment was about equally divided between bridges and cables. Boats and cables were used at four stations.

In 1904, S.G. Bennett, who was in charge of the investigations of storage possibilities in the Sacramento River valley, supervised the streamgaging activities in that basin. The stations in the remainder of the State were the responsibility of William B. Clapp, who was district hydrographer under Lippincott's supervision. Beginning with 1905 , all stations were put under the direct supervision of W.B. Clapp, and were so continued during the remainder of the period. Among the considerable number of Reclamation Service engineers who were assigned to stream gaging were W.V. Hardy, field assistant, during the entire period; Sawyer, assistant engineer, during 1906; LaRue, appointed engineering aid in June 1904 and continuing until March 1905, when he transferred to Idaho; W.F. Martin, appointed hydrologic aid in June 1905; and C.H. Lee, appointed hydrologic aid in August 1905. Why Martin and Lee were designated "hydrologic aids" is not known at this time, unless it was to differentiate them from the engineering aids who were directly involved in Reclamation Service activities.

\section{Arizona District}

The irrigation of arid lands in Arizona depended mainly on the construction of large reservoirs for hold-over storage (First ann. rept., Reclamation Service, p. 75, 1902). For that reason, irrigation investigations had been conducted actively during the years of the perdiem appointments. Early in the present period (1902-6), A.P. Davis resumed investigations on a large scale, concentrating his efforts on the Salt River project, which involved also the construction of the Roosevelt Dam. Stream gaging was more difficult in Arizona than in any other district. As A.P. Davis states on page 76 of the aforementioned report:

\begin{abstract}
The sources from which water may be obtained for reclamation are, taken as a whole, the most erratic or irregular in the entire country. There are comparatively few rivers which flow throughout the year. ${ }^{*} *$ The waters from these socalled cloudbursts rush off in a torrent, following the stream channels for a few hours and then disappearing. They take up and carry with them the loose dust and sand, gathering in the stream channels, roll onward the gravels and boulders, the mass quickly assuming the appearance of liquid mud.
\end{abstract}

With this condition and the necessity for records to be as accurate as possible, the problem was solved by detailing a resident hydrographer to a single station or to two nearby stations to take measurements every few days, and oftener during the floods that might occur in any month of the year. This procedure was expensive, so work was confined to those streams for which records were needed immediately. The number of stations was increased to 14 during the period. During the first part of the period, C.G. Williams was district hydrographer, but he was succeeded during the second year by Farish from whom Reed gradually took over the work.

Except for one station located at a bridge, the gaging stations were equipped with cables and all had either inclined or vertical staffs. In December 1905, Reed installed a Friez gage on the Chevelon Fork near Winslow, Ariz., and, in June 1906, a Friez gage on the Clear Creek near Winslow. In addition to the Reclamation Service stations, G.E.P. Smith, professor of irrigation engineering at the University of Arizona at Tucson, established a station on the Santa Cruz River near Tucson in 1905 and furnished the records to the USGS. 


\section{Division OF HydROLOGY}

The requests for information regarding wells and ground water had become so numerous during the first year of the existence of the Hydrographic Branch and the work of previous years had shown such need for specialization in future investigations that the Division of Hydrology was organized on January 1, 1903. The use of the term "hydrology" with special reference to ground water is peculiar to the USGS. The use originated through the fact that a study of geology is requisite to the determination of ground water, which determination was termed "hydro-geology," which was then contracted to "hydrology" (USGS 24th ann. rept., p. 196, 1903).

During 1902 the Geologic Branch had contemplated the creation of a well section whose staff would compile records from oil and gas wells. M.L. Fuller, a geologist, had prepared a plan for such a section (USGS 26th ann. rept., p. 184, 1905), but a lack of funds had prevented its formation. In November 1902, F.H. Newell presented to the Director a plan for a proposed well section to include not only water wells but also oil and gas wells. This plan was approved, and because M.L. Fuller had prepared the original plan for a well section, he was placed in charge of it on December 23, 1902. M.L. Fuller's section was made a part of the Division of Hydrology when it was created soon afterward.

Lack of funds in the Geologic Branch prevented the collection of records from oil and gas wells and therefore the well section staff confined their attention to records from water wells (USGS 26th ann. rept., p. 184, 1905). M.L. Fuller began compiling as complete a list as possible of the addresses of well drillers, well owners, and others interested in records of water wells, and the activities of the new Division during the first few months related to this compilation. (In making this statement it should be explained, however, that the western groundwater work under Darton was still continuing but had not yet been made a part of the activities of the new Division.) During that time, however, the plans for work in hydrology were gradually taking shape. The scope of these plans is best described by quoting from the first report of the new Division (USGS 24th ann. rept., p. 196-97, 1903):

The work of the division includes the gathering, filing, and publication of statistical information relating to the occurrence of water in artesian and other deep wells; the gathering and publication of data pertaining to springs; the investigation of the geologic occurrences from both stratigraphic and structural standpoints of underground waters and springs; a study of the laws governing the occurrence and flow of subterranean waters and springs, including the investigation of variations due to tidal, temperature, and barometric fluctuations; direct measurement of rate of underflow; detailed surveys of regions in which water problems are of great importance and urgency; and the publication of reports on irrigation, city water supplies, and other important uses of underground waters.

It would appear that the field of action for the new Division was indeed a wide one, and that little had been overlooked.

In the previous period (1894-1902), the ground-water work had been conducted by geologists detailed as needed to that activity in order to avoid unnecessary overhead expenses. At the beginning of the present period (1902-6), however, a time had been reached when both the quantity and quality of the investigations appeared to demand the permanent assignment to the new division of geologists who had specialized in ground-water studies in the past and who could devote their entire time to it in the future, thus becoming specialists. Close supervision over the purely geologic features of the investigation would need to be continued as in previous years, and on May 28, 1903, the Director approved instructions that stated that members of the Division of Hydrology should confer with the geologists in charge of sections of geology and that the section chiefs should have the same authority in geologic matters over geologists in the Division of Hydrology as over the geologists in their own sections (USGS 24th ann. rept., p. 196-97, 1903).

The ground-water work during the previous period had been conducted without any general 
plan and its nature, aside from the general studies of Darton and W.D. Johnson and special investigations on movement of ground water by F.H. King and Slichter, had been dictated largely by the immediate needs. These needs had been met largely by the well records collected through well drillers in the East, and by special ground-water studies in the West.

Before the beginning of fiscal year 1903, it was apparent that the needs of the West, particularly from the standpoint of the Reclamation Service, were so different from those of the East that a western section was organized to include the so-called reclamation States and territories. On May 18, 1903, Darton, who had already conducted ground-water studies in the West, transferred to the Division of Hydrology. On July 1, the western section was organized with Darton as chief and the eastern section with M.L. Fuller as chief. This organization was continued to the end of the period.

\section{EAstern Section}

From the beginning, there were marked differences between the East and the West in the character of the investigations. In the East, where flowing artesian waters were mainly limited to sections of the Atlantic Coastal Plain and to small basins in the glacial drift, the demand for information about ground water came mainly from isolated towns or industrial plants or from farms and estates seeking domestic supplies. There had been no previous general investigations of ground waters in the Eastern States and the work in this region was organized particularly for general studies. Broad general surveys of ground-water supplies, chiefly under the direction of local State or university geologists, were begun in Alabama, Mississippi, Louisiana, Arkansas, Tennessee, Iowa, and later by members of the eastern section in Ohio, Michigan, Minnesota, Iowa and other States, reports of which were subsequently published. Reports on minor ground-water problems that were written by several geologists in connection with their regular studies were produced through cooperation with the Geologic Branch.

The most ambitious and perhaps most important investigation in the East was conducted by
A.C. Veatch and others on the sources of ground water on Long Island in New York. This investigation was conducted in cooperation with the commission on additional water supply for New York City. During this investigation, Slichter was employed to measure the flow of the ground waters and the use of his apparatus for that purpose proved successful, enabling the USGS to predict the amount of water available for municipal supply in the localities examined. This is believed to have been the first successful quantitative groundwater study. At the end of the investigation, the Slichter apparatus was turned over to the Brooklyn Water Department for an extension of the investigation to new areas (USGS 25th ann. rept., p. 265, 1904). Other investigations having immediate application to problems were studies of ground-water supplies made for the War Department at forts in different parts of the country, and for a number of cities in which there were typhoid epidemics. All of these investigations, however, were limited to small areas and were of short duration.

By 1905, the scope of the well records had been broadened under Veatch, Samuel Sanford, and E.F. Lines to include borings from oil and gas wells, particularly in relatively unknown fields. Nearly 2,000 records were studied and 12,000 samples examined, classified, labeled, and filed. As a result of these labors, the furnishing of expert advice on the occurence of oil, gas, and artesian water became an important part of the work of the Eastern Section during the latter part of the period (USGS 27th ann. rept., p. 74, 1906). Statistics of production and value of table and medicinal waters were collected for publication in the annual volumes of Mineral Resources of the United States [1882 until 1925 when, by Executive Order, the Division of Mineral Resources, USGS, was transferred to the Bureau of Mines]. A general bibliography on ground-water publications was prepared and kept current.

The personnel of the section was built up at the start mainly by new appointments. The staff, besides M.L. Fuller as chief, included Veatch who had been previously conducting ground-water investigations in Arkansas for the Hydrographic Branch, and Cleveland Abbe Jr., B.L. Johnson, Samuel Sanford, and Lines who 
were appointed from the civil service lists and spent all of their time on the work of the Division. The exact amount of the allotments for the Eastern Section is uncertain at this time, but it is believed to have been about $\$ 15,000$ per year. As M.L. Fuller writes (ca. 1938):

The matter is complicated from the fact that throughout the whole time I was connected with the Division of Hydrology, allotments were received from both that Division and from Geology, and even if the allotments were obtainable, it would not always give the actual amount devoted to the work for the reason that the salaries of the permanent men were often not included in the allotments, which were for field expenses and for temporary men.

\section{Western Section}

When the Western Section was organized in 1903, the review of the geology and prospects for water in the Central Great Plains, which had been started by Darton during the previous period, was still in progress and became an important phase of the work on which Darton spent the greater part of his own time.

In accordance with the plan to broaden the field of activity to cover all reclamation States, an organization was created chiefly by transfers from the Geologic Branch. The first force, in addition to Darton as chief, included Mendenhall who transferred from the Alaskan Division, and George B. Richardson and Harry R. Johnson who transferred from the Geologic Branch, all assistant geologists. Gerald A. Waring was appointed junior geologist and assigned to the California work. In addition, William T. Lee and Cassius A. Fisher were field assistants. Having become eligible through civil service examination, William $T$. Lee and C.A. Fisher were appointed assistant geologists in 1904, as was C.E. Siebenthal. These geologists made up the permanent organization of the Western Section during its duration. Work was conducted to a limited extent in cooperation with State geologists.

The study of the geology and ground-water resources of the Central Great Plains covering
Kansas, Nebraska, South Dakota, eastern Colorado, eastern Wyoming, and parts of adjacent states, in which Darton had been working during previous years, was completed by him during the present period; a report on that study was published in 1905 as USGS Professional Paper 32. Darton also conducted special studies in South Dakota and Wyoming of the upturned strata on the flanks of the Rocky Mountains, including the Bighorn Mountains, the Laramie Range, and the Black Hills. The material thus gathered was used in the preparation of a number of reports about the geology and ground water of that region.

The Reclamation Service, when it was organized in 1902, started an investigation of ground water relative to irrigation in Southern California, which was one of the most important investigations conducted by the Western Section staff since its inception in 1903. Under Lippincott's supervision, Homer Hamlin sank test wells in the Los Angeles River basin and determined the rate of ground-water movement. Slichter's apparatus was used and Slichter himself supervised the beginning of this phase of the work. Water levels in many wells in that region were recorded and the lands irrigated by them were mapped. The results of the underflow tests were published in WSP 112 (1905).

By the latter part of 1903, Hamlin's services were needed on other Reclamation Service projects and Mendenhall was put in local charge of the Western Section work. The intensity of the investigation of the wells that were relied on for irrigation in Southern California is apparent from the legacy left to Mendenhall, which involved visiting 10,000 wells, measuring their depth, determining the position of the water table, testing the purity of the water, and mapping the lands on which the ground water was used for irrigation. This work was completed in 1904.

In the early years of the 20th century, Southern Californians thought of ground water as being unlimited in volume and were developing it at a rapid rate. In order to determine the effects of drought and further use on the future supply, Mendenhall in 1903 began a set of observations on the fluctuation of the groundwater levels in different parts of Southern 
California, particularly in the San Bernardino River valley. In this study, he used the streamgaging records at the base of the mountains to determine the amount of water entering the valley, and those records from the lower end to determine the amount leaving the valley. This apparently is the first use of stream-gaging records in connection with ground-water studies. Mendenhall did not use the Slichter method as Hamlin had done because he considered it too expensive and too local in its application for his immediate purposes. This investigation, which clearly showed shrinking supplies, indicated that Los Angeles could not rely on ground water for its future needs without curtailing the citrus industry and all other agricultural activities in Southern California.

The results of this study were used most effectively in graphic form by representatives of the city of Los Angeles in the campaign preceding the voting on bonds to finance the project for bringing water from Owens Valley (Mendenhall, oral commun., ca. 1938). The investigation of the foothill region continued during the remainder of the period, and a portion of the results were published in WSP's 137, $138,139,142$, all published in 1905, and 219 , published in 1908.

The value of ground water for irrigation was recognized in other parts of the West. William T. Lee investigated the Salt River Valley, Ariz., to determine not only the area from which such a supply could be obtained, but also the volume of the supply (WSP 136, 1905). He also conducted a geologic examination of the Colorado River with reference to dam sites. Siebenthal investigated the water supply from wells and the area that could be irrigated in San Luis Valley, Colo., where about 3,250 artesian wells were used extensively for irrigation (WSP 240, 1910). He also studied ground water in the Uncompahgre Valley, Colo. Fisher examined the artesian wells in an area of 1,800 square miles near Roswell, $\mathrm{N}$. Mex., and Slichter measured the rate of underflow in the Rio Grande Valley in the vicinity of El Paso, Tex. (WSP 141, 1905). Slichter also investigated the underflow of the South Platte River valley between Sterling, Colo., and North Platte, Nebr. (WSP 184, 1906).
A joint investigation of ground water in Texas was begun with the State Mineral Survey. It was believed that if ground water could be obtained, the Texas school lands owned by the State would become a source of income. Richardson was in charge of this investigation. He also studied the ground-water possibilities of the valleys of Utah Lake and Jordan River in Utah (WSP 157, 1906).

Investigations conducted by State and local geologists cooperating with the USGS included Oklahoma and the Panhandle of Texas by Charles N. Gould (WSP 154, 1906); the Republican River valley in Nebraska by G.E. Condra (WSP 216, 1907; eastern South Dakota by J.E. Todd and Charles M. Hall (WSP 90, 1904); the Yakima district, Wash., by Frank C. Calkins (WSP 118, 1905); eastern Oregon by I.C. Russell (WSP 78, 1903); and Washington by Henry Landes (WSP 111, 1905). T.U. Taylor, the resident hydrographer for Texas, investigated the ground waters of the Coastal Plain of Texas (WSP 190, 1907).

The total amount spent by the Western Section staff during the 3-year period ending June 30,1906 , was about $\$ 67,000$ (Darton, oral commun., ca. 1938), or an average of nearly $\$ 23,000$ per year.

\section{Division of Hydro-Economics}

As stated earlier, Marshall Ora Leighton was selected in 1901 primarily to study the quality of water, and when the Hydro-Economics Division was created in 1903, he was put in charge. Before his appointment he prepared, at F.H. Newell's request, a report on sewage pollution in the metropolitan area of New York City, which may be considered to be the onset of the quality-of-water investigations by the USGS. A little work had been done in 1897 , however, when members of the Division of Hydrography examined sources of pollution to the Potomac River, but that was an isolated investigation.

When the activities of the new Division were being considered, F.W. Clarke, chief chemist of the Geologic Branch, thought that stress should be placed on the relation between the chemical composition of water and the rocks 
over or through which it flowed. Leighton, on the other hand and with his background of sanitary engineering, was concerned with the pollution of water from an economic standpoint, and he felt that such an investigation was a proper field for the USGS in its inventory of the water resources because sewage and industrial waste impaired the water for many uses (W.D. Collins, oral commun., ca. 1938).

At that time, quality-of-water investigations were taking definite shape and many organizations, chiefly chemical departments of colleges and State boards of health, were making water analyses. These investigations, however, were based on painstaking chemical analyses, which were costly and required months and even years to reach definite conclusions with respect to even comparatively small areas. Considering the vast areas to be examined and the small amount of funds available, adoption of the then existing methods would, as Leighton expressed it (WSP 151, p. 16, 1905), postpone to future generations the benefits to be derived from such an investigation. He believed that a large number of approximate results would more nearly represent actual conditions than a few refined analyses, and that the most pressing need of the new Division was the development of simple field equipment so water could be "assayed" in the field.

The desirability of extending stream gaging to the Mississippi Valley as soon as possible led to the assignment of Leighton to the Chicago District at the beginning of this period. He was unable to devote much of his own time during the first year to quality-of-water investigations, but he arranged with the State boards of health of Ohio and Indiana to investigate the effects of strawboard wastes on the quality of water of streams (Leighton, oral commun., ca. 1938). In June 1903, while Leighton was still in charge of the Chicago District, Richard B. Dole, a chemist and sanitary engineer, was appointed engineering aid and assigned to quality-of-water investigations. He was first detailed in Brooklyn, N.Y., to the Mount Prospect laboratory of the Department of Water Supply, Gas, and Electricity of New York City to devise, with the help of D.D. Jackson, a new type of field equipment for USGS use in water assays. Little further work was accomplished until Leighton returned to Washington, D.C., in September 1903 to devote all of his time to the new activity. F.H. Newell then informed him that he had decided on the name "hydroeconomics" for the new division that was then created. He had not decided what the term meant, but liked the sound of it, and left to Leighton (oral commun., ca. 1938) the task of working out its significance in the USGS. Leighton's plan during his first year in Washington provided for collecting and classifying all analytical data heretofore obtained by different organizations, and the collection of new data by cooperating with university and State laboratories. He planned also to study the effects of sewage and industrial wastes on stream waters and the possible methods of reducing or eliminating such effects.

Assembling the field equipment for assaying water was completed during winter 1903-4, and Dole and Herman Stabler, the only other members of the Division, were ready to put it to practical use. Stabler had been appointed hydrographic aid on December 30, 1903, and had by chance been assigned to the HydroEconomics Division. Accordingly, the two started out in March for new worlds to conquer, which first consisted of the waters in the Des Moines River basin (Stabler, oral commun., ca. 1938). This first test of the new equipment demonstrated its suitability and it was used, with minor improvements, as long as the pollution investigations continued. The staff was increased by the appointment during 1904 of Selden X. Baker, W.W. Burnham, S.J. Lewis, and Horatio N. Parker, and plans were made to conduct independent investigations in addition to continuing the cooperative investigations of the previous year. It was Leighton's intention first to extend the quality-of-water investigations to all parts of the country, but he soon realized the impossibility of such an ambitious program and decided to confine the study to practical problems of immediate use (USGS 26th ann. rept., p. 210, 1905).

One of the most urgent investigations related to the effects of sewage and industrial pollution on the waters of Lake Champlain, long a basis for complaint by residents on both sides of the lake. This investigation, at the request of the Governor of Vermont, was conducted by Leighton from July to September 1904 , and 
the results were published in WSP 121 (1905). A year's investigation of the quality of water in Minnesota was begun in August 1904 under a cooperative agreement whereby the State Board of Health and the USGS each contributed $\$ 1,000$. Dole was assigned to the project, and WSP 193 (1907) contains the results of this work. A comprehensive investigation of the Potomac River basin was begun in fall 1904 in cooperation with the stream-gaging unit of the Hydrographic Branch, the Geologic Branch, and the Bureaus of Forestry and Fisheries. The purposes of the investigation were a thorough examination of the water supply, the sources and character of its pollution and the effect of such pollution on health, the effect of forests on streamflow, and the effect of industrial waste on fish. H.N. Parker conducted the hydroeconomics part of the investigation. The results were published in WSP 192 (1907).

Investigations of a more general character included the field determinations of the principal chemical constituents of ground and surface waters in Georgia, Indiana, and the upper Ohio River basin. The investigation in the Ohio River basin area was conducted by S.J. Lewis and the results published in WSP 161 (1906). Another cooperative agreement was made in 1905 with the State Board of Health of Ohio for a study of pollution from manufacturing wastes, to which Stabler was detailed. An incident of human interest (Stabler, oral commun., ca. 1938) occurred during this investigation, which required that hourly samples be taken for 48 hours. Stabler was unable to obtain assistance and had to take the samples himself. At the end of the 48 hours, he went to his hotel to spend the hour or so before train time in much needed rest. He neglected to place a call at the office, and the train arrived and departed while Stabler slumbered peacefully until the next day. Other minor investigations were conducted until the Hydro-Economics Division passed out of existence in 1906.

In addition to the special investigations briefly described, water analyses were obtained for the preparation of a so-called "normal chlorine map" of the country. An investigation into normal chlorine had been started by the personnel of the Massachusetts Board of Health in 1891, who had prepared a map showing lines of normal chlorine in that State. As additional information was obtained, it soon was obvious that there was no possibility of a normal chlorine map outside of the Atlantic Seaboard area because results of tests on water samples from nearby wells showed totally different results (Leighton, oral commun., ca. 1938). Near the seaboard, the normal chlorine content of the water fluctuated regularly with distance from the sea; further inland, the content of chlorine derived from the sea was practically zero, and the chlorine derived from other sources fluctuated widely.

Like the work of other divisions of the Hydrographic Branch, that of the HydroEconomics Division was associated with the activities of the Reclamation Service, and several investigations were conducted for that organization. One such investigation was the determination of the character and depth of the ground water on the proposed TruckeeCarson irrigation project, which was conducted by Stabler and Burnham. This was in reality an alkali survey, which required the boring of many holes to obtain samples of ground water. Little immediate use was made of the results, but, as Leighton stated to the author, they proved of considerable value to the Reclamation Service at a later date. Leighton started this investigation with Stabler, and the strength needed to lift the auger with its accumulated load of soil from the holes seemed too great for one man. Leighton left the investigation for several weeks and, while he was away, pondered the problem. As a result, Leighton, on his return, proudly showed Stabler a design for a mechanical device to assist one man in lifting the auger. Stabler, on whom the problems were more pressing, had already solved the question of a lifting device in the shape of an assistant who was 6 feet 4 inches in height and weighed 230 pounds of what Stabler termed "solid beef." One look at Stabler's "device" convinced Leighton that his own was not needed (Stabler, written commun., ca. 1938). Another activity in the West during 1904 was an investigation by S.X. Baker of the quality of the ground waters in the Salt River valley and what would happen when the new irrigation system that was being constructed was put into operation. 
About 1905, it was discovered that there was no pressing need for pollution studies and Clarke again urged on Leighton the mineral analyses of water. Leighton looked at the practical use of the contemplated study and decided it should be chiefly related to hardness with reference to use in boilers, laundries, textile establishments, and in the home. In the West, it would relate largely to the amount of alkali in waters that were used for irrigation (Collins, oral commun., ca. 1938). This latter view was doubtless influenced by the work for the Reclamation Service.

Determination of the mineral content of the water for industrial uses was started on July 1 , 1905 , when a contract was entered into with the State engineer of California. In the language of the agreement, the work was to make a study of the "natural waters of the State of California, their seasonal variation in composition and in physical characteristics, and the damage which they have sustained by reasons of pollution."

F.M. Eaton was detailed to this project from the Reclamation Service and laboratory space was obtained at Berkeley through the courtesy of the University of California. In December, 19 river stations were established from which daily samples of water were obtained. These samples were mixed at intervals of a few days and the composite samples were analyzed. The work of analyzing, which began January 1, 1906, was expected to continue for a year. But in the language of the Scottish poet, "the bestlaid schemes o' mice an' men gang aft agley." The earthquake of April 18, 1906, not only interrupted the field work, it also destroyed the samples already collected that were in the laboratory, which resulted in the suspension of the project until the next period of this History.

During the life of the Hydro-Economics Division, practically no analyses (as distinguished from field assays) were conducted by the Division staff themselves. A small laboratory with S.X. Baker in charge was fitted out in Washington, D.C., during summer 1904 for experimenting with new methods for assaying water to be used with the field equipment. It had been expected that a field laboratory would be installed at Fallon, Nev., in connection with the investigation in the Truckee-Carson River basin, and Burnham was sent to Fallon in early summer 1904 for that purpose. Because of delays caused by the proverbial governmental red tape, the equipment did not arrive until autumn and, by that time, the investigation of the character of the ground water had been completed, and the equipment was never unpacked (Stabler, written commun., ca. 1938).

\section{Reduction in Appropriation}

Throughout the period of the Hydrographic Branch, the annual appropriation was $\$ 200,000$. In spring 1906 , the appropriation for fiscal year 1907 was reduced to $\$ 150,000$ and, because this reduction had a lot to do with the end of the period of the history of the Hydrographic Branch, the cause of the reduction, which was quite apart from the merits of the work itself, will be described now at some length. As Leighton wrote to the author (ca. 1938), the stream-gaging appropriation was the innocent bystander in a struggle not aimed specifically at it, but because it was the weakest link in the chain making up the total appropriation for the Geological Survey, it broke, as weakest links always do. If the public interest had been sufficiently strong, the weakest legal link would have withstood the strain.

The real cause may be attributed to the persistent lobbying by USGS members, beginning with Powell's administration, and it is clear that the Major himself set the example. When Walcott succeeded Powell, he realized the unfavorable impression that had been created in the Congress and prohibited lobbying by members of the USGS. During the later years of his administration, however, which included the period covered here, Walcott relaxed his strict attitude and the branch chiefs again became active in pressing the claims of their respective activities. As a result, the appropriation for the entire USGS increased from $\$ 501,234$ to $\$ 1,513,500$ during the 12 years that Walcott was director. This large increase in appropriation made certain members of the House Committee on Appropriations, including Congressman Tawney of Minnesota who was serving his first year as chairman of the committee, resentful of Walcott's success in building up the USGS. They were, therefore, 
anxious to curb him (Leighton, written commun., ca. 1938).

For several years, all House appropriations had been under the control of Joseph G. Cannon, the Speaker of the House, who was Walcott's friend, and the committee members knew that they would be defeated if the issue was raised on the floor of the House with the Speaker in the chair. In searching for a weak spot wherein Walcott might be successfully assailed, it was found that although the Organic Act of the USGS authorized an investigation of the mineral resources, no mention was made of water and there was a reasonable doubt about water being defined by the Congress as a mineral resource. When the appropriations bill was considered by the House, sitting as the Committee of the Whole House with Congressman Watson of Indiana in the chair, the point of order was raised that the stream-gaging appropriation was not authorized by the Organic Act. The chairman sustained the point of order thereby automatically dropping the item from the bill. The Senate, which was friendly to Walcott, considered water to be a mineral resource and stream gaging therefore authorized by the Organic Act (George Otis Smith, written commun., ca. 1938), and restored the item in the amount of $\$ 200,000$. The item was reduced in conference to $\$ 150,000$ and Congress passed it in that amount.

Another weak link in the USGS appropriations was the item for the Technologic Branch, which was also under fire. Holmes, chief of that Branch, an indefatigable fighter who had had previous experience with legislative bodies, assumed the leadership in the fight made by both branches, Hydrographic and Technologic, to save their appropriations. He was aided in this fight by both Grover and Leighton. Holmes, during the crucial days when the appropriations hung in the balance, devoted all of his waking hours to the task, and in order that these hours might be as many as possible, worked far into the night and slept on a couch in his office. On one occasion Holmes called Grover at 2 o'clock in the morning and requested his immediate presence in his office (Grover, oral commun., ca. 1938). Like a good soldier, Grover obeyed the summons and presumably (since this was before the days of the taxi) called one of the once-familiar horse-drawn hacks, which was driven by a person wearing a coachman's livery, including a silk hat.

\section{Marshall Ora Leighton Appointed Chief Hydrographer}

It was apparent to F.H. Newell that heroic measures would be required to prevent serious curtailment of stream-gaging activities because of the weak legal position of stream gaging and the determination of the Congress to take full advantage of that weakness in its desire to reduce the total USGS appropriation. F.H. Newell was a past master at obtaining appropriations, but he was busy with the activities of the Reclamation Service and felt that he should relinquish the direction of the stream-gaging activities to a successor who would have the responsibility of regaining the recently lost ground. M.O. Leighton had been selected originally largely because of his qualities as a successful contact man, and F.H. Newell selected him as his successor. This was done early in June and Leighton became chief of the Hydrographic Branch on July 1, 1906.

\section{Progress in Branch Activities to June 30, 1906}

\section{By Natban C. Grover}

The withdrawal of F.H. Newell from the position of Chief Hydrographer closed an era in the Branch History. F.H. Newell had directed its activities almost from the beginning, had been largely responsible for the development of its methods and especially its policies, and had left the Branch organized into three major divisions manned by engineers, geologists, and chemists who were competent and aggressive. Two decades had been needed for the growth in public appreciation of the importance of water and of the value of reliable records of the quantity, quality, availability, and use of water, and for the inception and development of the Branch to the point where a stable Federal organization and program had been created and accepted. 


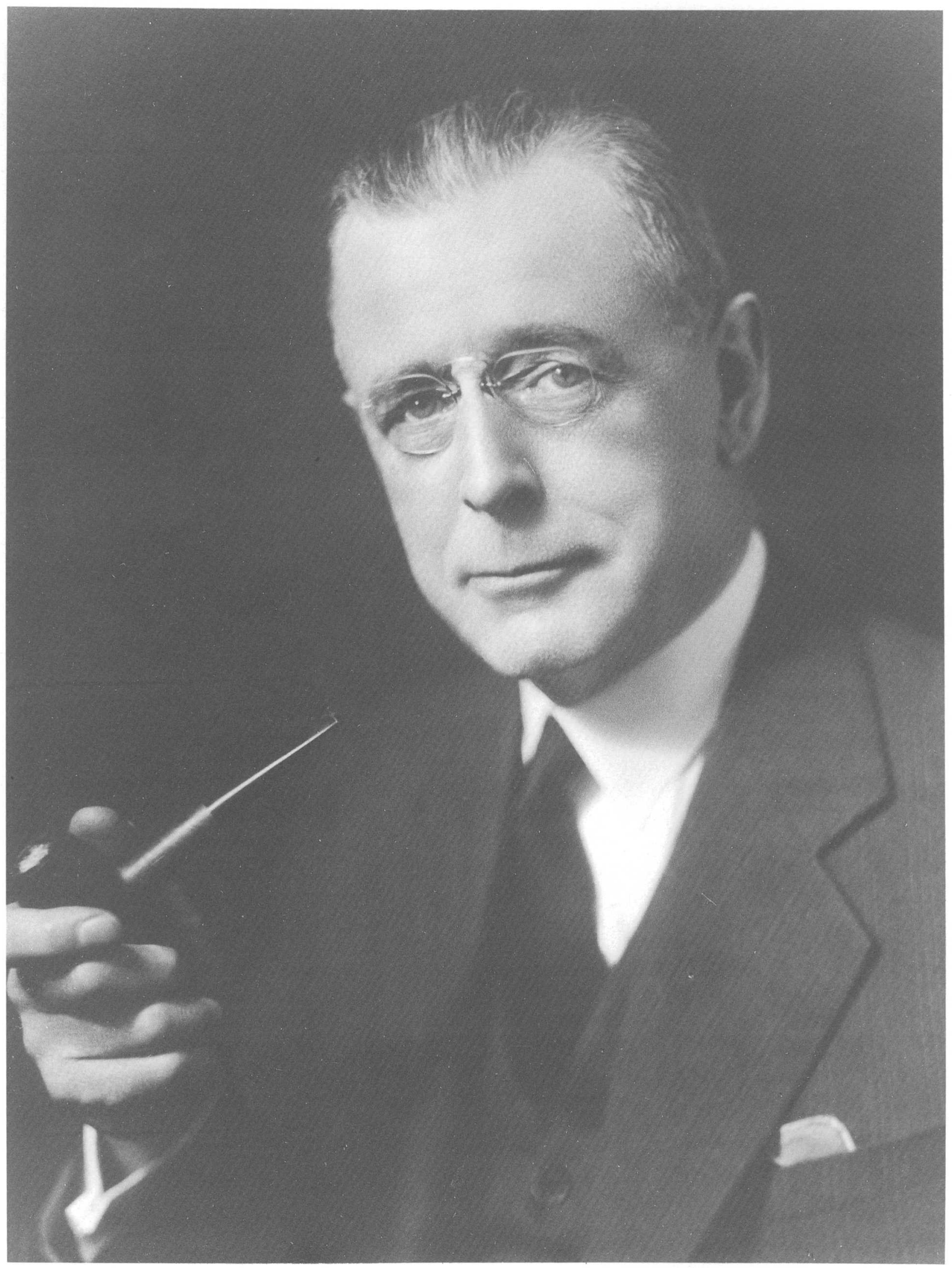

Marshall Ora Leighton

Chief Hydrographer 1906-13 
As long as there was enough water to serve all purposes, there had been no conflicts over its use and systematic information about it had not been necessary. Until conflicts developed, there had been no limitations or restraints on an individual who might encroach on the activities or rights of another in the use of water. The limitations on water were first felt in the arid West where irrigation was necessary. Powell, perhaps more than the other leaders of the early surveys, understood that information about the quantity of water available for use in irrigating that vast region. He, more than others, had the imagination to foresee the future of the West and the importance of water in its development. Powell was, therefore, active in obtaining funds for stream gaging, for surveying the lands, and for investigating other possibilities of irrigation. His ideas were, of course, not well developed in detail, but he was a pioneer blazing a trail in an uncharted and unknown field. Under these conditions, progress was necessarily difficult. Funds came slowly; there were no adequate instruments, equipment, methods, or techniques; and there were no engineers, geologists, or chemists who knew how to measure or study water. Nor did they appreciate the need for or the value of systematic records of the quantities of water in the ever-fluctuating surface streams or in the less rapidly fluctuating aquifers, or realize the important relation of the chemical quality of the water to its use.

A reality was gradually developed out of the Powell vision. F.H. Newell, more than all others, was responsible for converting Powell's concept of the necessity of a practical, going organization engaged in collecting reliable information. Unlike land, which remains in place, the equally essential and valuable water is always in motion and always changing in quantity and chemical quality. The methods and instruments of ordinary surveying were not applicable. Meters and gages for measuring, observing, and recording water data had to be devised, and methods for converting with accuracy the easily obtained records of stage into the more elusive records of discharge had to be developed. These things and many more were necessary before the recording of water data was practical.
F.H. Newell was not a man who worked out the details any more than Powell was. He evaluated needs, however, and organized his assistants to accomplish the desired results. He developed men by assigning tasks to them and holding them responsible for accomplishments. If they succeeded, they were given greater responsibilities; if they failed, they sought new jobs. He gradually brought together and used men of many and diverse talents, including first Babb, A.P. Davis, E.G. Paul, Matthes, J.C. Hoyt, R.E. Horton, Murphy, Stout, Fellows, Samuel Fortier, and Darton, among others. Somewhat later, Mendenhall, Leighton, Grover, Dole, William D. Collins, A.H. Horton, Robert Follansbee, M.L. Fuller, Veatch, Herman Stabler, Henshaw, Hanna, Hinderlider, H.K. Barrows, J.C. Stevens, Lamb, M.R. Hall, and Warren E. Hall were among others whose names continued for years to be associated prominently with the Branch. Working through these men and using their varied opinions and diverse abilities, F.H. Newell gradually brought order out of chaos.

F.H. Newell not only built an organization and directed its programs and policies, he also obtained the funds that were essential to its work. The going was rough and there were many trials and disappointments. From the failures, no less than from the successes, there finally was developed, however, a stable organization and a practical program of operation.

By 1906, stream gaging was nationwide, investigations of ground waters were being successfully conducted in both the East and West, Gilbert had begun his monumental work on the transporting capacity of flowing water, Slichter had pioneered in measuring the rate of motion of water through the ground, and Leighton had developed practical methods for analyzing water, had studied pollution and alkali, and was shaping his plans for studying the chemical quality of water relative to industrial and agricultural uses. By that time, the Price current meter had not only been developed in a form that gave reliable results over a wide range of velocities, it could be used by engineers, without assistance, when they were wading or working from a bridge, boat, or cable. Weights had been improved, staylines had been devised, 
the chain gage had been developed from the earlier wire gage, cables and suspended cars had been adopted, the wet cell and buzzer were being successfully used, and reliable clock-driven weekly gages had been built. Congressional authority had been obtained for the preparation of reports on the best methods of using the water resources, the limitation to 100 pages for WSP's had been removed, the complete yearly records of a gaging station had been compiled in one publication, and studies had been conducted of the essential accuracy of streamflow records. Murphy had investigated the reliability of the current meter, progress was being made in obtaining winter records, the organization of Districts was fairly complete, and cooperation with States had been started. This was a record of accomplishment that would be hard to equal in such a relatively short period.

Much remained to be done, of course, in the development of the organization and in instrumentation, equipment, and methods, but the groundwork had been soundly laid along many lines. The program of investigation of the country's water resources had thus been established on a basis that would support the growth of the country in future years. F.H. Newell felt, therefore, that he could leave to others the continuation of the important work he had started, and that he could devote his time and energies to the new and growing Reclamation Service. 


\section{Part IX-Early Years of the Water Resources BRANCH (1906-13)}

The period here considered began July 1, 1906, when Leighton became Chief Hydrographer, and ended June 3, 1913, when he resigned and was succeeded by Grover. During the years of the Hydrographic Branch, a long step forward had been taken by putting the general responsibility for stream gaging in the hands of men who devoted their entire time to it and who made it their sole interest. The field supervision in a large section of the country where water was then of the greatest importance, however, fell to the engineers of the Reclamation Service to whom stream gaging was a minor and uninteresting item in a crowded program of work. As a result, little attention was given to it and the field work was conducted more or less perfunctorily by young engineers who generally considered that work a stepping stone to other activities of the Reclamation Service. Thus, stream gaging in the West continued to be a stepchild.

In the 7 years from 1906 to 1913 , however, the separation of the Reclamation Service from other activities of the Branch resulted in the actual supervision and conduct of stream gaging in all parts of the country by personnel whose entire time and thought were given to it as the principal if not the only item of interest. It was a period in which rapid strides were made in improving techniques and accuracy of data, and may be considered, therefore, as the time when stream gaging came of age.

With enthusiastic personnel headed by an ambitious and optimistic chief, reduced appropriations were the only restrictions that prevented still greater advancement. It was a period of widespread interest in the conservation of natural resources, which brought additional State cooperation. A large part of Leighton's thoughts and energies were devoted at first to the prevention of further
Congressional cuts in annual appropriations and later to the restoration of the $\$ 200,000$ level attained during the previous period.

\section{Change in Name}

The reasons for changing the name of the Branch, which occurred soon after Leighton became chief, are interesting and important. Leighton felt that before he could convince the Congress that stream gaging was valuable and had the support of the people, it was necessary to publicize and popularize the work. One of the first moves was to change the name of the Branch from "Hydrographic" to "Water Resources," as Leighton himself states (written commun., ca. 1938):
There was a general insurgency against the high-hat designation that had hereto- fore been used. I had an idea that our work would be more fully appreciated if people could understand its character without resorting to a Latin dictionary or some similar aid of understanding. Mr. Walcott approved and in due course the Hydrographic Branch became the Water Resources Branch.

The official reason for changing the name was given by the Director as follows in the USGS 28th annual report (p. 3, 1907):

The change *** was made because the former did not correctly define the character of the work performed. The investigations are authorized by appropriations in successive sundry civil bills 'for gaging the streams and determining the water supply of the United States and for the investigations of underground currents and artesian wells and the preparation of reports upon the best methods of utilizing the water resources.' 


\section{General Organization}

When Leighton was put in charge of the Branch on July 1, 1906, he was appointed Acting Chief Hydrographer, which was changed to Chief Hydrographer (CH) February 1,1907 . This acting period was no more than the usual probationary period in civil service appointments-it was not F.H. Newell continuing some shadowy vestige of supervision-and Newell remarked when he turned the work over to Leighton (written commun., ca. 1938) that he was shedding the whole thing like an old coat.

Leighton's appointment as $\mathrm{CH}$ came as a surprise to most of the personnel of the Branch and, because his work had heretofore been concerned with the quality of water, the younger men in Washington, D.C., expected him to expand that phase of the work, possibly at the expense of stream gaging. They thought that at least the field work of water assays (the most obvious feature of the work and the only one known to the hydrographer) would be combined with that of stream gaging. They had visions of being burdened with "field kits" for assaying in addition to the regular equipment for stream gaging. In those days, when travel was chiefly by train, any considerable increase in equipment was not to be thought of lightly. But, like many worries in life, that one never materialized and no extreme changes in the routine field work of stream gaging followed.

Grover continued as Assistant Chief Hydrographer (ACH) until April 1, 1907, when he resigned to enter engineering practice outside the Government service. He was succeeded by J.C. Hoyt.

The Division of Hydro-Economics also shed its "high-hat" name and, with curtailed functions, became the Quality of Water Division, a term that was more readily understood. Dole was in charge. Similarly, the Division of Hydrology became the Ground Water Division with M.L. Fuller in charge until he resigned in 1907.

By 1911 , the increased field work required by the investigation of water-power sites and rights-of-way for the recently created Land Classification Board necessitated the creation of a Division of Water Utilization. At that time,
J.C. Hoyt's designation changed from ACH to Engineer in Charge, Division of Surface Waters. Mendenhall, who had succeeded M.L. Fuller, continued in charge of the Division of Ground Water, and Leighton took charge of the newly created Water Utilization Division. These assignments were effective during the last 2 years (1912-13) of the present period.

\section{Washington Office}

The reduction in the appropriations beginning July 1, 1906, made a reduction in the Washington, D.C., office force necessary. In June 1906, Murphy transferred to the debris investigation that was being started at Berkeley, Calif., and Henshaw transferred to the Alaskan work. In August 1906, the writer was put in charge of the Montana District and, in spring 1907 , Steward transferred to the California District. With the transfer of Murphy to Berkeley, the inspection of gaging stations was taken over by J.C. Hoyt in connection with his periodic visits to the districts as chief of the Surface Waters Division.

When J.C. Hoyt was appointed ACH in 1907, Bolster succeeded him as chief of the computing section and had Padgett and Marion Walters as regular assistants. Walters took over Steward's work of rating meters and handling equipment, having previously been his assistant. In 1908, G.C. Stevens joined the USGS and was temporarily attached to the computing section pending an expected assignment to the field. But, as the expected assignment never materialized, G.C. Stevens became a fixture in the Washington, D.C., office and succeeded Bolster as chief of the computing section when the latter resigned on August 31, 1912. Other regular members of the section for different lengths of time were J.G. Mathers, R.C. Rice, Henry J. Dean, and H.J. Jackson. In addition, C.E. Ellsworth was a part-time member of the section from 1908 to the end of the period, spending the summers in Alaska and the winters in Washington, D.C. Henshaw similarly divided his time between Alaska and Washington, D.C., from 1906 to 1910 when he was in charge of the Columbia River District. Willis E. Hall, who had joined the USGS in 1904, was the chief clerk of the Branch. 
The work of the computing section increased and broadened during the years beginning with 1908 as the activities caused by the conservation movement required surveys and computations incidental to several lines of investigations inaugurated by Leighton. There was much burning of midnight oil and desecration of the Sabbath in connection with some of these investigations in which time was an essential factor.

By 1911, the increases in State cooperation (without corresponding increases in USGS funds) had caused the work of the Branch to expand considerably. This expansion threw a heavier administrative and technical burden on the Washington, D.C., office and, in May of that year, the practice began of collecting a surcharge from each District funding allotment for the Washington, D.C., office. The surcharge at that time was 12.5 percent of the combined State and USGS allotments, per instructions issued May 18, 1911.

\section{FIELD}

When F.H. Newell resigned as $\mathrm{CH}$, he retained the title of Chief Engineer of the Reclamation Service and thereafter devoted his energies to that organization. With stream gaging and reclamation activities now separated, the unity of the field organization in the Western States ceased. Previously, Reclamation Service engineers had supervised the stream gaging in their States, but early in this period-the exact time differed among the different Statesdistrict hydrographers (whose designations were soon changed to district engineers) were appointed and made directly responsible to the $\mathrm{CH}$. This change in organization did not involve a change in personnel in most instances because those engineers selected had actually been in charge of stream gaging under the more or less nominal supervision of Reclamation Service engineers.

The Branch organization now consisted of young men, and the district engineers were rated as assistant engineers when they were put in charge of the districts; they advanced to the grade of hydraulic engineer in due time. The creation of the USGS organization in the West and the cutbacks in the East resulted in many changes in field personnel, during which the square pegs were more or less successfully separated from the round holes.

Just as the earlier tendency in the Eastern States had been to increase the size of the District with the employment of full-time hydrographers, so now the tendency in the West was to consolidate the work into relatively large districts. The reduction in appropriations, however, required the curtailment of Branch activities. Instead of making uniform reductions in all parts of the country, the needs of each section were studied and the work reduced or discontinued where it appeared to be least important (USGS 28th ann. rept., p. 3, 1907). The greatest reductions occurred in the upper Mississippi Valley States and in Texas, but all sections were affected, particularly when the appropriation was reduced to $\$ 100,000$ for fiscal years 1908 through 1910. Later, the field work required by the Land Classification Board and the increase in State cooperation resulted in the creation of new districts, notably in the Western States and Hawaii.

The reduced scale on which the Branch was forced to operate during the early years of the period prior to the increase in State cooperation had a disheartening effect on the personnel. To offset this as far as possible, Leighton adopted the policy of continuing regular promotions, stating that the personnel should not suffer because of reductions in funds. Thus he kept the organization substantially intact, with the everpresent hope of getting the $\$ 200,000$ appropriation restored.

The increase in the size of the districts threw so much additional work on the office staffs that it became necessary, in the larger ones, to have office engineers who would devote the greater part of their time and energies to keeping up the office end of the work. Apparently, the need for an office engineer was first definitely recognized in 1910: soon after the reestablishment of the office in Albany, N.Y., the work in the New England States was turned over to it and Covert (written commun., ca. 1938), the district engineer, requested the assignment of an experienced engineer as office engineer. Although the request was approved, for some reason-perhaps because 
no experienced engineer was available-no assignment was made. At the conference in January 1911, Covert explained at some length the value of an office engineer to a district. The other district engineers were interested, and the ensuing discussion showed the conferees to be in hearty sympathy with the idea. As a result of this discussion, the following instructions were issued on May 13, 1911:

During the coming year, it is desired to bring the technical and administrative office work in the various offices upon a uniform basis. By this, it is believed that both the standard of efficiency of our work will be greatly increased and most duplications eliminated. In order to carry out the proposed change, it will be necessary for each district office to have an office engineer and a general clerk.

At the beginning of the fiscal year, July 1, 1911, Glenn A. Gray in Colorado, Rice in California, and E.S. Fuller in Oregon-Washington were appointed office engineers. Later, office engineers were appointed in other districts as the needs arose and funds were available to pay the additional salaries. As the office engineers were generally more experienced than the field men, they became the first assistants to the district engineers. The number of field men, usually junior engineers and field assistants, depended on the size of the District, the character of the streams, the accessibility of the stations, and, especially, the funds available.

In January 1913, a request from the Branch for a special examination for junior engineers with an entrance salary of $\$ 1,080$ contained the requirement that each applicant should be a graduate of a recognized college of engineering or a candidate for a degree in civil engineering at the coming commencement. There had been no such requirement previously.

\section{Further Opposition to the Stream- Gaging Appropriation Item}

The failure of the Organic Act of the USGS to mention water specifically had subjected the item for stream gaging to the hazards of a point of order, so the obvious plan was to amend the
Organic Act and thus strengthen that weak spot. Leighton attempted to do this in 1907 and had a bill introduced in the Congress for that purpose. This bill was referred to the Rivers and Harbors Committee of the House where it died, chiefly because of the opposition of the Chief of Engineers, U.S. Army. A second attempt in 1908 met with the same result.

Not satisfied with reducing the stream-gaging appropriation from $\$ 200,000$ to $\$ 150,000$ for fiscal year 1907, and perhaps resentful that the Senate prevented its elimination entirely, Tawney, the chairman of the powerful House Committee on Appropriations, renewed his efforts in 1908 and succeeded in eliminating the stream gaging item from the Sundry Civil Bill that was reported to the House. Leighton was not idle. He devoted a large part of his time to contacts with members of the House in order to find someone who would carry the fight for the appropriation for stream gaging to the floor of the House-the only means by which the matter could be brought before that body for a vote. He succeeded at last in finding a member who was willing to take the lead in supporting the item. This was James Needham of Modesto, Calif., who came from a region where the value of stream gaging was well recognized.

The plan of campaign was that, when the USGS items were reached in the Sundry Civil Bill, Needham was to offer two amendments. The first was an item of $\$ 200,000$ for stream gaging that was to be offered with the expectation that Tawney would raise a point of order against it that would be sustained. The second amendment quoted the Organic Act of the USGS in which mineral resources were specified, and proposed an item of $\$ 200,000$ for an investigation of the mineral resources. To prepare the proper setting for Needham's effort, Leighton obtained a supply of Needham's stationery and on it wrote, for Needham's signature, letters to all members of the House except those known to be hostile, urging them to support the proposed amendments.

On the day when the USGS items in the Sundry Civil Bill were reached, most of the members who had received Needham's letter were in attendance. When he presented his first amendment, it went out on a point of order as had been anticipated. The second amendment 
was then offered and Tawney raised a point of order against it. This, however, was not sustained because the chair (Congressman Watson) ruled that it was not subject to a point of order. Needham, speaking in support of his amendment, stated that because water was a mineral, there was nothing to prevent the Director of the USGS from using the entire amount proposed $(\$ 200,000)$ for water resources, if he so desired. Tawney argued with Needham in an effort to have him withdraw his amendment, which was so obviously a subterfuge, and finally offered to allow $\$ 100,000$ for stream gaging in return for that action. Needham replied that if Tawney would promise to refrain from raising the point of order against that item in the future and would bring in a rule preventing his successors from doing so, he would withdraw his amendment. This was done, an appropriation of $\$ 100,000$ was made by the House, and that amount was carried in the Sundry Civil Act for 1908 (Leighton, written commun., ca. 1938). That was the last time the point of order was raised against the stream gaging appropriation and the House later adopted a rule that appropriations for work in progress were not subject to points of order.

Leighton had won his fight against the point of order but still had a long struggle on his hands because Tawney consistently opposed an increase in the appropriation and was successful in his efforts during the next 2 years. Leighton was limited in his further efforts by the attitude of the new Director. In May 1907, George Otis Smith became Director of the USGS and he at once prohibited Branch chiefs from lobbying for their particular appropriations. He thus hoped to allay the hostile attitude of the Congress. Because of the new policy, Leighton was unable to gain the support in the Senate. He continued his efforts to win support, however, and succeeded in obtaining an increase to $\$ 150,000$ for fiscal year 1911. This amount was appropriated each year during the remainder of this period.

One example of efforts to increase appropriations came to the author's attention in 1910 while he was in charge of the work in Minnesota, which was Tawney's State. When cooperation was arranged with Minnesota officials, they were told that because of Tawney's influence, the stream-gaging appropriation was so small that the USGS could not cooperate on a 50-50 basis.
Thereupon, State officials stated that they would do anything they could to overcome Tawney's opposition the next year. When the next year came, although Tawney had allowed an increase to $\$ 150,000$ for that year (and although the author was not privileged to look behind the scenes to know what steps were taken), it is recorded that Tawney was defeated for reelection. It is probable that the increase in funds for 1911 was the result of pressure brought by cooperating State officials from many States to obtain a more equitable division between Federal and State funds.

It may not be out of place to record that after Tawney's term of office expired in 1911, he was given a lame duck appointment to the International Joint Commission where he served until his death in 1919. That commission deals with the boundary waters between the United States and Canada, and Tawney came to appreciate of the value of streamflow records. At one time, he was incensed at the lack of necessary records and blamed the USGS for failing to obtain them. Leighton (oral commun., ca. 1938) took great pleasure in reminding him that it was his hostile attitude toward the USGS streamgaging appropriation that had prevented those records from being obtained. The experience gained during his term on the Commission, which showed the absolute necessity for such records, led Tawney to state that he had come to consider his opposition to the stream gaging items for the USGS as his major mistake as a Representative in the Congress (Grover, oral commun., ca. 1938).

Through Leighton's active participation in the work of the Inland Waterways Commission to which he was attached as advisory hydrographer (USGS 29th ann. rept., p. 72, 1908), he made contacts with influential men who were interested in rivers. It may be readily surmised that he missed no opportunity to preach the doctrine of increased appropriations for stream gaging.

Relative to Leighton's fight against the point of order raised by Tawney, it may not be out of place to present the following verses from the pen of G.M. Wood, USGS editor, which were inspired by that incident.

\footnotetext{
"Nature and Occurrence:

Water is wet and runs downhill; its gravity is 1 ;

The steeper the slope, the faster it'll run.
} 
In every puddle, pond and lake, in every stream it's found;

A lot of it is in the sea and some is under ground.

"Quality:

Water is a mineral, as everyone should know,

And chemists long ago found that it's chiefly $\mathrm{H}_{2} \mathrm{O}$.

But with this $\mathrm{H}_{2} \mathrm{O}$ is mixed a lot of other brew,

Some animal, some mineral, and some vegetable too;

And what we hydrologic sharps are doing every minute,

Is bottling up some watery slop and finding what is in it.

And having found what's in it we next attempt to say,

The why and wherefore of the thing, in an elemental way;

For water's made of elements and it's not incidental

That all we write about it should be strictly elemental.

"Uses:

Water is used for many things, by many people too;

Some use it to drink and some wash in it-a few.

It's also used in other ways-in sewers and in stews,

In paper mills and breweries, which furnish us our cues;

But most of all it's useful in enabling us to say

What we can tell about it in an elemental way."

-W.R. BRANCH

All About W Wter.

\section{Conservation Movement}

The interest in the conservation of natural resources became so widespread during the present period and had so much influence on the increase in appropriations for stream gaging, not only by the Congress but also by the States, that its origin will be sketched briefly.

The passage of the Reclamation Act in 1902 was a movement toward conservation, but that term was not generally applied and the word "conservation" as applicable to natural resources did not come into use until several years later. The germ of the conservation idea appears to have been planted in the public's mind in 1903 when President Theodore Roosevelt, in an address before the Society of American Foresters, clearly presented his opinion that forests had a definite value in preventing floods. Here the matter rested until 1907 when the President, in creating the Inland Waterways Commission, said:

It is becoming clear that our streams should be considered a great natural resource. The time has come for merging of local projects and uses of the inland waters in a comprehensive plan designed for the profit of the entire country. It is not possible to properly frame so large a plan without taking account of the orderly development of the natural resources.

Again, on June 10, 1907, before an assembly of newspaper editors, President Roosevelt said:

The conservation of all our natural resources and their proper use constitutes the fundamental problem which underlies almost every other problem of our natural life. Unless we maintain an adequate material basis for our civilization, we cannot maintain the institutions in which we take so great and just pride, and to waste and destroy our natural resources means to undermine these natural bases. So much for what we are trying to do in utilizing our public lands [is] for the public; in securing the use of the water, for forage, the coal, and the timber for the public. In all four movements, my chief advisor and the man first to suggest to me the courses which have actually proved so beneficial, was $\mathrm{Mr}$. Gifford Pinchot, the Chief of the National Forest Service. Mr. Pinchot also suggested to me a movement supplementary to all these movements; one which will itself lead the way in the general movement which he represents and with which he is actively identified, for the conservation of all our natural resources. This was the appointment of the Inland Waterways Commission.

During an inspection trip over the Great Lakes from Cleveland, Ohio, to Duluth, Minn., thence down the Mississippi River from 
St. Paul, Minn., to Memphis, Tenn., in May 1907 , members of the Inland Waterways Commission repeatedly discussed the policy of conservation and its bearings on general plans for waterways improvement. The President joined the party at Keokuk, Iowa, and, as might be expected, took a lively interest in the discussion. As a result, it was decided to hold a conference in Washington, D.C., during the ensuing winter to discuss the conservation of the country's resources. Roosevelt, with characteristic enthusiasm, welcomed the idea and, to give it the widest publicity and the greatest possible weight, decided on a conference of Governors, to which was invited the Governor of each State and three citizen advisors. Not overlooking perhaps the most important factor in practical conservation, the members of the Congress were also invited. This conference was held at the White House, May 13-15, 1908.

The Governors in attendance unanimously adopted a declaration (Proceedings, Governor's conf., 1908) that stressed the necessity for more careful conservation of the natural resources, and recommended more effective cooperation among the States and between the States and the Federal Government. They also recommended that State commissions be appointed to cooperate with a Federal commission. In accordance with the latter recommendation, Roosevelt on June 8, 1908, appointed a National Conservation Commission to study the problem and make a report that could be presented to the Congress at its next session (Rept. of Nat. Cons. Comm., S. Doc. 676, 60th Cong., 2d sess., p. 115).

As a result of the recommendations in the National Conservation Commission's report, the Congress in March 1909 created the National Waterways Commission, which was composed of Senators and Representatives. Many Governors appointed State commissions. There was so much interest in the conservation movement, which took different forms in different States, that in many instances the next sessions of the State Legislatures appropriated funds for the investigation of water resources. As a result, there was a considerable increase in State cooperation beginning in 1909. In addition, cooperation of a more or less temporary nature was arranged with the Forest Service as a direct result of the conservation movement.
Not only did the conservation movement arouse the interest of the States possibly for further water-resources development, but also in the control of such development, particularly with reference to water power. New York, California, Wisconsin, and Oregon enacted laws providing for such control, and Maine and Minnesota attempted to do so but failed. The Federal Government took further steps to control water power in the public domain. To further the cause of governmental control, either State or Federal, Leighton embodied in WSP 238 (1910) an address in 1908 before the National Irrigation Congress at Albuquerque, N. Mex., by the chief engineer of the French Department of Public Works on the public utility of water powers and their governmental regulation with special reference to France and Switzerland. Thus the term conservation became so popular and was used so frequently by the man in the street, sometimes without his realizing its meaning, that it became almost a byword.

\section{Cooperation}

During this period, cooperation with States and other Federal agencies came to play an important part in the maintanance and expansion of the stream-gaging program. The increase in cooperation more than offset the reduction in USGS appropriations, which reached a low of $\$ 100,000$ over a 3 -year period. The States that were most interested in water-resources investigations were the principal cooperators. The Reclamation Service, the Forest Service, and to a limited extent the Indian Service were the cooperating Federal agencies. Use was made of Weather Bureau stations at which records of gage height were furnished gratis, and private interests contributed to the cost of maintaining individual stations.

\section{STATES}

State cooperation increased greatly during this period as shown by the following annual amounts:

$\begin{array}{rrrr}1907 & \$ 20,000 & 1911 & \$ 60,740 \\ 1908 & 24,400 & 1912 & 94,396 \\ 1909 & 40,232 & 1913 & 108,594 \\ 1910 & 53,906 & & \end{array}$


The influence of the conservation movement on cooperation is evidenced by the funding increases in the years following the Conference of Governors. Not only did additional States make appropriations for stream gaging, but States previously cooperating increased their appropriations appreciably. Only three States discontinued cooperation.

In general, cooperation was conducted under agreements that provided that the work to be undertaken should be mutually agreed on and that it should be supervised by the USGS engineer of the District concerned. Generally, the work was actually conducted by the USGS personnel and State funds were used to pay a part of the cost. One exception was in Nebraska where the State's share of the cooperation was represented by the cost of the cooperative work conducted by regular State employees.

The State funds were usually derived from specific appropriations, made by the legislature to the proper State agency, for water-resources investigations, although during the earlier years of this period, State agencies allotted general funds at their disposal to the cooperative work. Most of the specific appropriations were made with reference to cooperation with the USGS. Some were available only for such cooperation, some on a 50-50 basis, and others merely authorized the State officials concerned to cooperate with the United States. The details of cooperation in each State follow.

MAINE.-Cooperation in Maine started in the previous period with the State Survey Commission and continued during the present period until 1911. The amount of State funds allotted annually ranged from $\$ 3,200$ to $\$ 3,500$.

In 1909 , the sentiment for conservation of the water resources led the legislature to create the State Water Storage Commission to collect information relative to the water powers of the State (Laws of Maine, 1909, ch. 212). The Commission was instructed to work in cooperation with the State Survey Commission and the USGS.

The two State commissions signed a 13-month agreement with the USGS on December 1, 1909, which provided that an employee of the USGS would be in charge of the hydrographic work. Under this agreement, the USGS allotted $\$ 3,000$ for water-resources investigations, and each of the two State commissions allotted practically an equal amount (or two State for one Federal dollar, that being the best arrangement the State could make). But the agreement contained the proviso that if the USGS recommendation for an increase of $\$ 100,000$ in the stream gaging item for the next fiscal year, 1911, be followed, the USGS would allot an additional $\$ 3,000$ (First ann. rept., State Water Stor. Comm., 1910, p. 12).

At the next session, in 1911, the legislature, in an economical mood, consolidated the State Survey Commission with the Water Storage Commission and reduced the appropriation for the next 2 years. Consequently, the State and the USGS each allotted $\$ 1,350$ for 1911 (Second ann. rept., State Water Stor. Comm., 1911, p. 17). The reduction in the allotment made it necessary for the district engineer, Babb, to resign from the USGS, which could not pay his salary, and he was appointed chief engineer of the State Commission (Babb, written commun., ca. 1938). As such, he continued to supervise the stream gaging. State cooperation virtually ceased in 1911 because of lack of funds.

During the 1913 session of the legislature, the chief engineer of the Water Storage Commission sponsored a bill requiring State control of water-power and water-storage companies under license fee. This aroused the waterpower interests affected and, as a result of the changes made in the personnel of the Commission during that year, the chief engineer lost his former supporters and soon found himself out in the cold. During the next 2 years, the USGS discontinued its stream gaging in Maine and the Commission conducted the work.

VERMONT.-As the time seemed to be ripe for considering Vermont's water resources, H.K. Barrows brought the matter of cooperation to the attention of the Governor in fall 1908, and later appeared before the legislature in support of it (Barrows, written commun., ca. 1938). As a result, the legislature in December 1908 made the following provision for State cooperation (Laws of Vermont, 1908, Public Act 215):

It is hereby enacted by the General Assembly of the State of Vermont:

SECTION 1. The Director of the United States Geological Survey being authorized to cooperate with the properly 
constituted authorities in the several States in making investigations of and reports upon the water resources of the States, the Governor is hereby empowered to enter into contract with the Director of the United States Geological Survey for the purpose of making such investigation and report for this State, Provided That such work shall include, first, the completion of the surveys of river basins already partially investigated; and Provided further, That the Director shall agree to expend for this purpose, and from funds placed at his disposal by the Government of the United States, sums equal to those hereinafter appropriated.

SEC. 2. For the purposes set forth in the preceding section, the sum of one thousand dollars for the year 1909, and a like sum for the year 1910, is hereby appropriated to be expended by the State, in accordance with the laws relating to, and the regulations of, the United States Geological Survey in such cases, Provided payment to be made on vouchers audited and approved by the Director of said survey, when presented to the auditor of accounts.

Similar bills were enacted biennially throughout the period whereby Vermont contributed $\$ 1,000$ annually on a 50-50 basis. The bill passed in 1912 increased the appropriation to $\$ 1,200$; during 1913 , only $\$ 1,000$ was contributed. Cooperation was through the State geologist.

MASSACHUSETTS.-Because use of water power was the outstanding phase of water-resources conservation in Massachusetts, the conservation movement took the form of an appropriation in 1909 for an investigation of the State's waterpower resources. The first two sections of the appropriation act are as follows (Acts and Resolves of Massachusetts, 1909, ch. 359):

Section 1. The sum of five thousand dollars may be expended for the determination of the amount of water power available on the streams of the Commonwealth and for investigating the best methods of utilizing the same, thereby providing for the people of the Commonwealth information that may serve to further industrial development.
SEC. 2. The Governor is hereby empowered to enter into a contract with the Director of the United States Geological Survey for the purpose of making the investigation aforesaid: Provided, That said Director shall agree to expend a like sum of money within the Commonwealth for the same purposes; and Provided further, That, if said Director should find that, by reason of the failure of the Congress of the United States to. provide a general appropriation sufficient to enable him to make an allotment of five thousand dollars for such work in this Commonwealth, the Governor may execute a contract for any part of the amount hereby appropriated, which part shall be equal to that allotted by the Director.

The requirement of equal expenditure limited the allotments for 1908 to $\$ 1,050$ because the USGS was unable to allot a larger amount. The amount in 1910 was the same, but was reduced to $\$ 825$ in 1911 .

In 1911, the legislature extended the availability of the 1909 appropriation by providing that the unexpended balance could be used to complete the determination of the amount of water power available in the streams of the Commonwealth. This unexpended balance was about $\$ 1,000$ and the 1912 cooperation provided for that amount.

During the 1912 session of the legislature, H.K. Barrows, who had resigned from the USGS and was in private engineering practice, was interested in having State cooperation continue. He wrote to the Governor's secretary requesting a report on the prospect of such continuance and urging such action. The Governor sent H.K. Barrows' letter to the legislature as a special message advocating State cooperation. As a result, the legislature appropriated $\$ 3,000$ annually for a period of 4 years. In this act (Laws and Resolves of Massachusetts, 1912, ch. 564), the Governor was authorized at his discretion to cooperate with the USGS, but the 50-50 clause, which had restricted the amount of cooperation in previous years, was omitted. The full amount of $\$ 3,000$ was contributed by the State during 1913.

NEW YORK.-Cooperation with the State engineer and surveyor of New York, started in 
1900 , continued during this period with an annual contribution of $\$ 1,500$. In 1905 , the legislature created the State Water Supply Commission to maintain equity among the municipalities of the State in sources for public water supplies, and to determine the public necessity for additional water supplies (Fourth ann. rept., State Water Supply Comm., p. 11, 1909). The River Improvement Commission was discontinued in 1906 and its powers and duties were transferred to the State Water Supply Commission. These duties, which were to prepare preliminary plans and surveys for the regulation of any stream of which the unregulated flow was a menace to public health and safety, necessitated additional streamflow records and, beginning September 1, 1907, the Commission paid gage observers at five USGS stations in the upper Hudson River basin. In 1908, an allotment of $\$ 1,950$ was made to the USGS, which increased to $\$ 2,700$ in 1909 and to $\$ 3,500$ in 1910 (A.W. Harrington, oral commun., ca. 1938). In 1910, the last year of the Water Supply Commission's existence, Covert, then district engineer, convinced the chief engineer of the Commission that, because stream gaging was of more immediate importance to the State than to the Federal Government, the State should provide the increased funds that were needed. Accordingly, a special item of $\$ 10,000$ was added to the appropriations bill and, after many conferences with the Governor and other interested parties, the appropriation was made.

The conservation of natural resources had appealed so strongly to the citizens of the Empire State that, in 1911, the legislature enacted the "Conservation Law" (Laws of 1911 , ch. 647) that created the Conservation Commission. There was virtually no opposition to this legislation because, according to the Commission (First ann. rept., Cons. Comm., p. 5, 1911), "The time was ripe, the press and public were ready. When Gov. Dix affixed his signature to the proposed legislation 'as a first and long step toward true conservation,' he but voiced the general hope and expectations."

The Conservation Commission succeeded the Water Supply Commission because it was the intent of the conservation law to bring under one head all duties and problems related to the administration of the forests and streams and the fish and game, and to give a powerful impetus to the conservation of the State's natural resources (First ann. rept., Cons. Comm., p. 5, 1911). The Conservation Commission continued the annual contribution of $\$ 10,000$ begun by its predecessor. The State cooperated during this period in following amounts:

$\begin{array}{rrrr}1907 & \$ 1,500 & 1911 & \$ 11,500 \\ 1908 & 3,450 & 1912 & 11,500 \\ 1909 & 4,200 & 1913 & 11,500 \\ 1910 & 5,000 & & \end{array}$

The USGS allotted $\$ 1,500$ in 1907 ; nothing in 1908 ; $\$ 2,000$ in 1909 ; and $\$ 2,500$ annually from 1910 to 1912 . The USGS allotment in 1913 is not now known.

Cooperation with the State engineer and surveyor was confined chiefly to those streams which furnished water for the Barge Canal. Cooperation with the Water Supply Commission and its successor covered all other sections of the State.

NORTH CAROLINA.-Cooperation with the State geologist of North Carolina, which was started in 1895, continued until December 31, 1909, and consisted of paying the gage observers at 12 stations about $\$ 450$ annually. No funds were provided by the State Legislature subsequent to 1909.

TENNESSEE.-The State Legislature of Tennessee, imbued with the idea of conservation of water power, adopted in 1911 a resolution directing the State geologist to conduct a full and careful investigation of the water-power resources of the State. The resolution as introduced carried an appropriation of $\$ 15,000$, but the clause containing the appropriation was lost. The State geologist tried, however, to comply so far as possible with the resolution and spent about $\$ 500$ for that purpose (Tennessee State Geol. Survey Bull. 17, p. 5, 1914).

It was decided to use this small amount in obtaining the information for a single river, which would be an example of what might have been accomplished in the State if the contemplated appropriation of $\$ 15,000$ had actually been made (Bull. 17, p. 81, 1914). Therefore, a 1-year contract with the USGS was prepared 
in November 1911 providing for an investigation of the water-power possibilities of the Doe River, which included a survey of the river and the establishment of three gaging stations. The work was conducted by the USGS and expenses were shared equally. The State's share was $\$ 717.97$.

MARYLAND, GEORGIA, AND ALABAMA.-Cooperation in Maryland, Georgia, and Alabama was limited to the State payment of gage observers. The Maryland Geological Survey and later the Maryland State Weather Service paid a few gage observer's salaries until 1910. The State geologists of Georgia and Alabama each paid gage observer's salaries in the amount of about $\$ 200$ annually during the entire period.

ILIINOIS.-In 1907, the legislature of Illinois created the Internal Improvement Commission, in part to study how to protect land along many of the rivers from being flooded. This study required records of streamflow, especially at flood stages. Such records were lacking, and Isham Randolph, chairman of the Commission, called on the USGS for assistance. Because 1907 was within the period of the lowest streamgaging appropriations from the Congress, the only cooperation that the USGS could offer was trained personnel whose salaries and expenses were to be paid by the Commission. The Commission accepted cooperation on this basis, and work was started in January 1908. Cooperation with the International Improvement Commission and its successor, the Rivers and Lakes Commission created in 1911, continued nearly to the end of the period. Beginning in 1910, the USGS made small annual allotments for the Illinois work. The amount contributed by the State during the first half of 1908 is not now known, but $\$ 1,000$ was contributed for fiscal year $1908, \$ 2,000$ for $1910, \$ 3,000$ for 1911 , and $\$ 2,200$ for 1912 . Cooperation was discontinued on September 30, 1912, when the Rivers and Lakes Commission had no funds to allot to the work.

MINNESOTA.-The State of Minnesota was at this time draining its extensive swamplands and was extremely receptive to the idea of conservation of natural resources. Its legislature, therefore, adopted on April 20, 1909, Joint Resolution 19, as follows (p. 11):

Whereas, the water supplies, water power, navigation of our rivers, drainage of our lands, and the sanitary conditions of our streams and their watersheds, generally form one great asset and present one great problem; therefore, be it Resolved by the House of Representatives (the Senate Concurring), That the State Drainage Commission be and is herebydirected to investigate progress in other States toward the solution of said problem in such States, to investigate and determine the nature of said problem in this State, to formulate a general plan for State supervision and control over its waters and all matters pertaining thereto and to report its findings and recommendations to the Governor on or before January 1, 1911, of which report 500 copies shall be printed.

Following the passage of the resolution, the State Drainage Commission authorized G.A. Ralph, its chief engineer, to investigate the possibility of enlisting the cooperation of some branch of the Federal Government in that investigation. After visiting Washington and interviewing Leighton, Ralph decided that the USGS was the organization he was seeking. Although the legislative act provided no appropriation, the Commission had funds that were available for the investigation and, on May 15, 1909 , signed a contract providing for a comprehensive investigation of the State's water resources, including river and reservoir surveys, and contributed $\$ 12,500$ to the USGS $\$ 2,750$ that would be available during the fiscal year beginning July 1 .

To equalize the contributions as nearly as possible, however, the contract provided that for the succeeding fiscal year, 1911, the USGS would contribute not less than $\$ 2,750$ and as much more as possible. The contract also contained the statement that it was understood that the USGS would in subsequent years when funds were available make allotments that would eventually equal the contributions made by the State (Rept. of the Water Res. Inv. of Minnesota, 1909-10, State Drainage Comm., p. 15, 1910). The State not only spent the $\$ 12,000$ called for in the contract, the amount was 
increased to $\$ 16,216.12$ in the first 15 months of the cooperation. The increase in the USGS appropriation made it possible to allot $\$ 6,000$ in 1911 instead of the aforementioned $\$ 2,750$.

The Drainage Commission, through its chief engineer, recommended to the 1911 session of the legislature an annual appropriation of $\$ 15,000$ for continuing the investigations. That official was, however, persona non grata with the legislature at the time, and any recommendation he made was looked on with disfavor. The Commission itself, an ex officio body composed of State officials, assumed an aloof attitude. Therefore, the author, acting through friends who were interested in the State's water resources, prevailed on the legislature to make an appropriation for both water-resources investigations and topographic mapping in the amount of $\$ 25,000$ for each of the years ending July 31,1912 , and July 31,1913 . Of these amounts, $\$ 11,210$ (1912) and $\$ 9,500$ (1913) were allotted for the water-resources investigations (E.V. Willard, written commun., June $28,1923)$. During the period, the total allotment of USGS funds for use in Minnesota was slightly more than $\$ 20,000$.

NORTH DAKOTA-Although no formal cooperative agreement was made, the State engineer of North Dakota, at the personal request of E.F. Chandler, began to pay gage observer's salaries in July 1906. The amount was $\$ 400$ annually. In addition, the State engineer later paid for minor equipment and for the field expenses of E.F. Chandler and his student assistants. During the worst years of the Branch depression, 1908-10, some or many of the stations were maintained entirely at State expense, the field work being conducted by assistants of the State engineer with one or two supervisory trips annually by E.F. Chandler. It is not possible to make an exact statement of the State expenditures because the records were destroyed when the State Capitol burned in December 1930. An estimate places the expenditures during this period at $\$ 1,500$ that, with $\$ 2,400$ for gage observers, makes a total of $\$ 3,900$, or an average of about $\$ 650$ per year (E.F. Chandler, written commun., ca. 1938).

NEBRASKA-The cooperation in Nebraska was somewhat different from that in any other State.
The State Board of Irrigation had a number of employees, chiefly for administering its water rights, who measured the ditches and smaller streams. In the previous period, these employees had maintained cooperative river stations under the direction of the State engineer who was also the USGS resident hydrographer. With the reduction in appropriation, the USGS could no longer pay the cost of stream gaging, and entered into a contract with the State Board of Irrigation (the State engineer was secretary) that provided for equal expenditures by the two parties. The unusual feature of the cooperation was the contribution of the greater part of the State's share in the form of the cooperative work conducted by regular State employees (Seventh bienn. rept., State Board of Irr., 1907-8, p. 11). Although this cooperative arrangement was theoretically in effect during the entire period, the USGS share was gradually reduced because of lack of funds to cover the cost of computing the records of the stations maintained by the State engineer.

MONTANA-When the stream-gaging appropriation was reduced in 1906 , Grover wrote to the State engineer of Montana suggesting the possibility of cooperation. One of the duties of the State engineer was to cooperate as far as possible with the USGS, so this suggestion was favorably received. In September 1906, he accompanied Grover and the author on a reconnaissance trip over the Flathead Indian Reservation where virtually no stream-gaging studies had been conducted in the past. The area was soon to be opened to entry and its irrigation possibilities were important. Seven gaging stations were established on the basis that the expenses were to be borne "mutually" (the expression used on page 40 in the State engineer's report for 1905-6). The State's share of the cooperation during that fall was $\$ 156.80$ and paid for the author's field expenses. During 1907 and 1908, the basis of cooperation was that the State would pay observer's salaries at stations maintained at its request, and the USGS would pay other expenses. Nine additional stations were established during that period and the State cooperation in the form of observer's salaries amounted to $\$ 929.35$.

State funds had previously been provided for the State engineer from the general appropriations of the Carey Land Act Board, of which 
he was secretary. In 1909 , however, the conservation idea in Montana took the form of enthusiasm for irrigation under the Carey Act. Accordingly, the Carey Land Act Board placed at the disposal of the State engineer the sum of $\$ 2,500$ to be used in stream gaging during 1909 and 1910, chiefly in connection with Carey Act projects. The State engineer employed his own hydrographer but arranged with the USGS to have him visit both State and USGS stations in the sections covered by his trips and to have the USGS engineers do likewise in the sections covered by their trips. Because no mention of cooperation with Montana is made in the Director's annual reports for those years, the arrangement was evidently not classed as cooperation although it was comparable with the arrangement in Nebraska.

At the end of 1910, the State's need for additional records was so great that the State engineer recommended a definite annual appropriation for stream gaging, which was to be used in cooperation with the USGS and spent under the direction of the USGS district engineer (Fourth bienn. rept. of State eng., $1909-10$, p. 17). There was practically no opposition to this recommendation. The authorizing act was approved March 2, 1911, and contained the following provisions:

Section 1 . The sum of six thousand dollars is hereby appropriated out of any moneys in the State Treasury not otherwise appropriated: Three thousand dollars of said sum to be available during the year 1911 and three thousand dollars to be available during the year 1912. Said money to be used by the State Engineer under the direction of the Carey Land Act Board for the purpose of measuring the streams and watersheds and compilation of data pertaining to the use and conservation of the waters of Montana as authorized in paragraphs two, three and four of Section 2244 of the revised codes of 1907 . Any money appropriated by this section that shall be used in measuring streams or watersheds that are now or will hereafter become a part of a Carey Project shall be reimbursed out of money collected by the Carey Land Act Board from the project of which it is a part.

Section 2244 of the revised code of 1907 to which reference is made authorized the State engineer to cooperate with the USGS in the collection of streamflow records and cooperation was continued along the lines previously adopted. Note that no reference was made to putting the cooperation under the USGS direction although such restriction had been requested by the State engineer. As a result of this omission, the method of cooperation continued as previously.

In 1913, the legislature provided in its budget for the State engineer's office an item for stream gaging, and State cooperation for that year was in the amount of $\$ 2,500$. It is impossible to give the amounts of the USGS allotments prior to 1913 because they were included with those for northern Wyoming and North Dakota. The USGS allotted $\$ 7,000$ to Montana in 1913 , and it is safe to state that the allotments exceeded those of the State in earlier years.

WYOMING-The State engineer of Wyoming began cooperation in 1907 to the extent of paying the gage observer's salary and the expenses of a USGS engineer in maintaining one station, and doubled the cooperation the next year by increasing the number of stations to two. In 1909 , the legislature made the first direct appropriation for stream gaging in the amount of $\$ 3,000$ for the 2 -year period $1909-10$. The work was conducted by the State engineer's office, chiefly through the water division superintendents, without USGS cooperation. In 1911, a similar amount was appropriated. When Parshall, who had been the USGS resident hydrographer prior to 1906 and was favorable to cooperation, became State engineer in 1911, an agreement was made with the USGS in that year whereby the parties spent equal amounts for stream gaging.

Unfortunately, Parshall did not realize or perhaps had not been informed that the USGS share must include office as well as field expenses, and he insisted that the USGS spend annually in actual field work an amount equal to that of the State- $\$ 1,500$. This was impossible because of lack of funds, and he declined to continue the cooperation at the end of 1912 .

COLORADO-During the later years of the previous period, the USGS had been paying the cost of all stream gaging in Colorado that was not 
incident to the administration of the water laws, which was wholly a State function. USGS funds were sufficient for the purpose at that time, whereas State appropriations were barely sufficient for the administrative work. At the beginning of this period, however, the picture materially changed and the USGS wrote to the State engineer calling attention to the reduced Federal funds and suggesting cooperation (13th bienn. rept. of State eng., p. 41, 1907). Accordingly, the State engineer made the following recommendation to the Governor:

This State has received almost untold benefit from the work of the U.S. Geological Survey in the matter of making * * " hydrographic surveys, and at this time, when the appropriation for the USGS has been greatly decreased, it is opportune for the State to provide, by appropriations, sufficient funds to continue the work and thus obtain an unbroken line of observations.

Although the State did not make an appropriation for cooperation, increased funds did become available to the State engineer's office. As a result, the State engineer during 1907 and 1908 contributed about $\$ 1,200$ toward the payment of USGS engineer's travel expenses and observer's salaries.

The State funds available for stream gaging came largely from filing fees in the State engineer's office. The boom in irrigation greatly increased the filings and correspondingly increased the fees. In addition, the legislature made two appropriations for hydrographic work in 1909 , which totaled $\$ 25,000$. Under Colorado law, lump-sum appropriations are automatically placed in "fourth and fifth classes," to be used if funds are available. That legislature, like many before and since, appropriated more money than was received during the ensuing 2-year period. Consequently, one of those two appropriations was never available and the other became available so late in the biennium that only a small part of it could be used. State funds used for hydrographic work during 1909 and 1910 amounted to almost $\$ 18,000$, however, of which $\$ 1,150.70$ was contributed to the cooperative USGS program in a manner similar to that of previous years. Thus it is evident that the idea of a separate
State organization, operating independently of the USGS, was taking form during those years, and that the State engineer who was then in office was not the individual who so enthusiastically urged a continuation of the work, by implication in cooperation with the USGS.

A separate State stream-gaging organization became firmly established during the years 1911 and 1912 when the State engineer's force was increased by legislative act to include a chief and six hydrographers. By providing for salaries and expenses of a definite number of employees instead of a lump sum, stream gaging was placed in the State's activities having first-class appropriations and thereafter always had the full fund provided by the legislature. This was one reason for setting up the separate stream-gaging organization. So firmly fixed was the idea of independent operation that during the 2-year period, 1911-12, the amount contributed to USGS cooperation was reduced to about $\$ 300$. In addition, the USGS obtained free transportation on railroads within Colorado.

NEW MEXICO-In 1907, the legislature of New Mexico created the office of Territorial engineer but made no provision for stream gaging although one of the duties of the new office was to supervise the Territorial water rights. The first appointee, Vernon L. Sullivan, soon realized the need for records of streams not previously measured by the USGS and in June established a gaging station. Early in July 1907, Leighton, while in Denver, wrote to Sullivan suggesting cooperation with the USGS. As a result, Freeman arranged a cooperative agreement whereby Sullivan was to establish and maintain a number of gaging stations, and the USGS was to pay his field expenses, gage observer's salaries, and furnish necessary equipment and supplies. A few months later, Sullivan's duties had so increased that he was unable to conduct the necessary field work, and the USGS furnished a hydrographer whose expenses were paid from the Territorial engineer's contingent fund. During the 2 years 1907 and 1908, 17 gaging stations were maintained. The annual cost of these stations was $\$ 3,400$ of which the Territory paid $\$ 1,105$ (First bienn. rept. of Terr. eng., 1907-8, p. 29). Thus the cooperation was on a basis of two USGS to one Territorial dollar. 
Late in 1908, Freeman wrote Sullivan that the USGS could cooperate during the next year on a 50-50 basis for any amount up to $\$ 2,500$. Sullivan accordingly recommended an appropriation of $\$ 5,000$ for the next biennium, which the legislature enacted. The Santa Fe railroad, instead of furnishing passes to the stream-gaging hydrographers, contributed $\$ 1,000$ annually to the State stream-gaging fund. Thus funds contributed by New Mexico for cooperation amounted to $\$ 3,500$ in each year 1909 and 1910 . In 1911 , the amount was $\$ 3,170$.

New Mexico acquired statehood in 1912 and the first State Legislature made an annual appropriation of $\$ 15,000$ to the State engineer's office for stream gaging. As soon as the new State engineer, J.A. French, was appointed, the author, who was then in charge of the Denver District, went to Santa Fe for a conference that resulted in a cooperative agreement providing that the State would contribute $\$ 5,000$ and the USGS $\$ 2,500$ in the first year. Before 1912, the New Mexico work had been supervised by the successive Territorial engineers. With this precedent and the fact that the State was contributing $\$ 2$ for each USGS dollar, the State engineer wanted to continue supervision over the proposed cooperative activities. As a compromise, the agreement provided for joint supervision and for the establishment of a suboffice in Santa Fe under the supervision of the Denver District.

The State engineer contributed $\$ 5,000$ to the cooperation in 1912, and he stated that if he was satisfied with the results that he would increase the amount during the year. Accordingly, New Mexico's contribution for 1913 was $\$ 7,957.82$.

IDAHO-The irrigation law of Idaho, enacted in 1903 as a result of the passage of the Reclamation Act in 1902, provided that one of the duties of the State engineer should be an examination of the streams of the State. The legislature, however, failed to make an appropriation for that purpose. The State Land Board appropriated $\$ 2,000$ from the Carey Act fund for use in cooperative stream gaging in 1909 , and a like amount in 1910. The USGS made substantially equal allotments. The State engineer stated on page 305 in his 1909-10 biennial report:

As practically all of the waters throughout the irrigated section of the State are being appropriated for irrigation and domestic purposes, it strikes us that a good liberal appropriation should be made to carry on the work outlined, and I would recommend that an appropriation of not less than $\$ 5,000$ be set aside for this purpose.

In 1911, the cooperative work was conducted from the District office in Salt Lake City, Utah, but State pride resented the fact that Idaho work was not supervised from an office in Idaho, and the State engineer (the executive officer of the Land Board) threatened to take over the stream gaging himself (G.C. Baldwin, written commun., ca. 1938). When Leighton learned of the situation, he went to Boise, Idaho, for a conference, still believing that in the interest of economy the work should be handled from the Salt Lake City office. During the conference, however, Leighton proposed that if the State Land Board through the State engineer would increase the State's allotment, the USGS would do likewise, thus making it possible to create a separate district for Idaho with headquarters at Boise. This was agreed to and the State's contribution increased to $\$ 5,000$ in 1911 and to $\$ 12,000$ in 1912 . In 1913 , funding decreased to $\$ 5,000$ because the Carey Act fund, which was the source of State allotments, had been depleted. It is impossible to give the exact amounts of the USGS allotments prior to 1913 because the Idaho, Utah, and Nevada allotments were lumped together. The allotment was $\$ 7,500$ in 1913 .

UTAH-In 1909, the Utah Legislature appropriated $\$ 2,000$ annually for the biennium 1909-10 to be used in cooperation with the USGS on a 50-50 basis. The legislature again took similar action 2 years later and the State and USGS each contributed $\$ 2,000$ annually from 1909 to 1912 . As the State engineer states (Seventh bienn. rept. of State eng., 1909-10, p. 22):

The control of these expenditures has practically been in the hands of the district engineer of the Water Resources Branch of this district, the State engineer acting only in a consulting and advisory capacity.

In addition to the regular appropriation, the State engineer allotted $\$ 1,080$ from his irrigation contingency fund during the 2-year 
period. In his biennial report for 1911-12, the State engineer used two unusual arguments in advocating a larger State appropriation. One was that Utah was not providing assistance to the USGS that was comparable with that of other States that had no greater natural resources; the other was that the USGS had previously spent more than half the funds used in obtaining the streamflow records then available, which recognized the fact that before 1909 , the State had made practically no contribution whatsoever. He went on to say that the USGS district engineer had said that the USGS would probably be prepared to cooperate with Utah on an equal basis in the amount of $\$ 10,000$ annually. On the basis of this argument, the State engineer recommended an appropriation of $\$ 20,000$ for the next biennium. Evidently the legislature was only half convinced because $\$ 5,000$ was contributed by the State in 1913. Because the USGS contribution was only $\$ 3,600$, it is evident that the district engineer was overly optimistic when, in the enthusiasm created by the prospect of a large increase in available funds, he thought the USGS could cooperate up to $\$ 10,000$ on a $50-50$ basis.

NEVADA-Cooperation in Nevada continued until 1908 with the State engineer holding a USGS appointment as resident hydrographer. The State paid his salary, but his field expenses on cooperative work were borne by the USGS. In 1908, neither USGS nor State funds for fiscal year 1909 would be sufficient to continue the cooperation, so it was discontinued on June 30, 1908 (Bienn. rept. of State eng., 1907-8, p. 29). Cooperation was not resumed until the beginning of the next period. During 1911, however, the State engineer paid the salaries of observers at four stations.

WASHINGTON-In 1903, the legislature of Washington authorized the Board of Geological Survey-which had been created in 1901 for several purposes, one of which was the gaging of streams - to cooperate with the USGS on a 50-50 basis (G.L. Parker, oral commun., ca. 1938). No further steps toward cooperation were taken, however, until the wave of enthusiasm for the conservation of natural resources swept the country following the Governors Conference in May 1908. At that time, Henry Landes, State geologist, and L.K. Armstrong, a mining engineer interested in the development of State water power, sponsored a movement to obtain funds for cooperation with the USGS, both in water-resources investigations and in topographic mapping (G.L. Parker, written commun., ca. 1938). J.C. Stevens and E.C. Barnard, the latter in charge of topographic mapping in the Northwest, appointed themselves a committee of two to sell the idea to the State Legislature at its 1909 session. With a set of lantern slides as an aid in their campaign of education, J.C. Stevens and Barnard addressed members of the legislature on diverse and sundry occasions: sometimes the audience included the entire legislative body, sometimes only the committee directly concerned with the hoped-for appropriations bill (J.C. Stevens, written commun., ca. 1938). The lantern slides must have been effective because the initial appropriation for cooperation was made at that time. The first section of that act read as follows:

SECTION 1. In order to complete the topographic map of the State of Washington, and for the purpose of making more extensive stream measurements, and otherwise investigating and determining the water supply of the State, there is hereby appropriated the sum of thirty thousand dollars $(\$ 30,000)$, for cooperation with those branches of the United States Geological Survey engaged in this work. This appropriation, however, shall be contingent upon, and not become available unless the United States Government apportion an equal amount to be expended for similar purposes within the State. The Board of Geological Survey is hereby authorized and directed to enter into such agreements with the Director of the United States Geological Survey as will insure that the said surveys and investigations be carried on in the most economical manner, and that the maps and data be available for the use of the public as quickly as possible.

Of the $\$ 30,000$ appropriated for the biennium, the Board of Geological Survey through the State geologist cooperated in stream gaging in the amount of $\$ 5,000$ during both 1909 and 1910 , that being as much as the USGS could 
allot for that purpose to the State of Washington. The initial agreement was signed May 1, 1909 (USGS 30th ann. rept., p. 96, 1909).

Succeeding legislatures made appropriations for the cooperation that continued during the remainder of the period. State allotments were $\$ 5,000$ in $1911, \$ 4,419$ in 1912 , and $\$ 4,000$ in 1913. The reduced allotments during the last 2 years were due to the inability of the USGS to allot more than those amounts.

OREGON.-The appropriation of $\$ 2,500$ made in 1905 for the use of the State engineer of Oregon in cooperative stream gaging was a continuing annual appropriation. During the present period, the cooperation was effective on the 50-50 basis.

During the 1911 session of the legislature, the State engineer, J.H. Lewis, realizing the need for expanding the stream-gaging program, started a movement for an additional State appropriation. He held several meetings that were attended by members of the legislature and addressed by interested citizens, including J.C. Stevens and D.C. Henny who advocated more liberal funds. As a result, the legislature created the "Survey Fund" that was to be derived from the State license tax on water power. The funds were to be spent under the direction of the State engineer to obtain data necessary to promote the development and use of the State's water resources. The State engineer was specifically authorized to establish and maintain gaging stations and was directed to enter into such agreements and contracts as would insure the conduct of the investigations in the most economical manner (Laws of 1911, ch. 137, p. 1). With the realization that cooperation might be defeated if the 50-50 basis of cooperation was required, the law was not specific on that point. The State engineer entered into a contract with the USGS for carrying out the provisions of this law under the joint supervision of the State and USGS. The contributions from these special State funds were $\$ 4,500$ in $1911, \$ 6,650$ in 1912 , and $\$ 4,500$ in 1913 (Oregon State engineer, oral commun., ca. 1938). Thus the total annual State contributions to cooperative stream gaging were $\$ 2,500$ each year from 1907 to 1910 ,
$\$ 7,000$ in $1911, \$ 9,150$ in 1912 , and $\$ 7,000$ in 1913. The USGS allotments were $\$ 2,500$ each year from 1907 to $1910, \$ 7,000$ in 1911 , $\$ 7,500$ in 1912 , and $\$ 5,600$ in 1913 .

CALIFORNIA-Cooperation, which had started in 1903 through the State Board of Examiners of California, continued during the first year of the present period in the amount of $\$ 10,000$. On March 11, 1907, the State Legislature created the Department of Engineering, duties of which included all cooperative engineering work between State and Federal governments. The legislature appropriated $\$ 10,000$ annually for hydrography. By 1909, the continuing cooperative appropriation was $\$ 15,000$ annually for topography, hydrography, and use and distribution of water for agricultural purposes. Of this amount, $\$ 9,000$ was made available annually for nearly 20 years for water-resources investigations, including both surface and ground water (H.D. McGlashan, written commun., ca. 1938).

The Department of Engineering was not the only State agency to cooperate in the waterresources investigations. By 1911, the conservation movement was in full swing in California and, on April 8, the legislature created the State Conservation Commission "for the purpose of investigating and gathering data and information concerning the subjects of forestry, water, the use of water, water power, electricity, electrical or other power, mines and mining, mineral and other lands, dredging, reclamation and irrigation *** ",

In determining its field of operations, the Commission found that additional streamflow records were necessary and recognized that the USGS already had personnel conducting that work. At that time, another Federal organization tried to obtain the cooperative funds earmarked for water-resources investigations, and it was only through the efforts of W.B. Clapp, the USGS district engineer, that the State/USGS cooperation was arranged. On August 7, 1911, the Commission entered into an agreement with the USGS that provided for a complete digest of all streamflow data in the State, records at additional stations to be established, and surveys of rivers having water-power and storage possibilities. The basis of the 
cooperation was that the USGS was to furnish trained men in addition to those already conducting regular USGS work, supervise the work that was to be conducted by the USGS according to its regular methods, and furnish the necessary equipment and supplies. For its part, the Commission was to pay all salaries and expenses of the men so employed. During $1911-12$, the Commission spent $\$ 9,291$ and $\$ 11,045$ during 1912-13 (McGlashan, written commun., ca. 1938).

The creation of the State Conservation Commission provided for an investigation of the water resources, but did not provide for State control of their development. That feature of the conservation program was provided for by the simultaneous creation of the State Board of Control (Water Power), with the same personnel, whose duty it was to receive applications for development of water power and to grant State licenses for a period of 25 years. To foster water-power development, the Board of Control, by an agreement with itself as the Conservation Commission, contributed to the cooperative funds $\$ 1,565$ for $1911-12$ and $\$ 7,140$ for $1912-13$.

The annual funds from all sources actually spent in California were as follows:

$\begin{array}{lrccrrr} & \text { State } & \text { USGS } & & \text { State } & \text { USGS } \\ 1907{ }^{a} \$ 10,000 & \$ 16,250 & 1911 & \$ 8,945 & \$ 9,000 \\ 1908 & { }^{a} 10,000 & 12,400 & 1912 & 20,867 & 9,000 \\ 1909 & 8,500 & 11,500 & 1913 & 27,186 & 9,000 \\ 1910 & 8,940 & 9,000 & & & \\ \\ \text { 'Appropriation. }\end{array}$

About $\$ 4,500$ annually of the USGS funds were devoted to ground-water investigations, leaving the remainder of the USGS money and all of the State allotments for use in stream gaging.

The USGS issued six WSP's $(295,1912 ; 296$, $1912 ; 297,1913 ; 298,1912 ; 299,1912$; and $300,1913)$ at a publication cost of $\$ 16,000$. This expenditure was in addition to the Federal funds listed previously, but was in compliance with the agreement for a complete digest of all streamflow data in the State.

ARIZONA.-Cooperation with Arizona was arranged near the end of the present period. Before 1910, the USGS had conducted a small amount of stream gaging in the State, but the results obtained by use of Federal funds alone were insufficient to meet the needs of the territory. When Arizona obtained statehood in 1912 , Clarence C. Jacob, the USGS engineer in Arizona, called attention to the need for additional stations, and this struck a responsive chord in the recently installed State officials. The Bureau of Irrigation Investigations, DOA, also wanted State cooperation and the legislature passed an act providing for cooperation with both Federal agencies. The act read in part as follows:

SECTION 1. For the purpose of making more extensive stream measurements, investigation of irrigation possibilities from surface and underground water resources in the various valleys of the State of Arizona, and otherwise investigating and determining the water supply of the State, there is hereby appropriated out of any funds in the State Treasury not otherwise appropriated, the sum of Six Thousand $(\$ 6,000)$ dollars annually, Three Thousand $(\$ 3,000)$ dollars for cooperation with the Water Resources Branch of the United States Geological Survey, and Three Thousand $(\$ 3,000)$ dollars for cooperation with the office of Experiment Stations, Irrigation Investigations, of the United States Department of Agriculture.

SEC. 2. This appropriation, however, shall be contingent upon, and not available unless the United States apportion an equal amount to be expended within the State of Arizona, Provided, also, That the experiments mentioned above be made in connection with the State experimental work, so that there will not be a duplication of work.

Sec. 3. The Director of the Arizona Agricultural Experiment Station is hereby authorized and directed to formulate and enter into such agreements with the Director of the United States Geological Survey and with the Chief of the Office of Experiment Stations, Irrigation Investigations, as shall insure economy of expenditure and promptness of publication, and secure avoidance of duplication of work and other embarrassments incident to the operation of State and Federal agencies in the same field. 
Arizona had no State engineer and because the director of the Experiment Station had influence with and the confidence of the legislature, he was made the cooperating State official (G.E.P. Smith, written commun., ca. 1938). On August 1, 1912, an agreement was signed providing for an allotment of $\$ 3,000$ from each party.

HAWAII-On March 22, 1909, the legislature of the Territory of Hawaii passed "an act to promote the conservation and development of the natural resources of the Territory," which provided in substance that a special tax of 2 percent should be levied and collected annually on all incomes in excess of $\$ 4,000$, and that all amounts so collected should constitute a special fund to be spent only for the encouragement of immigration and the conservation of natural resources, in the proportions of threequarters for immigration and one-quarter for conservation. The conservation fund was to be available at such time and in such manner as the Board of Allotment, with the approval of the Governor, should determine (WSP 336, p. 9, 1914). This act was subsequently amended, extending it to December 31, 1913.

At that time, no USGS funds were available. In November 1909 , however, the USGS released to the Hawaiian Department of Public Works a USGS engineer, W.F. Martin, to start waterresources investigations. During the remainder of that fiscal year (1910), the Territory spent $\$ 4,172$ on water-resources investigations (WSP 318, p. 13, 1913).

Beginning on July 1, 1910, formal cooperation was started with the Board of Conservation and each party allotted $\$ 5,000$ to the investigations during fiscal year 1911. So important were these investigations that the Territory increased its contributions to $\$ 12,000$ in 1912 and to $\$ 20,000$ in 1913 . The USGS was unable to increase its yearly allotments beyond $\$ 5,000$.

\section{Reclamation Service}

After the separation of the Reclamation Service from the USGS in March 1907, the ties between the two organizations were still strong and, with F.H. Newell as chief, the Reclamation Service continued to rely on the USGS for the stream-gaging records needed during the investigation and construction of irrigation projects. The cost of these stations had previously been paid directly from reclamation funds, but because that was no longer possible, the Reclamation Service paid the cost of specific stations by transferring funds to the USGS at stated intervals, usually quarterly. Gradually, however, as the reclamation projects reached the construction stage, the gaging stations directly connected with them came to be maintained by the Reclamation Service, and other gaging stations that had been maintained during the investigational stage were either dropped or continued by the USGS in cooperation with the States in which they were located. The stations in Montana were an exception to this general rule because during this period, the number of Reclamation Service stations increased slightly and most of them were maintained by the USGS at the expense of the Reclamation Service. Thus by the end of the period, Reclamation Service cooperation was of considerable importance only in Montana where 56 stations were maintained. Most of the remaining 41 Reclamation Service stations scattered throughout the West were maintained directly by them.

\section{Forest Service}

The agricultural appropriation bill approved March 4, 1907, contained the following provisions under the title "Survey of and Report on Appalachian and White Mountain Watersheds":

To enable the Secretary of Agriculture to examine, survey, and ascertain the natural conditions of the watersheds at and near the sources of the various rivers, having their sources in the Southern Appalachian Mountains, and the White Mountains, and to report to Congress the area of natural conditions of said watersheds, the price at which the same can be purchased by the Government, and the advisability of the Government purchasing and setting apart the same as natural forest resources for the purpose of conserving and regulating the 
water supply and flow of said streams in the interest of agriculture, water power and navigation ***.

This provision required streamflow studies, particularly in the interest of water power and navigation, and Leighton (working through Director Smith) prevailed on the Forest Service, which was then the agent of the Secretary of Agriculture, to make an allotment of $\$ 6,000$ to the USGS for stream gaging in the Southern Appalachian region (USGS 29th ann. rept., p. 74,1908$)$. Although the money was theoretically available during the fiscal year beginning July 1, 1907, it appears from the records that it actually became available in May of that year and was used until funds were exhausted in 1909. The money was used chiefly to maintain gaging stations in the South Atlantic States.

From the office studies made by Leighton, A.H. Horton, and Bolster, two reports were furnished to and published by the Forest Service as Circulars 143 and 144. In Circular 143, Leighton advocated reservoirs as an aid to navigation.

Another type of cooperation had its beginning in 1910. The conservation movement had stimulated interest in water power and, in the Western States, the power sites were chiefly in the national forests. At that time, the Forest Service issued permits to develop power, and so numerous were the inquiries and applications that by 1909 , the system of attaching an engineer to each Forest Service district to supervise water-power development was begun. O.C. Merrill became chief engineer in 1910 and, being a water-power enthusiast, instructed the district engineers of the Forest Service to obtain approximate records at points on the forest streams accessible to the Ranger headquarters. Some discharge measurements were also made.

In early fall 1910, J.C. Hoyt, while in the West, negotiated cooperation with the Forest Service whereby more gaging stations would be established on mountain streams. The basis of the cooperation was one of service. The USGS selected the sites where stations were established; the Forest Rangers were instructed in the use of the current meter and conducted discharge measurements. The USGS supervised the work and computed the records.
In 1911, 182 gaging stations were maintained, chiefly in California and Colorado, with a few stations in each of the other Western States where there were water-power sites in the national forests. The number increased to 233 stations in 1912, continuing during the remainder of the period. Many of these stations were so isolated that it was impossible for the Rangers to read the gages more often than once or twice a week. The results were fragmentary records.

WHITE MOUNTAINS INVESTIGATION.-On March 1, 1911, the Congress passed the law known as the Weeks Act (36 Stat. L. 962), which was "to enable any State to cooperate with any other State or States or with the United States, for the protection of the watersheds of navigable streams, and to appoint a commission for the acquisition of lands for the purpose of conserving the navigability of navigable streams." Section 6 reads as follows:

That the Secretary of Agriculture is hereby authorized and directed to examine, locate and recommend for purchase such lands as in his judgement may be necessary to the regulation of the flow of navigable streams and to report to the National Forest Reservation Commission the results of such examinations: Provided, That before any lands are purchased ${ }^{* * *}$ said lands shall be examined by the Geological Survey and a report made to the Secretary of Agriculture, showing that the control of such lands will promote or protect the navigation of streams on whose watersheds they lie.

The proviso requiring the USGS to conduct certain specific duties before a bureau in another Department could act is so unusual that the "inside story" of it is of interest.

During the hearings on the Weeks bill and the debates preceding its passage, it became apparent that the only legal pretext under which the Federal Government could acquire privately-owned land for forest purposes in the eastern part of the country where no public lands remained was to promote, protect, or improve navigation. The Army engineers were outspoken in their views that forests have no influence on streamflow, and neither President 
Theodore Roosevelt nor his chief advisor, Pinchot, wanted the Army engineers to be involved with the proceedings required by the Weeks Act. Because the only official engineering support of the effect of forests on streamflow came from the USGS with Leighton's initiative, the conservationists wanted USGS cooperation. The idea of making the USGS the determining agency in the acquisition of the lands originated at a conference in Pinchot's library, which was attended by Senator Weeks, Pinchot, F.H. Newell, G.O. Smith, Gannett, WJ McGee, and Leighton (Leighton, written commun., ca. 1938). The fruition of this idea was the proviso in the Weeks Act. The aforementioned proviso was not inserted in the act, however, without more or less strenuous opposition on the part of congressmen friendly to the Army engineers who resented the implication that only USGS engineers were competent to judge the effect of forests on streamflow relative to navigation.

Soon after the passage of the Weeks Act, New Hampshire offered land in the White Mountains to the National Forest Reservation Commission. Before this land could be purchased, however, it was necessary for the USGS to examine it and report that its control would promote or protect navigation. This definitely raised the moot question of the effects of forests on streamflow and, in order to answer it, the USGS wished to conduct an intensive survey for 1 year.

The Weeks Act itself carried no appropriation for that purpose, but the item for a survey and report on the Appalachian and White Mountains watersheds that was carried in the DOA appropriations bill 4 years previously provided $\$ 25,000$ that remained available until spent (Chief engineer, U.S. Forest Service, written commun., date unknown). Sufficient funds from this appropriation remained to finance the proposed investigation for at least 1 year, and Leighton believed an investigation of that length to be sufficient, as he wrote to the author:

We conducted the investigation for only one year because that period seemed sufficient. The basic principle was that a long period of years was not required. We were studying individual storms and snow clearances, and we thought the sizes and shapes of the storm-runoff graphs would be sufficient.

The investigation that started during September 1911 continued for 1 year.

\section{INDIAN SERVICE}

During the preceding period, the Indian Service had paid for the maintenance of a few gaging stations on the Uinta Reservation in Utah, but this work had been discontinued in 1905 when the reservation was opened to settlement. Stream gaging resumed in 1907 and continued through 1910 at an annual cost to the Indian Service of about $\$ 2,000$. By 1910 , the irrigation work of the Indian Service required additional streamflow records on Indian reservations and an arrangement was made similar to that with the Reclamation Service. During the remainder of this period, an average of 43 stations was maintained, except during 1911 when the number was reduced to 13 because of a reduction in available funds. The average annual cost was about $\$ 4,500$.

\section{New Districts}

The reduced appropriations for stream gaging during the entire period were not conducive to the establishment of new districts, but the renewed interest in the country's water resources, aroused by President Theodore Roosevelt, offset this handicap. (Roosevelt had first championed the cause of conservation of natural resources at the time the Reclamation Act was passed in 1902.) As a result of this renewed interest, cooperation was offered by the States of Minnesota, Illinois, and Hawaii and, to be in harmony with the spirit of the times, the USGS itself found funds to create a district in the Ohio River basin. But before these districts were established, the need for streamflow records in connection with placer mining in Alaska led to cooperation with the Alaskan Division of the USGS for that purpose. As this cooperation was first in point of time, it will be described first, and the establishment of new districts next. 


\section{Alaskan Cooperation}

In the early years of the century, placer mining played an important role in the development of Alaska. With typical American optimism, plans were being made and in some instances contruction had actually been completed to bring water through many miles of ditches to the placer deposits. Realizing the lack of knowledge of the flow of the streams to be diverted and also the proneness of promoters to over-estimate the available water supply, Dr. Alfred Hulse Brooks, chief of the Alaskan Division, knew that stream gaging was required requisite to successful placer mining. Without adequate topographic maps from which to determine the areas of the different drainage basins of the vast region, however, it was impossible to attempt such an investigation. In 1905, such maps were completed for the Nome region on the Seward Peninsula. In March 1906, Brooks arranged with the Hydrographic Branch to detail an engineer to start the Alaskan work and on March 21, 1906, he wrote the Director as follows:

In accordance with the plan approved by you, provisional arrangements have been made with the Division of Hydrography by which an investigation of the water resources of the southern slope of the Seward Peninsula is to be undertaken. This work is to be done by men detailed from the Division of Hydrography, whose field expenses are to be met from the Alaskan appropriation: Hydrography-\$2,200.

J.C. Hoyt was selected to begin this work. In his letter of instructions of May 3, 1906, the scope of the work was described as follows:

The field of your operations will be the Seward Peninsula and their purpose will be the investigation of water resources available for placer mining. It is probable that the immediate needs of the mine operators can best be met by a study of the water resources of the northern half of the area covered by the Grand Central special map. It is suggested that if possible, you make reconnaissance of some of the other mining districts of the Peninsula, especially Council and Solomon.
J.C. Hoyt was unable to devote the entire season, short as it was in Alaska, to this work and he took Henshaw with him from the computing section, who was to be his successor in that investigation. After a sea trip of 2,700 miles from Seattle to Nome, the party reached Seward Peninsula on June 11, 1906, in the closing month of the Hydrographic Branch. Alaska was an unknown territory to the stream gagers, so J.C. Hoyt asked one of the geologists of the Alaskan Division about the best method of transportation. He was told that a buckboard was the most convenient and accordingly he procured at Nome an ordinary vehicle of that type with a single horse. He and Henshaw started out in this vehicle to conquer new

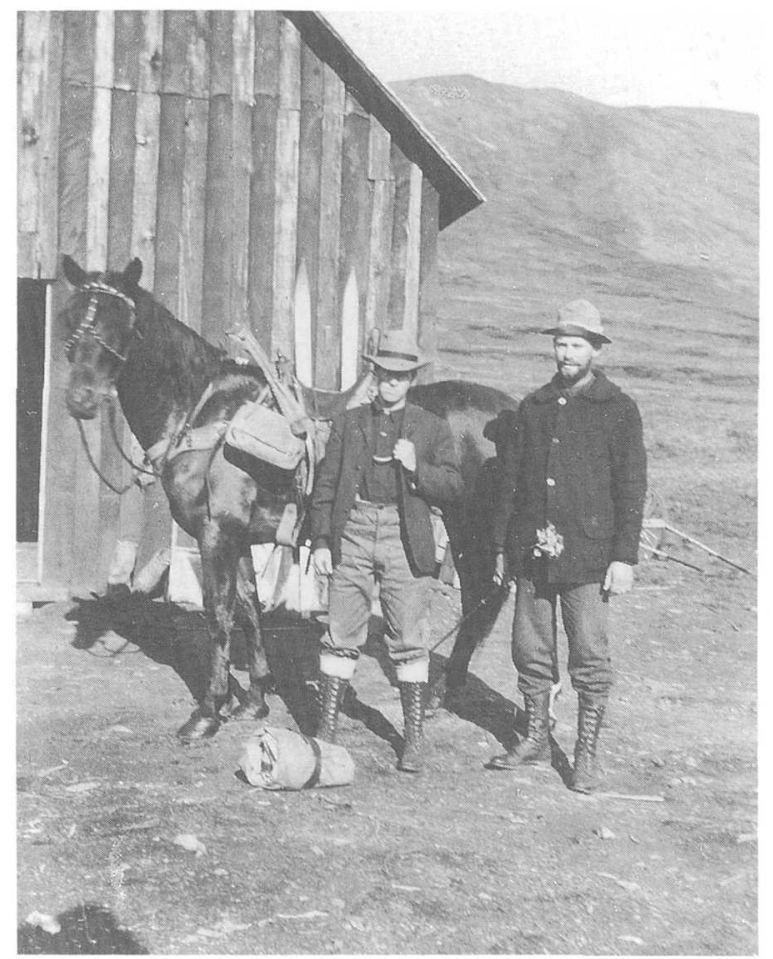

USGS engineers J.C. Hoyt (left) and F.F. Henshaw at Black Point, north of Nome, ALaska, 1906.

worlds, but found almost immediately that the buckboard advice given to them was good only so far as it went. The advice had not specified tires at least 4 inches wide to prevent sinking into the soft tundra, or that two horses were necessary because the tracks worn by two horses traveling abreast had a high ridge between them. After floundering along on their first day, during which time the buckboard sank into the tundra and the single horse slipped off 
the high center ridge first on one side and then the other, the buckboard was abandoned in disgust at the old Dorothy Roadhouse, 30 miles from Nome, where it still remained in 1932 (P.S. Smith, oral commun., ca. 1938). Thereafter, they traveled by "mushing" and the single horse was converted into a pack animal for supplies and equipment.

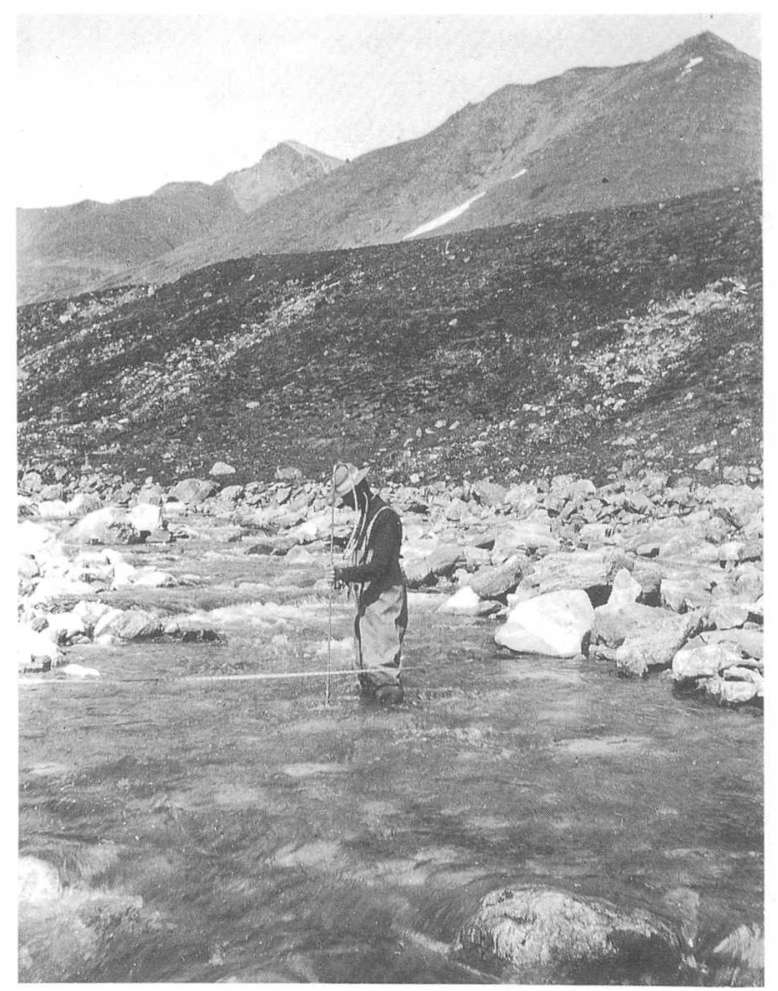

F.F. Henshaw making a discharge measurement, Grand Central River north of Nome, Alaska, 1906.

\section{Ohio River District}

A considerable chain of events led to the creation of the Ohio River District. In his capacity as advisory hydrographer, Leighton accompanied the members of the Inland Waterways Commission on some of their inspection trips. During one of these trips, two members of the commission asked Leighton if navigation could be improved by building reservoirs, and he promptly replied in the affirmative. They then asked the same question of General McKenzie, Chief of Engineers, and he not only replied as promptly in the negative, but added that Leighton had no grounds for believing reservoirs would help navigation. Here the matter rested temporarily. In due time, the Inland Waterways Commission formulated its report and advocated, among other things, the consideration of flood prevention in connection with the improvement of the waterways (Prel. rept., Inland Waterways Comm., S. Doc. 325, 60th Cong., 1st sess., p. 25, 1908). General McKenzie, a member of the Commission, presented a minority report stating that he was not in accord with the idea that the related subjects mentioned in the main report (including flood prevention) were necessarily associated with channel improvement. The report was presented to the President, and a short time later Leighton was called to the White House and asked by President Roosevelt if he agreed with General McKenzie's views on the necessary relation between flood prevention and navigation. On replying that he did not, Leighton was instructed to make a report within 5 days on the possible relation between flood prevention and navigation (Leighton, oral commun., ca. 1938). In order to do this, Leighton concentrated on the Ohio River basin, the greater part of which was covered by topographic maps on which possible reservoir sites could be outlined and their approximate capacities determined. By using all available assistance in the Washington, D.C., office and working long hours, the report was completed on time and published as an appendix to the report of the Commission (Prel. rept., Inland Waterways Comm., S. Doc. 325, 60th Cong., 1st sess., p. 451-490, 1908).

As a result of this preliminary study, Leighton became greatly interested in storage as a tool in flood prevention, and realized the need for additional streamflow records in the Ohio River basin as the basis for the preparation of a special report. As funds were too limited to maintain adequate stations in all sections of the basin, he decided to concentrate on one subbasin. The Pittsburgh Flood Commission, which was organized in 1908 as a result of the 1907 flood on the Ohio River, had started an intensive stream-gaging program in the Allegheny and Monongahela River basins. The Kanawha River basin was the next logical area to be investigated because of the large number of possible reservoir sites (Leighton, written 
commun., 1938). At the request of Theodore Burton, chairman of the National Waterways Commission, Leighton had already made a study of the Kanawha River basin for the Commission, which had disclosed reservior possibilities (Final rept., National Waterways Comm., S. Doc. 469, 62d Cong. 2d sess., p. 161). Accordingly, the Ohio River District was created in May 1908, and the new work was concentrated chiefly in the Kanawha River basin. A.H. Horton, who had returned to the Washington, D.C., office after the Chicago District closed and who had helped Leighton to prepare the Ohio River report during those five strenuous days, was put in charge of the new District.

\section{Minnesota District}

When the contract with the State Drainage Commission of Minnesota was signed on May 15, 1909, arrangements were made to organize a new District with headquarters in St. Paul, and I (the author) was selected as district engineer. However, as I was then completing the investigation of swamp and overflow lands and was unavailable for a few weeks, J.C. Hoyt took temporary charge of the work in order to start the stream gaging at the earliest possible date. He was assisted by Gray, who had been previously employed in Wisconsin on a per-diem basis, and C.B. Gibson, a field assistant. With most of the pioneering work finished when I took charge, most of the time was devoted to the organization of groups to conduct the river and reservoir surveys required for the complete study of the State's water resources under the cooperative agreement.

\section{Hawail District}

Early in 1908, Governor Frear of Hawaii proposed cooperation with the USGS. Unfortunately for the proposal, the Comptroller of the Treasury decided that it was illegal for the USGS to spend its stream-gaging funds in Hawaii, and the cooperation was necessarily postponed. Undaunted, Governor Frear came to Washington, D.C., the next winter (1909) and requested the Congress to authorize the expenditure of USGS funds in Hawaii. This authority was readily given (Leighton, written commun., ca. 1938). On March 22, 1909, the Hawaii Territorial Legislature passed an act appropriating Territorial funds. The particular interest of the Territorial officials in stream gaging was the revenue derived from leasing water to plantations (the Territory owned land and water in the mountains). Accordingly, in July 1909 when the meager USGS appropriation for fiscal year 1910 became available, Leighton and Mendenhall set sail from San Francisco, Calif., for Honolulu. When the steamer docked in Honolulu, it was invaded by local boosters loaded with leis that were flung around the necks of the passengers-an old Hawaiian custom. At the same time, the Royal Hawaiian Band, a Territorial organization dating from the days of the monarchy, was giving a concert of Hawaiian music ending with "Aloha," which is played on arrival as well as departure of passengers.

Sufficient USGS funds were unavailable for field work that year, but so anxious were the Territorial officials to have the investigations started as soon as possible, that an agreement was made with Marston Campbell, superintendent of the Department of Public Works, whereby a USGS engineer was detailed to that department until USGS funds were available. An investigation indicated that the new work would depart widely from regular streamgaging procedures, and that a man of great technical skills would be needed as district engineer. Accordingly, Martin, then an assistant engineer in the California District, was temporarily released from the USGS on November 23, 1909 (Martin, written commun., ca. 1938), and given an appointment as chief hydrographer in the Territorial Department of Public Works. During the remainder of that fiscal year, such assistance as was needed was furnished by local men. Not much help was required, however, because the first months were spent in travel around the islands to become acquainted with existing irrigation developments and to make measurements at the few stations established previously by the Department of Public Works. Beginning on July 1, 1910, with the increase in Survey appropriations, the Hawaiian District 
was formally organized and Martin was reinstated in the USGS and put in charge as district engineer.

\section{IMPROVEMENTS}

\section{EQUIPMENT}

Perhaps the greatest need in 1906 for improvement in equipment was for accuracy of measurements of high velocities. The standard meter indicated each revolution, and it was difficult and sometimes almost impossible to count the revolutions at high velocities. It was customary for the hydrographer, when measuring from a bridge, to make a mark with lumber crayon on the bridge rail for each five revolutions. Another need for improvement related to the difficulty, if not the impossibility, of keeping the meter in proper position even when using a stayline. Consequently, it was customary to measure the subsurface velocity and apply a coefficient. This procedure, like counting of revolutions during high velocities, was makeshift, and the engineers of the Branch thought that equipment should be developed so that velocities at high stages could be actually measured at assured depths.

The January 1905 conference had recommended that a meter be constructed for use in flood measurements that would indicate 5, 10, or 20 revolutions (G.C. Stevens, written commun., ca. 1938). In 1906, Steward was working on a device for this purpose, but had made little progress. J.C. Hoyt, who had been in Alaska that summer, had used the acoustic meter that indicated each 10 revolutions. On his return that fall, J.C. Hoyt instructed Steward to put lugs on the gear wheel of the meter that would make contact every fifth revolution (J.C. Hoyt, oral commun., ca. 1938). The resulting pentahead was made interchangeable with the then-standard single-point head. This, however, was not the first pentahead arrangement for a USGS meter. In the years of the perdiem appointments (1894-1902), a Haskell meter had that attachment and Hinderlider had developed a similar device in Colorado during the period of the Hydrographic Branch (1902-6).
The pentahead solved the difficulty of counting the revolutions at high velocities, but did not lessen the resistance of the equipment to the current or the danger of losing the tailpiece in swift water. The author recalls a personal experience that showed the need for a substitute for the screw connection between the tailpiece and meter yoke: In April 1906, while I was measuring Georges Creek at Westernport, Md., a shallow stream that had an exceedingly high velocity, the meter swung broadside to the current and, almost in the twinkling of an eye, the current unscrewed the tail and started it on its journey to the Chesapeake Bay!

While working on meter improvements, Steward substituted a sliding connection with set screw for the screw connection and thus saved many tailpieces in subsequent years. He also developed the thin weight hanger to pass through a slot in the yoke, thus eliminating the wide connection by which the old weight hanger had been attached. Steward also brought the meter suspension above the center of gravity, thus making a more perfect balance in low velocities.

Further reduction in equipment resistance was achieved early in 1907 when the heavy insulated meter cable that had previously been fastened directly to the meter was replaced by a single telephone wire connected with the meter at one end and to the meter cable at the other, the length of telephone wire being sufficient to keep the heavy meter cable out of the water. A fine insulated copper wire was wound around the telephone wire to complete the electric circuit. At least one measurement with similar equipment had been made nearly 10 years previously, however: M.R. Hall, at a station on a long railroad bridge in Georgia, found that he had left his meter cable in his buggy (for those were the horse-and-buggy days) and, rather than walk half a mile to get it, decided to use the wire gage on the bridge to suspend the meter, wrapped a small insulated wire around it, and so made the measurement (M.R. Hall, oral commun., ca. 1938).

Another reduction in equipment resistance was obtained by substituting torpedo weights for those of flatiron design. M.R. Hall designed the torpedo weight in 1906 following a suggestion by his assistant, F.A. Murray, that a 
weight shaped like a fish would be efficient. M.R. Hall was assisted by Warren E. Hall in making the pattern for the torpedo weight. At first they tried to hammer an iron weight into the approximate fish shape but abandoned the attempt after laboring for 3 days and making little progress. A small wooden Indian club was then put on a lathe and turned into the exact shape desired. From this wooden model, a cast was made in plaster of Paris, but it proved to be unsatisfactory because it went to pieces after being used a few times. Finally, a bronze mold was made from the wooden pattern and a lead weight was cast. Ten percent of antimony was added to the lead to harden it and make it fit the mold better. The proper balancing position of the screw hole used in fastening the weight to the hanger was determined by trial and error. The old brass pin with an eye, which had been used with the flatiron weight, was discarded in favor of the screw, and this change saved many weights in the later years.

The first weights to be cast were 6-pound size and were sent to Washington, D.C., for inspection. One or two minor changes were suggested and M.R. Hall was instructed to make similar weights of 10 - and 15-pound sizes. These three weights, particularly the 6- and 15 -pound sizes, became standard. The molds were turned over to the Washington, D.C., office and were sent to the Districts to be used in having the weights cast locally (M.R. and Warren E. Hall, oral commun., ca. 1938). These improvements complete those designed, during the present period, to reduce resistance of equipment to current.

In 1907, Steward devised a telephone receiver and dry battery, a suggestion made by L.C. Hill of the Reclamation Service at the 1905 conference. In its original shape, the telephone receiver did not have the headpiece and the operator had to hold the receiver to his ears; however, the headpiece appeared within a comparatively short time. The telephone receiver for stream gaging was devised independently by E.F. Chandler at about this same time in connection with work during winter in North Dakota. In discussing this work, E.F. Chandler wrote (ca. 1938): We developed *** forms of equip-
ment. For example, the old pattern of mercury-bichromate water buzzers used with current meters readily froze up and quit in below-zero weather, unless one carried an extra little square bottle that went in the buzzer, in an inside pocket where it would keep warm, and exchanged at quarter-hour intervals. So after awhile we invented the plan of using a pony-telephone receiver instead of a buzzer. (Of course some others made the same invention at the same time.)

In 1908, J.C. Stevens made his first flood measurements from a cable, which required heavy lead weights on the meter. The discomfort of trying to work, sitting cross-legged on the bottom of the simple box that was suspended from the cable, caused him to design the present type of car that has a seat at each end, an open space with a footrest in the center, and a pulley over which the meter cable operates. The first car so designed was installed on the Yakima River at Union Gap, Wash. (J.C. Stevens, oral commun., ca. 1938). The widelyused picture of that car shows Muldrow, in 1908 , using the old flatiron weight with the meter cable attached directly to the meter. Evidently new ideas were not adopted as rapidly then as later.

The design of the new cable car led to consideration of the proper size and sag of the cable itself. J.C. Stevens worked out the cable stresses for fluctuating conditions and prepared sag diagrams, which have since been used with some modification. Considerable sag in long cables made a hard up-hill pull to reach the bank from midstream and, to make the return easier, E.S. Fuller designed in 1912 a wooden cablecar puller that was standard equipment for many years. As E.S. Fuller stated at the Conference of Western Engineers held in Boise, Idaho, in January 1914, "The idea of the puller occurred to me one day as I was driving an exceedingly slow team of horses 7 miles from a gaging station to the nearest town, while nursing a very badly crushed finger which I had just used as a brake for a big water-logged gaging car."

The difficulties in using the Covert yoke in swift mountain streams with rocky beds led to the design of a rod that could be rested on the bottom, thus holding the meter in position and 
forming a brace for the engineer. G.H. Russell, a junior engineer in the Denver District, devised such a rod in about 1909, which was equipped with a foot plate and a sliding support to which the meter head and tail could be fastened. Freeman approved the design and had a sample made in Denver, Colo. This design was so satisfactory that it was adopted as standard and thereafter the rods and slides were manufactured by W. \& L.E. Gurley of Troy, N.Y., as regular equipment for wading measurements.

In 1908, M.R. Hall made patterns for bronze gage scales in 1-foot sections, with raised graduations and figures, and covering the range from 0 to 15 feet. These scales were generally used until they were superseded by enamel scales early in the next period. About 1912, Warren E. Hall devised the Hall clip for connecting the meter hanger with the suspending wire, which was then generally used.

The insertion of a telephone wire between the large cable and the meter to reduce the equipment resistance led Steward to devise, in 1907, the single-wire suspension, which eliminated the small insulated wire ordinarily wrapped around the large wire. With this suspension, the electric circuit through the earth and water was grounded by the free end of the single wire. Steward suggested this method to Lamb, who first used it in 1907 in Oklahoma and New Mexico. J.C. Stevens also used it in October 1907 in measuring the Columbia River at The Dalles, Oreg., in depths as great as $\mathbf{8 0}$ feet. This type of suspension was not used extensively, however, until many years later, but it continued to be used almost exclusively under Lamb's direction in the Helena, Mont., District (Lamb, written commun., ca. 1938).

A reel and boom was first used by the USGS in 1908 when A.H. Horton, who was in charge of the Ohio River District, needed to use heavy weights during flood measurements of the Ohio River. Recalling his earlier experience on the Lake Survey in using reels and booms to make deep soundings, A.H. Horton designed and built a reel and boom having a simple depth indicator at a cost of $\$ 80$. He designed a mold for a topedo-shaped lead weight of about 100 pounds, but found that the cost of lead would be prohibitive with his limited funds and so cast the weights of iron instead, thus making them about 75 pounds. When these weights were used, it was necessary to strap the boom to the bridge railing to prevent tipping. The weight and boom were transported from station to station by express and, because their combined weight was more than 100 pounds, the friendship of expressmen was not won. The Ohio River District office closed in 1913 and A.H. Horton shipped the reel and boom to G.L. Parker for use on the Columbia River. A.H. Horton was not the first engineer to use a reel in the USGS, however; J.C. Stevens used a "stock" reel (without boom) in measuring the Columbia River at The Dalles in October 1907.

The need for permanent benchmarks was brought out at the conference in January 1913. The Topographic Branch staff recommended a tablet to be set in a ledge, large boulder, or concrete post and labeled "Gaging station reference mark" in order to distinguish it from the tablet used in topographic mapping. This recommendation was adopted.

It became apparent, in March 1912, that the current-meter measurements of high water were sometimes too large. In order to impress on the field offices the necessity for staylines, instructions were issued to install them wherever needed. These instructions were theoretically correct, but their execution did not always lead to the desired results. A telephone wire stretched across the stream frequently was an irresistible attraction for passers-by.

\section{Automatic Gages}

At the beginning of this period, the USGS was operating five water-stage recorders. The first was installed on Kings River near Sanger, Calif., in April 1903, where the diurnal fluctuation in stage caused by the alternate melting and freezing of the mountain snow amounted to as much as 2 feet. Others were installed on Chevelon Fork near Winslow, Ariz., in December 1905, Miller Creek near Lorella, Oreg., in December 1905, Upper Klamath Lake near Klamath Falls, Oreg., in February 1906, and Clear Creek near Winslow, Ariz., in June 1906. These four gages were installed at stations where it was impossible to get satisfactory observers.

The use of automatic gages was considered at the beginning of the old Irrigation Survey and 
an instrument of the horizontal-cylinder type used by the CGS was installed at the historic Embudo, N. Mex., station in January 1889. Its operation, however, was unsatisfactory, due chiefly to the fact that the ink dried up in the pen in that arid climate. The following year another gage, presumably of the verticalcylinder type designed by Nettleton, was installed on the Rio Grande near Del Norte, Colo., but this gage also was unsatisfactory for reasons now unknown. In August 1892, an automatic gage of the circular-chart type was installed on Rock Creek at Washington, D.C., and operated more or less successfully until November 1894. This recorder was the property of the District of Columbia Department of Sewers, and the station itself was installed at the request of that Department. In December 1904, a gage of the same type and possibly the same instrument was installed on the Potomac River at Chain Bridge near Georgetown, District of Columbia, but it proved to be so unsatisfactory that it was replaced in March 1895 by a cylinder gage believed to be the one originally used at Embudo, N. Mex.

While the USGS was experimenting more or less unsuccessfully with automatic gages, other agencies were having better success. The earliest recorded use of an automatic gage, at least in this country, was on Sudbury River in Massachusetts by the Boston Water Works, the predecessor of the Metropolitan Water District. When a station was first established at a weir on the Sudbury River in 1875, a staff gage was read three times daily. But even with that painstaking striving for accuracy that is associated particularly with the New England engineering fraternity, it was felt that this record of gage heights was insufficient and that a continuous record of the changes in water levels of the Sudbury River was needed. Accordingly, Alphonse Fteley, in charge of the Sudbury work, devised in about 1876 what he called "a self-registering float." An endless sheet of paper moving between guides on a horizontal table was advanced by a clock at the rate of 1 foot per day. The float was suspended from a pulley by a slender metallic thread, and the slack was taken up by a counterweight. The motion of the pulley was transmitted to a horizontal wooden bar that carried the pencil mounted on two small rollers (Trans. Am. Soc., C.E., vol. 10, p. 229). A kerosene lamp suspended in the well and a small kerosene stove in the room over the well were used to keep the water from freezing in that well. The "self-registering float" was used only a few years.

Nettleton, while he was State engineer of Colorado, designed a vertical-cylinder gage and installed it on the Cache la Poudre River in 1884. It operated sucessfully during each irrigation season until 1891 when it was lost in a flood. It was later replaced by a French instrument made by Richard Freres. This instrument, unlike the American gages, had the one point of support for the pen arm several inches away from the chart on the vertical cylinder. The pen arm was connected with the float, the movement of which caused the recording pen to mark the arc of a circle on the chart. The lines marking the time, therefore, were also curved. The graduations of stage were straight horizontal lines. An illustration of this instrument is shown in volume 44 of the Transactions of the American Society of Civil Engineers (p. 157, 1900). In 1885, the State engineer installed a Nettleton gage on the Arkansas River near Pueblo, Colo., and operated it during three irrigation seasons.

The city of Philadelphia installed in $\mathbf{1 8 8 5}$ (Chief, Bur. Water Supply, Dept. Public Works, written commun., ca. 1938) three automatic gages of the horizontal-cylinder type in connection with a study for a new source of water supply. These gages had supply and receiving rolls somewhat similar to those used on the later continuous recorders. They were operated by spring-driven clocks and were manufactured by Black and Pfister of New York. These recorders were used for several years before being replaced by other automatic gages.

In 1893, A.K. Warren, engineer for the Kern Land Co., designed a gage that was used successfully for many years on the Kern River in California. In 1894, Mead operated a verticalcylinder instrument of his own design for several years on Clear Creek near Buffalo, Wyo.

In 1899, the Irrigation Investigations section of the Office of Experiment Stations needed automatic gages and asked Julien P. Friez for an instrument to record water levels. Friez was unfamiliar with the earlier automatic gages, and 
the closest instrument he knew about was a recording anemometer that had a vertical cylinder down which the clock carrying the pen traveled, as in the present Stevens type E recorders. When Friez saw that instrument, he remarked, "Hell, I don't want to know what time it is, I want to know the stage of the river." Thus evolved his idea of a horizontal cylinder with the clock at one end to activate the pen carriage. The cylinder, or drum as Friez called it, was connected with a float suspended by a copper ribbon that was perforated so as to pass over spines on the end of the drum and thus prevent slipping. Friez' original order book shows that five of these automatic gages, or "water-stage recorders" as they were designated, were shipped to Irrigation Investigations on March 21, 1900; five more were shipped a month later.

In June 1902, three registers were shipped by Friez to Lippincott at Los Angeles, Calif. (from notes taken by the author from original order book). One was installed on the Kings River near Sanger, Calif. The others were probably ordered for private interests because no mention of them appears in the California records during 1902 or 1903. In 1902, the Weather Bureau installed a long-distance recorder on the Tennessee River at Chattanooga, Tenn.

Appropriations during the first 2 years of the present period were so skimpy that no additional automatic registers were installed by the USGS. The Reclamation Service, however, installed a Friez gage on Link River at Klamath Falls, Oreg., in June 1908, and the Indian Service installed a Bristol pressure gage on Williamson River near Klamath Agency, Oreg., in October 1908.

In 1909, the Territorial engineer of New Mexico, who was cooperating with the USGS, believed that the staff gages then in use did not give true records of the flashy New Mexico streams and, because the proposed irrigation projects needed the best possible information about water supply, he wanted automatic gages installed. Accordingly, Freeman installed 17 instruments in New Mexico during 1909 and 1910. By the end of the period, the USGS had installed 40 Friez gages in several districts and cooperating organizations had installed 25 .

By 1909 , the New York District was considering the use of automatic gages. Covert, having fresh in mind the unfortunate experience with earlier New York records, was anxious to obtain the most accurate records possible, especially during winter. He wanted an instrument that would operate during cold weather and for a period longer than a week because isolated stations in northern New York could be visited only at infrequent intervals. He also wanted a gage that had charts that could be changed without disturbing the setting of the pencil, thus eliminating the possibility of incorrect settings by the observers. The Friez gage met none of these requirements. As Covert's headquarters were near the Gurley factory, he contacted Wendell Hess who was in charge of the Gurley design department and told Hess what he wanted. As a result of frequent conferences and considerable experimentation, the Gurley electric printing gage was designed to meet the first two of Covert's needs, and placed on the market in 1910. It printed the time at 15-minute intervals and the gage heights in feet and in hundredths, and was designed to run for 3 months without attention. The first gage of this type was installed on the Bog River in New York in 1910. Five of the gages were used in the White Mountains investigation in 1911. It was so difficult to operate them on batteries in the severe winter cold of that region, however, that the attempt was abandoned (O.W. Hartwell, written commun., ca. 1938). These gages were of intricate design and delicate construction. They also cost $\$ 275$, which was too much for the lean stream-gaging purse in those years. The high cost and frequent trouble with the mechanism kept the USGS from installing more than a few of these electric (battery) gages. The electric-driven clock was soon replaced by a weight-driven one, but this substitution neither simplified the complicated mechanism nor lessened the cost, and the USGS installed only a few of this type, too.

Shortly after the appearance of the electric gage, Gurley put on the market a sturdy 7-day horizontal-cylinder gage with a locking device that prevented the disturbance of the pencil setting when the charts were changed. This gage met the third of Covert's needs, and half a dozen of them were installed by the USGS during the present period.

The gages already described were rather expensive for those days and, after the USGS 
appropriation had been increased in 1910 and additional States had entered into cooperation, everyone concerned believed that an instrument manufactured to sell for less than $\$ 100$ would find a ready market. Accordingly, after a conference with Leighton who expressed an optimistic view of such a need, the Barrett \& Lawrence hydrochronograph was placed on the market at about $\$ 90$. This instrument had a vertical cylinder and was designed to operate for 31 days. A cylindrical glass float, 3 inches in diameter and weighted with sand to keep it vertical, was attached to the gage by a cord. The first hydrochronograph was installed in 1910 on the Sacandaga River at Hadley, N.Y. The USGS installed 14 of these recorders during this period.

With the exception of the Gurley electric gage and the Barrett \& Lawrence hydrochronograph, neither of which was entirely satisfactory, the gages had to have the charts changed weekly. There were many isolated streams, especially in the West, on which records were needed at points where visits were impractical more often than once a month. There was, therefore, an urgent need for a recorder that would operate reliably without attention for a month or longer. Soon after J.C. Stevens took charge of the Columbia River District in 1906, he noticed the daily fluctuations of the mountain streams as a result of alternate melting and freezing of the mountain snows during spring. J.C. Stevens once or twice hired observers to sit up all night and read the gages every hour, in the hope that the time of day [or night] when mean stage occurred could be determined. That hope was not realized, however, because as the snow line retreated with the advance of the season, the maximum stage occurred much later. At the conference in January 1908, J.C. Stevens explained a device for obtaining a record of stage at small expense. A little later he devised an instrument that he exhibited in crude form in Washington, D.C. He described this instrument in a letter [date unknown] to the author thusly:

The idea was merely to determine a mean daily gage height. The float operated a little printing roller that stamped the gage reading in figures whenever a change of 0.05 occurred. These figures were stamped on a narrow strip of blueprint paper. The roll was completely concealed in the dark except where it passed under a little window. The figures were stamped on the white side of the paper. During the daytime, the light would affect the paper but it [the paper] would not be affected at night. When removed, the strip was to be washed in water, and alternate light and dark bands would appear as corresponding to days. The average of the stamped gage readings could be taken as the average for the day.

J.C. Stevens soon found out that such a device would cost as much as a regular recorder and that it was not nearly as good. After resigning from the USGS in 1910, he devoted a considerable part of his time to the design of a so-called continuous recorder, which would operate as long as the weight that drove the clock and recorder could descend without reaching the bottom of the well. Working with Leupold and Volpel of Portland, Oreg., J.C. Stevens designed a continuous recorder that was placed on the market in 1912. This recorder had a horizontal cylinder and was equipped with a device for reversing the motion of the pencil when the limit of the chart was reached. Theoretically, the only uncertainty in the use of this recorder occurs when a peak stage coincides exactly with the point at which the reversal of the pencil motion occurs. J.C. Stevens estimated that the probability of this happening was about 1 in 10,000 (Newsletter, p. 9, July 16, 1915). Two of these recorders were installed by the USGS in 1912, one on the Raquette River at Piercefield, N.Y., and the other on the Chama River at Chama, N. Mex. Early in 1913, the Hawaiian District staff installed three Stevens gages. During the few months of 1913 that are in this period, four more Stevens instruments were installed.

Other types of automatic gages were installed by the USGS or cooperating parties, and the USGS was operating a total of 144 automatic gages at the end of the period. Other organizations, chiefly companies manufacturing new irrigation equipment, installed recorders of different types so that records obtained from a total of 215 stations that were equipped with automatic gages were being published by the 
USGS at the end of the period. At that time, streamflow records were recognized as necessary for irrigation purposes and were therefore more important to local and regional activities in the West than in the East. Consequently, the greater number by far of automatic gaging stations were in the Western States.

Most of the installations were crude, consisting of small box shelters over small wooden wells. Many of the wells were attached to bridge piers or set in the riverbank, and generally open trenches funneled the water to the wells. Covert's so-called "million dollar station" on the Sacandaga River near Hadley, N.Y., is considered to be the beginning of modern installations, but the great advance in installation occurred during the next period. The automatic gage situation, as it was at the end of this period, is indicated by the following extracts from Instruction dated April 24 , 1913:

Both the Stevens and Gurley gages are passing through an experimental stage. They have both been sufficiently tried to demonstrate that they will probably be satisfactory $*^{* *}$. In this connection the Branch is now repenting at leisure for the 40 Barrett \& Lawrence gages which were hastily purchased two years ago.

\section{METHODS}

FIELD.-The development in field methods related chiefly to improving the accuracy of the current-meter measurements. Perhaps the most important of these developments was the gradual substitution of the 0.2 - and 0.8 -depth for the 0.6-depth method of determining mean velocities. During 1906, H.K. Barrows, in his studies of winter measurements, found from a study of the vertical-velocity curves under ice cover that the mean of the 0.2- and 0.8-depth velocities was the mean in the vertical. He then investigated vertical-velocity curves made in open water and found that the curves indicated also that the average coefficient for reducing the mean of the 0.2 - and 0.8 -depth velocities to the mean velocity was 1.00 , with a much smaller range for individual curves than pertained to the 0.6-depth method. It was decided in the Branch, therefore, that the 0.2- and 0.8-depth method should be adopted as standard practice for streams deep enough for that method to be practical. There was some reluctance at first to adopt this method because of the longer time required, but more consistent measurements resulted in its acceptance after its superiority was clearly shown in reports at the January 1908 conference.

Measuring the Ohio River at flood stages, with depths as great as $\mathbf{8 0}$ feet and maximum velocities of 8 feet per second, provided an opportunity to investigate subsurface coefficients on large rivers. A.H. Horton began that work in 1908, devised a reel and boom for handling 100-pound weights, and measured 200 vertical-velocity curves for the stages of the Ohio River and its larger tributaries. He arranged these curves in order of depth and in order of velocity, but in neither arrangement could he detect any trend of change in coefficient. A.H. Horton stated to the author that 0.89 was found to be the average coefficient to reduce subsurface velocities to the mean. With this well-established coefficient, more reliance was then placed on the high-water measurements that were made on practically permanent-bedded eastern streams and computed from subsurface velocities and standard cross sections.

Another development in methods had to do with the computation of the current-meter notes. At the 1908 conference, J.C. Stevens presented a paper showing mathematically that the much simpler method (Stevens, Comparison of formulas for computations of stream discharge, Eng. News, June 25, 1908, p. 682-84) of average-end-areas for both area and velocity determinations was fully as accurate as the modified prismoidal formula that was then in use. The conferees decided to use the simpler method because of the time saved in computations.

At the same conference, loose-leaf notes for field work were discussed, and the conferees learned that several engineers had already been using them on their own initiative. These engineers were so enthusiastic that they easily convinced the others of the advantages, and the conferees voted to abandon the current-meter 
notebooks and level books then in use and to adopt loose-leaf books.

OFFICE.-The only important office change pertained to procedure in the computation of the stream-gaging records. Since the creation of the Division of Hydrography in 1894 , the records had been computed in the Washington, D.C., office, which involved much correspondence between the District and Washington, D.C., office. State cooperation often required the records to be published also by the State, so prompt computation of the records was necessary. It was impossible for the Washington staff, even with its personnel temporarily expanded during the winter months, to compute all the records as soon as desired. To relieve the situation, the records were computed in the District offices, beginning with the 1909 report, and transmitted to Washington, D.C., for review. The review required much less time than the original computations and, although it was occasionally necessary to have records revised, the time that was saved was sufficient to meet the needs of the cooperating officials for their State publications.

The increase in the number of records threw such a burden on the Washington, D.C., office in the preparation of longhand manuscript for the annual report that blueprints began to be used for that purpose in 1910. Apparently LaRue was the first to suggest blueprints. He obtained blueprint paper locally and sent 1 year's records to the Washington, D.C., office already in shape for the report (LaRue, oral commun., ca. 1938). In order to make blueprints possible, the double form known as 9-192, which had previously been printed on both sides of the paper, was changed slightly to eliminate the printing on the back; it was also printed on thin paper. Blueprint copies of the records in this form were used as manuscript for the printer during the remainder of the period.

The blueprint form was also used to meet the ever-increasing demand for unpublished records. The increase in requests was due not only to the greater interest in the records, but also to the fact that by 1910 the publication of the annual reports was about 2 years in arrears. There were so many requests for unpublished records that, about 1911 , the office of the Secretary of the Interior issued an order prohibiting advance records to be furnished except to cooperating officials. Although this order was in effect for 1 year or less, it caused resentment on the part of the public and no little embarrassment to the District engineers.

The blueprints of the records were so satisfactory that, within a year or 2 , it became the custom to blueprint all forms used in the computation of the records. The blueprint, however, necessitated a change in the crosssection sheets that were used for rating curves. Until about 1904 , bound books that had cross sections printed on both sides of the page had been used, but when the loose-leaf system was adopted, the cross-section sheets of different sizes obtainable from regular commercial stock were substituted. The paper of this commercial stock was so thick that the rating curves on them could not be blueprinted. Accordingly, in 1911 , sheets 10 by 15 inches printed on thin paper were purchased from commercial stocks (G.C. Stevens, written commun., ca. 1938).

By the latter part of 1912, the space for files in the Washington, D.C., office had become so crowded that it was no longer possible to file the gage-height records, and instructions were issued to retain such records in the District offices until further space was provided in Washington. Two years later, the congestion became so great that the current-meter notes also were ordered held in the District offices.

\section{AnNual Reports}

The wholesale change of names that took place at the beginning of the period extended even to the titles of the annual reports containing the streamflow records. The report for 1906 was changed from "Report of progress of stream measurements" to "Surface Water Supply of --" with the name of the particular basin. Leighton felt that "surface water supply" meant more to the layman than "report of progress of stream measurements." This title has been retained since that time.

The practice of rating the records for accuracy was adopted in the same year. It had been the custom to withhold from publication, 
sometimes for several years, records whose accuracy was not considered satisfactory. This caused considerable criticism by users of the records and, in an attempt to determine the most satisfactory procedure, Leighton discussed the subject with a number of leading engineers. John R. Freeman was of the opinion that the interests of the engineering profession would be best served if the records, instead of being withheld, were published with a statement of probable accuracy. By so doing, the records would be available and the users could make their own interpretations on the basis of the accuracy rating. That policy was adopted in the 1906 annual report. A further addition was made in the following year when general statements regarding accuracy, reliability, and use of the data were presented in the introduction.

Leighton used every possible method to stress the value of streamflow records, one of which was to insert in each station description in the 1907-8 report a statement regarding the chief use of the record. In the 1909 report, those specific statements were abandoned, but nearly a page and a half of the introduction was devoted to a discussion of the purposes of stream gaging, stressing the value of the records in connection with navigation, irrigation, domestic water supply, water power, drainage of swamps and overflow lands, and flood prevention. Leighton wrote this section of the introduction.

Users of streamflow records were often users also of Weather Bureau records, and it was felt that the users needs would be better served if both organizations grouped their records into the same regional divisions. Accordingly, the USGS and the Weather Bureau agreed, in 1909, to divide the country into the same 12 regions and to group their records by those regions.

The records for the 2-year period 1907-8 were the first so grouped by the USGS. These were the only 2 years combined in one report during the present period and this action was taken as a matter of expediency. The waterpower census prepared by the USGS during winter and spring 1908, as a result of the conservation movement, took up so much of the Branch personnel's time that it was impossible to prepare the 1907 report; it was, therefore, combined with that for 1908 in the following year.
The first major change in the form of publication of records, the substitution of daily discharges for the rating tables, was made in the 1909 reports. The change was in recognition of the increased and more intensive use that was then made of the records, particularly for water power-the new tables showed directly the daily fluctuations in discharge and the periods of deficient flow. A further change was made in the 1911 reports in which the station descriptions were reduced to essential facts and arranged under subheadings. The locations of stations in States under the land-office system of surveys were described by section, township, and range numbers at the request of the Land Classification Board.

One more change made during this period in the publication of streamflow records was the substitution of the climatic year for the calendar year. Engineers frequently make comparisons between precipitation and runoff, and it was believed that the calendar year was not the best unit of time for such comparisons. Engineers in all parts of the country were asked for statements as to the time when ground water was at its lowest and, therefore, the effects of carry-over storage would be a minimum. The replies indicated that the date fluctuated from August to November in different parts of the country. Because it is unwise to use more than one climatic year, September 30 was selected as the best compromise ending for a climatic year. Part XII of the 1911 reports (WSP 312, 1911) was the first report published on the new basis. This arrangement was extended gradually to the other parts of the annual report and by 1914 , all records were published on the climatic-year basis. Whereas the uniform grouping of stations by regions adopted by the USGS and the Weather Bureau facilitated the use of records, the adoption of the climatic year by the USGS had just the opposite effect, which was not corrected until many years later.

At about the time when the climatic year was being considered, Henry Gannett of the Topographic Branch had completed a study of precipitation and runoff, concluding that in regions where the mean annual precipitation was less than 20 inches, there was no reasonably uniform rule of the relation of runoff to rainfall; that is to say, because 
transpiration, evaporation, and percolation amounted to as much as 20 inches in such regions, the quantity of runoff depended on rates of precipitation and of melting of snow and not on the amount of annual precipitation. Instructions, therefore, were issued on March 17, 1913, that figures of runoff per square mile would not be published for areas where mean annual precipitation was less than 20 inches.

\section{WINTER RECORDS}

During summer 1906, Barrows studied the ice measurements that had been made during the previous 5 years, particularly the shape of vertical-velocity curves both under ice and in open water. He found that the open-water curve was approximately a parabola with the axis horizontal, and that in accordance with the properties of that curve, the mean of the ordinates at 0.2 - and 0.8 -depths was close to the mean ordinate of the curve. He found also that although the curves under ice differed widely in shape from open-water curves, they also were approximately parabolic in form and that the mean of the ordinates at 0.2 - and 0.8-depths for 46 curves was 1.002 of the mean velocity, with a range in coefficients from 0.98 to 1.04 , with one value only greater than 1.02 (WSP 187, p. 82-88, 1907). The coefficient to reduce the mid-depth velocity to the mean was found to be 0.878 , with a range from 0.82 to 0.92 .

The recommendation for future winter work permitted the use of either the 0.2 or 0.8 -depth method or the mid-depth method, with preference for the former. Measuring at least once a week, the average thickness of the ice as well as gage heights to the water surface was stressed. It was believed that ice-period rating curves could be drawn, referenced either to the underside of the ice or to the water surface, and that the discharge could be computed for the available gage heights. During this period, more attention was paid to winter records than previously, and attempts were made to follow the recommended procedure. Funds, however, were limited and the cost of making ice measurements was relatively high, so the winter records obtained were little better than intelligent estimates. A common method was to estimate the discharge from one or two measurements of discharge under the ice and to compare the estimates with records obtained at power dams or at stations on the same or similar streams that were not affected by ice. Apparently rating curves for ice-covered streams were little used because the method did not then seem to be practical.

Early in 1906, E.F. Chandler began winter measurements on the Red River at Grand Forks, N. Dak., and on one or two neighboring streams. He used student help and measurements were therefore obtained more frequently than was practical in other districts. E.F. Chandler was a natural investigator. He developed his own ideas from the results obtained, and his ideas regarding methods to be used in computing winter records were contrary to the instructions then in use. Regarding the accuracy of his methods, he wrote to the author, that

Of course many other field men in the northern range of States were developing methods ${ }^{* *} *$ at the same time. But except one man a single winter on the Yukon in Alaska, they credited me with having the most extreme winter conditions here. And most of the men would have only one or two seasons at a place and then be transferred, whereas, I was watching the same station year after year, and thus able to decide whether my conclusions were regularly applicable, or merely the accidental and fortuitous operation of nature in one single winter.

The principal method developed by E.F. Chandler was an adaptation of the Stout method for shifting channels and correction of gage heights of discharge measurements to make them plot on the open-water curve, and the preparation of a table of corrections to be applied to the gage heights that were recorded once or twice a week. E.F. Chandler computed discharges corresponding to the observed gage heights by using these gage-height correction tables and by making comparisons with temperature records. While this method was being developed and before it was given official approval, E.F. Chandler published only mean monthly discharges for the winter months. During winters 1911-12 and 1912-13, W.G. Hoyt, then District engineer in Minnesota, made a 
study of the Chandler method in connection with winter records for his own District.

While working in the Minnesota District during winter 1910-11, C.R. Adams studied flow under ice and concluded (Determination of streamflow during the frozen season, Eng. News, Feb. 2, 1911, p. 124-26) that if the control were open, there would be no backwater at the station even if the stream at the gage was completely covered with ice. The author believes that C.R. Adams was the first to call attention to that important fact.

\section{Control}

The first reference to "control" in an annual report was in 1906. The following paragraph was contained in the station description for Ocmulgee River at Pittman's Ferry near Jackson, Ga. (WSP 204, p. 37, 1907):

The section is deep at the measuring point and may change considerably owing to the filling of the bed, but the permanent rock shoal about 400 feet below will control the height of the water at the gage.

After a few measurements had been made at this station established May 18, 1906, M.R. Hall noticed that the measurements defined a rating curve that did not appear to change, even though the cross section at the place of measurement near the gage was subject to excessive scour and fill. The situation so puzzled him that he decided to investigate. Accordingly, he explored the stream channel below the station and found a permanent ledge of rock that controlled the height of water at the station in accordance with the amount of flow (M.R. Hall, oral commun., ca. 1938). Starting with the known conditions at this station, he investigated in 1907 all of his stations and found that those with permanent rating curves were above ledge rock in the streambed, and those with shifting curves had no ledge rock below them. It was then apparent that the discharge at a rock ledge must always be the same for the same gage height, and that this condition must hold true for any upstream section that was within its influence.

Further light on controls was shed by the behavior of the rating curve for Flint River near
Woodbury, Ga. After remaining permanent for several years, it suddenly "went to pieces," as M.R. Hall expressed it. An examination of the streambed led to the discovery that a fish trap had been constructed in a narrow section of the channel some distance downstream. The resulting artificial contraction of the channel "drowned out" the natural control and caused backwater at the station. As the trap gradually washed away, the contraction lessened and the discharge measurements plotted closer to the original rating curve. Finally, with the complete removal of the obstruction, the measurements again plotted to that original curve.

The term "control" came into use gradually, and it was not until 1913 that regular mention of it was included in the station descriptions published in the annual reports. The idea of multiple controls with the possibility of a reversal in the rating curve was only dimly recognized before the full function of a control was understood. In a discussion of rating curves during the days of the Irrigation Survey, F.H. Newell called attention to the possibility that a curve might reverse at the upper end as a result of the ponding of water above a constriction of the channel or above an obstruction, thus causing the discharge to increase at a less rapid rate than at lower stages. But he stated that such a condition had not actually been found (USGS 11th ann. rept., pt. 2, p. 20-21, 1891).

A study of the area curve made during the preceding period showed that overhanging banks would cause a reversal in the area curve, and that a reversal might also occur in the rating curve. No station with overhanging banks was found, but a series of measurements made in 1907 on Souris (Mouse) River at Minot, N. Dak., showed a decided reversal in the rating curve. The channel below the station was narrow and winding and the banks were covered with a thick, bushy growth of trees that hung over the channel on each side, producing the effect of overhanging banks and indicating an apparently logical reason for the reversal in the curve. A reversal was perhaps first recognized in 1906 in the rating curve for East Fork White River at Shoals, Ind. Here the reversal was believed to be caused by the contraction of section due to a railroad bridge a short distance downstream (G.C. Stevens, written commun., ca. 1938). This contraction was increased by debris lodged on the piers of the bridge. 
The instances of observed reversals were so few, however, that the concept of multiple controls was not considered during the present period. As so little was known about reversals, the accuracy of measurements indicating such conditions was in doubt. That was one reason why Bolster insisted on a high degree of accuracy in discharge measurements even though that might require rising at 4 a.m. (Bolster, written commun., ca. 1938).

\section{PoINT OF Zero Flow}

It was sometimes necessary to extend the rating curve below the lowest measurement in order to estimate the low-water discharge and, not infrequently, embarrassment to the Survey was considerable when subsequent low-water measurements showed such extensions to have been erroneous. This was particularly true on streams used for power where the low-water flow was extremely important. When the idea of control became established, Bolster conceived the idea that if the gage height of the lowest point in the control were known, which would be the point of zero flow, the lowest possible point of the curve would thusly be determined as long as the control itself remained unchanged. With that idea in mind, he took a level with him on his trip through the West in 1910 and surveyed the cross sections at the control whenever possible in order to determine the point of zero flow.

With the information thus available, it was possible to extend the lower part of the rating curves with more confidence and accuracy. Gradually, the determination of the point of zero flow became a part of the regular procedure when new gaging stations were established. H.J. Jackson, who was a stickler for precision, defined the point of zero flow as the low point in the locus of high points in the transverse cross section below the gage (A.H. Horton, oral commun., ca. 1938).

\section{Conferences}

During the first 2 years of the present period, no thought was apparently given to bringing the district engineers to Washington, D.C., for conferences where problems relative to the work of the Branch were discussed. The last conference of Reclamation Service engineers had been held January 9-14, 1905, and proved so fruitful in the presentation and discussion of new ideas that the results contributed considerably to subsequent improvements. The Water Resources Branch was highly decentralized so far as its stream-gaging activities were concerned. District engineers with permanent field headquarters away from Washington, D.C., had few personal contacts with each other or with Washington, and it was highly desirable that conferences be held so new ideas could be freely exchanged and desirable improvements in methods and equipment could be discussed and agreed on.

By 1907 , so many district engineers had changed jobs that few of those who remained had attended the 1905 conference. Therefore, it was felt that in spite of the small appropriations, another conference would be well worth the cost of bringing the district engineers to Washington, D.C., for a week or more. Accordingly, the first general conference of the USGS district engineers was held January 20-26, 1908. J.C. Hoyt, moreso than Leighton, was responsible for this conference because he was in direct charge of the stream gaging. As Leighton wrote to the author:

The conferences of district engineers were all inspired by John Hoyt. Whatsoever of credit there is to be given should go to John, and all the discredit, if any, should come to me. If I ever made a helpful suggestion concerning programs, it was not sufficiently important to remember. John used to bring me the program and I would approve and tell him to carry on. Beyond presiding over such sessions as John thought appropriate, I did little except to sit in a back seat and ask fool questions for the sole purpose of provoking the fellows into debate. Bill Freeman always rose to the bait. In fact, he could nearly always be depended upon to take the off side in any discussion. John Stevens always led off with the highbrow stuff, and then Bert Horton would back the Ohio River against any stream in the country. 
None of the fellows from the cold northern districts liked our Washington winters. I remember that if the thermometer descended to around 32 degrees during the conference periods, Lamb would want to go back to Helena, Montana, where the temperature was likely to be minus 20 , so that he could get warm again. Then there was Bill Hardy. As I recall, he came to two conferences, and the ladies in the office would invite him to luncheon so that he could tell them bear stories. They liked especially well the story about how he trapped the grizzly bear by the seat of his pants-I mean the bear's pants.

The exchange of ideas was usually followed by a more or less formal vote, the result of which was expected to become the policy of the Branch concerning the particular subject under consideration. The changes resulting from the conferences are described in the two earlier sections, Equipment and Methods. The program for the first conference was not actually made up until after the district engineers arrived. All were asked for suggestions and, as a rule, each man who suggested a topic immediately had it assigned to him.

As might be expected from Leighton's flair for publicity, particular attention was paid to that subject at the 1908 conference. A committee consisting of Mendenhall, Barrows, and Follansbee was appointed to make recommendations concerning publicity. The recommendations are as pertinent nearly 30 years later as they were then. Because the subject has not been considered formally in recent years, the recommendations of the committee, which were approved as expressing the policy of the Branch, are presented herewith:

It has long been recognized that, as an official organization supported by appropriation from the National Treasury, it is the duty of the Geological Survey and of the Water Resources Branch, as an integral part of the Survey, to make available to the public, in the most prompt and effective ways possible, the results of its investigations. Failure to do this is failure in duty and it results in failure of public support. As we believe firmly in the value of our researches, we believe also that a proper acquaintance with them on the part of the public will secure the support necessary for their continuance. It, therefore, becomes a double duty, a duty to our organization and to the people, to secure publicity in the most effective ways. To this end we recommend:

1st: That the press bulletins, which have been successfully used in the past, be continued and that no effort be spared to make them effective and to secure for them a general circulation in the technical and popular press.

2d: That the functions of the district offices, as centers of publicity, be even more fully recognized and developed than in the past, both by the district engineers and the central office, because these local offices, by reason of their general distribution throughout the United States, and the close relations that necessarily exist between them and the many engineering and public interests of the several localities, are most advantageously situated to attract local interests and to respond to local needs and thus to command, in the aggregate, a large share of public attention. Their effectiveness may be increased:

A. By making them local centers for the distribution of publications and of Survey information. Lists should be kept in each district office of newspapers, engineers, and organizations that will be interested in the work.

B. By the participation of the district engineers in the deliberations of local technical and engineering organizations.

C. By the distribution from these offices to the local press and to local engineers of results of work, other than formal publications, that may be locally useful or interesting.

D. By the delivery of lectures, illustrated or not, at appropriate times and places by the district officer or by a representative from the central office.

E. By impressing upon employees the necessity of unfailing courtesy, at all times, in their relations with the public. 
3d: That discredited publicity methods be avoided everywhere as far as possible. Among these discredited methods may be mentioned:

A. General and indiscriminate lobbying and solicitations for support.

B. Press bulletins and news items which, instead of being simple, frank statements of facts, contain more or less completely disguised special pleas for support.

C. The introduction of addresses or lectures, merely for the sake of advertising the work, into the programs of meetings where they are obviously out of place.

D. The securing of undue prominence for the individual doing the work rather than for the work itself. This is not intended to result in the failure to give proper credit to the individual but rather to avoid merely personal advertisement when it is the work of the Branch as an organization that is to be emphasized.

4th: That the greatest care be taken in correspondence to avoid offensive, brusque, and unreasonable attitudes. This is a matter which, while often ignored, is of the greatest importance and has a most direct bearing upon the standing of the organization. Just as the Survey will be judged by its representatives who are personally known, so will it be judged and its standing fixed in the much wider circle, whose only relations with it are through correspondence, by the character of that correspondence. Simple, unpretentious courtesy in all relations is one of the most effective means by which high standing for an individual or an organization is secured.

It is recognized that these suggestions are in the main nothing more than attempts to define and recommend such action as will be prompted by good judgment and good taste and high personal and public ideals and to eliminate the possibility of action that has any other basis. It is hoped also that they may tend to promote unity of method throughout the Branch.
The next conference was held on January 914,1911 , and the last during this period was held on January $6-13,1913$. The need for a field manual was discussed at the 1913 conference because stream-gaging methods and equipment had changed so much that the manual prepared 10 years previously (WSP 94, 1904) was obsolete. Six committees were appointed to prepare sections of the proposed manual. Only two of these committees functioned, but their labors resulted in the higher level of standardized station equipment and in a new method for computing winter records.

\section{Division OF Water Utilization}

The creation of the Water Utilization Division in 1910 resulted directly from the conservation movement. Just before Interior Secretary James R. Garfield resigned from the DOI in the closing days of the Roosevelt Administration (March 1909) he agreed with F.H. Newell and Pinchot, "the conservation triumvirate," on a plan to withdraw from entry by administrative orders all power sites in the public domain. This was immediately done in the form of blanket withdrawals selected by the Reclamation Service and pending field examinations. The withdrawals of large areas along the streams aroused much criticism in the West, just as similar withdrawals under the Irrigation Survey had done years earlier.

Richard A. Ballinger became Secretary of the Interior on March 4, 1909, and cancelled the withdrawals within a few weeks. Ballinger believed that Garfieid had exceeded his authority. On April 23, 1909, Ballinger directed the USGS to review the situation and recommend water-power withdrawals at specific sites (Herman Stabler, oral commun., ca. 1938). In order to act as quickly as possible, the USGS obtained from the General Land Office records of the status of all lands contained in the original withdrawals and selected therefrom only such non-patented land as might, by any stretch of imagination, be considered to have value for water power (George Otis Smith, oral commun., ca. 1938). Lands that had not previously been withdrawn were now withdrawn. Field 
examinations were made to determine more exactly the water-power value of these lands, and both Leighton and J.C. Hoyt conducted that work during summer and fall 1909.

Realizing that the USGS had accumulated much information pertinent to considering applications for Carey Act segregations and rights-of-way for irrigation and water power, Secretary Ballinger directed the General Land Office in fall 1909 to refer to the USGS all applications for reports thereof from the special agents. These applications were sent to the district engineers for field examination.

The next step leading to the creation of the Water Utilization Division was the passage of the Pickett Act (36 Stat. L. 2847) on June 25, 1910, Section 1 of which provided:

That the President may, at any time in his discretion, temporarily withdraw from settlement, location, sale or entry, any of the public lands of the United States, including the District of Alaska, and reserve the same for water-power sites, irrigation, classification of lands, or other public purposes to be specified in the orders of withdrawals, and such withdrawals or reservations shall remain in force until revoked by him or by an Act of Congress.

This authorization to classify and designate public lands for specific withdrawals significantly increased the workload of the USGS personnel. In order to meet this demand, Leighton created the Division of Water Utilization when the increased stream-gaging appropriation became available in July 1910 . It was the duty of the Division personnel to conduct investigations as needed for the classification of lands for water-power, irrigation, and reservoir sites. In describing the new Division, Leighton stated (USGS 32d ann. rept., p. 125-6, 1911):

The investigation of water-power sites, rights-of-way, et cetera, was first performed by the engineers of the division of surface waters in connection with their measurements of streamflow. This plan, however, resulted in a division of interest in both kinds of work, so that neither received the attention that it required, even to the extent of the small allotments available for the purpose. A new division was therefore organized, the members of which gave their entire time to the land-classification work.

Leighton took charge of the new division and was assisted by J.C. Hoyt during the remainder of 1910. LaRue, the first engineer assigned fulltime to the division early in 1911, had previously been district engineer in the Great Basin District. Carey Act projects had possibly been more actively promoted in Idaho than in any other State, and LaRue had conducted more investigations than any other district engineer. He personally knew of many Carey Act projects that were based on totally inadequate knowledge of available water supply and some in which available USGS records of water supply and been ignored (these projects were advertised as having been approved by the United States Government). LaRue (oral commun., date unknown) called Leighton's attention to this situation and suggested that such projects should be investigated and the sale of bonds prohibited. He was, therefore, the logical member of the Branch to be assigned to the new division. Murphy was the next full-time member of the division, detailed to it upon completion of the mining-debris investigation in 1911.

The classification of public lands concerned minerals as well as water, and other branches of the USGS, chiefly the Geologic Branch, were therefore involved. The Land Classification Board of the Geologic Branch acted as a clearing house for all branches. On January 1, 1911 , Mendenhall became chairman of the Board and its functions increased. On March 1, 1911, Grover was appointed chief engineer on his return to the USGS, his civil service status having been restored by Executive Order of President Taft. The Land Classification Board received full Branch status on May 1, 1912, ranking equally with Geology, Topography, and Water Resources. The new Branch had a number of divisions, but only one, the Division of Hydrographic Classification with Grover as chief, was concerned with the work of the Water Utilization Division. The Division was further subdivided into a section of water power under W.B. Heroy, and a section of irrigation under Herman Stabler. 


\section{River SuRveys}

River surveys by Water Resources Branch personnel ended during this period. Subsequent surveys were conducted by personnel of the Topographic Branch. Beginning with fiscal year 1911, all surveys except those in Minnesota and one in Tennessee were conducted by staff of the Topographic Branch.

The river surveys in Maine, which began in 1903, continued until 1909; those in Wisconsin, which began in 1905, continued until 1908 . Both surveys have been described in the "Hydrographic Branch" (see pt. VIII). New surveys were conducted in Vermont, Washington, Minnesota, and Tennessee.

\section{VERMONT}

Cooperation with Vermont, which began in 1909 , included river surveys as a part of the program of water-resources investigations, and this work began during summer 1910. Because only a small amount of money was available for the investigations, the expenditures for river surveys were limited to $\$ 750$, including the maintenance of the temporary gaging stations that were established for the river surveys. Covert, who was in charge of the Vermont work, selected Butterfield, who had previously worked on the Maine surveys, to conduct the Vermont surveys. The surveys were conducted by a party of two who used a plane table, magnetic bearings, and elevations that were crosschecked by reference to railroad benchmarks. As indicated in the unpublished 1910 Winooski River drainage basin surveys by Butterfield and G.M. Brett, no topography was mapped except at dam sites.

Fifty-one miles of the Winooski River from Richmond to Mollys Falls, 27 miles of the Waterbury and Mad Rivers, and six ponds on tributaries to these streams were surveyed. The total field and office costs per mile ranged from $\$ 5.35$ for the Mad River to $\$ 6.73$ for the Winooski River. Maps of these surveys were published in WSP 424 in 1917.

\section{WASHINGTON}

Water power is one of the great natural resources in the State of Washington and, when the cooperative agreement was signed on May 1, 1909, the signers decided that some rivers would be studied relative to water power, starting in the southern part of the State in the Cascade Range. The studies included river surveys to determine fall (the vertical distance that water descends in an identified reach of a stream). Two parties were organized with McGlashan as chief of one of them. Because of the rugged terrain of the drainage areas of the rivers to be surveyed, camp supplies were transported by pack horses. Accordingly, each party had a man who served as cook and packer and four pack horses to transport the two small tents and camp equipment.

All distances were measured by stadia and, because the falls were great, elevations were determined by vertical angles. Traverses were run by magnetic bearings except on the Klickitat and Lewis Rivers where local magnetic fluctuations made azimuth control necessary (these traverses were checked by solar observations). Ties were made to section corners wherever possible and the topography along the banks was mapped continuously. McGlashan wrote the author that rattlesnakes abounded and as many as 20 were killed in one day. The surveys lasted for 2 months and 248 miles of river were surveyed at an average field and office cost of $\$ 16.50$ per mile. Maps of these surveys were published in WSP 253 in 1910.

\section{Minnesota}

The cooperative agreement with Minnesota, signed on May 15, 1909, provided for a comprehensive investigation including river and reservoir surveys. When considering the method to be used in the river surveys, the author (who was in charge from 1909 to 1911 inclusive) was told by the cooperating State official that because the cost of the surveys in Wisconsin had been less than $\$ 10$ per mile, he expected that the cost of the Minnesota surveys would not exceed that figure. Having spent one season on the Lake Survey, the author was accustomed to the transit and stadia method with field sketching, and adopted it for the Minnesota surveys. A transit with a sensitive bubble 
was used as a level to obtain elevations of the main traverse, and the azimuth was obtained by magnetic bearings. The bearings were checked every few miles by observations on Polaris or the Sun. Ties were made to section lines and elevations were checked against railroad benchmarks.

The river surveys were started by two parties in fall 1909. Each party consisted of a topographer, a transitman, and two rodmen. Horses were used at first to transport the party to and from the field and a teamster was included in the party, but transportation by canoe was more practical and the teams later were abandoned. For the first survey, that of Rum River, temporary auxiliary gages were set at intervals of a few miles to measure changes in river stage during the survey in order to reduce all water surfaces to a medium stage. The changes in stage were found to be so slight, however, that auxiliary gages were not used in later surveys; the regular stream gages served all needs.

An experimental survey of the Red Lake River was conducted during the following winter because it was believed that the greater speed obtained by working on the ice would offset the delays due to temperature and storms. When the temperature dropped much lower than 30 degrees below zero, however, it was soon apparent that it was advisable to suspend operations. After a little experience, the time for suspension could be determined by the presence of "sun dogs" and frost particles in the air. The country was heavily timbered and so sparsely settled that camping was necessary. Accordingly, the party was equipped with most-essential sleeping bags as well as toboggans and snowshoes. Shelter was easily and quickly obtained by felling a few small trees and leaning them against large trees. The cost of the winter survey compared favorably with those surveys conducted during the open season, and several other winter surveys were conducted during the next 2 years.

From 1909 to 1912,26 rivers with a total length of 1,454 miles were surveyed. Streams draining the plateau region north of Lake Superior, which had an elevation of from 600 to 800 feet above that of the lake, had an average fall of 100 feet per mile. Most
Minnesota streams, however, had much less fall. The surveys were conducted by field assistants under the supervision of the author until December 1911 when he was succeeded as district engineer by W.G. Hoyt. The field costs were generally considerably less than the imposed limit of $\$ 10$ per mile.

Lake Mille Lacs, with an area of 207 square miles, and the upper and lower Red Lakes, with a combined area of 441 square miles, were surveyed as possible reservoir sites. In 1909, managers in the city of Minneapolis were considering Lake Mille Lacs as a possible source of water supply, and the State Board of Health cooperated in the survey of the lake to the extent of paying expenses in the amount of about $\$ 500$. While the sanitary feature of the proposed water supply was the ostensible reason for cooperation, the real reason was the desire of the State Board of Health to resume cooperative relations with the USGS in quality-of-water investigations conducted during 1906 and 1907.

The survey of the Red Lakes was conducted relative to increasing water-power development and to improving navigation on the Red River. On this survey, a unique arrangement was made for maintaining and transporting one of the two parties. The Indian Service, in its management of the Red Lake Indian Reservation, maintained a flat-bottom sternwheel steamer there to transport wood across the lake. The steamer was kept in service continuously although it was used only intermittently. It had ample sleeping accommodations for one party, so the Indian Service agreed to supply and transport the party surveying the lower lake for $\$ 8$ per day. The other party was not so fortunate and they had to stay with settlers and transport themselves in canoes. The resulting maps of the river and reservoir surveys, 98 sheets in all, were published in 1912 by the State Drainage Commission as Report of the Water Resources Investigation of Minnesota, 1909-12 (atlas).

\section{TeNNESSEE}

The agreement signed with the State geologist of Tennessee in November 1911 provided for a survey of Doe River to be made before the end of 1911 when the State funds would lapse. Accordingly, A.H. Horton organized a 
party of four consisting of junior engineer C.T. Bailey as recorder and chief of party, a transitman, and two rodmen. The transit and stadia method with field sketching was used and elevations were determined generally by vertical angles. Wherever possible, the transit was used as a level, but the fall was so great that this could be done only in a few instances. Azimuth was determined and checked by solar observation. The water surfaces, banks of the river, roads, and railroads were located by stadia shots, and the bank topography was sketched in to the elevation of the railroad grade.

The survey started December 13 and finished December 27, during which time 21 miles of river from Wilson Creek to Elizabethton were surveyed at a field cost of $\$ 12$ per mile. The resulting map and profile were published in 1914 by the State geologist as State Geological Survey Bulletin 17 entitled "The Water Powers of Tennessee." Transportation was a unique feature of the work. The railroad paralleled the river and train schedules were such that, by the special dispensation of the railroad management, the survey party was dropped off or picked up at the desired place each day. This is the only instance known to the author of a river survey with travel by train.

\section{Special INVESTigations}

\section{Mining Debris}

The investigation of mining debris had its beginning in a set of resolutions sent by the California Miners' Association to President Theodore Roosevelt on December 8, 1904. The customary whereases recited, among other things, that those engaged in hydraulic mining had been restrained by the Federal courts from discharging boulders, gravel, sand, clay, and other matters in suspension into the navigable waters of the State, thereby destroying that industry, that it was believed that by a rational application of the laws governing the deposition of sediment from torrential streams, hydraulic mining debris could be transported without prejudice to other interests, and that the question was primarily a geologic one to be solved only by geologists who had devoted their lives to the study of erosion and sedimentation in mountain as well as valley regions. The resolution itself was:

Resolved by the California Miners'
Association, That we beg you, as Presi-
dent of the United States, to assist in the
solution of this problem affecting all the
interests of a great commonwealth, by
instructing the Director of the United
States Geological Survey, through the
Secretary of the Interior, as part of his
study of the storage of flood waters and
the reclamation of waste land, to under-
take a particular study of those portions
of the Sacramento and San Joaquin
valleys affected by the detritus from tor-
rential streams.

The resolution stated also that the particular points to be considered were (1) the discovery of the most favorable sites for reservoirs for preventing floods and for storing water for different industries including mining, and (2) the selection of tracts of wasteland on which the detritus could be deposited (G.K. Gilbert, Prof. Paper 105, p. 13, 1917).

On receipt of the resolutions, the President directed the USGS to comply with the request. At that time, the Reclamation Service still was a part of the Hydrographic Branch and was equipped to study practical engineering problems connected with the control of surface waters, and the Division of Hydrography was collecting streamflow records. Thus, it was logical to connect the Hydrographic Branch with the desired investigation, which was started in April 1905 by personnel of the Geologic Branch. Gilbert, perhaps the most eminent USGS scientist at that time, was put in charge.

During the first year, personnel of the Hydrographic Branch did not participate actively. Gilbert devoted his time to a study of the regimen of the Sacramento River and its tributaries relative to the transportation of debris. The first year's work indicated that laboratory studies were needed to investigate the natural laws that govern the water transport of debris. Accordingly, Gilbert asked the Hydrographic Branch for assistance in conducting the proposed experiments. Murphy was the engineer of the branch with the most experience in 
laboratory work and he was detailed in June 1906 to assist Gilbert at Berkeley, Calif., where a special hydraulic laboratory had been installed in quarters provided by the University of California. As Gilbert states (Prof. Paper 86, p. 17, 1914):

In the work of the Berkeley aboratory, capacity for hydraulic traction was compared with discharge, with slope, depth, and width of current, and with fineness of debris; and minor attention was given to velocity and to curvature of channel.

Murphy conducted the actual experiments for 130 combinations of factors. The separate determinations of load and slope numbered nearly 1,200, and those of depth about 900 . The investigation continued until January 1 , 1909. In the course of the experiments, a specially constructed Pitot, or Darcy, current gage was studied. While the laboratory work was in progress, Gilbert devoted considerable time to rough measurements of the pits that had been excavated during past hydraulic mining operations in the Yuba River basin, from which estimates were made of the amount of material removed. He studied also the conditions affecting the debris-filled rivers. Certain relations of the amount of material carried by streams under fluctuating conditions were determined from the laboratory studies. The results of the laboratory phase of the investigations were published as USGS Professional Paper 86 in 1914.

\section{Water-Power Census}

UNDEVELOPED POWER.-When the National Conservation Commission was created for the purpose of inventorying the natural resources of the United States, several government bureaus were called on to furnish information in their particular fields of activities. Thus, the USGS with its records of streamflow, topographic maps, river profiles, and other information including fall of principal streams, was better equipped than any other bureau to inventory undeveloped water power. The Census Bureau had reported the developed power at 10-year intervals, but had made no attempt to estimate the undeveloped power.
After the Conference of Governors in summer 1908, the inventory of undeveloped water power was assigned to the USGS. Thereafter, over a period of about 6 months, the District Office staffs worked under high pressure to make an approximate estimate of the undeveloped water-power resources of the countryan estimate never before attempted in the United States. A profile of each stream large enough to be depicted on general maps was compiled from available elevations as a basis for estimating available heads. Each stream was then divided into sections and the drainage area was measured at the upper and lower ends of each section. In order to determine the available power on a uniform basis, the runoff per square mile was computed (1) for the minimum flow of each stream during the 7-year period 1900-6 so far as records were available, (2) for the assumed maximum development, and (3) for the additional flow that might be obtained from storage.

For estimating the power, Leighton decided to use the mean of the lowest two consecutive 7-day periods in a year as the minimum flow, and the flow that would be assured for 6 months in the year as the basis for estimates of maximum development. In arriving at this 6-months' low, the minimum weekly flow for each month of the year was determined, the minimum weekly flows were arranged according to magnitude, and the sixth value taken as the basis for estimating power, the mean of the sixth values for the years of record being used in each instance in the computations. The appropriate unit-runoff value was applied to the mean drainage area in each section to obtain the flow in the section. In the computation of power, the formula

$$
\mathrm{HP}=\text { sec.-feet } \mathrm{x} \text { fall in feet }
$$

was used, and the power at 80 percent efficiency was thus obtained. The estimate of additional power to be obtained by storage was much more of a hit-or-miss affair and in many instances was a pure guess.

The investigation called for judgment and the personal characteristics of the district engineers had full play, which was particularly true with 
respect to the sizes of streams to be included in the inventory. This situation is indelibly stamped on the author's memory, although he was working at the time on the swamplands investigation. Looking, purely by chance, at the estimates from a district with which he was familiar just as he had completed arrangements to leave on the next day for an 11-weeks' trip, the author noticed that the engineer had omitted many drainage areas of considerable magnitude. He is reminded of the saying of Ling Po, the Chinese sage, (with apologies to the "Catspaw") that "a closed mouth saves much trouble" - the author's comment on the missing estimates resulted in his immediate assignment to the job of supplying them, which delayed his trip at least a week and led to a complete change of his plans.

Finally, in late fall 1908, after many trials and tribulations, the inventory was completed and published as Report of the Natural Conservation Commission, vol. 2, S. Doc. 676 (60th Cong., 2d sess., p. 159-70, 1909). The USGS also published the inventory as WSP 234 in 1909. Crude though the inventory was, it was the only one available and was widely used until it was revised by USGS personnel in 1924.

DEVELOPED POWER.-While the estimate of undeveloped power was being inventoried by the USGS, Leighton and W.M. Steuart of the Census Bureau devised a special form for reporting developed water power, and Steuart sent it to all known operators of water-power plants in the country. In compiling the list of operators, letters of inquiry were addressed to practically all postmasters. Because the Organic Law of the Census Bureau prevented the publication of records for individual plants, only the total installed capacities by major drainage basins in each State were published (WSP 234, p. 32-45, 1909).

In 1911, the Land Classification Board of the USGS, in classifying public lands with respect to water power, needed descriptions of the individual water-power plants, and was unable to obtain such descriptions from the Census Bureau. The only recourse was an independent census by the USGS and the district engineers were instructed to obtain the information promptly for each plant.
Swamp and Overflow Lands

As early as the middle of the last century, attempts had been made to reclaim the swamplands of the southern States, and the so-called Swamp Land Act of 1850 gave to the States the public swamplands within their boundaries for reclaiming, either by drainage or levees. This Act may have set the precedent for the Carey Act passed in 1893, which gave arid public lands to the States if the States reclaimed them. The chief difference in principle between the two acts was that in the Swamp Land Act, the gift of land was outright, whereas in the Carey Act, the gift was contingent on reclamation. Little permanent reclamation of the swamplands was accomplished under the Swamp Land Act, however, because the difficulties were generally too great to be overcome by individual States.

The passage of the Reclamation Act in 1902, which provided for the reclamation of arid lands by the Federal Government, gave impetus to a movement to obtain similar aid for reclaiming swamplands. This movement was aided by the argument that whereas the Reclamation Act was of direct benefit only to the West, a similar swamplands act would aid the East, particularly the Southeast and to a lesser extent the Middle West. An essential difference in the two situations was, however, that the arid lands to be reclaimed were chiefly in Federal ownership, whereas the swamplands were owned either by the States or by individuals. This difference, however, did not dampen the ardor of the advocates of the proposal. The administration of the Reclamation Act had been given to a branch in the USGS, and it was believed that if legislation were enacted to extend Federal aid to the reclamation of swamplands, the precedent established with the Reclamation Act might permit the administration of swamplands reclamation to be given also to the USGS. A study of the problems of swamplands and overflow lands involving some 75 million acres was therefore begun by the USGS to disclose where such lands were situated, the magnitude of the problems of reclamation, and the methods to be used.

In about 1906, the Topographic Branch became involved because reclamation would 
require extensive topographic surveys, and W.C. Hall, a topographer, devoted much time to compiling information on the subject. He died in 1907 and no one else in the branch was available to continue the work. During winter 1907-8, the approaching Conference of Governors gave added impetus to swamplands as a possible type of conservation of natural resources, and Leighton saw an opportunity for the Water Resources Branch to promote their reclamation. Leighton thought that because stream gaging would play an important role in possible reclamation, the Water Resources and Topographic Branches should join in the investigation already started. I was in the Washington office at the time, and was offered the job temporarily of conducting the investigation started by W.C. Hall. I accepted the offer and devoted my time during the remainder of that fiscal year to compiling maps showing the principal swamp areas. Several months later, at about the time of the Governor's Conference in May 1908, I was called to the chief's office and was greeted with the question, "Follansbee, what do you know about swamplands?" I replied that I had been compiling information on the subject and Leighton said, "I have arranged with Topography to set up July first a joint allotment for your salary and expenses to enable you to find out where the swamp and overflow lands are and the nature of the problem." Then, turning to a large wall map, Leighton said, "Here is a map of the United States, go to it." With these vague instructions, the investigation began.

In a one-man investigation, the desired information was obtained for each major area by personal interviews with engineers and others in each locality who were conversant with the situation. Between July 1908 and May 1909, three field trips lasting 26 weeks were made to all large swamp and overflow areas except those on the Pacific Coast. Between trips, the information collected was compiled in Washington, D.C., by the author, both in statistical form and on base maps of the States. This completed the investigation. The only published report, however, was a summary prepared at the request of Henry Gannett and included in the final report of the National Conservation Commission (S. Doc. 676, 60th Cong., 2d sess., p. 361-373, 1909).

\section{White Mountains}

The White Mountains investigations required a higher degree of accuracy than in any previous study of runoff, and the field work and equipment used, particularly automatic gages and artificial controls, marked an advance in the USGS technique. Records of rainfall, snowfall, and snow accumulations, and topographic maps were needed in addition to records of runoff. The maps were a product of the Topographic Branch. Covert planned the hydrographic work and chose the gaging stations because New Hampshire was within his district and he was one of the foremost USGS exponents of thorough reconnaissance before selecting a site for a station. The project was supervised directly from the Washington, D.C., office because of the special nature of the investigation and Leighton's desire to keep in close touch with it. C.R. Adams transferred from the Upper Mississippi River District to be in local charge of the field work; Hartwell transferred from the Great Basin District as office engineer to keep the computations current and to provide supplies for the field camp; and Ms. Marian J. Dickman transferred from the Washington, D.C., office as the project clerk. C.R. Adams was at first assisted in the field by R.A. Smead, a junior engineer appointed for the project, and some half-dozen woodsmen who were familiar with the White Mountains region. Just before the spring break-up, more field men were needed, and junior engineers H.J. Jackson and C.F. Walker transferred from Washington, D.C., and G.H. Canfield was detailed from the Albany, N.Y., office.

Headquarters were established in North Woodstock, N.H., first in the basement of a drug store, and somewhat later in a three-room flat on the second floor of a private residence. The work was started in August 1911 with a thorough reconnaissance by J.C. Hoyt and Covert, and sites were selected for a dozen stations on small streams draining basins that had different types of forest cover. Covert used his own automobile on this trip and this is believed to be the first instance of the use of a car in stream gaging by the USGS. It was evident, however, that not more than seven stations could be operated satisfactorily, so seven were 
installed in the section known as Henry's Woods and equipped with automatic gages, chiefly Gurley electric-printing gages. Because printing gages were unavailable for all stations, a Barrett \& Lawrence hydrochronograph and a Friez gage were also pressed into service. The gages were installed in small shelters that were constructed of rough lumber, and either short intake pipes or open trenches connected the stilling wells with the streams. The charts were set using outside (staff) gages exclusively. Although the shelters were small, they were much more than the simple boxes that had generally been used earlier, and each had a door in the side for access to the chart. The gages were installed under C.R. Adams' direction.

In order to obtain records that were as accurate as possible, C.R. Adams equipped most of the stations with artificial controls that consisted of dams with rectangular cross sections about 3 feet thick, 3 feet high, and 10 feet long with flat crests in the form of $\mathrm{V}$ notches with slopes of about 1 to 3 (Hartwell, written commun., ca. 1938). Two controls were constructed of concrete, the others of timber. It was planned to keep the controls free of ice and to obtain continuous records during the winter months. It was so difficult to make the electric printing gages run on batteries during the severe cold weather and to keep the controls open that C.R. Adams gave up on the continuous records of stage and, instead, made daily current-meter measurements of discharge. For convenience in travel, which was by snowshoes, the field men lived in a log cabin near the field of operations. The winter temperatures were so low that no diurnal fluctuation in flow was noted. The ground was deeply frozen at the beginning of the winter, but the blanketing effect of the deep snow allowed the ground to thaw out gradually and little to no frost remained in it at the time of the spring breakup.

In addition to measuring the runoff, precipitation was measured in a large number of rain gages and with more than a hundred snow stakes. Regarding the snow stakes, Hartwell wrote (ca. 1938):

There were $2 \times 2$ stakes graduated by inches to a height of 66 inches. In many cases the total height of the stake was needed to indicate the accumulated snow covering. These stakes were visited weekly. The snow stakes were put out before the topographic surveys were made. The men attempted to cover the areas evenly by going along streams and at stated intervals going straight up the slope to the probable drainage-area line, setting two or three stakes on the way. After the topographic maps were prepared, one small knob was discovered upon the sides of which were three or four snow stakes within a very few hundred feet of each other. These stakes had been placed by climbing the knob from three different directions. After the map was prepared, this became known as Snow Gage Hill.

In April 1912, G.C. Stevens was detailed to the office part of the investigations and remained until the latter part of May. Early in June when it was obvious that the work would not last much longer, Hartwell transferred to the Albany, N.Y., office.

The investigation continued through summer 1912 and then was discontinued because the Forest Service funds allotted to that work were exhausted. C.R. Adams spent several succeeding months in Washington, D.C., computing the streamflow records, which were good, and attempting to draw conclusions about the effects of forest cover on runoff. Contrary to the optimistic belief that 1 year's records would suffice (which was contrary to the experience of the previous investigation conducted in the White Mountains during 1903-4), no definite conclusions could be reached. Some of the areas were covered with virgin forest, some had been cut over, and others had been denuded by forest fires. A major difficulty in determining the effect of forest cover on runoff was caused by elements other than the forest cover, such as steepness of the slope, exposure to sun and wind, size of the area, nature of the soil, and amount and type of precipitation (R.A. Smead, Trans. Am. Soc., C.E., vol. 99, p. 61-62, 1934). Although an attempt was made to allow for these factors, they still obscured the results and no report was ever published. 


\section{Summary of District Operations}

\section{New England and New York Districts}

New England and New York were separate districts during the years of the Hydrographic Branch, but they were so closely interwoven during the present period that they are here treated as one. On May 1, 1906, R.E. Horton resigned and, because economy was necessary, New York was combined with New England with the work conducted under Barrows' supervision from the Boston, Mass., office. Covert, assistant engineer, retained a suboffice in Utica, N.Y., and conducted the New York field work with one field assistant. Nineteen regular stations were maintained in addition to cooperative stations at dams. F.E. Pressey and Norcross were assistant engineers in New England, and Butterfield, Brett, and C.R. Adams were field assistants employed chiefly on river surveys in Maine. Norcross resigned in 1907 and Dana $M$. Wood was appointed assistant engineer. A further reduction in expenses was necessary in 1907 and, at Leighton's suggestion, Barrows accepted a per-diem appointment for part-time employment and opened an office as consulting engineer. At about the same time, Covert transferred to Alaska.

In fall 1907, additional cooperation with New York, through the State Water Supply Commission, increased the field work in that State, and there was a still further increase in 1908 and 1909. The attempt to operate the increasing number of stations under part-time supervision from Boston, Mass., was unsatisfactory because records related to water power had to be accurate. Leighton found it necessary, therefore, to pay closer attention to the New York gaging stations and to raise the standard of accuracy. Although practically no Federal funds were available at the time, Covert transferred from Utica to Albany, N.Y., in order to obtain, if possible, sufficient State cooperative funds to reestablish the New York District. Fortunately, Walter McCullough, the chief engineer of the State Water Supply Commission, realized that the Commission needed more and better records and that the State would have to pay most of the costs. Accordingly, the Water
Storage Commission increased its cooperation slightly in July 1909 and, in 1910, raised its contribution to $\$ 10,000$, thus putting the New York District on a firm basis.

Barrows resigned in spring 1909 and was succeeded as district engineer by Norcross who had rejoined the USGS. Thus from July 1909 to July 1910, New York and New England were again two separate districts. In July 1910, Norcross transferred to California and the New England (except Maine) and New York Districts were again consolidated, but this time with the district engineer, Covert, in Albany, N.Y., and the suboffice in Boston, Mass.

When the Albany office opened in 1909, Covert was assisted by W.G. Hoyt, junior engineer, and two field assistants. With the addition of the New England District (except Maine) and the gradual expansion of the investigations, increases in personnel were necessary. Canfield transferred from the Great Basin District in 1911, and Hartwell transferred from the White Mountains investigation in 1912 to the position of office engineer. George J. Lyon of Union College, who had previously been a field assistant in Colorado while he was a professor at Colorado College, was given a per-diem appointment and devoted his vacation time to construction. George K. Larrison was detailed to the District for a short time in 1912 until he went to Hawaii.

With funds sufficient to obtain adequate records in New York, Covert repaired the old stations and installed automatic gages. During the present period, he installed five automatic gages in New York and four in Massachusetts. In addition, the White Mountains investigation required the temporary installation of seven gages, making a total of 16 automatic gages installed in the District. The station on the Sacandaga River at Hadley, N.Y., is an example of Covert's care in selecting sites. This river, a flashy but important tributary of the Hudson River, was often jammed with logs. Beginning in 1909, Covert (written commun., ca. 1938) studied the stream over a period of 18 months before selecting the site for the station. Covert also considered artificial controls and the first concrete control was installed in 1912 on the Owasco Lake outlet near Auburn in cooperation 
with the local water company. The design and construction of special weirs for measuring streams draining small areas was another innovation. Current-meter measurements of low flow were not accurate, so Covert, at most sites, installed rectangular weirs that had metal crests with 2-foot notches. These weirs were rated volumetrically for low stages, and a weir formula was used for medium stages.

Cooperation with Vermont began in 1908 , which resulted in the establishment of several gaging stations and surveys of a few rivers. Increased cooperation with Massachusetts in 1912 made it possible to take better care of existing stations and to establish a few additional ones in that State. At the end of the period, 63 stations were being maintained-45 in New York, 12 in Massachusetts, and a total of 6 in Vermont, Connecticut, and New Hampshire.

\section{MaIne District}

Maine was a part of the New England District until late in 1909, and the field work was conducted by F.E. Pressey. The cooperative agreement signed in December 1909 provided that an employee of the USGS should be in immediate charge of the hydrographic investigations. Babb, who was then in the Reclamation Service, wanted an eastern assignment and he transferred to the USGS early in 1910 where he was assigned district engineer with headquarters at Augusta, Maine. F.E. Pressey was his stream-gaging assistant. Sixteen stations were generally maintained. The controls were fairly permanent and the stations well rated, but little field work was conducted. These stations were equipped with either staff or chain gages. In addition, water-power companies furnished records at seven dams. Early in 1913, as a result of the legislative battle over proposed State control of water powers, cooperation was discontinued and thus the USGS was conducting no work in the Maine District at the end of the period.

\section{Middle Atlantic [States] District}

At the beginning of the period, few or no changes were made in the stations. With increasing emphasis on the Ohio River basin, however, additional stations were established in West Virginia in 1907. Expenses had to be reduced because of the reduction in the Federal appropriation at that time, and the Pennsylvania gaging stations were turned over to the Pennsylvania State Water Supply Commission for operation. The Commission furnished the USGS with the discharge measurements and gage heights. Beginning in 1912, complete records were furnished by the Commission. The stations in New Jersey were gradually discontinued. Cooperation with the Forest Service resulted in the establishment and maintenance of two stations in southwestern Virginia, but this cooperation lasted only 1 year before the stations were discontinued. Maryland's cooperation ended in 1909, and six stations in that State were closed.

At the end of the period, only seven stations were being maintained in the Middle Atlantic District. In addition, gage heights for a station on the James River in Virginia were provided by a manufacturing company that had kept the record since 1900, and were published annually. G.C. Stevens, chief of the computing section in Washington, D.C., was in charge of the Middle Atlantic District, and a limited amount of field work was conducted by personnel of the computing section.

\section{South Atlantic [States] District}

At the beginning of the period, M.R. Hall was maintaining 96 stations, chiefly in North and South Carolina, Georgia, Alabama, and Tennessee, with a few each in Florida and Mississippi. He discontinued the numerous benchmark stations that had been maintained previously. During fiscal year 1906, the allotment for this district was $\$ 10,000$, but the reduction in the Branch appropriation for 1907 and again in 1908 reduced the allotments to $\$ 6,850$ (1907) and $\$ 4,900$ (1908). State cooperation was limited to a few hundred dollars annually for payment of gage observers in Georgia and Alabama. The reduction in the USGS allotment would have been felt severely except for a special allotment of $\$ 6,000$ for the 2-year period that was paid by the Forest Service 
for the establishment and maintenance of gaging stations in connection with the purchase of land in the southern Appalachian Mountains. During 1910 , the Branch allotment was $\$ 6,000$ but, from 1911 to 1913 , it was reduced to $\$ 4,000$ annually, even though there had been an increase in the Branch appropriation-which was, however, allotted largely for use in the public land States or in the West.

When the allotment from the Forest Service for the southern Appalachian work became available in May 1907, 38 gaging stations were established in that region, 10 of which were discontinued in the following December. The rest were maintained for different lengths of time until December 1909, when the special allotment seems to have been exhausted. After the discontinuance of these stations, an average of 51 stations was maintained District-wide during the remainder of the period. Except for a long-distance recorder operated by the Weather Bureau on the Tennessee River at Chattanooga, Tenn., and an automatic gage installed early in 1913 by a power company on the Ocmulgee River near Jackson, Ga., the gages in the District were about equally divided between chains and staffs. All measurements were made from either highway or railroad bridges or from boats at ferry cables. Most of the streams were too deep for wading measurements, except those in the mountains on which stations were established for the Forest Service.

During the period of the "Forest Service stations," the District personnel, in addition to M.R. Hall, were Warren E. Hall (who had civil service status) and several field assistants. With the discontinuance of those stations, the only appropriation was the USGS funding (from $\$ 4,000$ to $\$ 6,000$ annually) and the number of personnel had to be reduced. Lamb transferred from California to the South Atlantic District in November 1908 and remained until March 1909, when he transferred to Montana. Until 1912, one assistant was employed, changing at fairly short intervals. M.R. Hall resigned on August 22, 1912, and was succeeded as district engineer by W.E. Hall. After W.E. Hall became district engineer, the South Atlantic District was a one-man District until spring 1913 when a field assistant was again hired.

\section{Chicago District}

Beginning in July 1906, the reduced allotment for the Chicago District caused A.H. Horton, the district engineer, to reduce the number of his gaging stations from 55 to 19 and his assistants to one junior engineer. During this period, E.F. Chandler was maintaining a few stations in the Red River Valley in Minnesota and North Dakota, and he continued to report to A.H. Horton until 1909 when the Minnesota District was created. Thereafter, E.F. Chandler reported to the St. Paul, Minn., office.

With limited funds for field work, A.H. Horton devoted considerable time to a study of the records for stations at dams, chiefly in Michigan, that had been established by R.E. Horton several years previously. The more he dug into those records, the less he liked them. He was able to make discharge measurements at a few stations for comparison with the computed discharges, and found discrepancies ranging up to 30 percent. The obstruction of crests by ice or debris was one of the chief sources of error. The observers had usually reported the length of dam obstructed and had stated that the distances were measured. As a matter of fact, A.H. Horton stated to the author (oral commun., ca. 1938), it had generally been impossible to get onto the dams to make measurements, and the reported "measurements" were merely guesses. Another important source of error was the intermittent use of thin flashboards which would be gradually bent by the water pressure. The height of the flashboards were thus reduced, and this was never taken into account. The few gaging stations were maintained during the remainder of 1906 and until May 1907.

The further reduction in the appropriation for the next fiscal year resulted in the closing of the Chicago District office in May 1907, and A.H. Horton returned to Washington, D.C. Supervision of the few Wisconsin stations was turned over to L.S. Smith. Gray, one of his students who was appointed field assistant, conducted the field work in Wisconsin and to a limited extent in the Northern Peninsula of Michigan. The remaining stations, for which the gage observers were paid by power companies or other interested organizations, were 
maintained but with little or no field work by the USGS. Long-range nominal supervision was provided by A.H. Horton from Washington, D.C.

The creation of the Ohio River District in May 1908, and of the New York and Minnesota Districts in 1909, each of which took over some stations previously in the Chicago District, definitely caused the closing of the Chicago District. Most of the Wisconsin stations were discontinued in March 1909 when the river surveys were completed and funds were no longer available for gaging stations.

\section{Ohio River District}

Cincinnati was first chosen because of its central location as the headquarters for the Ohio River District when it was created in May 1908. A.H. Horton could find no available quarters in the Cincinnati Federal building, so he went across the Ohio River and obtained space in the Newport, Ky., Post Office building and established the District office there.

The U.S. Weather Bureau had for many years recorded gage heights along the Ohio River and A.H. Horton made measurements at several of these stations. The chief area studied in the Ohio River basin, however, was the New River-Kanawha River basin in West Virginia, Virginia, and North Carolina, where water power was of considerable interest and was being developed. One station had been maintained in that basin since 1895, and 22 new ones were established.

Measurement of the Ohio River, especially in flood, which involved depths of 80 feet and velocities of 8 feet per second, presented new problems because USGS engineers had had little experience in making measurements under such conditions. A.H. Horton was able to use a reel and boom to handle a 75-pound weight from the high bridges that spanned the Ohio River in order to measure many vertical-velocity curves from which the coefficient to reduce the subsurface velocity to the mean was determined. Discharge measurements were made usually by the 0.2 - and 0.8 -depth method. Because it was impossible to keep the meter from swinging downstream at the greater depths even with the 75-pound weight, the 0.8-depth measured along the general line from the water surface to the point at which the meter came to rest in the river bed was considered to be 0.8 of the vertical depth. Depths were obtained from the standard cross sections.

A.H. Horton thought that the navigation dams on the Ohio River and its principal tributaries would be good sites for gaging stations, especially since the Army engineers had for many years recorded the depth of water there. His only doubt related to the amount of leakage. To reassure himself on that point, A.H. Horton made measurements on the crest of and at a point a short distance downstream from Lock and Dam No. 2 on the Kanawha River. Alas for his hopes! The leakage amounted to as much as $\mathbf{5 0}$ percent or even more and, what was even more disconcerting, it fluctuated at different dates. In addition, the leakage through the locks, which could only be measured with considerable difficulty, also fluctuated from day to day and from month to month. Long-time records of the Ohio River had to be obtained. Sixty years of records of gage heights at dams were available, which A.H. Horton (oral commun., ca. 1938) used for computing the high-water discharge that was of principal interest at that time. These high-water discharge records were of immediate value in preparing a report on the Ohio Valley flood of March-April 1913 (WSP 334, 1913) by A.H. Horton and H.J. Jackson. Records for the other stages were not computed because of the unsatisfactory accuracy for low and medium stages.

Cooperation had been arranged with Illinois early in 1908, and A.H. Horton had been in charge before the creation of the Ohio River District. R.J. Taylor was detailed from the Washington, D.C., office to the Illinois work with field headquarters in the office of the Illinois State geologist in Urbana. He established a number of gaging stations before resigning in March 1909. Thereafter the field work in Illinois was conducted by the staff of the Ohio River District until September 30, 1912, when cooperative funds were no longer available. A few scattered stations were maintained in Indiana and Ohio where gage-height records were furnished. One small river survey was conducted in 1911 on the Doe River (Tennessee) and two stations were established in Tennessee. 
During this period the funds available for the Ohio River District were limited to the small USGS allotment, with little or no State cooperation except from Illinois, and the payment of a few gage observers in 1913 by the State geologist of West Virginia. Frequent changes in personnel occurred, and W.G. Hoyt, H.J. Jackson, C.T. Bailey, and J.C. Dort were among those detailed to the District at different times during this period.

\section{UpPer Mississippi River District}

The District established in Minnesota in May 1909 came to be known as the Upper Mississippi River District because of the inclusion of a few stations in Iowa and Wisconsin. District activities covered a wide range of waterresources investigations, of which steam gaging was only a small part. Early in 1911 , a station that had previously been maintained on the Menominee Indian Reservation in Wisconsin was reopened and a second station was established at the request of the Indian Service. In 1911 , the State geologist of Iowa made a small amount of money available for field expenses of the USGS to measure the discharge at four stations previously maintained in Iowa by Chicago District personnel. These stations were nearer to the St. Paul office than any other USGS office, so the work was assigned to the Upper Mississippi River District.

The Army engineers, and later the Weather Bureau, had recorded gage heights on the Mississippi River at St. Paul since the 1860's; before 1900, the Army engineers also had frequently measured discharge. USGS personnel began making measurements at this station as soon as the District was established. In 1911, records beginning in 1892 were computed when the operation of the reservoirs in the Mississippi River headwaters began.

The stream gaging, as distinguished from the river surveys, was conducted chiefly by USGS personnel who had civil service status. On the other hand, the river surveys were conducted by field assistants because State cooperating officials believed strongly that Minnesota men should be employed since State funds were paying for the greater part of those surveys. Gray remained with the District until he resigned on August 1, 1910. Until June 1911, the stream gaging was conducted by the author with the assistance of C.J. Emerson who was appointed field assistant in August 1909. Emerson remained until the latter part of 1912 , devoting most of his energies to river surveys. In June 1911, S.B. Soule was appointed junior engineer and devoted himself to stream gaging.

The stations in northwestern Minnesota were maintained by E.F. Chandler, who was assisted by several students; he transmitted not only the records from those stations to the St. Paul office, but also those of several stations he maintained in eastern North Dakota. Thus, the eastern part of North Dakota was considered a part of the Upper Mississippi River District.

At the end of the period, 53 stations were being maintained, of which one was equipped with an automatic gage and the others with staff gages. The author remained in the district until November 1911, when he transferred to Denver and was succeeded as district engineer by W.G. Hoyt, who transferred from Albany.

\section{UpPer Missouri River District}

When the Reclamation Service separated from the USGS, the stream gaging in western North Dakota that was put under the supervision of the Montana district engineer was continued by E.F. Chandler. Later, the work started in northern Wyoming was similarly assigned. The Montana District then came to be known as the Upper Missouri River District. This period was one of rapid expansion and the number of stations increased from 50 in 1906 to 133 by 1913 . In 1906, nearly all of the gaging stations were maintained in connection with the Reclamation Service irrigation projects, whereas less than half of the gaging stations had that connection at the end of the period.

The Water Resources Branch viewed State needs differently from the Reclamation Service and, as a result, new stations were established mainly on streams not previously measured where the records would be of value in connection with irrigation projects that were attractive to private enterprise. The change in view was promoted in part by the cooperation 
with the State engineer, arranged early in the present period. That official was interested chiefly in Carey Act projects that were then in their heyday in Montana.

International coordination was arranged with the Canadian Irrigation Office in 1913. Three international stations were jointly maintained.

A Barrett \& Lawrence gage was installed by the USGS in 1911, and one Gurley, one Friez, two Stevens, and four Bristol gages were installed within the period by cooperating organizations. A chain gage was read daily at one station as a check on the Bristol instrument. The remaining stations in the district were equipped with either chain or staff gages. Water power played so small a part in the District during this period that very few winter measurements were made except by E.F. Chandler in North Dakota and by the hydrographers of the Forest Service.

Morse, who had been in charge of stream gaging in Montana since spring 1905, resigned in August 1906, and the author transferred from the Washington, D.C., office to succeed him. The USGS headquarters were then in the Reclamation Service supervising engineer's office at Huntley. When State cooperation was arranged, the USGS headquarters, in order to be readily accessible from all parts of the State, moved to Helena, the State Capitol, in spring 1907.

The author was district engineer until February 1908 when he was put in charge of the swamplands investigation. He was succeeded by James E. Stewart, who remained until fall 1909, when he transferred to the California District and was succeeded by Lamb. Raymond Richards, M.C. McChristie, J.C. Beck, B.E. Jones, and Ralph R. Randell were all assigned to the District at different times during the period.

\section{South Dakota District}

During the period of the Hydrographic Branch (1902-6), South Dakota had been a subdistrict in the Denver District, and the stream gaging was supervised by Walter who was in charge of the Reclamation Service activities in the State. J.E. Stewart, the junior engineer, was put in charge of the stream-gaging field work in April 1906. When the Reclamation Service separated from the Hydrographic Branch, South Dakota became a separate District. There were 13 gaging stations in the District.

In spring 1907, when the Belle Fourche project was initiated, the Reclamation Service had no further need for streamflow records in that region and withdrew its support from the stream-gaging program. Work in that State was then discontinued, and J.E. Stewart transferred to Montana along with the unspent USGS allotment for South Dakota. Thereafter, until 1912, the only stream gaging in South Dakota was the maintenance of one or two stations by Reclamation Service employees in connection with the Belle Fourche project.

In 1911, when it was apparent that the Standing Rock, Rosebud, and Pine Ridge Indian Reservations were to be opened to settlement, the Indian Service requested that the USGS establish several streamflow gaging stations at points accessible from the railroad. E.F. Chandler investigated the possibilities for irrigation on the reservations, established three gaging stations in 1911 and one in 1912, and operated them during the remainder of the period.

\section{Rocky Mountain District}

The Denver District came to be known as the Rocky Mountain District during the latter part of this period. The reduction in allotment from $\$ 17,600$ at the end of the previous period to $\$ 12,150$ in 1906 caused all work in Kansas to stop and all but a few stations in Wyoming to be discontinued early in fiscal year 1907, leaving only 41 stations (chiefly in Colorado) maintained directly by the Rocky Mountain District. In addition, the State engineer of Nebraska was furnishing records that were computed by USGS personnel. With the discontinuance of the Oklahoma-New Mexico District in June 1907 and the beginning of cooperation with New Mexico, that territory assumed increasing importance; after New Mexico became a State and cooperation increased, a Subdistrict office was established in 1912 in Santa Fe. Wyoming became an active part of the Rocky Mountain District with the beginning of Indian Service 
cooperation in 1908 and reached its full activity when State cooperation was arranged in 1911. The district grew somewhat when the Oklahoma gaging stations were turned over to it in 1907 when the Oklahoma-New Mexico District disbanded, when Indian Service cooperation brought the Uinta Basin in eastern Utah again into the picture, and later in 1912 when a small section of Oklahoma was added when stations were established for the Reclamation Service.

Hinderlider resigned early in July 1906 rather than accept a per-diem appointment as district engineer for part-time service and because of a desire to engage in outside activities. He was succeeded by Meeker, who had been connected with the district since 1903. No State cooperation was then effective except in Nebraska, and that did not include funds for the essential office work. Furthermore, the Reclamation Service activities in stream gaging were limited to the maintenance by its own personnel of a few gaging stations on construction projects. Thus the only funds available at first were the USGS allotments. Meeker resigned in May 1907 and was succeeded by Freeman, who had been connected with USGS activities in Montana before transferring to the Reclamation Service. Freeman resigned in January 1912 and was succeeded by the author who transferred from the Upper Mississippi River District.

A number of field assistants were employed until 1908, one of whom was Lyon, a member of the faculty of Colorado College and a dollar-a-year man working to get field experience. Cooperation with New Mexico in 1908 necessitated an increase in personnel and G.H. Russell, Padgett, E.O. Christiansen, J.B. Stewart, R.H. Fletcher, and Gray were detailed to the Rocky Mountain District off and on during the remainder of the period. So many Forest Service stations were established in the district in 1910 and 1911 that the Forest Service detailed two hydrographers to the USGS.

Few winter measurements were made in the Rocky Mountain District until Freeman became district engineer because the records had heretofore been collected for irrigation purposes. But water power was then becoming important and records of minimum flow of the mountain streams during winter were necessary. Accordingly, winter measurements were begun in winter 1907-8. The streams were generally small, the entire cross section was cleared of ice, and open-water wading measurements were made.

The conservation movement, by calling public attention to the natural resources, resulted in many calls to the Rocky Mountain District staff for USGS publications. These calls had become so numerous when the USGS office moved into the Chamber of Commerce building in spring 1910 that space was provided for a public-use office, which was stocked with a complete reference file of USGS publications as well as with a supply of USGS publications (except topographic maps) for distribution. R.C. Miles was in charge of this public-use office. Miles was disbursing clerk for USGS activities in the Rocky Mountain region. The disbursing office was discontinued in January 1912, and the district engineer thereafter directed the public-use office. A few months later, the name was changed to "Distribution Office."

The annual Survey allotments to the district were:

$\begin{array}{rrrr}1907 & \$ 12,150 & 1911 & \$ 12,000 \\ 1908 & 7,750 & 1912 & 8,175 \\ 1909 & 6,100 & 1913 & 9,700 \\ 1910 & 7,500 & & \end{array}$

The very substantial increase in 1911 was the result of the increase in the Water Resources Branch appropriation for that year and to Leighton's evaluation of the conservation possibilities of the district. New State cooperation offered in other districts caused the reductions in the allotments for the next 2 years.

COLORADO.-The small number of personnel in Colorado in 1906 limited stream gaging to stations readily accessible from Denver. Cooperation with the State engineer made possible the establishment of a number of additional stations during the next 3 years. At two of these stations, local residents were hired to make almost daily current-meter measurements because of the shifting controls, the added expense being paid by the cooperators. With the beginning of the Forest Service cooperation, 60 stations were established. A few stations were also established in cooperation with other interests, but the interest in the State's water resources caused by the conservation movement had little effect on the USGS because the State engineer increased his own organization to care for the 
increasing needs of the State. At the end of the period (1913), 61 stations were being maintained by USGS personnel, of which 52 were Forest Service stations. Seven of the stations were equipped with recorders and the remainder chiefly with staff gages.

wYOMING.-Only a few stations were maintained in Wyoming until 1908 when cooperation with the Indian Service made possible the establishment of several additional stations. Cooperation with the Forest Service, which began in 1910, resulted in 12 new stations during the next 2 years, and cooperation with the State engineer in 1911 added 21 stations (several of these had been maintained independently by the State engineer). A high of 50 stations was reached in 1912 . With the discontinuance of State cooperation in 1912, USGS work ceased and only one station continued to be maintained by Reclamation Service personnel.

NEW MEXICO.-Cooperation with New Mexico, which was arranged in 1907, made possible the establishment of nine stations in that year, and the discontinuance of the Oklahoma-New Mexico District in June 1907 increased the number of stations by seven. Increasing Territorial and later State cooperation led to a rapid increase in the number of stations during the next few years, 20 being added in 1910 and 20 in 1912 . Many of these stations had been maintained during the earlier years of stream gaging, including the Embudo station, which was reopened in 1912. At the end of the period, 57 stations were being maintained by USGS personnel. Of these, 32 were equipped with recorders, which made New Mexico the leading State in that respect. The Reclamation Service was maintaining two stations and the International Boundary Commission one, making a total of 60 stations in the State.

The field work was directed from the Rocky Mountain District office in Denver until August 1912 when, as a result of a new cooperative agreement, a Subdistrict was established with headquarters in the State engineer's office in Santa Fe with Gray in charge. The field work was conducted by field assistants, including Emerson, who previously had been employed in the Upper Mississippi River District.
NEBRASKA.-During the entire period, the Nebraska work was conducted by the State engineer's force and the records computed by USGS personnel. Minor changes in stations were made, but the number remained substantially the same: 9 at the beginning and 11 at the end of the period. With the completion of the Pathfinder Reservoir in Wyoming, the station at the Wyoming-Nebraska State line became so important and was so shifting in its control that a resident hydrographer was employed to make almost daily measurements during the irrigation season.

UINTA INDIAN RESERVATION.--Renewed interest in irrigation caused the Indian Service in 1907 to reopen several gaging stations on the Uinta Reservation. H.C. Means, superintendent of irrigation, was in charge. Realizing the need for USGS experience, he requested cooperation. The basis of the cooperation was that the Indian Service would furnish a hydrographer and pay his expenses, and the USGS would supervise the work and compute the records. Fletcher was employed as hydrographer. This arrangement continued until fall 1910 when the work was discontinued. During 1909 and 1910, the State engineer of Utah paid the gage observers salaries.

\section{Oklahoma-New Mexico District}

The Oklahoma stations were operated from July 1907 to March 1908 as a part of the Oklahoma-New Mexico District. In fall 1912, Reclamation Service personnel investigated the possibility of an irrigation project in the vicinity of Lawton. No streamflow records were available, so the USGS was requested to establish and maintain two gaging stations and an evaporation station in the vicinity of Lake Lawtonka, the reservoir for Lawton's water supply. Denver was the nearest USGS office and the work was assigned to the Rocky Mountain District. The author established the stations in November 1912, and arranged with the Lawton city engineer to make the measurements because the distance from Denver made it impractical to conduct field work with regular USGS personnel. All expenses for the work, which continued through most of the 
next period (1913-19), were borne by the Reclamation Service.

The lack of irrigation projects in Oklahoma and the emphasis on the Carlsbad project in New Mexico by 1906 made the stations in the Oklahoma-New Mexico District of little value to the Reclamation Service. The district, therefore, was discontinued on June 30, 1907. Thereafter, until the following March, this region was part of the Rocky Mountain District. The few New Mexico stations connected with the Carlsbad project were thereafter continued by either the USGS or the Reclamation Service personnel, and the Oklahoma stations were abandoned.

Giles was in charge until fall 1906 when he resigned. He was succeeded by Lamb, who remained as long as the district existed and then transferred to California.

\section{Texas District}

Although the Texas District was discontinued in 1906, gage-height records at three of the stations were continued by interested organizations. During 1910, T.U. Taylor made a few discharge measurements. Using those and the measurements made before 1906 , he computed discharge records from 1907 to 1910 . One or more measurements were made in 1911, but no attempt was made to compute the daily discharges. The only other records available were for those stations maintained by the International Boundary Commission, which were furnished to the USGS for publication.

\section{Great Basin District}

During one part of the present period, the States of Utah, Idaho, and Nevada and the area encompassing the Snake River basin in Wyoming were brought under common supervision and were known as the Great Basin District. Headquarters were in Salt Lake City, Utah. The name was used even after Idaho and Nevada were removed from the district.

Stream gaging in the Great Basin District was supervised by Reclamation Service engineers until the separation of the Reclamation Service from the USGS in March 1907. On that date, LaRue, who had been in actual charge of the Idaho work, was appointed district engineer and moved his office from Boise to Salt Lake City. Nevada was added to the district at the same time.

In spring 1908, it was apparent that combined USGS and State funds would be insufficient for adequately continuing the Nevada work and cooperation with that State ended on June 30 . Thereafter, the little stream gaging that was conducted in the State was chiefly in the Truckee-Carson River basin. In August 1909, Reclamation Service personnel took over the work connected with the Truckee-Carson project. The few stations in the Humboldt River basin not directly connected with the TruckeeCarson project were maintained until fall 1910, when the increase in the appropriations made possible the extension of the work in Nevada and Arizona. An allotment for work in those two States was given to the California District, and thus Nevada was transferred to that district for greater convenience and economy of operation. As a result of the cooperative agreement with Idaho in fall 1911, that State, along with the small portion of Wyoming, became a separate district with headquarters in Boise.

When the work in the three States (Utah, Idaho, and Nevada) was consolidated, 42 stations were being maintained, a considerable number of which were for the Reclamation Service. The work continued with only the addition of a few stations until cooperation was arranged with Utah and Idaho in 1909. Thereafter, expansion was rapid and 117 stations were established during the next 3 years, 76 of them in Idaho. State cooperative funds in Idaho were then small, but exceedingly active irrigation interests accounted for the huge increase in Idaho stations.

The engineers of the many irrigation enterprises had as many different ideas regarding the requirements for accurate streamflow records. The most extreme was one who believed that reliable records could be obtained only by an automatic recorder, a good control, and two current-meter measurements daily. In order to meet these requirements at that one station, a USGS engineer was furloughed for 4 months, employed by the company of the doubting 
engineer, and, during that period, made the required two measurements daily (Lynn Crandall, written commun., ca. 1938). At the end of the 4 months, either the company funds were exhausted or the engineer had gained faith in the reliability of a rating curve.

A few stations were established in summer 1910 in the Green River basin in Wyoming in cooperation with the Forest Service. Because the operation by the Forest Service hydrographers was under the supervision of the Denver District, the stations were, therefore, not considered to be a part of the Great Basin District.

LaRue remained in charge of the Great Basin District until July 1912. Beginning in July 1910, however, Baldwin was the actual supervisor until he took charge of the new Boise, Idaho, office in November 1911. Thereafter, LaRue was again in actual charge of the work in the Great Basin District until June 1, 1912, when E.A. Porter completed his Alaskan assignment and succeeded LaRue as district engineer.

The separation of Idaho from the Great Basin District greatly reduced the number of stations, of course, and only 66 stations were being maintained at the end of the period, seven of which were equipped with recorders. During the first years, the field personnel were all field assistants, among whom was E.A. Porter, but, in 1909, the increasing workload required an enlarged force and regular USGS employees were detailed to the district for different periods of time. Among these were E.S. Fuller, appointed in April 1909; Hartwell, appointed in November 1909; Baldwin and A.B. Purton, both of whom transferred from the Coast and Geodetic Survey in 1910; and G.H. Canfield, Lynn Crandall, Dort, G.H. Russell, and Warren R. King, the latter appointed in July 1912.

\section{IDAHO DisTRICT}

During this period, the Idaho District consisted of the State of Idaho and the Snake River basin in western Wyoming. Chiefly, because of accessibility, the stations in the northern part of Idaho were maintained by the Columbia River and Montana Districts, although the expenses were paid by the Idaho District. On the other hand, for the same reason of accessibility, certain stations in the Malheur River basin in Oregon were maintained by Idaho District personnel and paid for out of the Oregon allotment. When Baldwin took over the Idaho District headquartered in Boise in November 1911,85 stations came with him from the Great Basin District, most of which were already maintained in cooperation with the Idaho District. Irrigation investigations were being conducted more actively than in any other western State and much local assistance was received. Only six stations were being maintained for the Reclamation Service. During the year and a half remaining in this period, 36 additional stations were established and, at the end of the period, 100 stations were being maintained, records for which were published. Recorders were installed at 20 stations and staff gages at the rest.

Baldwin transferred Purton and Lynn Crandall to the new Idaho District from Salt Lake City, Utah. Early in 1912, three field assistants were added to the list. In March 1913, Lynn Crandall transferred back to Salt Lake City. In April 1913, G.A. Wallace, junior engineer, transferred to the Idaho District from the Washington, D.C., office.

\section{Columbia River District}

The States of Washington and Oregon were grouped into the Columbia River District. During the later years of the period, a portion of northern Idaho was added.

When J.C. Stevens transferred from the Washington, D.C., office in spring 1906 to take charge of stream gaging in Washington and Oregon, the work was conducted under the direction of Henny, supervising engineer of the Reclamation Service. J.C. Stevens was appointed district hydrographer in July 1906, but even before the USGS created its own stream-gaging organization, Henny had put J.C. Stevens completely in charge of the work. J.C. Stevens continued to be in charge of the district until late spring 1910 when he resigned to enter private practice. He was succeeded by Henshaw, who transferred from the Alaskan work. Henshaw remained in charge during the remainder of this period. 
For the fiscal year ending June 30, 1906, the USGS allotment was $\$ 6,500$ and the Oregon cooperative allotment was $\$ 2,500$. In addition, the Reclamation Service was paying for many stations, particularly in the State of Washington, that had a direct bearing on their investigations. With the beginning of cooperation in Washington in 1909 and the increase in the Oregon cooperative funds in 1911, Reclamation Service cooperation became progressively less important; many stations in areas with Reclamation projects that did not reach the construction stage were continued at the expense of USGS and cooperative State funds. At the end of the period, Reclamation Service cooperation consisted chiefly in furnishing complete records for 31 stations maintained by its own organization on projects that had reached the construction stage.

Henshaw was very successful in obtaining cooperation from many sources and expansion was rapid: 235 stations were established, which, with the 64 already in operation, made a total of 299 stations. At the end of the period, however, only 188 stations were being maintained, including the 31 Reclamation Service stations. Available funds did not permit expensive installations, so only 10 stations were equipped with recorders. Nearly a third of the stations were equipped with cables.

Because the work did not expand greatly until 1909 , there was opportunity for special studies, of which the flow of the Columbia River was the most important. The Weather Bureau had recorded gage heights at The Dalles, Oreg., since 1892, and at Cascade Locks, 20 miles downstream, since 1878. In 1903, the Army engineers had made 20 measurements at The Dalles, chiefly using floats and covering a range in stage of some 10 feet. It appeared that if additional measurements at higher stages were obtained, computation of the discharge since 1892 would be possible because the channel was fairly permanent, and that the records might be extended back to 1879 by correlation of overlapping gage-height records, thus giving the longest record of discharge in the West and one of the long records in the country. As J.C. Stevens himself writes (WSP 252, 1910, p. 68):

In view of the value which long-time records of flow have in a general study of runoff conditions throughout the country, it is believed that the discharges determined $* * *$ will be welcomed by engineers of the country.

Accordingly, in the latter part of October 1907 , J.C. Stevens made a measurement at The Dalles, Oreg., using a boat and a threesixteenths-inch cable. (The Columbia River is navigable and the cable had to be lowered for passing boats.) The cable was attached to the boat at the oar locks. An outrigger with a reel was fastened to the end of the boat to aid in handling the meter in depths to 80 feet. The reel was a stock article and had a ratchet but no depth-indicating device. Therefore, depth was measured with a tape that was stretched along the outrigger. A large Price meter and a 15-pound weight were suspended by a piano wire and ground connection was provided. Because the velocity ranged between 1 and 2 feet per second, a heavier weight was not needed with the single-wire suspension. When the arrangements were perfected, J.C. Stevens waited for a calm day, but for a week the wind blew upstream with such force that an accurate measurement was impossible. Finally, in desperation after the long delay, the measurement was made at night by lantern light (J.C. Stevens, written commun., ca. 1938). In the 985 feet of width of the Columbia River, 10-point verticalvelocity curves were obtained at 11 sections, and these curves were used in computing the discharge.

The boat-and-cable method for the measurement of 95,000 second-feet by J.C. Stevens in 1907 was woefully inadequate for the measurement of nearly three-quarters of a million second-feet in 1908 because it was impossible to get the cable across the Columbia River. Floats were used as a last resort. In advance of the high-water period, a thousand-foot range (which included the section used in making the current-meter measurement in 1907) had been laid off along the bank. White flags were attached to floats that were made of lumber 2 inches square by 5 feet long and weighted so they would float at a submerged depth of 4 feet. An assistant in a motorboat placed the floats in the river above the upper section, and the points crossing the upper and lower sections were obtained using a transit. The transitman also made a note of the times of crossing. The 
path of each float was then plotted and the surface velocity for each longitudinal section traversed was computed. The vertical-velocity curves that were obtained the previous fall were used in determining the coefficient to be applied to the surface velocities. These coefficients that were determined from the curves showed considerable range in value, and a value of 1.05 was chosen. At a somewhat later date, the coefficient was reduced to 0.92 and the discharge was recomputed (McGlashan, written commun., ca. 1938). From two float measurements made by McGlashan in 1908, and the measurements made in 1903 (Army engineers) and 1907 (J.C. Stevens), a rating curve was constructed that covered the range of stage of the available records, and the daily discharge was computed.

When cooperation was arranged with Washington State officials in 1909, J.C. Stevens conducted river surveys as the basis for the first of a series of reports on the water powers of the Cascade Range, part I, southern Washington, published in 1910 as WSP 253. Subsequently, other river surveys were conducted by Topographic Branch personnel as the basis for part II of the report, prepared by Henshaw and G.L. Parker and published in 1913 as WSP 313. Other special studies included the use of water in the Yakima Valley and the improvement of station equipment, especially cables and cars.

The annual USGS allotments to the Columbia River District for the 7 years were:

$\begin{array}{rrrr}1907 & \$ 6,600 & 1911 & \$ 12,000 \\ 1908 & 7,000 & 1912 & 12,000 \\ 1909 & 8,500 & 1913 & 9,600 \\ 1910 & 7,500 & & \end{array}$

When J.C. Stevens took charge of the Columbia River District in 1908, the field work was conducted by field assistants. The succeeding changes in general brought civil service appointees to the staff. McGlashan was appointed hydrographic aid September 19, 1906, and remained until October 1910 when he transferred to California. Ellsworth was appointed hydrographic aid April 26, 1907, and remained until his transfer to the Alaskan work in May 1908. Howard Kimble, who was appointed junior engineer on April 14, 1908, continued to the end of the period. L.R. Allen was appointed junior engineer on October 15, 1908 , and resigned a year or so later. F.C. Ebert was appointed apprentice engineer on September 1, 1909, and remained until August 1911 when he transferred to California. R.W. Davenport and F.B. Storey were appointed junior engineers on July 1, 1910; Davenport remained until his transfer to the Alaskan work near the end of the period and Storey remained to the end of the period. E.S. Fuller transferred from the Great Basin District in October 1910, became office engineer in July 1911, and continued in that position until the end of the period. G.L. Parker transferred from the Washington office in April 1911 and A.H. Tuttle in August 1912. R.C. Pierce was appointed junior engineer on August 1, 1912. A few field assistants were employed for different lengths of time, including Charles Leidl from April 1911 to April 1912, and two Forest Service hydrographers beginning in fall 1910.

\section{California District}

The California District included all of the State, except for that portion in the Truckee River basin that was included in the Great Basin District. When the Branch appropriation was increased in 1910, an allotment was made for Nevada and Arizona, and these States were then added to the California District. W.B. Clapp, who was in charge of stream gaging in the State under the Reclamation Service, continued as district engineer until his death on December 26, 1911. Because of Clapp's failing health, McGlashan, his principal assistant, was made acting district engineer on June 29, 1911. McGlashan became district engineer on January 3, 1912.

The work in California was so important that the allotment was increased from $\$ 14,500$ in 1906 to $\$ 16,250$ in 1907 , the peak during this period. Starting in 1910, the work increased substantially as a result of Forest Service cooperation and the conservation movement (the conservation movement brought much additional cooperation to the USGS). During this expansion, the considerable number of stations in Owens Valley, which had been 
maintained by the USGS in cooperation with the City of Los Angeles, were gradually being taken over by the city's Aqueduct Board.

At the end of the period, 172 stations were being maintained by the USGS. The rapid expansion did not permit the installation of many recorders, and only 13 USGS stations were so equipped. Staff gages were used almost exclusively; cables were used at 53 stations. The Reclamation Service cooperation during this period was insignificant. Two concrete controls had been built on southern California streams during the days of the Hydrographic Branch and three more were constructed in 1912 in small streams with shifting natural controls.

The work in the northern part of the State had increased to such an extent by 1910 that the district office moved from Los Angeles to Sacramento. Not only was this location more central, it put the district engineer in closer touch with the cooperating State officials. W.B. Clapp was not in favor of the change, and compromised by opening a subdistrict office in Sacramento in space provided by the Weather Bureau. Finally, the office moved to San Francisco in July 1911 and the Sacramento office was closed. A subdistrict office was retained in Los Angeles with Ebert in charge.

The following men, chiefly civil service appointees, were assigned to the California District: Martin to November 1909; Sawyer to December 1906; Steward, season of 1907; Lamb, July 1907 to November 1908; Hardy, February 1907 to July 1909; R.E. Haines, January 1909 to May 1910; J.E. Stewart, November 1909 to October 1912; Norcross, July to October 1910; McGlashan, beginning October 1910; Ebert and Rice, beginning July 1911; Christiansen, July 1911 to July 1912; Lasley Lee, appointed August 1911; Charles Leidl, beginning August 1912; G.H. Canfield, beginning January 1913; and Murphy, beginning January 1913. In addition, the Forest Service furnished three hydrographers, beginning in fall 1910 .

NEVADA-With the increase in the Branch appropriation in July 1910 , provisions were again made for conducting stream gaging in Nevada. A similar situation existed with respect to Arizona, and $\$ 6,000$ for both States was allotted. There was no State cooperation and this amount was too small for a separate district, so it was necessary to combine these stations with the nearest district. Because the work in Nevada would be chiefly in the western part and the work in Arizona also would be too far from Utah, both States were assigned to the California District. The joint allotment was reduced to $\$ 4,870$ in 1912 , and no money for Nevada was allotted at all in 1913. Personnel of the Office of Experiment Stations and the Reclamation Service began to make measurements in July 1911 and, by 1912, practically all field work in Nevada was being conducted by them. At the end of the period, 19 stations were maintained, some of which were established at the end of the period, but practically no field work was conducted by USGS personnel. One station was equipped with a recorder and the others with staff gages. Cables were installed at five stations.

ARIZONA.-During the first part of the period, stream gaging in Arizona was confined chiefly to stations of direct interest to the Reclamation Service and the work was conducted by engineers of that organization. With the allotment of USGS funds, Jacob was appointed junior engineer in July 1910 and detailed to Arizona. Work began in August 1910. Several more stations were established in 1911 when State cooperation was arranged with a USGS allotment of $\$ 3,000$ matching State funds. At the end of the period, 17 stations were maintained, two of which were equipped with recorders and the remainder with staff gages. The Reclamation Service furnished records for four additional stations.

\section{Hawail District}

In Hawaii, the rainfall is sharply divided between the windward and leeward sides of the mountains. Rainfall is ample on the windward sides and so scanty as to require irrigation on the leeward sides. By the beginning of the 20th century, agricultural development had reached a stage where definitive knowledge of the available water supply was needed.

The first measurements of record were made during 2 months in fall 1901 using weirs at 
seven points at the Bishop Estate. The water department of Honolulu built a weir on its source of supply in 1903, and has maintained it since that date. The Maui Agricultural Company set a gage on its open ditch in 1904, which was later rated by USGS personnel. Beginning in 1906, the leading sugar and other agricultural companies began to install weirs on their ditches. On passage of the Territorial Act of March 22, 1909, which made funds available, the Department of Public Works began a study of the water resources of the Island of Kauai, and established several stations equipped with Watson recorders. [Autbor's note: The foregoing is a record of the study of streamflow to the time Martin was reinstated in the USGS on July 1, 1910, and the Hawaiian District was organized by the USGS in cooperation with the Territorial Department of Public Works.]

The five principal islands of the Hawaiian group stretch for a distance of 360 miles from northwest to southeast, each separated from another by 20 to 75 miles of open water. It was apparent that when the work was extended to all of the larger islands that a comparatively large field staff would be required in the widely separated islands. The transfer of USGS engineers from the mainland took considerable time, so Martin at first had two field assistants. The first classified engineer to follow Martin was C.H. Pierce, assistant engineer, in September 1910. Although he transferred from the Indian Service, he had made measurements at USGS stations under Butterfield's direction while he (Pierce) was a student at the University of Vermont. J.B. Stewart and Hardy, field assistants, came from the mainland in July 1911. Christiansen, junior engineer, transferred from California in July 1912. Martin resigned in March 1912 and C.H. Pierce, who wanted to return to the mainland, remained as acting district engineer until August, when Larrison transferred from the New York District and was appointed district engineer. Although Larrison had been with the USGS but a short time, he had had several years of Federal engineering experience in the Philippines. With the increase in territorial funds in July 1912, the staff grew, and Bailey and Dort, junior engineers, transferred from the Ohio River District in December. Because the USGS allotment was not increased and additional engineers were paid by the Territory, seven local men were employed for different lengths of time during the remainder of the period.

When the Hawaii District was formed, most of the existing stations were equipped with weirs, and the accuracy of these weir records needed to be studied. Therefore, an investigation of the existing weir records was conducted during the first year. Each weir was examined and, where standard conditions were not found, current-meter measurements were made. Regarding the results, C.H. Pierce writes (WSP 318, 1913, p. 17-18):

Unquestionably, a weir properly constructed and of a type for which accurate coefficients have been determined is one of the most convenient and reliable means of measuring small quantities of water. In practice, however, weirs rarely conform to the requirements. ${ }^{* * *}$ if these essential conditions are not complied with, especially if the velocity of approach is considerable, and the contractions are imperfect, the Francis formula will not give accurate results. This is particularly true if the weir is improperly constucted and there is leakage around and under it, as so frequently is the case in practice. Observations made $*^{*} *$ in Hawaii show that of the weirs used $*^{*}$ not all are giving accurate results.

C.H. Pierce cites examples showing errors of from 6 to 10 percent and, in one case, that of a 25-foot Cippoletti weir with an extreme error of 23 percent. With these examples in mind, the newly established stations were practically all of the current-meter type in open channels. When the number of personnel was finally sufficient, an engineer was detailed to each of the Islands of Oahu, Kauai, Maui, and Hawaii.

One USGS study, which involved a group of 83 stations on the Island of Hawaii, was unlike any other investigation in USGS annals. The eastern slope of the mountain mass that culminated in Mauna Kea, with its extreme elevation of nearly 14,000 feet, is exposed to the trade winds. Because the summit of Mauna Kea is only 17 to 20 miles from the sea, the slopes are steep and the runoff occurs in many small parallel streams so close together that the 
83 stations were all within an area some 15 miles wide. The south side of the island is comparatively arid, and a proposal was being considered to intercept these small streams at an elevation of about 2,500 feet for irrigation in the Kau district.

C.H. Pierce was detailed to this project. The mountainside was covered with a dense mass of fern-like trees intertwined with creepers of various kinds and was inaccessible except on foot, so a camp was established at the 2,500foot elevation and a path was constructed along the 2,500-foot contour across the streams that were to be measured. C.H. Pierce gathered his equipment at Hilo and hired several men to carry it up the mountainside from the end of the road, which was 2 miles from the site of the camp; however, the helpers quit when the packing began. C.H. Pierce then returned to Hilo and found two men formerly of the Russian army who were stranded and willing to work. They in turn found two more of their compatriots, and these four helpers carried the equipment to the site of the camp and built the trail. Two of them remained on the job as observers and, subsequently, when they had to leave, other Russians took their places.

When the rude camp was finished near the center of the region to be investigated, the path was cut and staff gages were placed on each stream. Two men stayed to read the gages and make current-meter measurements under C.H. Pierce's direct supervision. The men were to traverse the path one day, read the gages and make occasional measurements and return the next day, staying overnight in a tent at either end of the trail. It was soon apparent that it was impossible to obtain daily readings because all supplies had to be packed in from Hilo (WSP 318,1913, p. 346). On one occasion, one of the men returning from Hilo read the gages as he came to them and, having no way to record the stages, cut a bamboo pole on which he scratched the number of each gage and its reading. It is evident from this that C.H. Pierce had inspired this observer, at least, with the USGS spirit of finding a way to overcome obstacles.

As work progressed, it became apparent that only 24 of the 83 streams had sufficient continuous flow to warrant current-meter measurements and ratings (WSP 373, 1915, p. 154). The 24 stations represented 98 percent of the total flow from the area. These stations were continued until July 1913 when it was clear that reservoir sites were unavailable and that a diversion project was not feasible without reservoirs.

A line of rain gages was also established at 500-foot vertical intervals, which extended to an elevation of 5,000 feet. These were to be visited once a month, but as it finally worked out, the visits were at 3-month intervals. C.H. Pierce, with local helpers, began to establish these gages and, in the first afternoon, reached a point in the forest at 2,000 feet elevation, beyond the "cane line." As rain threatened, the last gage that was set up-before the men sought shelter for the night in an old leaky hut that proved to be poor protection from the storm-measured rainfall of about 10 inches by the next morning (Martin, written commun., ca. 1938)

Field conditions fluctuated throughout the islands that comprised the Hawaii District and the engineers dressed accordingly. On the "83-stations" work, the dense growth wet by the frequent rains made it necessary to wear 16-inch boots over the tops of which were securely fastened oiled cotton leggings that extended to the thighs to prevent water from entering the boots. At other stations, the costume sometimes consisted of a "lei" and tennis sneakers, the "lei" being a telephone receiver hanging around the neck.

At the end of the period, 165 stations were being maintained in the Hawaii District. Most of the streams were small and the measurements were made by wading or from small footbridges. A few, however, were sufficiently large to require cable installations and the cars were commonly equipped with canopy tops to protect the engineers from the frequent rains and the tropical sun. Thirty-one stations were equipped with recorders, the Friez and Barrett \& Lawrence instruments predominating.

\section{Alaska}

Alaska was not really a regular disrict of the Branch. The work there was conducted by members of the Branch for the Alaskan Division, Geologic Branch, at the latter's expense, and under the general supervision of its chief, Dr. A.H. Brooks. J.C. Hoyt, who started the 
investigations in 1906, continued to supervise the technical details and the preparation of the reports. During part of the time, parties that operated independently conducted the field work in the different regions of the State.

Gaging stations were operated on the principal streams to show the water supply that was available for placer mining where the ground had previously been prospected (mined). So limited were the funds that only the cooperation of the mine operators and ditch companies in furnishing gage heights and other assistance made possible the collection of as many records as were obtained. Henshaw said that "To name in detail all the companies furnishing assistance would be to give the roster of the mining companies operating." Outside of the scattered mining districts, the region was a wilderness. The isolation of the lone miners made government assistance and the occasional visits by USGS engineers doubly welcome, which was shown by the kind hospitality and spirit of helpfulness offered at all times by residents of the Territory. Even with this help, it was impossible in many situations to obtain daily gage heights and often the only records were the discharge measurements obtained by the USGS engineers who visited the stations at fairly regular intervals.

As only a few members of the Branch have been in Alaska (1938), some considerable description of field conditions appears to be warranted. Transportation costs to the interior points were high, resulting in high prices for all commodities. The smallest coin in circulation was the quarter, which took the place of the nickel in the States. The price of the simplest meal-a mere "hand-out" -was $\$ 1$, as was also a place in which to spread one's bedroll under the same roof with several other people. A box of matches and a four-page local newspaper each cost a quarter. In Fairbanks, 3 pounds of potatoes sold for the usual $\$ 1$. For a minor service, such as delivering a letter to an outlying camp by a traveler passing that way, $\$ 1$ was customarily paid. The charge for an ordinary hotel room in the larger towns or in a roadhouse was $\$ 3$ a day, and a steak dinner cost about the same.

Two routes were available for reaching the interior of Alaska. One was the year-round,
all-American route by boat from Seattle, Wash., to Valdez, Alaska (1,750 miles), thence by stage to Fairbanks, Alaska (360 miles). This route between Valdez and Fairbanks was traveled regularly in winter by stage with a two-horse team hitched to a double-end sleigh with seats for two persons in addition to the driver. There were roadhouses with relays of horses at 20-mile intervals. With favorable weather, 10 days were required for that part of the trip between Valdez and Fairbanks. The international route was a 1,000-mile boat trip from Seattle to Skagway, Alaska, thence by narrow-gage railroad to Whitehorse, Yukon Territory, Canada (110 miles), over White Pass. The trip from Whitehorse to Dawson, Yukon Territory, Canada (400 miles), was by a small river steamer, thence 700 miles by a large steamer to the mouth of the Tanana River where another change was made to a smaller steamer for the 275-mile journey up the Tanana River to Fairbanks. This route was open only from early June to late September; within that period, the trip from Seattle to Fairbanks could be made in 2 weeks if there were no delays at transfer points. The return trip, 1,100 miles against the river currents, took much longer.

The international route was generally used, and because everyone interested in the short mining season was anxious to reach Fairbanks as soon as possible, the first river steamers in spring were usually crowded with miners and merchants. The opening of navigation on the Yukon River depended on the breakup of the ice at Dawson. In order to be on hand for the first boat, the travelers usually arrived at Whitehorse some time in advance of the expected date of breakup, remaining there until the ice broke up in Lake Lebarge. Then they proceeded by boat to Dawson. (During the wait, it was customary to set up a pool in which the participants predicted the exact minute when the ice would begin to break up at Dawson.) The boat between Dawson and the mouth of the Tanana River was a flat-bottom sternwheel like those then in use on the Mississippi and other large rivers. Any livestock was tethered on a scow that was pushed ahead of the steamer.

During this period of time, transportation in Alaska was by steamboat, rowboat, raft, horseback, horse-drawn and dog-drawn sled, and last 
but not least, walking (Ellsworth, written commun., ca. 1938). The trails on the ridges were hard but, in the valleys, the trails led across the spongy "tundra" and travel was difficult.

Daylight during much of the short summer lasted from 16 to 20 hours. The long daylight hours enabled the engineers to make the long trips between mining camps or roadhouses, which reduced the amount of camp equipment and provisions that had to be carried each trip. Saddle blankets were used for bedding, and beans, bacon, and ready-mixed pancake flour were the standard provisions. It was frequently possible to catch fish and shoot birds and thus vary the monotonous diet. Although the temperatures were high, reaching $90^{\circ}$ Fahrenheit, the ground remained frozen within a few feet of the surface, and considerable areas were underlain by clear ice. The marshy tundra and the high summer temperatures were responsible for swarms of mosquitoes. USGS engineers always wore gloves and veils and clothes that were heavy enough to prevent mosquito bites.

Towns and post offices were few and far between, and in their absence, gaging stations were described as "above or below" a creek or "at mouth," or in one instance, "at claim 6 below." The names of the streams ran the gamut from "Mastodon Creek," bringing visions of the mastodon remains unearthed in a frozen condition after a sleep of a million years, to "Forty-five Pup," which raises only a vision of bewilderment to the author who has never been in Alaska.

When the work in Alaska was planned, five seasons of observation in each district was thought to be sufficient (WSP 314, 1913, p. 11). The stations were generally equipped with staff gages. With few exceptions, the streams were small and measurements were taken when wading. The Price acoustic meter was used almost exclusively. The 0.2- and 0.8-depth method was used extensively, and the uniformly satisfactory result obtained in Alaska during the first year was a large factor in the decision by the Branch to make that its standard method. With bridges few and far between, some high-water measurements on the larger streams had to be made using floats. A few cables were installed in cooperation with mining interests. Staff gages or reference points were used in obtaining gage heights. Because there were practically no rainfall records, rain gages provided by the Weather Bureau were also installed and operated.

When work began on June 11, 1906, the small allotment of $\$ 2,200$ (subsequently increased to $\$ 2,970$ ) necessitated limiting the investigation to an area on Seward Peninsula that stretched inland 40 miles from Nome, Alaska, to the Kigluaik Mountains, a region of rich placer deposits. One enterprising miner had installed a gage on Kruzgamepa River in May 1906, and had read it morning and evening. J.C. Hoyt continued the station, and its subsequent rating showed that the flow caused by the melting snow during May and the first part of June had been much greater than that later in the season. Nine regular gaging stations were maintained and measurements were made at many other points. Henshaw continued the work until October 3, 1906.

The first season's work demonstrated the value of the streamflow records to the placer mining industry and, in 1907, Brooks decided not only to continue the work of the previous season but also to extend the investigations to the Fairbanks region in the upper Yukon River basin $\mathbf{4 0 0}$ miles inland. Two parties were needed because the areas to be investigated were 550 miles apart. The allotment was increased to about $\$ 5,500$, of which about $\$ 300$ was contributed by the Water Resources Branch (unpub. report of field work for 1907).

Raymond Richards was detailed to Alaska as Henshaw's assistant in the Seward Peninsula, and Covert transferred from the New York District on detail to the Fairbanks region. A total of 27 stations were maintained on the peninsula and in the Fairbanks region. Covert, one evening while seated close to a smudge and fighting mosquitoes, was heard to mutter, "I don't know what to do. If I don't do a good job, I'll be fired, and if I do, I'll be sent back here next year' (Leighton, oral commun., ca. 1938). He was sent back.

So valuable had the streamflow investigation proven to be that the allotment was increased to $\$ 9,900$ for 1908 . It was decided to increase the work in the Seward Peninsula and the Yukon-Tanana region in which Fairbanks is located, and Henshaw and Covert were each given an assistant. For Henshaw, A.T. Barrows, 
a recently appointed junior engineer, was detailed from the computing section, succeeding Raymond Richards. Ellsworth transferred from the Columbia River District as Covert's assistant.

During winter 1907-8, Covert recalled his previous year's experience in starting the work after the spring runoff had occurred, and recommended that an engineer should return to Fairbanks early in the coming spring, going via the winter route over the ice and snow from Valdez. "Having stuck his neck out, that trip was hung on it," and Covert reached Valdez on March 23, 1908. It was still winter in Alaska, with temperature nearly $50^{\circ}$ Fahrenheit below zero.

When Covert reached Fairbanks, the streams were still frozen solid. Several additional stations were established and in due time Covert proceeded to Circle and met Ellsworth and his party of two helpers with four pack horses who had come down the Yukon River. With this outfit, Covert and Ellsworth started a reconnaissance of the region between Circle, Alaska, and Fairbanks, and established 12 stations at which daily gage heights were observed.

In regard to the 1908 work, Covert stated (WSP 228, 1909, p. 8):

In 1908, the work was continued along lines similar to those followed in the previous year, but the records cover a longer period (May 1 to October 15) * * * Daily records were kept at a few regular stations, established at convenient points in the different drainage basins, and miscellaneous measurements were made in the surrounding country. This plan afforded the best opportunities for procuring comparative data. In this region where water storage is lacking, daily records are highly important, but are very difficult to obtain. Outside of the placer mining creeks, the country is practically a wilderness where it is almost impossible to get observations other than those made during the occasional visits of the engineer.

Henshaw and A.T. Barrows continued the more important stations in the Seward Peninsula and extended the investigation to the Solomon and Casadepaga River basins and
Fairhaven precinct. Altogether, 21 stations were maintained, generally from June to September. The results were published in the annual report of mineral resources of Alaska for 1908 (Bull. 379-E, 1909, p. 201-28, YukonTanana region; Bull. 379-F, 1909, p. 370-401, Seward Peninsula).

The allotment for 1909 was reduced to $\$ 8,300$ and the field staff to three. Ellsworth, without an assistant, returned to the YukonTanana region, succeeding Covert who had been put in charge of the New York District. Henshaw and Glenn L. Parker returned to the Seward Peninsula. G.L. Parker had transferred from the Coast and Geodetic Survey on January 1, 1909.

Following the precedent set by Covert in 1908, Ellsworth arrived in Fairbanks via Valdez on April 1, beating Covert's record by 2 days. The Yukon River, principal highway of the vast interior region of Alaska and by far the most important river in Alaska, was a challenge to Ellsworth's ingenuity to measure it. Early in May, before the ice broke up, Ellsworth measured at Rampart, Alaska, and developed the cross section. When it is stated that the width of the Yukon River was 1,560 feet and the ice $4 \frac{1}{2}$ feet thick, it can be readily imagined that this measurement was a fair day's task. Several weeks later while the ice was going out, chunks were timed over a 500-foot stretch where the flow was uniform. From the velocity thus measured and the cross section previously determined, the discharge was computed as $\mathbf{3 6 8 , 0 0 0}$ second-feet. The later measurements were made at a stage 30 feet higher than that before the breakup.

With an allotment of $\$ 4,600$ in 1910 , the scope of the investigations had to be reduced. Ellsworth and G.L. Parker reached Fairbanks March 3 and devoted their energies until the latter part of May to a study of winter streamflow by measuring several streams through ice 2 to $3 \frac{1 / 2}{2}$ feet thick and to preparations for the coming season's work. Ellsworth started investigations in three new regions and continued through the season. The large area to be covered, the slow means of transportation, and the many areas within the general region, necessitated that G.L. Parker discontinue previous stations in two areas and concentrate on those 
in the Fairbanks and Circle regions. It was not possible to detail an engineer to the Seward Peninsula but, by an arrangement with several mine operators, gage-height records were obtained at a number of the old stations. G.L. Parker visited those stations in September, made some measurements, and collected the gageheight records. The complete results of the Seward Penisula investigation were published in WSP 314 in 1913.

An increase in appropriations for the Alaska Division made it possible to increase the streamgaging allotment to $\$ 6,500$ in 1911 . The USGS engineers were Ellsworth and E.A. Porter. They reached Eagle, Alaska, a town on the Yukon River near the International Boundary with Canada, in April, having traveled from Skagway to Whitehorse by train, and thence by horseteam sled. They measured the Yukon River at Eagle through the ice, using the verticalvelocity-curve method. The holes were cut at 50-foot intervals over a width of 1,600 feet. In May, they installed a gage below the town of Eagle. The gage consisted of a white strip about 3 feet wide painted on the rock face of a high bluff, and graduated in black paint at intervals of a quarter of a foot with the even feet marked by numbers sufficiently large to be read by telescope from Eagle about a half mile away. The observer read the gage to eighths of a foot. Seven discharge measurements were made during May using ice floats over a 500-foot range in the cross section determined through the ice. In 1912, two measurements were made using driftwood and one measurement using bottle floats carrying flags. This station was maintained during the open seasons of 1911 and 1912 , and the regular work continued in the same areas as in 1910.

The year 1912 was the last year of streamgaging investigations in the Yukon-Tanana region; the investigators were Ellsworth and Davenport. The party went first to Eagle via Skagway, reaching there May 19, and conducted float measurements of the Yukon. The remainder of the season was spent in continuing the work of the previous year. At the end of that season, Brooks wrote (Bull. 542-A, 1913, p. 14):

The investigations of the Yukon-Tanana region have been carried on since 1906.
It is believed that the stream gaging data *** are sufficient to serve as a guide to the placer miner. In view of the urgent demand for investigations of water supply in other parts of the Territory, the work in this region will be discontinued for the present.

The work during 1913, unlike that of earlier years, was a water-power reconnaissance of the lower Copper River basin and the Prince William Sound region where rapid development had led to the need for water power. The USGS reconnaissance involved not only streamflow but also available head. For streamflow, current-meter measurements were made and gages were installed where it was possible to do so, which were read at intervals depending on the availability of observers. The possible head at the different power sites was estimated from available maps, supplemented by aneroid barometer readings. The allotment for the work was $\$ 6,300$. Ellsworth and Davenport started the investigations May 5 and continued until the latter part of November. The results of the investigations were published in WSP 372 in 1915.

Relative to the continuation of the Alaskan investigations, Brooks wrote in WSP 372, page 10 , that "these investigations should be followed by studies of streamflow extending through a period of years sufficiently long to afford data for accurate generalization on stream volume. This work will be begun as soon as circumstances permit. For the present it must be deferred, as the annual grant of funds must be used for what are believed to be more important surveys and investigations."

\section{Division of Water Quality}

In 1906, the Division of Hydro-Economics' name was changed to the Division of Water Quality. Leighton at first thought that by emphasizing the pollution of streams-which was becoming of interstate interest-rather than stream gaging, he might make a stronger appeal to the Congress for funds. As he became more familiar with stream gaging, however, he changed his mind. Dole succeeded Leighton in charge of the division and continued as its chief 
until it was merged with the Division of Ground Water on June 30,1910 . The merge was chiefly for administrative reasons because Dole's interests were technical rather than administrative. The work itself continued under his supervision.

At the beginning of this period, cooperation was arranged with the Rhode Island State Board of Health, and Herman Stabler went to Providence to study the pollution of streams in that vicinity-the last USGS work involving sanitary analyses. Thereafter, the work of the Division of Water Quality was confined to determining the chemical character of surface and ground waters, which had been started in California earlier.

The chemical aspects of water appealed strongly to Dole, who was a chemist, and he pushed the work as vigorously as the attenuated funds would permit. Dole established 62 water-quality sampling stations in July 1906 on streams east of the 100th meridian, from which daily samples were taken by local "samplers." For convenience in transportation, laboratories were established not only in Washington, D.C., but also in Athens, Ga., and Iowa City, Iowa, where State universities furnished space.

Cooperative agreements were arranged with the States of Illinois and Kansas for the investigation of the quality of the surface waters of the United States. In Illinois, cooperators were the State Geological Survey, the State Water Survey, and the engineering experiment station of the University of Illinois, all in Champaign-Urbana. The agreement, which was for 1 year, provided for the investigation of mineral and organic constituents of the surface and ground waters of Illinois, and for experimental work on how water acts in steam boilers, the purification of waters for industrial and domestic uses, and other similar problems. The Survey assigned Collins to the State laboratory in Urbana to conduct the chemical analyses of the surface waters from 26 sampling stations. He began work on July 16, 1906, and continued until the following April, when he was succeeded by C.K. Calvert who continued the work until June. The reduction in appropriation for fiscal year 1908 made it necessary to discontinue the cooperation. The cooperating parties agreed to retain Calvert for the next 3 months to complete the analyses of the collected samples, the results of which were published in 1910 in WSP 239.
The cooperative agreement with the Kansas State Board of Health was arranged in December 1906. The original plan of the scope of the work was considerably broader than that actually conducted, but problems in wording of the State law providing for the water-quality investigation reduced the State funds available and a corresponding reduction in the scope of the work. In actuality, the USGS paid the salary of an engineer for 16 months, the expenses of operating 23 sampling stations for 11 months, and the preparation and publication in 1911 of WSP 273 , which contained the results of the investigation. The Kansas Board of Health paid the engineer's field expenses and a small amount toward the maintenance of the sampling stations. The State University laboratories personnel conducted the chemical and bacteriological analyses. H.N. Parker was in charge of this work and made many "assays" in the field.

The California investigation, which was interrupted by the earthquake and fire of April 1906, resumed on July 1,1907 , with a new agreement with the State Department of Engineering. Walton Van Winkle, assistant analyst, was in charge of the work and, from December 1907 to December 1908, analyzed samples from 18 regular stations, most of which were also streamflowgaging stations. The University of California furnished laboratory space in Berkeley. The results were published in WSP 237 in 1910.

At the Jamestown Exposition held in Virginia from April to November 1907, a small laboratory that contained a drying oven for use in analyses was installed as part of the USGS exhibit. Here Collins, who had transferred from Illinois to be in charge of the exhibit, made a few analyses of samples from eastern streams as a demonstration of the work being conducted by the Division of Water Quality. During the chilly fall days toward the end of the exposition, the interest in Collins' exhibit increased and ever larger crowds listened to his explanation of the work being done in analyzing water; and so rapt was the apparent interest that he unconsciously expanded his remarks to some considerable length. Finally, the real reason for the increased interest dawned on him when he overheard one apparently interested listener remark to another, "I don't understand what he says, but I like to hear him talk, as it gives me an excuse to stay by 
this little oven which is the only warm place in the whole exposition" (W.D. Collins, oral commun., ca. 1938).

At the beginning of the period, the personnel of the Division of Water Quality were Dole, H.N. Parker, and Herman Stabler. To provide chemists for the new work, an examination was held and Collins, H.S. Spaulding, M.G. Roberts, Walton Van Winkle, and J.R. Evans were appointed. Roberts was assigned to the Washington, D.C., laboratory, Collins to the Illinois cooperative program, Spaulding and Walton Van Winkle to Iowa City, Iowa, and Evans to Athens, Ga. The Athens, Ga., laboratory was closed in spring 1907 when the lengthening shadow of the impending second reduction in appropriations made drastic retrenchment imperative, and Evans resigned. Spaulding also resigned in spring 1907. At that time, a few stations were discontinued, and the samples from the remainder were analyzed either in Washington, D.C., Iowa City, or at the Jamestown Exposition. Chase Palmer was appointed in May 1907 and remained with the Division until July 1908. At the close of the Jamestown Exposition in fall 1907, Collins came to the Washington, D.C., laboratory to take the place of Roberts who had resigned at that time.

In June 1908, when it was known that the appropriation for the next fiscal year (1909) would be no larger than the 1908 appropriation, all field operations and analyses were discontinued. Herman Stabler transferred to the Reclamation Service, Collins to the Bureau of Chemistry in the DOA, and Parker resigned. During the 2 remaining years before the Division merged with the Division of Ground Water, the remaining personnel were Dole and Walton Van Winkle, the latter employed on the West Coast. Dole devoted his time to preparing for publication the analyses of the surface waters east of the hundredth meridian (WSP 236,1909 ). Quality-of-water investigations that continued during the remainder of the period are described under the Division of Ground Water section that follows.

\section{Division of Ground Water}

With the reduction in funds on July 1,1906 , the eastern and western sections of the Division of Hydrology were combined and the work of what was henceforth known as the Division of Ground Water continued on a more modest scale. Darton returned to the Geologic Branch at his own suggestion, and M.L. Fuller became chief of the Division. He resigned in fall 1907 to enter private practice and, for the next few months, the Division had no official head. Mendenhall, in charge of the California investigations, transferred to Washington in January 1908 and supervised Division activities; on July 1, 1908, he was appointed chief. He was appointed chairman of the Land Classification Board on January 1, 1911, and although he remained in nominal charge of the Division of Ground Water, Oscar E. Meinzer became the active director. By July 1, 1912, Mendenhall's duties on the Land Classification Board required his entire attention, and Meinzer became acting chief of the Division and chief a year later.

Following the practice of the previous period, which was even more necessary because of the reduction in the Branch appropriation, much of the work before 1911 was conducted by geologists of the Geologic Branch who were detailed to the Division for specific investigations. So close was the relation between the studies of ground water and geology in many investigations that no sharp line could be drawn between them.

This relationship was especially pronounced in the eastern and southern States where a geologic study of the Atlantic Coastal Plain with special reference to ground-water resources was conducted by USGS personnel in cooperation with the State geologists concerned. This study was a result of a conference of State and Federal geologists held in Washington on December 31,1906 . Being primarily a groundwater study, M.L. Fuller was placed in charge of the general investigation. It was also a geologic study, and Geologic Branch contributed funds liberally to it. In fact, the largest allotment during 1907 for any project of the Geologic Branch was for the Coastal Plain study; the funds exceeded in amount the allotment from the Division of Ground Water, thus giving the chief geologist control of the investigation. It was his hope that all ground-water work would be placed in the Geologic Branch (M.L. Fuller, written commun., ca. 1938), which indeed happened when M.L. Fuller 
resigned and T. Wayland Vaughan of the Geologic Branch became the supervisor of the Coastal Plain study.

There were, however, a small group of men who gave their entire time to the work of the Division of Ground Water, chiefly in the West. In addition to M.L. Fuller who resigned in 1907, Mendenhall, Waring, H.R. Johnson, and F.G. Clapp were members of the Division at the beginning of the period. F.G. Clapp resigned late in 1907. The other geologists who had been associated with the Division of Hydrology returned to the geologic work with Darton. As a result of a civil service examination held for geologists, Meinzer and S.R. Capps were given appointments as geologic aids in June and July 1906, respectively, were employed during that summer, and returned to their university work in the fall. On July 1, 1907, both were given fulltime appointments as junior geologists. Capps remained in the Division of Ground Water until spring 1908 when he transferred to the Alaskan Division. H.R. Johnson resigned in 1909.

On July 1, 1910, when the Quality-of-Water Division merged with the Division of Ground Water, Dole became a member of the Division, with Walton Van Winkle as his assistant, and continued in charge of the chemical analyses. In August 1910, Herman Stabler, who had been in the Reclamation Service during the previous 3 years, returned to the USGS and was assigned to ground-water work. In September 1910, Waring resigned and went to Brazil to start an investigation of Brazil's water resources for the Brazilian government. Herman Stabler transferred to the Land Classification Board in March 1911. These resignations left no older, experienced geologists or engineers in the Division when Meinzer took over the direction of its activities in 1911. A.J. Ellis and Everett Carpenter were appointed junior geologists in May and June 1911, respectively, and Kirk Bryan, geologic aid, in August 1912. With a comparatively inexperienced field organization, only a small amount of field work was conducted and the latter part of the period was chiefly one of "liquidation," as Meinzer (oral commun., ca. 1938) describes it, during which time the results of the field work that had been completed earlier were prepared for publication.

In the flush days of the Hydrographic Branch, the allotments for the Division of Hydrology had been about $\$ 40,000$ per year. During the present period, the funds were reduced drastically and, of the amounts allotted, several thousand dollars were transferred annually from 1907 to 1911 to the Geologic Branch for the Division of Ground Water share of the Atlantic Coastal Plain investigation. As a result, the allotment available for direct expenditures by the Division was about $\$ 8,500$ per year until 1911 , when the increase in the Branch appropriations, the cessation for all practical purposes of contributions to the Geologic Branch, and the merging of the quality-of-water investigations with those of ground water, increased the allotment to about $\$ 17,000$. This amount was available annually during the remaining 2 years. During the earlier years (1906-10) of this period, about $\$ 4,500$ from the USGS allotment to California under the cooperative agreement with that State, which covered both surface- and ground-water investigations, was spent annually on ground-water investigations in that State. From 1911 to 1913, however, no State funds were made available for that purpose. The drastic reduction in the annual allotments, which caused most of the experienced geologists to leave, was a serious blow to the work of the Division and set back by a full generation, not only the investigation itself, but also the development of methods that in later periods contributed so successfully to the intensive and quantitative character of the work (Meinzer, oral commun., ca. 1938).

\section{States}

By 1909 , the greatest demand for groundwater studies came from the arid States where surface waters were insufficient to irrigate the lands already settled. The settlement of the arid lands had been given an impetus by the Homestead Act of 1909, and successfull settlement was possible only when sufficient groundwater supplies were available for domestic and stock use. In view of this situation, the USGS planned to investigate the arid and semi-arid valleys of the West prior to settlement, so far as the funds would permit (USGS 31st Ann. Rept., p. 102, 1910). This plan made it necessary to concentrate USGS funds in the West and, during the remaining years of this period, little work was conducted in the East. 
The only extensive new investigation by $\mathrm{Di}$ vision staff in the East was a study of the ground water of Connecticut for municipal and private uses, which was conducted in cooperation with the State Geological and Natural History Survey through Professor H.E. Gregory of Yale University. The work was conducted by Professor Gregory, who held an appointment as geologist in the Geologic Branch, assisted by A.J. Ellis, junior geologist. The investigation begun in 1911 continued into the next period, and the results obtained during 1911 and 1912 were published in 1916 as WSP 374 . The expenses of the investigation were shared equally by the USGS and the Connecticut State Geological and Natural History Survey.

The work in California conducted directly by USGS members was largely reduced in favor of the group of Western States lying directly eastward, where the land-settlement situation was more serious and public lands were available in large acreage. During 1912 and 1913, however, a large part of the small Federal allotment for ground-water studies was spent in the Sacramento and Santa Clara Valleys. California, Oregon, and Washington may be considered as forming a far western section during the period when Mendenhall was in the field because investigations in those States were under his supervision.

OHIO.-During fall 1906, M.L. Fuller investigated availability of ground-water supplies in southwestern Ohio for public and private use. He was assisted by F.G. Clapp and Capps. The results were published as WSP 259 in 1912.

MINNESOTA.-At the beginning of this period, Professor C.W. Hall, University of Minnesota, was conducting an investigation of ground water of southern Minnesota. M.L. Fuller cooperated in the investigation, conducting, with F.G. Clapp's assistance, the field work in the eastern part of the area. The next year, in an attempt to demonstrate the value of the ground-water phase of the study of water resources in Minnesota (Leighton, oral commun., ca. 1938), a cooperative agreement with the State Geological Survey and the State Board of Health was arranged, and Meinzer was assigned to cover the southwestern part of the State and to complete the entire report on the southern part of Minnesota. This was published in 1911 as WSP 256.
IOWA.-For several years, the artesian water of Iowa had been investigated by Professor William H. Norton of the Iowa State Geological Survey. In summer 1906, an agreement was reached with the Iowa State Geological Survey for a comprehensive study of ground water from shallower sources, including chemical constituents. The investigation, which was under the joint supervision of M.L. Fuller for the Survey and Norton for the State, was divided into three parts: (1) artesian waters by Norton, (2) the waters of the drift and country rock by H.E. Simpson, and (3) the chemical and industrial qualities of all of the artesian waters by W.S. Hendrixson. Meinzer was one of three geologists who assisted Hendrixson, beginning in 1906, and after July 1, 1907, was the only full-time member assigned to that project (the others were all part-time employees). Norton, Simpson, and Hendrixson were college professors and the requirements of their college work were such that the investigation was not completed until fall 1909. To speed it up, Meinzer was sent out in 1909 to help with the field work and to him fell the task of completing the voluminous report (994 pages), which was published in 1912 as WSP 293.

INDIANA.-During fall 1907, F.G. Clapp began an investigation of the ground water of north-central Indiana, with special reference for its use as public and private water supply. The work was completed by Capps and the results published in 1910 as WSP 254.

UTAH.-An investigation of Beaver Valley, Utah, was conducted by Willis T. Lee in 1906. This project was conducted in cooperation with the Utah State engineer and officials of Beaver County, and the results were published in WSP 217 in 1908. Another cooperative investigation with the Utah State engineer was conducted in 1908 when Meinzer studied the occurrence of ground water in Juab, Millard, and Iron Counties in the southeastern part of the State. This study was designed to supplement and coordinate the work conducted earlier by Richardson and Willis T. Lee. The basis of the cooperation was that the State paid Meinzer's field expenses and the USGS his salary and incidental expenses. Its object of the study was to determine the ground water that was available for irrigation. 
WSP 277 (1911) contains the results of this work. In 1911, the resultsof an investigation to determine the feasibility of using ground water for irrigation in Boxelder and Tooele Counties by Everett Carpenter were published in WSP 333 (1913).

NEW MEXICO.-During summer 1909, Meinzer conducted a study of the feasibility of using ground water for irrigation in Estancia Valley, N. Mex., the work being chiefly a basis for the classification of the public land under the Homestead Act of 1909. A preliminary report was published as WSP 260 (1910) and a final report as WSP 275 (1911). WSP 275 also contained the results of a brief field examination in Portales Valley at Vaughn. An agreement was made with the New Mexico Agricultural Experiment Station in 1911 for an investigation of the Tularosa Basin to determine the feasibility of using ground-water sources for irrigation. This work was conducted by Meinzer. The qualityof-water determinations were by R.F. Hare in the laboratories of the Experiment Station. The work continued during a part of 1912 and the results were published in 1915 as WSP 343.

ARIZONA.-An agreement was signed in fall 1910 with the Arizona Experiment Station for a study of the Sulphur Springs Valley, which involved reconnaissance geologic work, studies of groundwater levels, cost of recovery by pumping, chemical character of ground water, soil types, and other facets that might affect ground water. Meinzer was in charge of the investigation, which continued through spring 1911. Meinzer concentrated on the ground-water studies. F.C. Kelton of the Experiment Station conducted the test of the pumping plants, and the chemical analyses were conducted at the Experiment Station laboratory under direction of W.H. Ross. WSP 320 (1913) contains the report of this investigation.

CALIFORNIA.- The investigation of ground water in the southern foothills belt of California began in 1903; that of the San Joaquin Valley began in a preliminary way in 1905 and continued during 1907 and 1908 (Mendenhall, WSP 222, 1908). In 1908, an investigation of the desert region in the vicinity of Indio was conducted (Mendenhall, WSP 225, 1909). In 1908, H.R. Johnson studied the ground water in Antelope
Valley and parts of the Mojave Desert (WSP 278, 1911). During 1909, a 2-year study of California springs, with special reference to those springs having medicinal properties, was begun by Waring and completed in 1910 (WSP 338, 1915). The investigation was probably brought to a close sooner than it otherwise would have been because Waring resigned in summer 1910 .

When the Water Quality Division merged with the Division of Ground Water in 1910, a study of the chemical quality of water and of pumping costs in the San Joaquin and San Jacinto Valleys was conducted by Dole and Herman Stabler. In this investigation, the field kit developed in the early days of the Hydro-Economics Division was used to make several hundred field assays of water and, while so engaged, Dole was the first member of the Branch to officially use an auto. Not being permitted to purchase a car with USGS funds, he arranged with a dealer in the San Francisco Bay region to rent a second-hand "Rambler" on a monthly basis. The cost of the rental was so high that by the end of the season, the amount paid equalled the price of the car, but the title still remained with the dealer. On one occasion, Herman Stabler accompanied Dole in the car and as happened more frequently then than now, a blowout occurred far from a service station (if there were any in those days). There was no spare tire, so the tow-rope was wound around the blow-out in the clincher tire, and in that manner the car limped back to town. They had so much trouble with the car that at the end of the season, Dole shipped it back to the dealer by freight, fearing that it would not reach home under its own power (Herman Stabler, oral commun., ca. 1938). The results of the investigation in the San Joaquin Valley were combined with the general study of the ground waters that Mendenhall had started in 1905; the resulting report was published as WSP 398 (1916). In this paper, the contours of the ground water above sea level were given and these showed an "island." In later years, this island turned out to be a "dome"-now known as the "Button Willow" gas field. The quality-of-water study in the San Jacinto Valley was combined with the general ground-water study of that region and published as WSP 429 (1919).

In 1910 the Survey agreed to publish as a water-supply paper the results of an investigation begun by the City of Los Angeles in 1908 
of the relation of ground water to runoff, and the loss through evaporation or transpiration in the Owens Valley. C.H. Lee, an engineeringgeologist, was in charge of this work. It was completed in 1911 and the report was published in 1912 as WSP 294. In this study, careful measurements were taken of all streams tributary to Owens Valley and of transpiration from salt grass and evaporation from soil surfaces under fluctuating conditions of ground-water levels. The USGS published this report because the results would contribute certain fundamental facts involved in all ground-water investigations, which the USGS itself had been unable to study (USGS 32d Ann. Rept., p. 130, 1911). By 1911, the USGS funds for work in California were reduced so much that the field work was limited to a cooperative investigation with the State Conservation Commission. In this study, C.H. Lee investigated the effect of steps taken previously by several southern California communities to measure how the absorption of flood waters added to ground-water supplies. This investigation continued into the next period of this History. The only ground-water investigations in California conducted by Division personnel during the remainder of this period were a study of the Sacramento Valley by Kirk Bryan and an investigation of the Santa Clara Valley by W.O. Clark, a graduate student in geology at Stanford University. Both investigations continued into the next period of this History.

OREGON AND WASHINGTON.-The first investigation in Oregon was by G.A. Waring in Lake County in 1906 and published as WSP 220 in 1908. Waring used this investigation as a basis for his study in 1907 of the Harney Basin in Oregon (WSP 231, 1909) that adjoined Lake County on the east, and the lower Yakima Valley in Washington (WSP $316,1913)$.

The next investigation in these two States was one of the quality of the surface waters of Washington, which began late in 1909 under a cooperative agreement with the State Board of Health, and included a study of the seasonal variation in composition, physical characteristics, and pollution of the surface waters of Washington State. It was the same type of investigation that had previously been conducted in Illinois and California. The Board of Health conducted the bacteriologic work and the USGS the chemical work. The field expenses were shared by both organizations (although the word "equally" was not used in that connection). Walton Van Winkle, assistant chemist under Dole's supervision, conducted the USGS share of the investigation, which consisted of collecting samples from 17 gaging stations and analyzing them in the laboratory of the University of Washington. Results were published in 1914 as WSP 339. On July 1,1911 , the USGS entered into an agreement with the Oregon State engineer for a period of 14 months for a cooperative survey to determine the chemical composition of the waters of that State (WSP 363, p. 7, 1914). The agreement provided that the investigation was to be conducted by a member of the USGS. Because the Washington investigation of a similar nature had been completed, Walton Van Winkle was assigned to Oregon. The State allotted $\$ 2,350$ to this investigation (Oregon State engineer, oral commun., ca. 1938). A more ambitious project than the one just completed in Washington, it required the collection of samples from 23 stations, most of which were stream-gaging stations. The laboratory work, which involved nearly 1,000 analyses of water samples, was furnished gratis by Willamette University. This study was completed in October 1912. Walton Van Winkle resigned from the USGS in February 1913.

\section{INDIAN RESERVATIONS}

In spring 1909, the Indian Service entered into an agreement with the USGS for an investigation of the ground waters of the Navajo and Moki Reservations in New Mexico and Arizona and allotted $\$ 3,000$ for the work. Gregory of Yale University was in charge of this project. So anxious was the Indian Service to obtain the results that preliminary reports were furnished to that agency immediately on the completion of each major unit (USGS 30th Ann. Rept., p. 93, 1909). The investigation continued through the remainder of this period, the Indian Service making an additional allotment of $\$ 1,500$ for that purpose in 1911.

\section{Evaluation of the Period}

\section{By Nathan C. Grover}

The early years of the Water Resources Branch, 1906 to 1913, were years of great 
difficulty. At the beginning of the period, the leadership by men who had guided the development from inception of the studies of water was withdrawn and new leadership was substituted. The new personnel were young men who were for the most part inexperienced not only in administration but also in responsibility for the accomplishment of results. The Branch was the principal USGS target of Chairman Tawney of the powerful Appropriations Committee of the House of Representatives. Tawney was opinionated and persistent and his position in the House was one of great influence.

When Leighton became chief of the Branch, he faced a most difficult situation. His courage, initiative, and perseverance overcame Tawney's objections, and the "point of order" menace was removed. He put the finances of the Branch on a sound basis; he changed and defined the scope of the quality of water work to be conducted by USGS personnel; and he encouraged and developed the ground-water work within the limitations imposed by the meager funds. Leighton built up an organization that has endured without major change for a quarter of a century; he brought J.C. Hoyt, Meinzer, A.H. Horton, and others to the fore; he developed State cooperation and put it on a sound, uniform, and equitable basis; he expanded and strengthened the system of districts; and he developed a group of district engineers that have been the efficient backbone of the stream-gaging organization. Covert, R.C. Pierce, Ellsworth, Lamb, Henshaw, Baldwin, G.L. Parker, McGlashan, and the Halls (Maxie and Warren) have conducted and led others in conducting the field work. In the development of methods, equipment, personnel, and organization, Leighton was ably assisted by J.C. Hoyt. To J.C. Hoyt more than to Leighton is due the credit for the improvements in instruments, equipment, and methods. There was doubtless much more true progress made in the technique of collecting systematic records of streamflow and preparing those records for publication in the 7 years when Leighton was $\mathrm{CH}$ than in all of the 18 years from the Embudo camp of instruction to the withdrawal of F.H. Newell from stream gaging. Leighton had, of course, the broad base left by F.H. Newell on which to build, and on that base Leighton and J.C. Hoyt built wisely and well. 


\section{Part X-Maturing Years (1913-19)}

This period of the maturing years of the Water Resources Branch began with the appointment of Nathan Clifford Grover as Chief Hydraulic Engineer (CHE) on June 3, 1913, and ended June 30, 1919-a date selected more or less arbitrarily as the time when the State cooperation began to increase in considerable amounts. During the first year of the period, one more attempt was made to obtain an increase in the annual appropriation from $\$ 150,000$ to the long-sought goal of $\$ 200,000$, but this, like previous attempts, was unsuccessful. Thereafter the Branch advanced along the more or less even tenor of its way without running after what had proved to be "false gods." The period was in marked contrast to the previous one when each year brought high hopes that always faded for an expansion of the work. The succession of failed hopes had created considerable restlessness among the Branch personnel and did not appear to be conducive to good esprit de corps.

The Branch had weathered the Congressional storm that threatened stream-gaging appropriations by the "points of order" with respect to its appropriations, and its future appeared brighter and more secure than during the previous period. Wide recognition of the value of the work of the Branch was shown in a practical manner by an increase in the amount of cooperative funds offered.

The Federal appropriations for gaging streams were practically unchanged throughout the period, except for 1 year when the item was increased by $\$ 25,000$ for special work, and the cooperative State funds fluctuated between the narrow limits of $\$ 107,000$ and $\$ 120,000$ until 1919 when funding increased to $\$ 126,000$. During this period, unlike the two previous periods, no unusual interest in water was aroused to increase either Federal or State expenditures for its study. As a result of the stability of the available funds, the number of gaging stations was nearly constant $-1,148$ in 1913 and 1,251 in 1919. This statement is not intended to indicate that new stations were not established because many were, but an almost equal number were discontinued. The increases and decreases followed the changing amounts of cooperative funds offered by the several States. The character of changes and growth in the work was intensive rather than extensive. Improving methods and equipment was stressed, particularly improved equipment, in order to increase accuracy. This stress was initiated and promoted to a great extent by J.C. Hoyt, who was deeply interested in raising standards, especially with improved equipment. During these years, the technical personnel of the Branch grew from 63 in 1913 to 86 in 1919, exclusive of the Division of Enlarged and Stock-Raising Homesteads discussed later in this volume.

Viewed in retrospect, this period is one during which the Water Resources Branch was approaching maturity in its personnel and activities, and as a result was able to function economically and efficiently and to produce more uniform and satisfactory results. The new group of engineers who had succeeded the older group that left the USGS to form the Reclamation Service, had continued the work of gaging streams, investigating ground waters, and studying the problems related to the best use of the water resources of the Nation, and had been successfully wrought into a working organization. This new group was necessarily composed of young men with a nucleus, generally in the East, of men who were somewhat older and more experienced in USGS work. The organization had been largely perfected in the previous period; new district engineers had been selected and instructed in technical and administrative duties. Cooperation with States had been expanded and put on a workable basis, with 
interested and effective officials to represent the States in the cooperative relations.

This period, therefore, was essentially free from organizational or policy difficulties, and was properly devoted to the development of personnel and to improvements in equipment and in details of field and office methods. It was inadequately financed for the amount of work that should have been done, and, as a result, the highest values could not always be attained by its trained personnel. During these years, World War I occurred, which led to the creation of the Division of Enlarged and Stock-Raising Homesteads and the Division of Power Resources. The personnel were affected to a limited extent by the call to arms, and the regular program of the Division of Ground Water was almost entirely suspended during 1918 in order to do the work needed by the War and Navy Departments.

During these years, as stated before, more attention than ever before was paid to the development of personnel. The aims and methods of such development were clearly set forth at the 1914 conference in a paper presented by Grover, from which the following is abstracted:

The accuracy and value of the work of the Water Resources Branch depend more largely on the personnel than on any other one factor. It is the man that counts most, and our biggest problem is to select and develop the right type of man.

The Branch, like every other organization, needs men who are capable, adaptable, and amiable. The Survey has always taken pride in the practical value of the data collected and published under its auspices. Its engineers must therefore have an appreciation of the practical. They must not only understand how to do streamgaging work and everything connected therewith, but also be able actually to do these things.

If the Branch is to be efficient it must be made up of efficient men. Not every man who is obtained from the civil service register will be efficient in our work. If he is not, he should not be retained. If he is to make a success in this or any other work he must be interested, enthusiastic, and loyal.

The next important point in the development of a personnel is to give each man the broadest and best experience that is possible. The flexibility of an organization and its ability to expand and undertake new and different work does not depend primarily on the versatility of one or two men, but on the availability and adaptability of many.

Probably in no other branch of the government service is it as necessary for every man to be a diplomat. In our Branch the men work singly and each is, or should be, the personification not only of the Branch but of the Survey in his personal bearing and in his relations with people he meets. In considering the adaptability of young men for our work, the important characteristics of personality should be given careful consideration.

In choosing new district engineers and in developing men for those important positions, personal characteristics and ability to meet men affably, to make friends easily, and to maintain their respect becomes increasingly important. Cooperation is generally dependent on the ability of the district engineers to inspire and maintain cordial relations with cooperating parties. An ability to meet people easily and to make friends is, as in other organizations, an extremely valuable characteristic, and in district engineers a practical necessity.

The real test of the successful development of a man for future usefulness in this Branch is his ability to accept responsibility. Development in this as in other respects can be made only with opportunity. Some district engineers can and do give the young men every opportunity to develop ability to do independent work; others do not appear able to say to a man, 'This is your job, do it.' Instead, they insist on giving minute instructions and directing personally every detail of the work.

I will ask you (district engineers) whether you would prefer to have the Washington office undertake to direct the conduct of the work in your district, or to have authority given you to conduct it under the most general instructions given only after consultation with you. You would not be worthy of your position if you would consent to continue except under the latter conditions, and I would not be 
worthy of my position if I attempted to impose on you the former conditions. In the same way each of you should give to each man in your district responsibility for certain work and see that he does that work well.

It will be possible under a system of broad training to get a better grade of men if it becomes known that it is the policy of the Branch to develop men. Personally I think of and refer to other members of the Branch not as assistants but as associates. In like manner a district engineer should have his associates, not his assistants, in field and office. Some of the best and most active minds in the Branch are to be found in our junior engineers. The district engineer who does not give the young men opportunity to develop is working contrary to the best interests of his district and the Branch.

On May 7-8, 1917, the USGS moved from its quarters in the Hooe Iron building on $\mathrm{F}$ Street N.W., which had been occupied since 1886 , to the DOI building at 18 th and F Streets N.W., then nearing completion. There was great pressure for office space in Washington, D.C., at that time because of war activities, and the move into the new building was doubtless hastened somewhat because of this situation. The change in quarters was announced thus (Newsletter, May 29, 1917):

The Water Resources Branch moved on May 7 and 8, and for about a week practically all work was suspended, and everyone took a hand in packing before moving and later in unpacking and getting settled in our new quarters. These are on the second floor of the south end of the middle wing. We have on the east court 7 rooms, which are 14 by 20 feet, and on the west court we have 5 rooms 14 by 20 , and 5 rooms 28 by 20 feet.

By the end of the period, however, the pressure for office space had led the Congressional committee in charge of the assignment of space in government buildings in Washington, D.C., to assign about 80,000 square feet in the DOI building to the Treasury Department, resulting in a loss to the Branch of about 40 percent of its office space. As the editor of the
Newsletter plaintively said (July 24, 1919), "Visions of 'lots of space,' partly realized in May 1917, are now nothing but mirages."

\section{Nathan Clifford Grover Appointed Chief Hydraulic Engineer}

Leighton resigned from the USGS on June 3, 1913 , in order to enter private practice. Grover was then chief engineer of the Land Classification Board, having been reinstated in the USGS and given that appointment on March 1, 1911. In view of his previous connection with the Branch as ACH in charge of the surface-water investigations from July 1, 1904, to April 1, 1907 , he was made chief of the Branch on June 3, 1913, with the title of CHE, which was more fitting than the title of $\mathrm{CH}$, which had been given to Leighton. Thus began service as chief of a USGS branch that has lasted (1938) for a quarter of a century, a longer period than any other chief of a USGS branch has served.

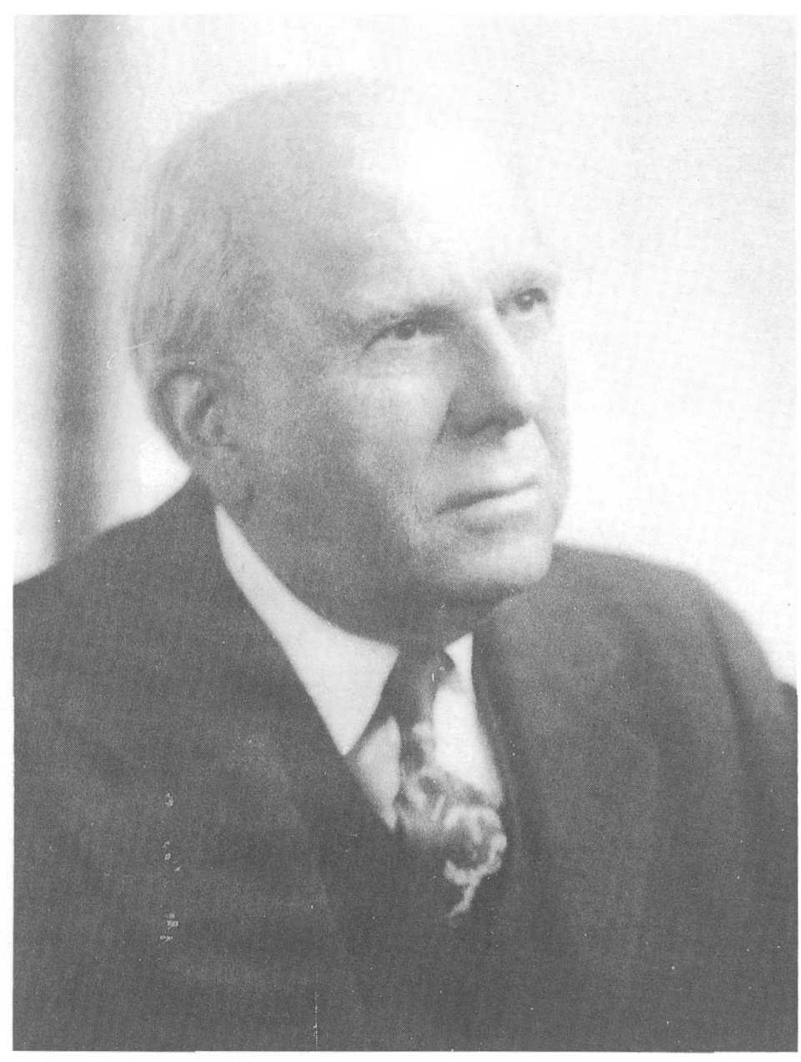

Nathan Clifford Grover Chief Hydraulic Engineer 1913-39 


\section{General Organization}

The general organization in effect during the previous years, so far as it related to the Division of Surface Water under J.C. Hoyt and the Division of Ground Water under Meinzer, continued during the present period. The Division of Water Utilization under Grover continued until 1917 when it virtually merged with the Division of Enlarged and Stock-Raising Homesteads, which was created in 1917 as a result of a special appropriation for examination of lands under the Stock-Raising Homestead Law. This new division was under the direct supervision of Grover. In 1918, the ground-water and quality-of-water work were again separated when the Division of Water Quality was organized under A.A. Chambers. In 1917, the Division of Power Resources was organized under Heroy.

The increase in cooperation with officials of Eastern and Central States gradually resulted in a reduction of the proportion of Branch Federal funds spent in the Public Lands States from 80 percent during the previous period to a low point of 62 percent during 1917. Thereafter, the increase, due largely to the work of the Division of Enlarged and Stock-Raising Homesteads, which was entirely in the Public Lands States, raised the proportion of Branch Federal funds spent in those States to 85 percent during the remaining 2 years of the period.

The work of the personnel of the Division of Water Utilization and later of that of the Division of Enlarged and Stock-Raising Homesteads was closely connected with the work of the Land Classification Board and there was thus mutual interest between the two organizations. In fact, the Board members were more directly concerned with the results obtained than were Branch personnel. The funds of the Land Classification Board were not so closely allotted as those of the Water Resources Branch, and unencumbered funds were sometimes available to pay salaries of a few additional engineers detailed to it from the Water Resources Branch when periods of financial stringency made such details desirable.

\section{Washington, D.C., Office}

No change in the plan of organization was made when Grover became $\mathrm{CHE}$, and the functions of the Washington, D.C., office continued essentially as before. G.C. Stevens was in charge of the computing section and had as regular assistants H.J. Jackson, Mathers, Padgett, and Walters, the latter in charge of Branch equipment. H.J. Jackson resigned in August 1918, Mathers transferred to the Land Classification Board in 1915 and Padgett in 1914, leaving Walters the only assistant to remain essentially throughout the period, and he was in the Army from August 1918 to February 1919.

Dean, another regular member of the computing section who was reappointed January 2, 1914, remained until he entered the Army in 1918 (he had some previous absences due to military duties and to several temporary district assignments generally to assist in office computations). Other engineers were assigned to the section for periods of a few months pending transfer to the districts. On November 28, 1915, B.J. Peterson became a member of the computing section when he transferred from the Ohio River District. Mrs. B.D. Wood was employed full-time as editorial clerk in the Branch until July 1, 1916, when she was given a per-diem appointment for part-time employment at her request. W.E. Hall was chief clerk of the Branch during the entire period.

The higher standards of station equipment introduced during this period made advisable the centralized purchase of much more material than in previous years, and led gradually to a new function for the Washington, D.C., office, namely, that of storekeeper. In fall 1913, turnbuckles and hardware for cable cars were purchased, and the announcement of that action contained the following statement (Instructions 43, Oct. 30, 1913):

It is believed that a large saving can be made by extending the practice of having the Washington office order such supplies as are of general use and for the various district offices to keep on hand a small stock of all such articles.

This arrangement contemplated placing orders that represented the combined yearly requirements of the districts, and shipping the articles to the districts as needed.

Most of the material for use in the field continued to be purchased directly by the 
district offices, but in many instances those offices failed to exercise sufficient care in observing the rigid regulations governing such purchases. For the period July to September 1914 , the auditor for the DOI suspended $\$ 6,000$ from USGS accounts for such failure. He finally compromised by waiving the disallowance pending the preparation of new regulations governing purchases. In anticipation of the new regulations, the Washington, D.C., office made arrangements to supply the district offices "such articles as are generally used throughout the Branch, such as turnbuckles, cable car hangers, gage rods, gage boxes, etc. Supplies of these and possibly many other articles will be kept in stock in Washington, and it is expected that each district will order in such quantities that there will always be a limited supply of the various articles in stock' (Instructions 8 , June 18,1915$)$. By 1917 , the list of articles had so increased that a five-page price list was issued on May 1.

\section{FIELD}

The numerous changes in district engineers that had occurred during the previous period by the final separation of the Branch from the Reclamation Service had been completed. The district engineers in 1913 were generally men who, with the more attractive outlook for the Branch, preferred to stay with their chosen work indefinitely. An important factor was the large measure of responsibility and freedom of action of the district engineers.

The logical result of reasonable assurance of the future of the Branch and of the attractiveness of the work was that no changes occurred among the district engineers of the established districts, except in the Great Basin District where successive resignations by E.A. Porter and Jacob necessitated changes. Similarly, there were fewer resignations among the younger men. The death of Gray in October 1918 necessitated the appointment of a new district engineer in Texas. The maturing of the district engineers during this period was recognized by their advancement in rank from assistant engineer to engineer. They were, however, still "youngish"-Interior Secretary Franklin K.
Lane at the 1917 conference remarked that he was surprised that such young men held such responsible positions (Lamb, oral commun., ca. 1938).

As a result of the firmer basis of funds, personnel, and cooperation, there were few changes in the boundaries of the established districts. Just at the close of the previous period, the Columbia River District was divided into the Oregon and Washington Districts. Only two states, New Mexico and Minnesota, ceased cooperation. When Wisconsin began cooperation, the district headquarters and substantially the whole organization moved from St. Paul to Madison. When Texas offered cooperation within a few months of the discontinuance of the New Mexico District, a part of that district's personnel transferred to Texas. Cooperation offered by Kansas in 1917 resulted in the creation of a new district in that State, and the resumption of cooperation with Maine caused the reestablishment in 1915 of the New England District as distinct from the New York District. There was the equivalent also of a district in Alaska to conduct work financed by the Forest Service and the Alaska Division of the USGS.

The salary classification remained unchanged during the period, except that entrance salaries ranged from $\$ 1,080$ to $\$ 1,200$ beginning in 1916 instead of being fixed at $\$ 1,080$ as established in 1913. Assistant engineer salaries ranged from $\$ 1,380$ to $\$ 2,000$ and those for engineer from $\$ 2,400$ to $\$ 3,000$.

Although war activities did not greatly affect the established program of the Branch, personnel were affected because many members, including district engineers, joined the Armed Forces. Necessary changes in assignments of those members remaining are recorded in the appropriate parts of this History.

An effect of the war, which applied to all government employees as well as to a large part of the population, was caused by the rapid increase in the cost of living that began to be noticed in 1917. As a partial remedy for this situation and its affect on those in the lower grades, the Sundry Civil Act signed on June 30, 1917, contained the following:

That to provide during the fiscal year nineteen hundred and eighteen, for 
increased compensation at the rate of ten per centum per annum to employees who receive salaries at a rate per annum less than $\$ 1,200$, and for increased compensation at the rate of five per centum per annum to employees who receive salaries at a rate not more than $\$ 1,800$ per annum and not less than $\$ 1,200$ per annum, so much as may be necessary is appropriated.

No provision was made for those whose salaries were greater than $\$ 1,800$ because it was assumed that they would be able to absorb the higher costs. In the Sundry Civil Act for fiscal year 1919, the increase or bonus was increased to a flat amount of $\$ 120$ per annum for all employees receiving $\$ 2,500$ or less, and those receiving between $\$ 2,500$ and $\$ 2,620$ received an amount that made the total compensation $\$ 2,620$ (40 Stat. L. 757,814 ).

The increase in prices was general, and was as much as 50 percent and even 75 percent on some materials and equipment used in the regular Branch work. With no corresponding increase in available funds, the inevitable result in many districts was to defer purchases. Not only were prices rising rapidly, but the manufacturers were so busy with war orders even before the United States entered the war that orders placed by the USGS were delayed far longer than ever before. As an example of these delays, the following is quoted from the Newsletter dated December 18, 1915:

Eight hundred enamel gage sections were ordered July 27. Part were delivered October 6 and part October 8 , not according to specifications. The differences were adjusted October 14 , and 300 sections, which we need badly, are still undelivered.

The American Steel and Wire Co. has recently demanded forty days for delivery f.o.b. factory for 450 feet of plow steel aerial cable.

We are informed that one of the large companies doing galvanizing has issued a statement to the effect that no orders would be accepted for delivery prior to August 1917.

Early in 1917 , the scarcity of paper became so acute that the Interior Secretary's office (Instructions, Jan. 5, 1917) called attention to "the absolute necessity of economizing in the use of paper on account of scarcity as well as the great advance in price. The Department has already been embarrassed in the effort to procure a sufficient supply for the bureaus and offices as some of the contractors have been unable to fill orders, thus making it necessary for the Department to purchase paper on open market wherever it could be found. Such procedure has caused long delays in obtaining a supply even for immediate use." Further instructions were issued on two later dates during that year regarding economy in use of paper and other office supplies, the last one (July 13, 1917) adding that " . . . although prices had increased 35 to 50 percent, the appropriation for them had remained the same."

\section{APPROPRIATIONS}

In spring 1914, another attempt was made to reach the goal of $\$ 200,000$ by having the Senate increase the $\$ 150,000$ appropriation as it was passed by the House. The Senate not only increased the general appropriation but added, at the insistence of western Senators, $\$ 100,000$ for boring exploratory wells that might be used for irrigation. As in previous attempts, however, the Senate increase was lost in conference, and $\$ 150,000$ was finally appropriated. Each year thereafter, estimates for increased amounts for stream gaging were submitted to the Interior Secretary's office and urged at the hearings on the Sundry Civil bill. One hundred and fifty thousand dollars was appropriated annually until 1917 when an item of $\$ 25,000$ for exploratory well drilling increased the amount for fiscal year 1918 to $\$ 175,000$. In addition, an item of $\$ 150,000$, available until spent, for classifying the lands under the Homestead Act of 1909 was made available to the Water-Utilization Division and the newly created Division of Enlarged and Stock-Raising Homesteads. In the last year of this period, not only was the well-drilling item omitted, but all regular appropriations were subject to a small percentage reduction that cut the $\$ 150,000$ Branch appropriation to $\$ 148,244.10$.

\section{Cooperation}

Cooperation was greater from 1913 to 1919 than during the previous period. The average 
annual total of State cooperation was about $\$ 115,000$, which was twice the average of the previous period. Cooperation with Federal organizations increased to a lesser degree, but did amount to about $\$ 25,000$ annually, exclusive of the contribution of some $\$ 4,000 \mathrm{annu}$ ally by the USGS Alaskan Division. The equivalent cash value of assistance received annually from other sources averaged about $\$ 20,000$, a larger amount than had been received previously. The total annual cooperation, therefore, was about $\$ 160,000$, an amount that exceeded the Federal streamgaging appropriation.

States

The conservation movement, which had caused an increase in State cooperation for stream gaging from $\$ 20,000$ to $\$ 109,000$ annually during the previous period, had largely lost its impetus by 1913. Although the high level of State cooperation then reached was thereafter maintained, the allotment did not materially increase within this period. Gains in some States during the period were largely offset by losses in others. The net result was a nearly constant total of State cooperative funds as follows:

$\begin{array}{rrrr}1914 & \$ 119,787 & 1917 & \$ 117,201 \\ 1915 & 106,848 & 1918 & 115,571 \\ 1916 & 118,516 & 1919 & 126,312\end{array}$

The States generally recognized the futility of insisting on 50-50 cooperation and, except in a few instances where available State funds were limited by law to the amount of USGS funds allotted, the cooperating agencies made agreements on the basis of the funds available from both parties. The details of cooperation within each State follow.

MAINE.-In November 1914, stream gaging in Maine was taken over by the State Public Utilities Commission and some time later, the exact date not now being known, cooperation was resumed with the USGS on the basis that the field work was to be conducted by an employee of the Commission but under USGS supervision. In the language of the Commission Report for 1915 (vol. 2):
The methods of conducting the field work are at all times subject to the approval of competent engineers of the Geological Survey, and the final computations are checked by their district engineer, preparatory to publication by the Washington office. The Geological Survey has also furnished the necessary instruments for carrying on the field work, and forms for use in the computation of results.

The annual State allotments were:

$\begin{array}{lrrrr}1915 & \$ 75 & 1918 & \$ 3,670 \\ 1916 & 4,515 & 1919 & 5,000 \\ 1917 & 5,640 & & \end{array}$

From the small amount of the 1915 allotment, it may be assumed that cooperation began near the end of fiscal year 1915. During this period, the USGS made no specific allotments for Maine, and limited its expenditures to payments for occasional supervisory trips and for equipment and supplies furnished.

NEW HAMPSHIRE.-Interest in water resources, particularly water-power possibilities, arose in New Hampshire at a later date than in the other New England States. By 1915, this interest had become so strong that the State Legislature passed an act authorizing an investigation of the water powers but no funds for the purpose. The manufacturing activities, resulting largely from the production of supplies for the belligerents in World War I, demonstrated the increasing importance of water power and, in 1917, the State Legislature enacted the following law (J. Res. 256, approved April 12, 1917):

Resolved by the Senate and House of Representatives in General Court convened:

That the Governor, with the advice and consent of the Council, shall appoint a commission to investigate the possibilities for the conservation and better utilization of water power in the State by means of storage reservoirs or otherwise in accordance with the provisions of chapter 90 of the laws of 1915 , and make a report to the next legislature.

The commissioner so appointed may employ engineering assistance and incur expenses incidental therein, and is empowered to enter into a cooperative agreement with the director of the United States Geological Survey for the purpose of making the investigation aforesaid. 
The Governor is authorized to draw the warrant for a sum not to exceed $\$ 3,000$ for the above purposes.

In July 1917 , C.H. Pierce had a conference with George B. Leighton, the New Hampshire Commissioner of Water Conservation and Water Power, that resulted in a cooperative agreement whereby the USGS would collect the field data needed by the State. The scope of the investigation was to include not only a minor amount of stream gaging, but also, as a major activity, field examinations to find possible sites for storage reservoirs and to ascertain their capacities, and to obtain information as to the possibility of increasing the power capacity of the present and prospective plants (C.H. Pierce, oral commun., ca. 1938).

In the report to the legislature at the end of the 2-year period, the Commissioner stated (Rept. of comm. on water cons. and water power, 1917-18):

Shortly after my appointment I entered into an agreement with the U.S. Geological Survey for a joint investigation and assistance, particularly in field work. This arrangement has been satisfactory and much has been accomplished at a minimum expenditure that could not otherwise have been done.

He then called attention to the importance of continuing the study of the State's natural resources, pointing out the acute shortage of coal during the previous year that had underscored the importance of the further use of water power to reduce the amount of coal consumed and to obtain greater economy in operating costs. He concluded by saying (Rept. of comm. on water cons. and water power, 1917-18) that "the water which goes over the dam does no work, but if this water can be saved and allowed to pass down the stream when the stream would otherwise be low, this water will help turn the wheels." The commissioner's plea was successful and further State appropriations were allotted. During this period, the State allotments were $\$ 1,060$ in 1918 and $\$ 2,395$ in 1919 . The Survey allotment was $\$ 1,000$ each year.

VERMONT.-The act of the 1912 session of the State Legislature of Vermont appropriating
$\$ 1,200$ annually for stream gaging in cooperation with the USGS (No. 289, Acts of 1912) continued in effect during this period. The State geologist was the cooperating official until 1917 when the legislature amended the Act of 1912 by designating the State engineer as the cooperating State agency. The annual State allotments were:

$\begin{array}{rrrr}1914 & \$ 1,200 & 1917 & \$ 1,245 \\ 1915 & 900 & 1918 & 1,065 \\ 1916 & 1,440 & 1919 & 1,330\end{array}$

The USGS allotted $\$ 900$ annually.

MASSACHUSETTS. - Although a 4-year appropriation of $\$ 3,000$ annually was apparently allotted at the 1912 session of the State Legislature of Massachusetts, it seems to have been only in the nature of an enabling act to be made effective by a specific appropriation of $\$ 3,000$ each year. When C.H. Pierce presented his bills to the State for work done during July 1915, he was much surprised by a statement from the State auditor that no funds were available because the legislature had failed to appropriate the customary $\$ 3,000$ for fiscal year 1916 . Continuation of State cooperation was vital to the maintenance of the new district, so C.H. Pierce turned for assistance to the Commission on Waterways and Public Lands. The duties of the Board of Harbor and Land Commissioners, the predecessor of the Commission on Waterways and Public Lands, were defined by the 1915 session of the legislature, as follows (Res. of 1915, ch. 113):

Resolved that the Board of Harbor and Land Commissioners is hereby authorized and directed to investigate the matter of conserving, utilizing, and equalizing the flow of water in the rivers and natural streams.

The Commission on Waterways and Public Lands inherited these duties. The Commission was sympathetic toward cooperation, realized the need for streamflow records in connection with its work, and made an allotment for that year from its own funds. Thereafter, a regular item for cooperation was set up in the budget of the Commission and its successor, the Department of Public Works. The annual State allotments were:

$\begin{array}{rrrr}1914 & \$ 3,000 & 1917 & \$ 2,370 \\ 1915 & 3,350 & 1918 & 2,025 \\ 1916 & 2,520 & 1919 & 3,240\end{array}$

The annual USGS allotment for Massachusetts was $\$ 2,250$. 
NEW YORK.-Cooperation in New York continued during the period with the Conservation Commission and the State engineer. The following annual allotments for each cooperator were:

$\begin{array}{ccrr}\text { Year } & \begin{array}{c}\text { Conservation } \\ \text { Commission }\end{array} & \begin{array}{c}\text { State } \\ \text { Engineer }\end{array} & \text { Total } \\ 1914 & \$ 10,000 & \$ 1,500 & \$ 11,500 \\ 1915 & 10,500 & 1,400 & 11,900 \\ 1916 & 12,240 & 1,560 & 13,800 \\ 1917 & 9,835 & 1,500 & 11,335 \\ 1918 & 8,860 & 2,170 & 11,030 \\ 1919 & 8,630 & 2,380 & 11,010\end{array}$

The USGS allotment was $\$ 2,500$ annually until 1918 , when it increased to $\$ 3,500$ and to $\$ 4,000$ in 1919 .

Power shortages during the war underscored the dominant position that power occupied in the conservation of the State's water resources. As the Conservation Commission reported (Eighth ann. rept., p. 25, 1918):

The need for power to operate war industries and the shortage of coal placed additional emphasis upon the necessity for immediate development of the State's water powers.

NORTH CAROLINA.-Although the chief use of the streams of North Carolina was for power, there had been no cooperation with the State geologist since 1909. When Carl G. Paulsen became district engineer, he found that the State geologist, Dr. Joseph Hyde Pratt, was interested in the stream-gaging program. Although available State funds were small, the State [Geological] Survey, beginning on October 30, 1918 , contributed $\$ 280$ during 1919 toward the establishment and maintenance of three new stations. This small contribution was the beginning of more extensive cooperation that led to the establishment of a district office in Asheville a few years later.

GEORGIA.-Cooperation with the State geologist of Georgia, which had been in effect prior to 1913, was discontinued until the last year (1919) of the present period. This discontinuance of cooperation was due probably to lack of available funds because the State geologist maintained at all times a sympathetic attitude toward the USGS work. In fall 1918, additional records in southern Georgia were needed and Paulsen made arrangements with the State geologist to furnish a part of the funds required for that work. The State's contribution was $\$ 505$ during 1919 .

ALABAMA.-Cooperation with the State geologist of Alabama continued during the present period and, as in the previous period, consisted of paying gage observers salaries in amounts ranging from $\$ 170$ to $\$ 205$ annually.

WEST VIRGINIA.-During 1914 and 1915, the State geologist cooperated in the maintenance of eight stations in West Virginia. The only available information regarding this cooperation is a statement in the Director's annual report that cooperation during 1915 amounted to $\$ 1,400$.

KENTUCKY.-The 1912 session of the Kentucky Legislature passed an act creating a State Geological Survey and authorized it to cooperate with Federal organizations, particularly the USGS, in geology and topographic mapping. One of the duties of the State Survey was to report on the water powers of the State. Referring to this latter duty, the State geologist stated in 1913 (First Ann. Rept., State Geol. of Kentucky, p. 10), “*** these (reports) will be taken up from time to time as opportunity affords. Reliable estimates of capacity can only be based on long-continued gaging readings of the flow of streams and but few of these have been made in Kentucky." After the flood of March 1913, A.H. Horton, in charge of the Ohio River District, arranged cooperation with the Kentucky State geologist starting in 1915 (Newsletter, April 17, 1914). State funds were allotted as follows:

$\begin{array}{rrrr}1915 & \$ 670 & 1918 & \$ 250 \\ 1916 & 315 & 1919 & 250 \\ 1917 & 420 & & \end{array}$

The USGS funds were not itemized by State, but rather were lumped together for the Ohio River District.

TENNESSEE. - The conservation movement was responsible for the creation of the State Geological Survey of Tennessee in 1909. A portion 
of the Act creating that Survey is as follows (Tenn. State Geol. Survey Bull. 15, 1912, p. 6):

SECTION 5.-Be it further enacted, That the said State Geological Survey shall have for its objects and duties the following $*^{* * *}$ :

An investigation of the forests, streams, and water powers of the State with especial reference to their conservation and development for industrial enterprises.

SEC. 8.-Be it further enacted, That the said Commission (governing the Survey) is hereby authorized to enter into cooperation with the United States Geological Survey and other scientific Bureaus of the Federal and State governments for the prosecution at joint expense of such work in the State as shall be deemed of mutual interest and advantage ${ }^{* * *}$.

In 1918, when cooperation began, Wilbur A. Nelson was State geologist and was a waterpower enthusiast as indicated by the statement in his administrative report for 1919 (Tenn. State Geol. Survey Bull. 23, p. 9):

Each year that a stream remains unharnessed, each year that adequate hydroelectric power plants are not built, means just so much total loss to the State in revenue from its wasted and neglected water powers. ${ }^{* * *}$ Let us plan ahead, and let it be said that Tennessee realizes that the greatest benefits can come to the State through the greatest and quickest development of its water-power possibilities.

With a State official eager to promote waterpower utilization, Paulsen, the interim district engineer for the Southern States, contacted Nelson regarding cooperation in fall 1918 and so interested him in a statewide stream-gaging program that, although the State had no funds available for such work at the time, Nelson solicited funds from several Chambers of Commerce in hopes of obtaining general support for an appropriation out of the next session of the State Legislature. A fund of several hundred dollars was subscribed and used to establish from 10 to 15 stations. They were established while the legislature was in session. The Governor showed considerable interest in the cooperative program, and one of the first stations established was on a stream near the Governor's home in central Tennessee in order to increase his interest. To establish this station, it was necessary for Paulsen to travel by mule more than 20 miles over almost impassable muddy roads (Paulsen, written commun., ca. 1938). During fiscal year 1919, the State geologist contributed $\$ 660$ that had been raised as described above.

ILLINOIS.-Cooperation with the Lakes and Rivers Commission of Illinois, which had ceased on September 30, 1912, was resumed in June 1914 when State funds were again available. The chief need for the records in Illinois related to floods (Ann. rept., Rivers and Lakes Comm. of Ill., 1916). On July 1, 1917, the work of the Rivers and Lakes Commission was taken over by the Division of Waterways, Department of Public Works and Buildings, which continued the cooperation. Concerning the value of the records, the Division of Waterways stated (First ann. rept., Ill. Dept. of Pub. Works and Bldgs., 1918):

By means of two stations the amount diverted from Lake Michigan through the Sanitary Canal is determined. This has an important bearing upon the request of Chicago to the War Department to authorize the diversion of a greater amount of water.

And again a year later (Second ann. rept., Ill. Dept. of Pub. Works and Bldgs., 1919):

Compilation of streamflows by the maintenance of gauging [sic] stations at various points on streams of the State has proven a most important and valuable detail of the work of the division. This information is called for almost daily in connection with various projects of municipalities, railroads, etc.

The annual amounts allotted were:

$\begin{array}{rrrr}1915 & \$ 3,400 & 1918 & \$ 2,675 \\ 1916 & 2,355 & 1919 & 2,550 \\ 1917 & 2,580 & & \end{array}$

It is impossible to give the USGS allotments as they were included in district allotments, except for 1918 and 1919 when the amount was $\$ 1,000$ for each year. 
WISCONSIN.-The investigation of the water powers of Wisconsin conducted during the previous period showed the large amount of power available and, probably influenced by the wave of enthusiasm for conservation of natural resources that had swept across the country beginning in 1909, the State Legislature at its 1913 session enacted the Water Power Act (Ch. 755, Laws of 1913) that gave the State Railroad Commission jurisdiction over the water powers of the State. Paragraph 3 of Section $1596-53$ is as follows:

The commission shall establish and maintain gaging stations upon the various navigable waters of the State and shall take such other steps as may be necessary for the purpose of determining the characteristics of such waters and maintaining records of the same.

Navigable waters were specified because, in Wisconsin, the ownership of the bed of a navigable stream to its high-water line belongs to the State. Hence, by virtue of that ownership, the State has the right to exercise control over the water powers of those streams.

In fall 1913, W.G. Hoyt arranged cooperation with C.M. Larson, chief engineer of the State Railroad Commission. In this cooperation, the USGS was to establish a District Office at Madison in the quarters occupied by the Commission, thereby being in close touch with the Commission's engineers. Whereas Minnesota cooperation was declining, the District Office moved from St. Paul to Madison, on December 1,1913 . The cooperative agreement signed November 20,1913, provided for expenditures as follows (Soule, written commun., ca. 1938):

(a) the party of the first part, $\$ 1,000$ to be expended during the fiscal year ending June 30, 1914, and such sums annually thereafter as can be provided depending on the Federal appropriation.

(b) the party of the second part, $\$ 10,000$ annually during the period that this contract is in force.

Apparently the agreement was silent as to the supervision of the work but as subsequent events show, the stream-gaging activities were under USGS supervision. The amounts allotted by the Railroad Commission were as follows:

$\begin{array}{rrrr}1914 & \$ 11,861 & 1917 & \$ 5,970 \\ 1915 & 8,800 & 1918 & 5,055 \\ 1916 & 6,000 & 1919 & 5,160\end{array}$

The first year's work included the installation of gaging stations and the extra field work necessary to rate the stations as rapidly as practical. The program of work evidently caused the Commission to allot a larger amount than was originally specified. Subsequently, the cost of maintaining the stations was materially less, and the State allotments were reduced accordingly. The USGS allotments were $\$ 1,900$ in 1914 , and $\$ 2,500$ annually for 1918 and 1919 . For 1915 to 1917 the allotments were not itemized from those for the other States in the district, but probably averaged about $\$ 2,500$.

Certain features of the Water Power Act were objected to by the power interests who took the act to the Wisconsin Supreme Court where it was declared unconstitutional. Accordingly, the legislature repealed that act in 1915 and enacted a new law that contained the greater part of the provisions of the original act, but omitted those parts that had been declared unconstitutional. The act that passed in 1915 contained the authority for the subsequent State cooperation.

MINNESOTA.-Cooperation with the State Drainage Commission of Minnesota continued until June 30,1917, though in a lesser amount than in earlier years. At its 1917 session, the State Legislature refused to make the necessary appropriation because of a political fight on the Commission, and cooperation ceased. The Drainage Commission allotted the following amounts:

$\begin{array}{rrrr}1914 & \$ 3,500 & 1916 & \$ 2,400 \\ 1915 & 2,100 & 1917 & 2,470\end{array}$

There were two reasons for the decrease in State funds: (1) The completion of the special surveys required for the report on the State's water resources and (2) the feeling that the State should "ease up" on its contribution until the USGS had spent an amount equal to the State's liberal contributions during the previous period. Throughout the entire period, however, the USGS allotted funds for Minnesota in accordance with the understanding, reached when the original contract was signed in 1919 , that the USGS would attempt in subsequent years to equal the amounts allotted by the State. The USGS allotments were $\$ 3,500$ for 1914 and about the same from 1915 through 1917 , although the allotments for those years were included with those for the entire district. 
IOWA.-Cooperation with the State Geological Survey of Iowa that started during the previous period was continued. Flood data were of highest value in Iowa, particularly to the State Highway Department much concerned with providing adequate waterway openings, and W.G. Hoyt had a conference in 1918 with Thomas H. MacDonald, the chief engineer of the recently created Iowa Highway Commission (later chief, U.S. Bureau of Public Roads), which resulted in additional cooperation. (This additional cooperation would become so important early in the next period that a separate district would be created in Iowa.) The following State funds were allotted:

$\begin{array}{cccr}\text { Year } & \text { USGS } & \begin{array}{c}\text { Highway } \\ \text { Commission }\end{array} & \text { Total } \\ 1914 & \$ 500 & -\ldots & \$ 500 \\ 1915 & 450 & -\ldots & 450 \\ 1916 & 500 & -\ldots & 500 \\ 1917 & 500 & -\ldots & 500 \\ 1918 & 500 & \$ 315 & 815 \\ 1919 & 545 & 1,150 & 1,695\end{array}$

NORTH DAKOTA.-Cooperation in North Dakota continued, except during 1914, with the State engineer, who paid for gage observers and minor equipment in the following amounts:

$\begin{array}{rrrr}1915 & \$ 350 & 1918 & \$ 385 \\ 1916 & 500 & 1919 & 600 \\ 1917 & 300 & & \end{array}$

The USGS allotted $\$ 450$ in 1914 , and $\$ 300$ annually in 1915, 1918, and 1919.

SOUTH DAKOTA.-In summer 1914, F.H. Newell learned that the South Dakota State engineer had a small fund for hydrographic surveys related to one or more possible irrigation projects along the Cheyenne River. F.H. Newell pointed out the need for stream-gaging records and suggested cooperation with the USGS. As a result, the Denver Office established and maintained two stations on the Cheyenne River. The cost to the State until June 30,1915 , was $\$ 960$.

One of the stations was maintained subsequently, as the State hoped that the Reclamation Service might be induced to construct the Angostura project, which had been surveyed by the State engineer; the State paid the observers salary for the next year, which amounted to $\$ 180$. Private interests met this expense until fiscal year 1919 when the State again paid it. Thus, the entire amount expended by the State during the period was $\$ 1,320$.

NEBRASKA.-Cooperation whereby the State engineer of Nebraska collected the field data and the USGS computed the records ceased at the end of 1914. Special investigations on the North Platte and Platte Rivers, beginning in 1915, required the entire attention of the State organization and the stations in other parts of the State were discontinued.

KANSAS.-Although Kansas was the first State to cooperate with the USGS, the cooperation lasted only from spring 1895 to the first of November 1896 when the cooperating agency, the State Board of Irrigation Survey, was legislated out of existence. Thereafter, little interest was shown for several years in the surface waters of the State, except in the Kansas River basin where the severe floods of 1903, 1904, 1908 , and 1915 caused the citizens to feel that measures must be taken to protect the valley from future floods. In 1917, the Kansas State Legislature created the Kansas Water Commission, a part of whose duties were defined as follows (Laws of Kansas, 1917, ch. 172, p. 218):

SeCtion 4.-As soon as practical after organization, the Commission shall, in connection with the Federal Government, by way of securing financial and professional aid and assistance, work out a systematic general plan for the complete development of each watershed in the State in order to secure the most advantageous adjustment of the interest involved in matters of floods, drainage, irrigation, water power and navigation. * * * Water development of all kinds throughout the State shall conform to the general plans adopted by the Commission.

SEC. 5.-This Commission is hereby authorized, and directed to establish and maintain river gauging stations and to make such surveys and other investigations as may be necessary to a complete knowledge of the subjects herein assigned to it for investigation.

The funds for the Commission were to come from the State tax on sand removed from the beds of the navigable rivers, ownership of which rested with the State. 
In order to start the study of the floodcontrol problems as soon as possible, H.B. Walker, engineer for the newly-appointed commission, suggested cooperating with the USGS, and cooperation was put into effect May 11, 1917. In the selection of gaging stations, particular attention was to be paid to flood-prone streams. When the law creating the commission was enacted, it was thought that the funds from the sand tax would be enough to finance extensive investigation. After the Commissioners were appointed and cooperation arranged, however, a suit against the new law rendered the sand tax temporarily uncollectible. It was essential to start stream gaging without delay so, pending favorable outcome of the suit, emergency measures in the form of a small allotment from the general funds of the State were taken to finance the beginning of the investigations.

The cooperative agreement was for a period slightly longer than 2 years, ending June 30 , 1919. The amounts allotted were as follows:

\begin{tabular}{crr} 
Fiscal year & USGS & \multicolumn{1}{c}{ State } \\
1917 & $\$ 243$ & $\$ 1,000$ \\
1918 & 2,500 & 2,815 \\
1919 & 2,500 & 3,250
\end{tabular}

TEXAS.-By 1913, irrigation in Texas had reached such a stage of development that a general irrigation law was needed, and the 1913 session of the legislature enacted such a statute. A Board of Water Engineers composed of three engineers (one each from the three water divisions into which the State was divided) was created to administer the new law. The first Board was appointed effective September 1, 1913.

One of the duties of the new Board was defined as follows (Sec. 42, ch. 171, Gen. Laws Reg. Sess., 33d Leg.):

It shall be the duty of the Board to make, or cause to be made, measurements and calculations of the flow of streams from which water may be appropriated ${ }^{* *}$ * commencing such work in those streams most used for irrigation or other beneficial uses.

No appropriation was made for this phase of the Board's activities, however, and stream gaging was limited during 1913 to the purchase of one current meter (First rept., Board of Water Eng., p. 10, 1915). Recognizing the expense attached to a stream-gaging program in a State of the size of Texas, the report further states that "the Board hopes to be able to arrange for cooperative work in stream measurements with the Hydrographic Division of the United States Geological Survey, provided an adequate appropriation will be made for the purpose by the next legislature. By cooperation much more extensive and valuable measurements can be secured than by independent investigations by the National and State governments."

With this favorable attitude foreshadowing future cooperation, the USGS resumed work in Texas after a lapse of 7 years. An allotment of $\$ 1,500$ was made and district engineer W.E. Hall was instructed to establish some of the old stations and consult with T.U. Taylor regarding the Texas work (Grover, written commun., ca. 1938). In October 1914, W.E. Hall established four stations at points where the Weather Bureau maintained gages. During the next 9 months, W.E. Hall spent considerable time in Texas, becoming acquainted with the Board of Water Engineers and others interested in the State's water resources. Although the USGS was unable to allot any large amount of money for work in Texas in that fiscal year, a substantial allotment was made in the next fiscal year. On July 8,1915 , cooperation was arranged on the basis of a State allotment of $\$ 6,000$ to the USGS $\$ 4,000$ for the first year. The work was to be supervised by the USGS, using engineers of both Federal and State organizations.

Beginning in 1916, the Texas State Legislature appropriated $\$ 10,000$ annually for cooperative stream gaging during the remainder of the period, and the amount was augmented slightly during 1917 and 1918 from other funds at the Board of Water Engineers' disposal. The amounts allotted during each Federal fiscal year were:

$\begin{array}{crr}\text { Fiscal year } & \text { USGS } & \text { Texas } \\ 1916 & \$ 3,335 & \$ 8,500 \\ 1917 & 4,000 & 10,295 \\ 1918 & 4,000 & 10,965 \\ 1919 & 4,000 & 9,830\end{array}$


Regarding the USGS amount shown for fiscal year 1916, other credits increased this amount to $\$ 3,692.53$. The total USGS expenditure during the State fiscal year, which ended on August 31 , was $\$ 4,416.50$, which more than met the terms of the agreement.

MONTANA.-During the period, Montana appropriated money to the State engineer's office for conducting stream gaging as much as possible with the USGS, and the cooperation started in 1909 continued. In this regard, the State engineer stated (Sixth bienn. rept., 1913-14, p. 4), "In supervising the expenditure of State funds for stream gaging I have continued to cooperate with the United States Geological Survey. In this work C.S. Heidl, state hydrographer, has been in active charge of field work under the direction of this office and most satisfactory results have been obtained." The annual State amounts of each year of cooperation were:

$\begin{array}{rrrr}1914 & \$ 2,500 & 1917 & \$ 2,760 \\ 1915 & 2,500 & 1918 & 1,720 \\ 1916 & 2,875 & 1919 & 2,205\end{array}$

The reduced allotments during 1918 and 1919 were due to war activities. As stated by Lamb (Newsletter, July 27, 1917):

By order of the Governor, the State engineer was commissioned a Major in the Second Montana Regiment and placed in charge of military intelligence work, with orders to use any State funds coming under his office. Our stream gaging fund, being the largest, was taken first.

WYOMING.-Cooperation with Wyoming, which had ceased on September 30, 1912, was resumed on April 1, 1915, when a new State engineer took office. During the interim, the USGS had been compelled to discontinue its work in Wyoming except at a few stations, chiefly those in which the Reclamation Service was interested.

The engineers who worked in Wyoming were aware of the need for a more extensive program and so was J.B. True, the new State engineer. As True told the author afterward, his first official letter was one suggesting that cooperation be resumed as soon as possible. This was done and cooperation continued during the remainder of the period. The annual State allotments were as follows:

$\begin{array}{lrrr}1915 & \$ 1,600 & 1918 & \$ 4,450 \\ 1916 & 5,010 & 1919 & 4,815 \\ 1917 & 4,895 & & \end{array}$

It is impossible to give the USGS allotments for Wyoming as the allotments for the District were not itemized by State. Whereas the greater part of the District's work was in Wyoming, it is certain that USGS funds at least equalled those of the State.

COLORADO.-The USGS work in Colorado during the period was limited chiefly to the mountainous region. A number of those mountain stations that were previously maintained by the State were turned over to the USGS, and the State engineer paid gage observers salaries and some additional expenses. A new State engineer in 1917, who wanted additional stations established in the western part of the State, paid most of the expense of establishing and maintaining them. An average of 14 stations were maintained during the period in cooperation with the State. The annual amount of State cooperation was:

$\begin{array}{rrrr}1915 & \$ 480 & 1918 & \$ 600 \\ 1916 & 485 & 1919 & 700 \\ 1917 & 530 & & \end{array}$

The USGS allotment for the district was not itemized by State.

NEW MEXICO.-Cooperation with New Mexico was continued until January 1, 1915. The State funds spent during the period were $\$ 12,000$ for 1914 and $\$ 7,200$ for the first half of fiscal year 1915. The USGS allotment was $\$ 4,500$ for each of those fiscal years.

IDAHO.-Cooperation with Idaho was continued until December 1914. The State funds were derived from the Carey Act fund, and the allotment for fiscal year 1914 was $\$ 9,000$. By fiscal year 1915, the Carey Act fund had then become so depleted that it was possible to allot only $\$ 1,900$ for that fiscal year. The failure in 1913 of the Kuhn banks and allied companies that were heavily involved in irrigation and power projects in Idaho, had caused virtual cessation not only of the construction of such 
projects, but also of the initiation of new projects. This situation was reflected in the small amount of money available in the Carey Act fund.

Realizing the need for continuity of streamflow records and for continued cooperation, the State engineer recommended a direct appropriation for stream gaging. In February 1915, the Idaho State Legislature appropriated $\$ 12,000$ for the next 2 years, but the newly-elected Governor vetoed the bill-he was determined to reduce by $\$ 1$ million all appropriations made by the legislature (Baldwin, written commun., ca. 1938). Two years later, the State engineer recommended an appropriation of $\$ 10,000$ to be used in cooperation with the USGS and, mindful of the Governor's opposition to such cooperation, added the further recommendation that the money could also be used for stream gaging by the State engineer independently of the USGS. The Governor again vetoed the appropriation.

A new Governor elected in 1918 recommended in his message to the legislature an appropriation for cooperation, and the legislature appropriated $\$ 20,000$ for the next 2 years. The legislation was effective on April 1, 1919, but the money was not available until May 7 . During the few remaining weeks of this period, $\$ 1,310$ of State funds were spent. At that session of the legislature (1919), the State government was reorganized, the State engineer's office was abolished, and its duties were transferred to the newly-created Department of Reclamation headed by a Commissioner of Reclamation. The USGS allotments were as follows:

$\begin{array}{rrrr}1914 & \$ 4,500 & 1917 & \$ 4,000 \\ 1915 & 4,500 & 1918 & 2,800 \\ 1916 & 4,000 & 1919 & 2,800\end{array}$

UTAH.-Cooperation with Utah continued during this period with funds derived from two sources. The State Legislature appropriated $\$ 10,000$ for each 2-year period for cooperation with the USGS on a 50-50 basis for the regular stream-gaging program. In addition, the State engineer made allotments from an irrigation contingent fund for special investigations. Although the State appropriation of $\$ 10,000$ for the biennium 1913-14 was an increase of $\$ 3,000$ annually, the State engineer stated that this increase was insufficient, because "at least 75 percent of the applications for water during the past two years have been from smaller streams where few or no records are available" (Ninth bienn. rept., State eng., 1913-14, p. 14). The plea for additional funds was unsuccessful. Again in 1918, the State engineer, in another plea, made the following statement (11th bienn. rept., State eng., 1917-18, p. 13):

Within the past two years it has been found difficult with this fund to even maintain the stations previously established on account of the increased cost of water-stage recorders, equipment, and increased salary of government hydrographers. Even the gage readers, who generally are persons living within the vicinity of gaging stations, have in a number of cases asked for increased pay for reading staff gages. It appears evident that a larger appropriation will have to be made for this work.

This plea also was unsuccessful.

It is impossible to determine the exact amount of State funds used each year from both stream gaging and irrigation sources because the record of the allotments from the irrigation contingent fund is made only for each 2-year period in the State engineer's biennial reports. An equal division between the 2 years is therefore assumed, except for the 1913-14 biennium when the fund was used chiefly on the Sevier River investigation, active field work for which began in 1914 and the entire amount is credited to that year. Annual expenditures from State funds were:

$\begin{array}{rrrr}\text { Year } & \begin{array}{c}\text { Stream } \\ \text { gaging }\end{array} & \begin{array}{c}\text { Irrigation } \\ \text { contingent }\end{array} & \text { Total } \\ 1914 & \$ 5,500 & \$ 4,391 & \$ 9,891 \\ 1915 & 4,100 & 1,240 & 5,340 \\ 1916 & 5,015 & 1,237 & 6,252 \\ 1917 & 5,180 & 1,832 & 7,012 \\ 1918 & 5,000 & 1,832 & 6,832 \\ 1919 & 5,000 & 1,800 & 6,800\end{array}$

The USGS allotments were $\$ 4,500$ annually for 1914 and 1915 , and $\$ 4,000$ annually from 1916 to 1919.

Nearly as important as the regular State cooperation in collecting records of streamflow was the special cooperation arranged between the State engineer and the water users of the 
Sevier River basin whereby the USGS investigated the flow of the Sevier River and the canals that diverted water from it. This investigation was needed in order to obtain essential data for use by the State and the courts in adjudicating existing water rights and in determining the advisability of granting new rights (11th bienn. rept., State eng., 1917-18, p. 13). The study began in spring 1914 and lasted until spring 1919. Its cost was as follows:

$\begin{array}{lr}1914 & \$ 13,745 \\ 1915-16 & 6,955 \\ 1917-18 & 6,319 \\ 1919 & --\end{array}$

The high cost for 1914 was due to the installation of new stations equipped with recorders. The cost in excess of the amount paid from the State contingency fund was borne by the water users.

NEVADA.-Soon after E.A. Porter was appointed district engineer of the Great Basin District, he, as a former Nevadan with a wide acquaintanceship in the State, began to try to interest the officials of the State and others in the resumption of cooperation (E.A. Porter, oral commun., ca. 1938), which had died of lack of interest early in the previous period. He got help in this effort when a new water code was enacted during the 1913 session of the legislature, which aroused public interest in the water resources. As a result, the legislature appropriated $\$ 5,000$ for the next 2 years to be used in cooperation with the USGS (Bienn. rept., State eng., 1915-16, p. 103). Like amounts were appropriated during the remainder of the period. That the State engineer realized the insufficiency of the State appropriation is shown by his biennial report for 1919-20 (p. 20):

Prices for all kinds of labor and material as well as for transportation and field expenses have continued abnormally high. It has, therefore, been impossible to take up any appreciable amount of new work.

The USGS allotted $\$ 2,500$ annually.

ARIZONA.-Cooperation, which had begun in 1912 with Arizona through the Director of the Agricultural Experiment Station, continued through this period. The annual amount of such cooperation was as follows:

\begin{tabular}{crr} 
Fiscal year & USGS & \multicolumn{1}{c}{ State } \\
1914 & $\$ 3,000$ & $\$ 3,000$ \\
1915 & 3,000 & 3,900 \\
1916 & 3,500 & 3,960 \\
1917 & 3,500 & 4,040 \\
1918 & 3,500 & 2,980 \\
1919 & 2,500 & 3,015
\end{tabular}

WASHINGTON.-Cooperation continued with the Washington State Board of Geological Survey through Henry M. Landes, State geologist. At each session of the legislature, an appropriation was made to the State Board for waterresources investigations and topographic mapping in cooperation with the USGS. The division of funds between the two Branches of the USGS was left to the discretion of the State geologist who allotted the following amount to water-resources investigations during each USGS fiscal year:

$\begin{array}{rrrr}1914 & \$ 4,816 & 1917 & \$ 6,232 \\ 1915 & 5,941 & 1918 & 6,863 \\ 1916 & 6,045 & 1919 & 11,035\end{array}$

The flexibility of funds permitted the substantial increase in 1919 when the Topographic Branch, operating under the War Department, was devoting its personnel to topographic mapping desired for military purposes. Thus, topographic mapping could not continue in cooperation with the State, so that part of the funds that otherwise would have been used for cooperative topographic mapping was spent instead for cooperative stream gaging. The annual USGS allotments were:

$\begin{array}{lllr}1914 & \$ 4,500 & 1917 & \$ 4,038 \\ 1915 & 4,500 & 1918 & 4,346 \\ 1916 & 4,120 & 1919 & 5,497\end{array}$

(This was not the total amount of Federal funds available during these years because the Indian Service made annual allotments ranging from $\$ 2,000$ to $\$ 3,300$ for stream gaging by USGS personnel.)

OREGON.-Cooperation with the Oregon State engineer continued during the period. The continuing appropriation of $\$ 2,500$ annually, begun in 1905, was effective through 1914. At the 
1915 session, the State Legislature repealed that act (C.L. Batchelder, written commun., ca. 1938) and thereafter the money was allotted from the State survey fund. The annual expenditures were as follows:

\begin{tabular}{crr} 
Fiscal year & USGS & \multicolumn{1}{c}{ State } \\
1914 & $\$ 4,500$ & $\$ 10,000$ \\
1915 & 4,500 & 11,000 \\
1916 & 4,000 & 7,300 \\
1917 & 4,000 & 5,700 \\
1918 & 4,000 & 6,935 \\
1919 & 4,000 & 5,735
\end{tabular}

The need for published records became so great that the State engineer entered into an additional contract with the USGS in 1913 whereby each party was to contribute $\$ 3,000$ for use in compiling and printing streamflow data. A similar contract was executed in 1914 and, as a result, all streamflow data in Oregon from 1878 to September 30,1910 , were reviewed and revised where necessary and published as WSP 370 in 1915. The State engineer published the monthly summaries up to September 30, 1914 (Water res. of Oreg., Bull. 4, 1915).

CALIFORNIA.-Cooperation with the California State Department of Engineering continued during the period. The continuing appropriation of $\$ 9,000$ annually, begun in 1909 , was available throughout this period. For the first 2 years, allotments were also made by the State Conservation Commission, which in 1912 had taken over the duties of the State Board of Control (water powers). The Conservation Commission was an investigation body charged with a specific duty and was given one appropriation to last until its work was completed (McGlashan, oral commun., ca. 1938). It had, however, taken over the duty from the Board of Control of receiving applications for the use of water for power purposes. The Conservation Commission prepared a bill to provide for State administration, by an organization to be known as the State Water Commission, of water use for all purposes. That act was passed by the legislature in 1913, but its operation was suspended by a referendum petition until it could be voted on at the general election held in November 1913. The act was approved at that election and went into effect on December 19, 1914. The commissioners were appointed in March 1915. In referring to the act, the commission report stated (Jan. 1, 1917, p. 7) that "it was a new procedure to those who knew only of the old method of filing on water by posting notices on the stream and recording same in the county recorder's office." The duties of the new commission required records of streamflow, so the practice of its predecessor was followed and annual cooperative allotments were made to the USGS. The annual expenditure of State funds by the USGS was as follows:

$\begin{array}{ccccc}\text { Year } & \begin{array}{c}\text { Depart- } \\ \text { ment of } \\ \text { Engi- } \\ \text { neering }\end{array} & \begin{array}{c}\text { Conser- } \\ \text { vation- } \\ \text { Commis- } \\ \text { sion }\end{array} & \begin{array}{c}\text { Water } \\ \text { Commis- } \\ \text { sion }\end{array} & \text { Total } \\ 1914 & \$ 8,994.97 & \$ 9,611.58 & -. & \$ 18,606.55 \\ 1915 & 9,005.01 & 1,377.13 & -- & 10,382.14 \\ 1916 & \mathbf{8 , 9 9 9 . 9 7} & -- & \$ 3,623.79 & 12,623.76 \\ 1917 & \mathbf{8 , 9 9 9 . 8 8} & -- & 6,867.52 & 15,867.40 \\ 1918 & 9,069.90 & -- & 7,157.56 & 16,227.46 \\ 1919 & 7,191.70 & -- & 8,569.34 & 15,761.04\end{array}$

Following the precedent set in previous years, the annual USGS allotment of $\$ 9,000$ to match the State's continuing appropriation was used for both surface and ground-water investigations. The annual division of such funds between the two types of work was as follows (McGlashan, written commun., ca. 1938):

$\begin{array}{ccc}\text { Year } & \text { Surface water } & \text { Gound water } \\ 1914 & \$ 4,500 & \$ 4,500 \\ 1915 & 4,500 & 4,500 \\ 1916 & 4,000 & 5,000 \\ 1917 & 4,000 & 5,000 \\ 1918 & 4,000 & 5,000 \\ 1919 & 4,000 & 5,000\end{array}$

The California District employees conducted water-plane measurements in southern California. The Division of Ground Water transferred $\$ 166$ in 1914 to the surface-water fund and $\$ 200$ annually from 1915 through 1919 for use in making those measurements.

About 1908, the City of San Francisco, in its struggle to obtain additional water supplies, applied to the Interior Secretary for a permit to construct storage reservoirs in the upper Tuolumne River basin. The permit was granted on May 11, 1908. The principal site proposed, 
Hetch Hetchy, was and still is within the boundary of Yosemite National Park, and the proposal to "desecrate" a National Park for utilitarian purposes evoked so much opposition that on February 25, 1910, a different Interior Secretary called on the City Fathers to show cause why the Hetch Hetchy site should not be eliminated from the permit, thus requiring a study by the city officials of all available sources of water supply. A Board of Army Engineers was appointed to study the resulting data and to make recommendations to the Interior Secretary. The USGS reported on the available water supply. The source of water supply that included the use of the Hetch Hetchy site turned out to be the most economical, so the Board recommended that the permit be not thus amended (Hetch Hetchy Valley, Rept. of Advis. Board, Army Eng., to Sec. of the Int., Feb. 19, 1913). Finally, on December 19, 1913, the Congress enacted the Raker Act, granting to San Francisco the right to develop the Hetch Hetchy site. Section 9(i) of the Raker Act contained the following proviso (38 Stat. L. 247):

That the said grantee shall, at its own expense, locate and construct, under the direction of the Secretary of the Interior, such weirs or other suitable structures on sites to be granted, if necessary, by the United States, for accurately measuring the flow into and out from the reservoirs or intakes of said district, and into and out from any reservoirs constructed by the said grantee, and at any other point on the Tuolumne River or its tributaries, which he may designate, and fit the same with water-measuring apparatus satisfactory to said Secretary and keep such hydrographic records as he may direct, such apparatus and records to be open to inspection by any interested party at any time.

During its investigation, San Francisco had maintained four gaging stations. In spring 1914, the USGS took over those stations and later established the stations required by the Raker Act. The cost of the work, which was repaid to the USGS by the City of San Francisco, was as follows (McGlashan, written commun., ca. 1938):
$1914 \$ 724.26$
$1917 \$ 3,601.00$
$1915 \quad 4,162.43$
1918
$2,454.58$
1916
$3,928.72$
1919
$2,144.51$

A multiparty cooperation in an intensive study of runoff in southern California was begun in spring 1916. The County of Los Angeles contributed approximately $\$ 15,000$ for the 5 -year period ending June 30,1920 , as covered by the agreement.

The value of the Los Angeles County records thus obtained led W.A. Johnstone, president of the State Water Commission, to advocate similar cooperation in the Santa Ana River basin between the USGS and San Bernardino, Riverside, and Orange Counties. The primary object of the project related to State adjudication of the water rights in the Santa Ana River basin. At that time, there was a strong tri-county organization in these counties which sponsored the proposal, and the three counties agreed to contribute $\$ 1,000$ each annually. Local interests, however, leaned more to flood control than to water-rights adjudication because the floods of 1914 and 1916 had shown the need for flood control. Funds were not available for the installation of permanent stations at 15 sites on streams at the base of the mountains and at 18 sites on canals. Therefore, the State Legislature was induced to appropriate $\$ 5,000$ to the State Water Commission for that purpose because the primary need for the records was for State use. After this appropriation was allotted, an agreement was signed in February 1919 (Ebert, oral commun., ca. 1938).

HAWAII.-Until June 30, 1913, cooperation had been conducted with the Hawaii Territorial Board of Conservation. Beginning on July 1, 1913, the cooperating agency was the Board of Agriculture and Forestry, in accordance with an Act (56) of April 4, 1913, section 1 of which was as follows:

The Board of Agriculture and Forestry is hereby authorized to create and maintain a division of hydrography for the investigation and determination of the water resources of the Territory by the gaging of streams and rainfall and other means, in cooperation with the United States Geological Survey, or otherwise, and in furtherance thereof to take over and exercise the functions of the Territory in the conduct of the present hydrographic survey of the Territory. 
A companion Act (57) provided that, for the 2-year period ending June 30,1915, half of all revenues derived from water licenses issued by the Territory should be apportioned to the Division of Hydrography for the conduct of the hydrographic survey. By 1915, the amount of water-license revenues available for the Division of Hydrography was insufficient to meet the immediate needs of the water-resources investigations. Many water licenses and land leases involving comparatively large supplies of government water were to expire within the next few years, and the basis for equitable renewals or new leases was dependent on knowledge of total quantities and seasonal variations in streamflow. An early expansion of the stream-measurement program was therefore essential because data previously collected were insufficient to be used to equitably fix rentals (Rept. of Gov., Terr. of Hawaii, 1916). To meet this pressing situation, funds were made available by appropriations from the general Territorial funds. On March 23, 1917, the Territorial Division of Hydrography was transferred under the Commissioner of Public Lands; the Commissioner made extensive use of the streamflow records to determine the values of water licenses.

For the fiscal year 1914, the Territorial contribution of $\$ 15,000$ was $\$ 5,000$ less than for the previous year. At the beginning of fiscal year 1915, it appeared that the Territorial contribution would be further reduced to $\$ 10,000$-the prevailing economic conditions caused by the passage of the "Free Sugar Bill"' by the United States Congress had caused the Territorial Governor to issue instructions to curtail all expenses (M.H. Carson, written commun., ca. 1938). Before the end of the year, however, another contribution brought the total for 1916 to $\$ 15,400$. During the remainder of the period, the actual expenditures from direct appropriations by the Territorial Legislature were (Comm. of Pub. Lands, written commun., ca. 1938):

$$
\begin{array}{rrrr}
1916 & \$ 19,137 & 1918 & \$ 18,411 \\
1917 & 16,001 & 1919 & 18,568
\end{array}
$$

Additional Territorial funds were also allotted for water-resources investigations. The 1913 session of the legislature appropriated
$\$ 5,000$ for an investigation of the surface waters of North and South Kona on the Island of Hawaii, and the Governor allotted $\$ 3,000$ of this amount for that purpose. This special investigation lasted from July 1, 1913, to December 31, 1914, and included intermittent streams (streams that carried water for a few hours only following heavy rains). Regular gaging stations were not maintained. The annual USGS allotment was $\$ 5,000$ for 1914 and 1915 , and $\$ 4,500$ from 1916 through 1919.

\section{FEDERAL}

The principal Federal cooperating agency was the Reclamation Service, which increased its cooperation from about $\$ 8,000$ annually at the end of the previous period to an average of $\$ 12,500$ for this period. This increase was caused generally by requirements of new investigations. The need for more complete knowledge of the water supply for its different irrigation projects caused the Indian Service to increase its annual cooperative funds from an average of $\$ 4,500$ during the later years of the previous period to about $\$ 7,700$ for this period.

The Forest Service continued its cooperation of service, but in lesser amounts. It was, however, responsible for starting cooperation with the Alaskan Division and with the County of Los Angeles. In both of these investigations, the Forest Service furnished the services of its employees. Beginning in 1916, the National Park Service cooperated in the establishment and maintenance of five gaging stations in Yosemite, Yellowstone, and Glacier National Parks. The monetary value of this cooperation is not now known because the National Park Service furnished materials and labor, but it is estimated to be $\$ 4,000$. A small amount of cooperation was received from the Army Engineers, Pittsburgh District. A brief synopsis of each agency's cooperation follows.

RECLAMATION SERVICE.-The operation by Reclamation Service personnel of its own streamgaging stations on projects that had reached the construction stage continued during this period, except in Montana where the USGS continued to operate all but two of the stations for 
which the Reclamation Service needed records. One reason for this exception was that most of the Reclamation work in Montana was still in the investigational stage, owing largely to a dispute with Canada over water rights. The dispute led to international joint administration by Canada and the United States of the waters of the St. Mary and Milk Rivers, and the very considerable stream gaging required in this effort was provided by USGS personnel with the cost paid directly by the Reclamation Service. The total amounts paid are not now known. The average annual expenditures by the USGS of Reclamation Service funds in Montana was about $\$ 7,000$.

Special investigations in several States resulted in the Reclamation Service authorizing the USGS to establish and maintain a number of widely scattered stations. A project under consideration in Oklahoma required two river stations and an evaporation station. Near the close of the previous period, the USGS Denver office was requested to establish and maintain these stations, and they were continued during this entire period at a cost of $\$ 1,500$ annually. Cooperation between the State of Oregon and the Reclamation Service, which began in 1913, resulted in allotments totaling $\$ 1,102$ to be paid to the Survey for stream gaging during this period.

The frequent flooding in the lower Colorado River in California made the Imperial Valley residents apprehensive and, early in 1914, Interior Secretary Franklin K. Lane, a Californian, allotted $\$ 50,000$ from the reclamation fund to the Reclamation Service to study possible reservoir sites in the Colorado River basin. This study required streamflow records and during the following 3 years, the Reclamation Service paid the USGS for the installation and maintenance of eight stations in the Colorado River basin for periods ranging from 1 to 3 years. Silt samples were taken at some of these stations. The stations were at isolated sites and the cost of maintenance was relatively high. The total allotment by the Reclamation Service was about $\$ 8,500$ (Bureau of Reclamation, written commun., ca. 1938).

In connection with a study of water rights on the North Platte River, the Reclamation Service in 1913 authorized the installation and operation of three stations for the purpose of measuring flow into Pathfinder Reservoir in Wyoming. The cost of establishing and maintaining these stations was about $\$ 2,200$. Beginning in 1918, two stations were installed and operated at a cost of $\$ 420$ in connection with a project on the Wind River in Wyoming.

The completion of the Arrowrock Resevoir in Idaho in 1915 and the enlargement of Jackson Lake Reservoir in Wyoming in 1916 led the Reclamation Service to authorize the installation and maintenance of six streamflowgaging stations. Apparently four stations were actually constructed at a cost of $\$ 1,332$. The cost of the special investigation to determine the capacity of Arrowrock Reservoir in 1916 was $\$ 2,120$. This was not all of Reclamation Service cooperation in the Idaho District, however, because the cost of the special investigations during 1917 and 1918 of loss of water from the Snake River during its movement downstream after being released from storage led to the establishment of the Idaho Falls office, which was paid for $(\$ 8,600)$ by the Reclamation Service.

FOREST SERVICE.-Cooperation with the Forest Service, which began in 1910 , continued on a gradually lessening scale during this period. Cooperation consisted chiefly of the services of rangers as gage observers at stations maintained by the USGS (the practice of detailing Forest Service hydrographers to the USGS generally had been discontinued). The records were fragmentary because the rangers were unavailable to read the gages daily. Because higher standards of accuracy were needed, it was decided by both organizations to discontinue the stations that could not be equipped with recorders or attended daily by paid observers; therefore, most of the cooperative stations were discontinued.

Under the cooperative agreement with the Forest Service in 1910, a number of stations on streams in southern California were maintained more or less intermittently, and the records were so unsatisfactory that, in early spring 1914, Ebert and F.H. Fowler, the latter a district engineer of the Forest Service, inspected those stations to determine their future. In January of that year, disastrous floods in southern 
California had aroused public interest in floodcontrol measures (Fowler, oral commun., ca. 1938). The Forest Service was anxious to arrange cooperation with the USGS for work in the Angeles National Forest in Los Angeles County where stations would be established on streams draining the southern slope of the San Bernardino Mountains. The Forest Service anticipated that the resulting records would disclose the effects if any that different types of forest cover had on floods. Such cooperation was proposed in November 1915, but was declined by the USGS because funds were insufficient to obtain records of that accuracy.

At about this same time, Fowler had contacted the supervisors of Los Angeles County who agreed to cooperate with the Forest Service and USGS for the establishment of the desired stations. On February 15, 1916, a 5-year agreement that was signed between officials of the Forest Service and County of Los Angeles set forth the reasons for the county's interest and the amount it was willing to contribute:

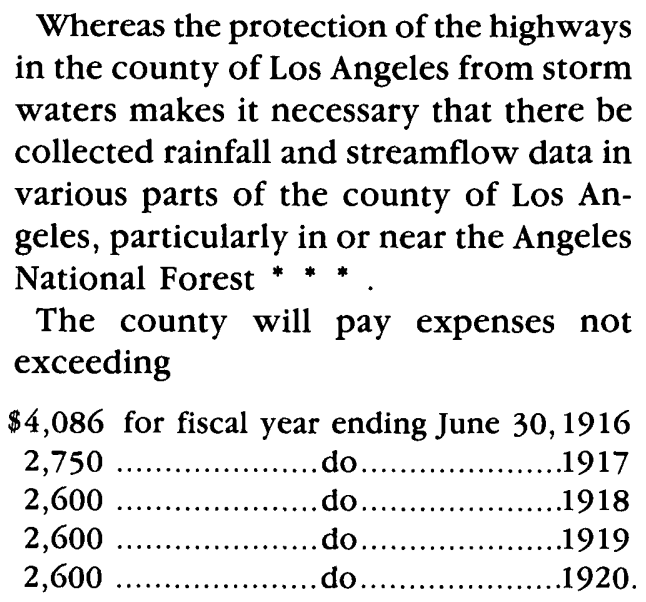

The large amount that was made available for the few remaining months of the first fiscal year was for the purpose of constructing the new stations. In addition, the county agreed to furnish an automobile for the engineer's use and to pay not more than $\$ 1,000$ annually for its operation.

With the assurance of additional funds, the USGS agreed to cooperate. Under this arrangement, the Forest Service had general administrative charge of the project and furnished a hydrographer; the Weather Bureau selected the sites for rain gages and furnished the equipment; and the USGS installed and operated the
13 gaging stations, chiefly by supervising the work of the Forest Service hydrographer. To insure permanent structures that would withstand floods, concrete controls were installed at most of the stations. The original plan of operation was followed until June 1917 when the USGS was put in charge of the entire project.

INDIAN SERVICE.-The Indian Service continued to make allotments to the USGS for the operation of gaging stations related to its irrigation projects, the average number of which was 58 during the period. Although stations were maintained in most of the Western States, most were in Washington, Idaho, Montana, and Oregon. The average annual allotment was about $\$ 7,700$. In addition, the Indian Service asked the USGS to conduct a special investigation of the Gila River in Arizona, preparatory to an adjudication of Indian water rights and, in April 1914 , allotted $\$ 3,000$ to the USGS for the installation and operation of gaging stations on the Gila River and for studies of return flow. Apparently because of a lack of funds, no further appropriation for the Gila River work was made until fiscal year 1919 (Grover, written commun., ca. 1938).

NATIONAL PARK SERVICE.-In 1916, soon after the creation of the National Park Service, J.C. Hoyt, ever alert to possible cooperation, called to the attention of its Director the desirability of installing recorders on important streams in national parks at points easily accessible to tourists. If recorders were installed, they would add instructive attractions, help the USGS in its study of the Nation's water resources, and incidentally bring USGS work to the attention of many persons who otherwise would not learn of it. The National Park Service was favorably disposed and, to insure building structures that would harmonize with the rustic surroundings, prepared a sketch of a small pavillion with a pedestal in the center to support the recorder. Along the sides of the pavillion were seats where the tourists might rest after studying the operation of the recorder (from photograph of sketch, furnished ca. 1938 by Ebert). During fall 1916, two such installations were built, one in Yosemite National Park and the other in 
Yellowstone National Park. A standard shelter was also constructed at an inconspicuous site in Yosemite National Park. In 1918, three more shelters were installed, one each in Yosemite, Yellowstone, and Glacier National Parks. During all of these installations, the National Park Service furnished materials, labor, and subsistence for the engineers while they were working in the parks.

ARMY ENGINEERS.-The severe floods in the Ohio River basin during spring 1913 resulted in a study by the Army engineers of the runoff from that river basin. Although discharge had been measured previously, the measurements had been taken during so-called critical stages, either high or low, and continuous records of daily discharge had not been kept. In winter 1915, the Army engineers realized that knowledge about the flow of the many tributaries entering the Ohio River was also needed; at the request of Major Harold Fiske who was then in charge of the Army's Pittsburgh (Pa.) district, Grover and A.H. Horton met with him on January 20, 1915. A cooperative agreement was arranged tentatively whereby the USGS would establish and maintain gaging stations and bill the Army engineers for the expense. Although the exact expenses to be repaid were not specified, this would have been of little concern if Major Fiske had remained in the Pittsburgh office. Unfortunately, he transferred before the first expenses were billed by the USGS and was succeeded by an officer who was none too sympathetic toward the cooperation. The first bill presented for payment contained, as usual, an item for office work. The new officer protested the inclusion of such an item because he felt that the repay expense should be limited strictly to field work; however, the bill was paid as presented. During the remainder of the period, the cooperation was limited chiefly to payment of gage observers salaries. Army engineers made most of the measurements, except for a few check measurements made by the USGS at its own expense. The records were computed and published by the USGS. Beginning in 1915, the Army engineers conducted extensive surveys in the Ohio River basin, furnished gage heights for several stations, and base data for 30 additional stations.

\section{JoInt Operation of InTERnational STATIONS}

Joint operation of international stations by USGS and Canadian engineers on the St. Mary and Milk Rivers on the State of Montana/Canada boundary began in 1913 as a result of conflicting claims by the two countries on the waters of those streams. The Canadian government began streamgaging in 1896 when, following the passage of an irrigation law in 1894 , five gaging stations were established in the Prairie Provinces (Manitoba, Saskatchewan, and Alberta), three of which were equipped with nilometers-horizontal-cylinder 7-day recorders manufactured by J.S.J. Lallie, Denver, Colo. (written commun., Asst. Dir., Dominion Water Power and Hydrometric Bureau, to Grover, ca. 1938). This use of the term "nilometer" shows USGS influence because that name had been used in the days of the old Irrigation Survey. In succeeding years, additional stations equipped with staff gages were installed. The method used by the Canadians has been described in the report entitled "Irrigation in the northwest territories of Canada, 1902" (p. 77, 1903) as follows:

All the streams within the semi-arid region are carefully numbered at different points in their length to determine the cross-section of the channel at the different stages of low water, high water, and flood discharge, and the actual discharge of water at the time of measurement is determined by use of current inches (meter?; [italics and question R.F.]) to measure the velocity of the stream.

Having determined the actual discharge at the date of measurement, sufficient data as to general slope of the bed of the stream and its character, and the probable discharge at the different stages of high water and flood stage is then calculated by use of Kutter's well-known formula.

We have endeavored to supplement the isolated measurement of discharge of streams by keeping a record of their rise and fall by establishing a gauge. On larger streams self-recording instruments are used.

The report shows hydrographs of stage from three nilometers and from the 24 staff-gage 
records, but no attempt was made to compute the daily discharge. The only discharge records presented were those for low, high, and flood discharge at each station.

It is not known whether the work continued during the years immediately following 1902; because the use of the recorders was discontinued in 1902, it seems probable that all operations ceased at that time. In 1907, P.M. Sauder was conducting some work in the Province of Alberta. In order to learn how the work was being done in the United States, Sauder visited Babb's Reclamation Service camp in Montana and was advised to get in touch with the author, who was then in charge of the USGS rivermeasurement work in that State. Sauder spent a day in the Helena, Mont., office inspecting office methods. Because the author had a railroad pass good for himself and a field assistant, Sauder assumed the temporary role of field assistant, spent a day or two in the field, and thereby became somewhat acquainted with USGS field methods and equipment.

Following Sauder's trip, the Canadian Parliament in 1908 made the first specific appropriation $(\$ 10,000)$ for stream gaging in Alberta and Saskatchewan. The appropriation was available so late in that year that it was not until 1909 that work was started. An organization for that specific work was headquartered in Calgary, Alberta. A further appropriation of $\$ 10,000$ was allotted for that year. The Canadian organization closely followed the USGS procedure. In his report for 1910 , Sauder stated that "when the Hydrographic Survey was being organized, and [sic] on various occasions some valuable assistance was received from members of the staff of the United States Geological Survey. The United States Geological Survey has been studying the surface flow of water for several years and have thoroughly systematized the work and developed some new and useful methods."

When the Reclamation Service built a canal from the St. Mary River to the Milk River, a serious international situation arose regarding water rights on both sides of the international boundary, which made imperative an international agreement regarding the equitable division between the two countries of the waters of those two streams. In 1909 , a treaty was signed by the United States Secretary of State and the British Ambassador providing for the creation of an International Joint Commission (IJC). One of the important duties of the IJC, which was organized in 1912, was the resolution of the division of the waters of the St. Mary and Milk Rivers.

At the time the IJC was organized, USGS and Canadian engineers were maintaining independent stations within a few miles of each other on three international streams. Acting in the spirit of the IJC, Lamb sent Jones, while he was on a field trip in 1912, to contact the Canadian engineers regarding joint operation of the international stations. The Canadians were in favor of joint operation, so the matter was taken up formally between the two governments and an agreement was reached-one station would be installed on each stream and operated jointly by the engineers of both countries. The expense of establishing each such station would be borne by the country in which it was located. Care was taken in selecting the sites so that half of the stations would be in one country and half in the other, thereby dividing the cost about equally. The responsibility for operating and maintaining a station rested also with the country in which it was located, but the engineers from each country had unhindered access to and from each international station regardless of which country operated the station.

As soon as the agreement was reached, Lamb and F.H. Peters, Canadian Conmissioner of Irrigation, conducted a field reconnaisance for the express purpose of establishing four stations. They selected a new site on the St. Mary River rather than either existing station; at the eastern crossing on the Milk River, the Canadian station established in 1909 was selected; on the South Fork Milk River, the USGS station established in 1905 was selected; and on the North Fork Milk River, a new site replaced the existing American and Canadian stations. Water-stage recorders were installed at three of the four new stations. These four stations, together with two stations on Swift Current Creek that had been established in 1912, were placed in joint operation in 1913, the data collected independently were exchanged, and the final computations were decided on in joint conference. In 1917, stations on three tributaries of the Milk River and one on the St. Mary 
Canal were jointly installed and operated and, in 1918, three additional stations were established, making a total of 13 international stations in operation at the end of the period. The USGS share of the cost of installing and operating these stations was repaid by the Reclamation Service.

The joint operation of these 13 stations was preparatory to the establishment of water rights of the St. Mary and Milk Rivers, which was to be made by the IJC as provided for in Article VI of the treaty. The language of this article was conducive to different interpretations and, as the construction of the St. Mary-Milk River canal was nearing completion, it was necessary for the IJC to decide immediately on a working arrangement under Article VI. A number of hearings resulted in the conclusion that the only satisfactory way of dividing the water was through a commission of two competent engineers, one appointed by each government, and, in fall 1917, the IJC issued an order empowering such a commission for that purpose. The American member was the director of the Reclamation Service. He delegated his authority to Lamb as district engineer, who placed Jones in actual charge of the field work. This work began in 1918, and continued throughout the remainder of this period.

Two stations in the Columbia River basin also were operated jointly by the USGS and Canadian engineers during this period. During 1913 and 1914, a gaging station on Pend Oreille River (Clark Fork) was maintained by Washington District personnel on the American side of the international boundary at Metaline Falls, Wash., and another on the Canadian side by personnel of the British Columbia Hydrometric Survey. An investigation in 1915 by engineers of the two governments indicated conclusively that measuring conditions were better at the American station than the Canadian site, and thereafter the Metaline Falls station was operated jointly and identical records published by both governments. This arrangement proved so satisfactory that in 1916 , the Canadian station on the Columbia River at Trail, British Columbia, near the international boundary, was adopted as an international station. The 820-foot cable required at Trail was furnished by the Canadian engineers; the 75-pound iron weight and reel originally used by A.H. Horton on the Ohio River and a chain gage were furnished by the USGS. Measurements were made jointly by the two organizations about once a year, but the main burden of operating the Pend Oreille River station was carried by the USGS and that of operating the Columbia River station by the British Columbia Survey (G.L. Parker, written commun., ca. 1938).

The following is quoted from the first report of the Railway Belt Hydrographic Survey (Water Res. Paper no.1, 1914), which was organized under the Dominion Water Power Branch in 1911 to show further the influence of USGS methods on Canadian stream gaging during its formative period:

In organizing the Railway Belt Hydrographic Survey ${ }^{*} * *$ it was decided to study the water resources in a comprehensive manner, and with the most modern methods. Accordingly, for the purely hydrographic work the methods of the United States Hydrographic Survey were adopted almost to the minutest detail. $*^{*} *$

In order that the greatest efficiency should be attained and early mistakes avoided, one of the expert hydrographers of the United States Survey, Mr. C.R. Adams, was borrowed from Washington (St. Paul district) for a period of three months. Under Mr. Adams' direction a number of gaging stations were established $*^{* *}$, the hydrographers were instructed according to the most approved methods, and the whole work commenced in smooth working order.

Later, the Railway Belt Hydrographic Survey became the British Columbia Hydrometric Survey.

\section{Current Meters}

RATING

The USGS rated its current meters at the Chevy Chase rating station until 1909. At about that time, J.C. Hoyt thought that, because one of the functions of the Bureau of Standards was the calibration of instruments for both governmental and private organizations, USGS meters 
should be rated by that Bureau. The Director of the Bureau of Standards agreed with this idea and included in his estimates for the next year an item for such rating. The necessary appropriation was made by Congress, and the Bureau of Standards took over the Chevy Chase station in 1909. The Bureau installed mechanical equipment for propelling the car and for recording time, and began the rating not only of USGS meters but also of those for other agencies, both governmental and private. At first the Bureau reported to the USGS only the results of the velocity runs of the current meters from which USGS personnel plotted the curves and computed the rating table. Within a short time, however, the rating curves were also furnished, and that procedure has since been followed.

In order to meet the needs of the Navy Department in determining the resistance of water to different shapes of ship models, the Bureau of Standards in 1915 constructed a tank 400 feet long, 6 feet wide, and 6 feet deep. This tank, which was covered and therefore available for use throughout the year, was equipped for rating current meters. A car with a platform 8 by 10 feet spanned the tank. The car was electrically propelled, had a range of speed from one-tenth of a foot to 20 feet per second, and could be stopped in a short distance. A special mechanism that was mounted on the car in which the operator rode recorded time, distance, and revolutions of the meter (Newsletter, May 24, 1915, p. 1).

With better facilities and more accurate methods for rating meters and in line with the general purpose of improving the accuracy of the records, comparative ratings of meters with different methods of suspension were begun in spring and summer 1916 when the Bureau of Standards personnel conducted two complete ratings for each of the two new combination meters, one rating on a hanger with different arrangements of meter and 15-pound weights and the other rating on a rod. These ratings indicated that a correction was needed for certain unusual combinations of weights and meter. It was also " "*** noted with interest that the ${ }^{* * *}$ test proves further the statements that have heretofore been made in regard to rod and cable ratings, namely that there is practically no difference in a rod rating and one using a cable, under the ordinary suspension" (Instructions no. 14, series 1916).

Additional sets of similar ratings using a 30-pound weight were made in 1917 . From the 1916 and 1917 tests, the following conclusions were drawn: If the meter was placed above the weight or weights, the ratings were within 1 percent and ordinarily no corrections needed to be applied; if the meter was below the weights, the difference in ratings fluctuated from -4 to +3 percent; and if the meter was used on a rod in velocities of 2 feet per second or less, a coefficient of 0.98 was needed whereas no correction was necessary for higher velocities.

\section{Modification}

The current meter was modified in 1917 by making the single and penta heads interchangeable. This "combination" meter with two heads eliminated the necessity for carrying two meters in the field when both swift and sluggish streams were to be measured, and became the standard current meter used in the Branch.

\section{IMPROVEMENT IN EQUIPMENT}

When the rating of current meters was taken over by the Bureau of Standards, the standard suspension during rating was a single telephone wire to which a fine insulated copper wire to complete the electric circuit was fastened with adhesive tape. This suspension was a make-shift at best and, although it had been used for several years, was not satisfactory either to the Bureau or the USGS. In 1915, C.E. Van Orstrand of the Geologic Branch designed a small insulated cable with breaking strength of about 200 pounds (Newsletter no. 27, 1915) that consisted of two soft copper wires for contact and a fine steel wire for suspension. This cable was known as the "Van Orstrand cable" and was used for many years.

The larger lead weight was the next improvement in equipment, which was needed for measuring large rivers, particularly in the Northwest. As already stated, two stations (one each on the Pend Oreille and Columbia Rivers) 
were being maintained jointly in 1915 with the British Columbia Hydrometric Survey. At the Columbia River international station, it had not been possible to measure the high-water discharge except by surface-velocity determinations at a standard cross section, and G.L. Parker had considerable doubt as to the proper coefficient to use to reduce this surface velocity to the mean velocity.

With this doubt in mind, G.L. Parker argued for heavier weights at the 1915 San Francisco conference and, as usual, a committee was appointed. The members of this committee were to provide patterns for the specified weights as follows: Baldwin for 20-pound weights, G.L. Parker for 30-pound weights, and E.A. Porter for 60-pound weights. The upper limit of 60 pounds was set because a special torpedoshaped weight of that size had been made during the previous year by Salt Lake District personnel for use at the Bluff, Utah, station on the San Juan River. Within a few months, G.L. Parker submitted a sketch for a 30-pound weight that followed the shape of the 15-pound weight then in use, except that the nose was slightly more rounded and the tail vanes were placed 45 degrees from the vertical axis. The tail vane change was intended to make the weight more stable when it was placed on a flat surface (G.L. Parker, written commun., ca. 1938). This sketch was sent to M.R. Hall in Atlanta, Ga., who made a wooden pattern for casting. The plan was that the pattern would be loaned to any district so that the weights could be cast locally (Newsletter, April 22, 1916); however, as it turned out, the Oregon District had 72 weights cast for use by all interested districts.

Soon after the pattern for the 30-pound weight was made, engineers of the Reclamation Service at Yakima, Wash., designed a 20-pound weight similar to the Parker 30-pound weight, but there was not enough difference between the two to justify the USGS carrying the 20 -pound weight in stock. No action was taken on a 60-pound weight because E.A. Porter resigned the following winter and the need for heavier weights was not widespread at that time. There was at that time a practical reason also for not using such a heavy weight: Trains were then used extensively and because equipment was carried as hand baggage, no more weight was included than was absolutely necessary (G.L. Parker, written commun., ca. 1938). Thirty pounds was apparently the practical limit under such conditions.

The 30-pound weight, however, did not solve all sounding needs in deep and swift streams, and in some instances it was necessary to use more than one 30-pound weight. On the Columbia and Colorado Rivers, as many as three 30-pound weights were used, all suspended from a single airplane wire (Ellsworth and G.L. Parker written communs., ca. 1938). In a measurement on an Arizona stream, the 30pound weight had a tendency to float when velocities exceeded 10 feet per second, and it was finally necessary to make the soundings using a freightcar drawbar (Newsletter, Nov. 22, 1916 , p. 11).

The next development of equipment, which logically followed the introduction of the 30-pound weight, was a small reel that G.L. Parker had constructed in 1916 for use in a standard gaging car. This reel was designed by Paulsen and was about 3 feet in circumference with a yacht steering wheel instead of a handle. Like other reels built for specific stations, the (G.L.) Parker reel did not come into general use. R.C. Pierce designed a reel for use on the San Juan River near Bluff, Utah, in 1915 and Ellsworth one for the Colorado River at Topock, Ariz., in 1917.

\section{WATERSTAGE RRECORDERS}

The name "automatic gage" was changed at the San Francisco conference held October $18-23,1915$, to "water-stage recorder" because it was more descriptive and more in line with the trade names used by different manufacturers. Just as the increase in State cooperation to more than $\$ 100,000$ annually during the later years of the previous period made it possible for the Branch to install a considerable number of recorders, so the increase in cooperation in excess of $\$ 100,000$ led to the installation of many more recorders during the present period.

The Friez and Gurley weekly and the Stevens continuous water-stage recorders were most 
used by the USGS in 1913. By 1914, the demand for a less expensive instrument and one that could be changed weekly led J.C. Stevens to design what came to be known as the "type E recorder." As J.C. Stevens states (written commun., ca. 1938), "I conceived the idea of using a collapsible drum and cylindrical charts which were much more adapted to a vertical (than a horizontal) drum that could be lifted off. The first design had a horizontal float pulley and two guide pulleys to direct the lines. There was too much friction and not much chance to change gage scales, so this plan was discarded in favor of a vertical pulley and helical gears. There was also the advantage of having the weight of the clock itself to add to the spring power to be had with a vertical drum." This recorder, which was placed on the market at about half the cost of the continuous type, proved to be satisfactory once the original clock was replaced by a better one. J.C. Stevens also designed a long-distance recorder which had a limited field of use.

No material change was made in the Friez recorder, but the Gurley 8-day recorder underwent some modification that made it easier to operate. The Gurley printing recorder likewise underwent some changes and although in its improved state it was not satisfactory in cold climates, it operated fairly well in warm climates and was used to a considerable extent in California. The Barrett \& Lawrence recorder was so unsatisfactory that the manufacturers became discouraged and did not attempt to improve it, and all but 10 of the 40 Barrett $\&$ Lawrence recorders purchased by the Branch were discarded during this period.

In order that the district engineers might become familiar with the different recorders and could test them under widely fluctuating conditions, each district engineer was requested in 1915 to purchase one or more each of the Friez, Stevens, Gurley graph, and Gurley printing recorders for future installations. In making this request, the Washington, D.C., office stated (Instructions no. 2 , series 1915) that "each of these gages has been tested in one or more of the districts and has strong advocates. It is desired that comparative tests should be made, so far as possible, in all the districts."

At the end of the period, 449 stations were equipped with recorders of which the Stevens continuous and type $\mathrm{E}$ accounted for 248 , the Friez for 70, the Gurley 7-day for 61, Gurley printing for 15 , Bristol for 16, Barrett \& Lawrence for 10 , and miscellaneous for 29 . The 449 stations equipped with recorders represented 36 percent of the 1,251 stations then maintained.

The relatively small cost at which a pressure recorder could be installed led about 1915 to the trial of a pressure recorder known as the Dexter. The Dexter, it was thought, might eliminate at least some of the errors inherent in the Bristol recorder. The few Dexter recorders used by the Branch, however, proved so unsatisfactory that they were discarded.

\section{Gaging-Station Equipment}

With a few notable exceptions, the gagingstation equipment in 1913 was crude when judged by present-day (1938) standards. In most instances, the recorder installations consisted of wells built of rough lumber that were attached to bridge piers or abutments or set close to the edge of the water, with small wooden boxes on top of the wells in which recorders were placed. The cables were supported in a crude manner, frequently with poles or trees for supports and wooden dead-men for anchorages. Many benchmarks were notorious for their instability.

One of the first recorder shelters set into the bank and that had a short intake was built in 1903 at the Kings River station near Sanger, Calif. It had the usual well and box made of rough lumber, but the box was covered by a roof resting on corner posts to protect the recorder from the "unusual" rain while the charts were being changed. The sides were open except for the diagonal braces for the posts. An "unusual" flood, which should have been anticipated in that State where the "unusual" occurs every day, washed away the box and recorder in January 1914. When the recorder was found 2 weeks later at a point several miles downstream, the newspapers of the State disclosed much alarm because the recorder was believed to be a new type of infernal machine (McGlashan, written commun., ca. 1938). It is not clear, however, why even 
this unusual event should have caused any excitement in a State that is so thoroughly accustomed to the "unusual."

Covert began the thoughtful and deliberate modernization of gaging-station equipment in New York State during 1910 as a result of a need for a continuous record of the flow of the Sacandaga River, a flashy stream subject to severe ice and log jams. Covert studied the possible sites at all seasons and stages of water over a period of 18 months, and finally selected one where it was necessary to place the shelter fairly close to the edge of the bank. In order to withstand impacts by ice and logs, he built a concrete shelter that was connected with the river by an intake pipe 60 feet long. Before designing this shelter, Covert asked the Washington, D.C., office for information on such designs but was told that such information was not available and that he must work out his own salvation (Covert, oral commun., ca. 1938). The well and shelter were 3 feet square inside, which made it possible to use a ladder to enter the well and inspect the float in operationan impossible feat in the small wells then generally used. For the 300-foot cable, Covert built cable supports of squared timbers that had sheaves for supporting the cable, complete with concrete anchorages. Many boulders were removed from the channel in the hope that the boulder-free channel would remain in that condition. But like similar attempts made before and since, that part of the improvement was not an unqualified success because subsequent floods brought in additional boulders. It is cited here only because it illustrates the futility of such feeble efforts of man to change Nature's activities. The total cost of the installation (in excess of $\$ 1,000$ ) was so much greater than the installation of any previous gaging station that it became known as the "million dollar station."

A few months later, the station on the Genessee River at St. Helena, N.Y., was equipped with a concrete shelter and, profiting by experience with the Sacandaga shelter (which proved still to be somewhat small for easy entrance to the well), the inside dimensions were increased to 4 feet square. Two years later, a third concrete shelter was installed, on Owasco Lake Outlet near Auburn. None of these New York stations had reinforced concrete because Covert believed in sufficiently heavy walls to make the concrete solid (Covert, oral commun., ca. 1938).

The successful operation of the New York stations indicated that many previous difficulties connected with the operation of recorders had been due to improper installations (Instructions, June 28, 1912). In 1912, Covert was instructed to prepare detailed plans for installations like those he had used in New York. He employed Lyon, then professor of civil engineering at Union College who had previously been a voluntary employee in the Denver District, to prepare the detailed plans desired.

At the conference of January 1913, a lively interest was shown in improving gaging-station equipment, largely as a result of Covert's pioneering work, and a committee consisting of Covert, Lyon, and C.H. Pierce was appointed to prepare a report on standard equipment for gaging stations; the report was expected to be part of a proposed manual. Designs were made, not only for recorder shelters and cable equipment, but also for such minor equipment as inclined and vertical staffs and hook and chain gages as well as for permanent benchmarks that had been largely neglected previously. Two paragraphs of the report were devoted to artificial controls. Lyon made most of the designs under Covert's supervision. The report was issued in fall 1913 entitled "Plans and Specifications for Current-Meter Gaging Stations." The plans for recorder shelters provided for either plain concrete or timber structures; those for cableways provided for sag based on the formula developed by J.C. Stevens in 1906.

No additional concrete shelters were built until January 1914 when the installation of a permanent station on the American River at Fair Oaks, Calif., with the well and shelter on the side of a nearly vertical cliff, seemed to require reinforced concrete construction. As McGlashan (written commun., ca. 1938) states, "There were two factors which influenced us in deciding to reinforce this structure. It was believed necessary to strengthen the well (on account of the high bank which caves off considerably). It also seemed desirable to use reinforcing in order to be sure that cracks would not form in the concrete." Previous plans and specifications did not provide for reinforcement, so plans incorporating such provision were prepared in the California District. 
Only a few copies of the preliminary plans and specifications for current-meter gaging stations were printed in 1913 and the supply was soon exhausted. Before revisions, district engineers presented criticisms of the published plans and proposed other plans that had been used, including the California plans for reinforced-concrete shelters. A chief source of dissatisfaction was the failure to recognize the cheaper types of construction made necessary in many districts by the limited funds. The criticisms were discussed at the conference of December 7-12, 1914, and as a result of the suggestions and plans offered, Lyon prepared a second report that was published in 1915 as WSP 371 . This publication contained plans for the different types of recorder shelters then favored, including both plain and reinforced concrete. In announcing this paper, the Washington, D.C., office stated in Instructions 20 (1915) that "It is believed that the new publication contains the 'last word' on Survey equipment for gaging stations. The plans and specifications are to be considered the standard of the Survey in all districts."

WSP 371 resulted in improved gaging-station equipment but, viewed through the vista of the ensuing 20-odd years, the belief that the "last word" had been spoken was obviously too optimistic. Indeed, anyone who thinks that any word on any subject at any time is final should be examined for sanity. The continuing changes in the equipment and methods illustrates that nothing is stable except instability.

One result of the publication of WSP 371 was the use of reinforced concrete instead of plain concrete in later well and shelter installations. Another result was the erection of cables in order to obtain better measuring sections at some stations where bridges had been used previously.

That same year, 1915, but before WSP 371 was issued, construction of the Arrowrock Dam in Idaho was nearing completion and the Reclamation Service, in cooperation with the Idaho District, decided to install four permanent stations on the Boise River. Reinforced concrete shelters were built from plans prepared by the Idaho District (Baldwin, written commun., ca. 1938). At the time when concrete shelters were being built in the Idaho District, cooperating parties in northern California were building two shelters and the USGS itself two shelters, all based on the standard plans (McGlashan, written commun., ca. 1938). Increased cooperation in southern California in 1917 made possible the beginning of concrete shelter construction in that part of the State and 12 shelters were constructed during the remainder of the present period (Ebert, written commun., ca. 1938).

Although the New York District had pioneered in concrete shelters, no more stations of that type were built there during this period because of a lack of funds. Other districts, however, were interested and financially able to construct this type of shelter, and three were built in Kansas, one in Texas, and one in Washington. On June $30,1919,29$ concrete shelters were in use.

There were other stations where permanency was needed but funds were insufficient for expensive concrete construction. At some of these stations, timber shelters were built on concrete wells. The first structure of this type was erected on the San Joaquin River near Friant, Calif. Six more of these structures were built in California, three in Yosemite National Park in cooperation with the National Park Service. Two similar stations were installed in Yellowstone National Park and one in the Washington District.

The number of recorder installations increased from 215 to 449 , but concrete shelters were used at only a small number of them. Other shelters were the standard types or variations on them. Nevertheless, these shelters were definitely of a higher order than those constructed previously.

More than 100 cables were erected during this period. The longest, 820 feet, was on the Pend Oreille River at Metaline Falls, Wash. The equipment for this installation was specially designed. Less than half of the cables erected conformed to the standard plans because of the higher cost of the standard equipment, and the necessity for stretching the funds available in some districts as far as possible.

The high standards of equipment served as an excellent advertisement for the USGS work. This was particularly true in such tourist centers as Yellowstone, Yosemite, and Glacier National Parks where the stations were specially designed to blend into the beauties of the scenery. In connection with the Yosemite National Park station, McGlashan stated (Newsletter, July 27, 1917):

The display shelter for the Friez waterstage recorder, installed at Yosemite last 
season, has been attracting a great deal of attention. In order to brighten the life of the operator at the power plant adjacent to this gaging station, and give him a chance to attend to his regular duties, as well as furnish reliable information to the thousands of tourists who are visiting Yosemite National Park this year, a suitable sign and explanation regarding the operation of the instrument and the use of the records have been placed inside the case.

One feature not included in the plans contained in WSP 371 was a flushing device for the intake pipe. This omission may be ascribed to lack of experience of the compiler and his advisers who had worked chiefly on eastern streams where flushing devices were little used, and to an unpardonable lack of appreciation of "special western conditions" of which the author is positive that they had often and forcefully been advised. The suggestions of the more experienced district engineers, however, resulted only in the following statement that appears on page 14 of WSP 371 :

On certain streams carrying silt in large quantities it has been found necessary to eliminate the intake pipe, the water entering the well (direct by means of a trench).

A flushing device suggested in 1915 and used thereafter to a limited extent consisted of an endless gage chain operating over a roller at the outer end of the intake with another roller inside the shelter. The motion of the chain was expected to stir the deposited silt to such an extent that it would become dislodged. This device did not prove to be satisfactory and was soon abandoned. The California District installed valves in the intake pipes of a few wells. By pumping or bailing water into the well, a head sufficient to flush the intake was obtained (McGlashan, written commun., ca. 1938).

During the later years of this period, however, the installation of recorders on siltladen streams, particularly in the West, made a flushing device imperative. Apparently the first station so equipped was on the Skagit River at Reflector Bar, Wash. This station had a 4-inch intake pipe 35 feet long that became filled with silt. When the pipe was dug up, it was discovered that the silt deposit was limited almost entirely to the outlet end. It seemed therefore that flushing from the middle point might be more effective than flushing from the well. Accordingly, in fall 1917, G.L. Parker installed a 3 -inch riser pipe, extending 7 feet above the ground surface, from the middle of the intake pipe. Thus, it was possible to flush either to the river or to the well by placing a plug in the opposite end of the intake. No funnel was provided and water was poured from a bucket directly into the pipe. This flushing device was used only during low stages and proved fairly satisfactory (G.L. Parker, written commun., ca. 1938). Two more stations in Washington State (Nisqually River near La Grande and White River near Buckley) were equipped with flushing devices during this period. At these stations, however, a different arrangement was used: each flushing device had two separate intakes, one of which was connected by suitable valves and pipes to a small reservoir outside the shelter and the other to a municipal water system.

\section{Artifical Controls}

Artificial controls are used to stabilize the relation between stage and discharge, and hence are built on streams where the natural controls are unstable. Because of the cost of construction, the use of artificial controls during this period was limited to small streams that ranged from 10 to 30 feet in width; only one was 80 feet wide. Although dams and weirs, strictly speaking, are artificial controls, the term has been generally applied to low structures that cause little or no pondage above them. This limitation was indicated in one of the first writings on the subject (the 1913 Covert/Lyon report "Plans and Specifications for CurrentMeter Gaging Stations" discussed earlier in the Gaging-Station Equipment section):

In constructing an artificial control, care should be taken to preserve as nearly as possible the natural conditions of the channel, that is, it should be made to conform closely to the natural bed of the stream and should not project into the channel, as such projection will greatly 
reduce the sensitiveness of the station at low stages.

The beginning of artificial controls antedates the present period by 1 year. Whereas several so-called artificial controls were constructed during the White Mountains investigations in 1911 and in New York during 1912 and 1913, those structures were more properly classed as weirs, and are not considered here.

The simplest form of artificial control is a plank placed on edge in a trench across a small channel, so it is probable that some were installed and not recorded. The first recorded installation of an artificial control occurred in 1912 when E.A. Porter installed 2-inch planks set edgewise in a trench across Huntington Creek in Utah. The planks were held in place by iron posts driven into the streambed. In that same year, E.A. Porter constructed a control on Muddy Creek on the Utah-Wyoming border near Cokeville, Wyo., by driving sheet piling 4 feet into the streambed and leaving 4 inches extending above the bed. Both controls were satisfactory until they were destroyed the next year by floods. In fall 1913, E.A. Porter designed two more controls, profiting by his previous experience. One, on the Logan River in Utah, was a concrete cutoff wall 25 feet long and 10 inches wide that extended 6 inches above the streambed. The other, on Beaver River at Rockyford Dam near Minersville, Utah, was of grouted-boulder construction. Boulders that averaged 2 feet in diameter were placed in a 3-foot-deep trench that followed the crosssectional profile of the streambed. The interstices were filled with cement grout and, when completed, the control extended a few inches above the streambed. The grouted-boulder type was so satisfactory that four of them were built in connection with the intensive investigation of the Sevier River in Utah that began in 1914.

In 1912, the year E.A. Porter started building controls, the USGS began to maintain the gaging stations in southern California that were connected with the storage project of the Volcan Land and Water Company. The low-water flow was a very small fraction of the floodflow and, during the greater part of the year, the streams meandered over broad, sandy channels strewn with boulders. Here, the artificial control was used to stabilize the stage-discharge relation and also to define the low-water channel and direct the flow toward the recorder well. The control was a narrow layer of concrete 1 foot or more in thickness built between the larger boulders and covering the smaller ones. The first of these controls was built on the San Luis Rey River near Pala, Calif., in September 1912, and the second on Santa Ysabel Creek near Ramona, Calif., in November 1912. Seven more of this type were constructed during the next 3 years. Severe floods destroyed these controls during January 1916. Another control constructed during that period, in which the concrete had been poured to bedrock, withstood the flood. As a result of that experience, the 10 artificial controls built during the remainder of this period had the concrete down to bedrock if the bedrock was within 10 feet of the streambed. At stations where there was a greater distance to bedrock, reinforcing and granite boulders were embedded in the concrete, and these have successfully withstood subsequent floods (Ebert, written commun., ca. 1938).

Several artificial controls were constructed during 1915 and 1916, chiefly by Paulsen, on the Colville and Yakima Indian Reservations in Washington. These were low concrete structures and proved generally satisfactory. One of them, which extended $1 \frac{1 / 2}{2}$ feet above the streambed, caused scour on the downstream side. This problem was solved by extending and reinforcing the apron. Another control, constructed by a cooperating engineer, had to be rebuilt a year later because water got into the excavation for the foundation and the concrete was weak. After reconstruction, the control served for many years. Its performance, however, was somewhat disappointing because of the growth of moss on its crest and to its submergence at high water as a result of backwater caused by overhanging brush below it. As a result, there was a reversal in the rating curve for medium-low stages (G.L. Parker, written commun., ca. 1938).

Harrington constructed an artificial control on Cottonwood Creek near Arrowrock, Idaho, in October 1915. This station was isolated, with only one possible source of labor within several miles, that of a rancher's family. The busy father 
and sons declined the additional work, but two daughters in their late teens volunteered. Because it was necessary to keep the manual work to a minimum, a small concrete wall 15 feet long was constructed across the stream following the natural profile of the stream (Harrington, oral commun., ca. 1938).

Artificial controls were constructed also in Northern California. In November 1916, a 1-foot-thick concrete wall was built across Fresno River near Knowles, Calif., between the solid rock outcrops, the top of the wall being somewhat higher than the lowest point in the control. This control has been fairly satisfactory, but shifting sand upstream of the control causes some trouble. A similar control was built on Eleanor Creek near Hetch Hetchy Reservoir in Yosemite National Park in fall 1915, consisting of a concrete wall 25 feet long built in three sections between large boulders.

In 1915, an artificial control was built by the Georgia Power Company under W.E. Hall's supervision. The station, on the Chattooga River near Tallulah Falls, Ga., was in a pool above the irregular, rocky crest of a fall about 100 feet high. During low water, trash collected in the crevices and caused considerable fluctuation in the control. To overcome this problem, a railroad tie was bolted in concrete across the narrowest part of the crest, thus forming a horizontal weir on which trash would not lodge. This successful control is still there (W.E. Hall, written commun., ca. 1938).

Personnel of the Hawaii District were also constructing artificial controls. The first one was built in December 1913 on West Wailuanui stream near Kaneohe, Oahu, and was a low concrete dam 30 feet long with crest about 1 foot above the streambed. During 1914, three similar controls were constructed; one was of reinforced concrete and the other two were not. The two that were not reinforced were destroyed by floods several months later and were replaced by reinforced structures. Reinforced concrete was used for five other controls built during the remainder of this period. Some of the later controls had sections of slightly lower elevation for the low-water discharge. In January 1919, an artificial control in the form of a low elliptical concrete sill about 5 feet long and 8 inches high was built across the lowwater channel between rock outcrops.
The New Mexico District personnel constructed three artificial controls during the period, but details are not now available.

\section{Field EQuipment}

A ruling of the Comptroller General in August 1914 that rubber boots and similar wearing apparel could not be purchased from Federal funds was, from the viewpoint of the field man, the most important change that related to field equipment. Fortunately, this ruling was in effect for no more than 17 months. This decision was not made with respect to USGS purchases, but rather the Reclamation Service furnishing rubber boots to laborers employed for certain kinds of work in which the boots were needed constantly. The Comptroller General ruled that rubber boots were regular clothing for the laborers and so could not be furnished by the Federal Government. The decision was general in its terms, and because it applied to all governmental agencies was interpreted as prohibiting the purchase of waders by the USGS for the field men. Those districts that had non-Federal cooperative funds were generally able to obtain the needed waders by using those funds, but those districts that had only Federal funds were forced either to make the old waders last until nothing was left to patch but the patches or to do without. (So far as the author is aware, the field men were not required to purchase waders from personal funds.) To clarify this situation, the Interior Secretary's office issued instructions in January 1916 that authorized the purchase of rubber boots and waders for official use. The instructions were apparently worded so as to meet the objections raised by the Comptroller General, and such articles have been purchased from Federal funds since that time.

The most important change in equipment, from the standpoint of accuracy of records, was the substitution of enameled scales that were graduated to 2-hundredths for bronze or to tenths for wooden scales. The enameled scales were first used by Ebert (written commun., ca. 1938) in southern California:

(These) were the solution of enabling $*^{* *}$ canal walkers to read a staff 
gage. They could put down the figure when the water was at a marked graduation, otherwise, they were at sea. To get anywhere we needed more marked graduations and, being a good painter, the enamel plate graduated and marked in 0.02 intervals was thought of and a dozen 2-foot gages made up by a local enameling works.

These scales proved so satisfactory that early in 1914 , the Washington, D.C., office had a supply made in 3-foot lengths and sent samples to each district with the statement that that type of scale would be carried in stock (Instructions 4, Feb. 14, 1914).

Covert was the first to make signs that showed the cooperative aspects of the work. He placed them on new shelters in order to capitalize on the advertising value of the improved shelters and the public interest in them. A few other districts wanted similar signs, and the Washington, D.C., office obtained bids on them in 1916.

\section{WINTER RECORDS}

At the close of the previous period, such winter records as were published were mean monthly discharges only, which had been estimated from a few ice measurements that were compared with streamflow at stations that remained open. These estimates were liable to considerable error because of the personal judgment involved. Not only was there lack of uniformity in data and procedure, but no two engineers who used the same base data would make the same estimates.

W.G. Hoyt in fall 1912 conducted the first study of winter measurements with regard to the computation of daily discharges. Discharge measurements in Minnesota during winter 1911-12 had shown such low flows, even lower than the record-low flows during the summer months of 1910 (the year of the Great Plains drought), that he realized the need for a more intensive study of winter streamflow. E.F. Chandler had shown the relation between temperature and discharge, but in the absence of frequent discharge measurements, it was impossible to compute the daily discharge even approximately. W.G. Hoyt set out, therefore, to devise a method for correcting the gage heights, which were ice-affected, for backwater. In his study, the records of the Rainy River at International Falls, Minn., were used. There, the entire winter flow passed through the turbines of a power plant on the Canadian side of the river and the daily flow was computed by Canadian engineers. The river gage was situated some distance downstream where the ice affected the stage. A study of gage heights, discharges, and temperatures, which reached lows of perhaps $50^{\circ}$ Fahrenheit below zero, demonstrated that as the temperature went down, the gage height went up with the increase in backwater. To show this relation more strikingly, W.G. Hoyt plotted the gage heights upside down with respect to temperature and thus showed directly the relation between the two (W.G. Hoyt, oral commun., ca. 1938).

At the January 6-13, 1913, conference, W.G. Hoyt presented a paper on the subject of winter measurements and estimates. He showed the results of his preliminary studies and explained his methods of correcting gage heights for backwater to make them plot on the open-water rating curve, and of determining effective daily gage heights from discharge measurements and temperature records. A committee (W.G. Hoyt, Hartwell, and Lamb, all stationed in districts where winter records were important) was appointed to consider the problems of winter records more fully, and to recommend a method of procedure.

In winter 1913-14, more measurements of ice-affected streams were made than in previous years, including a series of 35 measurements made between February 3 and April 5 on the Kootenai River at Libby, Mont. This series was obtained without special reference to the study of winter records and came about through fortuitous circumstances. A New York power company that was contemplating power development on the Kootenai River near Libby sent an engineer early in winter 1913-14 to measure its flow. His results were so much lower than the estimated flow that the accuracy of his work was doubted; the company asked the USGS to detail an engineer at the company's expense to make daily measurements during the 
remainder of the winter. Jones was detailed to that work under Lamb's direction. In this work, Jones recorded gage heights and temperatures (Jones, oral commun., ca. 1938).

During spring and summer 1913, W.G. Hoyt made a study of the available records, which included 23 ice measurements on the Red River at Grand Forks, N. Dak., that were made by E.F. Chandler during winters from 1906 to 1913 , and a few measurements made during the winters of 1912 and 1913 at several stations in Minnesota and New York. This study again demonstrated the direct relation between temperature and discharge. For a further study of the relation between temperature and discharge, frequent measurements would be needed under a considerable range of temperature at the same station. For that purpose, the almost daily measurements from November 1896 to March 1897 of the Mississippi River above the Crow Wing River in Minnesota, which were made by the Army engineers, were used. These measurements, which were made under a variety of conditions, demonstrated clearly the relation of temperature to discharges, and the relation of temperature to backwater.

With these established relations as a basis, methods were devised for reducing ice-affected gage heights to obtain open-water ratings and for computing daily discharges. The procedures involved changes in gage-height cards and books and the addition of new forms. Before these changes were authorized, a preliminary report was sent to the district engineers in September 1913 for criticism. The proposed procedure met with approval and the new forms were printed with some modifications. The results of the study were prepared and completed before the end of the calendar year 1913 as WSP 337 . Not only was the procedure adopted, but new accessories for making winter measurements were devised. The new method was put into practice early in 1914 and resulted in more accurate and detailed winter records. Instead of limiting the published winter records to mean monthly values, either daily discharges or mean discharges for periods of several days were accepted as sufficiently accurate for publication.

As a result of the interest in winter records, an increasing number of stations were operated during winter each succeeding year. The increase in stations at which winter records were kept involved much more winter field work and new conditions and types of transportation. Perhaps the most isolated winter stations maintained during these years were in Yellowstone National Park; the park authorities cooperated with the Idaho District (this was when Yellowstone National Park was administered by the Army, before the creation of the National Park Service). Baldwin was anxious to obtain winter measurements at the park stations and detailed Paulsen, then a junior engineer, to the work. At the park headquarters, Paulsen was outfitted with skis and a pack sack, and two soldiers acted as guides to take him to the Army posts in the park where shelter and subsistence were furnished. The guides were changed at each post, but the lone engineer could not be changed, and he made the 200-mile ski trip in about 2 weeks' time.

\section{Motorcycles AND Automobiles}

During the closing years of the previous period, motor-propelled vehicles were coming into public use but, in general, the funds available to the districts were too limited to permit the purchase of either motorcycles or automobiles. Beginning in 1911, Covert used his own Ford car on USGS work in New York and, in 1912, Ebert used his Ford car in southern California. In each instance, the owner was paid $\$ 5$ per day for his car when it was actually used officially. Covert received the $\$ 5$ for all expenses, but Ebert was furnished oil and gasoline in addition (Covert and Ebert, written commun., ca. 1938). Each man reports that he lost money on the transaction. Ebert cites the cost of tires at $\$ 27$ each, or 4 for $\$ 100$, and adds that a tire that lasted 3,000 miles was considered satisfactory, and that a life of 3,500 miles was exceptional. The only other personal car that was used to any extent was Jacob's Buick, used during 1913 in Arizona. Jacob was paid a now unknown rate, but whatever it was, he likewise lost money on that transaction (McGlashan, written commun., ca. 1938).

In those days, a few USGS engineers owned automobiles, and the experiences cited above certainly lacked inducement for someone to make a purchase in the expectation of using the 
car officially. The field work, however, involved more speedy methods of transportation than railroads and livery and, about 1911 , the Columbia River District purchased two motorcycles, one of which was "used," from cooperative funds. The use of motorcycles was somewhat disastrous, as shown later, and ended within 3 years.

Hawaii was, next to California, the district with the largest financial resources at this time and was the first to acquire an automobile for official use. In August 1912, shortly after Larrison was appointed district engineer, he wanted to buy a car. Larrison shopped around until he found a used Cadillac for which the dealer wanted $\$ 1,000$. Because all purchases from territorial funds amounting to $\$ 1,000$ or more required a formal contract and the approval of the Governor with the inevitable delay of several months, the dealer, rather than delay and perhaps lose the sale, reduced the price to $\$ 998$ and the deal was completed forthwith (C.H. Pierce, oral commun., ca. 1938). The Cadillac was replaced by a Hupmobile roadster during July 1913, and three motorcycles were also purchased to provide rapid transportation on each of the larger islands that comprised the district.

By 1913, the field work in western districts had generally grown so much that transportation costs had to be reduced and speedier means of transportation provided, if possible. Utah officials authorized the purchase in May 1913 of a motorcycle at a cost of $\$ 332$ for use in the upper Sevier River basin. Apparently the purchase of automobiles was not then covered in the Federal statutes, and when a short time later an automobile needed to be purchased with USGS funds, the Interior Secretary's authority was obtained under a statute that required prior authorization for any purchase in excess of $\$ 500$ (Grover, written commun., ca. 1938). Under this authority, the first automobile, a Ford touring car, was purchased in July 1913 by the USGS with $\$ 600$ in Federal funds. It was used in Nevada. In the same year, another Ford automobile was purchased from cooperative funds and used by the USGS in the Sevier River basin in Utah.

At the end of the first season's use of the motorcycle in the upper Sevier River basin, E.A. Porter computed the cost savings compared with the use of a mule or horse team (no railroad travel being involved) at $\$ 957.55$ (Conf., Water Res. Br., Boise, Idaho, Jan. 1914, p. 64). The cost of operating the motorcycle, including depreciation at $\$ 1.00$ per day, was 5 cents per mile. The Ford operated 4,691 miles during its first season at a cost for operation alone of 5 cents per mile, or 7.6 cents per mile if depreciation was included at a rate of $\$ 2.00$ per day. E.A. Porter cited the Reclamation Service, which had 14 Fords in use at a corresponding average operating cost of 8.4 cents per mile. The depreciation cost of $\$ 2.00$ per day was evidently used on the basis that the life of the Ford would be 300 working days, which presumably would extend over several years.

In spring 1914 , arrangements were made for a cooperative investigation of the Salmon Falls River in Idaho. The area to be covered was 45 miles in length and far from a railroad, and the engineer assigned to it could not make sufficiently frequent measurements if he traveled by mule or horse team. Available State funds permitted the purchase of a motorcycle, but not an automobile (Baldwin, written commun., ca. 1938), and Baldwin suggested to the Washington, D.C., office that a motorcycle would be suitable. Probably on account of a serious accident in North Yakima, Wash., some years earlier when Howard Kimble, riding the Columbia River District motorcycle, fractured his skull in a collision with a streetcar in North Yakima, and of another serious accident involving John J. Sanford while riding the Sevier River motorcycle the previous year, this suggestion was not received with favor, and the purchase of a motorcycle for official use was prohibited (Grover, oral commun., ca. 1938). Baldwin believed, however, that a motorcycle with an attached sidecycle car was outside the ban, and he bought one.

Because the first use of this particular vehicle (without the sidecar attachment, incidentally) resulted in a formulation of a definite USGS policy regarding motorcycles, the incident is worthy of record. The motorcycle was delivered one Saturday afternoon in May 1914, and Baldwin spent the rest of that day and the next learning to operate it. Believing that he had mastered the art of riding the motorcycle and had learned its idiosyncrasies, he started Monday morning on a 250-mile trip to the Salmon 
Falls area to deliver the new vehicle to Harrington, who was detailed to that project. Baldwin had not gone very far before he realized that his experience in riding on the pavements of Boise was of little value when traveling the sandy roads of the desert. About 60 miles from Boise, at a point that fortunately was near the railroad, Baldwin came to a stretch of road torn up by graders. Here the motorcycle skidded, fell on him, and broke his leg. After lying for an hour unable to move, he saw a train approaching and succeeded in flagging it down with his red bandanna handkerchief. The train turned out to be a "special" to which the private car of the division superindendent was attached; the superintendent not only had Baldwin put in his car and the motorcycle loaded on the baggage car, but wired ahead to Glenns Ferry to have the railroad surgeon meet the train with a stretcher. It was only the proximity of the railroad to the scene of the accident that saved Baldwin from a lingering death in the desert. Baldwin's leg was set at Glenns Ferry. The motorcycle was sent by express to a point 60 miles from Harrington's headquarters, and delivered from there by a local mechanic.

Baldwin's accident - the third serious onewas the proverbial last straw and, on May 29, 1914 , Grover announced the following policy (Instructions 26):

(I) will make a rule of the Branch that
motorcycles shall not be purchased or
utilized for our work. This rule will ap-
ply to cooperative as well as regular Fed-
eral work and insistency by cooperative
parties on the use of the motorcycles will
be sufficient reason for not entering into
a cooperative agreement.

A repercussion of this policy was heard in fardistant Hawaii, in the following succinct announcement in the Newsletter dated September 15,1914 , to wit, "For sale, 3 good motorcycles." Motorcycles being taboo, the Branch turned to automobiles to meet its expanding transportation needs.

The purchase of automobiles by the USGS was legally recognized in 1914 and the Sundry Civil Bill for the fiscal year ending June 30 ,
1915, contained the following provision (Grover, written commun., ca. 1938):

$$
\begin{aligned}
& * * * \text { Including the purchase for field } \\
& \text { use only of not exceeding four motor- } \\
& \text { propelled vehicles at a total cost not ex- } \\
& \text { ceeding } \$ 2,800 \text {. }
\end{aligned}
$$

Each subsequent appropriation provided for the purchase of automobiles and within a year or two, such purchase was authorized "for field use only by geologists, topographers, and engineers," and the limitations imposed related to "motor-propelled, passenger-carrying vehicles." The Sundry Civil Bill for fiscal year 1919 authorized the exchange of old cars for new ones (Newsletter, July 22, 1918, p. 2).

The Model-T Ford was preeminent in the low-price field, and it was used almost exclusively in 1914 and the years immediately following. During the remainder of the period, 18 automobiles were used by the districts, practically all roadsters or touring cars. In Montana, an automobile rented for 5 cents per mile. The first automobile used by the Division of Ground Water, a Ford touring car, was purchased using Sundry funds in 1915 for use in Montana. The survey of desert watering places during 1917 led to the use of four additional cars. These also were Fords, but because of the necessity of carrying considerable quantities of supplies, including water, gasoline, foodstuffs, et cetera, the cars were equipped with "slipon" truck bodies, and are believed to have been the first trucks used in the Branch. Six automobiles were in use by the Division of Ground Water at the end of the period.

License plates were not required at first (E.A. Porter, written commun., ca. 1938), but soon the States began to enact laws for licensing automobiles. The license fee was a State tax and it could not be levied on Federal property (Grover, written commun., ca. 1938); thus, during the remainder of this period, it was customary for the USGS to request and receive complimentary plates from the State in which each car was to be used.

The automobile also brought the automobile thief who was partial to the Ford. Because safety locks were not a part of the standard equipment, the following instructions were issued December 15, 1915:

In order to eliminate, so far as possible, danger from theft, all employees of the 
Water Resources Branch who have official automobiles in their custody, are instructed to equip such machines with some form of safety locking device.

The cost of operation was of considerable interest and importance and, in 1916, an automobile cost sheet (form 9-215) was devised with instructions to report at regular intervals. Some of the resulting cost data, taken from different issues of the Newsletter, are of interest for comparison with those of the present day:

Operating cost of Ford automobiles, exclusive of depreciation

\begin{tabular}{|c|c|c|}
\hline Office & Mileage & $\begin{array}{l}\text { Average cost } \\
\text { per mile }\end{array}$ \\
\hline Boston ............ & $\$ 7,930$ & $\$ 0.060$ \\
\hline Albany ............. & 7,480 & .050 \\
\hline Atlanta .............. & 6,477 & .058 \\
\hline Madison ........... & 7,405 & .046 \\
\hline Topeka............. & 9,197 & .062 \\
\hline Boise.............. & 10,466 & .079 \\
\hline Do. & 5,528 & .046 \\
\hline Portland... & 28,110 & .070 \\
\hline Do. & 9,923 & .059 \\
\hline San Francisco.. & 9,529 & .072 \\
\hline Los Angeles..... & 22,613 & .032 \\
\hline Do. & 15,190 & .032 \\
\hline Phoenix ........... & 15,823 & .073 \\
\hline Austin ............ & 7,904 & .048 \\
\hline
\end{tabular}

The low cost of operating the two cars in southern California, the first being sold at 22,613 miles and succeeded by the second, is believed to have been due chiefly to the fact that both were used almost exclusively by one man, whereas the others were generally used by more than one man. (The record-low operating cost of 1.83 cents was the result of Murphy operating his own personal Ford on generally level roads.)

The operation of the early automobiles furnished a wealth of human-interest material. Perhaps the standard method of starting the "Model T" on a cold winter morning had the widest application in the Branch. According to Purton (written commun., ca. 1938), it went something like this:

1. Jack up rear wheel.

2. Crank like (Purton was too modest to write "hell").

3 . Insert lighted newspaper under carburetor.

4. Crank some more.
5. Grab shovel and throw dirt on gaily burning carburator and engine.

6. Either start on 4 days' work or get nearest team of mules to tow you around until you do start.

Then Purton adds:

Other features of sainted memory are the coal oil and carbide headlights, which were succeeded by those operated from the magneto with attendant difficulties; the age of moth balls and other gland treatment for the gasoline; changing and repairing tires before the advent of the demountable rims and free air.

The animal was not without its good points, however, for it developed brawn and ingenuity. No one could push a Ford up countless hills or through axle-deep mud without coming out a better man, or a dead one.

Another item of interest resulted from the proclivity of the Ford to boil over on hills. This fact was underscored by the experience of Batchelder and Revoe C. Briggs in the Oregon District in 1917. On a trip that led across the steepest hills of northern Oregon, they recorded (Newsletter, Sept. 24, 1917, p. 8) that an

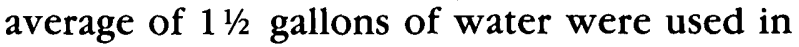
the radiator for every gallon of gasoline consumed, and wound up their description with the illuminating statement that "Job of the Bible may have had his trouble but he never drove a 2-year-old Ford over Oregon roads." This Oregon car carried as a part of its regular equipment a bedroll and a metal-lined box containing 2 days' provisions. Batchelder wrote that "it was a rare occurrence to put in a week's field work in the Cascade Mountains without the necessity of spending one or more nights on the road due to a mechanical failure of the car, or to the impassable condition of the roads."

The condition of roads with the not infrequent mud holes is glimpsed from Ebert's (written commun., ca. 1938) experience in southern California:

Every impassible mud hole had a local farmer with his team standing by. The standard charge for a tow was $\$ 3$ for a Ford, and $\$ 5$ for other makes of cars. For obvious reasons a good paying mud hole was very, very slow in drying out. 
Although muddy roads were a trial to the operators of the early Fords, sandy roads in the desert were an equal trial. A picture of the grief caused by such roads is given by the following extracts from a letter written by John S. Brown, a geologist who was locating and marking the desert watering places, to Meinzer (dated Nov. 18, 1917):

On Friday noon, Nov. 9, the car got in some rather heavy sand at the end of the canyon, and something ripped in the rear end. We worked all the afternoon and couldn't get it apart to find the trouble. When finally opened [we found that] a roller bearing had locked in the drive shaft and it took eight men with a garage full of tools two hours to get it open. We walked to Niland [Calif.] that night, fifteen miles south. Got the promise of a [mule] team available Sunday, Nov. 11. When we took it out it was so poor and the driver so poor that we only got half way to the car by 11:00 a.m. and having but one feed and can of water had to turn back.

[B.W.] Broderson and I then took the team to Mecca [Calif.] to look up [a man] whom [sic] we thought could tow us out. He was busy with another party. Finally a Mr. Hook from Coachella [Calif.] thought he could go out by way of Dos Palmas [Calif.] and bring us in with a new Oakland. He promised to bring all the repairs he could think of and sufficient tools. After considerable trouble with sand we got to the car at 10 a.m., Monday. We had picked up a party of four prospectors in a Dodge car ${ }^{* * *}$. All of us finally got the car apart next day, but one or two pieces were lacking, as practically the whole rear end was warped or broken ***

The Overland [stage] towed us part way to Niland, but had to give up and finally got in itself with us [sic]. Repairs could be had at Calipatria [Calif.], ten miles south, so we went there. On the way Hook burned a bearing in his Oakland and so Broderson and I got repairs and went back alone. We found an irrigation ditching party and [they] loaned us four mules to go after the car that night. At 1:00 a.m. we got her into Niland ***. Next day, Wednesday, we fixed the car in running shape ourselves.

Before leaving the subject of Ford cars, the author cannot refrain from including the following paraphrase of the Twenty-third Psalm (Newsletter, Sept. 30, 1918):

The Ford is my auto. I shall not want [another]. It maketh me to lie down beneath it. It soureth my soul. It leadeth me in paths of ridicule for its name's sake. Yes, though I ride through the valleys I am towed up the hills, for I fear much evil. For thy rods and thy carburetor discomfort me. I anoint my tires with patches, my radiator runneth over. I prepare for blowouts in the presence of mine enemies. Surely, if this thing follows me all the days of my life I shall dwell in the bug-house forever.

\section{Studies of Effect of Variable Slope on Discharge}

The slopes of many southern streams are so small that it is impossible to find sites for stations near the mouths of the streams where there is no backwater effect. The measurements by Grover and Murphy of the Allegheny and Ohio Rivers, showing the effects of rising and falling stages on discharges, had interested M.R. Hall and in 1908 he conducted a study of the Yazoo River at Greenwood, Miss., and the stages of the Mississippi River into which the Yazoo flows. He found that the stages at Greenwood were directly related to those of the Mississippi at Vicksburg, Miss. M.R. Hall made discharge measurements at Greenwood during 1908, 1909, 1911, and 1912, which showed that the effect of backwater prevented the computation of daily discharges from observations of stage on a single gage at Greenwood. He therefore installed a second gage at Philipp, Miss., some distance above Greenwood, and readings on the Philipp and Greenwood gages showed the fluctuating slope of the Yazoo. M.R. Hall devised a method of applying a slope correction to the Greenwood measurements, obtaining what he termed the "normal discharge" and, by its use, was able to compute the daily discharge. At the conference held January 6-11, 1913, W.E. Hall described this method, which aroused considerable interest because other districts had similar problems. W.E. Hall and C.H. Pierce were delegated to prepare a description of the Hall method for publication, and it appeared in WSP 345-E (1915). 
Backwater represents only one of the difficulties in obtaining records of discharge of streams that have flat slopes. Another more common difficulty results from the different slopes that pertain to rising and falling stages and their consequent effect on discharge. During winter 1913-14, Jones became interested in a report by Henshaw that contained the results of certain discharge measurements that were taken during changing stages, and Henshaw's suggestion that the rate of change in slope divided by the velocity would give the increase in slope due to the rate of change. During summer 1914, Jones also interested C.R. Hauke, engineer of the Indian Service, who cooperated in a further study of the problem by varying the flow in the Agency Ditch near Harlem, Mont., so measurements could be taken at different stages, after the station had already been rated for constant stages. Another series of measurements was made on the Little Missouri River near Alzada, Mont. Both series of measurements showed the correctness of Henshaw's suggestion and the method was developed and published in WSP 375-E (1916). No further studies of the effect of changing slope on discharge were made during this period.

\section{INTEGRATORS}

The increase in the number of recorders in use by the USGS caused a great increase in the office work of computing mean daily gage heights and discharges from the charts. This increase in work was felt particularly in the Columbia River District where several recorders were installed on streams that either were controlled by power plants or were subject to diurnal fluctuations resulting from the alternate melting and freezing of mountain snow during spring and summer months. The use of a polar planimeter to determine the mean daily gage height was suggested about 1913 to E.S. Fuller. E.S. Fuller, then office engineer, realized the possibility of modifying the planimeter (itself a mechanical integrator) so as to make a gageheight integrator by which the mean daily gage height could be obtained by tracing the hydrograph from midnight to midnight, instead of tracing all four sides of the figure representing the daily hydrograph. E.S. Fuller (written commun., ca. 1938) describes the development of such an integrator thus:

Enlisting the help of a neighbor who owned a small foot-power lathe, I built the first gage-height integrator and put it into practical use in the Portland [Oreg.] office.

In the spring of 1914 I was transferred to the Washington office and took my integrator with me. It was decided to build several more of them, and *** four new gage-height integrators were made up in the next few months.

So highly regarded were these integrators that the June 1914 Newsletter contained the following statement:

Four Fuller integrators have been finished and have been sent to the field offices to be tested. Experiments in this office indicate that this instrument will go a long way toward solving the problem in connection with the office work on automatic records.

Further tests in the district offices, however, emphasized the fact that an application of rating curves to the mean daily gage heights did not give mean daily discharges if there was considerable curvature in the rating curve within the range of stage covered. The next step was the introduction directly into the integrator of the stage-discharge relation for each station, and E.S. Fuller considered several methods for accomplishing this. He selected one method and incorporated it in a rough working model of a discharge integrator that was tested in the Washington, D.C., office. It was exhibited at the December 1914 conference and, in the ensuing discussion by USGS engineers, several improvements were suggested that were incorporated into the working model. In February 1915 , this "improved" model was turned over to Carl $\mathrm{H}$. Au, a mechanical engineer in Washington, D.C. (later one of the engineers of the Branch) to use in constructing what came to be known as Integrator Number 1 . Au made many improvements, and his fine workmanship made the integrator a practical instrument.

The first integrator was finished and placed in operation several months later. It was exhibited at the San Francisco, Calif., conference 
in October 1915 and the usual discussion brought out suggestions of further minor changes to promote ease of operation; these were incorporated in the second integrator that was completed in June 1916 . So highly regarded was this instrument that in the Newsletter dated October 23, 1916, the Boston office staff wrote that "The integrator has been tried out in the Boston office and pronounced a 'great success.' It's not only a time saver, but the most accurate method of determining daily discharges for streams having rapid fluctuations in stages." A few further changes were made in the design, and two more integrators were constructed during the next few months. When these were completed, the Washington, D.C., office stated (Newsletter, Jan. 18, 1917, p. 1) that "it is now believed that the integrator is in final form and that any future changes will be trivial."

Here again the aspiration for perfection and finality was doubtless doomed to disappointment or to a liberal interpretation of "trivial." Before leaving the subject of integrators during the present period, one final quotation from E.S. Fuller may not be out of place:

I have had the pleasure of seeing it [Integrator number 1] busily at work, when I have dropped in to see McGlashan from time to time during the past 20 years. Incidentally, I have in the last year or so tried several times to borrow this integrator from Mac for a day or two so that I might investigate its adaptability to our own work in the Los Angeles County Flood Control District, but he always claims he can't spare it, even though the last time I talked with him, he also had one of the latest batch of new integrators in use $*^{*} *$. Such is the reward of the poor designer of the Discharge Integrator.

\section{Refinement in Office Methods}

With the exception of a new procedure for computing records during the frozen period [sic] and the development and use of the discharge integrator, the changes in office methods were limited to refinements of well established methods. The refinements were to reduce to a minimum the labor involved in their use and to increase the accuracy of the records.

The new procedure for computing winter records, which became standard practice beginning with winter 1914-15, required a revision of the observer gage-height books and cards. Heretofore it had been necessary to have one set of books and cards for the open season and another for the frozen season. Because the new procedure did not require certain data previously considered necessary during the frozen season, two sets of books and cards were unnecessary and the new forms were designed for use throughout the year. That the Washington, D.C., office list of districts interested in frozenperiod supplies needed revision is shown by the Arizona District engineer's comments in the October 15, 1914, Newsletter (p. 11):

It is not understood exactly what the Washington office had in mind when it supplied this district with gage height and discharge forms for ice conditions. We have been looking in vain for several weeks for a shipment of ice from the same source. Ice sells here for about one cent per pound the year around.

A new form for current-meter notes (9-275a), form 9-249a (for backwater computation), and form 9-279b (a hydrograph sheet) were prepared for field use during the frozen period and for computation of daily discharges.

A minor change in office methods that might also be termed a refinement related to the computation of daily discharges of streams with shifting channels. The Bolster graphical method of determining the amount of shift between measurements had been more or less generally used since 1906. Although it was a quick method as used, it could not be checked exactly, and the Washington, D.C., office felt that this was a weakness. Accordingly, about 1917 (the exact date is uncertain because the change was gradual), it was decided to revert to the original Stout method-determining mathematically the amount of change in daily gage heights to bring them into conformity with a series of curves drawn parallel to the standard rating curve, as determined by plotting the discharge measurements and assuming uniformity of change between measurements. This was was a method that could be checked. 
In order to give the office engineer a truer conception of the accuracy of individual current-meter measurements, a first sheet (form 9-275c) for meter notes to be filled out by the field engineer was prepared and sent to each district in April 1914. A limits-of-use table was sent to the districts at the same time. The increased use of gage scales graduated to quarters, 10ths, or 200ths, had resulted in gageheight records to hundredths throughout the entire range of stage, and had added considerably to the labor of computing the daily discharges. To reduce the amount of work, some districts set arbitrary limits for each station, using gage heights to half tenths or 10ths for medium and high stages. This was a rough-andready method that did not find favor with the mathematically minded engineers of the Branch. They devised a mathematical formula for the elimination of hundredths above certain gage heights, based on the assumption that by so doing the limit of allowable errors so introduced would be 2 percent for staff and chain gage records, and 1 percent for recorder records (J.C. Hoyt and N.C. Grover, River discharge, John Wiley and Sons, Inc., 1916, p. 105). This formula was expanded into a limitsof-use table by Randell.

The increasing use of water-stage recorders led to an inspection card (form 9-176b) and to a form for the computation of hourly discharges (form 9-179). With the gradual use of the integrator, however, this latter form fell into disuse.

The station description form (form 9-197) underwent two changes during this period. The form in use for many years was printed on both sides of the paper and because it could not be blueprinted, was out of line with the other forms. In 1912, when the procedure of presenting station descriptions under separate headings was adopted, the station description was revised by the substitution of two forms (form 9-197 and form 9-197a), both of which were printed on one side of the paper. The first form was for information pertaining to the physical facts, location, equipment, conditions of measurement, et cetera, and the second for the information that was required for the annual reports. With the general revision of forms during 1914 , the station description form was again revised and again reduced to one form (form 9-197). At the same time, a cross-section sheet (form 9-213a) was prepared for use with the station description form. Even with these changes, the description of stations too often did not contain sufficient information to enable the office engineer to judge of the accuracy of the resulting records. To remedy this situation, the Washington, D.C., office in 1915 prepared lengthy instructions for preparing field descriptions, and presented them on the reverse side of the field station description (form 9-277). Nothing, by any stretch of the imagination, now appears to have been omitted from these instructions, and they and the station description form have remained unchanged to this day (1938).

\section{AnNuAl Reports}

The principal change made during this period in the contents of the annual reports was the elimination of the tables of daily gage heights and, as usual, the change followed a conference discussion. At the December 7-12, 1914, conference, G.C. Stevens presented a paper on progress reports (as the annual reports were then called) and, in the ensuing discussion, the desirability of continuing the publication of both daily gage heights and daily discharges was questioned. Under the pressure to keep down the cost of publication, different items were always being reviewed to determine what might be omitted with least loss to the public. In response to such pressure and in accordance with views expressed at the conference, the Washington, D.C., office decided the following July to discontinue the publication of gage heights beginning with the 1914 report. A paragraph on extremes of stage and discharge, both for the report year and for the period of record, however, was then published in the station description.

The 1913 report contained the long-time records of the Tennessee River at Chattanooga, Tenn., which extended back to 1874 , and a "deficiency table" showing the days in each year that the flow was below different discharges (WSP 353, p. 150, 1915). This table was so useful that similar tables for selected if not 
for all stations would be included in subsequent annual reports (Instructions 12, July 1, 1915). A paper on duration tables presented at the San Francisco conference in fall 1915 caused considerable discussion. Complete records of daily discharge were needed for the computation of deficiency tables and so most of the stations on ice-affected power streams [sic] in the northern part of the country were eliminated. The majority of western stations were chiefly of use to those interested only in irrigation, and they were not particularly interested in deficiency tables. As a result of this situation, and of the not inconsiderable labor involved in preparing them, less than a dozen deficiency tables for stations in the Southeastern States were published in the annual reports. Such tables were, however, used quite extensively in three special WSP's issued during this period (WSP 415 (1916); 424 (1917); 491 (1920)).

Several papers on the accuracy of streamflow records were presented at the San Francisco conference in 1915. The ensuing discussion brought out the fact that the accuracy rating was, to a considerable extent, the arbitrary opinion of the engineer making the rating and that the ratings were therefore not comparable throughout the country. A committee consisting of R.C. Pierce, Jacob, Crandall, and H.J. Jackson was, therefore, appointed to study and come up with a more rational method of accuracy rating (Instructions 17, Nov. 11, 1916). As an aid to this study, Grover and J.C. Hoyt prepared a paper dealing with accuracy of streamflow data (WSP 400-D, p. 53, 1917) in which the different factors affecting the accuracy of records were clearly set forth. The committee made its study and report during the following year and, beginning with the annual reports for 1916 , the accuracy ratings were based on the different factors that affected accuracy.

During the early years of the Branch, many records collected by outside parties were published by the USGS, but there had been no basis for selection between which records should be published and which records should not. To create such a basis, the conference held December $7-12,1914$, adopted the following resolution (Instructions 48, Dec. 19, 1914), which was approved by the Director:

It is the sense of this conference that records of river discharge collected by individuals, corporations, municipalities, states, or other Federal bureaus, but not in cooperation with the Water Resources Branch, should not in general be published in the progress reports of the Survey if they are published elsewhere. If not published elsewhere, however, such records may be published by the Survey if the district engineer in whose district they have been collected has such information that he is convinced of their reliability.

(If the author did not inspire this resolution, he profited greatly by it through the very considerable reduction in records to be prepared for publication in the Rocky Mountain District.)

The practice of using blueprint copies of the records of daily discharge for printer's copy, begun in 1910, was discontinued during the first year of the present period. Many of the blueprints submitted were so poor that the Government Printing Office refused to accept them and, in December 1913, arrangements were made to have black paper negatives made from form 9-192a from which black and white prints were made for printer's copy (Instructions 53, Dec. 13, 1913). This practice continued until spring 1916. By that time, the district offices had been equipped with adding machines that made typed records, as a part of the process of computing the monthly means, that were acceptable as printer's copy. Accordingly, forms for that purpose (form 9-211b and form 9-211c) were devised and instructions were issued for their use (Instructions 9, May 3, 1916).

The division of the annual reports into individual volumes that covered drainage basins, which had begun with the publication of the 1907-8 reports continued. Because of the large number of records in the North Pacific drainage basins, however, the records for those basins were published in three volumes instead of one, beginning with the 1913 report.

The lag time in publication of the annual reports gradually widened during this period, and took about 3 years for the 1918 report. The lag was due to several causes-the lack of Washington, D.C., office personnel to prepare the manuscripts promptly, the soporific effect of the lag on many district engineers who in 
turn fell far behind in the computations, and the small USGS printing appropriation that was insufficient for the publication of all USGS manuscripts. The limitation of funds was perhaps the most potent obstacle to the prompt preparation and publication of reports. In an attempt to reduce the lag time, the records for 1919 and 1920 were combined and finally published in 1923. The lag was not reduced materially, but some cost savings occurred, thus relieving to a small extent the drain on printing funds.

\section{CONFERENCES}

So frequent were the conferences during this period that it might appropriately be called the "years of many conferences." The ability to hold so many conferences was doubtless fortunate because, in these maturing years, the opportunities for discussions about technical problems related to the work of the Branch were of unusual value.

The value of conferences was expressed by A.P. Davis, director and chief engineer of the Reclamation Service, with reference to a conference of that organization (Newsletter, Nov. 22,1916, p. 2):

The greatest benefit I hope to obtain from this conference is a mutual acquaintance and exchange of ideas so as to get the best teamwork and strive for the same thing. People have different points of view, and differences of opinion relative to the importance of things and regarding proper policies to be pursued, and it is of course necessary to decide what the proper course and policy should be.

The Reclamation Commission aims at infallibility and we want your help and we expect suggestions, and at the same time when a decision is arrived at, we want teamwork in carrying out the policy when it is arrived at. We have come here to get better in touch with each other and what we are aiming at, to get a better idea of our mutual good intentions, where there are differences of opinion, and a more cordial cooperation, and to get effective teamwork without which no organization can succeed.
A further evaluation of conferences was succinctly expressed [author unknown] as follows in the June 30, 1918, Newsletter:
"You have a dollar, I have a dollar.
We swap.
Now you have my dollar
And I have yours,
We are no better off.
"You have an idea, I have an idea.
We swap.
Now you have two ideas, And I have two ideas.
We are both better off."
Why IS A CONFERENCE?

The investigations that began as a result of the last conference in the previous period were so fruitful in raising the standards of work of the Branch that it was obvious that annual conferences would be desirable, especially because everyone was working so hard to improve equipment and increase accuracy of records. In deciding on annual conferences, it was also decided that conferences in alternate years should be held in the West because so much of the work of the Branch was in the West.

In accordance with this plan, a conference was held in Boise, Idaho, January 27-30, 1914. Because of the expense involved, however, the attendance was limited to the district engineers and selected office engineers from six western districts (CHE, written commun. to Director, March 2, 1915), Reclamation Service engineers in Boise, and two members of the British Columbia (Canada) Hydrometric Survey. Twenty-nine papers covering many phases of field and office work were presented during the 4-day meeting. A subject that appeared for the first time on a conference program, but one that became increasingly important in subsequent years, was transportation costs with special reference to automobiles. It was presented by E.A. Porter. The conference papers and discussions were mimeographed and sent to each district office (Rept., Conf. of western eng., Water Res. Br., USGS, Boise, Idaho, Jan. 1914).

The Boise conferees decided that the latter part of November or the first part of December was the most convenient time for future 
conferences. Accordingly, the next conference was held in Washington, D.C., Dec. 7-12, 1914. The attendance included 17 individuals from other organizations. At that time, the comparable Canadian organizations, both Dominion and Provincial, were in their formative years, and were asking the USGS for advice. Therefore, officials from each Canadian organization were invited and four attended the conference. The Indian Service was represented by five members. Other organizations accounted for the remainder.

This was Grover's first general conference as CHE. In his opening remarks, he outlined his conception of the development and relations of personnel, which has been largely responsible for the development of the Branch.

During the 6-day session, 38 papers were presented, and the ensuing discussions provided an international exchange of ideas. The manufactures of the Friez, Gurley, and Stevens recorders had displays of their latest models. With so long a program and so many conferees from outside organizations, the usual executive sessions for district engineers only were postponed until the following week. Most of the papers presented were mimeographed and furnished to the district offices (Proc., Conf. of eng., Water Res. Br., USGS, Washington, D.C., Dec. 1914).

Following the procedure of alternating the conference between Washington, D.C., and the West, the 1915 conference was scheduled for the West. The railroads were offering low rates to San Francisco for the Panama Pacific Exposition, so that city was selected and the date was moved up from December to the week of October 18-23 in order to take advantage of those low rates. The program was so loaded with topics (42) that two evening sessions were required to complete it. Although formal papers were presented, only a few of them were mimeographed for distribution to the district offices, for reasons not now known.

The idea of western conferences was so popular, and the space available for a conference in the old USGS quarters in Washington, D.C., was so limited, that it was decided that the next conference would be held in the West. Denver was selected and the week of
January $15-20,1917$, was chosen by the district engineers. Instead of preparing a set program in advance, each district engineer was notified that he was expected to discuss topics under seven headings that included field and office operations, public relations, and the organization and operation of his district. There were therefore to be 16 papers, and an arbitrary limit of half an hour was set on each paper. The discussions arising from these papers formed the basis of the conference program, to which were added such other topics as the district engineers chose to introduce (CHE, written commun., Sept. 29, 1916). In addition to the district engineers, J.C. Hoyt, A.H. Horton, and G.C. Stevens were present from the Washington, D.C., office. No record of the proceedings of that conference is now available. The Denver conference was the last held in the West because the district engineers came to the conclusion that Washington, D.C., was the logical place to hold future conferences, not only because it was the headquarters of the USGS, but also of other government bureaus. A considerable number of districts were cooperating with other governmental agencies and the district engineers welcomed the opportunity to confer informally with the officials of those agencies.

The next conference was held in the new USGS quarters in Washington, D.C., during the week of October 15-20, 1917. No program was prepared in advance, but a program committee was appointed at the first session; they prepared a program of 21 topics. A chairman and secretary were appointed for each half-day session. One afternoon was devoted to a trip to the Army engineer training camp on the campus of American University, and another to the Bureau of Standards to see the meter-rating facilities. This was the last conference during the present period because, by the next fall when the annual conference would have been held, war activities in Washington, D.C., precluded having a conference.

At the conference held in December 1914, the conferees voted to start each session promptly at the times set, usually 9:30 in the morning and 1:30 in the afternoon, and to insure prompt attendance, a fine of 25 cents was levied for tardiness. Promptly at the appointed time, the door was closed and a sergeant-atarms, usually one of the larger men present, was 
stationed at the door to collect cash from the tardy ones. At one conference, a western district engineer made so leisurely a trip eastward that he was a day late and was fined $\$ 5.00$. No district engineer has been a day late since that time. At the closing session of each conference it was usually voted to spend the amount collected in fines, a not inconsiderable sum, to purchase flowers for the wives of the Washington, D.C., office engineers who had entertained the members of the conference at different social functions. This precedent was not followed at the war-time conference in October 1917. Those conferees voted to send the money to those Branch members who were in the Army-none being in the Navy because they apparently had sufficient dealings with water in civil life. In the Newsletter for January 1918, the chairman of the committee entrusted with the fines fund announced that a crisp new $\$ 2$ bill had been mailed to each of 11 Branch members.

A topic that bobbed up at each conference until it was finally settled in 1917 was the plea of the district engineers to keep the original computation form (form 9-192a) and transmit a blueprint, on the grounds that the district offices had frequent requests for advance data that could easily be met by furnishing blueprints of the computation forms if the originals were available. This plea was especially strong at the Denver conference in 1917. It was in vain, however, because the Washington, D.C., office decided that the advantages in having the original copy filed there were greater than those to the district office in retaining it (Instructions 5, March 7, 1917). Thus closed unsuccessfuly an effort of some years standing.

Another perennial argument at the conferences, and one that continued beyond the present period, was the relative merits of chain and staff gages. A.H. Horton was the chief advocate for the chain gage, and G.L. Parker, who could see no good in chain gages, was the chief advocate for the staff gage. The result was that each advocate became more firmly convinced of the righteousness of his cause, or, to quote the Persian poet of Naishapur: " **** but evermore, Came out by the same door wherein I went." A poetically(?)-minded and anonymous member of the Branch described the discussion as follows (Newsletter, July 17,1914, p. 8):

\author{
"There was a young man from the West \\ Who thot that a chain gage was not best. \\ He wrote and he talked, \\ He knocked and he balked, \\ But it continued in use by the rest. \\ "There was a mathematician of wisdom \\ Who questioned the care and precision \\ Of chains measured West \\ And the conditions of test, \\ And the Chief bore him out in this freedom. \\ "A standard chain gage it is said \\ Is the only one that can be well read. \\ But, pardon the wonder, \\ What in the thunder \\ Is a standard chain gage instead?"
}

\section{NewSLETTERS}

If the author's memory has not played him false, the Newsetters had their beginning at the conference held January 6-13, 1913. R.B. Marshall, chief geographer, was present at one session and told of the practice of the Topographic Branch in sending at intervals to the field parties what he called "round robin" newsletters containing items of interest, mostly of a personal nature. His description of the great interest shown in these newsletters led the conferees to believe that newsletters would be welcomed by the Water Resources Branch. Marshall's further suggestion that newsletters might be exchanged between the two branches was not considered practical because of general lack of acquaintance and common interests.

On February 13, 1913, the first issue of what was called the Monthly Bulletin appeared, typed on regular correspondence paper. In order to give the new publication official standing in the Branch, it bore the label of "Instructions," each issue was numbered in an "Instructions series," and was so designated until July 1914, when the Bulletin was considered sufficiently well established to stand on its own merits. When the July 1913 issue appeared, the Branch had a new chief who changed the name from Monthly Bulletin to Newsletter. In the first issue, the district engineers were requested to 
include items for the Bulletin in each monthly report. The Newsletter of July 1914, however, contained the statement that numbers would be issued on the 15th of the month, and that items should be submitted by separate letter no later than that date. The warning was given that the items were to be short and to the point because the amount of material that could be used was necessarily limited. Many districts failed to contribute regularly, however, and a plea was made in October for regularity of contributions. That plea met with only temporary success.

In the early issues the contributions to the Newsletter were grouped under a few main headings, but, perhaps to stimulate competition among the districts, the issue for February 1914 announced that, at Baldwin's suggestion, future Newsletters would be arranged by districts and the space limited to one page for each district. The next issue contained contributions from only four of the 13 districts and the editor announced that "It may be assumed that these districts [not contributing] take little if any, interest in the Newsletter. If only four of the thirteen districts have sufficient interest in its continuance to furnish news for a monthly issue, it may well be decided that the undertaking is not worth the effort. It rests with the district engineers to show by their actions whether or not they want a Newsletter in the future." This plain language had the desired effect because everyone wanted the monthly Newsletter to continue, even though the more or less general attitude had been "let George do it." No further reminders were needed and a majority of the districts contributed to each issue during the remainder of the period. The system of using carbon copies in issuing the Newsletter continued until January 1918 when the typed newsletter was photolithographed down to a smaller sized sheet and issued in that form, the increased cost being divided among the districts.

The Newsletters contained personnel notes, information as to status of publications, items of more or less local interest pertaining to streamflow and hydraulic engineering activities, and considerable human interest material. Some district engineers discussed technical matters to a limited extent, but the Newsletter was not then generally used as a medium for the exchange of technical information.

\section{Special InVestigations}

\section{Public Health Service, Ohio River}

The Public Health Service began a detailed study of the sanitary condition of the Ohio River in 1913 with special reference to the river's capacity for self-purification. The help of the USGS was solicited in obtaining additional information on discharge and, on May 1, 1914 , Ellsworth was detailed to the work with R.M. Adams, junior engineer. The Public Health Service furnished several assistants and equipment and paid all expenses. The discharge was measured at different stages at a number of points on the river between Pittsburgh, $\mathrm{Pa}$., and the mouth and on the principal tributaries. Among the points of measurement were the crests of dams on the Ohio River during stages when the depth of water was 1 foot or less. It was found that a satisfactory measurement could be made on a dam of broad crest that had a small (3:10) slope if the measuring section was far upstream from the crest to permit the taking of vertical-velocity curves to demonstrate the applicability of the 0.2-, 0.8-depth method. It was concluded that measurements could probably be safely made with a head of 1 foot or less. As stated in the Newsletter dated June 21, 1915:

\begin{abstract}
Having the point of zero flow the lowest point in the dam, a measurement with, say 0.8-foot head on the dam and one with 3.0-foot head on the dam, the stage at which there is a measurable velocity in the pool above the dam, the lower part of the rating curve can be located much more accurately than by the use of assumed weir coefficients.
\end{abstract}

From vertical-velocity curves based on velocity observations at 0.2 -depth intervals, it was found that the mid-depth velocity was 5 percent less than mean, the 0.6-depth velocity was about 3 and 4 percent greater than the mean, and the $0.2-, 0.8$-depth velocity was 1 or 2 percent less than the mean (Newsletter, Aug. 19, 1915).

For the purposes of the investigation, the average rate of travel of the water from point to point had to be determined. At first, floats 
were used, but they were unsatisfactory. Later, the mean velocity was computed at close intervals, using known discharges and crosssectional areas that were available as a result of a recent survey by the Army engineers. The USGS participation in the Ohio River investigation lasted until September 30, 1915.

\section{Tides in Golden Gate}

Gilbert's investigation during the previous period indicated that the deposition of debris in the tidal prism bordering San Francisco Bay was influenced by the tides in the Golden Gate (a 2-mile-wide strait leading from the Pacific Ocean into San Francisco Bay, which is spanned by the famous Golden Gate Bridge). Definite information on the velocity of these tides was therefore needed, which involved measuring velocity, in water 324 feet deep, at frequent intervals during periods of at least 24 hours to cover ebb and flood tides in the entrance to one of the busiest ports on the west coast. The undertaking was so unusual as to be worthy of record in this History.

In his characteristic manner of thorough preparation, Gilbert, in September 1914, obtained the cooperation of the Lighthouse Service, the U.S. Army Engineers, and personnel of the USGS San Francisco office. A steel "midchannel" buoy was anchored in Golden Gate midway between Fort Point and Lime Point, the site of the present Golden Gate suspension bridge. The messenger boat Suisun, which was placed at Gilbert's service, was moored to this buoy. The San Francisco office loaned Rice and Leidl to make the current meter measurements.

The general plan included two series of subsurface observations by current meter, each covering a period of over 24 hours, on such dates that one would be within a period of lunar high declination and the other within one of zero declination (Prof. Paper 105, p. 108, 1917). The periods that met these requirements were from 11:00 a.m. September 12 to 11:00 a.m. September 13, and from 10:00 a.m. to midnight, September 19, 1914, but fog made it unsafe to continue the observations for the full 24-hour period. A third series of velocity observations from a little later in the month, although the tidal conditions were not as satisfactory, verified the results obtained September 12-13.

During the first period, 255 velocity measurements were made, an average of one every 5.8 minutes. The measurements were using the standard Price meter at a depth of 34 feet, which was deeper than the draft of most vessels entering Golden Gate. These velocities were measured at a single point in Golden Gate-in mid-channel between Fort Point and Lime Point-so Gilbert thought it best to have the current meter submerged so far below the surface that it would be unaffected by surface currents and drift. The depth of water at this point was 54 fathoms (324 feet) and he decided that placing the meter at about 34 feet deep would be satisfactory.

The Price current meter was suspended by galvanized sash cord with insulated return wire from an outrigger or boom off the side of the boat near the stern. Two 15-pound weights were used. Simultaneous measurements were made from a second outrigger off the opposite side of the boat, using first an Eckmann and later a Haskell-Warren current meter. Unfortunately for the comparisons, the Eckmann meter became defective in service and the Haskell-Warren meter lost a propeller blade. Only the Price meter operated satisfactorily throughout the measurements.

The effect of vertical motion on the action of the Price current meter was later studied by Rice who found that, although the effect was considerable at low velocities, it was negligible at velocities of 3 feet or more. Because the measured velocities in Golden Gate at flood tide fluctuated chiefly between 2 and 8 feet per second, the results obtained by the Price meter were used.

Sextant observations on nearby lighthouses were used to site, on the hydrographic (nautical) chart of Golden Gate, the positions of the anchored boat during ebb and flood tides. In describing this work, Rice writes (ca. 1938) that "the most uncomfortable part " * * was the period when the tide changed, for then the boat rode the buoy and we had all the excitement of a rough voyage."

It is believed that this study of velocities of the tidal currents through Golden Gate represents the first use of a current meter in Golden 
Gate, earlier observations of velocity having been made by floats. The results obtained were of great interest to both the Lighthouse Service and the Army Engineer office at San Francisco. Gilbert had considerable conferences and correspondence with these branches with respect to the results. He definitely established by these measurements the time lag between the change in direction of the tides and the change in direction of the velocities in and out of Golden Gate, which had a practical application in navigation at that port.

\section{Summary of District Operations}

\section{New England District}

At the beginning of the period, New England was still combined with New York and Covert had his headquarters as district engineer in Albany, N.Y. Whereas this combination was unsatisfactory, it had been necessary because of the meager funds available. In spring 1915 when cooperation with Maine was resumed, an independent district in New England was again created and C.H. Pierce became district engineer with headquarters in Boston, Mass.

The Boston office opened May 1, 1915, and C.H. Pierce's first task was to obtain office space in the Federal building. Finding all space allotted in that building, he turned for assistance to the Governor, who was the cooperating State official. The assistant Secretary of the Treasury at that time was a Bostonian, and the governor appealed to him for space. This appeal could not be ignored and office space on the 25th floor of the Federal building was finally allotted to the USGS (C.H. Pierce, oral commun., ca. 1938). When the office opened, W.A. Elwood was C.H. Pierce's only assistant; Elwood was office engineer-clerk-stenographer. Within a few weeks Hardin Thweatt was appointed junior engineer. Twenty-four stations were then being maintained in the New England District.

Cooperation with New Hampshire, effective in July 1917, resulted not only in the establishment of nine additional stations in that State, but also a field reconnaissance to find the places and capacities of possible sites for storage reservoirs and opportunities for increasing the power capacities of existing power plants. In this examination, C.H. Pierce, who did most of the work himself, used the maps from previous private surveys, and conducted practically no new surveys himself.

There was then much interest in water power in New England and particular attention was paid to winter records. Minimum temperatures in northern New England were sometimes as low as 50 degrees below zero, which made operation of recorders extremely difficult even though kettle lamps were kept burning in the wells and oil cylinders were installed for the floats. During one period of extremely cold weather, an inch or two of ice was found in the oil cylinder under a 10-inch layer of oil. A sidelight on these conditions was given by an observer in northern Vermont, who reported in the January 23,1918 , Newsletter that "it was $49^{\circ}$ below zero yesterday morning and $52^{\circ}$ below this morning. Don't look for any records until about July first unless the weather changes."

A streamflow "barometer" was devised to help predict river stage and in planning field work to obtain measurements at stations where they were most needed. This "barometer" consisted of a diagram on which was plotted, for one of the large rivers considered typical of New England, the daily stages as they were received from the observer 24 hours later. Having a knowledge of the rainfall during the previous 24 hours and the weather forecast for the coming 24 hours, trends of stage were predicted (Newsletter, July 22, 1918). In an effort to stimulate interest among engineers in Massachusetts, C.H. Pierce compiled Massachusetts streamflow records from all sources, and Dean was detailed from the Washington, D.C., office to help him with it (WSP 415, 1916). During the following year, C.H. Pierce compiled a similar report for Vermont (WSP 424, 1917). At the end of the period, 39 stations were being maintained, of which 20 were equipped with recorders. Private interests, chiefly power companies, furnished records for nine additional stations.

While C.H. Pierce was in military training camp from February 15 to July 16, 1918, Hartwell transferred from the New York District as 
acting district engineer. Other engineers in the district were Hardin Thweatt, June 17, 1915, to September 4, 1917; H.W. Fear, July 17 to September 27, 1916, and November 6, 1917, to January 31, 1919; Stackpole, June 15, 1917, to June 30, 1919; J. Wendell Moulton, August 16 to September 4, 1918, and February 3 to March 9, 1919; and Arnold N. Weeks, April 22 to July 31,1918 . Also, R.H. Suttie, September 30, 1918, to August 21, 1919; B.L. Bigwood, April 1 to June 30, 1919; R.S. Barnes (per diem), May 1-8, 1915, December 16, 1915, and May 4, 1916; and G.F. Adams, July 1 to September 27, 1915.

The annual Survey allotments to the New England District were:

$\begin{array}{rrrr}1914 & \$ 3,150 & 1917 & \$ 4,500 \\ 1915 & 3,150 & 1918 & 5,500 \\ 1916 & 4,500 & 1919 & 5,500\end{array}$

The amounts shown for fiscal years 1914-15 were the New York District allotment. New York became a separate district on May 1, 1915, and the increase in funds for fiscal year 1916 and subsequent years was due to the establishment of the separate New England District and to additional State cooperation.

\section{Maine District}

When cooperation was resumed in 1915 , stream gaging continued to be conducted by Public Utilities Commission employees under the supervision of the USGS whose engineers made field inspection trips and checked the computations of the records. G.C. Danforth, assistant engineer of the Public Utilities Commission, was in actual charge of the work until 1918 when he was succeeded by A.F. McAlary. An average of 15 stations was maintained, of which three were equipped with recorders. In addition, other individuals furnished records for stations that were maintained chiefly at dams. The number of these records increased from 9 to 16 .

\section{New York District}

Until May 1, 1915, New England was combined with New York and Covert operated stations in these States. Sixty-three stations were being maintained, of which 45 were in New York. During the first 2 years, the New England stations increased from 18 to 24 , and the New York stations decreased from 45 to 43 . Available funds were not sufficient to permit the wide use of recorders, but, where regulated flow required their use, recorders were installed at base stations. In order to be assured that recorders were installed where there was real need for them, Covert would install a small recorder in a portable shelter for a few days. Recorders increased from 7 to 17 during the period. Most recorder wells were from 15 to 20 feet deep and it was difficult to read hook gages. As a remedy, a small lightbulb was connected by 25 to 30 feet of insulated wire to two dry-cell batteries (Newsletter, Aug. 17, 1914).

To obtain records of flow at two canal stations with fluctuating slope, two recorders were installed at each station, 1.81 miles apart on one and 2.53 miles apart on the other. Covert was New York District engineer during the entire period. Hartwell was office engineer except from February 15 to July 16, 1918, when he was acting district engineer in the New England District. Other engineers in the district were C.H. Pierce, June 3, 1913, to May 7, 1915; C.S. DeGolyer, June 3, 1913, to March 1915; and E.D. Burchard, September 1914 to May 1919. Also Aldace H. Davison, October 4, 1915, to May 7, 1917, and August 1, 1919, to June 26, 1920; R.M. Adams, September 1914 to April 16,1915 ; Moulton, July 16,1917 , to August 15 , 1918; and Carson, April 4, 1918, to June 30, 1919. Lyon, a per-diem appointee, was hired to prepare standard plans for gaging station equipment, which he completed in 1915.

At the end of the period, 51 stations were being maintained, of which 17 were equipped with recorders. Records for five stations, principally at dams, were furnished by other individuals.

\section{Middle Atlantic States District}

The seven base stations in New Jersey, Maryland, and Virginia, which constituted the Middle Atlantic States District, were under the direct supervision of G.C. Stevens who, in 
addition to being chief of the computing section, was district engineer of the Middle Atlantic States. With the merging of the Ohio River District and the Middle Atlantic States District in August 1918, the district's area was enlarged to include West Virginia, Kentucky, and Ohio. The number of stations was increased to 33, of which 31 were equipped with chain gages and two with recorders. Personnel from the computing section were used as needed. Because the Middle Atlantic States District was operated by Washington, D.C., office force, the only allotment for the district was about $\$ 600$ annually for field expenses.

\section{South Atlantic States District}

The South Atlantic States District, with headquarters in Atlanta, Ga., and long on size but short on funds, was temporarily enlarged by the addition of the State of Texas from fall 1914 until September 1915 when the Texas District was created. To operate the 40 stations in the district (including a few established in Texas), district engineer W.E. Hall had from one to three part-time field assistants. So much of his time was spent in the field that it was a relief to him when the Texas District was created. As W.E. Hall quipped in the August 19, 1915, Newsletter, "Now that we have managed to swap Texas onto Mr. Gray we can begin to catch a long breath. While that small State belonged to the district, our territory was 2,000 miles long and 400 miles wide. It is still 400 miles wide." Although all South Atlantic and eastern Gulf States were considered to be in the South Atlantic States District, the average number of 34 stations were located in Georgia, Alabama, North Carolina, and Tennessee, with one lone station in South Carolina.

Water-power development was then particularly active in Georgia and although State officials did not cooperate during this period until 1919 , considerable assistance, chiefly in the form of services, was received from power companies. One such company conducted an intensive stream-gaging program, which involved the installation of the first artificial control and the first cable in the district. At Tallulah River at Tallulah Falls, a foot bridge was built over the crest of the dam at the falls in order that the flow over the roller gate could be measured (Warren E. Hall, oral commun., ca. 1938).

The growth of interest in water-power development during and after World War I resulted in an increase in the number of stations. The increase in water-power development therefore increased the workload on the small district office staff through requests for records. The most important site was on the Tennessee River at Muscle Shoals, the gaging station being at Florence, Ala., and in connection with this development, the district staff furnished discharge records daily to the Army engineers (Newsletter, April 19, 1918). In addition to the stations maintained by the USGS, records were furnished by cooperators for some half-dozen stations, the number fluctuating slightly during the period. Nine stations were equipped with recorders and the others with staff or chain gages.

In 1913, cooperation began with the Florida Everglades Engineering Commission (Isham Randolph; Leighton, who had resigned on June 3,1913 , to enter private practice; and E.T. Perkins). The Engineering Commission had a 6-month contract with the commissioners of the Everglades Drainage District to determine the adequacy of the Everglades Drainage District plans for draining the Everglades. The cooperative work consisted of establishing gaging stations on canals leading from Lake Okeechobee to the Atlantic Ocean, and W.E. Hall acted as consultant in selecting sites for the stations. The stations were maintained by the Engineering Commission, which employed B.M. Hall, Jr., and Dean for that purpose. Many discharge measurements were made, but the controls were extremely poor because of the flat slopes and the sudden and extreme fluctuations in flow as a result of winds on the lake. At the expiration of the Engineering Commission's contract, Leighton tried to promote cooperation with the State for the purpose of continuing the Everglades stations, but he was unsuccessful because the State agencies could not finance the program. B.M. Hall tried to maintain one slope station afterwards, but it was located 60 miles from the railroad and the expense was too great. The results of the 
discharge measurements made from May to September 1913 were published in WSP 352 (1915) and records of daily discharge were published in Senate Document 379, 63rd Congress, 2d Session.

W.E. Hall was district engineer until September 30, 1917, when he entered the Army. The district functioned without a district engineer until January 1, 1918, when Paulsen succeeded him. As Paulsen wrote (ca. 1938), "The Atlanta assignment came to me as somewhat of a surprise because from September to December 1917, I was in the Army at Camp Lewis, Washington, and I was on the point of leaving for France with a newly acquired commission when War Department orders, at the request of the Secretary of the Interior, were received relieving me from further active Army service for Survey duty." A sidelight on his duties appeared in the January 23, 1918, Newsletter:

C.G. Paulsen spent a few days in Washington en route to Atlanta. He is going to attempt to be acting district engineer, office man, field man, charwoman, mechanician, and fill all the other positions that Warren $\mathrm{E}$. Hall held down in that district.

Paulsen was acting district engineer until March 19, 1918, when he was appointed district engineer with the understanding that W.E. Hall would resume his former position on his return from military service. Paulsen remained as district engineer until June 20,1919, when he transferred to the Idaho District and W.E. Hall resumed his old position.

The Survey allotments were practically the only source for payment of salaries and office and field expenses. These allotments were:

$\begin{array}{rrrr}1914 & \$ 4,150 & 1917 & \$ 4,500 \\ 1915 & 5,500 & 1918 & 4,500 \\ 1916 & 4,500 & 1919 & 5,000\end{array}$

The 1915 increase was a result of the addition of Texas to the district.

Paulsen's only full-time assistant in the district was A.H. Condron who was there during 1919. Cooperation with Tennessee and North Carolina in that year made the employment of Condron possible.

\section{Ohio River District}

By the beginning of this period, the idea of preparing a report showing the possibility of using storage to prevent floods on the Ohio River had been abandoned, leaving as the purpose of the proposed report an intensive study of the water resources of the New-Kanawha River basin. Six years had passed since field work had begun, and the time was approaching when the report should be pushed to completion. To help with the preparation of the report, the Ohio District Office was moved to Washington, D.C., on August 3, 1913, (A.H. Horton, oral commun., ca. 1938); the field work was continued from there. At that time, 29 stations were being maintained, a few of which were outside the New-Kanawha River basin. Most of these stations were discontinued after 1916, because the 8 years of records then available were sufficient for the report, and the funds were needed for other parts of the district.

The flood of 1913 created additional interest in flood prevention. The Rivers and Harbors Bill, signed March 4, 1915, contained a proviso directing the Army engineers to make examinations and surveys in the Ohio River basin and devise plans for flood protection (Rept., chief of eng., 1915, pt. 1, p. 2,956). Shortly thereafter, the Army engineers began their investigations, established some 30 gaging stations in the Ohio River basin, and furnished the base data to the USGS. They also cooperated with the USGS in maintaining five additional stations outside the basin. Cooperation with Kentucky, which was arranged at this time, resulted in the establishment of a few stations in the Kentucky portion of the district, and emphasis shifted from the New-Kanawha River basin to other basins during the remainder of the Ohio River District's existence-in August 1918, the Ohio River District was combined with the Middle Atlantic States District for economic reasons, and the 24 Ohio stations were then maintained by the Middle Atlantic States District.

ILLINOIS.-With the resumption of cooperation with the State of Illinois, a suboffice opened in Chicago. William Kessler was appointed junior engineer on August 1, 1914, and assigned to 
that office. In March 1916, Kessler transferred to the Texas District. Long-distance supervision from Washington, D.C., proved unsatisfactory, so Illinois work was transferred to the Upper Mississippi River District. Peterson was detailed to Illinois from July 8 to December 5 , 1914, except for October 1 through November 14,1914 , when he was on temporary detail to the Upper Mississippi River District. During the Washington-operated period, personnel were chiefly from the computing section. The USGS allotments to the Illinois work were:

$\begin{array}{rrrr}1914 & \$ 6,000 & 1917 & \$ 8,000 \\ 1915 & 6,000 & 1918 & 8,000 \\ 1916 & 6,000 & & \end{array}$

\section{UPPER MISSISSIPPI RIVER DISTRICT}

Although the nominal boundary of the Upper Mississippi River District remained stable during this period (Illinois was added later in the period), a new district was virtually created by the transfer of the headquarters from St. Paul, Minn., to Madison, Wisc., the gradual elimination of all but four base stations in Minnesota, and the establishment of 48 stations in Wisconsin in 1914. The operation of the Wisconsin stations became the major activity of the district during the period. A suboffice was maintained in St. Paul under the direction of Soule until it closed on July 7, 1917.

When the district office moved to Madison on December 1, 1913, the USGS was already maintaining two stations in Wisconsin for the Indian Service. Power and logging companies and the Army engineers were collecting records at 13 stations on the principal streams. Two of these records were obtained at power plants and another at a dam built by the Army engineers, by computing the flow through the plants using a weir formula. Most of the other records consisted of gage heights only, the longest period of record being that of station Chippewa River at Chippewa Falls that extended back to June 1888. The next longest period of record was station Fox River at Rapide Croche Dam kept by the Army engineers since 1896. The USGS proceeded to make discharge measurements and rate the remaining 10 stations. Thirty-six additional stations were established during the first year. The State's need for records in connection with its water-power investigations was so urgent that the Railroad Commission wanted the new stations estabished as rapidly as possible. Thus a unique situation confronted W.G. Hoyt in establishing stations on streams that he had never seen before and were severely affected by ice. With a map showing the locations of the new stations, he started to work and installed 29 stations during that winter. W.G. Hoyt wrote in the March 19, 1914, Newsletter that "it was found necessary and in most cases desirable to install chain gages. It is believed that on streams affected by ice conditions, the chain gage is absolutely the most satisfactory gage." A few additional stations were established and a few discontinued in succeeding years with the result that 49 stations were being maintained at the end of the period, of which three were equipped with recorders. Winter records were a vital part of the Wisconsin program and monthly measurements were made during the winter.

The close contact that the USGS maintained with the Railroad Commission (desk space was allotted in the Commission offices) led to duties aside from the regular stream-gaging program. W.G. Hoyt wrote (ca. 1938) that "these additional duties included studies and reports on the power capacity of various developed and undeveloped power sites in the State, the preparation of duration curves, the determination of probable output at the various undeveloped sites in terms of firm power and secondary power, the preparation of reports on backwater conditions resulting from the raising of the crest heights of dams, amd similar studies needed by the Commissioner in connection with the administration of the Water Power Act."

The Iowa work was handled from Madison but, in April 1919, a subdistrict was created with headquarters in Ames, Iowa. An average number of six stations was maintained during that period. Bolster was given a per-diem appointment and operated the stations from an office in Keokuk, Iowa. The few stations operated in the eastern part of North Dakota by E.F. Chandler were reduced to two on the Red River in 1917.

W.G. Hoyt was district engineer during the entire period and had in addition to USGS 
engineers, a number of Wisconsin State employees. The district personnel were W.G. Hoyt, June 3, 1913, to June 30, 1919; E.F. Chandler, June 3, 1913, to June 30, 1919; G.H. Canfield, December 1, 1913, to March 1915; and Soule, June 3, 1913, to July 7, 1917, and July 1, 1918, to June 30, 1919. Also Peterson, June 23 to October 20,1913, and October 1 to November 14, 1914; Eugene L. Williams, November 1915 to May 31, 1917; H.C. Beckman, December 8, 1914, to June 30, 1919; and R.B. Kilgore, September 1916 to May 1918.

\section{UPPer Missouri River District}

The area of the Upper Missouri River District was the same as it was at the close of the previous period and included Montana and the western part of North Dakota. The eight North Dakota stations were continued under the immediate supervision of E.F. Chandler who operated also four stations in South Dakota for the Indian Service until 1918.

More than half the stations in Montana were operated for and at the expense of the Reclamation Service, and many of the remaining stations were operated in connection with Carey Act projects. With little change in the annual amount of either State or Federal funds, there was correspondingly little change in the regular stream-gaging program.

An important feature of the Upper Missouri River District activities was the joint operation [with Canada] of the international gaging stations for the Reclamation Service and, beginning in 1918, the regulation of the waters of those streams. Jones was in charge of this work.

A station installation worthy of note is that on Swift Current Creek at McDermott Lake in Glacier National Park in Montana. This station was originally established in 1912 and equipped with a timber shelter for the recorder. In 1918, the construction by the Bureau of Public Roads of a highway to Many Glaciers Hotel required the relocation of the station. The National Park Service wanted the new recorder shelter to harmonize with its rustic surroundings and, because the old shelter had been destroyed by the construction of the highway, the National Park Service wanted the Bureau of Public Roads to construct the new shelter. With the help of the Bureau of Public Roads, a shelter was designed somewhat similar to the type used in Yosemite Valley in California (Lamb, written commun., ca. 1938). The Stevens recorder was placed in a glass case on a pedestal in the side of which was a plate glass window through which the operation of the float could be observed by the tourists. The pedestal was in the center of a covered timber well with space around the recorder for visitors. Posts extending above the floor supported the roof (Newsletter, Aug. 23, 1918). The cost of the installation, about $\$ 2,500$ (Lamb, written commun., ca. 1938), however, was paid by the National Park Service and Great Northern Railway.

In this district, a flexible cable similar to that used for current-meter suspensions was used instead of the copper chain of the standard chain-gage equipment. This cable does not stretch and has been in use for the past 25 years (Lamb, written commun., ca. 1938).

At the end of the period, 85 stations were being maintained of which 11 were in cooperation with the Canadian government and 7 with the Indian Service. Nineteen stations were equipped with recorders, including 11 international stations. Lamb continued in charge of the district, with E.F. Chandler on a per-diem basis in immediate charge of the stations in North and South Dakota. Tuttle transferred to the district January 3, 1916, and served as office engineer. Other engineers in the Upper Missouri River District included Jones, June 3, 1913, to February 1916, and during 1918 to June 30, 1919; Randell, June 3 to August 22, 1913; J.B. Stewart, June 3 to August 31, 1913; M.D. Anderson, February to May 8, 1917; and State hydrographer C.S. Heidel, June 3, 1913, to June 30, 1919.

\section{Kansas District}

Cooperation with the newly-appointed Water Commission of Kansas was effective May 11, 1917. Rice, who had previously been in the Hawaii District, was appointed district engineer and established an office in Topeka on June 1 . With the small amount of funds available, Kansas started as a one-man district. That year (1917) six stations were established, two 
of which were operated by the Weather Bureau. The next year, four more stations were established and two more during the last year of the period, making a total of 12 stations in the Kansas District. Of these stations, three were equipped with water-stage recorders. One was a long-distance recorder that led from the Kansas River to the office of the Weather Bureau in Topeka, a distance of 3,200 feet. The other stations were equipped with chain or staff gages. Near the end of the period, the district personnel increased 100 percent: Eugene L. Grant transferred to it.

\section{TeXas District}

In accordance with the arrangements for cooperation in Texas, the district office opened in Austin on September 1, 1915, the beginning of the State fiscal year, with district engineer Gray, junior engineer R.C. Pierce, and three State hydrographers. At that time, 18 gaging stations were being maintained. Four had been established by W.E. Hall the previous fall; Board of Water Engineers hydrographers had established 14 in June and July 1915. Four of these were equipped with recorders.

With an area of 266,000 square miles in the district drained by very flashy streams, the amount of work that could be done could only be determined by trial and error. Concerning this, Gray wrote in the December 18, 1915, Newsletter (p. 11) that "thirty-two stations have been selected as the final number which can be maintained with the available funds. The importance of streamflow data in Texas will warrant the installation of several hundred stations ***. Several cable and automatic gage installations are being made, and an effort will be made to equip all stations with the standard plans and specifications." New stations were gradually installed and, by the end of the period, 41 were being maintained, 12 equipped with recorders.

The disturbing situation along the Rio Grande border caused by successive revolutions in Mexico caused the International Boundary Commission to discontinue its work of measuring the Rio Grande in 1915. As Gray stated
(Newsletter, Nov. 27, 1915, p. 13):

Work along the Rio Grande, especially in the vicinity of Brownsville, [Tex.] has been abandoned and will not be resumed until the Carranza regime gains control of the Mexican side. Mexican bandits are operating along the border for the express purpose of killing "Americanos" and it is feared that a hydrographer suspended from a cable might stop some of the bullets.

One of the principal duties of the Board of Water Engineers was the adjudication of the water rights of Texas streams and considerable preparatory work, other than routine stream gaging, became the responsibility of the district staff beginning in 1918. The first special work was three seepage investigations of the Colorado River and its tributaries: one in spring, the second in mid-summer, and the third in fall. They were conducted by H.B. Kinnison and C.E. McCashin. Each investigation covered about 1,200 miles of river and involved measuring tributaries, diversions, and main streams at such intervals that the seepage losses and gains could be determined (Newsletter, April 19, 1918, p. 8). Gray's experience in conducting similar investigations in New Mexico doubtless led him to suggest such investigations to the State officials. Investigations were later extended to include the North Conchos and Pecos Rivers.

An investigation of rice culture along the lower Colorado River was started in spring 1919 as the first step in the adjudication of the water rights. This investigation involved not only records of river and canal discharge and capacities of eight pumping plants, but also records of evaporation and a study of the transmission and use of water in the irrigated rice fields (Ellsworth, written commun., ca. 1938). Kinnison and McCashin were detailed to this work, which began in April 1919 and lasted until September 1919, the end of the rice irrigation season. During this time, the investigation was hampered by abnormally high rainfall. The excessive rainfall covered the roads and there was so much water in the rice fields that the levees were cut to drain off the excess. McCashin wrote (ca. 1938) that "driving a Model T Ford in low gear day after day over roads that 
were inundated, wore out two differentials and three sets of tires in 4,000 miles."

In measuring the water discharged by the 48-, 60-, and 72-inch pipes used in some of the pumping plants, "Tulane" pilot tubes were constructed with arms extending across the entire diameter of the pipes. One of the first capacity tests of a pump having a 72 -inch discharge pipe required a record of the revolutions of the engine. Because time was an important element in the investigation, ways and means had to be improvised until a mechanical counter could be obtained, which McCashin (written commun., ca. 1938) describes as follows:

I removed the balance wheel from a cheap alarm clock and soldered an extension on the escapement lever. Then I used the coils and bell clapper-arm of an electric door bell and fastened the bell clapper to the extended escapement lever after removing the vibrator spring from the door bell. I then put the bell in a circuit with a battery and let the engine drive rod complete the current at each revolution. Each contact actuated the bell clapper once, which moved the escapement arm over. This escapement moved twice for each second of time in a clock. The pumpman would read the time by hands on the clock twice a day. Twice the time interval in seconds between his readings of the time on the clock gave the number of revolutions of the engine.

Gray continued to be in charge of the district until his untimely and greatly mourned death on October 14, 1918, in the first "flu" epidemic. He was succeeded on November 28 by Ellsworth. During the entire period, the field force consisted of both USGS employees and State hydrographers. Personnel included R.C. Pierce, September 1915 to February 1916; William Kessler, March 1, 1916, to January 1917; R.J. Hank, September 1915 to June 30, 1919; Edgar O. Francisco, June 4 to August 31, 1917; E.P. Congdon, July 6, 1917, to May 31, 1919; McCashin, February 16, 1918, to June 30,1919 ; and Kinnison, July 26,1918 , to June 30,1919 . Of these, Hank was employed as State hydrographer until given a USGS appointment on June 2, 1917, and McCashin was State hydrographer until his USGS appointment on September 12, 1918.

\section{Rocky Mountain District}

At the beginning of the period, the Rocky Mountain District was comprised of the States of Colorado, Wyoming, and Nebraska, and three Reclamation Service stations in Oklahoma. The State work in Nebraska was discontinued at the end of 1914. In April 1915, New Mexico became a part of the district. A small number of stations in the Chama River basin in New Mexico, where an extensive irrigation project was under investigation, were maintained until fall 1917 . In July 1914 , two gaging stations were established in western South Dakota; one was discontinued in 1915, but the other continued to be maintained throughout the period.

In 1913, of the 61 stations in Colorado, 52 were maintained on mountain streams in cooperation with the Forest Service whose employees furnished the gage-height records, many of which were fragmentary. The number of stations was gradually reduced until in 1919, only 15 Forest Service stations were maintained out of a total of 43 stations. Most of these stations were equipped with staff or chain gages, and recorders were installed at four stations. The State engineer maintained an extensive independent stream-gaging program in all parts of the State except the Colorado River basin. The USGS activities were chiefly confined to the Colorado River basin, and the State engineer cooperated in the maintenance of an average of 14 stations. State records on the principal streams were no longer published after 1914.

With no cooperation in Wyoming in 1913, the only work was the establishment and maintenance of a few stations for the Reclamation Service in connection with the inflow to Pathfinder Reservoir. Cooperation with the State engineer resumed in April 1915 and 50 stations were established or reestablished during that year. A few stations were established in 1916, making the total number 62 the high point for the period. The number gradually declined to 50 by 1919 . Nearly all of the stations were equipped with chain or staff gages; recorders were installed on 10. The Reclamation Service furnished records for an average of six stations during the period. 
The annual USGS allotments to the district were:

$\begin{array}{rrrr}1914 & \$ 6,500 & 1917 & \$ 7,500 \\ 1915 & 6,500 & 1918 & 7,500 \\ 1916 & 8,500 & 1919 & 7,000\end{array}$

The increased allotments beginning in 1916 were due to the resumption of State cooperation with Wyoming and the addition of New Mexico to the district.

The author was in charge of the district during the period and other members of the district were Raymond Richards, June 3 to July 15 , 1913; Fletcher, June 3, 1913, to July 9, 1916; W.R. King, June 1, 1915, to September 15, 1916; P.V. Hodges, August 1, 1916, to June 30, 1919; H.K. Smith, May 1, 1916, to June 30, 1917; Fear, October 11, 1916, to November 1, 1917; Soule, July 10, 1917, to June 30,1918 ; and Spiegel, July 16, 1918, to June 30, 1919.

\section{New Mexico District}

New Mexico, which had formerly been a subdistrict under the Denver office, joined with Arizona to make a full district on July 1, 1913. The district office was in Santa Fe. Gray was district engineer and W.R. King transferred from Salt Lake City as office engineer. Emerson and Frank O'Brien, junior engineers, and four State hydrographers were the field force in New Mexico. The State engineer discontinued cooperation on January 1, 1915, and Gray wrote in the February 18, 1915, Newsletter (p. 11) that "the State hydrographers who have worked under the direction of the Survey have continued as State hydrographers under the direction of the assistant State engineer. Property has been divided, but the gaging stations are still undivided."

With the discontinuance of State cooperation, only the small USGS allotment was available for the remainder of the fiscal year, and the USGS thus reduced its field work to the maintenance of 15 stations. Emerson transferred to the California District in February 1915. The district office closed in April 1915, and Gray transferred to the Land Classification Board in Washington, D.C. New Mexico was again made a part of the Denver District, and
W.R. King transferred to Denver. The stations were reduced to seven, most of which were in the Rio Chama basin, and George S. Cowdery, Jr., a local engineer, was given a per-diem appointment to operate them. When Cowdery entered the Army in September 1917, all USGS stations in New Mexico were discontinued.

The New Mexico District was progressive during its short life. Of the 62 stations in operation when cooperation ceased, half were equipped with recorders, chiefly Stevens, and a third with cables. Three concrete artificial controls had been installed. At the Embudo station on the Rio Grande, there was a 16-foot concrete well covered by a cobblestone shelter. The shelter was built largely as a hobby by the artistic gage observer. Special investigations to determine seepage gains and losses were conducted on the Rio Grande and its tributaries during fall 1913.

Six stations were operated also in the San Juan River basin in Colorado (just over the New Mexico State line) as a matter of convenience and economy. These stations had been built in the previous period by Denver District personnel in cooperation with the State engineer.

\section{IDAHo District}

The Idaho District included the State of Idaho and the Snake River basin in western Wyoming. The stations in northern Idaho were operated for the Idaho District by employees of the Washington District. Baldwin was district engineer until the Idaho Falls office opened on May 22, 1919, and continued supervision of the entire State until Paulsen took charge of the Idaho District on June 25, 1919.

State cooperation ended at the close of 1914 . At that time, it was hoped that cooperation would be resumed in 1917, and the number of stations was reduced during 1915 and 1916 only to an average of 67 from the 100 maintained at the beginning of the period. As Baldwin wrote (10th bienn. rept., State eng., 1913-14, p. 182):

On October 1, 1914, practically all field work at State cooperative stations was discontinued and about 25 local observers were notified that payment for 
services rendered after that date could be made only if additional State funds were provided.

The curtailment of funds necessitated a reduction in personnel, and Paulsen transferred to the Washington District in October 1914. The following April, Purton transferred to the Great Basin District and L.W. Roush was furloughed for 1 year, leaving Harrington as Baldwin's field personnel. In 1916, Harrington was made a special deputy State engineer and was assigned to a special investigation in the upper Boise River basin to determine the capacity of the recently constructed Arrowrock Reservoir using records of inflow and outflow and stages in the reservoir. The work lasted from April 1 to October 31. Harrington had a motorboat for transportation on the reservoir and a hand-power speeder on the Boise and Arrowrock Railroad. Beyond the limits of the reservoir and railroad, his transportation was by saddle horse and walking to the $\mathbf{1 0}$ gaging stations (Newsletter, May 22, 1916, p. 14).

A special investigation was conducted in 1914 in the Salmon Falls Creek basin above Salmon Reservoir, chiefly in Nevada, where the effect of the flow of the Salmon Falls Creek on the irrigation of considerable areas was in dispute. Accordingly, an agreement was signed between the State engineer, the Twin Falls Salmon River Land and Water Company, and the Utah Construction Company. USGS personnel, in cooperation with the State engineer, were to collect records of flow from May to September at 21 gaging stations on streams and canals. Land actually irrigated and land that was proposed for irrigation were to be surveyed. The cost of this investigation, about $\$ 1,500$, was divided equally between the State and each of the private companies. The agreement contained the following statement: "All data secured will be tabulated and prepared in the form of a report ${ }^{* * *}$. Since this report will be prepared by a representative of the U.S. Geological Survey, who can not well take the position of drawing conclusions, only actual facts will be given." Harrington spent his entire time on this work during that season.

Cooperation with Yellowstone National Park officials was started in 1913 in order to obtain runoff records from the important streams rising in the park at points above what Baldwin termed "man-made disturbances of flow." Sites for the stations were selected along tourist routes where they could later be developed into objects of interest and hence have publicity value (Baldwin, written commun., ca. 1938). Four stations were first established and soldiers were detailed to read the staff gages daily because the Army was then in charge of the park. Transportation and subsistence were also furnished. In 1916, J.C. Hoyt arranged with officials of the recently created National Park Service to improve the existing stations, particularly on the Yellowstone River above the upper falls, one of the places most visited by tourists. Paulsen was borrowed from the Washington District and, in October, he installed a recorder in a shelter patterned after the stations in Yosemite National Park, which gave full view of the recorder. In October 1918, a similar structure was completed on the Madison River near West Yellowstone.

With the completion of the Arrowrock Reservoir, accurate streamflow records were needed and, in 1915, the Reclamation Service authorized monies for the installation and maintenance of four recorder stations. The enlargement of Jackson Lake Reservoir was completed in fall 1916 when the Reclamation Service authorized the installation of recorders and cables at two stations, one just below the reservoir and the other on the Snake River just below the Wyoming-Idaho State line.

The new dam at Jackson Lake was built by the Reclamation Service and paid for by the Twin Falls North Side Land and Water Company and the Twin Falls Canal Company, which two companies thereby acquired stored water needed to supplement their normal flow rights. The Reclamation Service owned the original storage capacity of 380,000 acre-feet. It was expected that 100,000 acre-feet would be sold to Snake River users. With this diverse ownership and interest in the stored water, it was necessary to know, with a high degree of accuracy, the water losses for a distance ranging from 140 to 300 miles down the Snake River. In fall 1916, the USGS and Reclamation Service investigated jointly the feasibility and cost of conducting a detailed study lasting at 
least 1 year to determine the losses incurred in transporting stored water down the Snake River. A report of this investigation was sent to the State engineer who was responsible for the distribution of the water.

Before action was taken on this report, hopes of renewed State cooperation were again blasted: the Governor vetoed the legislature's appropriation for the second time. All stations, except 40 that were maintained at the expense of Federal bureaus, were then discontinued (Newsletter, Aug. 24, 1917, p. 11).

In June 1917 , the water users of the upper Snake River, chiefly the Reclamation Service, agreed to finance the water-loss investigation in the Snake River. Baldwin, with T.R. Newell and Anderson as assistants, started the work in July by establishing 52 gaging stations at the mouths of tributary streams between Jackson Lake and Heise, Wyo., and continued until September 30 . The country was so rough and there were so few roads that transportation was by saddle horse. The continuation of the work during the irrigation season of 1918 was later authorized and was conducted from May 1 to September 30 of that year by T.R. Newell, E.C. Howard, and C.W. Keif. At the end of the investigation, the relative 62 stations were discontinued.

As a result of the 2-years water-loss investigation, special cooperation between the Reclamation Service, the Snake River water users, and the USGS was arranged in May 1919. In accordance with the terms of the agreement, a USGS office opened in Idaho Falls, Idaho, on May 22 with Baldwin in charge. He took with him to the new office several engineers from the Boise office and responsibility for the maintenance of 25 stations either in the vicinity of Idaho Falls or of importance in the distribution of Snake River water. Because the operations of the Idaho Falls office fall properly in succeeding periods of this History, they will not be described here.

Those left in the Boise office at the end of the period were A.G. Hewel, Albert G. Fiedler, and Ms. E. Hazel Haugse, who was the engineerclerk. So proficient was Ms. Haugse in the technical office work that Dean, who was detailed to the district from August 1 to December 31, 1917, to compile the reports for 1915 and 1916 wrote in the August 24, 1917, Newsletter (p. 11) that "Miss Haugse should be officially recognized with promotion to junior engineer on duty as office engineer." Many changes in engineering personnel occurred during the period as shown by the following list: Purton, June 3, 1913, to March 31, 1915; R.C. Pierce, June 3, 1913, to January 10, 1914; L.W. Jordan, July 2, 1913, to February 6, 1914; Paulsen, September 10, 1913, to October 2, 1914, and September 18 to November 25, 1916; Roush, January 14, 1914, to April 1, 1915, and April 1 to October 18, 1916; Harrington, February 16,1914 , to January 15,1917 ; and William Kessler, February 1, 1917, to November 1918. Also T.R. Newell, January 29, 1917, to March 12,1917 , June 9,1917 , to November 1917 , and May 6, 1918, until transfer to Idaho Falls; Anderson, July 12 to September 30, 1917; Howard, June 2, 1918, until transfer to Idaho Falls; Kilgore, May 22 to July 29, 1918; Hewel, April 1 to June 30, 1919; and Fiedler, April 1 to June 30, 1919.

\section{Great Basin District}

In 1913, cooperation was resumed with Nevada and that State was again added to the Great Basin District. E.A. Porter was district engineer until his resignation on February 21, 1916. Jacob succeeded him on March 18, 1916, and remained in charge until he in turn resigned on March 31, 1918. Purton was district engineer during the remainder of the period.

The Sevier River investigations nearly doubled the amount of work in the district beginning in 1914 . During that year, 40 recorders were installed at new and existing stations in accordance with the standard designs then coming into use (Ninth bienn. rept., State eng. 1913-14, p. 69). A total of 67 stations, 24 on streams and 43 on canals, were operated during the investigation that continued until spring 1919. Most of the gaging stations, however, were continued until the end of water year 1919 (Sept. 30, 1919). Two engineers were detailed to the work, Davenport who transferred to the district in March 1914 and J.J. Sanford. In November 1914, Davenport transferred to the Washington, D.C., office and was succeeded the next season by Dort who remained 
during 1915 and 1916. After Porter resigned, he was the water commissioner on the Sevier River and, as a part of his duty, conducted the field work previously conducted by Dort. J.J. Sanford remained with the investigation until January 1919 , and was succeeded by G.H. Russell who had been in the district during 1912.

Beginning in 1913, the Utah Power and Light Company began an extensive water-power investigation and equipped 15 gaging stations with water-stage recorders. A former USGS field assistant was employed as hydrographer and the field data for these stations were furnished to the USGS during this period.

Foreshadowing the later intensive study of the Colorado River, the Reclamation Service in May 1914 authorized the installation of three recorders on the Green and Colorado Rivers and the installation of a station in October on the San Juan River near Bluff, Utah. This Utah station had perhaps the distinction of being the most isolated station in the country-it was $\mathbf{1 8 0}$ miles from the nearest practical railroad contact. Any hydrographer who was detailed to that station would devote a large part of his time to that station. That this was not a particularly desirable assignment is shown by Porter's statement (Newsletter, Mar. 15, 1915):

It will probably be up to one of these (new) men to visit the station on San Juan River near Bluff. At present none of the available men seems keen for the trip. The papers have been full of Indian troubles at and near Bluff and it appears that "old Polk" and his tribe of renegade Piutes will scalp the first hydrographer who appears.

R.C. Pierce drew this choice assignment, which consisted of making frequent discharge measurements, but found that, like many anticipated troubles in life, the "Indian troubles" did not materialize. He did, however, find "troubles" connected with measuring the river because the conditions were the worst ever experienced. The velocity was so rapid at medium and high stages that it was impossible to obtain accurate soundings and velocity determinations with 30 or 40 pounds of lead attached to a bare wire, so it was necessary to use a heavier weight. With the 15-pound weight as a model, a mould was made in the Great
Basin District office and a 60-pound lead weight was cast. This weight was used on an improvised wooden reel 4 feet in diameter that was equipped with handles and placed on the cable car. Even with this equipment, it was impossible to obtain soundings at extreme high stages, and only surface velocities could be measured. Another source of trouble was that silt caused rapid wear of meter parts. So heavily silt-laden was the San Juan River near Bluff that in one sudden flood when the river rose 15 feet in half an hour, it looked like concrete being poured down a chute. A sample of the water taken at that time was three-fourths sand and silt (R.C. Pierce, oral commun., ca. 1938). These troubles were forerunners of similar ones to come later at stations on the lower Colorado River. R.C. Pierce transferred to Texas in September 1915 and having a part-time resident hydrographer at Bluff stopped. The station was discontinued in September 1917.

A minor investigation that was worthy of note was conducted at the State dam on the Logan River in Utah during several weeks in summer 1916. The State Agricultural College operated a power plant at the dam, and several irrigation canals diverted water from the river below it. A geologic fault was believed to cross the valley at the upper end of the reservoir that was formed by the dam, and the irrigators protested the storage of water above the suspected fault. Because the Agricultural College was a State institution, the State engineer asked the USGS to investigate and Jordan and Purton were detailed to do so. As the water in the reservoir declined during summer, more of the original channel was uncovered at the upper end of the reservoir and measurements were made at short stretches in the uncovered channel. No loss in the river channel was detected until the receding reservoir level exposed the fault zone across the river channel-measurements below the fault zone indicated a 10 percent loss. Thereafter, storage above the fault zone was permitted only in the nonirrigation season when the water loss was unimportant.

When Jacob resigned in 1918, he was appointed Federal water commissioner in the Uinta Basin where the Indian Service had constructed an irrigation system covering Indian lands. Additional streamflow records were 
needed, not only to show the possibility of additional irrigation, but also to enable Jacob to administer existing rights. The Indian Service allotted $\$ 2,200$ during 1918 , and $\$ 1,520$ during each of the next 2 years to make it possible for the USGS to obtain the needed records. The number of stations in Utah increased from 66 at the beginning of the period to 102 at the end, and the number of recorders increased from 9 to 70 .

When cooperation with Nevada resumed in spring 1913, 15 stations were established and two of the six stations that had been operated by the Office of Experiment Stations were taken over by the USGS. The next year, the four remaining stations were taken over. At the end of the period, 18 stations were being maintained. The number of stations equipped with recorders increased from four to seven. Cooperation by the Reclamation Service consisted of furnishing complete records for an average of five stations.

Numerous changes in Great Basin District personnel took place during this period, and included E.A. Porter, June 3, 1913, to March 1, 1916; Frank Weber, June 3 to December 1913; Lynn Crandall, June 3, 1913, to February 21, 1916; J.J. Sanford, June 3, 1913, to January 1919; Purton, April 1, 1915, to June 30, 1919; Anderson, February 3 to September 14, 1914; Jordan, February 1914 to summer 1919; and Davenport, March to November 1914. Also Dort, April 1915 to December 1, 1916; R.C. Pierce, June to September 1, 1915; Jacob, March 18, 1916, to March 31, 1918; William E. Dickinson, April 5 to August 21, 1916, July 25 to November 15, 1917, and June 16-30, 1919; J.W. Bones, March 20, 1918, to June 30, 1919; and G.H. Russell, season of 1919.

ARIZONA.-Except for a period of less than 3 years when it was an independent district, Arizona was attached either to the California or New Mexico District. At the beginning of the present period, Arizona was part of the California District but, on July 1, 1913, it was combined with the New Mexico District with headquarters at Santa Fe. This change was made chiefly because New Mexico stream gaging was more nearly comparable with Arizona than with California. Severance of cooperative relations with New Mexico on January 1, 1915, foreshadowed the early discontinuance of work in that State. Because existing Indian Service cooperation apparently gave assurance of sufficient funds to warrant the creation of a separate district, Arizona was made a separate district in February 1915 with headquarters at Phoenix. Jacob, who had been in local charge of the Arizona work since 1910, was made district engineer. On March 16, 1916, he was transferred to Salt Lake City and junior engineer Anderson, who had transferred from Salt Lake City on September 14, 1914, was placed in charge until July 11, 1916, when Ellsworth became district engineer. The district funds were so small that when Ellsworth transferred to Austin, Tex., on November 28, 1918, Arizona again became part of the California District.

In 1913, 17 stations were being maintained by Jacob. Indian Service cooperation, which began in April 1914, resulted in the installation in the Gila River basin of recorders and cable equipment at seven stations, four of which were first established at that time. The next year, in addition to the river stations, records were obtained on 23 canals. With the discontinuance of Indian Service cooperation in 1916, only the river stations were subsequently maintained. Spiegel was appointed junior engineer at the beginning of the Indian Service cooperation and conducted the field work until the close of cooperation. He transferred to Denver on July 15,1918 . By the time Arizona became a part of the California District, no one was left in Arizona-Anderson had transferred to the Helena, Mont., office in February 1917 and McGlashan detailed J.F. Kunesh, assistant engineer, to the Arizona work.

A feature of the construction work that was out of the ordinary was the installation of a recorder in a sloping well on the San Francisco River near Clifton, Ariz., where the topography made this advisable as a measure of economy. The well was placed at an angle of about $41^{\circ}$ with the horizontal. To prevent the float from overturning and revolving around the guide wire, a weight was attached to the guide tube.

At the end of the period, 24 stations were being maintained, of which 20 were equipped with water-stage recorders. In addition, the Reclamation Service furnished records for three 
stations. During this period, a beginning was made in the installation of stations on the lower Colorado River. In March 1915, the Reclamation Service indicated that they wanted records that would be better than those at Yuma, Ariz., and authorized Jacob to spend $\$ 500$ to conduct a reconnaissance of the lower Colorado River. He examined all accessible sites between Bull's Head and Mojave Canyon and concluded that the only practical site for the proposed station was 2 miles below Topock, Ariz. Nothing further was done until January 1917 when Ellsworth installed a recorder in an 18-inch galvanized corrugated iron pipe 40 feet long at the Topock site. This pipe was set in concrete and bolted to the base of the rock cliff on a slope of about $17^{\circ}$ with the vertical. A shelter and timber well were placed on top of the pipe to accommodate the fall of the weight clock and the movement of the float counterweight, the weight of which was reduced by pulleys. A guide wire prevented the float from striking the side of the pipe. This wire produced some sliding friction, so the graph was sometimes "stepped" instead of smooth. The station was reached by a winding trail that crossed several deep gulches via light foot planks and ladders along the California side of the river. A light wooden truss bridge crossed Mojave Wash. The total cost of this installation, exclusive of the recorder, was $\$ 1,107.37$, half of which was paid by the Reclamation Service (Dickinson, written commun., ca. 1938). The original plan contemplated the erection of a cable of about 700-foot span, but this was not done for the reason succinctly stated in Dickinson's report describing the establishment of the station:

Completed construction of gaging station except erection of cable, which was stolen on reel.

Measurements during 1917 were made either from the bridge at Topock or from a boat at the station site. A cable was finally erected in 1918. To make it easier to measure with heavy weights, the standard sit-down car was modified by taking out the footrest and using a platform instead at enough distance below the frame of the car that the engineer could operate the meter while standing. A wooden reel was attached to the side of the car. Dickinson, who was detailed to the Arizona work on November 16, 1917, from Salt Lake City, remained until December 27, 1917, when he entered the Army.

\section{Washington District}

The events leading up to the creation of a separate district in the State occurred in 1912, and the Washington District actually was established at the very end of the previous period.

During summer 1912, Leighton visited Tacoma to inspect the municipal power plant then being constructed. While he was there, the State geologist, who was cooperating with the USGS through the Columbia River District headquartered in Portland, Oreg., told Leighton that the State of Washington would prefer to have a district office within the State. The work in the Columbia River District had reached a point where it was almost too much to be administered as one district, and Leighton was sympathetic to the idea. He stated, however, that before a new district office could be established, he must be assured that the State would continue its cooperation.

The Washington State Legislature was to meet the following winter, so the new office was not to be established until the action of the legislature on the appropriation for the next biennium was known. In the meantime, preparations were made to establish the new office and Henshaw, who was in charge of the Columbia River District, was given the choice of either the Oregon or Washington District when the division should be made. He decided to remain in Oregon because Oregon appeared to offer greater possibilities (Henshaw, oral commun., ca. 1938). G.L. Parker, his assistant, was then selected to be district engineer in the Washington District.

When word was received that the Washington State Legislature had made an appropriation for the next 2 years, G.L. Parker was given the go-ahead to establish a district office. He visited the principal cities in the State, but could obtain suitable quarters only in a Federal building in Tacoma. He therefore established the Tacoma office on May 31, 1913 (G.L. Parker, 
oral commun., ca. 1938). G.L. Parker took Tuttle and Storey with him from the Columbia River District. J.T. Hartson, a State employee, completed the list of engineers. The immediate problems confronting G.L. Parker included bringing the records up to date (they were a year or more in arrears) and improving the equipment at the gaging stations.

The State's interest in its water resources centered largely on water power and a majority of the stations were on streams having considerable power value. Until the last year of the period, the total amount of State and USGS funds available annually did not vary greatly and the number of stations operated each year was substantially the same (62 at the beginning and 58 at the end of the period). In addition, about five stations in northern Idaho were maintained at the expense of the Idaho District. The work was intensive, rather than extensive, with much effort spent in improving both station equipment and the accuracy of the records. The number of recorders installed increased from 8 to 33 . Six artificial controls were constructed and flushing devices were installed at three stations.

The damp climate in the western part of the State resulted in the Stevens recorders company manufacturing a waterproof chart paper that was used extensively. It was also fire-resistant, as shown by the following report from a gage observer (Newsletter, April 19, 1918, p. 10):

Someone had torn away the sheet iron from the back of the gage and had torn the sheet off and tried to burn it and as it would not burn very well they throwed the record into the creek, where it caught upon a snag and I recovered it there. I have got most of it back except a week or two which was burned. $* * *$ There was no trace nor did they leave any marks as I could find to give any bent as to who done it.

Not only was special waterproof paper used, but in at least one instance a special shelter was built by a private company to protect the engineer from the rain while he was making measurements. This shelter was described in the Newsletter dated October 15, 1914 :

One of the gaging stations has ***a "recorder's" house built especially for protecting the recorder during the long rainy season occurring on the west side of the Cascade Mountains. The recorder's house is about $10^{\prime} \times 10^{\prime}$ in plan and is a separate structure from the ${ }^{* * *}$ gage shelter. It is provided with a stove and a table. By means of electrical equipment the contacts made by the meter operate a buzzer in the house, so that the man who handles the meter only has to make soundings, manipulate stayline, and set the meter.

Unlike its activities in the neighboring States of Oregon and Idaho, the Reclamation Service limited its work in the State of Washington to the construction and operation of irrigation systems and its own stream-gaging stations as needed. The records were furnished to the USGS. Twenty-seven records were furnished in 1914 and 18 records in 1919 . Other organizations furnished eight records.

During the first year, G.L. Parker continued to work on the series of reports on water power of the Cascade Range. Part III on the Yakima River basin (WSP 369) was published in 1916.

G.L. Parker continued as district engineer during the period, and Tuttle was office engineer until he transferred to Montana on December 31, 1915. Tuttle was succeeded by Lasley Lee. Storey requested furlough on April 13,1914 . Other employees in the district included C.O. Brown, May 1914 to November 1916; Paulsen, October 6, 1914, to September 17, 1916; J.E. Stewart, April 1915 to July 1918; Lasley Lee, July 1916 to June 30, 1919; T.G. Bedford, July 9, 1918, to December 1918; and Dickinson, November 23, 1918, to June 30, 1919. Also Howard, January to May 1919; J.T. Hartson (State), June 1913 to May 1917; John McCombs (State), December 1916 to March 1918; Kilgore (State), August 1918 to June 30, 1919; and D.J.F. Calkins, August 15, 1918, to June 30, 1919.

\section{Oregon District}

At the close of the preceding period, the Columbia River District was divided into the Oregon and Washington Districts. Henshaw, who had been in charge of the Columbia River 
District, continued in charge of the Oregon District.

When the State cooperative funds came entirely from the State survey fund (beginning in 1915), the availability for use was restricted generally to streams having power possibilities. With this restriction and the subsequent reduction in both State and Federal funds, it was impossible to operate all existing stations. There was much public interest in both irrigation and power projects, and when the situation became public knowledge, private individuals and companies were glad to furnish needed assistance, as Briggs wrote (ca. 1938):

\begin{abstract}
Mr. Henshaw did not hesitate to beg, borrow, or even commandeer services or materials to obtain needed streamflow records. He enlisted the services of many engineers in both public and private practice to make current-meter measurements and to send the results to him. He persuaded many an employer to add the duties of gage reader to the other duties of a foreman, ditch-walker, or laborer. In central and eastern Oregon where distances were great and accommodations were few, the manager of more than one rich cattle ranch found himself host to an uninvited guest with a current meter.
\end{abstract}

As Henshaw himself stated (Sixth bienn. rept., State eng., [1917?], p. 162), "About 15 engineers in various parts of the State make meter measurements at more or less regular intervals on stations reported by the Survey; these results are accepted as though made by a regular hydrographer. Their work is checked by Survey engineers, and these measurements are of great assistance in computing results at a considerable number of stations." Even with this help, Henshaw stated (Newsletter, Mar. 22, 1917 , p. 11) that he was operating more stations than he could properly maintain in the hope that the available funds would be increased.

The stream-gaging requirements were further influenced when the 1913 State Legislature appropriated $\$ 50,000$ for investigating possible irrigation and power projects. That action was in anticipation of cooperation with the Reclamation Service and was contingent on the allotment of a similar amount of money by the
Reclamation Service. A contract between the State and Reclamation Service was signed in 1913 , and the ensuing investigations involved the installation and operation of stations in connection with those projects. The Reclamation Service allotted $\$ 1,102$ to the USGS for stream gaging during this period, and also furnished complete records for several stations.

The Indian Service, in its irrigation operations on the Klamath and Warm Springs Indian Reservations, also needed an extensive stream-gaging program. From 1913 to 1918 , a total of $\$ 6,163$ was allotted to the USGS for that purpose.

One of the first cooperative investigations with the Reclamation Service was the study of the flow of the Columbia River at The Dalles, Oreg., estimates of which, extending back to 1878 , had been computed in 1909. There was considerable doubt about the accuracy of the rating curve used in 1909, and in 1913 the Reclamation Service paid part of the cost of obtaining additional high-water measurements. Unlike the measurements made in 1907 and 1908 , these measurements were made by adding into the measured flow of the Columbia just above the mouth of Snake River the amount of inflow between that point and The Dalles, which was computed from records obtained at gaging stations on the tributaries (WSP 362, 1917 , p. 529). Three measurements were thus made that indicated that the 1908 float measurements, computed with a surface coefficient of 1.05, were in error. The Dalles records were recomputed in 1914. As an indication of the amount of labor involved, an employee in the Portland, Oreg., office, in a communication to the Newsletter dated August 17, 1914, in describing this work, added that "We found a note saying that there were records on the Nile extending back about 3,500 years; Mr. Dean stated that he didn't want to revise any of their records, 35 years being enough for him."

Although the occurrence of diurnal fluctuations of discharge due to melting snow and glaciers had long been known, similar fluctuations due to the operation of power plants and logging ponds had apparently not been fully considered until the present period, as indicated by the following contribution to the Newsletter dated April 17, 1914:

On a recent visit to a gaging station on Hood River, gage heights were observed 
in one day corresponding to discharges varying from 280 to 1,350 second-feet due to the operation of a power dam above. Such operations have been suspected but never proved. This was at medium high stages. An attempt was immediately made to induce the cooperating parties to purchase a self-recording gage. Otherwise, the station will probably have to be discontinued.

A recorder was installed and the station was continued with much more certain and accurate results.

At the beginning of the period, 109 stations were being maintained, of which three were in the White Salmon River basin in the Washington District and were operated for that district at its expense. The 13 stations in the Malheur and Owyhee River basins in the eastern part of Oregon were not included-they were operated by Idaho District personnel at the expense of the Oregon District. Most of the stations were equipped with staff gages, but recorders had been installed at 14 . By the end of the period, the number of stations had increased to 149 , of which 8 were in the Warner Valley in California and 4 in Washington; 59 stations were equipped with recorders.

E.S. Fuller remained in the Portland district as office engineer until March 14, 1914, when he transferred to the Washington office. He was succeeded by Batchelder who transferred from the Salt Lake City office and who remained until he resigned on December 7, 1918. Batchelder was succeeded in turn by Briggs. Others in the district included J.E. Stewart, June 3, 1913, to March 1915; Randell, August 1913 to February 4, 1914; Hodges, January 26, 1914, to July 31, 1916; I.L. Collier, March 9, 1914, to January 15, 1915; and Briggs, July 8, 1917, to June 30,1919 . Dean was detailed to the Portland office from May to September 1914, where he recomputed the Columbia River records and compiled the data for WSP 370 (1915). Paulsen was "borrowed" from the Boise office from October 1914 to April 1915.

\section{California District}

The California District included the entire State of California and, as of December 1, 1918, the State of Arizona. The district had become so firmly established during the previous years that the principal changes were those of expansion. Available State funds were sharply reduced during 1915 and 1916 , but interest in California's water resources was so strong that a very considerable amount of assistance was received from other sources.

Cooperation with the City of San Francisco, which began May 1, 1914, resulted in what may be termed a separate activity for operating the four stations previously maintained by the city, and for establishing and operating additional stations in the vicinity of Hetch Hetchy Valley. Because of the isolated sites of the stations and the large diurnal fluctuations of the streams that drained the western slopes of the High Sierras, recording gages were required (the citymaintained stations had previously been equipped with recorders). The region was so isolated, particularly during winter, that until city officials had a railroad built to Hetch Hetchy in 1916, the hydrographers were at times without mail for a month or more during winter. Lasley Lee was put in charge of these operations and his assistant was Hardy, who transferred in from Hawaii. The first work was the improvement of equipment for the existing stations.

At the station near the Hetch Hetchy dam, a circular masonry well and shelter were constructed. This came about because the city employee assigned to the work was skilled in that type of construction. The other stations were generally of the conventional masonry or concrete type. Hardy wanted to return to Hawaii, so Emerson transferred from Santa Fe, N. Mex., in February 1915 to succeed him. Lasley Lee transferred to the Washington District Office in July 1916 and Emerson continued the work, assisted by Harlowe $M$. Stafford who resigned in October 1917. Thereafter, because the construction period was over and road improvements had made the stations more accessible, Emerson continued the work alone. In addition to cooperation with the City of San Francisco, the Turlock and Modesto Irrigation Districts assisted in the maintenance of gaging stations in the lower Tuolumne River basin.

Floods during January 1914 in southern California were so severe that cooperation was 
arranged with three counties in southern California, which made possible the installation and equipping of most substantial gaging stations. The multiagency cooperation in Los Angeles County that was arranged in February 1916 was under the general administration of the Forest Service. Dort transferred to the Forest Service and was placed in charge of the work of establishing 20 gaging stations. H.J. Tompkins, a Forest Service hydrographer, was his assistant. In June 1917, the work was placed entirely under USGS supervision, Dort transferred to other Forest Service work, and Tompkins continued in charge of stream gaging under Ebert's supervision. In February 1919, a similar investigation was started in cooperation with San Bernardino, Riverside, and Orange Counties, but the full account appears in the next volume of this History.

The construction of a power plant for use in Yosemite National Park made it necessary to install recorders at two stations on the Merced River in cooperation with the National Park Service. Accordingly, in fall 1916, the Park officials offered to furnish materials and labor for these installations and Ebert was detailed to do the work. The Happy Isles site was near a favorite point of interest to tourists and the park officials furnished an artist's sketch of the structure to be built (Ebert, oral commun., ca. 1938). With this sketch as a suggestion (it could hardly be called more), Ebert constructed a masonry well and covered it with a timber structure that resembled the sketch. At the less conspicuous Pohono Bridge site, a standard concrete welltimber shelter was constructed. In fall 1918, the Park Service paid for the installation of a recorder on Tenaya Creek.

An investigation that was perhaps unique up to that time was the determination of the amount of water entering the ground [recharge] from which water was pumped for irrigation. The first four stations for that purpose were installed in the Santa Clara Valley in January 1917; the records from these stations were to be used in the ground-water studies that were being conducted by W.O. Clark. Two of these stations were on Coyote Creek, one where the creek entered the valley and the other near where the creek emptied into San Francisco Bay. (The other stations were on the two principal tributaries.) Water was not diverted from the creek, so the loss in flow at the lower creek station, which was indicated by the comparison with flow at the other stations and corrected for evaporation and transpiration, was the amount of water entering the gravels.

The wholesale destruction of stations by the January 1916 flood further emphasized the need for permanent and substantial equipment and, with sufficient funds for that purpose, 14 reinforced-concrete structures for recorders were installed during the period, all but two being in southern California. Also, because records of the highest accuracy were required for the southern California stations, 19 concrete controls were constructed. The measurement of water levels in wells, which had been started by personnel of the Division of Ground Water during the previous period, was continued by Ebert, who made the measurements once or twice a year.

During 1913-19, the USGS and cooperating organizations were actively engaged in installing recorders and, by the end of the period, 58 recorders were in use. The number of stations decreased from 172 to 163 at the beginning of the period, generally because of the discontinuance of Forest Service stations, records from which were fragmentary. The reduction in State funds also necessitated a reduction in number of stations. Later, stations discontinued about equalled those established and, at the end of the period, 161 were being maintained. Of these, 42 were maintained by cooperators who furnished the records to the USGS.

McGlashan was district engineer during the period and Ebert continued in charge of the suboffice at Los Angeles. Rice was office engineer until he transferred to Hawaii in April 1915, and was succeeded by J.H. Morgan. Morgan resigned on November 1, 1918, and was succeeded by William Kessler who transferred from the Idaho District. Other engineers in the district were G.H. Canfield, June 3 to July 1913; Lasley Lee, June 3, 1913, to June 30, 1916; Charles Leidl, June 3, 1913, to December 31, 1918; Dort, February 1915 to June 1917; Hardy, May 1914 to February 1915; Emerson, February 10, 1915, to June 30, 1919; Stafford, June 1916 to October 2, 1917; Kunesh, July 26, 1916, to June 30, 1919; and Bedford, December 1918 to June 30, 1919. 


\section{Alaska District}

In 1914 , the growing scarcity of wood pulp in the United States led the Forest Service to investigate the possibility of obtaining a supply from the forests in southeastern Alaska. Leonard Lundgren, district engineer of the Forest Service, conducted a reconnaissance for the possibility of developing water power needed for pulp and paper mills. Streamflow records were needed for a study of the practicality of such development, and the Forest Service asked the USGS to cooperate in a streamgaging program. Brooks, chief of the Survey's Alaskan Division, was also interested in streamflow records because of the recent construction near Juneau of several large mills for the processing of about 10,000 tons daily of goldbearing ore, which required considerable power; it was also possible that similar mills might be installed in other parts of southeastern Alaska (Canfield, written commun., ca. 1938). Cooperation was arranged in spring 1915 on the basis of a contribution of $\$ 4,900$ from the USGS Alaskan Division, the loan by the Water Resources Branch of the services of an experienced engineer, and a contribution by the Forest Service of transportation by boat and assistance by rangers and other employees of an annual value of $\$ 2,000$ to $\$ 3,000$. Canfield was detailed to this work and began operations in May 1915.

Because field conditions in southeastern Alaska were radically different from those of the interior where stream gaging had previously been conducted, a detailed account appears warranted. Southeastern Alaska is mountainous, with many freshwater lakes offering storage possibilities at elevations from 100 to 2,500 feet above sea level located from $1 / 4$ to 2 miles from the tidal coastline. The streams flowing from those lakes were water-power possibilities, and records of their flow were needed. The heavy precipitation of the region is indicated by the following dialogue between a tourist and a native Alaskan (Newsletter, Apr. 22, 1916, p. 17):

Tourist: Does it rain all the time? Native Alaskan: No, sometime it snows.

In 1914, private interests had installed two gaging stations equipped with home-made recorders and had made a few current-meter measurements. When Canfield arrived at Ketchikan in May 1915, he began a reconnaissance for sites for the 10 gaging stations wanted by the Forest Service. Among them were the two stations previously installed. At one of these stations, measurements were to be made from a flimsy bridge made of footlogs and although he continued to use it, Canfield was ever conscious of the fact that in full view below the bridge was a series of rapids dropping 400 feet to tidewater in a short distance. At the other station, he found a cable with a sling seat supported by a single sheave. Here, likewise, he was extremely conscious of the fact that, a short distance downstream, the stream began a descent of 1,000 feet to tidewater 1 mile distant. Although he installed standard recorders at these stations, Canfield continued to use the footbridge and cable.

There were practically no roads except near the towns, and all transportation was by water; the long trips were made by coastal steamers, and the shorter ones by gasoline launches or "cruisers" furnished by the Forest Service. The fleet consisted of one 65-foot and four 45 -foot cruisers, the latter used by the rangers. The cruiser speed ranged from 6 to 10 miles per hour. To construct the stations, a party of three plus Canfield and the necessary materials and supplies were taken by cruiser to a point near the outlet of the selected stream whence materials were taken ashore by rowboat. A precipitous trail through dense timber and underbrush led from the beach to the selected site. The materials were "back-packed" and, because weight was an important factor, 2-inch cedar planks 12 feet long were generally used. The back-packing was strenuous work and one forest ranger stated that it was the hardest work he had done in 6 years (Newsletter, Feb. 19, 1916, p. 19).

The most difficult station to reach was the one on Speel River, the largest selected river. This station was 7 miles from the beach and to reach it, there was a 2-mile pack over the ridge to the first lake, three-quarters of a mile float down that lake to its outlet, another pack of half a mile to the second lake, a 3-mile float down that lake to its outlet, then a 1-mile pack to the point where the outlet stream entered 
Speel River. Here the river was so swift that in rafting the material the remaining half-mile to the site, ropes were attached to the raft and the men on the shore made an attempt to guide it (one man was also on the raft). The raft tore loose and rolled over several times in the turbulent water. Although the man on the raft managed to hold on, the knapsacks filled with fresh provisions and the supply of tobacco were lost. The trip took 3 days. During construction, the party lived in a log cabin and subsisted on canned provisions that had not been on the illfated raft.

The installations followed standard plans except that most of the wells were placed in the bed of the stream, usually in a pool between the stretches of rapids, thereby eliminating intake pipes. The shelters were built for ranges of stage from 5 to 10 feet, except on Speel River where the range was 20 feet. Cables were erected for use in making discharge measurements. Most of the cable cars were covered with galvanized iron roofs to protect the engineer from rain and snow. The cable spans were from 150 to 200 feet, except the one on Speel River that was 300 feet.

Of the nine stations established in 1915, eight were equipped with Stevens continuous recorders. The stations were usually visited monthly. Because of swiftness of current and relatively warm water flowing from the lakes, backwater due to ice rarely occurred and the records were continued throughout the year. As ice formed in the wells, however, oil cylinders were used.

As in the earlier work in Alaska, mosquitoes were so bad during summer that nets were worn over one's head, which were to be lifted for each mouthful of food during meals. Another pest during late summer was a black gnat so small that it was called a "noseeum." Field work in that mountainous region also had its tragic side as Canfield wrote (ca. 1938):

The view of Swan Lake recalls a tragedy which occurred while I was making a reconnaissance for the installation of a gaging-station structure on that stream. One of the men employed for construction work was returning down the trail from the lake. I was ahead, he was in the middle, and another man was bringing up the rear. The trail was only a game trail, or a fishermen's trail, leading up to the lake. After passing a particulary bad point on the trail, I looked back and saw only the man in the rear, the one in the middle being missing. We found marks made by his feet down a steep slope and the ax which he was carrying on the edge of the stream; apparently he lost his foothold and slid down this steep bank and fell over into the stream, which was at a flood stage at that time. We searched both banks of the stream, which contained several rapids and one or two falls 30 feet high before it reached tide water. Also, we searched the shores of the bay for a day or two but were unable to locate his body. However, our work, like the show, "must go on," and the gagingstation equipment was installed after it appeared to be useless to continue the search any longer. The next spring his skeleton was found on the beach five or six miles from the mouth of this stream.

During the period of the Alaskan one-man district, Canfield conducted the work from headquarters shared with the Forest Service, first in Ketchikan and later in Juneau. Except for the indication of objectives by the Forest Service at the start, the work was both directed and executed by Canfield, and he adjusted his field work to the availability of Forest Service boats and personnel (Canfield, written commun., ca. 1938). In early summer, the sun set at 11 p.m. and rose at 2 a.m., making long hours of work possible.

During winter 1916-17, Canfield went to Washington, D.C., and C.O. Brown was detailed from the Tacoma office to continue the work. Although Canfield reported directly to Brooks and the Alaskan Division, his records, which he had computed, were reviewed by the computing section of the Water Resources Branch.

The number of Alaskan stations gradually increased to 20 , all equipped with recorders. On April 1, 1921, cooperation with the Alaskan Branch was discontinued because the reduced appropriation to that Branch precluded continuing the annual allotments that had ranged from $\$ 1,400$ to $\$ 4,200$. Canfield's expenses and salary were paid from that allotment, so the USGS participation in the Alaskan stream gaging 
ceased and Canfield returned to Washington, D.C., where he remained for several months working on reports of applications for Alaskan permits to the Federal Power Commission. The stream gaging was continued until 1927 on a reduced scale by Forest Service personnel (Bull. 836-C, 1933, p. 137) and permittees of Federal Power Commission. The Alaskan records were published in a series of USGS Bulletins under the general titled "Mineral Resources of Alaska"' (Bull. 712, for example, published in 1920).

\section{Hawail District}

This was a period of improving equipment and accuracy of records in Hawaii, which resulted in a decrease in the number of stations and relocations and rehabilitation of existing stations. As Carson writes (ca. 1938):

The decline in the number of stations was caused by a weeding out of unreliable stations, and the improvement of those retained. The first stations were nearly all staff-gage stations, many of them graduated only to 10 ths, and read only once a day. Some of them were on ditches where the location was chosen because of the availability of observers; and the flow of the stream was determined by measuring the ditch before and after it crossed the stream and picked up the stream water. Where recorders were used, the shelters were generally flimsy scaffoldings roofed with paper, frequently without side walls. Many of the sites were poorly chosen. By substituting a single station at a well-chosen site on a stream for two ditch stations and by dropping those (latter) stations from which unreliable records were being obtained, the number of stations was reduced.

In 1913, 165 stations were maintained, of which 31 were equipped with recorders. The revamping of the stream-gaging program reduced the number to 81 by 1919 , and records for 65 of these were published. Of the stations with published records, 47 were equipped with recorders, chiefly of the continuous type.

The recorder shelters were of inexpensive and of simple construction. The greatest cost was for the transportation of materials, especially to stations at high elevations far from roads, so it was imperative that the least expensive structure should be used to cover the recorder. This policy was responsible for some unique structures (W.E. Armstrong, written commun., ca. 1938).

The passage of the Free Sugar Bill by the United States Congress caused a financial stringency in Hawaii during 1914 and awakened the sugar planters to the realization that very considerable savings in operating expenses would result from greater efficiency in using water for irrigation. This situation resulted in cooperation for investigations of ditch seepage, evaporation, and general duty-of-water studies. The Hawaiian Sugar Planters Association paid the cost of all material, labor, and equipment, and Hawaii District personnel conducted the investigations and computed the records. This cooperation lasted until 1917.

A regular part of the district work was the maintenance of rainfall stations, a function started during the previous period. These stations gradually decreased from 64 in 1914 to 33 in 1919 because of a lack of Territorial funds for that purpose. The 33 stations were then turned over to the Weather Bureau. A wide range in rainfall was found to occur at practically the same elevation-perhaps the greatest range was from 561 inches at the 5,060-foot elevation to 18 inches at the 4,500-foot elevation only 15 miles apart.

The district engineer was also the chief hydrographer of the Territorial Division of Hydrography. The records of streamflow were vital to the Territory in determining the value of the leases of public lands that depended on available water supply. Because the Territory was paying a major part of the cost, considerable man-hours were spent by the personnel to obtain and prepare data for the Commissioner of Public Lands to use in determining the value of the leases, and for the Territorial Attorney General to use in adjudication proceedings.

The Hawaii District in its capacity as Territorial Division of Hydrography was not limited to the study of surface waters, and records of artesian wells on the Island of Oahu were kept. This work was started by the Department of Public Works about 1909 as a result of a visit 
of Mendenhall, then in charge of the Division of Ground Water of the USGS. In 1915, the Hawaii Legislature created the Water-Supply Commission to investigate the water resources of Hawaii, with particular reference to the artesian wells on the Island of Oahu. The Commission, with Larrison as chairman, conducted a detailed investigation in the Honolulu area and reported to the 1917 State Legislature. As a result of that report, the legislature passed an act defining the waste of artesian water and gave the chief hydrographer of the Territorial Division of Hydrography authority to investigate and prevent such waste. At the beginning of 1917 , the artesian well work was turned over to the Hawaii District in its capacity as the Division of Hydrography. Sixteen wells were measured, the height of water in them being referenced to mean sea level, samples of water were tested for salt, and a close watch was kept for possible waste (W.E. Armstrong, written commun., ca. 1938).

Hawaiian streams are small, and because most of the irrigation and municipal problems involved pumping for which million-gallonsper-day is the generally accepted unit, the USGS changed the unit in 1915 for the Hawaiian reports from second-feet to million-gallons-perday. At the same time, the period for which records were published was changed to the fiscal year ending June 30 (Newsletter, July 16, 1915). This was done to coordinate the publication year with the fiscal year and to accommodate Hawaiian water conditions, because generally July is the Hawaii dry period (W.E. Armstrong, written commun., ca. 1938).

Larrison was in charge of the Hawaii District during this period except from October 21, 1917 , to January 14,1919 , when he was in the Army. When he entered the Army, Larrison resigned his position as chief hydrographer of the Division of Hydrography but did not resign his position as district engineer. Bailey, who succeeded Larrison, was appointed chief hydrographer by the Territory, but was acting district engineer of the USGS. Bailey was appointed Commissioner of Public Lands on February 19, 1919, under whose direction the Division of Hydrography functioned. Bailey was office engineer until October 22, 1917, when he was succeeded in that position by
J.E. Stewart whom he appointed acting chief hydrographer for the Territory. Other engineers in the district were Christiansen, June 3 to December 31, 1913; Howard Kimble, July 1, 1913, to March 31, 1915; Dort, June 3, 1913, to February 5, 1915; Hardy, June 3, 1913, to March 1914, and March 15, 1915, to June 30, 1919; E.E. Goo, June 3, 1913, to June 30, 1919; and G.R. White, June 3, 1913, to April 15, 1914. Also Herbert A.R. Austin, December 27, 1913, to June 30, 1919; Rice, April 15, 1915, to May 15, 1917; R.D. Klise, August 10, 1915, to June 30,1919 ; J.E. Stewart, August 1918 to June 30, 1919; J. Kaheaku, September 11, 1913, to June 30,1919 ; J.B. Mann, February 7 to June 28, 1918; and A.H. Wong, August 1, 1918, to June 30, 1919.

\section{Division of Ground Water}

In contrast with the previous period, which was one of liquidation, the present period was one in which the spade work was done in the development of quantitative methods of determining ground-water supplies. Or, as Meinzer expressed it (oral commun., ca. 1938), the period was one of feeling the way in developing methods to determine the safe yield of groundwater supplies year by year during this period. The ground-water work was conducted generally for irrigation purposes. Congressional action resulted in two specific lines of investigation not heretofore undertaken: locating and marking desert watering places, and exploratory drilling for irrigation supplies. Also, war activities required the Division to conduct special investigations and prepare reports on ground-water supplies for military camps.

\section{Quantitative Investigations}

Demand for information relative to the complete use of ground-water resources in arid regions initiated the development of quantitative methods. The information required was not the actual quantity of ground water in a particular area, but rather the rate of replacement year after year, which determines the safe level of withdrawal or amount of yield.

Apparently the first investigation of a quantitative nature was conducted by $C$.H. Lee in 


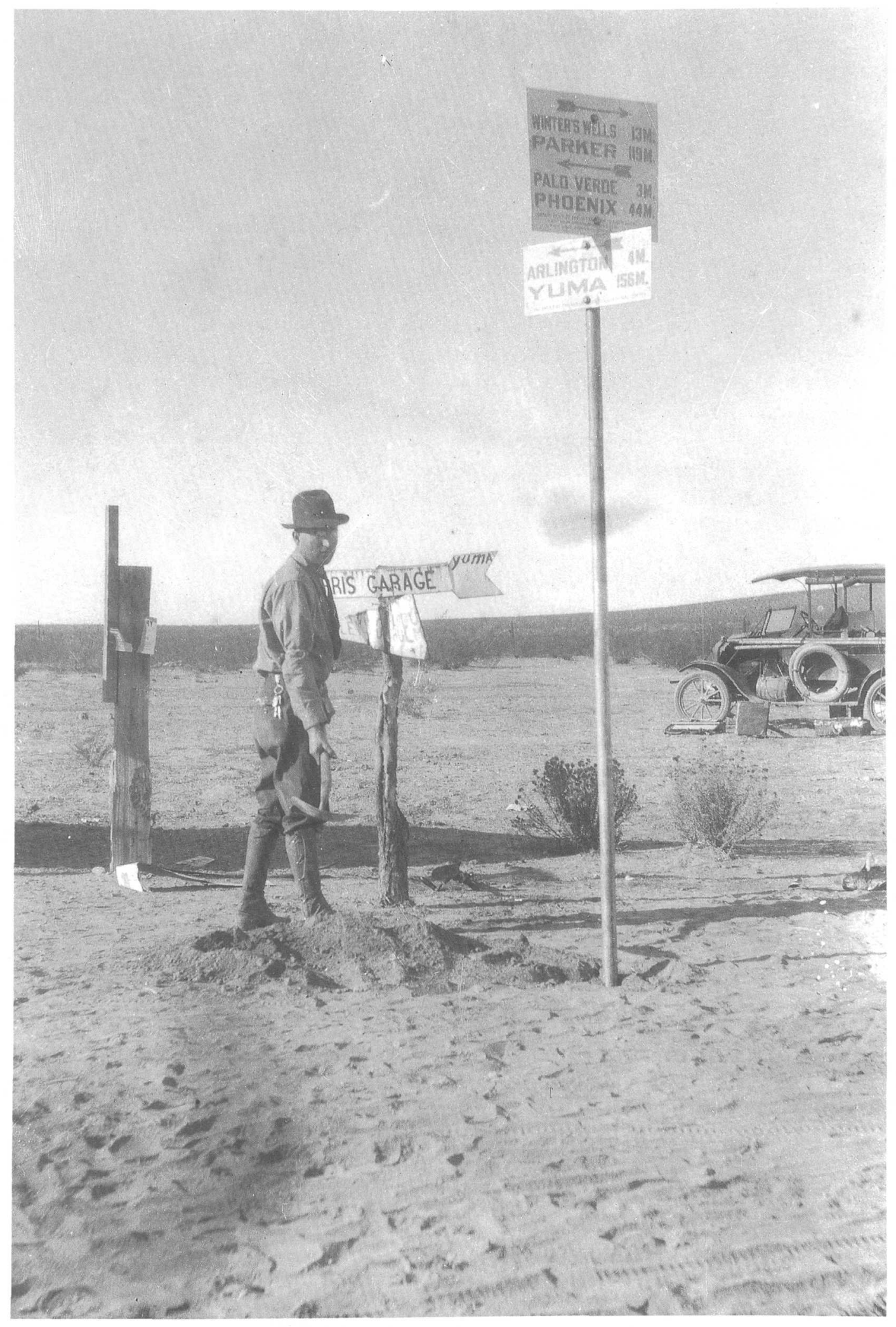

The first desert watering place signpost erected in late 1917 or early 1918 by the U.S. Geological Survey. (From USGS Water-supply Paper 490-A, 1920. Photograph number “'C.P. Ross No. 62," USGS Photographic Library.) 
part of the Owens Valley in California from 1908 to 1911 . In that study (WSP 294, 1912), he measured or computed the water losses via recharge in streambeds, measured discharge of springs, measured evaporation from water and soil, conducted experiments to determine how much precipitation recharged to the permanent ground water, measured ground-water fluctuations, and determined the porosity of the soil covering the aquifer. From these data, C.H. Lee computed the annual yield of ground water.

Faced with the persistent question "What is the safe year-by-year yield from ground-water supplies?," Meinzer developed a four-way approach to the problem. The first is the intake or absorption method, where one or more gaging stations are operated on a stream, one at the point where the stream enters the valley and others at points farther downstream; with intervening diversions taken into consideration, the difference in flow between the upper and lower stations represents the loss by percolation [recharge to ground water] through the streambed. This and the other three methods, the discharge method (where the water discharged from the saturated zone and evaporated from soil and vegetation is measured), the water-table method (where the fluctuation in ground-water level during recharge is measured), and the underflow method (where the rate at which water percolates through a selected cross section is measured-Slichter's method of measuring ground-water flow (WSP 140, p. $65-85,1905)$ is to some extent applicable to this method) are discussed at length in WSP 638-C, pages 99-144 (1932).

These four methods were developed during this period and wherever possible, independent determinations by two or more methods were used as checks. The quantitative methods involve investigations covering a period of years and are much more expensive than the methods used previously that enabled investigations of specific areas to be completed within a few months or even weeks. A lack of funds and of personnel trained in these methods permitted only a few investigations of this type to be conducted during this period-two in California, one in Nevada, and one in Connecticut, the latter a by-product of a general investigation that was being conducted in the State.
The first investigation by the USGS in which the quantitative method was used was a study of the ground-water resources of the Santa Clara Valley in cooperation with the State of California. The valley is a region of intensive cultivation of crops that are dependent on irrigation, generally with ground water. The knowledge of the reliable yield was so vital to the continued prosperity of this region that it was selected for study in 1912. W.O. Clark was assigned to the project, which continued until 1917. A number of reports were issued, the first being "Ground-water resources of Niles cone and adjacent areas, Calif." (WSP 345-H, 1915, p. 127-168) covering the years 1913-14. For more than 20 years there had been a conflict of interest between the farmers who depended on ground water for irrigation and water companies supplying the San Francisco Bay cities from the same source, and this study was an attempt to determine the sources of the ground water, the quantity being withdrawn, and the amount available.

The next report dealing with this region was "Ground water for irrigation in the Morgan Hill area, Calif." (WSP 400-E, 1917, p. 61-105). A proposal to establish an irrigation district led DOA personnel to ask the USGS to report on the possibility of obtaining ground water for irrigation before a decision was made with respect to plans for storage of a water supply.

The final report on the Santa Clara Valley, Calif., was published in 1924 as WSP 519. During the course of the general investigation, additional gaging stations were needed for studying the recharge through the streambed of water from the stream, and four stations were established by the California District staff for that purpose.

In 1914, San Diego County officials realized that a ground-water study was needed, but they were unable to finance it. The recent and rapid development of pumping for irrigation had threatened to reduce the ground-water supply. Edward Fletcher of the Volcan Land and Water Company guaranteed $\$ 1,000$ to start the work and arranged cooperation with the USGS (Ebert, oral commun., ca. 1938). Other officials, including those of the State of California and city of San Diego, contributed to the investigation that was conducted from September 1914 to 
August 1915 by A.J. Ellis and C.H. Lee. The results of the investigation were published in 1919 in WSP 446.

An examination of the Big Smoky, Clayton, and Alkali Spring Valleys in the vicinity of Tonopah and Goldfields, Nev., was conducted by Meinzer during 1913 and 1914. Surface water was so scarce in this important mining region that a quantitative study of the groundwater resources was conducted. In 1915, Purton made additional discharge measurements of the streams entering the valley for the purpose of obtaining further information on the intake or absorption. WSP 423 (1917) contains the results of this study.

During the course of the general investigations in Connecticut begun in 1911, Meinzer conducted from 1913 to 1916 a quantitative study of Pomperaug Basin. This area was selected not because its ground waters were extensively developed, but because the ground-water conditions were fairly representative of those throughout the State and the area was a convenient unit for study with fewer complications than were found in most areas. The results were published in 1929 as WSP 597-B (Meinzer and N.D. Stearns).

In describing the development of the quantitative methods at the end of this period, Meinzer wrote in his paper "Quantitative methods of estimating ground-water supplies" (Geol. Soc. America Bull., vol. 31, p. 329-338, 1920):

There are two very encouraging features of the work: The first is that we have methods that are fairly dependable and applicable. The work of the future is to refine these methods and to apply them in sufficient detail rather than to devise new ones. ${ }^{*} * *$ The second encouraging feature is that the three main methods-intake, discharge, and watertable-are absolutely independent of one another. In many areas two or three of these methods can be applied, and in this way checks can be obtained on the accuracy of the work.

This was written in 1920 and, in the intervening years, the experience gained has led to additional comment by Meinzer (written commun., ca. 1938):

Our experience since that time has shown that quantitative methods can be classified under the four heads described. However, there have been vast developments in principles and application since that time, and many of the intricate things we attempt to do now were not thought of at that time.

What may be termed the old-line investigations, which resulted in descriptive reports on selected areas, were continued. With the exception of the Connecticut investigations, these areal surveys were chiefly conducted in the arid West as during the previous period.

\section{Areal Surveys}

The Sacramento Valley study, begun in $\mathbf{1 9 1 2}$ by Kirk Bryan, was completed in November 1914 and the results were published in 1923 as WSP 495. Further study of the ground water in San Jacinto and Temecula Basins in California was conducted by Waring in 1915 to update Mendenhall's studies begun in 1904. This was published in 1919 as WSP 429.

Studies in San Simon Valley, Ariz., by A.T. Schwennesen in 1913 and 1915, was published in 1919 as WSP 425-A. Studies in Paradise Valley, Ariz., by Meinzer and A.J. Ellis in 1914, were published in 1916 as WSP 375-B. The water analyses were conducted by personnel of the Arizona Experiment Station.

Cooperation with the New Mexico Agricultural Experiment Station, begun in 1911, continued during 1913. An investigation of the southern part of Grant County was conducted by Schwennesen and the soil and water analyses by R.F. Hare of the Experiment Station. The results were published in 1918 as WSP 422.

In Montana, cooperation was arranged in 1915 whereby the State engineer was to collect well records and the State Board of Health and Montana State College were to snalyze the water. At that time, very few ground-water studies had been conducted in Montana and little information was available relative to the eastern and central parts of the State where settlement was rapidly taking place (Meinzer, written commun., ca. 1938). Work was begun by A.J. Ellis in 1915 and continued through 1917. A report dealing with the Little Bitterroot Valley was published in 1917 as WSP 400-B. 
An investigation of the Reese River basin and adjacent parts of the Humboldt River basin in Nevada was conducted by Waring in 1916 . The results were published in 1919 as WSP 425-D.

An investigation of ground water for irrigation in the Lodgepole Valley in Wyoming by Meinzer was published in 1919 as WSP 425-B. A similar study in the Quincy Valley of Washington by Schwennesen and Meinzer was also published in 1919 as WSP 425-E.

The only investigations in the eastern part of the country were those that had begun in Connecticut in 1911 in cooperation with the State Geological and Natural History Survey. This work was conducted chiefly by H.E. Gregory, A.J. Ellis, and others, and continued through 1917 when it was interrupted by World War I. The results were published as WSP 397 (A.J. Ellis, 1916), 449 (Waring, 1920), 466 (H.S. Palmer, 1921), and 470 (H.S. Palmer, 1920 ), in addition to the aforementioned WSP 597-B by Meinzer and Stearns (1929).

\section{INDIAN RESERVATIONS}

The cooperative work with the Indian Service for an investigation of ground-water resources on the Navajo and Moki Reservations begun in 1909 was continued by Gregory and completed in 1915. Reports were furnished that bureau on completion of each major unit. In addition, Gregory published the results of his work in 1916 in WSP 380. In 1915, Schwennesen investigated water resources of the San Carlos Reservation and published his results in WSP 450-A (1921). The value of the work to the Indians, with special reference to the Navajo Reservation investigation, was expressed by the Commissioner of Indian Affairs in his 1917 report, as follows:

One of the field men reports that with the additional water developed, the Navajo's stock has increased more in the past 5 years than it did in the preceding 50. That our efforts in their behalf are not unappreciated the following excerpt taken from a field report will show:

'Proud and thankful owners are they (the Navajos) to know that The Great White Father at Washington has at last come to their rescue, by sending men and machinery with which to develop their water resources.'

\section{Desert Watering Places}

The initiation of the work of finding and marking the desert watering places was due chiefly to the efforts of George W. Parsons, an enthusiastic resident of Los Angeles, Calif. Parsons' intent was to save the lives of those who might become lost in the desert, and at last he succeeded in getting the backing of the southern Californians in gaining the support of the local Congressmen (Meinzer, oral commun., ca. 1938). As a result, an act of Congress (39 Stat. L. 518), approved August 21, 1916, authorized an appropriation of $\$ 10,000$ for the purpose of discovering, developing, protecting, and rendering more accessible for the benefit of the public, springs, streams, and water holes on the arid public lands. Such watering places were to be marked, and signs were also to be erected along accustomed lines of travel. This was merely an authorization, and it was not until the passage of Sundry Civil Expenses Act of June 12,1917 , that the appropriation was actually made.

The work to be done for $\$ 10,000$ was a tall order and, as it was obviously impossible to cover the entire arid public lands, the effort was confined to that part of the arid region through which a stranger could not travel safely without directions to watering places. The area selected was about 60,000 square miles in southeastern California and southwestern Arizona-the hottest and most arid part of the United States, one of the least explored, and where the danger of perishing from thirst was very real (WSP 497 , 1923 , p. xiii). Furthermore, to help not only with the regular ground-water program but also to cover a larger desert area, regular funds of the Division of Ground Water were combined with the special $\$ 10,000$ fund.

The area to be investigated was divided into four parts. John S. Brown, David G. Thompson, and Clyde $P$. Ross were given appointments and each assigned to one of the parts, and Kirk Bryan was assigned to the fourth. Each geologist was provided with a nontechnical 


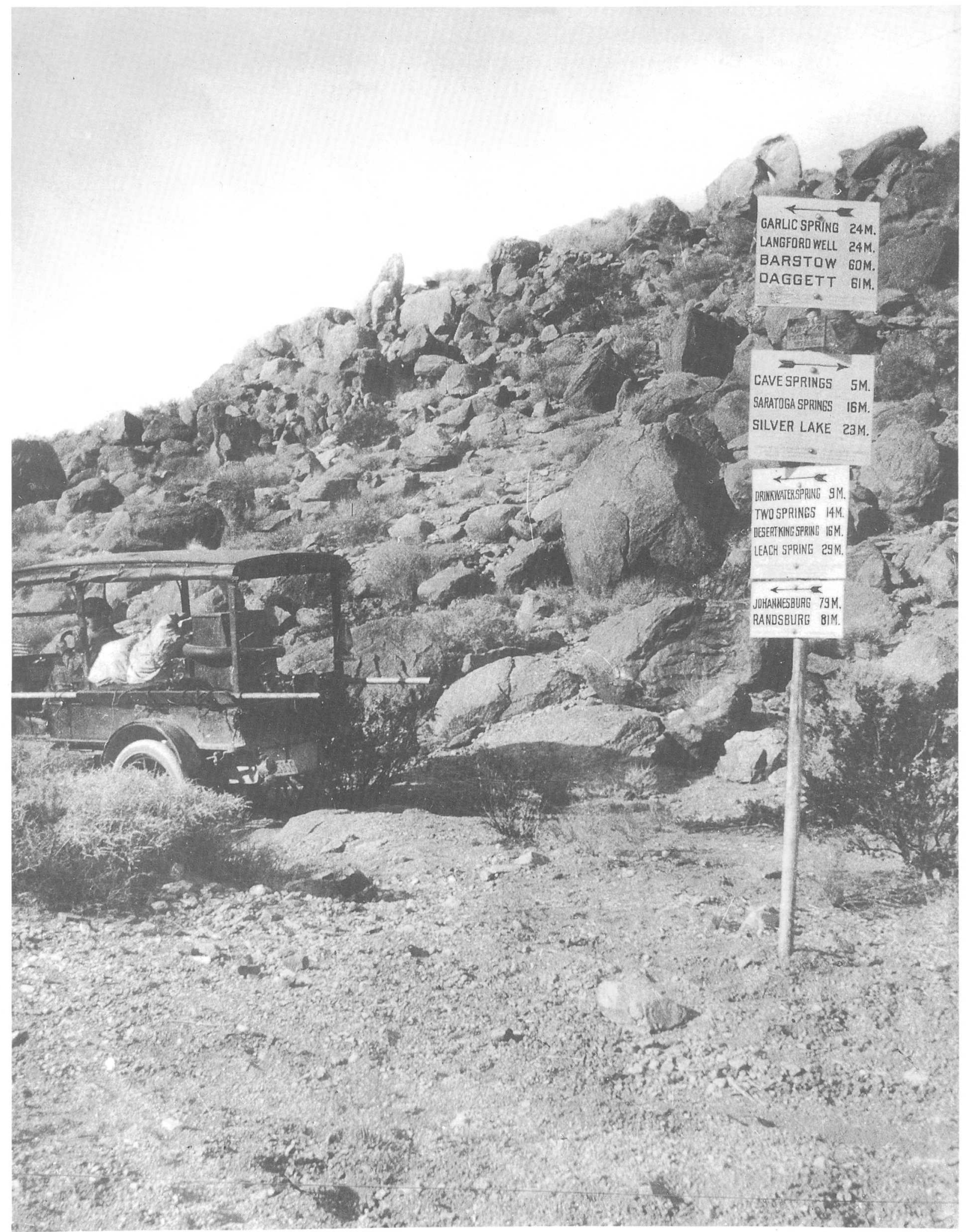

Typical desert watering place signpost erected circa 1917-18 by the U.S. Geological Survey. (From USGS WaterSupply Paper 450-A, 1920. Photograph number “D.G. Thompson No. 179," USGS Photographic Library.) 
assistant, a plane table and other necessary equipment, and most important of all, a Ford car that had a truck body. As D.G. Thompson wrote (ca. 1938):

Ford trucks of 1917 vintage [were] equipped with extra strong rear springs, ordinary front springs which broke frequently, and springless horsehair seat pads, a set-up not at all conducive to comfort when riding over desert 'washboard' roads.

Their instructions were to map the roads and watering places at a scale of 1:125,000, sketch the topography, collect samples of water, erect signposts directing travelers to watering places, and obtain as much information as possible regarding geography, geology, and hydrology of each area with special reference to developing additional water supplies (WSP 497, 1923, p. xiv). The work began in 1917 and continued until about March 1918.

As would be expected, desert field conditions were radically different from those found elsewhere. The hazards of motor travel have already been touched on in connection with motorcycles and automobiles. As insurance against emergency delays on long trips, heavy tanks holding about 25 gallons of water were bolted under the rear end of the truck bodies. This arrangement gave unexpected results as the blast from the exhaust pipe gave a plentiful supply of hot water in the tanks. For drinking water, it was necessary to use water bags that were kept cool by the rapid evaporation from their surfaces.

The furnishing of information regarding the watering places was the first consideration and the office work was devoted to the preparation of the maps for use in the guidebooks to be issued. The Topographic Branch loaned Renshawe to draw the relief maps. The areas mapped were close to the international border, and information on this little-known region was so important to the Army in connection with its military map of the United States that in August 1918, four Army officers were detailed to assist in completing the maps and making them immediately available (Newsletter, Aug. 23, 1918).

Guidebooks showing routes to the desert watering places and containing suggestions to travelers were issued for each section mapped: WSPs 490-A, Salton Sea region, Calif., 1920; 490-B, Mohave Desert region, Calif., 1921; 490-C, Gila region, Ariz., 1922; and 490-D, Papago country, Ariz., 1922. Each report contained the following "General Advice":

To one taking the proper precautions the desert is much less to be dreaded than the average stranger imagines. Only in midsummer heat is it really dangerous. *** No matter in what sort of vehicle or for what length of time it is planned to enter the desert, adequate provision for possible misfortunes should be made. Probably more fatalities and hardships result at present from the failure of automobilists to know the road or to take a little food or an extra supply of water than from any other cause. ${ }^{* * *}$ Oil and gasoline more than enough for probable needs should be taken, and it should be remembered that desert roads may require twice as much per mile as pavement.

Other suggestions pertained to clothing and proper procedure if the traveler did get lost. The reports containing the additional scientific data obtained were issued later (WSP 497, 1923; 498, 1923; 499, 1925; and 578, 1929). In all, 305 desert watering places were located, marked, and mapped during the period.

\section{EXPLORATORY Drilling}

For several years, a group of Congressmen from the Western States were interested in obtaining an appropriation of $\$ 100,000$ for exploratory well drilling in order to show that using ground water for irrigation was feasible in those regions where surface waters were scarce. An appropriation item was prepared by the Secretary of the Interior and the Directer of the USGS and was included in the estimates for 1917 with the expectation that the funds might be appropriated within the next few years (Newsletter, July 19, 1916). Anticipating eventual favorable action, Meinzer asked members of the Division for suggestions regarding favorable localities, methods of drilling, relative advantages of contracting the drilling 
out and (or) of directing supervision of drillers employed to operate USGS rigs, legal aspects of obtaining land on which to drill, and permissible investigations in connection with the exploratory drilling. It was not until 1 year later, fiscal year 1918, that Congress passed the desired appropriation, an increase of $\$ 25,000$ for the Branch with the proviso that the $\$ 25,000$ be used for drilling exploratory wells in arid regions (USGS 39th Ann. Rept., 1918, p. 110).

The country was then at war and costs were mounting rapidly, so the work was concentrated in one locality in order to make the funds stretch as far as possible. The drilling rig was previously used by the USGS in potash explorations (Newsletter, Nov. 11, 1917). After a reconnaissance conducted during summer 1917 that covered parts of western Utah and eastern Nevada, a favorable place for the new work appeared to be the Steptoe Valley of Nevada. On November 21, the Secretary of the Interior approved this site. Meanwhile, the ex-potash rig had been undergoing extensive repairs and alterations for 2 months, and it was not until late December that the rig was finally shipped to Ely, Nev. Drilling began on December 22. W.O. Clark was in charge of the project. Three wells-97, 915, and 122 feet deep-were drilled. The drilling was completed June 25, 1918. The field work was completed July 4 when the last pumping test was conducted. In writing of the work (WSP 467, 1920, p. 11), Meinzer states that "The work was done under extraordinary difficulties. The shortness of the interval between the approval of the project and the end of the fiscal year in which the work was to be done necessitated the organization and prosecution of the drilling during the cold winter period; moreover, the work had to be done while the war was in progress, when the necessary equipment, materials, and workmen were almost unobtainable and the cost of everything was excessive."

Although the next year's appropriation contained the same language relative to well drilling, the additional sum of $\$ 25,000$ was omitted and therefore the well drilling was discontinued. Each succeeding annual appropriation contained the same authorization, but the work could not be resumed because of lack of funds. The exploratory drilling was successful and the results were presented in detail in the aforementioned WSP 467.

During these years, Meinzer prepared a bibliography on ground-water publications, which was published as WSP 427 (1918). In an attempt to standardize ground-water terms, he prepared a glossary and after submitting it for criticism to engineers and others interested in ground waters (Newsletter, Apr. 19, 1918), published it as WSP 494 (1923). Another paper, by A.J. Ellis, presented the history of water witching, pointing out the futility of the divining rod method in finding ground water (WSP 416 , 1917). The scientific world was so interested in the findings contained in this report that it was reprinted almost entirely in the Scientific American (Newsletter, Apr. 19, 1918).

\section{WAR WORK}

The war years $1917-18$ brought a virtual cessation of regular work because of the many requirements of the Division of Ground Water from the War and Navy Departments. Shortly before the United States entered the war, Meinzer prepared a comprehensive digest of information relating to water supplies available for use at military camps, which was transmitted to the War Department. As soon as the United States declared war, many problems arose regarding water supplies for the many military and naval establishments that were built in different parts of the country. The War and Navy Departments called on the USGS for help in solving these problems, and this work took precedence over all other work (USGS 39th ann. rept., 1918, p. 118).

In September 1918, a request was received from General John Joseph "Blackjack" Pershing for two water-supply geologists and suggesting that Meinzer be the senior scientist (Newsletter, Sept. 30, 1918). He and Kirk Bryan were selected for these positions (Bryan was already in the Army and in France). Meinzer was commissioned Captain and Bryan Second Lieutenant of Engineers. While Meinzer was awaiting transportation to France, however, the armistice was signed and, some time later, both he and Bryan returned to USGS work. During this period, A.J. Ellis was Acting Chief of the Division of Ground Water. C.P. Ross and J.S. Brown were also in the Army. 
The annual allotments for the Division were as follows:

$\begin{array}{rrrr}1914 & \$ 16,800 & 1917 & \$ 21,200 \\ 1915 & 17,500 & 1918 & 43,650 \\ 1916 & 19,000 & 1919 & 15,400\end{array}$

From 1914 to 1918 the allotments included those for quality of water, and although it is not possible to list separately the amounts for that work, they probably were from $\$ 6,000$ to $\$ 7,000$ annually. The allotment shown for 1918 included the $\$ 25,000$ for drilling wells. The allotment for 1919 did not cover the quality of water work because a separate division had by then been created. During these years, $\$ 1,400$ was allotted annually by the Division of Ground Water to the Coastal Plain investigations that were conducted by Geologic Branch personnel. Participation by Division of Ground Water personnel consisted of reviewing for publication the papers on ground water that were submitted by Coastal Plain section personnel.

Cooperators were the Arizona State Experiment Station during 1913-14 and the New Mexico State Experiment Station during 1913. The Montana State engineer, State Health Board, and State College also cooperated from 1915 to 1917. From 1913 to 1915, the Indian Service cooperated, but the funds contributed are now unknown. In Connecticut, the State Geological and Natural History Survey contributed $\$ 1,000$ in $1914 ; \$ 1,000$ in $1915 ; \$ 1,555$ in 1916; and $\$ 770$ in 1970 .

Meinzer was in charge of the Division of Ground Water during the period and had the following personnel: A.J. Ellis, June 3, 1913, to June 30, 1919; Waring, February 15, 1915, to May 31, 1917; Everett Carpenter, June 3 to July 23, 1913; Kirk Bryan, June 3, 1913, to June 30, 1919 (on per diem in 1915; in the Army Apr. 30, 1918, to Mar. 1, 1919); W.O. Clark, June 3, 1913, to June 30, 1919; and Schwennesen, January 19,1914 , to June 30,1919 . Also D.G. Thompson, June 15, 1917, to June 30, 1919; C.P. Ross, July 18, 1917, to June 30, 1919 (in the Army July 23, 1918, to Feb. 3, 1919); J.S. Brown, October 4, 1917, to June 30, 1919 (in the Army Aug. 5, 1918, to Jan. 13, 1919); and C.W. Riddell, January 28,1918 , to June 30 , 1919.

\section{Division of Water Quality}

At the beginning of this period, the quality of water work was, for administrative reasons, a part of the Division of Ground Water. It was, however, distinct from the ground-water work, and Meinzer exercised no supervision over it. Dole continued in charge of the work, which at this time was restricted to studies of the mineral content of waters. One reason for the restriction, aside from the lack of funds to cover a wider field, was that by an act effective July 1, 1913, the Public Health Service was authorized to study the sanitary side by investigating stream pollution and purification of sewage and of water.

Very little field work was conducted and, because the Division had no laboratory of its own until January 1918 , only a few analyses were made, either in the laboratory of the Geologic Branch or by private laboratories under contract. Dole devoted a part of his time to a socalled comprehensive report, a compilation of unpublished data obtained from different sources. Only a small part of his time was given to the project, as shown by the following tongue-in-cheek statement in the November 20, 1914, Newsletter:

\begin{abstract}
Mr. Dole's expert knowledge of chemical and sanitary subjects is so heavily drawn upon not only by the Water Resources Branch, but by other branches of the Survey and by the Interior Department that in the last year and a half he contrived to put only three days' work on his new project.
\end{abstract}

Thereafter, Dole devoted more time to his work, which he hoped to publish as a USGS Professional Paper. Only the first part of the report was completed at the time of his death on January 21,1917 . C.H. Kidwell, who then began working on the report, proposed that the report be prepared in cooperation with Clarke of the Geologic Branch (Newsletter, Nov. 20, 1914). Kidwell resigned on May 18, 1920, however, before the report was finished; Clarke prepared a report on the composition of the river and lake waters of the United States, incorporating much of Dole's data, which was later published by the Geologic Branch as USGS Professional Paper 135 in 1924. 
During this period, the Alaskan Division was able to obtain numerous samples of water from the major streams of Alaska. Analyses of these samples were made in the Mineral Laboratory (Geologic Branch) in space provided through the courtesy of Clarke. Although glacial silt of colloidal fineness interfered with the progress of the work and special methods of analysis had to be developed, the analyses were completed during several weeks of intense work. The results provided data on the mineral composition of subarctic streams, adding materially to the meager information previously available (WSP 418, 1917). In addition, Dole prepared and published in collaboration with other members of the USGS reports on the quality of the ground waters of Georgia (WSP 341, 1915), Arkansas (WSP 399, 1916), Texas (WSP 375-G, 1916), and California (WSP 398, 1916), and on the radioactivity of mineral waters (WSP 418, 1917).

Chambers succeeded Dole in charge of the quality of water work. One of his first projects was to equip and arrange for a water-testing laboratory in the new DOI building that was specially designed for rapid, accurate work in the mineral analysis of surface and ground waters to determine their value for domestic, industrial, and irrigation uses.

The laboratory had not long been in operation when the War and Navy Departments found it a convenient place from which to quickly obtain, as was often necessary in wartime, reliable mineral analyses of water and information relative to the value of available supplies for camps, cantonment, and manufacturing purposes of different types directly or indirectly related to production of war materials. Work for the military soon became an important function of the laboratory. In order for the work to proceed smoothly and efficiently, the Division of Water Quality was established on January 2, 1918, reporting directly to the CHE with Chambers in charge. The personnel list, in addition to Dole, included Fred E. Keating, May 6 to August 23, 1918; Chambers, March 22, 1915, to June 30, 1919; E.C. Bain, January 24, 1913, to August 23, 1914; C.D. Parker, November 14, 1914, to February 24, 1915; Kidwell, July 31, 1917, to June 30, 1919; Ms. Margaret D. Foster, June 15, 1918, to June 30, 1919; Ms. Addie T. Geiger, November 7,1918 , to June 30, 1919; and Mrs. G.S. Goodman, June 3, 1913, to June 30, 1919. Until its separation from the Division of Ground Water, the Division of Water Quality allotments were included in those for the Division of Ground Water. During 1919, a separate allotment of $\$ 9,500$ was made for the Division of Water Quality.

\section{Division of Water Utilization}

The activities of the Division of Water Utilization included the field work in the investigations of water-power withdrawals, applications for rights-of-way for irrigation and water-power projects across public lands, Carey Act set-asides, and examination of land for designation under the Homestead Act of 1909.

The acts of Congress admitting Arizona and New Mexico to statehood in 1912 provided for the classification of large areas of public lands in those States, and the act of June 13, 1912, extended the Homestead Act to California and North Dakota. Thus, at the beginning of the period, the work of the Division of Water Utilization was greater than during the previous period when it had been conducted primarily by LaRue and Murphy. Because the actual classification of the public lands, based largely on the field work, was the function of the Land Classification Board, that Board was closely connected with the work of the Division, and the relation between the two became closer during this period because of Grover's previous connection with the Land Classification Board. In view of this fact and of the limited amount of funds of the Water Resources Branch that were available for the water-utilization program, the need for a larger field staff to handle the work was met by detailing to the Division during the field seasons Heroy, W.N. White, and V.E.J. Mayer of the Land Classificiation Board. LaRue and Murphy continued as fulltime members of the Division and, in August 1916, Dickinson was detailed to assist LaRue.

The procedure involved in the designation of lands subject to entry under the Homestead Act differed considerably from the procedure under the Carey Act. Instead of determining 
that water was available for irrigation under the Carey Act, it was necessary under the Homestead Act to designate public lands for which a feasible supply of water was not available, thus requiring the examination of large areas. Such examinations required, first, a study of existing irrigation projects and available water supplies, including all available engineering reports thereon, to determine whether surplus water was available for additional lands in the vicinity of the projects. If there was no surplus water and if the likelihood of ground-water supplies was also not feasible, the public lands-if nonmineral, nonforested, and reasonably capable of supporting a familywere then designated as subject to entry for homesteads under the Homestead Act.

The classification of lands for water-power withdrawals, under the Water-Power Act of February 15, 1901 (31 Stat. L. 790), involved a reconnaissance of streams having potential water-power value to determine the approximate location of power and reservoir sites, and a study of streamflow records to estimate the probable power value. If public land was even a small part of the area within a possible power site, that land was subject to withdrawal and the government retained control of the site by virtue of the small area of public land.

By the beginning of this period, the set-aside of Carey Act lands had been practically completed. In general, the examinations for waterpower withdrawals were conducted by Murphy and LaRue, both of whom were also conducting the examination of land for entry under the Homestead Act. Heroy, W.N. White, and Mayer were working generally in the Homestead Act work because the examination of the numerous and widely-scattered applications constituted a large part of the Division's activities. The reports of the field staff were reviewed by the Land Classification Board, which classified the lands under the different acts and prepared the appropriate withdrawal orders for signature of the President.

The amount of public land subject to waterpower withdrawals increased in 1916 when a considerable area in western Oregon, chiefly in alternate townships that had been granted to the California-Oregon Railroad, reverted to the Federal Government. Owners of the interlocking land wanted to make exchanges with the Federal Government in order to consolidate the holdings. Before this could be done, the value of the various tracts for power purposes had to be determined in order to protect the public interest in the water-power sites. LaRue and Dickinson as his assistant were assigned to this work, which lasted until July 1917. In the absence of profile surveys of rivers draining the Cascade Range, reconnaissance surveys were conducted to determine power values.

The investigation of desert-land entries to determine available water supplies constituted a relatively small part of Division activities, the most notable instance perhaps being the examination of land in the Imperial Valley. This work, which required a study of the water supply and possibilities for further irrigation in the upper Colorado River basin, may be considered the beginning of LaRue's work on the Colorado River (LaRue, oral commun., ca. 1938).

When the Division of Enlarged and StockRaising Homesteads was created in spring 1917, the Division of Water Utilization merged with it.

\section{Division of ENLARgED AND STOCK-Raising Homesteads}

At the time that the Homestead Act of 1909 was passed, 320 acres of nonirrigable land was thought to be sufficient to support a family raising livestock. By 1916, little public land suitable for that purpose remained, and the USGS supported the enactment of a range law in connection with the 320-acre homesteads. Instead, the Congress enacted the so-called StockRaising Homestead Law on December 29, 1916 (39 Stat. L. 862), which contained among others, the following provisions:

Section-1. That from and after the passage of this act it shall be lawful for any person qualified to make entry under the homestead laws of the United States to make a stock-raising homestead entry for not exceeding six hundred and forty acres of unappropriated unreserved public land in reasonably compact form: 
Provided, bowever, That the land so entered shall theretofore have been designated by the Secretary of the Interior as 'stock-raising' lands.

SEC.-2. That the Secretary of the Interior is hereby authorized, on application or otherwise, to designate as stockraising lands subject to entry under this act lands the surface of which is, in his opinion, chiefly valuable for grazing and raising forage crops, do not contain merchantable timber, are not susceptible of irrigation from any known source of water supply, and are of such character the six hundred and forty acres are reasonably required for the support of a family.

SEC. -10 . That lands containing water holes or other bodies of water needed or used by the public for watering purposes shall not be designated under this act, but may be reserved under the provisions of the Act of June $25,1910^{* * *}$.

Provided, That the Secretary may, in his discretion, also withdraw from entry lands necessary to insure access by the public to watering places reserved hereunder and needed for use in the movement of stock to summer and winter ranges or to shipping points, and may prescribe such rules and regulations as may be necessary for the proper administration and use of such lands. Provided further, That such driveways shall not be of greater number or width than shall be clearly necessary for the purpose proposed.

So many applications were received for entry under this law that a much larger field staff was necessary. The Sundry Civil Appropriation Act of June 12, 1917 (40 Stat. L. 105), contained the following item:

For the examination and classification of lands requisite to the determination of their suitability for enlarged homesteads, stock-raising homesteads, public watering places, and stock driveways, as required by the public land laws, to be immediately available, $\$ 150,000$.

Heretofore the field work of classifying the public lands had been conducted by Division of Water Utilization personnel at the expense of the general appropriations for the Water
Resources Branch and the Land Classification Board, and the field staff had necessarily been small. Anticipating the appropriation of funds for the classification of lands for stock-raising homesteads, the Civil Service Commission held a special nonassembled examination open to graduates of engineering and agricultural colleges and to those with experience in land classification, and established a register of eligibles.

When the appropriation became available, the Division of Enlarged and Stock-Raising Homesteads was organized with Grover as chief and A.E. Aldous as assistant chief. Murphy transferred to the Division immediately, but LaRue did not transfer until he had completed his assigmment in Oregon in July 1917. Thus, the Division of Water Utilization merged with the new division as both LaRue and Murphy continued in a limited way to examine waterpower sites, the chief remaining work of that division.

Thirty eligibles were appointed as land classifiers and junior land classifiers almost immediately and, within a few months, the number increased to considerably more than 100 (H.C. Cloudman, oral commun., ca. 1938). To obtain the most expeditious action on the hundreds of pending applications, the Secretary issued instructions that the field work should be limited to the lands covered by the applications. Accordingly, the new staff of classifiers was organized into parties each consisting of a chief and nine assistants and assigned to examine applications in a designated region. The men worked in crews of two or three and were furnished with Ford cars for transportation and with field equipment, including plane tables with open-sight alidades. Pertinent facts regarding land, soil, vegetation, timber, and available water supply if any were recorded.

Although the general procedure was similar to that followed in classifying land for entry under the Homestead Act, greater attention was paid to the carryinng capacity of rangelands because the land now being examined was in most instances of poorer quality. If the land under examination had so low a capacity for carrying stock that 640 acres was insufficient to support a family (30 cattle or the equivalent in sheep), it was classified as unsuitable for entry. In a study by LaRue in Arizona, he found that, 
depending on the quality of rangeland, the area needed for a single cow fluctuated from 30 acres to 3 townships (LaRue, oral commun., ca. 1938).

Within a few months, Aldous devoted his time solely to the office work for the Land Classification Board and Cloudman, who had joined the USGS in July, was put in charge of the field parties. The field season lasted from May to October, after which the classifiers went to Washington, D.C., to prepare their reports. The reports were assembled and reviewed by Aldous and presented to the Land Classification Board as bases for recommendations to the Secretary of the Interior regarding final action on the applications.

The Sundry Civil Act of July 1, 1918, contained a further appropriation of $\$ 197,268.60$ for classification work, which continued until November 1918 when the appropriation was so nearly exhausted that it was necessary to reduce the force to 25 men who transferred to Washington, D.C., to prepare the reports. Additional funds were unavailable until July 1919 , and little additional field work was conducted during this period.

\section{Division of Power Resources}

The Division of Power Resources was an outgrowth of the wartime activities of the Fuel Administration. During the years of World War I before the United States entered the conflict, the manufacturers of ammunitions for the belligerents had needed such an increase in power that, when the United States entered the conflict in April 1917, it was obvious that Federal control of power resources, particularly coal, would be necessary. The Fuel Administration was created by Executive Order on August 23, 1917, and Harry A. Garfield was appointed United States Fuel Administrator. The main purpose was to insure an equitable distribution of fuel at reasonable prices consistent with a fair margin of profit to miners and dealers. An administrator was appointed in each State to oversee the program.

The Fuel Administration was divided into several bureaus, two of which were directly connected with this History: the Bureau of Statistics, the duty of which was to compile statistics on the production, distribution, and consumption of coal, and the Bureau of Conservation, the duty of which was to initiate plans for the conservation of power resources (U.S. Fuel Admin. rept., 1917-19). Whereas the Bureau of Conservation had no field staff of engineers of its own and time was a vital factor in its activities, a cooperative agreement was signed with the USGS in spring 1918 whereby USGS engineers would be detailed to the Fuel Administration whenever specific power problems needed to be investigated (USGS 40th ann. rept., 1919, p. 155).

The Division of Power Resources was organized on July 1,1918 , to provide the greatest possible service to the Fuel Administration in studying power problems. Heroy, who had been in charge of the Section of Hydrographic Classification, Land Classification Board, transferred to the Water Resources Branch to be placed in charge of the Division. Before the United States entered the war, Heroy had discovered that no government organization had complete records of existing power resources, and he conceived the idea of preparing a record of electric power stations and the relation of power requirements to fuel supplies, and maps showing existing transmission lines (Heroy, oral commun., ca. 1938). In August 1918, A.H. Horton was detailed to the Division.

One of the first tasks was to compile a mailing list of all electrical utilities. Then data began to be collected pertaining to installed capacities, fuel requirements, operation, and output of electrical power plants. In cooperation with the Bureau of Statistics, weekly reports were received and these were used in special investigations.

The special investigations were usually conducted at the request of the State administrator and were under the direction of the USGS district engineer in whose district the investigations were conducted. These investigations included, as described by A.H. Horton in the USGS 40th annual report in 1919 (p. 155), a "reported shortage of power and poor power service affecting the production of war necessities, especially in the mining of coal; economies to be gained by interconnection of electric 
power stations; opportunities for the substitution of water power for fuel power; installation of additional generating equipment of power plants; increase of facilities for water storage and for use of stored water to increase the production of power by hydroelectric plants; the feasibility of financing and constructing new water-power developments; and the obtaining of licenses for the purchase of construction materials and generating equipment required for such developments."

A.H. Horton might have added that it was also necessary to obtain from the Railroad Administration authority to ship materials via the railroads because, under wartime regulations and because of the tremendous increase in freight traffic, prompt service could not be provided for all shipments and freight had to be shipped in order of the priority determined by the Railroad Administration. As the investigations proceeded, it was soon evident that a marked shortage of power throughout the country would occur. To speed up the investigations, 13 engineers, then chiefly in the consulting business, were employed on a per-diem basis to assist in the investigations. Among these were Harley and J.C. Stevens, former members of the Branch.

Reports of many of the investigations were sent to the Fuel Administration and, in connection with some investigations, to the War Industries Board, the Capital Issues Committee, and the War and Navy Departments. The program of field investigations was in full swing during the latter part of 1918 and numbered more than 50 , but was cut short when the armistice was signed. A few investigations that contributed to the saving of fuel during the ensuing winter were continued.

Soon after the armistice, Administrator Garfield asked the DOI to continue those functions of the Fuel Administration that were of permanent value to the country. Thus, the USGS agreed to continue to collect fuel statistics, including those of power development and output and consumption for electric power generation (Newsletter, Dec. 30, 1918). Weekly power company reports were superseded by reports at the end of each month, beginning with February 1919. The power companies were sympathetic toward the program of fuel conservation. The great demand for electric power after the war caused fuel prices to remain high, and because power rates were not raised, the companies looked for relief to economies in fuel consumption. At about that same time, the USGS first called attention to the wide fluctuations in the consumption of fuel per kilowatt-hour, which showed clearly the difference between efficient and inefficient equipment and methods (A.H. Horton, oral commun., ca. 1938).

Cooperation with the Fuel Administration ended in January 1919, and thereafter the work was conducted entirely by personnel of the Division of Power Resources. USGS personnel included Heroy (chief), A.H. Horton, G.D. Thomas, Ms. B.B. Borst, Ms. H.G. Broughton, Ms. E.M. Klemm, and Ms. Edith Paul, who resigned on April 1, 1919. Heroy resigned June 30,1919 , and was succeeded by A.H. Horton. The USGS allotment for the Division of Power Resources during 1919 was $\$ 12,000$.

\section{War ACTIVITIES}

In contrast with the Topographic Branch, which was taken over as a unit by the Army, the Water Resources Branch was but lightly touched by World War I. Its normal activities, except those of the Division of Ground Water, were scarcely disturbed. Only rapid increases in prices necessitated the deferral of purchases of equipment and of construction of new gaging stations. The requirements of the Fuel Administration, however, did increase considerably the work of Branch employees. Like all other groups of citizens, many of the members of the Branch joined the Armed Forces of the country.

As early as 1916, the lengthening shadow of a possible war caused a wave of preparedness to sweep over the country and a few training camps were established when citizens enrolled for military training. Several members of the Branch attended these camps. In keeping with the times, the USGS Director sent a letter to the Interior Secretary calling attention to the engineers in the USGS and their availability for military activities, and concluding with the following suggestion (Newsletter, Mar. 21, 1916):

Considering that the Government has in the Geological Survey an organized 
body of trained men who are willing and anxious to do their part toward 'preparedness,' I respectfully suggest that the attention of the Secretary of War and the military committees of Congress be called to this corps and that they be requested, when considering any plan for a reserve corps or similar organization, to enroll the engineers of the Geological Survey as a part of it.

Although this suggestion was ignored, several employees of the Branch enrolled in the engineer officers reserve corps that was created some months later, or joined units of the $\mathrm{Na}$ tional Guard.

When war was declared on April 6, 1917, the tempo of war activities quickened, as indicated by the following excerpts from two Newsletters:

Military activities in Washington are rapidly increasing. Many of the departments are adjusting their work so as to be of more use to the Army. There is a large amount of voluntary practice drilling both by men in and out of the Government service. (Apr. 18, 1917).

War activities are very evident in Washington. The training camp at Fort Myer is under way and the town is filled with people who have come to advise in regard to the various phases of the war situation. An example of the magnitude of the task is shown by the appropriation for engineering equipment. This appropriation for last year was $\$ 100,000$, while for the coming year it is $\$ 35,876,000$. (May 29, 1917).

The passage of the draft law required every male citizen between 18 and 45 to register for military duty, with provision for deferred classification of certain groups including those whose work was essential to the Federal Government. The effect of this law on the employees of the Branch is indicated by an excerpt from the Newsletter of September 30, 1918:

All the employees of the water Resources Branch, with the exception of four, were included in the registration on Sept. 12. The Director has stated that he considers the tasks which most of these men are now doing as necessary work in which they cannot be replaced without substantial material loss to the
Government and that he intends to recommend them for deferred classification *** , unless individuals object for personal reasons. Necessary affidavits have been submitted to the Secretary's office for approval for men whose draft numbers have been received. Some of the men have filed objection to such deferred classification.

The armistice was signed 2 months later.

The following members of the Water Resources Branch were in the Military Service during World War I (USGS 40th ann. rept., 1919, p. 141-2):
Richard Aitken

Herbert A.R. Austin

Charles R. Bell

Leland Bell

Revoe C. Briggs

John S. Brown

Kirk Bryan

Earl H. Buchanan

John W. Campbell

Harold C. Cloudman

Frederick C. Corey

George S. Cowdery, Jr.

Aldace H. Davison

Henry J. Dean

Jesse E. Dickerson

William E. Dickinson

Joseph J. Dirzulaitis

Charles J. Downing

Max Drill

Donald A. Dudley

Joe B. Entringer

Albert G. Fiedler

Edgar O. Francisco

Raymond E. Gaylord

Wilbur R. Gore

Marcus L. Gossard

Eugene L. Grant

Homer E. Grosbach

Warren E. Hall

Oliver W. Hartwell

Bryant L. Hopkins

Bernard A. Howell

Clarence C. Jacob

Reid Jerman
Fred E. Keating

Joseph Krauskopf

William A. Lamb

George K. Larrison

Otto Lauterhahn

Ariel Lindquist

George J. Lyon

Floyd B. McGregor

Lester R. McNeely

Paul G. Mayer

Oscar E. Meinzer

Arthur H. Montford

Robert E. Morgan

J. Wendell Moulton

Malcolm G. Murray

John R. Neale

Carl G. Paulsen

Charles H. Pierce

Roy H. Quinn

James P. Reddick

Clyde P. Ross

John J. Sanford

Albert H. Shunk

George H. Smalley

M. Reginald Stackpole

James E. Stewart

Herman A. Stone

Harry Thompson

Marion I. Walters

Arnold N. Weeks

Eugene L. Williams

Allen L. Willie

Leon Willie
Merritt L. Shearer

Evaluation of the Years from 1913

TO 1919

\section{By Nathan C. Grover}

During the years from 1913 to 1919 , the previously established work of the Water 
Resources Branch was essentially stable and there was added the temporary new work in examining land for entry under the Homestead and Stock-Raising Homestead Acts and the emergency duties incident to World War I. Work related to the Homestead Acts became suddenly and for a period of a few years one of the important activities of the Branch, bringing to it a large temporary force (totaling about 150 technical persons) consisting of geologists, agriculturists, and engineers who were assigned to field surveys that would serve as bases for classifying lands for entry under those acts (must be chiefly valuable for grazing and raising forage crops, must be such that 640 acres can support a family, and must be nonirrigable and nontimbered). Because many of the problems were new to the Branch and to the USGS, a new organization was set up with Heroy as the first principal motivating force, and with Aldous, who transferred from the DOA, as the responsible agriculturist and administrative chief of the division. H.L. Shantz, a DOA expert on plants in their relation to the environment, and C.F. Marbut, chief of the Bureau of Soils, served as consultants and advisors in connection with this work.

World War I brought many new problems and responsibilities that were largely related to water supplies, both surface and underground, for military establishments and to the needs for water in connection with essential war activities. This emergency work was conducted largely by the regular personnel, and necessarily curtailed to some extent the regularly established programs. In connection with this work, the Division of Power Resources was created with Heroy as chief. The activities of this division led to the statistics of power work that continued after the war and served the country in an important way in problems of energy supply.

Many of the engineers and geologists of the Branch entered the Army and Navy and served in the activities of those two services. Some were assigned to special duties related to technical problems in connection with water supplies for the Expenditionary Force. Others served with troops in different capacities.

During this period, the joint operation of international stations on the United
States/Canadian boundary was started in connection with the international aspects of the waters of the Milk and St. Mary Rivers. This practice has been continued and expanded in the years since.

The regular work of the Branch was continued, enlarged, and strengthened. The strengthening involved expansions of an old science-hydrology-and the creation of a new art-that of studying water on and beneath the surface of the land, including the development of instruments, equipment, methods, and techniques. Progress was slow in this creative work. The school at Embudo, N. Mex., had laid a foundation by testing all known methods and instruments. During the first years of specific appropriations for stream gaging, funds were too meager for any considerable development work. From 1902 to 1906, the interests of the senior members of the Branch related to the work of the newly created Reclamation Service and not to the study of water. Slow progress nevertheless was made through these early years, however, and also from 1906 to 1913 when the struggle for Branch existence was acute.

From 1913 to 1919 , the group of young and enthusiastic engineers and geologists made noteworthy progress. The enumeration of a few changes will serve to emphasize the significance of the period in improving technique and equipment: Artificial controls were developed in form and construction and became recognized parts of gaging stations at sites where the conditions warranted; the methods for collecting winter records were greatly improved both in the information collected and in the practical methods of using it to obtain acceptable results; the discharge integrator was devised and perfected, thereby increasing the accuracy of the records and decreasing the work involved in computations; methods for quantitative investigations of ground water were developed and applied; instruments and methods were improved; and cooperation with States continued and in some cases extended. The period, therefore, was an important one in the maturing, stabilization, and growth of the Branch activities along sound lines.

In the previous period, the fight for existence had been waged and won. In the present 
period, the struggle was continuous for adequate finances but without the ever imminent danger of extinction from the point of order. The Branch personnel, following the departure of the Reclamation Service, were reaching maturity. There was time for work where previously there had been a struggle for life. There was an opportunity for many improvements in instruments, equipment, and methods. These men and women grasped the opportunity and developed rapidly along many lines that led to increased accuracy of results and greater efficiency in obtaining them. The improved records of the period are enduring evidence of their success. 


\section{NAME INDEX}

\section{A}

Abbe, Cleveland, Jr.

Abbot, H.L.

Adams, A. Judson

Adams, C.R.

Adams, G.F.

Adams, R.M.

Agassiz, Alexander

Ahern, Jeremiah

Aitken, Richard

Aldous, A.E.

Allen, L.R.

Anderson, M.D.

Armstrong, L.K

Armstrong, W.E.

Arnold, Sydney

Atkinson, Rha L.

$\mathrm{Au}$, Carl $\mathrm{H}$.

Austin, Herbert A.R

\section{B}

Babb, Cyrus C. 3, 49-51, 53, 55, 57-59, 61-62, 72-73, 75, 105, $108-9,121,130,170,217$

Bailey, C.T.

Bain, E.C.

Baker, J.S.

Baker, Selden $X$.

Baldwin, G.C. $240,250-52$

Ballinger, Richard A.

Bannon, T.M.

Barbour, E.H.

Barnard, E.C

Barnes, R.S.

Barrows, A.T.

Barrows, Harold $\mathrm{K}$. 156,159

Batchelder, C.L.
$164,173,182,263$

272

72

116-18

$137,178,194,209,220,223,228-30$,

$160-61$

$35-36,41,47,50$ 67

138

243

185-86 $78,93,98-101,121,130-31,153$

$211,231,258$

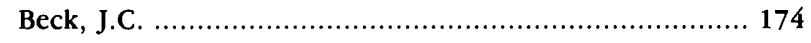

Becker, George F. .............................................. 21

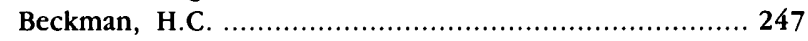

Bedford, T.G. ......................................... 256, 259

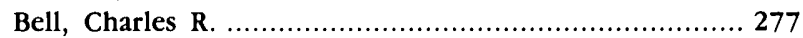

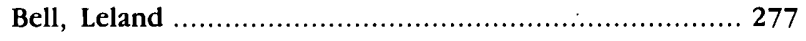

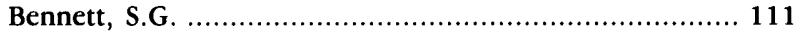

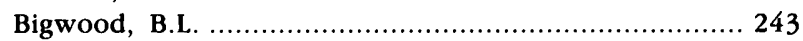

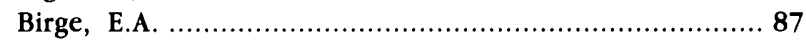

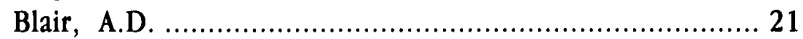

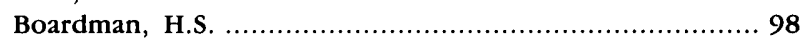

Bodfish, Sumner .............................................. 21

Bolster, Roy H. .......... 86, 89-90, 124, 142, 158, 234, 246

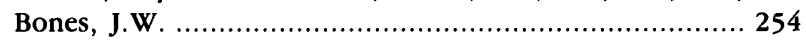

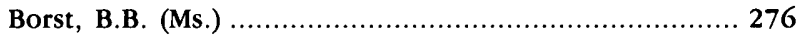

Brett, G.M. ............................................. 162, 169

Briggs, Revoe C. ........................... 231, 257-58, 277

Broderson, B.W. .......................................... 232

Brooks, Alfred Hulse ............. 144, 183, 185, 187, 260-61

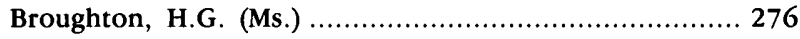

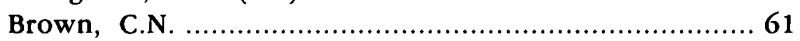

Brown, C.O. ........................................ 256, 261

Brown, John S. ........................ 232, 267, 270-71, 277

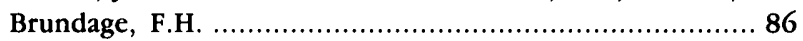

Bryan, Kirk .................. 190, 193, 266-67, 270-71, 277

Buchanan, Earl H. ............................................... 277

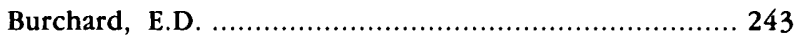

Burnham, W.W. ...................................... 116-18

Butterfield, A.D. ........................... 98, 162, 169, 182

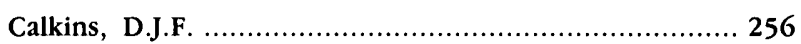

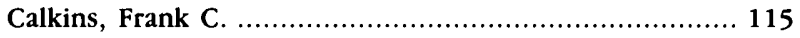

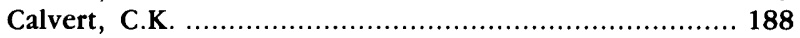

Campbell, John W. ....................................... 277

Canfield, G.H. .............. 167, 169, 178, 181, 247, 259-62 
$C$ (cont.)

Cannon, Joseph G

Capps, S.R.

119

Carpenter, Everett

190-91

Carpenter, L.G

$190,192,271$

Carson, M.H.

$44,70,103,106$

Chamberlin, Thomas Chrowde

$213,243,262$

Chambers, A.A

Chandler, A.E.

198,272

Chandler, E.F.

$171,173-74,227-28,246-47$

Chittenden, H.M

Christiansen, E.O.

Christie, P.H.

Clapp, F.G.

Clapp, S.K.

Clapp, William B.

$95,104,110$

Clark, F.A.

Clark, William Bullard

Clark, W.O

Clarke, F.W

Cloudman, Harold C.

Cogswell, Filmore

Collier, I.L.

Collins, William D.

$68,92-93,103,105,134,148,156-57$

Condra, G.E.

Condron, A.H

Congdon, E.P.

Corey, Frederick C.

Covert, C.C.

$167,169-70,185-86,194,222,224,227-28,242-43$
Cowdery, George S., Jr. ............................. 250

$178,236,254$

Crandall, Lynn

Crofts, H.P.

Cunningham, Allen

Curtis, George E.

$175,181-82$

34,36

190-91

101,103

$111,139,180-81$

... 21

61

$193,259,265,270-71$

$115,118,271-72$

$274-75,277$

56,71

258

$116,118,121,188-89$

$88-89$
115

245

249

$101,125-26,132,148,151,153,162$,

............................ 250, 277

............... 44

\section{D}

Darton, Nelson Horatio

Davenport, R.W.

avis, Arthur Powell ........ 3, 51, 53-57, 60-62, 65, 69, 72,

74-75, 79, 108, 110-11, 121, 237

Davis, James $\mathrm{D}$

18

Davis, Jennie T. (Mrs.) ............................................. 53

Davison, Aldace H. ............................... 243, 277

Dean, Henry J. ............. 124, 198, 244, 252, 257-58, 277

DeGolyer, C.S. .................................................. 243

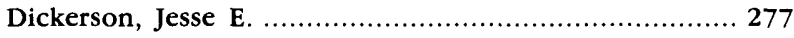

Dickinson, William E. ................... 254-56, 272-73, 277

Dickman, Marian J. (Ms.) ...................................... 167

Dils, N.S. .................................................. 73, 109

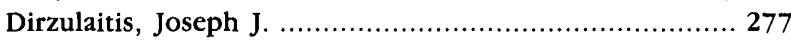

Dobson, Adna ............................................... 107

Dole, Richard B. ...... 116-17, 121, 187-90, 192-93, 271-72

Dort, J.C. .................. 173, 178, 182, 252-54, 259, 263

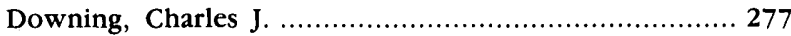

Drane, Brent S. ................................................ 102

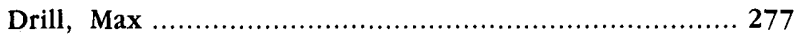

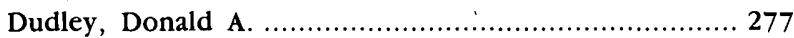

Dutton, Clarence E. ......... 1, 13, 21-22, 27-29, 33-34, 36,

39-40, 44, 46-47

Dyar, H.M.

$36,41-42,44$
E

Eaton, F.M. ..................................................... 118 Ebert, F.C. ......... 180-81, 212, 214-15, 223, 225-26, 228, $231,259,265$

Ellet, Charles, Jr. 30,90

Ellis, A.J.

190-91, 266-67, 270-71

Ellis, T.G. ......................................... 31, 37-38

Ellsworth, C.E. ............ 124, 180, 185-87, 194, 220, 240, 248-49, 254-55

Elwood, W.A. 242

Emerson, C.J.

$173,176,250,258-59$

Emery, Roe ...

Emmons, Samuel F. .............................. 6, 7, 20-22

Entringer, Joe $B$.

Evans, J.R. 277 189

\section{F}

Farish, W.A

Fear, H.W.

$35-36,39-42,45-47,111$

.

Fellows, A. Lincoln .............. 71, 85, 105-6, 121

Ferguson, George E. ............................... v

Fiedler, Albert G. ........................... 252, 277

Fisher, Cassius A. ................................... 114

Fisher, Frank .................................... 36, 115

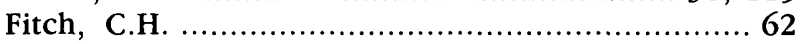

Fletcher, R.H. ........................... 175-76, 250

Flynn, B.H. ................................. 61, 87

Follansbee, Robert ............ v, 2-4, 46, 86, 104, 109,

$121,124,127,134,137,146-47,159,162-63,166-67$, $173-76,208,217,250$

Follette, W.W. 103

Fortier, Samuel ................... 54, 72-73, 108, 121

Foster, Margaret D. (Ms.) ......................... 272

Francisco, Edgar O. ....................... 249, 277

Frazier, Arthur H. ................................... 48

Freeman, John R. ............................. 155

Freeman, W.B. ...... 109, 136-37, 149, 151, 158, 175

French, J.A. ........................................ 137

Friez, Julien P. .............................. 150-51

Fuller, E.S. ......... 126, 148, 178, 180, 233-34, 258

Fuller, M.L. ............... 112-14, 121, 124, 189-91

\section{G}

Gannett, Henry ............. 22-23, 29, 49, 53, 143, 155, 167

Gardner, James T. ........................................... 9-10

Garfield, James R. ............................................... 160

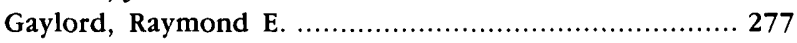

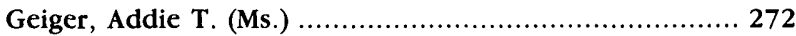

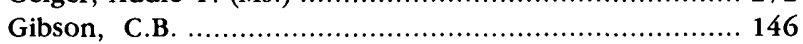

Gilbert, Grove Karl .......... 13-14, 21-22, 66, 121, 164-65, 241-42

Giles, J.M. ................................. 102, 108, 177

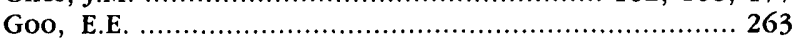

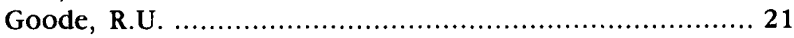

Goodman, G.S. (Mrs.) .............................................. 272

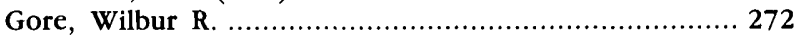

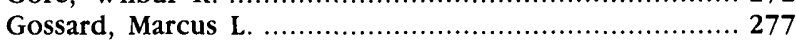

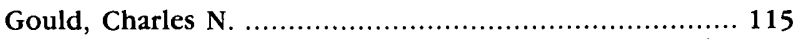

Grant, Eugene L. ............................................ 248, 277

Gray, Glenn A. ....... 126, 146, 171, 173, 175-76, 199, 244 248-50 


\section{$G_{\text {(cont.) }}$}

Gregory, H.E.

$191,193,267$

Grosbach, Homer E.

277

Grover, Nathan Clifford .......... 2, 4, 57, 79, 85, 89-90, 92, $100,102,119,121,123-24,127,134,161,193,195-98$, 207, 215-16, 229-30, 232, 235-36, 238, 272, 274, 277

Grunsky, C.E. 32,74
$6,15,30-31,38-39,91$ $76,96-97,102$

Irving, R.P. $35-36,41,47$

Hague, Arnold 7, 21-22

Haines, R.E. 181

Hall, B.M. $59,74,76,97,102,244$

Hall, Charles M. 68,115

Hall, C.W. 19189 ,

Hall, Maxie R. .... 3, 58, 67, 85, 97, 102, 108, 121, 147-49, $157,170-71,194,220,232$

Hall, Warren E. .............. 76, 97, 102, 121, 148-49, 171, $914,207,226,232,244-45,248,277$

Hall, W. Carvel 98, 167

Hall, William Ham $27,31,37,42,44-45$

Hall, Willis E. 124,198

Hamlin, Homer $67,114-15$

Hank, R.J. 249

Hanna, F.W. $3,89-90,92,103-5,121$

Hardy, W.V $111,159,181-82,258-59,263$

Hare, R.F.

192,266

Harley, George F. $89,110,276$

Harrington, A.W.

Harrison, Frank

Harroun, P.E. 36,42 Haskell, E.E. 55,75

Haugse, E. Hazel (Ms.) ......................................... 252

Hayden, Ferdinand Vandiveer ................ 8-11, 15, 20-21

Heilbron, E.H 87,104

Hendrixson, W.S. 191

Henny, D.C.

139,178

Henry, D. Ferrand ... 32

Henshaw, Fred F. ............ 86, 121, 124, 144, 178, 180, 184-86, 194, 233, 255-57

Hering, Rudolph 32

Heroy, W.B. $161,198,272-73,275-76,278$

Hewel, A.G. .. 252

Hinderlider, M.C. $45,105-8,121,175$

Hines, Charley $87,103-4$

Hoag, W.R.

250,258

Hodges, P.V. $84-85,88$

Hollister, George B.

$59,65,119$

Holmes, Joseph A

67,69

Hopkins, Bryant L.

Hopson, L.D. 277 orton, A.H. ...... 99-100, 102-4, 121, 142, 146, 149, 153,

$158,163,171-72,194,203,216,218,238-39,245,275-76$ Horton, Robert E. $66,77-79,85-96,91-94,100-1$, $121,169,171$

Howard, E.C. 252, 256

Howell, Bernard A. 277

Hoyt, John Clayton.......3, 53, 59, 84-86, 88, 90, 106, 121, $124,142,144,146-47,158,161,167,183,185,194-95$, $198,215,218,235-36,238,251$

Hoyt, W.G. ..... 156, 163, 169, 173, 205-6, 227-28, 246-47

Humphreys, Andrew A.

Humphreys, D.C.

\section{$\mathbf{H}_{\text {(cont.) }}$}

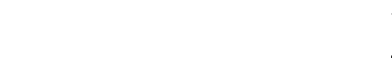

I $35-36,41,47$

Jackson, D.D. .........................

Jackson, H.J.

............................... 116

, Wenry ........

Jacob, Clarence C. ..... 140, 181, 199, 228, 236, 252-55, 277

Jerman, Reid ............................................. 277

Johnson, B.L. ........................................... 113

Johnson, E., Jr. ..................................... 103-4

Johnson, Harry R. .............................. 114, 190, 192

Johnson, W.D. ...............................67, 92, 113

Jones, B.E. .................... 174, 217-18, 228, 233, 247

Jordan, L.W. ....................................... 252-54

\section{K}

Kaheaku, J. ................................................ 263

Keating, Fred E. ....................................... 272, 277

Keif, C.W. ............................................. 252

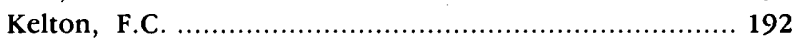

Kendall, L.B. .................................... 35-36, 73

Kessler, William ....................... 245-46, 249, 252, 259

Kidwell, C.H. ....................................... 271-72

Kilgore, R.B. ................................. 247, 252, 256

Kimball, J.P. ........................................... 21

Kimble, Howard $\ldots \ldots \ldots \ldots \ldots \ldots \ldots \ldots \ldots \ldots \ldots \ldots . \ldots \ldots, 229,263$

King, Clarence ...................... 5-7, 10, 15-17, 20-22, 66

King, F.H. .................................... 66-67, 113

King, Warren R. ................................... 178, 250

Kinnison, H.B. ..................................... 248-49

Klemm, E.M. (Ms.) ...................................... 276

Klise, R.D. ................................................. 263

Krauskopf, Joseph ................................... 277

Kunesh, J.F. ....................................... 254, 259

\section{L}

Lamb, William A. ............. 106, 108, 121, 149, 159, 171, $174,177,181,194,199,208,217-18,227-28,247,277$ Landes, Henry ..................................... 115, 138 Lane, A.C. ............................................. 36, 47 Lane, Franklin K. .................................... 199, 214 Lane, W.B. ................................................. 44 Larrison, George K. ................. 169, 182, 229, 263, 277 LaRue, E.C. ............ 109, 111, 154, 161, 177-78, 272-75 Lauterhahn, Otto ...................................... 277

Lee, C.H. ........................ 111, 193, 263, 265-66

Lee, Lasley .................................. 181, 256, 258-59

Lee, William T. ......................................... 114-15

Lee, Willis $\mathrm{T}$. ............................................. 191 


\section{L (cont.)}

Leidl, Charles

Leighton, Marshall Ora

$180-81,259$

$123-25,127,129,133,136-37,142-43,145-46,152,154-55$, $158-59,161,165-67,169,185,187,191,194,197,244$, 255

Lewis, J.H.

$96,110,139$

Lewis, S.J. 116-17

Lindquist, Ariel 277

Lines, E.F. 113

Lippincott, J.B. 114,151

Lyon, George J. $55,58,62-63,67,74-75,85,110-11$, $169,175,222-24,243,277$

\section{$\mathbf{M}$}

McCashin, C.E.

248-49

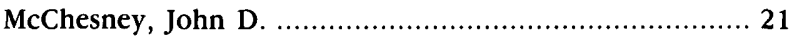

McChristie, M.C. .............................................. 174

McConnell, I.W. ................................................. 104

McGee, W J ................................................ 143

McGlashan, H.D. ......... 139-40, 162, 180-81, 194, 211-12, 221-24, 228, 234, 254, 259

McGregor, Floyd B.

277

McNeely, Lester $\mathbf{R}$

277

Mackenzie, A. .................................................... 32, 37

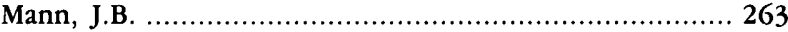

Marr, Robert A. .

Marsh, Othniel C.

... 30

Marshall, R.B.

Martin, W.F

7,18

Mathers, J.G

.. 239

Matthes, Gerard $\mathbf{H}$

$111,141,146-47,181-83$

Maxwell, George $\mathbf{H}$

124,198

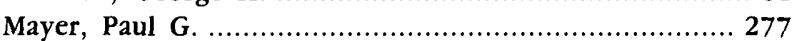

Mayer, V.E.J.

Mead, Elwood

272-73

Meek, Fielding B

Meeker, Ralph I.

$44,54,56,72,150$

Meinzer, Oscar E.

106,175 269-71, 277

Mendenhall, Walter Curran ............66, 114-15, 121, 124, $146,159,161,189-90,192,263,266$

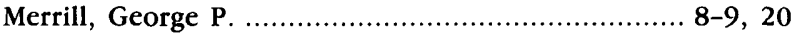

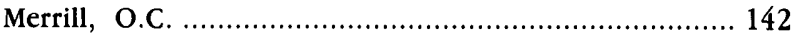

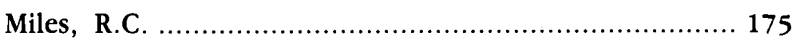

Mills, Anson ........................................ 41-42, 44

Mills, F.J. ........................................................... 73

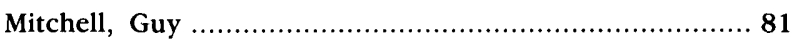

Mitchell, J.W. ...................................................... 35-36

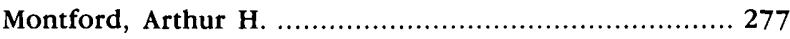

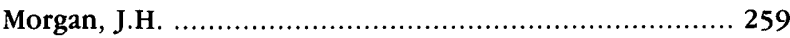

Morgan, Robert E. .............................................. 277

Morse, H.M. .......................................... 109, 174

Moulton, J. Wendell .................................... 243, 277

Muldrow, W.C. ................................... 110, 148

Murphy, E.C. ........... 3, 56, 65, 67, 69, 84-85, 88-90, 93, $100,107,110,121-22,124,161,164-65,181,231-32$, 272-74

Murray, F.A.

Murry, Malcolm G.

277

Myers, E.W. $59,76,85,102$
Neale, John $\mathbf{R}$. 277

Needham, James ............................................ 126-27

Nettleton, Edwin S. ....... 27, 29, 32, 45, 47-48, 54, 70, 150

Newberry, John S. ............................................. 18

Newcomb, Simon .................................................. 18

Newell, Frederick Haynes ......... 1, 3, 27-29, 33-36, 39-41, $44,46-47,49-51,53-56,58-62,65-68,71-72,77,79-85$, 87-88, 99, 109, 112, 115-16, 119, 121-22, 124-25, 141, 143, $157,160,194,206$

Newell, T.R. 252

Newlands, Francis

$81-82,95,109$

Noble, Theron A 109-10

Norcross, T.W.

$93,101,169,181$

Norton, William $\mathrm{H}$ 191

O'Brien, Frank 250

Olberg, C.R. 62

\section{$\mathbf{P}$}

Padgett, Harold D.

$86,124,175,198$

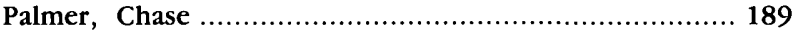

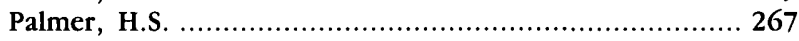

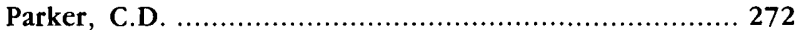

Parker, Glenn L. ........... 138, 149, 180, 186-87, 194, 218,

220, 224-25, 239, 255-56

Parker, Horatio N. ............................ 116-17, 188-89

Parshall, A.J. ............................ 72, 85, 106, 135

Paul, Edith (Ms.) ........................................... 276

Paul, E.G. ..................... 3, 57-58, 60-65, 76-77, 84-86, $100-2,121$

Paulsen, Carl G. 256, 258, 277

Peale, A.C. $203-4,225,228,245,250-52$,

Peterson, B.J.

Pierce, Charles $\mathbf{H}$. 232, 242-43, 277

Pierce, R.C.

Pinchot, Gifford

Place, A.E.

Porter, Dwight

Porter, E.A. 229-30, 237, 252-54

Powell, John Wesley ... Prall, C.T.

Pressey, F.E. $198,246-47$

. $46,182-83,199,222,229$, $180,194,220,236,248-49,252-54$ $81,128,143,160$

$178,187,199,210,220,225$

Pressey, H.A.

Price, William Gunn

Pumpelly, Raphael

Purton, A.B.

$1,11-13,15-16,18,20$ $92,100-1,169-70$ $61,65,79,84-85$ .. 48,58 $178,231,252-54$

\section{Q}

Quinby, George T. $29,35-36,39,41,44,47$ Quinn, Roy $\mathbf{H}$. 277

Rafter, George w. 77 Ralph, G.A. 
$\mathbf{R}_{\text {(cont.) }}$

Randell, Ralph R.

Reddick, James P.

Reed, Howard S.

$174,235,247,258$

Renshawe, John H.

Rice, R.C.

Richards, Raymond

Richardson, George B.

Riddell, C.W.

Roberts, M.G.

Robertson, Robert

Rogers, William B.

Romero, Juan

Roosevelt, Theodore

Ross, Clyde P.

Ross, D.W

Ross, W.H.

Roush, L.W

Russell, G.H

Russell, I.C.

Russell, W.G.

Ryon, A.M.

Sanford, John J.

229, 252-54, 277

Sanford, Samuel

113

Sauder, P.M.

217

Sawyer, W.C.

$86,102,110,181$

Schurz, Carl

Schwennesen, A.T.

Shearer, Merritt L.

266-67, 27

Sheridan, Philip Henry ...................................... 7

Sherman, William Tecumsch ..................................... 7

Shirley, F.S. .................................................... 73

Shumway, Dick ............................................. 35-36

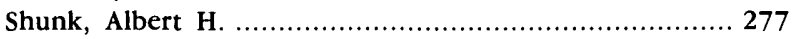

Siebenthal, C.E. ........................................ 114-15

Simpson, H.E. ................................................ 191

Slichter, Charles S. ................. 66-67, 113-15, 121, 265

Smalley, George H. ........................................... 277

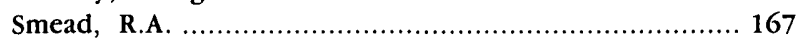

Smith, F.D. ............................................... 72

Smith, F.M. .............................................. 44, 47

Smith, G.E.P. .................................... 111, 141

Smith, George Otis ............. 3, 19, 119, 127, 142-43, 160

Smith, H.K. .................................................. 250

Smith, L.S. ............................... 88, 99, 103, 171

Smith, P.S. ..................................................... 145

Soule, S.B. .......................... 173, 205, 246-47, 250

Spaulding, H.S. ............................................. 189

Spiegel, J.B. ................................... 69, 250, 254

Stabler, Herman .................. 3, 17, 22, 66, 116-18, 121,

$160-61,188-90,192$

Stackpole, M. Reginald

Stafford, Harlowe M.

$94,243,277$

Stearns, N.D.

258-59

Stevens, G.C.

266-67

$235,238,243$

Stevens, John C.

$158,178-80,221-22,276$

Stevenson, James
$S$ (cont.)

Steward, W.G

$86,110,124,147-49,181$

Stewart, J.B. $175,182,247$

Stewart, James E.

$174,181,256,258,263,277$

Stockman, L.R.

$88,92,103,109$

Stone, Herman A.

277

Storey, F.B.

180,256

Stout, O.V.P. ...... 54, 64, 67-69, 91, 106-7, 121, 156, 234

Sullivan, Vernon L. ........................................ 136-37

Suttie, R.H.

243

Swendsen, G.L.

$73,85,108-9$

\section{$\mathrm{T}$}

Tarr, R.S

$35-36,44$

Taylor, L.H.

$73,85,110$

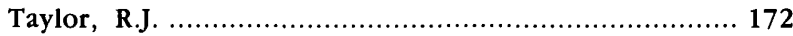

Taylor, Thomas U. ... 61, 75-76, 85, 88, 103, 115, 177, 207

Thomas, G.D. ......................................... 276

Thompson, Almon H. ..................... 13, 22, 27, 29, 49

Thompson, David G. $267-69,271$

Thompson, Gilbert

21

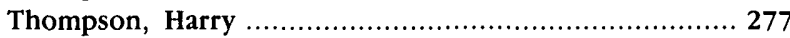

Thurtell, Henry .............................................. 110

Thweatt, Hardin ............................................. 242-43

Tillinghast, F.H. ....................................... 93, 101

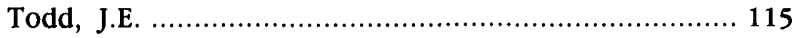

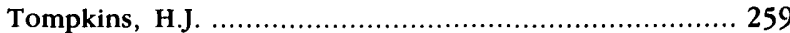

Tompkins, Vincent ................................... 54, 73

Trowbridge, William P., Jr. ......... 18, 35-36, 41-42, 44-45, 47, 50

Tuttle, A.H

$180,247,256$

Van Winkle, Walton

$188-90,193$

Vaughan, T. Wayland

190

Veatch, A.C.

113,121

Waesche, G.E.

87,104

Walcott, Charles Doolittle

$21,51,88,118-19,123$

Walker, C.F.

167

Wallace, G.A. ............................................ 178

Walter, Raymond $\mathbf{F}$.

$87,105,107$

Walters, Marion I.

$86,124,198,277$

Ware, W.J.

Waring, Gerald A.

... 74

Weber, Frank

271

Weeks, Arnold N.

254

Weymouth, F.E.

243, 277

Wheeler, George M.

105

Whistler, J.T.

$9,13-16$

White, Charles A. ........................................... 22

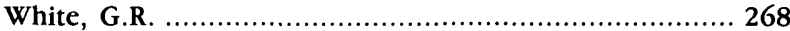

White, W.N. ............................................... 272-73

Whitney, Charley ….............................................. 42

Willard, E.V. ..................................................... 134 


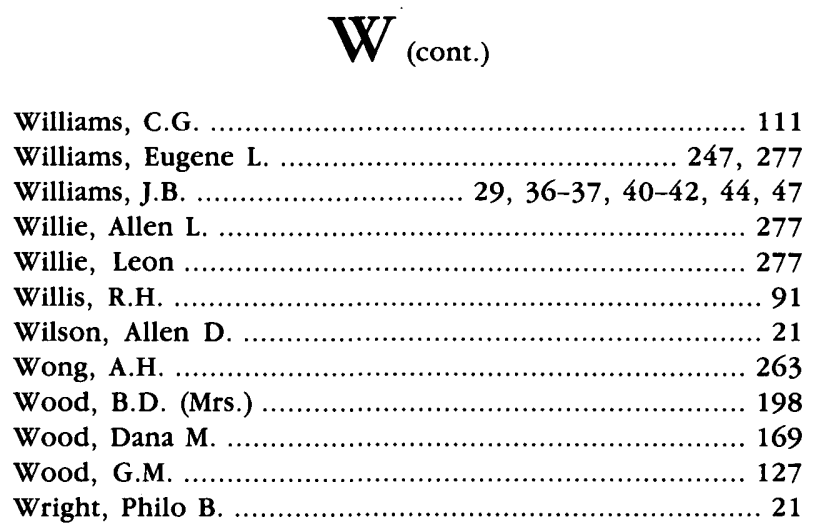


The U.S. Geological Survey, a bureau within the Department of the Interior and the Nation's largest earth-science agency, was established in 1879 following several Federally-sponsored independent natural resource surveys of the West and Midwest. National interest in developing arid and semiarid lands resulted in the establishment in 1888 of the Irrigation Survey, the forerunner of the Water Resources Division, to study the availability of water for irrigation, sites for reservoirs, and artesian areas of the arid and semiarid lands of the United States. The Irrigation Survey was terminated in 1890 , but streamflow measurements continued in a modest way until 1894, when Congress authorized the Geological Survey to gage streams and determine the water supply of the United States, including the investigation of ground water and artesian wells in arid and semiarid regions.

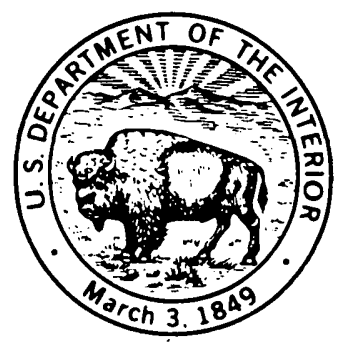

